RELIGION AND SOCIETY IN ASIA

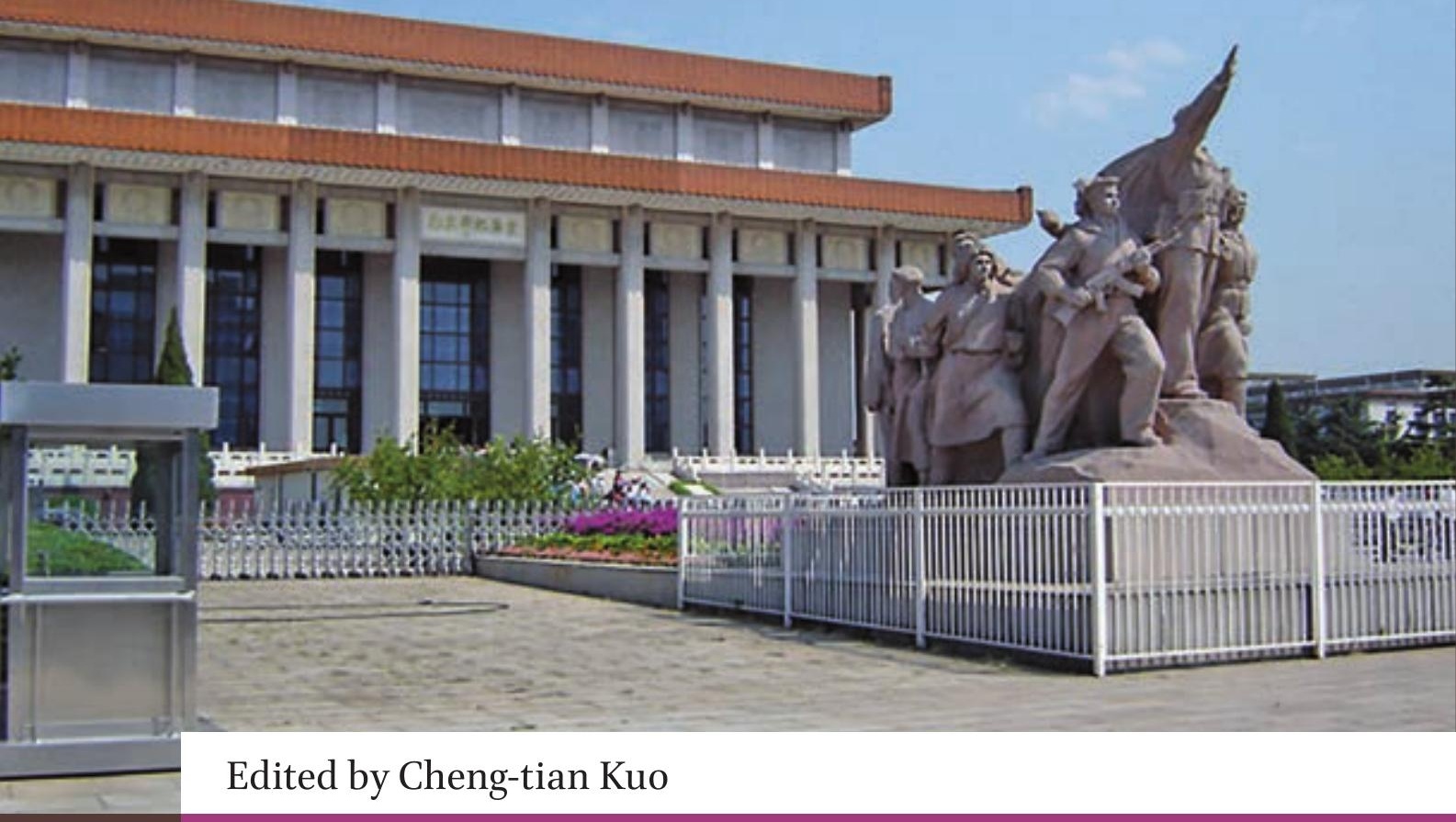

\title{
Religion and Nationalism in Chinese Societies
}


Religion and Nationalism in Chinese Societies 


\section{Religion and Society in Asia}

The Religion and Society in Asia series presents state-of-the-art cross-disciplinary academic research on colonial, postcolonial and contemporary entanglements between the socio-political and the religious, including the politics of religion, throughout Asian societies. It thus explores how tenets of faith, ritual practices and religious authorities directly and indirectly impact on local moral geographies, identity politics, political parties, civil society organizations, economic interests, and the law.

It brings into view how tenets of faith, ritual practices and religious authorities are in turn configured according to socio-political, economic as well as security interests. The series provides brand new comparative material on how notions of self and other as well as justice and the commonweal have been predicated upon 'the religious' in Asia since the colonial/imperialist period until today.

\section{Series Editors}

Martin Ramstedt, Max Planck Institute for Social Anthropology, Halle Stefania Travagnin, University of Groningen 


\section{Religion and Nationalism in \\ Chinese Societies}

Edited by Cheng-tian Kuo 
This book is sponsored by the 2017 Chiang Ching-kuo Foundation for International Scholarly Exchange (Taiwan; SPoo2-D-16) and co-sponsored by the International Institute of Asian Studies (the Netherlands).

Cover illustration: Chairman Mao Memorial Hall in Beijing

(c) Cheng-tian Kuo

Cover design: Coördesign, Leiden

Typesetting: Crius Group, Hulshout

Amsterdam University Press English-language titles are distributed in the US and Canada by the University of Chicago Press.

$\begin{array}{ll}\text { ISBN } & 9789462984394 \\ \text { e-ISBN } & 9789048535057 \text { (pdf) } \\ \text { DOI } & 10.5117 / 9789462984394 \\ \text { NUR } & 718\end{array}$

(c) Cheng-tian Kuo / Amsterdam University Press B.V., Amsterdam 2017

All rights reserved. Without limiting the rights under copyright reserved above, no part of this book may be reproduced, stored in or introduced into a retrieval system, or transmitted, in any form or by any means (electronic, mechanical, photocopying, recording or otherwise) without the written permission of both the copyright owner and the author of the book. 


\section{Table of Contents}

Notes on Chinese Names, Terms, and Transliteration

Preface

1 Introduction

Religion, State, and Religious Nationalism in Chinese Societies Cheng-tian Kuo

\section{Part I Chinese Religion and Nationalism before 1949}

2 The Idea of Chineseness and Ethnic Thought of Wang Fuzhi Chi-shen Chang

3 Missionizing, Civilizing, and Nationizing

Linked Concepts of Compelled Change Julia C. Schneider

4 The Nation in Religion and Religion in the Nation Adam Yuet Chau

5 History and Legitimacy in Contemporary China Towards Competing Nationalisms Robert D. Weatherley and Qiang Zhang

6 Pilgrimage and Hui Muslim Identity in the Republican Era Yuan-lin Tsai

\section{Part II Religion and Nationalism in Contemporary China}

7 Religion and the Nation

Confucian and New Confucian Religious Nationalism Bart Dessein 
8 Yiguandao under the Shadow of Nationalism

Traitors, Conspirators, Traditionalists, or Loyalists?

Ching-chih Lin

9 Daoism and Nationalism in Modern and Contemporary China Shu-wei Hsieh

10 Nationalism Matters

Among Mystics and Martyrs of Tibet

Antonio Terrone

11 'We Are Good Citizens'

Tension between Protestants and the State in Contemporary China Yen-zen Tsai

\section{Part III Religion and Nationalism in Taiwan and Hong Kong}

12 Religion and National Identity in Taiwan

State Formation and Moral Sensibilities

Edmund Frettingham and Yih-Jye Hwang

13 Multiple Religious and National Identities

Mazu Pilgrimages across the Taiwan Strait after 1987

Hsun Chang

14 Salvation and Rights in Hong Kong

Mariske Westendorp

Index 


\section{Notes on Chinese Names, Terms, and Transliteration}

This book adopts Chinese pin-yin transliteration. In most of the text, an English translation is provided first, followed by either Chinese pin-yin transliteration or (traditional) Chinese characters, or by both, when the Chinese characters first occur.

Some well-known Chinese names and places or those related to Taiwan and Hong Kong may use other spelling systems to accommodate local dialects; for instance, Sun Yatsen, Taipei, and Taiwanese authors of this book. In most cases, Chinese characters are provided after the transliteration.

All Chinese names retain the Chinese order of family name first, followed by the given name.

Chinese names and places use normal font; Chinese terms are italicized.

Standard academic transliteration is used for religious jargon of Islam and Tibetan Buddhism. 



\section{Preface}

'(Jesus) got up and rebuked the winds and the sea, and it became perfectly calm. The men were amazed, and said, "What kind of a man is this, that even the winds and the sea obey Him?"'

Matthew 8:26-27; New American Standard Bible

Dense smog and cloud constantly hovered over Beijing all year long. But on 3 September 2015, the seventieth anniversary of the establishment of the People's Liberation Army, a 'military-parade blue sky' (yuebinglan 閲兵藍) was all over Beijing. Even though it lasted for only one day, the whole world was amazed: What kind of a State is this, that even the winds and the smog obey Her? Cheng-tian Kuo

The above comparison illustrates a new pattern of religion-state relations called religious nationalism in China and its impact on those in China, Taiwan, and Hong Kong. It is no longer the state versus religion, but hybrid mixtures of religion and nationalism in these three Chinese societies.

On a hot summer day in June 2015, I received a mysterious long-distance phone call from the Chinese government in Beijing. The official asked me whether I would be available to attend a conference in early September. I thought the conference would be the long-overdue National Religious Conference which had been held once every ten years. So I immediately said OK. Then, the officials whispered a sentence to conclude our short communication: 'There will be a military parade!' I cheerfully replied: 'That's great! I have never been invited to a military parade before.' But why would the Chinese government hold a military parade in September, not on 1 October - National Independence Day - like they had always done? I wondered. It must be because of the National Religious Conference for which I have been invited, I naively thought. In the following two months, I did not receive any concrete confirmation about this secretive invitation until one week before my scheduled flight. One official solemnly gave me very detailed instructions about the security measures I should follow once I arrived in Beijing, because 'the entire city will be under martial rule.'

I arrived in Beijing three days earlier so that I could do some interviews with my academic friends and give a talk at the State Administration for Religious Affairs (SARA). On the day of my arrival, the sky was packed with dense smog as usual, but the street traffic was unusually light due to the 
martial rule. All the shops were closed, including the beverage vending machines in the massive subway system. Governmental officials received last-minute orders to strictly limit their use of official cars during the week and to promptly leave town in the early afternoon of 2 September; otherwise, they would have to stay one long night in their office. My talk at the SARA was first postponed, then, canceled at the last minute. The entire central government in Beijing was almost shut down and ordered to do nothing else except to accommodate the military parade.

At five o'clock in the morning on 3 September, some other guests and I went through the waterproof security checks at the secluded hotel, boarded the designated buses to the parade platform, and waited for other distinguished guests to arrive. The sky began to reveal a golden light and crystal blue with only a few traces of white cloud. Everyone in the audience started to praise the blue sky as if they had the luck to see the aurora of the North Pole. Not for long, though. The next morning when I opened the curtains at my hotel, the sky was packed with dense smog and acid drizzle again; so was the next day and the next. On my airplane back to Taipei, I jotted down the verses from Matthew above and applied them to the 'miracle' of the military-parade blue. After all, the military parade was not just a secular ceremony but also a sacred religious ritual for the Chinese Communist Party-State in search of political-religious legitimacy. It is a religious ritual of the state religion, which I call 'Chinese Patriotism'.

This book discusses the origin, development, content, and implications of religion-state relations in contemporary Chinese societies, i.e. mainland China, Taiwan, and Hong Kong. On the one hand, state policies toward religions in these societies are deciphered and their implications for religious freedom are evaluated. On the other hand, Chinese Buddhism, Tibetan Buddhism, Daoism, Christianity, Islam, and folk religions are respectively analyzed in terms of their theological, organizational, and political responses to the nationalist modernity projects of these states. What is new in this book on religion and nationalism in Chinese societies is that the Chinese state has strengthened its control over religion to an unprecedented level. In particular, the Chinese state has almost completed its construction of a state religion called Chinese Patriotism. But at the same time, what is also new is the emergence of democratic civil religions in these Chinese societies, which directly challenge the Chinese state religion and may significantly transform their religion-state relations for better or for worse.

This book could not have been published without the compassionate support of the following persons and institutions, to whom I express my 
most sincere appreciation. The International Institute for Asian Studies (IIAS) and the Ministry of Education of the Republic of China in Taiwan jointly sponsored a Taiwanese Chair of Chinese Studies program, which enabled me to convene the conference on New Religious Nationalism in Chinese on 21-22 April 2016 in Leiden, the Netherlands. Most of the chapters in this book are revised versions of these conference papers. Deputy Director Willem Vogelsang and staff members (in particular, Martina van den Haak and Sandra van der Horst) of the IIAS provided the most cozy and efficient working environment. The Chiang Ching-kuo Foundation for International Scholarly Exchange and the National Chengchi University provided additional funding to the conference to bring in more Taiwanese scholars than the previous Taiwanese Chair programs. It also generously funded the production of this book. Research assistants Huang Yuchia, Chang Chenghao and Huang Iwei added extraordinary warmth and comfort to the conference, like the tulip blossom in the Netherlands. Huang Iwei, Song Chunli, and Chen Li painstakingly corrected all the style problems in these book chapters. At Amsterdam University Press, Dr. Stefania Travagnin of the University of Groningen, Commissioning Editor Saskia Gieling, and copy-editor Roger Nelson patiently guided us through the laborious editing and publication process. Finally, on behalf of all the authors of this book, I express my most sincere gratitude to the two anonymous reviewers who provided very helpful and detailed comments on each chapter of this book. 



\title{
$1 \quad$ Introduction
}

Religion, State, and Religious Nationalism in Chinese Societies

Cheng-tian Kuo

\begin{abstract}
Originating in the common responses to threats of modernity in the beginning of the twentieth century, three models of religion-state relations have respectively taken shape in China, Taiwan, and Hong Kong, and each has important implications for both internal stability and external relations. In China, a totalitarian state religion of Chinese patriotism has been under construction and has almost fully established itself. In Taiwan, the initiation and consolidation of democracy after 1987 has contributed to the rise of a civil religion shared by many religions that provides for healthy checks-and-balances between the state and religion. In Hong Kong, there has been increasing confrontation between the totalitarian Chinese patriotism and a fragile civil religion.
\end{abstract}

Keywords: China, Taiwan, Hong Kong, religion, nationalism

\section{Three models of religion-state relations in Chinese societies}

Since modernity started threatening the Chinese nation at the beginning of the twentieth century, three models of religion-state relations have taken shape in China, Taiwan, and Hong Kong, and each has had important implications for both internal stability and external relations. The 'Rise of China' has been fanatically propelled by a state religion called 'Chinese patriotism.' ${ }^{1}$ An 'imagined community' of 'China' serves as the supreme God to be worshipped by all Chinese. ${ }^{2}$ The core catechism of this state religion is a political Trinity: patriotism, socialism, and the rule by the Chinese Communist Party (CCP). All other religions should be submissive to this state religion and integrate the Trinitarian political theology into their respective theologies. Freedom of religion, although in incremental

1 For the debate on the 'peaceful' rise of China, see Guo (2006).

2 Anderson (1991). 
progress, remains confined within the glass ceiling of Chinese patriotism and is meticulously restricted to pre-approved clergy, time, and place.

In Taiwan, checks-and-balances between the state and religion have largely replaced the state's dominance over religion. Taiwanese religious groups probably enjoy more freedom and autonomy than their counterparts in Western democracies. ${ }^{3}$ They also regularly exercise significant influence over state policies and in democratic elections. The Taiwanese state maintains effective legal instruments to curtail illegal activities of fanatic religious groups, at the same time promoting normal religious activities without 'excessive entanglement' or 'discrimination.' ${ }^{4}$ In turn, most religious groups have gradually adapted to democracy by integrating democratic values into their theologies and organizational structures. They begin to endorse a 'civil religion' which is not closely linked to either Chinese patriotism or Taiwanese nationalism. ${ }^{5}$ Harmony and cooperation, rather than conflict, characterize the relationships between not only the state and religion but also among religious groups in Taiwan.

By contrast, religion-state relations in Hong Kong are moving precariously between the Chinese model and the Taiwanese model. Emanating from the Christian community, a fragile civil religion is under construction by Christian leaders, intellectuals, independent mass media, and democratic parties. They also organize various democratic movements to challenge the Hong Kong government and the Chinese state. In response to these challenges to Chinese patriotism, the Chinese state and Hong Kong government have rapidly tightened their leash on Hong Kong's Christian community and civil religion.

Inherited from the common responses to the threats of modernity, why have China, Taiwan, and Hong Kong developed such different models of religion-state relations? What has happened during the past one hundred years that may have caused these differences? And what are the practical and normative implications for religion-state relations, political stability, and external relations of these Chinese societies?

Before proceeding to the next section and to other chapters of this book, let me define the core concepts used in this book: religion, the state, nationalism, and religious nationalism. A common definition of 'religion',

3 U.S. State Department, Religious Freedom Report (Taiwan), annual issues.

4 Since Lemon vs Kurtzman (1971), these two criteria have been considered by the U.S. Supreme Court in cases related to violation of the principle of separation of state and religion.

5 'Civil religion' refers to citizens' strong commitment to democratic values and institutions, not necessarily linked to particular religions. The term was coined by French philosopher Jacques Rousseau but was made popular by Bellah (1967). 
especially for Chinese religions, is the one offered by C.K. Yang, who put most Chinese religions into a continuum between 'institutional religion' and 'diffused religion'. An institutional religion is 'a system of religious life having (1) an independent theology or cosmic interpretation of the universe and human events; (2) an independent form of worship consisting of symbols (gods, spirits, and their images) and rituals; and (3) an independent organization of personnel to facilitate the interpretation of theological views and to pursue cultic worship'. Confucianism, Buddhism, and Daoism as practiced by the Chinese dynasties, temples, and shrines fall into this category. A 'diffused religion' is 'a religion having its theology, cults, and personnel so intimately diffused into one or more secular social institutions that they become a part of the concept, rituals, and structure of the latter, thus having no significant independent existence'. Various folk religions (including folk Confucianism, folk Buddhism, and folk Daoism) fall into this category. ${ }^{6}$ Yang's definition of religion is largely applicable to most Chinese religions but may encounter problems when some folk religions (e.g. Yiguandao discussed in Chapter 8 of this book) become institutionalized in response to modernity. Nevertheless, Yang's definition appropriately directs our attention to the cores of any religion, namely, theology, ritual, and clergy, no matter how institutionalized or diffused they are.

The 'state' (sometimes, 'government') in the Chinese context refers not only to traditional dynasties or kingdoms before 1911 but also to the modern states of the Republic of China (ROC) and the People's Republic of China (PRC), although this definition is not intended to imply China's unification or Taiwan's independence. The Hong Kong government (not a modern state) was a colonial government of the United Kingdom before 1997, and a local government of the PRC since then. The core of a traditional Chinese state is the emperor and his/her royal family. A bureaucracy (including the military) is established to serve the interests of the royal family. The territory and subjects are regarded as the properties of the emperor, and are frequently subject to expansion or contraction because of war with other kingdoms. A modern state is defined by political scientists as a political entity consisting of a fixed territory, a people (including different ethnic groups) living within the territory, a government governing the territory and the people, and the sovereignty of the government to govern its territory and the people without the permission of other states.

Adapted from the definitions provided by scholars of nationalism, a 'nation' (minzu 民族 or guozu 國族) is defined as 'an imagined political 
community' bounded together by 'imagined' common history, people of ethnic ties, culture, religion, language, government, sovereignty, and territory. ${ }^{7}$ A nation is imagined because it does not necessarily meet, nor exclude, scientific evidence or international laws. Nationalism is thus an ideology that combines and elaborates these imaginations. Again, nationalist imaginations are different in kinds and degrees across temporal and spatial contexts. Furthermore, according to the above definition, the concept of nationalism is applicable to the nationalism of traditional kingdoms before the eighteenth century, whose people and territory frequently changed ownerships and definitions, as well as to the modern nationalism that originated in the early eighteenth century, which has distinctive components of people's sovereignty and fixed territory.

As noted above, there are two Chinese translations of 'nation': minzu 民 族 or guozu 國族. In Chinese politics, academics, and mass media, minzu has been the favorite term since it was invented more than one hundred years ago by Liang Qichao 梁啟超 to refer to the newly imagined 'Chinese nation' (zhonghua minzu; see Chapter 2 of this book for the origins of the Chinese nation). But Liang and most Chinese also use minzu to refer to the fifty-six ethnic groups, which together constitute the one and only Chinese nation. To differentiate a nation from an ethnic group, a growing number of the Chinese elite, including CCP Secretary General Xi Jinping, have employed guozu to refer to the Chinese nation and minzu to refer to any one of the fifty-six ethnic groups. ${ }^{8}$

The combined term of religious nationalism refers to the interpenetration, overlapping, or syncretism of religion and nationalism. It consists of two subcategories: a nationalism that incorporates existing religious elements or develops a new state cult in nationalist ideologies, state bureaucracies, public education systems, and national holidays; and a religion that incorporates nationalist imaginations in its theology, ritual, and religious organization. The former can be labeled as religious nationalism; the latter, nationalist religion. There are different kinds and degrees of religious nationalism as well as nationalist religion across temporal and spatial contexts. Unless specified, the concepts of 'religious nationalism' and 'nationalist religion' are used interchangeably in this book in order to emphasize the mutual influence between religion and nationalism in both traditional and modern

7 Anderson (1983, pp. 6-7); Gellner (1983, pp. 5-7); Hastings (1997, pp. 3-4); Hobsbawm (1992, pp. 5-13).

8 Kuo (2014, pp.10-13); Xi Jinping inaugural address (17 March 2013), http://lianghui.people. com.cn/2013npc/n/2013/o317/c357183-20816399.html. 
China, as compared to the one-sided dominance of the state over religion described by the modernity approach discussed below.

Rogers Brubaker calls our attention to religious nationalism in the development and studies of state-religion relations. Most of the studies on state-religion relations belong to one of three types: those that treat religion and nationalism as analogous phenomena, those that use religion to explain nationalism, and those that treat religion as part of nationalism and analyze their interpenetration and intertwining. The emerging religious nationalisms in Algeria, Egypt, India, Iran, Israel, Northern Ireland, Palestine, Pakistan, Turkey, and the United States, however, are different according to Brubaker. It is 'a distinctively religious type of nationalist program that represents a distinctive alternative to secular nationalism'. In religious nationalism, religion 'provides a distinctive way - or a distinctive family of ways - of joining state, territoriality, and culture'. ${ }^{9}$ Brubaker's definition covers the first subcategory of religious nationalism used in this book but does not refer to the second subcategory of religious nationalism (i.e. nationalist religion). While consistent with Brubaker's insights on religious nationalism, most chapters of this book keep a balance between these two subcategories.

\section{Two theoretical approaches: Modernity and revisionism}

Since John Locke started promoting the thesis of separation of state and religion four hundred years ago, the modernity approach has been the dominant explanation and prescription for religion-state relations in the world. ${ }^{10}$ It postulates that the state should be free from the interference of religion in secular matters so that the state and society may mobilize their resources and talents more effectively to build up a modern nation-state. During the Enlightenment, Immanuel Kant further degraded religion as something irrational and harmful to modernity; religion was better confined to the private sphere of families and religious compounds. Emile Durkheim similarly treated religion as superstition harmful to modernity and would finally be replaced by the development of rationality-based science. ${ }^{11}$ 
The modernity approach deeply influences how major historians (re-) interpret the rise of nationalism in Western countries. Since modern statebuilding is regarded as scientific and religion is viewed as anti-scientific, the two cannot be compatible. Religion is treated either as anti-state-building or is totally absent from analyses. Instead, the modernity scholars prefer to focus their analysis on the factors of industrial revolution, military technology, printing, and rational bureaucracy, which allegedly contributed to modern state-building. ${ }^{12}$

Applying the modernity approach to religion-state relations in modern China, Chinese intellectuals and politicians around 1900 promoted various modernity programs to reform or to eliminate religions in order to build up a powerful Chinese state. Most folk religions in the countryside or religions of the ethnic minorities were regarded as superstitious and needed to be replaced by modern schools teaching science. This modernity program is almost as 'colonizing' and 'missionizing' as the Western powers, as Julia C. Schneider in this volume argues. Large institutional Buddhism and Daoism underwent reforms following the model of Western Christianity. Neo-Confucians made great efforts to 'reimagine' Confucianism as a secular and rational philosophy compatible with modernity programs. However, none of these religious reforms would appease Chinese atheists who aimed to eliminate all religions, including Christianity, which allegedly came to China under the aegis of Western imperialism. As the following sections demonstrate, the modernity approach continues to influence the academic analysis and religious policies in contemporary Chinese societies. ${ }^{13}$

In retrospect, the modernity approach is only partially correct in terms of empirical evidence and normative implications. Recent scholarship on religion-state relations argue that the traditional Chinese state was a 'religious state' (or 'religio-political state'), the Chinese society was a 'religious society', and the state sponsored a 'state religion' of Confucianism. ${ }^{14}$ Even when the Chinese state (e.g. the powerful Ming Dynasty) tried to control

\footnotetext{
12 Anderson (1991); Gellner (1983); Hobsbawm (1992).

13 Wang (1977); MacInnis (1989). Ashiwa and Wank's book (2009) applies Talal Asad's secularization thesis to modern Chinese religion-state relations and is another exemplar of the modernity approach. Mayfair Yang's book (2008) tries to distance itself from the modernization theory by emphasizing the modernity's discursive process between the modern Chinese state and religions. Although its major arguments are closer to the revisionist school, I would still put Yang's book in the modernity school because it underestimates the mutual influence (albeit asymmetrical) of state and religion in both traditional and modern China.

14 These 'revisionist' works include: Chau (2011); Goossaert and Palmer (2011); Lagerwey (2010); Dean (2009); Platt (2007); Yang (1961); Yang (2012); Yu (2005).
} 
religion, its efforts were short-lived and ineffective. In Chinese history, various religions permeated Chinese politics from the basic political/religious unit of family up to the imperial court. Religious freedom and tolerance were largely maintained in the dynastic government and in society. Furthermore, the authority and legitimacy of centralized Chinese dynasties were buttressed by various major religions. Chinese religions also provided political justification for the mobilization of rebellions against weak and corrupt dynasties. Therefore, religion is not necessarily anti-state-building but may become complementary to state building, which became the core of the modernity program in the Republican era. In this volume, Adam Yuet Chau describes how, in the early Republican era, the Chinese literati tried to incorporate 'religion in the nation' and 'the nation in religion'. In fact, a nationalist program based purely on secular appeals may soon run out of steam, as Robert D. Weatherley and Qiang Zhang's chapter in this volume demonstrates.

The normative and empirical validity of the revisionist approach gets a boost from the recent and fast developments in neurotheology, an interdisciplinary study of religious behaviors. Although still in its infancy of academic development, neurotheology has generated a vast amount of scientific evidence to support the theses that 'rationality is a slave to emotion' (an argument first proposed by David Hume), that religious/ spiritual thinking is part of human nature (just as rationality and emotion are), and that 'religious (god) brain' (or 'religious circuits' in the brain) may enhance or constrain human rationality and emotion. ${ }^{15}$ This religious brain consists of various circuits connecting different functional parts of the brain to generate religious feelings, theological thinking, and images of transcendental gods. The thalamus receives incoming religious signals from sensory organs (eyes, ears, nose, mouth, and skin) and forwards these signals to different parts of the brain for response. The amygdala sends out quick emotional responses of anger, aggression, fear, and sexual desire to religious signals. The septum reinforces or regulates religious anger, fear, and pleasure generated by the amygdala. The hippocampus compares and learns new religious signals based on memory. The frontal lobe conducts rational thinking on religious signals and produces theological or moral arguments. The anterior cingulate generates a sense of peace, loving, and compassion associated with religion. And the parietal lobe enables humans to construct spatial and temporal dimensions of religion as well as of other

15 Barrett (2011); Fingelkurts and Fingelkurts (2009, pp. 293-326). Jeeves (2013); Newberg and Waldman (2009); Ramachandran and Blakeslee (1998). 
transcendental ideologies, aliens, and mystical powers. It strengthens and prioritizes the thinking circuits related to these concepts as guiding principles to emotional and rational behaviors. Thus, humans get feelings of holiness and unity with supernatural powers when these concepts are stimulated by external signals.

Thus, neurotheology challenges the very foundation of the modernity approach, its zealous faith in rationality, and its empirical and normative controversies. For instance, the fundamentalism research project led by Martin Marty regards the rise of religious-political fundamentalisms around the world in the 1980 s as temporary irrational responses to modernity that would be withered away by modernity. ${ }^{16}$ But if rationality, emotion, and religious thinking are all interrelated and interdependent parts of human nature, then, the explanation and normative goals of any modernity program should be revamped, to include all these facets of human nature. If religion is a cause of the 'clash of civilizations', it should also be a part of the solution. ${ }^{17}$

Neurotheology puts emphasis on individuals' religious behaviors. But individuals live in institutional settings and are molded by the institutions, such as family, clan, school, work place, and most important of all, religion and the state. Thus, in addition to neurotheology, empirical and normative claims of the revisionist approach get another boost from theories of institutions. ${ }^{18}$ The symbiosis of the state and religion is ubiquitous in human history. ${ }^{19}$ Anthropologists have traced the importance of religion to political leadership in primitive societies. The evolution of human societies from primitive tribes, ethnic groups, kingdoms to dynasties was accompanied and supported by the development of various religions. The rise of Western nation-states since the early eighteenth century, which was the core of the modernity program, also witnessed the symbiosis of the state and religion. No modern state was established without the support of a dominant domestic religion or without creating a new state religion for its own sake. For example, the Church of England independently created the religious/national identity of England; French nationalism claimed its origin in Joan of Arc's divine calling to fight against the English; the United States established the first democratic state because most Americans

\footnotetext{
16 Marty and Appleby (1995).

17 Huntington (1996).

18 Classical works on institutionalism include North (1990), Powell and DiMaggio (1991); March and Olsen (1979). Ashiwa and Wank's book (2009, pp. 6-12) applies this institutionalism to the analysis of state-religion relations in China.

19 Cook (2005); Davis (2005); Diamond (1999).
} 
believed it to be the 'New Heaven and New Earth' on earth; the Protestantturned-Eastern-Orthodox Catherine II transformed Russia into a modern state with the blessings of the Eastern Orthodox Church, and the Meiji reform installed the State Shinto for the very purpose of social and political modernization. ${ }^{20}$ Even the atheist communist regimes in Eastern Europe transformed Marxism into a state religion in order to consolidate their legitimacy and to facilitate modernity programs. ${ }^{21}$ Since the 1980 s, the 'Third Wave of democracy' has contributed not only to the establishment of democracies but also 'religious nationalisms' in developing countries, which rebeled against secular nationalism and its modernity programs. ${ }^{22}$ Finally, Robert Bellah points out the rise of a 'civil religion' in Western democracies, despite the general decline of Christian religiosity in these democracies. Citizens develop strong emotional commitment to democratic institutions and values through education, mass media, public museums, laws, and national holidays. According to Yang's definition of religion discussed before, civil religion can be regarded as a 'diffused religion' merged into the political system, society, and institutional or diffused religion. Strengthened by theories of neurotheology and institutionalism, this chapter (and most chapters of this book) take various revisionist perspectives to reassess the interpenetration and interdependence of the state and religion in modern Chinese societies.

\section{A revisionist interpretation of religion-state relations in modern China}

Based on the neuro-institutional assumptions, a revisionist interpretation of the emergence of modern 'China' can be traced to one hundred and thirty years ago when modern nationalism was first introduced to China, or to traditional Chinese dynasties. The Chinese modernists would argue the impetus to the rise of Chinese nationalism and nation-state probably should not be traced back to any time earlier than 19oo. A simple reason is that modern nationalism and the nation-state emerged in Western Europe only in the early eighteenth century and were not introduced in China until the late nineteenth century. But before then, as Chishen Chang says in this volume, there were already various dynasties (chaodai 朝代) and 
different interpretations of China (zhongguo 中國), mostly of Han ethnic rulers governing flexible amounts of territories and subjects in East Asia. On the one hand, these dynastic governments were religious states in the sense that they maintained their legitimacy by mixing secular governance with various institutional religions: Confucianism, Daoism, and Buddhism. On the other hand, local elites and the people regularly mixed their religious rituals and values into their secular lives, and constituted a diffused religious society. The Qing Dynasty (1644-1911), ruled by the Manchu ethnic group, was the last religious dynasty before the modern Chinese state (the Republic of China) was established in 1911.

Chinese intellectuals and political leaders began to 'imagine' a political community called 'China' only in the late nineteenth century when the Qing Dynasty failed to stop the repetitive invasions by other modern states. The incompetent Qing Dynasty signed a series of unequal treaties with other modern states, and surrendered a significant part of its territory or sovereignty to them (Great Britain in 1840, 1858 , and 1886; France in 1858 , and 1884; Russia in 1858, and 1864; and Japan in 1872 and 1895). Together, these treaties shattered the traditional sacred image of the Chinese dynasty being the 'central territory' (zhongtu 中土) or 'all-under-heaven' (tianxia 天下).

Emulating the Japanese State Shinto modernity program, neo-Confucian reformers of the Qing Dynasty responded to external threats by promoting a State Confucianism in order to modernize the whole nation around a god-like emperor. ${ }^{23}$ Bart Dessein's chapter in this volume provides a detailed analysis of this State Confucianism as a state religion. At the same time, it aimed to reform, if not eliminate, folk religions that deviated from State Confucianism and were deemed as 'evil cults' (yinci 淫祠). ${ }^{24}$ But this modernity program, called the Wuxu Reform (wuxu bianfa 戊戌變法, 1898, also called 'Hundred Days' Reform'), flew in the face of the ambitions of Empress Dowager Cixi 慈禧 who was the de facto supreme ruler of the dynasty but did not fit into the patriarchal neo-Confucianism. She found an alternative source of political and religious legitimacy in the traditional folk religion of White Lotus (bailian jiao 白蓮教) which worshipped the Mother of No Birth (wusheng laomu 無生老母) as the omnipotent creator of the universe. The Queen Mother staged a palace coup, terminated the neo-Confucian reform, and instructed the White Lotus to exorcize all foreign 'demons' out of the 'central territory'. The White Lotus led the Boxer Rebellion (quanluan 拳亂) against the foreign demons from 1898 to 1900 . In 1900, a military alliance 
of eight nations (Great Britain, the United States, France, Russia, Prussia, Austria, and Japan) swiftly crushed the Boxer Rebellion and threw the Qing Dynasty into anarchy. Dr. Sun Yatsen 孫逸仙 took advantage of the anarchy and led a Han-ethnic revolution to establish the Republic of China in 1911.

But the Republic of China was actually a republic of convenience made possible by the anarchy and a truce among different religions and political forces. The very concepts and legitimacy of both the Republic and China were unfamiliar to most Chinese people and were contested among political leaders and intellectuals. The neo-Confucians' repeated attempts to establish State Confucianism came to a halt in 1916, because all other religions and the atheists opposed it. Since Sun Yatsen was a Christian, along with a high percentage of Christian presence in the Republican government, all other religions and the atheists were suspicious of a Christian Republic on the rise. Buddhism and Daoism had decentralized structures in traditional China and were too weak to challenge the rising modern state. White Lotus' claim to integrate Confucianism, Buddhism, and Daoism in one religion only served to discredit their scientific nature of modernity. Furthermore, most Tibetan Buddhists and Xinjiang Muslims did not want to be part of the Republic or the Chinese nation due to their distinctive religious traditions of theocracy and distinctive ethnicity. In this volume, Antonio Terrone traces various ways in which Tibetan Buddhists resisted China's nationalist modernity program.

The political and religious anarchy in the early Republican era contributed to the rise of a new state religion, called 'Chinese nationalism'. China became the new god above all other gods (Buddha, Confucius, Laozi, Jehovah, Allah, Mother of No Birth, and others). The Chinese state officials and intellectuals became the greatest prophets and priests among all religious clergy, although they were free to take on other religious identities. All other religions were supposed to serve this supreme god and obey the new political revelations of its prophets and priests. Following neo-Confucian Liang Qichao's creative definition, the ‘Chinese nation' (zhonghua minzu 中 華民族）now included not only the ethnic Han people, but also the Manchu, Mongolian, Muslim, and Tibetan. ${ }^{25}$ All of them were given, voluntarily or otherwise, membership to this new state religion overnight. The holy national land became the fixed territory inherited from the Qing Dynasty, including Taiwan which was ceded to Japan in 1895 .

The catechism of Chinese nationalism was based on a creative hermeneutics of the separation of state and religion. Around 1900 when the 
phrase 'separation of state and religion' was first introduced to China, it was translated into zhengjiao fenli 政教分離, rather than zhengjiao fenli 政教 分立, by most Chinese intellectuals and politicians and has been the most popular translation since. The former translation connotes that the state and religion are segregated entities and have no interaction between them while the latter accurately captures the authentic meaning of the American separation of church and state. Even worse, influenced by the French law of laïcité ('secularization') passed in 1905, Chinese political leaders and intellectuals used the former translation to justify the state's arbitrary intervention in internal affairs of religion while forbidding religion from intervening in the state. The separation of state and religion thus became a one-way separation. ${ }^{26}$ Hence, the modern Chinese state was fully justified by this political catechism to intervene in all religions while forbidding religion to intervene in politics.

The first component of the religious modernization program promoted by the KMT government was to turn temples and shrines into schools of modern education. Christian churches were left out because they were protected by unequal treaties with Western states. Besides, Christian organizations brought in their own modern education systems complementary to the modernity program. The second component of the modernity program was to organize traditional religions into hierarchical national religious associations so that the state could promote other modernity programs through them. However, some political leaders and intellectuals inserted a third component in the modernity program, that is, to eliminate all religions but Chinese nationalism. After all, all religions are exclusive to some extent against other religions. If the god of Chinese nationalism is the supreme and true god, what is the use of all other minor or false gods? ${ }^{27}$

Christian General Jiang Jieshi 蔣介石 (or Chiang Kaishek) defeated Chinese warlords and unified China in 1928. By mixing neo-Confucianism and Christianity in the modernity program, he ushered in the Golden Ten Years of rapid economic growth and social transformation under the guidance of an authoritarian Chinese state, which was legitimized by Chinese nationalism. ${ }^{28}$ Unfortunately, Japan's invasion in China from 1937 to 1945 cut short Jiang's modernity program. After World War II, the civil war between the Nationalist Party (Kuomintang 國民黨; KMT) government and the CCP

26 Kuo (2016).

27 On religion-state relations in the Republican era, see Goossaert and Palmer (2011, pp. 50-63); Duara (2008, pp. 43-64).

28 Goossaert and Palmer (2011, pp. 69-79). 
from 1945 to 1949 could be interpreted as a contest for orthodoxy within the Chinese nationalism. Mao Zedong 毛澤東 won the contest, and Jiang Jieshi's views became political heresy. From then on, three different models of religion-state relations developed in China, Taiwan, and Hong Kong.

In China, religion-state relations went through three periods of transformation. ${ }^{29}$ The first period, from 1945 to 1957 , saw the gradual withdrawal of the United Fronts strategy by which the CCP formed an amicable alliance with almost all major religious groups, including Daoism, Buddhism, Protestantism, Catholicism, Islam, and folk religions. The United Fronts strategy respected the autonomy of religious groups, which in turn provided religious justification for the CCP's fights against the Japanese and the KMT before 1949. At the same time, Chinese communism began to develop its quasi-fundamentalist religious form. Describing the Chinese religious nationalism during the Yan'an Period (1942-1946), David E. Apter and Tony Saich said they were amazed by what was contained in 'its logocentricism certain proto-religious characteristics intertwined in a secular theory of politics that identified logos with power'. In fact, as 'compared to most religious movements,' they argue, 'the Yan'anites may have been more deeply sincere. $3^{30}$ It was this type of religious nationalism that significantly contributed to the establishment of the PRC. After 1949, the United Fronts strategy shifted gear and aimed to reeducate various religions in order to rally them behind this emerging Chinese communist state religion.

Radical communists in the CCP did not tolerate the existence of religion under communism. Therefore, the second period, from 1957 to 1979, saw attempts to eliminate all religions during the Great Leap Forward and the Cultural Revolution, for the purpose of promoting a communist modernity program. During this period Chinese nationalism further developed its socialist theology along with the Mao cult. ${ }^{31} \mathrm{CCP}$ chairman Mao Zedong was treated as the Pope, if not the god, of Chinese nationalism. He was praised as the Great Helmsman, the Great Teacher and the Messiah of Workers. His pictures were displayed and worshipped in government offices, factories and family living-rooms. His speeches were edited into the Little Red Book, to be recited by all Chinese people performing worship rituals in front of Mao's pictures. The zealous Red Guards served as religious police spying on anyone who might show contempt for Mao's picture or for the Little Red

29 The following discussion on the Chinese case draws from Goossaert and Palmer (2011, chapters 6 and 7 ).

30 Apter and Saich (1994, pp. 3, 179).

31 For the Mao cult, see Myers (1972, pp. 1-11); Zuo (1991, pp. 99-110); Overmyer (1986). 
Book. Transgressors were subject to public criticism, imprisonment or the death penalty. The death of Mao and the downfall of his radical vanguards called an end to the second period of religion-state relations and ushered in the third period, from 1979 to the present.

The third period of religion-state relations witnessed the return of the United Fronts strategy with a new political theology of Chinese nationalism. The reformers at the central government needed a new source of legitimacy to justify reform policies because the old political theology of radical socialism was discredited due to economic disasters. The massacre of students in 1989 further accelerated the theological reform of Chinese nationalism. ${ }^{32}$ It got a slightly different name, Chinese Patriotism (aiguo zhuyi 愛國主義). 'China' remained its supreme god but with increasing tolerance of other religions under the condition that they internalize Chinese patriotism into their theology and organizational structures. Richard Madsen calls it the 'CCP's neo-imperial sacral hegemony'.33 I call this new political theology the 'Chinese Trinity': China, socialism, and the CCP are the three holy personas in one god. China is socialism; socialism is the CCP government; and the CCP government is China. One cannot love one without loving the other two personas. Conversely, one cannot reject one without rejecting the other two. In the minds of CCP leaders, the constitution of the PRC is not the supreme law of the land; the Chinese Trinity is. Applied to religion-state relations, the Chinese Trinity requires all other religions to place 'love your state' above 'love your religion' (aiguo aijiao 愛國愛教). The political theology of Chinese Trinity takes precedence over the theology of each religion, and the latter should be modified in order to integrate the former. More details of this Chinese patriotism are discussed in the next section of this chapter.

In Taiwan, religion-state relations started similarly but evolved quite differently from those in China. Defeated by the CCP in mainland China, the KMT government had already lost its legitimacy in the eyes of the Taiwanese people who still had a vivid memory about the massacre of Taiwanese elites by the KMT military in February 1947. Trained as a model communist, Jiang Jingguo 蔣經國, the eldest son of President Jiang Jieshi, promoted an extensive reform of the KMT and the state, and merged the two into a Leninist party-state, similar to the one in communist China. The party-state organized various religious groups into hierarchical associations whose leaderships were appointed or approved by the KMT. Being afraid of possible persecution by the atheist CCP in China, many leaders of various 
religions fled to Taiwan along with the KMT government, including Daoism, Buddhism, Protestantism, Catholicism, and Islam. They had no choice but to support the KMT party-state and help it consolidate its legitimacy among the Taiwanese believers. ${ }^{34}$

The state religion of Chinese nationalism, which the KMT government promoted in mainland China before 1949, was kept intact afterwards but with a new political theology. First, the asymmetrical religion-state relations of the Republican era in China were transplanted to Taiwan. Secondly, similar to the Chinese Trinity, the KMT party-state merged the KMT with Chinese nationalism but minus socialism and the CCP rule; Taiwan was part of China, and China needed the KMT rule. And thirdly, the same level of religious freedom as in traditional China was also applied to Taiwanese religious groups, except for those which carried a different political agenda than the KMT's, as in the case of the Presbyterian Church in Taiwan. The KMT party-state did not and could not eliminate Taiwanese religions because neo-Confucian President Jiang Jieshi became a devout Christian after 1949, Jiang Jingguo was a nominal Christian, and the United States, pressured by domestic human rights groups, always looked over the KMT's shoulder.

The KMT's state religion of Chinese nationalism began to crumble during the political democratization during the mid-1980s. Both the god of China and the priestly KMT were severely challenged by the rise of Taiwanese nationalism adorned with a religious fever. In fact, it was the Presbyterian Church in Taiwan (PCT) that led the religious/political challenge to the KMT's state religion. In a series of public statements addressed to both the Taiwanese people and the international community, the PCT promoted democratic reforms to challenge the life-long priestly role of the KMT, and it espoused Taiwan's independence as an alternative god to China. ${ }^{35}$ Under pressure from both the domestic democracy movement and the U.S., the KMT party-state finally lifted martial law in 1987.

From 1987 to the present, the state religion of Chinese nationalism continuously lost its believers. After President Jiang Jingguo died in 1988, his successor Li Denghui 李登輝 (or Lee Tenghui), a Presbyterian, began to promote a state religion of Taiwanese nationalism. ${ }^{36}$ In 2000 , he helped the candidate of the opposition party (Democratic Progressive Party, DPP) Chen Shuibian 陳水 扁, who was also a believer in Taiwanese nationalism, to topple the KMT 
government. During the Chen regime, the state actively promoted Taiwanese identity in the mass media and the education system through revising Taiwanese history, propagating the Taiwanese dialect, and subsidizing those 'homeland' (xiangtu 鄉土) cultural activities. Although the returned KMT regime tried to rejuvenate Chinese nationalism from 2008 to 2016 in order to contain the rise of Taiwanese nationalism, more and more Taiwanese were attracted to the latter. There seems to be a revival of Taiwanese nationalism since DPP President Tsai Ing-wen 蔡英文 took power in 2016.

Concomitant with the decline of Chinese nationalism and the rise of Taiwanese nationalism has been the gradual consolidation of a civil religion shared by the majority of Taiwanese religious groups. Although not as active democrats as the PCT, Buddhist Compassion Relief Association (Ciji 慈 濟 or Tzu Chi), Buddha's Light Mountain (Foguanshan 佛光山), Dharma Drum Mountain (Fagushan 法鼓山), and the Enacting Heaven Temple (Xingtiangong 行天宮) helped smooth Taiwan's democratic transition by promoting peace and tolerance among contending political forces. ${ }^{37}$ After 1987, religion-state relations in Taiwan experienced fundamental transformation as a result of democratization. Various religious groups are no longer subject to the guidance of Chinese nationalism nor the strong state. Due to their significant influence in increasingly competitive democratic elections, they have developed a checks-and-balances relationship with the democratic state. Inter-religion relations in Taiwan are best characterized as tolerant, harmonious and cooperative (e.g. in ethical issues and in disaster relief works).

As for the antagonism between Chinese nationalism and Taiwanese nationalism, most Taiwanese religious groups seem to keep an equal distance from both so as not to offend either the Chinese or Taiwanese nationalists. On the one hand, they eagerly explore the astronomical religious market in China and do not want to blaspheme Chinese patriotism with Taiwanese nationalism. On the other hand, Taiwanese nationalism has yet, if ever, to develop into a solid state religion. Except for the PCT, which constitutes only two percent of the Taiwanese population, no other major religious groups in Taiwan publicly endorse Taiwanese nationalism. It is more like the New Age movement in Western societies: it has many audiences but few believers.

In Hong Kong, religion-state relations have taken yet another developmental path, different from both China and Taiwan. The British colonial government fully respected religious freedom of all religions and did not establish any state religion in Hong Kong from 1898 to 1997. Although many Chinese religious groups fled to Hong Kong after 1949 and enriched Hong 
Kong's religious market, the principle of two-way separation of state and religion was maintained. The Anglican Church was treated as equal to other Christian denominations as well as other Chinese religions. It was an extension of the economic laissez-faire principle of the British government to religious affairs. Religion's participation in public policies was rare and limited to educational and charity projects..$^{8}$

The British and the Chinese governments began negotiation on the handover of sovereignty in 1979. China's supreme leader, Deng Xiaoping, laid down the principle of 'one country, two systems' (yiguo liangzhi一國兩制) in 1984 and promised that existing political, social, and economic systems in Hong Kong would not be altered in the next fifty years. Most religious groups in Hong Kong took Deng's promise on face value and welcomed the handover of sovereignty. After all, they thought the CCP state would be just another colonial master to live with. The Protestant and Catholic community, which together constituted about seven percent of the Hong Kong people, had a brief discussion about whether to support or oppose the handover of sovereignty, or whether Hong Kong independence was an option to be placed on the negotiation table. A consensus was soon reached to support the handover of sovereignty, because the other two options were simply unrealistic.

However, many of the Protestant and Catholic leaders still had a vivid memory of the persecution of Chinese Christians during the Great Leap Forward and the Cultural Revolution. The massacre of students in 1989 only heightened their concern for religious freedom. At the same time, Taiwan lifted martial law in 1987 along with any restrictions on religious freedom. The guarantee for religious freedom, Hong Kong Christian leaders thought, would be better provided by a democratic government in Hong Kong rather than by the promise of the diseased Chinese leader Deng Xiaoping. Therefore, an annual political ritual is established on 1 July every year; while the Hong Kong government holds a celebration ceremony at the Chief Executive Office in memory of the Chinese promise, the Christians lead a massive pro-democracy demonstration marching toward the Chief Executive Office in fear of a broken promise anytime soon.

Furthermore, influenced by the political theology of Social Gospel, Hong Kong Christian leaders began to promote a 'public theology' (gonggong shenxue 公共神學) which, they frequently commented on, was based on political, social, and economic policies, such as human rights, democratic 
governance, gender equality, income equality, and immigrant welfare. ${ }^{39}$ They also expanded their proselytism from Hong Kong to China via the convenient access across the border, because they soon realized that their religious freedom would ultimately depend not on Hong Kong's democratization alone, which was always fragile, but on the growth of the Christian population in China. That is why Christian theological seminaries in Hong Kong generously offer fellowships and scholarships to Chinese Christians and actively provide training lessons for both three-self churches and family churches in China.

The Chinese government is aware of the political and religious activities of Hong Kong Christians in both Hong Kong and China and is not likely to tolerate them forever under the iron canopy of Chinese patriotism. Particularly, the Umbrella Movement in 2015 probably stepped on the last nerve of the Chinese government. In addition to the regular democratic slogans, some leaders of the Umbrella Movement made contact with social activists and DPP politicians in Taiwan, and some even proposed Hong Kong independence in order to speed up democratization in Hong Kong as the opposition movement did in Taiwan in the 1980s. And many of the leaders of the Umbrella Movement are Christian pastors and elders. It is not a surprise that since 2015 the Chinese government has tightened its control over Christians in Hong Kong and Guangdong Province, which shares the border with Hong Kong.

The above narrative describes the evolution of religion-state relations in China, Taiwan, and Hong Kong. How will they evolve in the near future? What are the implications for religious freedom, domestic political development and regional relations? The next section tries to answer these questions from the perspective of five issues (signs) of religious nationalism being developed in these Chinese societies: state religion, separation of state and religion, religious autonomy, traditional religion as superstition, and applicability of democracy to Chinese societies. Although interrelated, these issues consist of idiosyncrasies that deserve separate treatments.

\section{Signs of new religious nationalism in Chinese societies}

\section{The construction of state religion}

By 2015, the Chinese government had almost completed the construction of a full-fledged state religion, called 'Chinese patriotism'. The god of this state religion is 'China' (zhongguo 中國; or Chinese state). Its aliases include 
Han, Dragon or the Yellow Emperor. It has a Trinitarian political theology: China is socialism, socialism is the CCP rule, and the CCP rule is China. ${ }^{40}$ The great prophets of this state religion include Marx, Lenin, Mao Zedong, Deng Xiaoping, and former and current general secretaries of the CCP. Usually, the incumbent general secretary is the greatest prophet because it is he who interprets and reinterprets what earlier prophets have said. Their writings and speeches constitute the holy scripture to be studied and memorized by all CCP members throughout the year. All CCP members, schoolteachers, and religious leaders serve as political priests to proselytize the holy scripture to all Chinese people. Its religious holidays include 30 May, 1 July, 7 July, 1 August, 3 September, 18 September, and 1 October to pay tribute to the martyrs of Chinese patriotism. These 'patriotic education bases' of museums and memorial halls in major cities are holy places where these national holidays are held and local school pupils and government officials are required to visit them regularly. The devils and arch enemies of Chinese patriotism are Japan, the United States, national separatists (in Tibet, Xinjiang, Taiwan, and Hong Kong), and democracy activists, who blaspheme or rebel against Chinese patriotism. The People's Liberation Army is given, through rituals like the military parade on 3 September 2015, a special religious status of guardian angel for the protection of China and the holy war against domestic and foreign devils. ${ }^{41}$

$\mathrm{Xi}$ Jinping 習近平 summarized well the religious nature of Chinese patriotism in his speech delivered to Politburo members on 30 December 2015: 'We need to raise the patriotic feeling and consciousness of the people through memorial activities of major historical events, patriotic education bases, Chinese traditional holidays, and national funerals and rituals'. ${ }^{42}$ The same thesis was elaborated in his speech to the National Religious Conference held on 22-23 April 2016, which would serve as the concrete guideline for future Chinese religious policies. ${ }^{43}$

The Chinese communist state's paradoxical attitude toward religion probably exposes the fundamental differences between atheist patriotism and

40 One of the major 'hymns' promoted by the CCP is 'No CCP, No New China'. Chinese Communist Party News, http://cpc.people.com.cn/BIG5/64156/64157/4544006.html, accessed 9 March 2016.

41 I owe the last point to Petra Andelova of the Metropolitan University at Prague for her helpful comment.

42 Chinese Communist Party News, http://cpc.people.com.cn/n1/2015/1231/c64094-27997763. html, accessed 9 March 2016.

43 'Xi Jinping's Important Speech at the National Religious Conference'. http://www.sara.gov. cn/xwzx/tplb/333676.htm, accessed 25 April 2016. 
nationalist religion, as well as the limits of political mobilization of atheist patriotism. According to the neurotheology discussed in the second section of this chapter, it is the belief and emotion associated with supernatural powers that effectively inspires believers to take altruist behaviors like patriotism. But atheist patriotism relies much more on non-theist emotion and rationality and too little on the supernatural powers of religious circuits in the brain. Hence, the political legitimacy of an atheist state is constantly under challenge when it fails to deliver economic performance or when it encroaches upon the autonomy of major religions.

However, one should not push the above argument too far and suggest that Chinese religious groups (Christians in particular) may follow their counterparts in Western societies to become significant political forces of democratization in the near future, as the modernity approach might imply. ${ }^{44}$ The major differences lie in the Trinitarian nature of the Chinese state: the unity of the Leninist state, communism, and patriotism. This 'perfect dictatorship', as Stein Ringen calls it, is a Leviathan strengthened by its quintessential religious patriotism which permits only complementary political influence but strictly and effectively prohibits political challenge from religious groups. ${ }^{45}$

By contrast, Taiwanese nationalism has not yet developed into a fullfledged state religion. It has a big curious audience but few devoted believers. Although about sixty percent of the Taiwanese identify themselves as distinctive from the Chinese, ${ }^{46}$ 'Taiwan' is only a vague object of identification and has not acquired a holy status as a god. Paul Katz describes it as only one (and probably not the strongest) of the various identities of Taiwanese people. ${ }^{47}$ After all, the official name of the Taiwanese state is still the Republic of China, not the Republic of Taiwan. Who are the great prophets of this ‘state religion’? A list of potential prophets may include Lin Xiantang 林獻堂, Jiang Weishui 蔣渭水, Li Denghui (popularly dubbed the 'Moses of Taiwanese Exodus'), and Chen Shuibian (the self-proclaimed

44 In retrospect, Carsten T. Vala's optimistic assessment of the Protestant Shouwang Church to challenge the Chinese state has turned out to be the proverbial exception that only proves the rule. The Church has failed to conclude a business contract to buy a meeting place, and half of its believers have left the Church since an open confrontation with the state broke out about ten years ago; see Vala (2012).

45 Ringen (2016).

46 Election Study Center National Chengchi University. The Distribution Trends of Taiwanese/ Chinese Identity of Taiwanese People (June 1992-October 2015). http://esc.nccu.edu.tw/course/ news.php?Sn=166, accessed 6 April 2016.

47 Katz and Rubinstein (2003). 
'son of Taiwan'). But there is no general consensus about this list, not to mention that Chen Shuibian has been serving a jail term for corruption. The DPP, the Taiwan Solidarity Union, and the newly formed New Power Party may qualify as its political priests. But the DPP is losing its zeal to pursue Taiwan independence because of the fear of invasion by China. There is a national holiday on 10 October, but it belongs to the Republic of China. The memorial day of Taiwan's retrocession to China on 25 October is not viewed as an appropriate day for Taiwanese nationalism. The national holiday of 28 February, in memory of the massacre by the KMT military, is probably the only religious holiday of Taiwanese nationalism, and the 228 Memorial Hall may be its only political temple. However, it is a private organization sparsely visited by domestic and foreign tourists. Taiwanese nationalism used to treat first-generation mainlanders as devils, and second-generation as devil's children, both of whom were strong believers in Chinese nationalism. Since most of the first-generation mainlanders have passed their average life expectancy and many second-generation mainlanders have Taiwanese spouses, Chinese patriotism and the CCP have become the greatest devils. Chinese married to Taiwanese, as well as the one million Taiwanese living in China since 1987 , are seen as untrustworthy. However, most Taiwanese do not support such a fundamentalist version of Taiwanese nationalism, which violates universal human rights - the gods of Taiwan's rising civil religion.

Probably, one can say that a civil religion, not a Taiwanese religion, is in the early stages of consolidation in multi-ethnic and multi-religion Taiwan, which bestows godly status to universal human rights and democracy rather than Taiwanese nationalism or Chinese patriotism. Theories of democracy and experiences of Western democracies constitute the political theologies of the civil religion. In the past thirty years, this civil religion has been tenaciously promoted by intellectuals, civic groups, families, education system, mass media, students, political parties, the state, as well as religious leaders. They freely commemorate these democratic gods on national holidays, at regular elections, in schools, and in the streets (like the Sunflower Movement in 2014, which almost decimated the KMT in the subsequent elections because of violating a democratic procedure in the legislature).$^{48}$ Major religious groups have started to incorporate democratic values into their theologies, and democratic institutions into their organizational structures. For instance, all the four largest Buddhist

48 'Sunflower Movement', The Diplomat, http://thediplomat.com/tag/sunflower-movement/, accessed 7 April 2016. 
organizations in Taiwan adopt Humanistic Buddhism (renjian fojiao 人間 佛教) and are developing international lay-believer organizations. Most Protestant churches are governed by boards of directors who are elected by the congregation. Lay believers are given more decision-making powers, while clergy are made accountable for their professional performance. Even the supreme god of Jade Emperor (Yuhuang dadi玉皇大帝) of folk religions is being reinterpreted as a rotating position to be elected by common gods.

The civil religion has become the most popular state religion after three turnovers of ruling parties in 2000, 2008, and 2016. Its guardian archangel is the United States;Japan may soon become another one in the aftermath of it having expanded its national security zone to cover Taiwan in September 2015. The devils threatening the growth of this civil religion include the CCP and domestic human-rights abusers of the past and present.

It appears that Taiwan's civil religion is more powerful and resilient than Chinese patriotism or Taiwanese nationalism. However, this optimism needs to be checked by four caveats. First, it is a new religion, only thirty years old. It takes generations for a new religion to consolidate and establish itself. Secondly, with growing human and material resources, Chinese patriotism and Taiwanese nationalism are competing with Taiwanese civil religion in the political/religious markets. Thirdly, major religious groups in Taiwan are still in the early stages of adapting to democratic values and behaviors. Finally, like atheist Chinese patriotism, which relies too much on secular emotion and rationality, a civil religion without strong support from major religious groups may quickly reach the limits of political mobilization and face political challenges to its legitimacy whenever it fails to deliver economic performance or whenever it encroaches upon religious autonomy.

In Hong Kong, despite the emerging whispers of Hong Kong independence, there is little trace of a state religion of any kind. Joseph Y.S. Cheng points out that (state) Confucianism might have contributed to Hong Kong's political stability and economic development before 1997. Even if it did, it no longer exerts influence after $1997 .{ }^{49}$ In its place, there is an embryonic civil religion, modeled after its Taiwanese counterpart, promulgated by intellectuals, mass media, students, democratic parties, and the minority Christian community. Mariske Westendorp's chapter in this volume further demonstrates that some Buddhists have also embraced this public theology and support the democracy movement. Its political theology consists of Western democratic theory and Christian 'public theology' which has its roots in American Christian fundamentalism of the 1980s. This civil 
religion annually celebrates its holidays on 4 June (in memory of the 4 June massacre of Chinese students in 1989) and 1 July (to protest the handover of sovereignty from Great Britain to China without a democracy being installed in Hong Kong). It conducts its religious activities in universities, streets, churches, and at the June Fourth Museum. The devils are the CCP and Hong Kong's pro-China political and business leaders. However, this civil religion is not shared by most religious groups in Hong Kong, not even by the majority of the Christian community.

It is the god of Chinese patriotism who looms large over Hong Kong and the civil religion is its arch nemeses. Since 1997, the Chinese government has gradually taken over Hong Kong's mass media, intimidated intellectuals, and restrained the expansion of democratic parties. During the days when the Umbrella movement was at its peak in 2015, Hong Kong democrats were nervous about whether the Chinese military and the armed police, which are the guardian angels of Chinese patriotism, would intervene..$^{50} \mathrm{In}$ March 2016, the June Fourth Museum announced that it would close for business on 4 June due to constant harassment by the Hong Kong government. ${ }^{51} \mathrm{An}$ escalated blow to Hong Kong's civil religion came in November 2016 when the Executive Committee of the People's Congress in Beijing delivered a constitutional opinion to disqualify two newly-elected councilors of the Hong Kong Legislative Council due to their pro-Hong-Kong-independence statements at the inauguration ceremony. Without political prophets, priests, and temples, Hong Kong's civil religion is not likely to have many believers in the near future.

\section{Separation of state and religion}

In China, the one-way separation of the state and religion of the Republican era is totally discarded. All other religions are parts of the state and serve the state religion of Chinese patriotism. Accordingly, all other religions should demonstrate their loyalty by incorporating Chinese patriotism into their respective theologies and by joining the national religious associations created by the state. Under the guidance of the State Administration for Religious Affairs (SARA), the goal of patriotic education in theological seminaries is to 'establish an army of clergy who have passion for the state, accept the guidance of the Party and the government, insist on the socialist 
way, and are able to communicate with the people'.$^{2}$ Following a master textbook of religious education of Chinese patriotism, SARA has cooperated with national religious associations, theological seminaries, and religious scholars of the five official religions to publish a series of religious textbooks of patriotism. ${ }^{53}$ Together, they would consolidate the hegemony of Chinese patriotism over every other religion in China. The table of contents of the master textbook, Textbook of Patriotism (Aiguo Zhuyi Jiaocheng 愛國主義 教程), spells out clearly the Trinitarian theology of Chinese patriotism to be incorporated into each religious textbook. Chapter One explains why Chinese patriotism urgently needs to be promoted in the current environment. Chapters Two to Four reimage the history of 'China' and how important the CCP was to the state-building of China. Chapter Five explains the constitutional foundation of Chinese patriotism while Chapters Six and Seven elaborate the reasons why all religious groups need to support the two personas of Chinese patriotism (socialism and the CCP rule). Chapters Eight and Nine urge the readers to support the national unity and sovereignty of the third persona, i.e. the god of China.

Nevertheless, there seems to be some resistance from other religious textbooks to accept everything said in the master textbook. Absent from all other religious textbooks is the role of the CCP in each religion's history and theology. Nor is socialism an important subject in these textbooks. The only persona of the Trinitarian Chinese patriotism discussed in great length in other religious textbooks is China, not socialism, not the CCP rule. All other religious groups claim to have made great contributions to the establishment and consolidation of the Chinese state, and commit to do so continuously. ${ }^{54}$ This persistent religious autonomy and political concession is well analyzed by Tsai Yenzen's chapter on Chinese Christianity and by Hsieh Shuwei's chapter on Chinese Daoism in this volume.

The administrative subordination of religions to the CCP state is clear from its chain of commands and controls. Each religious group has to join the state-sponsored local religious association; only one association, per religion, exists at a particular administrative level. A local religious

52 SARA (2005, p.3); Kuo (2011, pp. 1042-1064).

53 Chinese Patriotic Catholic Association and Bishops Conference of Catholic Church in China (2002); State Administration for Religious Affairs (2005); National Committee of Three-Self Patriotic Movement of the Protestant Churches in China and China Christian Council (2006); Islamic Association of China (2006). Two more patriotic textbooks of Chinese Buddhism and Tibetan Buddhism are scheduled for publication.

54 More arguments of civil religions are presented at the Center of Religious Study of State Administration for Religious Affairs of P.R.C. (2010). 
association is a mandatory member of a higher-level religious association. So on and so forth, until they all belong to the national religious association. SARA has set up four departments to supervise Buddhism and Daoism (First Department), Protestantism and Catholicism (Second Department), Islam (Third Department), and other religions as well as theological seminaries (Fourth Department). ${ }^{55}$ SARA also has branch offices at each administrative level, although not necessarily at the town level due to shortage of personnel. Parallel to the SARA administrative system is the party's United Fronts administrative system, which supervises both SARA's work and religious groups. Appointments of clergy and theologians in religious groups need prior approval from SARA. ${ }^{6}$

In Taiwan, the one-way separation of state and religion has been gradually replaced by the American version of checks and balances between state and religion. ${ }^{57}$ Even during the martial law period, most religious groups maintained high autonomy in theological and management matters. The KMT party-state kept only the power for appointment of the leadership of the National Buddhist Association and the National Daoist Association. After 1987 , the state has confined itself to maintaining contacts with religious groups on public policies applicable to all social organizations, such as taxation, land use, building safety codes, financial fraud, and sexual harassment. Gone are the state's interference in personnel and management of religious groups, nor does the state adjudicate theological disputes among different religious denominations. The state regularly provides small-scale subsidies to promote religious activities without discrimination. At the other end of religion-state relations, not only do Taiwan's religious groups openly support different party candidates in elections, they also cooperate to organize demonstrations and lobby groups on ethical policies such as abortion, prostitution, gambling, divorce, and homosexual marriage.

In Hong Kong, due to its colonial heritage, the state and religion are largely separated in the sense that the state and religion interfere with each other's business as little as possible. The exception is the Christian community, which regards its divine calling to intervene in public policies and to protest restraints on religious freedom by the Hong Kong government as well as the Chinese state. After the Umbrella Movement, the Chinese government started imposing restrictions on some Hong Kong theologians

55 State Administration for Religious Affairs of P.R.C., http://www.sara.gov.cn/index.htm, accessed 24 March 2016.

56 Chan and Carlson (2005).

57 Kuo (2013, pp. 1-38). 
who provided training courses to Chinese Christians in both China and Hong Kong. But no clear restriction by the Hong Kong government on religious freedom in Hong Kong has been reported..$^{8}$

\section{The conflict between state sovereignty and religious autonomy}

This controversy is mainly associated with the Chinese Catholic community but is intertwined with religious policies for Islam and Tibetan Buddhism. The Vatican has insisted on its religious autonomy and the right to appoint bishops in all Catholic communities around the world. But the Chinese government has insisted that this would violate the state sovereignty of China. The Chinese government continues to appoint Chinese bishops with or without the Pope's approval. This controversy is more complex than a semantic debate about whether the Vatican is referring to religious 'autonomy' (zizhuquan 自主權) while China has invented a new term called 'religious sovereignty' (zongjiao zhuquan 宗教主權) and deems the two incompatible. There is no such term as 'religious sovereignty' in political science textbooks or in international laws. But this does not prevent the CCP state from injecting nationalism into Chinese religions. In fact, the Chinese state is reluctant to seek a compromise with the Vatican on this issue for three possible reasons associated with Chinese patriotism. ${ }^{59}$ First, during the civil war from 1945 to 1949, the Vatican publicly sided with the KMT government and moved its embassy to Taiwan afterwards. The Vatican is still one of the two-dozen states that recognize Taiwan as an independent state. Second, the Vatican is not only the headquarters of the global Catholic community but also a sovereign state recognized by most states in the world. How can a foreign state have the right to appoint religious clergy in China? Chinese nationalists ask. Thirdly, due to the national trauma of imperialist invasion, the CCP government has insisted that all Chinese religions should follow the three-self principles of self-finance, self-management, and self-proselytizing (ziyang zizhi zichuan 自養, 自治, 自傳), and not to receive financial help or managerial direction from foreign religious groups. Over the past sixty years, this policy has helped to establish a vast group of Chinese bishops and their followers who have vested interests in maintaining the status quo to counter those who have maintained underground churches accepting the Vatican's authority. Finally, the Polish revolution in 1989 is dubbed by the

$5^{8}$ US State Department. Religious Freedom Report: China (Includes Tibet, Hong Kong, and Macau), annual reports. Accessed 6 April 2016.

59 For a more nuanced critical view of China-Vatican relations, see Leung and Wang (2016). 
CCP leadership as an 'unholy alliance' between the Polish Catholic Church and the American Central Intelligence Agency. Beijing has no intention to encourage the Chinese Catholics to follow the Polish exemplar.

Since 2000, Catholic experts in Beijing have frequently mentioned an incoming establishment of diplomatic relations between China and the Vatican because the two sides had reached a consensus over the appointment of bishops. That is, the Chinese government would propose a list of bishop candidates and the Pope would pick only from this list, the person whom he deemed able to please God. Then, the Chinese government and the Vatican would simultaneously announce the appointment to save the face of both governments. The Chinese government also wanted the Vatican's embassy in Taiwan to move to Beijing immediately. If that should happen, it would constitute a watershed of religion-state relations in China, and not just a breakthrough in Beijing-Vatican diplomatic relations. But is Beijing ready to concede on the definition of religious sovereignty? Will Beijing apply the new principle to leadership successions in other Chinese religions? Will the vested interests of the Chinese Catholic clergy not impede this arrangement? This controversy about religious sovereignty is also applicable and linked to Tibet over the appointment of the Dalai Lama, although it is only a smaller part of a more heretic problem of Tibetan independence. ${ }^{60}$

In the Taiwanese Catholic community, which constitutes less than one percent of the population, religious autonomy has never been an issue since 1949. Most of the first-generation Taiwanese Catholics came from mainland China after 1949 and demonstrated their consistent loyalty to the KMT state. The state fully respected the religious autonomy of the Catholic Church, through which Taiwan could still have a voice, albeit small, in the world community. Even if China establishes a diplomatic relationship with the Vatican, it is not likely that the Catholic Church in Taiwan would make a loud political noise about it.

In the post-1997 era, Hong Kong's Catholic community has been in close cooperation with the Protestant community to implement its Social Gospel agenda. During his tenure as Hong Kong's bishop from 2002 to 2009, Bishop Joseph Zen Ze-Kiun 陳日君 assumed a critical role in transforming the social and political roles of Hong Kong Catholics. He frequently commented on religious freedom, social justice, and democratization in Hong Kong as well as human rights in China. The appointment of Bishop Zen seemed to be a unilateral action by the Vatican, amidst a low point of diplomatic relations between China and the Vatican. It is not clear whether Bishop 
Zen's successor Tang Han 湯漢 was jointly appointed by China and the Vatican or not. The fact that Bishop Tang has kept a low political profile while Cardinal Zen continues active engagement in social and political issues would further make China think twice before making concessions on religious 'sovereignty'. The last thing Beijing wants to see under the iron canopy of Chinese patriotism is a Polish-style 'unholy alliance' replicated in Hong Kong.

\section{The 'superstition' of Chinese traditional religions}

The CCP government continues to follow policies hostile to folk religions of the Republican era. The fact that the Boxer Rebellion caused the national humiliation during the Eight-States Alliance War has become an institutional memory of the CCP: folk religion is not a politically reliable religion, it is a superstition, and the CCP has no intention to see the reincarnation of the White Lotus in communist China. The CCP has developed two strategies to control folk religions since 1949. One strategy is to deny the existence of any folk religion. Previous folk religions were either merged into Daoism or Buddhism, or forcefully eliminated. Folk religion is not among the five officially recognized religions. The other strategy is to explain the controversy away. The term 'folk religion' is replaced by 'folk custom and culture' (mingsu wenhua 民俗文化). Since 1979, economic liberalization has resulted in the resurgence of folk-religion activities in the countryside, such as religious rituals held for the opening of businesses, weddings, funerals, and on traditional religious holidays. Most local officials and party cadres have failed to stop this wave of resurgence in intensity and in quantity, but fear that the Beijing government may reprimand them for not suppressing these activities. Therefore, they have invented this new hermeneutics of 'folk custom and culture'. In fact, even the Boxer Rebellion is given a new nationalist interpretation. 'They demonstrated the extraordinary courage and sense of justice of the Chinese people even in front of the enemy's butcher's knife'. ${ }^{61}$ Finally, folk religions now belong, de facto, to the jurisdiction of the Fourth Department of SARA. And some provinces (e.g. Hunan) have adopted experimental regulations on folk religions, making them semi-official. But Falungong remains solidly on the blacklist of evil cults.

In Taiwan, the KMT party-state also maintained the anti-folk-religion policies of the Republican era. Similar to the CCP, the party-state put pressure on folk religions to join either the Daoist Association or the Buddhist 
Association. Otherwise, they would be subject to harassment by local police, tax authorities, and the fire department. However, due to the deep-rooted popularity of folk religion among local elites, the pressure was not high and implementation of the hostile policies was lax, as in traditional dynasties. Furthermore, similar to the CCP's second strategy toward folk religion, local officials of the KMT state called these folk-religion activities as 'folk custom and culture'. Even after 1987 when religious freedom was fully guaranteed, some government officials preferred to keep the term 'folk custom and culture' to avoid criticism for violating the state's neutrality when they provided subsidies to these activities. For instance, the annual parade of goddess Mazu is very often called a 'folk custom and culture'. Other than this, the Taiwanese state and society have largely abandoned the Republican era's treatment of folk religion as superstition and accept it as one of regular religions protected by the constitution. Furthermore, different Mazu temples have actively played important political roles, both in the Taiwan independence movement and in the China unification movement, as Chang Hsun's chapter in this volume aptly analyzes.

Another example is Yiguandao, which is a syncretistic folk religion combining Confucianism, Daoism, and Buddhism. It was declared an 'evil cult' by both the CCP government from 1949 to the present and by the KMT party-state from 1949 to 1987 . Yiguandao had an ambiguous relationship with the White Lotus in terms of its major deities, rituals, and catechism. During WW II, it proselytized in east and northeast China occupied by Japanese forces. Therefore, both the CCP and the KMT declared it an 'evil cult'. After WW II, it proselytized to KMT officials in order to exonerate its 'political crimes' during the war. But it bet on the wrong political side again; the CCP won the civil war, and major leaders of Yiguandao fled to Hong Kong or Taiwan. The KMT government did not grant Yiguandao the status of a legal religion until after the lifting of martial law, while the CCP has not officially removed it from the blacklist of evil cults.

In Hong Kong, the British colonial government did not bother Chinese folk religions. Neither has the Hong Kong government done so since 1997. Most folk religions are not involved in the debate over democratization, unification, Hong Kong independence, human rights, or other social issues. They also keep a safe distance from the activities of Falungong.

\section{The applicability of Western democracy in the Chinese context}

In light of the above analysis, the CCP government is not likely to reverse its staunch objection to Western democracy applied to China's religion-state 
relations. Western democracy severely challenges, if not blasphemes, every sacred component of Trinitarian Chinese patriotism. In the eyes of China's political prophets and priests, democracy would diminish the sacred status of the Trinitarian god of 'China' by promoting multiple gods of other religions; democracy would discredit socialism; and democracy, the worst evil of all, would abolish the CCP rule. Although during the Hu Jintao regime from 2002 to 2012, the CCP government encouraged the 'deepening of democratization' to allow greater religious freedom, judicial justice, and civic participation in public policies, it was promoted under the iron canopy of Chinese patriotism. ${ }^{62}$ Even worse, in the past five years of the Xi Jinping regime, a rearguard phenomenon orchestrated by the 'fundamentalists' of Chinese patriotism seem to have replaced the liberal Chinese patriotism. There has been little talk about the 'deepening of democratization' in the mass media or in the academic community. In its place is the 'seven no-talks' (qibujiang 七不講; CCP Document \#9 May 2013) forbidding university professors and the mass media to discuss subjects related to universal values, freedom of press, civil society, civic rights, historical errors committed by the CCP, privileged capitalist class, and judicial independence. ${ }^{63}$

In Taiwan, democracy is the new game and the 'only game in town' ${ }^{64}$ Although religious freedom was relatively well-protected during the martial law period, it is much better protected by the democratic institutions of independent courts, elections, energetic civic organizations, schools, autonomous mess media, and subsidiaries of international NGOs in Taiwan. After three peaceful turnovers of government, Taiwan's democracy has been consolidated considerably and provides for a healthy checks-andbalances relationship between the state and religion. However, the phantom of Chinese patriotism constantly scrutinizes Taiwan's democracy from the other side of the Taiwan Strait. As long as Taiwan's democracy does not officially declare independence, Chinese patriotism is not in a hurry to start a holy war against it.

By contrast, it is a very different story in the case of Hong Kong's religionstate relations. After all, China exercises full sovereignty over Hong Kong. Democracy in Hong Kong is still a dream to be realized, if ever, because it directly challenges the 'China Dream'. Although the Chinese government

\footnotetext{
62 Kuo (2014).

63 BBC China. Xi Jinping New Deal: Sixteen requirements after seven no-talks. http://www. bbc.com/zhongwen/trad/china/2013/05/130528_china_thought_control_youth, accessed 6 April 2016.

64 Linz and Stepan (1996, pp. 5-14) argue that only when strategic elites unanimously regard democracy as 'the only game in town' does this new democracy become a consolidated democracy.
} 
has announced that popular elections of the legislature would be held in 2020 and direct elections of the chief executive officer would be held in 2017, new constraints have been imposed on these 'democratic' elections. It is to the credit of democratic movements (particularly the Christian community) that a civil religion is on the political horizon. But the democratic movements in Hong Kong since 1997 seem to justify Beijing's concern that democratic movements are getting out of hand and are corrupting the minds of believers in Chinese patriotism. In the mind of Chinese political prophets and priests, is it not much easier to convert the seven-million Hong Kong people to Chinese patriotism, than to convert the 1.3 billion Chinese people to Hong Kong's civil religion?

\section{Conclusion and chapter outlines}

What is new about religious nationalism in Chinese societies, and what are the implications for their internal stability and external relations? Theoretically speaking, this chapter contributes to the study of religious nationalism through the revisionist approach strengthened by neurotheology and new institutionalism. It assumes that religious thinking is part of human nature and is an integral part of empirical analysis as well as of the normative prescription for religion-state institutional relations.

In China, aided by the omnipresent and omnipotent Leninist state, the state religion of Chinese patriotism is close to becoming the hegemonic religion of all religions, not only requiring all other religions to be submissive to it but also to integrate Chinese patriotism into their theologies and organizational structures. Thus, the Leninist state's totalitarian control over religion has reached a historically high point never seen in traditional and modern China, or elsewhere in the world. However, the religious textbooks of patriotism also reveal some new resistance to this omnipotent and omnipresent state religion. While expressing support for China's glory and unification, most religions are reluctant to integrate socialism and the CCP rule in their theologies and organizational structures. Quite a few arguments related to civil religion are competing with Chinese patriotism in these textbooks. It remains to be seen whether Chinese patriotism will tolerate (and if yes, to what extent) the emergence of civil religion in the society. But the prospects for resolving China's territorial disputes with its neighbors do not look bright; after all, these territories have been sanctified by Chinese patriotism as the 'holy national lands' (shensheng guotu 神聖 國土). 
In Taiwan, the rise of Taiwanese nationalism since the 1970s reached its zenith during the DPP regime (2000 to 2008), lost its momentum during the KMT regime (2008 to 2016) and came back strongly after the DPP took over the government again in 2016. Chinese nationalism filled the minds of most Taiwanese from 1945 to 1987 , and it was rejuvenated during the KMT regime from 2008 to 2016. KMT lost power in 2016 but it may rise from near extinction with the help of the Chinese state, which worries about the independence-leaning tendency of the DDP regime. Squeezed between Taiwanese nationalism and Chinese nationalism, a young civil religion is shared by many religions which gradually adapt to political democratization by incorporating democracy in their theologies and organizational structures, and exercise a healthy checks-and-balances relationship with the democratic state. It may take generations for the Taiwanese civil religion to consolidate their religious and political support, barring a unification war in the Taiwan Strait.

In Hong Kong, what is new about religious nationalism is that it includes an embryotic civil religion and Hong Kong nationalism. However, these two religious nationalisms are not widely nor deeply shared by Hong Kong's other religious groups, which tilt more toward Chinese patriotism. Furthermore, given the special political relationships between Hong Kong and China, political theologies of religious nationalisms of the two clash head-on with Chinese patriotism. Lacking a geographical and political buffer zone like its Taiwanese counterparts, the Chinese state and the Hong Kong government are not likely to respond kindly to these political 'heresies'. ${ }^{65}$

Finally, for the general theoretical and normative question about compatibility between religion and democracy, the Taiwanese model probably provides a moral and practical alternative to existing theories of religionstate relations, such as the state's dominance over religion (the modernity approach), religious fundamentalism, and the strict separation of state and religion. ${ }^{66}$ In particular, it may help to gradually transform Chinese patriotism into a civil religion with Chinese characteristics for the benefit of Chinese people and neighboring countries.

The fourteen chapters of this book are divided into three parts. After an introductory chapter, Part I analyzes the origins of Chinese religion-state

65 In an immediate response to the announcement on the internet about the establishment of the Hong Kong Nationalist Party, the China Liaison Office in Hong Kong sternly warned that it would not tolerate its existence. United Daily News, 1 April 2016.

66 Juergensmeyer (1993, chapters 7 and 8) proposed legal suggestions for the coexistence of religious nationalism and democracy but could not find workable cases to substantiate his proposal. 
relations before 1949. Part II discusses the contemporary religion-state relations in China. Part III explores contemporary religion-state relations in Taiwan and Hong Kong.

Chapter 1 (Religion, State, and Religious Nationalism in Chinese Societies) compares the modernity approach and the revisionist approach of religion-state relations in China. Building on the revisionist approach but adding theories of neurotheology and institutionalism, it compares three models of religious nationalism in China, Taiwan, and Hong Kong. Five different dimensions of this religious nationalism are further elaborated in order to lay down the common theoretical and empirical foundations of all the chapters in this book.

Part I (Chinese Religion and Nationalism before 1949) explores the origin of religion-nationalism relations in the late nineteenth century to the early twentieth century when Western nationalism was introduced to China. Chapter 2 (Idea of Chineseness and Ethnic Thought of Wang Fuzhi) studies the first Chinese theory of nationalism by Wang Fuzhi (1619-1692). Wang employed a Daoist concept of 'ether' ( $q i$ 氣) to define a Chinese nationalism that goes beyond traditional loyalty to dynastic rulers. His definition of Chinese nationalism inspired many nationalist intellectuals around 1900. Chapter 3 (Missionizing, Civilizing, and Nationizing: Linked Concepts of Compelled Change) makes convincing arguments that the contents of Chinese nationalism in traditional and modern China are very similar to those of Christianity in the colonial era. Both aimed to convert the inferior cultures (religions)to their superior ones. Chapter 4 (The Nation in Religion and Religion in the Nation) studies how the Chinese nation and religion construct each other by the conception of 'religious sphere' (zongjiaojie 宗教 界). However, the end result is mutual influence and resistance of the nation and religion. It helps to explain, among many Chinese cases of state-religion conflicts, why the CCP state has invented and insisted on the principle of 'religious sovereignty' in negotiating with the Vatican on the appointment of bishops in China. Chapter 5 (History and Legitimacy in Contemporary China:Towards Competing Nationalisms) studies two nationalist incidents in modern Chinese history (the destruction of the Old Summer Palace in 1860 and CCP-KMT relations in the Republican era) which the current CCP state has reinterpreted for the promotion of new nationalist programs. It demonstrates vividly that when these nationalist programs are promoted only in a rational manner without religious devotion and holiness, they easily fall into endless rational debates which ironically undermine these nationalist programs and the very legitimacy of the CCP state. Chapter 6 (Pilgrimage and Hui Muslim Identity in the Republican Era) explores how 
the Chinese Muslim developed both Chinese nationalist and cross-national identities in the Republican era through the Islamic pilgrimage ritual (hajj).

Part II (Religion and Nationalism in Contemporary China) focuses on contemporary religion-state relations in China, although traditional and Republic relations are not ignored. Chapter 7 (Religion and the Nation: Confucian and New Confucian Religious Nationalism) discusses the religious aspects of New Confucianism promoted by the contemporary CCP state. State Confucianism existed in Chinese dynasties and continues to exist in modern China in the form of 'orthopraxy' (the center of all religions) but not in the form of 'orthodoxy' (the hegemonic religion excluding all other religions). In contrast to the CCP's State Confucianism, Chapter 8 (Yiguandao under the Shadow of Nationalism) demonstrates that a religious Confucianism (Yiguandao) may be more popular and sustainable among the Chinese. But State Confucianism in both China and pre-1987 Taiwan had persecuted this religious Confucianism for its cooperation with external and internal political enemies. Chapter 9 (Daoism and Nationalism in Recent and Contemporary China) analyzes the efforts by contemporary Daoist leaders to promote Daoism in order to build a community, forge cultural self-identity, and strengthen the nation-state. It concludes that the CCP state's effort to modernize Daoism according to the Christian model has resulted in the serious reduction of complexity and dynamics of Daoism, which is the only native religion among the five official religions recognized by the state. Chapter 10 (Nationalism Matters: Among Mystics and Martyrs of Tibet) uses two case studies (Tibetan Buddhist encampments and self-immolations) to demonstrate that Tibetan Buddhists have a choice between moderate fundamentalism and militant nationalism in response to Chinese religious nationalism. Chapter 11 ('We Are Good Citizens': Tension between Protestants and the State in Contemporary China) analyzes all the major religious policies and church confessions in contemporary China. It concludes that both the CCP and house churches support Chinese nationalism but emphasize different parts of it, resulting in their antagonistic relationships in the past and in the foreseeable future.

Part III (Religion and Nationalism in Taiwan and Hong Kong) studies contemporary religion-state relations in Taiwan and Hong Kong. Chapter 12 (Religion and National Identity in Taiwan: State Formation and Moral Sensibilities) compares the Buddhist Foguanshan which subscribes to Chinese identity, and the Presbyterian Church which is an active proponent of Taiwan independence. These two cases clearly demonstrate that the boundary between the sacred and the secular is easily transgressed, and that the state and religion continuously construct each other. Chapter 13 (Multiple 
Religious and National Identities: Mazu Pilgrimages across the Taiwan Strait after 1987) analyzes a cross-strait pilgrimage from Xingang Mazu Temple (Taiwan) to Yongchun (China) which resulted in the establishment of a Taiwanese branch temple in China. It demonstrates how local politicians employ the pilgrimage for both religious and political purposes, not necessarily consistent with the nationalist programs of the central governments. Chapter 14 (Salvation and Rights in Hong Kong) compares Catholicism and Buddhism (more emphasis on the latter) as major proponents of a civil religion against the Chinese state religion of patriotism during the Umbrella Movement in 2014. However, unlike their Christian counterparts who were motivated by a common political theology, Hong Kong Buddhists were motivated by personal salvation. Therefore, this chapter not only demonstrates that the state and religion are neither dichotomous nor conflictual, such as the modernity approach assumes, but they can be coherent institutional actors as well as diffused individuals, thus, making the study of Chinese religious nationalisms even more nuanced and fascinating.

\section{Bibliography}

Anderson, Benedict. 1991. Imagined Communities: Reflections on the Origin and Spread of Nationalism, 2nd ed. London: Verso.

Asad, Talal. 2003. Formations of the Secular: Christianity, Islam, Modernity. Stanford, CA: Stanford University Press.

Ashiwa, Yoshiko, and David L. Wank, eds. 2009. Making Religion, Making the State: The Politics of Religion in Modern China. Stanford, CA: Stanford University Press.

Barrett, Justin L. 2011. Cognitive Science, Religion, and Theology: From Human Minds to Divine Minds. West Conshohocken, PA: Templeton Press.

Bellah, Robert. 1967. 'Civil Religion in America'.Journal of the American Academy of Arts and Sciences, 96 (1): 1-21.

Brubaker, Rogers. 2015. Grounds for Difference. Cambridge, MA: Harvard University Press.

Chan, Kim-Kwong, and Eric R. Carlson. 2005. Religious Freedom in China: Policy, Administration, and Regulation: A Research Handbook. Hong Kong: Hong Kong Institute for Culture, Commerce and Religion.

Chau, Adam Yuet. 2011. Religion in Contemporary China: Revitalization and Innovation. London: Routledge.

Cheng, Joseph Y.S. 2015. 'Confucian Values and Democratic Governance in Hong Kong'. In John Fuh-sheng Hsieh, ed. Confucian Culture and Democracy. Hackensack, NJ: World Scientific Publishing Co., pp. 161-196. 
Chinese Patriotic Catholic Association and Bishops Conference of Catholic Church in China 中國天主教愛國會, 中國天主教主教團 eds. 2002. Zhongguo Tianzhujiao Duli Zizhu Ziban Jiaohui JiaoyuJiaocai 中國天主教獨立自主自辦教會 教育教材 (試用本) (Chinese Catholic Textbook of Independent, Autonomous, and Self-managed Churches). Beijing: Zongjiao Wenhua Chubanshe.

Cook, Michael. 2005. A Brief History of the Human Race. New York, NY:W.W. Norton \& Company.

Crossman, Richard, ed. 1949. The God That Failed. New York, NY: Harper \& Row. Davis, James C. 2005. The Human Story: Our History, from the Stone Age to Today. New York, NY: Harper Perennial.

Dean, Kenneth. 2009. 'Further Partings of the Way: The Chinese State and Daoist Ritual Traditions in Contemporary China'. In Yoshiko Ashiwa and David L. Wank, eds. Making Religion Making the State. Stanford, CA: Stanford University Press.

Deng, Shaoguang 鄧紹光 ed. 2015. Heping Zhishilun:Cong Lixing de Baoli Zouxiang Duihua de Keneng 和平知識論: 從理性的暴力走向對話的可能 (Epistemology of Peace: From the Violence of Reason to the Possibility of Dialogue ). Hong Kong: Yinxiang Wenzi.

Diamond, Jared M. 1999. Guns, Germs, and Steel: The Fates of Human Societies. New York, NY: W.W. Norton \& Company.

Duara, Prasenjit. 2008. 'Religion and Citizenship in China and the Diaspora'. In Mayfair Mei-hui Yang, ed. Chinese Religiosities: Afflictions of Modernity and State Formation. Berkeley, CA: University of California Press, pp. 43-64.

Durkheim, Emile. 1995. The Elementary Forms of Religious Life. New York, NY: The Free Press.

Fingelkurts, Alexander A., and Andrew A. Fingelkurts. 2009. 'Is Our Brain Hardwired to Produce God, or Is Our Brain Hardwired to Perceive God? A Systematic Review on the Role of the Brain in Mediating Religious Experience'. Cognitive Process, 10: 293-326.

Gellner, Ernest. 1983. Nations and Nationalism. Ithaca, NY: Cornell University Press. Gentile, Emilio. 2001. Politics as Religion, trans. George Staunton. Princeton, NJ: Princeton University Press.

Goossaert, Vincent and David A. Palmer. 2011. The Religious Question in Modern China. Chicago, IL: University of Chicago Press.

Guo, Sujian. eds. 2006. China's Peaceful Rise in the 21st Century: Domestic and International Conditions. Surrey, UK: Ashgate Publishing.

Hardacre, Helen. 1989. Shinto and the State, 1868-1988. Princeton, NJ: Princeton University Press.

Hastings, Adrian. 1997. The Construction of Nationhood: Ethnicity, Religion and Nationalism. New York, NY: Cambridge University Press. 
Hobsbawm, E.J. 1992. Nations and Nationalism since 1780:Programme, Myth, Reality, 2nd ed. New York, NY: Cambridge University Press.

Islamic Association of China 中國伊斯蘭教協會 ed.20o6. Musilin Aiguo Zhuyi Jiaocheng 穆斯林愛國主義教程 (Muslim Textbook of Patriotism). Beijing: Zongjiao Wenhua Chubanshe.

Institute of Religious Study of State Administration for Religious Affairs of P. R. C. 國家宗教事務局宗教研究中心 ed. 2010. Zhongguo WudaZongjiao Lunhexie 中國五大宗教論和諧 (Discussion about Harmony from Five Major Religions of China). Beijing: Religious Culture Press.

Jeeves, Malcolm. 2013. Minds, Souls and Gods: A Conversation on Faith, Psychology and Neuroscience. Downers Grove, IL: InterVarsity Press.

Jiang, Pisheng, Siyan Yang, and Yuanyuan Liang, 江丕盛,楊思言,梁媛媛 eds. 2008. Zongjiao Jiazhi yu Gonggong Lingyu: Gonggong Zongjiao de Zhongxi Wenhua Duihua 宗教價值與公共領域: 公共宗教的中西文化對話 (Religious Values and Public Sphere: The Dialogue between Chinese and Western Cultures about Public Religions). Beijing: China Social Sciences Press.

Juergensmeyer, Mark. 1993. The New Cold War: Religious Nationalism Confronts the Secular State. Berkeley, CA: University of California Press.

Kant, Immanuel. 1999. Kant: Religion within the Boundaries of Mere Reason: And Other Writings. New York, NY: Cambridge University Press.

Katz, Paul, and Murray A. Rubinstein, eds. 2003. Religion and the Formation of Taiwanese Identities. New York, NY: Palgrave Macmillan.

Kuo, Cheng-tian. 2008. Religion and Democracy in Taiwan. Albany, NY: State University of New York Press.

Kuo, Cheng-tian. 2011. 'Chinese Religious Reform: The Christian Patriotic Education Campaign'. Asian Survey, 51(6): 1042-1064.

Kuo, Cheng-tian. 2013. 'State-Religion Relations in Taiwan: From Statism and Separatism to Checks and Balances'. Issues \& Studies, 49(1):1-38.

Kuo, Cheng-tian 郭承天. 2014. Guozu Shenxue de Minzhuhua: Taiwan yu Zhongguodalu 國族神學的民主化:臺灣與中國大陸 (The Democratization of National Theologies: Taiwan and Mainland China). Taipei: Chengchi University Press.

Kuo, Cheng-tian. 2016. 'In the Beginning, There Were Exegetic Mistakes of ChurchState Relations in China'. Shi Hui, 19: 175-200.

Kuo, Ya-pei. 2008. 'Redeploying Confucius: The Imperial State Dreams of the Nation, 1902-1911'. In Mayfair Mei-hui Yang, ed. Chinese Religiosities: Afflictions of Modernity and State Formation. Berkeley, CA: University of California Press, pp. $65^{-84}$.

Lagerwey, John. 2010. China: A Religious State. Hong Kong: Hong Kong University Press. 
Leung, Beatrice and Marcus J. J. Wang. 2016. 'Sino-Vatican Negotiations: Problems in sovereign right and national security'.Journal of Contemporary China, 25(99): 467-482.

Liang, Qichao 梁啟超. 1936. Yinbingshi Wenji 飲冰室文集 (Yin-bing Chamber Collected Works). Shanghai: Zhonghua Press.

Linz, Juan, and Alfred C. Stepan. 1996. Problems of Democratic Transition and Consolidation. Baltimore, MD: Johns Hopkins University Press.

Locke, John. 1685/1955. A Letter Concerning Toleration. New York, NY: The Liberal Art Press.

MacInnis, Donald E. 1989. Religion in China Today: Policy and Practice. Maryknoll, NY: Orbis.

Madsen, Richard. 2007. Democracy's Dharma:Religious Renaissance and Political Development in Taiwan. Berkeley, CA: University of California Press.

Madsen, Richard. 2010. 'The Upsurge of Religion in China'. Journal of Democracy, 21(4): 58-71.

March, James G., and Johan P. Olsen. 1979. Ambiguity and Choice in Organizations, 2nd ed. Oslo: Universitetsforlaget.

Myers, James. 1972. 'Religious Aspects of the Cult of Mao Tse-Tung'. Current Scene, 20(3): 1-11.

National Committee of Three-Self Patriotic Movement of the Protestant Churches in China and China Christian Council 中國基督教三自愛國運動委員會, 中國 基督教協會 ed. 2006.Jidujiao Aiguo ZhuyiJiaocheng 基督教愛國主義教程 (試 用本 (Christian Textbook of Patriotism). Beijing: Zongjiao Wenhua Chubanshe. Newberg, Andrew, and Mark Robert Waldman. 2009. How God Changes Your Brain: Breakthrough Findings from a Leading Neuroscientist. New York, NY: Ballantine Books.

North, Douglass C. 1990. Institutions, Institutional Change and Economic Performance. Cambridge, UK: Cambridge University Press.

Overmyer, Daniel L. 1986. Religions of China. San Francisco, CA: Harper \& Row.

Platt, Stephen R. 2007. Provincial Patriots: The Hunanese and Modern China. Cambridge, MA: Harvard University Press.

Powell, Walter W., and Paul J. DiMaggio. eds. 1991. The New Institutionalism in Organizational Analysis. Chicago, IL: University of Chicago Press.

Ramachandran, V.S., and Sandra Blakeslee. 1998. Phantoms in the Brain. New York, NY: HarperCollins Publishers.

Ringen, Stein. 2016. The Perfect Dictatorship: China in the 21st Century. Hong Kong: Hong Kong University Press.

Rubinstein, Murray A. 1991. The Protestant Community on Modern Taiwan: Mission, Seminary, and Church. Armonk, NY: M.E. Sharpe. 
State Administration for Religious Affairs (SARA) 國家宗教事務局 ed. 2005 . Aiguo ZhuyiJiaocheng 愛國主義教程(Textbook of Patriotism). Beijing: Zongjiao Wenhua Chubanshe.

Tocqueville, Alexis De. 1969. Democracy in America, ed. J.P. Mayer. Garden City, NY: Anchor Books.

US State Department. Religious Freedom Report (Taiwan), annual issues.

Vala, Carsten T. 2012. 'Protestant Christianity and Civil Society in Authoritarian China'. China Perspectives, 2012/3: 43-52.

Wang, Zhixin 王治心. 1977. Zhongguo Sixiangshi Dagang 中國思想史大綱 (Outline of the History of Chinese Thought). Taipei: Taiwan Zhonghua Press.

Yang, C.K. 1961. Religion in Chinese Society: A Study of Contemporary Social Functions of Religion and Some of Their Historical Factors. Berkeley, CA: University of California Press.

Yang, Fenggang. 2012. Religion in China: Survival and Revival under Communist Rule. New York, NY: Oxford University Press.

Yang, Mayfair Mei-hui, ed. 2008. Chinese Religiosities: Afflictions of Modernity and State Formation. Berkeley, CA: University of California Press.

Yu, Anthony C. 2005. State and Religion in China: Historical and Textual Perspectives. Chicago, IL: Open Court.

Zhao, Chongming 趙崇明. 2013. Zhanling Zhonghuan yu Jiaohui Zhengzhi 佔領 中環與教會政治 (The Occupation of Central and the Politics of Church). Hong Kong: Jidao Press.

Zuo, Jiping. 1991. 'Political Religion: The Case of the Cultural Revolution in China'. Sociological Analysis, 52(1): 99-110.

\section{About the author}

Kuo, Cheng-tian. Chair of Taiwan Studies, IIAS and Leiden University, the Netherlands; Distinguished Professor of Religious Politics, Political Science Department, National Chengchi University, Taiwan.

Email: ctkuo@nccu.edu.tw 



\section{Part I}

Chinese Religion and Nationalism before 1949 



\title{
2 The Idea of Chineseness and Ethnic Thought of Wang Fuzhi
}

\author{
Chi-shen Chang
}

\begin{abstract}
This chapter explores Wang Fuzhi's ethnic thought from new perspectives. ${ }^{1}$ First, I will analyze three connotations of Chineseness - geographical, cultural, ethnic - upheld in the history of Chinese ethnic thought. Second, Wang's major contributions to the development of Chinese ethnic thought is outlined, such as presenting new concepts concerning the nature of the Chinese and the 'barbarians', and the new ethics that regards the protection of the Chinese interest as the ultimate good and the supreme natural law. Finally, I will compare Wang's ethnocentric ideas to the idea of 'Chinese nation' advocated by Liang Qichao at the turn of the twentieth century, and examine the impact of Wang's ethnocentric works on the intellectuals in late nineteenth-century China.
\end{abstract}

Keywords: Wang Fuzhi, ethnicity, Chinese nationalism, Chineseness

\section{Levenson's thesis and the connotations of Chineseness}

Regarding the origins of Chinese nationalism, the most influential view, in terms of insight and originality, might be that proposed by Joseph Levenson. According to Levenson, Chinese nationalism was mainly the product of the crisis of Chinese culture which was, in turn, the product of the Western impact on premodern China. In his presentation of the famous 'culturalism to nationalism thesis', ${ }^{2}$ Levenson outlined the historical process of the emergence of nationalism in early twentieth-century China. He argued that Chinese nationalism originated from a change in the object of loyalty. Before the nineteenth century, the ethically legitimate object of loyalty was Chinese culture or 'human civilization' (tianxia 天下; or all-underheaven) for the cultivated elite, and the 'dynasty' (chaodai 朝代) for the

1 In this chapter, the term "ethnic thought" has two meanings: the thought on ethnicity and ethnocentric thought.

2 Townsend (1996). 
masses. Challenged by the West, Chinese culture lost its appeal of universal validity. As the Chinese intellectuals could not bear to accept a China inferior to the West, and Chinese culture could not serve as the base for regaining superiority, they turned to the Chinese 'state' (guo 國) as the new object of loyalty, and the masses were mobilized to follow. The result was the birth of Chinese nationalism. But the story did not end there. The shift from culturalism to nationalism produced an identity crisis, as the allegiance to the Chinese state could not satisfy the Chinese intellectuals' need for a cultural identity, and neither could Western culture, as it would never be regarded as their own. The spiritual schism caused by the need of abandoning the previous cultural identity on the one hand, and the sense of homelessness in a Westernized world on the other, caused the Chinese intellectuals trapped in a state of spiritual rootlessness, and formed the essence of modern Chinese intellectual history.

Despite its originality and insightfulness, Levenson's thesis has some drawbacks which have drawn a great deal of criticism. Especially its theoretical simplicity at the expense of historiographical accuracy received major criticism. Scholars have pointed out that there was a tradition in Chinese history which emphasized the ethnic distinction between 'Chinese' ( hua 華) and 'barbarians' ( $y i$ 夷). ${ }^{3}$ This distinction dated back to the South Song period (1127-1279) or even earlier, a fact which was either silenced by Levenson in his thesis, or distorted when he portrayed the late Ming thinker Wang Fuzhi and the late Qing thinker Zhang Binlin 章炳麟 (1869-1936) as culturalists. ${ }^{4}$ Schwartz, Lin, Cohen, Duara, and Townsend also pointed out the methodological prejudice, misunderstanding, or inadequacy inherent in the 'tradition-modern' and 'emotion-reason' dichotomies employed by Levenson as the analytical framework of the thesis. ${ }^{5}$

Considering the deficiency of Levenson's thesis in accounting for the emergence of Chinese nationalism, other more accurate and hence less controversial approaches might be worthwhile. I have attempted such an approach, which focuses on the connotations of the term 'China' (zhongguo 中 國) that were formed and used in Chinese history before the eighteenth century, and analyzes the change of primacy among these connotations.

3 For instance, Tillman (1978); Dikötter (1992); Duara (1995, p. 58-61); Townsend (1996, pp. 3-4, 13-14); Lodén (1996); Chang (2009b); and Yang (2014). I am indebted to Professor Hoyt Tillman for informing me about Yang's PhD dissertation in his Wang Meng Ou Lecture delivered at National Chengchi University on 2 November 2015.

4 Levenson (1968, pp. 96-97).

5 Schwartz (1972); Lin (1979, pp. 104-105); Cohen (1984, pp. 61-79); Duara (1995, pp. 89-90); Townsend (1996, pp. 1-24). 
According to a 'cultural language approach', ${ }^{6}$ there were three major connotations of the term 'China' in Chinese history, namely the geographical, the cultural, and the ethnic. ${ }^{7}$ Before the Song period, the most often used connotations were either the geographical or the cultural ones. But from the Song period on, a gradual shift took place and the ethnic connotation of China became more and more prominent in some intellectuals' use of the term. The idea that 'China' (the geographical-political China) was the China of the 'Chinese people' (zhongguoren 中國人) and should not be ruled by aliens eventually appeared from the late Yuan period on. It gathered momentum during the Ming period, but was suppressed under the Manchu reign. In the last years of the Qing period, that idea rapidly peaked due to the provocative propaganda by anti-Manchu revolutionaries. From then on, the ethnic connotation of China became the primary connotation, and the other two were assimilated into it and eventually lost the autonomy they used to enjoy in defining China and Chinese identity. This change of primacy among the three connotations of China marked the emergence of Chinese nationalism. ${ }^{8}$

The merit of this approach lies therein that it partly incorporates Levenson's insights but without his historical inaccuracies. Levenson was correct in partly identifying two connotations of Chinese identity, namely the cultural one (tianxia) and the geo-political one (guo), but he missed the ethnic one. He was therefore inclined to overemphasize the factor of culture, taking the crisis of Chinese culture as the decisive force in the shift of loyalty from culture to state. What he ignored was the importance of the ethnic connotation of China in defining Chinese identity, and it was the mobilization of this connotation that largely caused the change of the content of Chinese identity, which then led to the emergence of Chinese nationalism.

Focusing on the changes of Chinese identity reflected in the changing primacy of the connotations of China, the above approach might shed a different light on our understanding of the modern intellectual history of China, since the latter was situated in the longue durée of Chinese history viewed as a history of identity (similar to Levenson's approach) or ethnic thought. Understood in this way, modern Chinese intellectual history would no longer be viewed as a dilemma caused by the difficult transition from

6 Chang (200gb, pp. 8, 18).

7 Chang $(2015$, p. 6).

8 Regarding the change of primacy among the three connotations of China from the sixth to the seventeenth century, see Chang (2009b, pp. 227-323). 
tradition to modernity, but instead as the creative endeavor in search of new connotations of China and hence new meanings of Chinese identity. ${ }^{9}$ In contrast to Levenson's thesis, which asserted that it was the crisis of the cultural China that resulted in the shift of loyalty to the political China, ${ }^{10} \mathrm{I}$ would suggest that it was the connotation ethnic China (China as an ethnic polity) which overtook geographical and cultural China and, once mixed with the new idea of modern 'state', became the primary connotation in the early twentieth century. This idea then of the ethnic Chinese nation drove the historical Chinese culture to transform and rejuvenate. This stage of ethnic-driven cultural transformation could be viewed as the latest development in the long history of Chinese identity.

The clarification of the three connotations of Chineseness would thus lay the foundation for a new theoretical framework, which is different from that of Levenson, for understanding the formation of Chinese nationalism. In the second section of this chapter, I attempt to explain these connotations. Such understanding will also be used as a guide to analyze the ethnic thought of Wang Fuzhi. In addition, I examine the impact of the circulation of Wang's ethnocentric works on the educated elites between 1840 s and 1894 .

A few words regarding the Chinese term of zhongguo 中國 in this chapter might be necessary. It is well-known that the term 'China' might be etymologically related to Qin 秦, and thus was probably a term used by peoples outside China to refer to geographical China. If that was indeed the case, it means that there might have been no such term as 'China' before the Qin period. On the other hand, the term zhongguo had been used in pre-Qin texts, thus to render it as 'China' might be susceptible to a certain form of anachronism, if the term is discussed in the pre-Qin context. Moreover, when the term zhongguo was used in post-Qin historical texts, in some cases it referred to the 'Central Plain' (zhongyuan中原), in other cases it referred to a culture which stood for the human civilization. In both cases, to render the term as 'China' would make it difficult to convey the above meanings, since 'China' is normally understood as referring to a geographical-political domain rather than a culture, and the scope of this domain is much larger than that of the 'Central Plain'. Nevertheless, to replace 'China' with zhongguo would be rather awkward in style. To balance conceptual accuracy and style, the tentative solution I adopt is to render the term as zhongguo whenever necessary (e.g. when dealing with its connotations in the pre-Qin 
period, or when rendering it as 'China' might be misleading), and use 'China' in the remaining parts of this chapter. ${ }^{11}$

\section{Zhongguo and its three major connotations}

The term zhongguo had already appeared in the Western Zhou period (1046-771 BC). Its earliest use might have either referred to the former domain of the Shang polity $(1675-1046 \mathrm{BC})^{12}$ or to luoyi 雒邑, also known as Chengzhou 成周. It might also mean 'the city that was located in the middle of the peoples or polities, with medium distance to them from all directions'. ${ }^{13}$ During the 'Spring and Autumn' (chunqiu 春秋, 770-476 BC) period, zhongguo had about six meanings: (1) the domain of the king of Zhou 周; (2) the political bloc with the king of Zhou and his guardian vassals as its heads (zhuxia 諸夏); (3) the political-geographical domain of the zhuxia bloc; (4) the area inside the city walls of a polity's capital; (5) the domain of a polity; (6) human civilization. ${ }^{14}$ In the Warring States (zhanguo 戰國, 403-221 BC) texts, zhongguo developed at least eight meanings: (1) the zhuxia bloc; (2) the Central Plain; (3) Nine Provinces (jiuzhou 九州); (4) the area of the Three Jins (三晉); (5) the capital of legendary sage-kings; (6) the area within the bounds of a state or one's homeland; (7) a medium-size state; (8) a cultural community which symbolizes the human civilization. ${ }^{15}$ When used in the third meaning, zhongguo was equivalent to Nine Provinces, 'four oceans' (sihai 四海), or 'inland among surrounding oceans' (hainei 海內), and all three of the latter terms referred to a geopolitical land mass estimated to be a quadratic domain with 3,000 Chinese miles ( $l i$ 里) on each side. ${ }^{16}$ It is

11 I would like to thank Professor Cheng-tian Kuo for his suggestion concerning this issue.

12 The rendering of zhongguo as 'the Central State' by Hsu and Linduff (1988, p. 96) seems to be an example of this view.

13 Chang (2009a, pp. 172-184) listed three meanings of zhongguo during the Western Zhou period: (1) luoyi; (2) one of Zhou's capitals; (3) central state (Shang polity).

14 Chang (2009a, pp. 185-19o). Regarding the connotation of zhuxia, see Chang (2009c).

15 Chang (2009a, pp. 218-233). For a somewhat comprehensive list of all the entries in the Warring States texts in which zhongguo was used (there are 108), see Chang (2009c, pp. 219-233). In the recently published critical edition of Zhan Guo Zong Heng Jia Shu 戰國縱橫家書, there is one additional entry:「秦雖強, 終不敢出塞流河, 絕中國而攻齊」 (In spite of its superior force, Qin dares not to go out of the fortress and march along the river, cross the Central Plain and attack Qi. Zhan Guo Zong HengJia Shu, No.8, p. 215), in which the term zhongguo might refer to the Central Plain. For the cultural and quasi-ethnic connotations of the concept of China during the Warring States period, see Chang (2009a, pp. 166-18o).

16 Chang (2011, p. 32). The above content was taken from Chishen Chang and Kuan-Hsin Chen , 'Tracking Tianxia: on Intellectual Self-Positioning' in Wang Ban ed. 2017. Rethinking Chinese 
noteworthy that, although zhongguo has been translated as 'the Central State', 'the Central Country' or 'the Middle Kingdom' in later times, there seems, in the Warring States texts, to be no example of the term being used to refer to these meanings. ${ }^{17}$ In other words, during the Warring States period, it seems that the term was not used to refer to a unitary political community.

Among the above eight meanings, the second (zhongguo = the Central Plain), third (zhongguo $=$ Nine Provinces) and the eighth $($ zhongguo $=\mathrm{a}$ cultural community) could be regarded as the origins of three major connotations of Chineseness in later times. The second and the third meanings formed the political-geographical connotation of Chineseness, whereas the eighth meaning formed the cultural connotation of Chineseness. As for the ethnic connotation of Chineseness, it was derived from the politicalgeographical one. The three connotations of Chineseness are explained as follows:

\section{The political-geographical connotation of Chineseness}

Zhongguo $=$ the Central Plain. The meaning of zhongguo as referring to the Central Plain (the area which has today's Henan 河南, western part of Shandong 山東 and eastern part of Shanxi 陝西 as its core) could be traced back to its meanings in the Western Zhou 西周 period and the Spring and Autumn period, which respectively referred to the area of the ex-Shang 商 polity and the political-geographical domain of the zhuxia polities. The Central Plain had been the center of the political world from Shang to the Spring and Autumn period, and therefore enjoyed a privileged status compared to other areas. Polities or peoples in this area tended to consider themselves as China, and considered those in other areas as 'barbarians'. ${ }^{18}$

Zhongguo = Nine Provinces. The idea of Nine Provinces had several origins as well as versions. ${ }^{19}$ According to the most famous version, i.e. The Tribute

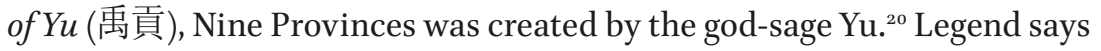
that Yu terminated the Great Flood (the metaphor of chaos and disorder) with a divine hydro-engineering work, which had the strong metaphorical

Visions of World Order, Durham: Duke University Press.

17 Fairbank (1974, p. 2).

18 The primary meaning of yidi during this period might be 'outsiders of zhuxia' rather than 'barbarians'. See Chang (2009c).

19 Chang (2009c, pp. 200-205); for detailed citations of these versions, see Chang (2009b, appendix 11).

20 See Legge (1935/2000). 
implication of creating a new order. After the work was done, Yu established the restored lands into nine provinces within the political framework of a unitary kingdom. ${ }^{21}$ It has been pointed out by many scholars that the locations of these provinces reflected the geo-political reality from late Spring and Autumn period to the Warring States period, which suggests that these versions of the Nine Provinces probably appeared during this time. ${ }^{22}$ If that is the case, the significant implication of Yu's establishment of Nine Provinces is that, at least from the late Spring and Autumn period on, a notion was gradually forming that envisioned a unitary kingdom where the major polities of the time were its local administrative units. In other words, the discourse of Nine Provinces emerging from a multi-polity system presented an imagination of a unitary kingdom. When such a kingdom became a reality from the Qin period on, Nine Provinces also became the symbol of the territorial domain of China. One example could be found in a text from the Han 漢 period:

The reason why the Annals of Spring and Autumn emphasized the Unity was that, due to the Unity, the world within the six limits shared the same customs, and Nine Provinces were ruled under the same set of principles. ${ }^{23}$

As both the Central Plain and Nine Provinces could be symbols of China, it might be convenient to call the former the 'symbol of China in the narrow sense' and the latter the 'symbol of China in the broad sense'. The Central Plain as the 'symbol of China in the narrow sense' had particular significance during the period of multiple kingdoms. During such periods, since no kingdom was able to rule the whole domain of Nine Provinces, the kingdom that ruled the Central Plain enjoyed a more prestigious status as the legitimate ruler of China than the others. ${ }^{24}$

\section{The cultural connotation of Chineseness}

At least by the late Warring States period, a notion had been formed that zhongguo stood for a cultural community in which its peoples shared a common culture. The oft-mentioned characteristics of this common culture included language, costumes, customs, and values. In the case of language 
and costumes, the idea that zhongguo was a domain where peoples within it shared the same language and costume could be found in The Springs and Autumns of Mr Lü (呂氏春秋):

The size of the domain composed with polities where their peoples wore the same costume of hats and sashes, reaching each other easily by boats and carriages, and could communicate with each other with no need of translators, was about a square with 3000 li on each side. ${ }^{25}$

In the debate kindled by king Wu lin of Zhao about converting Chinese costume to that of $\mathrm{Hu}$ 胡, one opponent's argument showed that China was regarded as a cultural community with a civilization higher than that of $\mathrm{Hu}$ :

Prince Chen said: '... According to your servant's knowledge, China is the realm in which the wise and intelligent men live, to which the variety of resources and wealth flow and converge, in which the teachings of sages was taught, the values of benevolence and righteousness, the culture delivered through classics like Books of Poetry, Historical Documents, Rites and Music, is practiced, and the excellent arts of all sorts are applied. It is, therefore, a realm to which peoples from afar come and learn, and a role model for barbarians to follow' ${ }^{26}$

From the Han period on, the idea of zhongguo as a unitary cultural community continued to be held, and the content of this culture was more or less fixed:

Language (spoken and written): Chinese

Type of economy: sedentary agriculture

Type of polity: a monarch rules over peasants with bureaucrats as aides. Value system: Confucianism (with sages kings and sages as its symbolic figures) and sacred classics as the core; a doctrine of ethical relations between the ruler and the ruled, parents and children, husband and wife, the elder and the junior, and between friends; the cultural performance of rites and music; the political doctrine of benevolent rule.

One example in the text of the Song period showed this connotation of zhongguo: 
China (zhongguo) is the world which has been ruled by teachings of sages, where its inhabitants were practicing four major occupations and wore the civilized costumes ... where life is regulated by morality, people are cultivated by civilized rites and music, with the principles regarding five ethical relations prevalent as their norm. ${ }^{27}$

\section{The ethnic connotation of Zhongguo}

Wang Mingke has pointed out that, by the Warring States period, a notion had emerged which considered the mythical figure of Yellow Emperor (Huangdi 黃帝) as the common ancestor of various clans living in China. ${ }^{28}$ According to this notion, for a people to be regarded as ethnic Chinese, their recent ancestor must be acknowledged as the descendent of Yellow Emperor. Otherwise they would be regarded as ethnic 'barbarians'. In this chapter, I use 'ethnic Chinese' to denote peoples imagined as one homogenous ethnic group living in the domain of China, and 'ethnic China' to denote China understood (or imagined) as an ethnic polity, namely, a political body composed of people of the same ethnicity.

It is noteworthy that from the Qin period on, the notion of ethnic Chinese was, conceptually speaking, simply the derivative of that of geographical China. The reason for this is as follows: since Yellow Emperor was the ancestor of the ethnic Chinese, he was the very first Chinese and there could be no Chinese prior to him. But if there could be no Chinese prior to Yellow Emperor, he could not be a descendant of any Chinese, how then could he be claimed to be ethnic Chinese? It seems that the only reason to claim so was that he was born and lived in the domain of geographical China. In other words, for the concept of ethnic Chinese to be a reasonable one, it has to build on the concept of geographical China. This means that there could be no concept of ethnic Chinese until the concept of geographical China came into existence. Therefore, in the case of China, the concept of ethnic Chinese and that of geographical China were not two independent concepts, but rather the former was intimately connected with the latter. The inner connection of ethnicity to geography seems to be somewhat particular of China, and might call for further attention.

27 Shi Jie, 'Deviant Creeds', first essay, Writings of Mr Shi of Zulai, Book 5, p. 60.

28 Wang (2006, pp. 75-86). It appears that, for the term 'di' in Haungdi 黃帝, 'Lord' might be a better translation than the conventional 'Emperor', as the latter was the translation for Huangdi 皇帝, a term coined by the First Emperor of Qin by combining 'huang' and 'di'. 
A note on the relationship of the notion of 'ethnic Chinese' with 'the Han' or 'ethnic Han' might be of some interest. First of all, the term zhongguo was used in the Warring States text to refer to the people living in the geographical zhongguo, who were different in nature to peoples of outside areas: 'Peoples in the areas located in the five cardinal directions, such as zhongguo, rong, yi, are of their own respective natures. Among these natures, none of them may be applied to any other'. ${ }^{29}$ The term zhongguo in the text apparently had an ethnic connotation, referring to a people whose ethnicity was different from other peoples. Compared to this, the term 'the Han' or 'ethnic Han' appeared later, as it was the product of the establishment of the Han Dynasty. Second, summarized in a very general way, two terminological pairs used to refer to the ethnic Chinese and other peoples of different ethnicity could be found in the texts of historical China. One pair is 'Chinese versus yidi'. ${ }^{30}$ The above-quoted Warring States text provides an example of its use. The other pair is ' $\mathrm{X}$ versus Han', in which $X$ could be any ethnic group, while Han referred to the ethnic Chinese. It appears that the 'Chinese versus yidi' pair, when used by the ethnic Chinese literati, often implied a certain sense of superiority to yidi. According to my limited knowledge of Wang Fuzhi, in his works he very rarely, if ever, used Han to denote ethnic Chinese..$^{31}$

With the three connotations of Chineseness as a tool, researchers can discern two ways in which the term zhongguo was used in Chinese historical materials. One of them is referential, using the term China to refer to a political-geographical domain, a unitary cultural community, or an ethnic group. The other way is normative or identity-laden, using the term zhongguo to express the user's opinion about what zhongguo is supposed to be, or the zhongguo with which the user identified. These two ways may be independent from each other, but sometimes they coincide. An example of zhongguo used to denote a political geographical domain could be found in the following early Tang 唐 text: 'The First Emperor (of Qin) built fortresses in remote areas, which contributed to the disintegration of China'. ${ }^{2}$ Another middle-Tang text showed that zhongguo was used to denote a unitary cultural community (represented by the zhuxia bloc): 'In

29 'Sagacious King's institutions', in Book of Rite, p. 247. See Chang (2009c, p. 226, n. 88, entry 75). 3o Terms like man蠻, yi, rong戎, di狄 appeared in the Warring States records of ideas of the Spring and Autumn period. One of their original meanings might simply be 'outsider' rather than 'barbarian'. See Chang (2009c).

31 I would like to thank one of the reviewers of this chapter for raising the question of 'Han' for discussion.

32 Chu Suiliang, 'Pleading against the stationing of troops in Gaochang'. 
his Annals of Spring and Autumn, Confucius treating those vassals who adopted the rites of "barbarian" as "barbarian", whereas treating those who upgraded themselves by following the rites of the Chinese as Chinese. ${ }^{33}$ As for China used in the form of 'people of China' (zhongguo zhi ren 中國 之人, the Chinese) to denote an ethnic group, the following late Yuan text provided an example: 'Because, regarding the people of our China, Heaven would certainly mandate men of China to well look after them. There is no possibility that a "barbarian" would be allowed to rule them' ${ }^{34}$

\section{Wang Fuzhi's major contributions to the development of Chinese ethnic thought}

More than half a century ago, Etienne Balazs already described Wang's Discourses on The General Mirrors (Du Tongjian lun 讀通鑑論) as 'impregnated with a nationalism', and remarked that some contentions in Wang's Book of Yellow manifested a 'nationalist tribune'. ${ }^{35}$ In 1968, Vierheller published his study of Wang's ethnic thought and called it 'proto-nationalism. $3^{6}$ In the same year, McMorran also completed a PhD dissertation on Wang's thought as a whole, focusing on his philosophical thought on 'ether' ( $q i$ 氣 or chi), treating his ethnic thought as an application of his theory of ether to ethnic issues. ${ }^{37}$ McMorran called Wang's ethnic thought 'nationalism', which emphasized the distinction between Chinese ( $h u a$ 華) and 'barbarians' ( $y i$ 夷) and urged that 'the Chinese must preserve their integrity as a nation' by strict observance of the rule of separation which kept China and the 'external barbarians' separated from each other. ${ }^{38}$ In this chapter, I shall deal with Wang's ethnic thought in the following way. 1) Outline the major contributions made by Wang to the development of Chinese ethnic thought. 2) Analyze the similarity of Wang's ethnic thought to and its difference from the nationalist ideas in early nineteenth-century China.

As mentioned before, in the history of Chinese ethnic thoughts before Wang, the term zhongguo had two prevalent meanings: one referred to the political regime which ruled over geographical China (either in its narrow or broad sense), the other referred to the unitary cultural community which

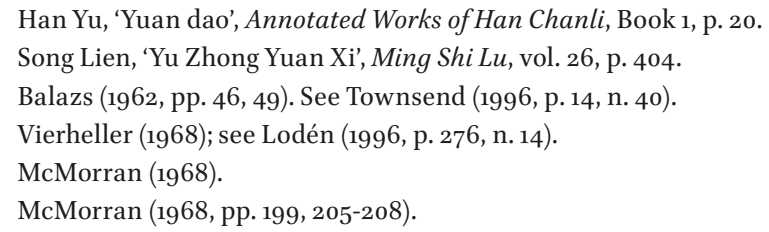


was located in geographical China and was the center of human civilization. This cultural community was open to anyone (regardless of the person's ethnicity) who was willing to join it, and whoever could preserve this cultural community was entitled to rule geographical China.

Wang's significant contributions to the development of Chinese ethnic thought, which to a certain extent were linked to the formation of Chinese nationalist thought in the early 1900s, are as follows.

First, he upheld the ethnic meaning of zhongguo as the term's primary meaning, a contention very much against the traditional meanings of the term. In this ethnic meaning, zhongguo was understood as a geographical domain which belonged to the ethnic Chinese alone.

Second, to support the above claim (i.e. China belongs to the Chinese alone), he argued that the Chinese as an ethnic group were formed due to the 'geographical ether' (diqi 地氣) of geographical China. The ethnic character of the Chinese was determined by the latter, and was, therefore, different from that of the 'barbarians', whose ethnic character was determined by their respective geographical ethers, and these geographical ethers differed from that of geographical China.

Third, he proclaimed that to separate the Chinese from the 'barbarians' and to protect the former from being violated or confused by the latter was the primary raison d'etre of the regime established by the Chinese.

Fourth, he reinterpreted the meaning of the cardinal Confucian virtues of 'benevolence' (ren 仁), 'righteousness' ( $y i$ 義) and 'loyalty' (zhong 忠) from the above ethnocentric standpoint. Regarding benevolence, he argued that the essence of 'benevolence' consisted in defending one's own ethnic fellows from the violation by the other ethnic groups, and that of 'righteousness' in ethnic self-rule (ruled by one's own ethnic people for the interest of the ethnic polity). As for 'loyalty', Wang maintained that loyalty was not supposed to be practiced towards whatever regime that ruled geographical China, but must be devoted to the ethnic polity and the ethnic regimes alone, and never to alien regimes. He also reinterpreted another significant concept of 'orthodoxy' (zhen 正 or legitimacy),, ${ }^{39}$ arguing that the regimes which enjoyed the highest degree of orthodoxy were those which defended the Chinese from being violated by the 'barbarians'. If a regime pursued its own interest at the expense of the interest of the Chinese (e.g. making the polity of China too weak to defend itself against the invasion of the 'barbarians', thus paving the way for the latter's conquest of geographical China and consequently subjugating the 
Chinese), it had committed a crime against China (understood as an ethnic polity). We shall elaborate the above ideas in more detail.

The first important expression of Wang's aforementioned ideas was an unpublished book, Book of Yellow (Huan Shu 黃書), ${ }^{40}$ a work which was said to be completed when Wang was 38 . The term Yellow has several meanings: it refers to the color yellow; situated in the context of the legendary lineage of China, it refers to Yellow Emperor, the common ancestor of the Chinese; in the context of the discourse of Five Elements (wuxin 五行), it refers to the central position (zhong 中), as yellow is the color of the earth, and the positon of the earth is in the center. In other words, Book of Yellow as the title implied that it was a book written for the Chinese who were the descendants of Yellow Emperor. If the book was written for the Chinese, for what purpose? The central aim was to urge that the protection of the Chinese from offences by the 'barbarians' was the foremost raison d'être of the regime established by the Chinese. In the postscript of Book of Yellow, Wang says:

Whoever becomes king by recapitulating the spirit inherent in the legacies from antiquity and following the principle of Nature, if he ruled according to the way set up by Xuan Yuan 軒轅 and established the China of the Chinese, and sheltered her from the disasters caused by alien species made of secondary ethers, upholding and nurturing China so she could fully realize her resources, the Way of governance is exhausted. ${ }^{41}$

The reason for interpreting the Way (note: "the Way" with a capital W is a term commonly used in English works of Chinese intellectual history. For example, please see Schwartz, Benjamin. 1996. China and Other Matters. Cambridge and London: Harvard University Press, p. 59, para.2, line 6) of governance as sheltering one's own kind from the disasters caused by alien kinds was premised by a cosmological theory presented at the very beginning of the book. Wang argued that, although Nature nurtured all the living beings with various resources via their endless and boundless mutual intercourses and interactions, it was also the primary law of Nature to distinguish different species from each other and to protect each from the invasion by or confusion with the others. He admitted that species originated from the same primordial unity, but argued that due to the difference of the environments where they live later on, they developed into different species and must thenceforth not mix with one another. 
According to Wang, it was against Nature's design that creatures differentiated from their original unity into diverse species. However, since Nature could do little to stop that, the self-boundaries drawn up by each species was, consequently, the primary law of Nature for each species to follow. That the sage was said to embody the gracious deeds of Nature was precisely due to their dutifully following the above-mentioned primary law of Nature:

If we observe the Beginning in Nature, we cannot but be amazed by the grandness of its design. How great that there were metals that shone, woods that supported, earth that accumulated, with illuminating fire, blowing wind, and moisturizing water to nurture them, letting these elements mutually nourish and impregnate one another, separating and combining them by continuous and abundant movements of melting and compression. Thus the mighty grace prevails boundlessly with no ending. Nevertheless, it is also Nature's work to clarify creatures of the same kind, closing the boundaries between each other, setting up their own positions and sheltering them, which appears to be Nature's greatest concern. This is why mountain creatures have cloven hoofs and those in the marshes have webbed feet; why the strengths of animals used for riding and animals used for ploughing lie in different directions; why the method of wet-cultivation is suited to the southland, and that of dry-cultivation to the cold climate in the northland. It is not because Nature is so cruel to make creatures dissolve from their original unity and ramify from their primordial lineage, but it could do nothing to stop that. So Nature does the above things to ward off disasters from their invading each other. Therefore the sage who, having observed that all species do so and each encloses its own boundary against the other, undertook the position of master of the world, carried out the work of distinguishing the intelligent from the brute, clarifying the similarity in appearance, building high citadel walls when the boundaries were badly maintained, in order to ward off the disasters of invasion and make members of the same species save themselves collectively. In this sense, the saying 'the sage's greatness coincides with the grace of Nature' is no exaggeration. ${ }^{42}$

42 Huan Shu, 501. Parts of this passage were translated by De Bary (1999, p. 34). I adopt one sentence from his translation with some minimal changes (the sentence about mountain and marsh creatures and the methods of cultivation). The rest of the translation is mine, and I alone am responsible for any errors. 
Almost three decades later, Wang repeated this cosmological theory again in his Explanatory commentaries on Zhang Zai's Correct Introduction to Knowledge (Zhang ZiZheng Mong Zhu 張子正蒙注). In his annotation of the sentence 'the ether of Nature, despite its immensely diverse movements of agglomeration, dispersion, attraction, and repulsion, expresses rules which are natural and not abnormal', he explained that

When the ether agglomerates, its existence is visible, but when it is dispersed one may suspect that it is non-existent. Once it has agglomerated and assumed forms and images, then as regards talents, matter, nature, and feelings, all accord with their own categories. They accept what is similar and oppose what is different; thus all things flourish in profusion and form their several categories. Moreover, the formation of each of these categories has its own organization (tiao li 條理). ${ }^{43}$ So it is that dew, thunder, frost, and snow all occur at their proper times, and animals, plants, birds, and fish all keep to their own species. There can be no frost or snow during the long summer days, nor can there be dew or thunder in the depth of winter. Nor can there be between man and beast, plant and tree, any indiscriminate confusion of their respective principles. ${ }^{44}$

In 'On Unity and Division' (li he 離合), Chapter Seven of Book of Yellow, Wang presented his theory of geographical ether and its connection to the ethnic character of the Chinese. He outlined the domain of China (roughly corresponding to the domain directly ruled by the Ming Empire), ${ }^{45}$ arguing that the geographical ether of this domain was different from those of the areas adjacent to it. He pointed out that this domain of China belonged to the Chinese with Yellow Emperor as their common ancestor. He then made a rather interesting claim that among the descendants of Yellow Emperor, some dwelt in geographical China, others in areas outside it. Due to the difference in geographical ether, they gradually formed into peoples of different ethnicities. Despite them being brothers at the beginning, with the passage of time they lost the memories of their original kinship and slaughtered each other as alien species. Although this is a tragedy, Wang lamented, it must be accepted as the outcome of Nature, and it was

43 Tiao li has the connotation of 'rule' or 'principle'.

44 De Bary (1999, pp. 28-29); also see McMorran (1968, pp. 193-194).

45 It is noteworthy that Manchuria, Mongol, Xinjian, Tibet, and Taiwan were not included in the geographical zhongguo outlined by Wang. 
particularly important to consolidate the barriers between them to save one's own kind:

From the ancient sage kings onward, some clans were granted with names and prided themselves as the noble ones, whereas some of the others declined and moved to the desert areas. Therefore, the peoples who scattered in South and North and had very different customs were actually descendants of the same few clans at the beginning. Originally, they carried the same lineage, sharing the same blood, being closely bounded by inter-marriages, and were in cordial terms with one another, like arms and armpits. After their bonds dissolved and were forgotten, they, who were brothers and kin in the past, fought each other in the field and received blades (note: the original Chinese means "blades of weapons") from each other, with flesh and blood splattering around and clans annexing and conquering each other. Are these not the heart-breaking tragedies over which Nature deeply mourned? However, acknowledging the harms caused by alien species, Nature let it be and moved along out of necessity (meaning: cannot but do so). For Nature, it was particularly worrisome that the boundaries were too demolished to save the survivors, so there were mountains and plateaus as walls and rivers as gaps to stop invaders. ${ }^{46}$

It is noteworthy that this view was repeated in another of his unpublished works: Discourses on The General Mirrors (Du Tongjian lun), which later became his most widely known work: ${ }^{47}$

Nature begot all creatures with the primordial ether, and the geographical environments confined them within different areas, which resulted in the transformation of the creatures' natural endowment and the differentiation of their natural dispositions ... The difference in terrains defined the attributes of the creatures' natural endowments. These attributes suited their transformed nature, and constituted the principles of their life..$^{48}$

46 Huan Shu, p. 535 .

47 It is almost certain that the work was written in his late years (see Chuan Shan Quan Shu 16, p. 74). Evidence from 1687 indicates that he might have been composing this work in this year. See Chuan Shan Quan Shu 16, p. 371.

48 Du Tong Jian Lun, p. 485. 
But, in Discourses on The General Mirrors, he further expressed an interesting view, maintaining that the Chinese and the 'barbarians' were of the same species (which differentiated into different kinds), whereas the greater people (junzi 君子) and the lesser people (xiaoren 小人) were of different kinds. The difference between the Chinese and the 'barbarians' was mainly that of ethnicity rather than nature, and their respective ethnicities were shaped by the geographical ether of the geographical areas where they lived:

In this world, there are two fundamental forbidden lines: that between the Chinese and the barbarians, and that between the greater men and the lesser men. It is not that they were of no difference originally but the ancient kings created artificial forbidden lines between them.

The Chinese and the barbarians are born in different areas. Since their areas are different, their ethers (natural endowments) change accordingly into different ones. Since their ethers differ, so do their habits. With their habits being different, their knowledge and conducts could never be the same. In each species, some members are superior and some inferior. However, since species are confined by their respective geographical boundary, and their ethers are different, so species must not confuse together ${ }^{49}$ Confusion like this would result in the destruction of the human pole, ${ }^{50}$ and the people of China would consequently be overwhelmed by them (i.e. the 'barbarians') and suffer. The reason for preventing that at the very beginning was to maintain the human pole by which the life of human beings is protected, and such an endeavor was in accordance with Nature.

The greater men and the lesser men are born of different kinds. That they are of different kinds are due to their difference in nature. Since their natures differ, so do their habits. As their habits are different, their knowledge and conducts could never be the same. It is true that within the same kind there are those who are clever and those who are brute. However, since people are born of different kinds, and different kinds prefer different things, different kinds must not confuse together. ${ }^{51}$ Such a confusion would result in the travesty of humanity, and the poor and the vulnerable would consequently be overwhelmed and suffer.

49 I.e. the superior members of 'barbarian' species must not cross the boundary to rule the Chinese.

$5^{0}$ 'The human pole' signifies the boundary between human beings (i.e. Chinese) and uncivilized lesser humans (i.e. the 'barbarian').

$5^{1}$ I.e. the clever members of the lesser men must not replace the clever members of the greater men to rule. 
The reason for preventing such a confusion from being prevalent was to preserve humanity and to ensure the abundance of human life, and such an endeavor was in accordance with Nature. Alas! The confusion of the lesser men with the greater men was no different from that of the 'barbarians' with the Chinese, but some people did not take it seriously, without knowing how disastrous it would be!

Among the lesser men, the clever ones and the brute ones formed different types. The brute ones are content to stay in their brute state and be trapped in it without harming others, whereas the clever ones use their cleverness to harm others. The brute ones are the farmers and gardeners who trapped themselves without harming others ... The merchants are the clever ones among the lesser men, and their disregard for humanity and harming others' lives is to the utmost extent. Because their ethers and the barbarians' ethers constantly attract each other, and their essence and that of the barbarians constantly get along with each other, the barbarians' rise to power and the merchants' rise in status are concomitant ... To summarize, there are two fundamental forbidden lines in this world, but their essence is one. Of what does this one essence consist? The distinction between righteousness and interest ... Therefore, although all of them are humans, barbarians differ from the Chinese by their geographical difference, whereas the greater men from the lesser men by their kinds, and the forbidden lines between them cannot but be strictly maintained..$^{2}$

According to this view, the Chinese and the 'barbarians' were of the same species but of different ethnicities (their ethnicities were due to the respective geographical ethers), while the greater persons and the lesser ones were of different kinds in spite of their sameness in ethnicity. Wang asserted that the ethnic character of the 'barbarians' was akin to the nature of the clever part of the lesser persons (i.e. the merchants), so the two got on well. He also proclaimed that the Chinese culture was intimately linked with the geographical ether of China's geographical domain, and, consequently, was not suitable for the 'barbarians' to adopt or follow. ${ }^{53}$

With the theory of ethnic difference as the justification for the separation of the Chinese and 'barbarians', Wang asserted that to separate the Chinese from the 'barbarians' and to protect the former from being violated or confused by the latter was the primary raison d'etre of the regime established by 
the Chinese. He urged every Chinese regime to do everything necessary to protect the Chinese from being ruled by the 'barbarians', including allowing itself to be usurped or overthrown by another Chinese regime:

Therefore, either one's intelligence is no greater than looking after oneself, or one's strength is great enough to conquer the world, whoever can protect one's own kind deserves to be the latter's ruler, and whoever can defend one's own kind deserves to be the latter's great lord. Therefore, the sage, by first granting all the clans their legitimate titles, showed his unrivaled prestige (as the sole ruler of the Chinese). He then protected this seat of prestige, rectified the disorders, and left this seat to his descendants or sages in later generations. This seat could be succeeded by abdications, inheritance, or revolutions, but must never be taken by the alien kinds. ${ }^{54}$

Measured by this principle, he condemned the rulers of those regimes in Chinese history, who, driven by the suspicion that the subjects might become too powerful and would eventually take the throne, adopted the policy of centralization of power which weakens the strength of the local districts, making the latter vulnerable when confronting the invasions of the 'barbarians'. The prominent examples of such regimes were Qin and Song, which, in Wang's opinion, had committed great crimes against the Chinese. ${ }^{55}$

In the Postscript of Book of Yellow, Wang presents a reinterpretation of the meanings of benevolence and righteousness, the core virtues of Confucianism. He argues that, against the traditional understanding of their meanings, these virtues must serve the interest of the ethnic polity for the sake of the latter's preservation, rather than serve the universal human civilization without ethnocentric concern:

At the beginning, human beings relied on their rulers to unite them and establish institutions, so that the latter could set up boundaries for their own groups, keep themselves away from those who were hostile and harmful, and ward off the alien kinds. Therefore, benevolence means

54 Huan Shu, p. 503.

55 See McMorran's translation (1968, pp. 197-198) of a famous passage from 'On the Essence of the Pole', Huan Shu, p. 504. The main theme of Chapter Two of Huan Shu, 'Gu Yi 古儀 On the ancient model of institutions', was criticism of the policy of centralization of power, with the Qin and Song dynasties as typical examples. 
loving one's own kind, and righteousness means setting up the rules and norms for one's own kind to follow, so that the polity was well constructed and could support itself on its own strength. Both of the virtues have as their common aim the nurturing of the vital ether of the Chinese composed of descendants of Yellow Emperor. For the moment, if a people could not defend themselves, what is the point to advocate meanings of benevolence and righteousness other than the above ones? ${ }^{56}$

In a similar vein, Wang criticizes the 'sagacious' statesmen of East Jin ( 東晉, 317-420) who made a great effort to discourage the military leader Huan Wen's 桓溫 plan of northern expedition to recover the Central Plain, worrying that if Huan succeeded, he would gain enough prestige to usurp the royal throne. According to Wang, they misunderstood the meaning of loyalty as being loyal to the sovereign, without realizing that loyalty should be devoted to preserving the integrity of one's own ethnic polity:

Their primary concerns lies with ... preventing the possible usurpation of the seat of the Heaven's Son, and the public opinions at that time all concurred with their concerns as self-evident. The opinions of the later time followed those of earlier times and thus expressed no disagreement. Alas! If they would have taken into account the fundamental forbidden line in this world, the fundamental distinction between humans and animals, and the great lineage descending from the ancient sage kings (of China), they would realize that if Huan Wen's military success would eventually lead to his success in usurpation, this would still be preferable to allowing the alien kind be the ruler of the Central Plain (which crossed the forbidden line, blurred the demarcation, and terminated that lineage)..$^{57}$

Another novel as well as shocking idea proposed by Wang is that the crime of violating the political obligation of the subjects to their monarch is lesser than that of violating the political obligation of the Chinese to China. Therefore, if a regime established via usurpation has done well in defending the Chinese from being violated by the 'barbarians', it is more legitimate than those which failed to do so, despite the latter being established via less illegitimate ways. He thus praised the Song Dynasty established by Liu Yu as the dynasty which had the highest degree of orthodoxy during the period 
between Han and Tang, as Liu Song had done well in both attempting to and succeeded in recovering parts of the Central Plain..$^{8}$

Before Wang Fuzhi, the ethnocentric strand of Chinese ethnic thought had developed for at least several hundred years. ${ }^{59}$ Wang's major contribution consisted in his stern assertion of a type of Confucianism with prominent ethnocentric characters. In the very first few years of the twentieth century, when Chinese nationalism was germinating while Confucianism was still the commonly held intellectual orientation, it was this kind of ethnocentric Confucianism which served revolutionaries like Zhang Binlin as an ideological canon against the loyalist Confucianism upheld by Kang Yuwei 康有為. With the fall of the Qing Dynasty and the birth of the Chinese Republic which had been constantly hard-pressed and eventually invaded by foreign powers, this ethnocentric Confucianism developed into a nationalist Confucianism which replaced the culturalist Confucianism as the mainstream Confucianism for most of the surviving adherents of Confucianism. Thus viewed, Wang's ethnic thought did play a significant part in the formation of Chinese nationalism.

\section{Wang's view regarding the relation between religion and ethnicity}

If Confucianism was regarded, by some Confucians (Wang Fuzhi seems to be one of them), as a type of religious alternative to God-worshipping religions such as Buddhism or Daoism, this would raise an interesting question about the relation between religion and ethnicity. Once we take into account that Confucianism is conventionally regarded as the essence of Chinese culture, and that the performers of Chinese culture were conventionally regarded as Chinese regardless of their ethnic backgrounds, as well as that Confucianism was regarded by some as an alternative religion, the connection between Confucianism and Chinese ethnicity would be as that between religion and ethnicity, provided that 'being Chinese' is regarded as an ethnic identity.

What was Wang Fuzhi's view on the connection between religion and ethnicity in the above sense? One passage in his Du Tong jian lun deserves

58 “漢之後, 唐之前, 唯宋氏猶可以為中國主也 In the period after Han and before Tang, Liu Song was, in comparison with other dynasties, the only dynasty that deserved to be the head of the ethnic Zhongguo.(Du Tong Jian Lun, p. 549)

59 Chang (200gb, pp. 256ff). 
some attention. In this passage, Wang comments on the construction of culturally symbolic buildings by the 'barbarian' ruler Shile 石勒. ${ }^{60}$ In his comment, he mentions two concepts - 'the lineage of reign' (zhitong 治統) and 'the lineage of Dao' (daotong 道統), in which the former referred to the seat of the son of Heaven whereas the latter refers to Confucian teaching. According to Wang, both of the lineages were so important that they should not be appropriated illegitimately, and whoever do this eventually would be punished by Heaven. He then condemned the corrupted Confucians for selling the lineage of Dao to the barbarians and bandits by suggesting such illegitimate rulers to adopt the Confucian teaching. Once they performed some symbolic practices (e.g. construction of symbolic buildings, such as Mingtang 明堂) which were closely related to Confucian tradition, they were eulogized as sage kings by those corrupted Confucians, who then were rewarded by those rulers. Nevertheless, Wang argues that such symbolic buildings and rituals were not essential to the lineage of Dao, which explains why the aforementioned illegitimate rulers could easily steal them and were willing to do so. As for its essence, this could not be stolen, as it consisted in distinguishing ethical relations, educating people, ruling people benevolently, placing virtue above all other concerns, learning how to improve one's reverent attention constantly, etc. Since these teachings were all about self-discipline and cultivation, they, according to Wang, could not possibly be welcomed by the illegitimate rulers and were unlikely to be adopted by them, thus they could not be stolen by them.

What Wang says in the above comment could be interpreted as dealing with the issue of the relation between religion and ethnicity. The core of this issue lies in this question: if the barbarians were Confucianized (religion), does that mean they were already sinicized, and thus should be regarded as Chinese (ethnicity)?

Wang's answer to this question might be more ambiguous than his confident tone let on. If the barbarians were merely Confucianized at the formal level, it is relatively easy to judge that they were not truly Confucianized, and therefore not truly sinicized. But, what if they were Confucianized at the essential level? Would they be consequently judged as indisputably sinicized? According to Wang's view expressed in the above comment, he could not but concur, which would, however, contradict with his ethnocentrism. It seems that, to maintain a consistent ethnocentrism, Wang would have to claim that religion does not grant ethnicity, only other elements do, and the geographical ether seems to be the foremost among them. This interesting 
example indicates that, if in Europe from the Westphalian Treaty onwards, religion determines nationality, in Wang Fuzhi's thought, religion does not determine ethnicity (understood as proto-nationality). ${ }^{61}$ Moreover, if Wang's view of the distinction between the formal and essential levels of Confucianism was applied to contemporary China, one might say that the so-called revival of Confucianism in mainland China might be merely in the formal sense. ${ }^{62}$

\section{The similarity and difference between Wang's ethnic thought and early twentieth-century Chinese nationalism}

Despite that Wang's ethnocentric thought has been widely seen as the forerunner of Chinese nationalism, little research has endeavored to fathom either its qualification as 'nationalism' or its relations to Chinese nationalism as it emerged at the turn of the twentieth century. This is understandably so, since both questions are not easy to answer. Here I will try to tackle both of these questions in a very rudimentary way.

It has been commonly recognized that nationalism as a concept is notoriously difficult to define. One of the causes of this difficulty, it seems to me, might be that it is a term people use to refer not to a single thing but a wide variety of phenomena. Each definition of nationalism refers to some of the phenomena and leaves more out, while any attempt at proposing a broad enough definition would be too broad to define anything.

To give the title of this section meaning without going astray in order to find an ideal definition of nationalism, I shall compare Wang's ethnocentric thought to a historical phenomenon that took place at the turn of the twentieth century and which has been generally described as Chinese nationalism. The salient features of this phenomenon include: the apprehension that the Chinese state would become colonies of foreign countries, the fear of extinction in the Darwinist sense of natural selection among countries and races, the consensus that to change the political order of the Chinese state from an imperial organization to a national one was the primary way out of the endangered situation.

Compared to Chinese nationalism, Wang's ethnocentric thought shares some of the former's features. In the latter, there is also the fear of being

61 I would like to thank Professor Lennert Gesterkamp for raising the question of the relation of religion and nationality.

62 See the fourth and fifth sections of Professor Bart Dessein's article in this volume. 
conquered by the 'barbarians', and of the fall of civilization as its consequence. The conquest of the Chinese state by aliens was of their gravest concern, as was the possible extinction of the ethnic Chinese. Nevertheless, Wang did not seek to change the imperial order of the state, while the nationalists did. He utterly rejected the possibility of people ruling themselves without a monarchial sovereign leading them. ${ }^{63}$ Accordingly, if both Wang and the late-Qing nationalists had ethnic self-government as their primary concern, they were different at least in one point: the former understood ethnic self-government as 'China ruled by an emperor who is Chinese', whereas the latter as 'China ruled not only in the name of but by the Chinese nationals. ${ }^{6}{ }^{4}$ With respect to the idea of popular sovereignty, Wang's ethnocentric thought is in direct opposition to the Chinese nationalists. This is one of the reasons why Cheng-tian Kuo questioned the claim that Wang's ethnocentric ideas are the origin of Chinese nationalism. ${ }^{65}$

To illustrate the aforementioned difference, some reference to the way Liang Qichao 梁啟超 (1873-1929) introduced the conception of 'nation' to his fellow Chinese at the eve of the twentieth century might be helpful. The difference may be summarized as follows: China was imagined by Wang as an ethnic imperial state, whereas by Liang as a popular nation, with ethnic Han as its core component but civic in its nature. ${ }^{66}$

In an essay On the General Picture of Competition among the Nations and the future of China (Lun jin shi guomin jin zheng zhi da shiji zhongguo qian $t u$ 論近世國民競爭之大勢及中國前途), Liang argued that the Chinese in the past had been familiar with the term guojia 國家 (the polity) for a long time, while completely ignorant of the concept of guomin 國民 (nation). The difference between the two, according to Liang, was that with guojia, the state was considered as the private property of the royal house, whereas with guomin the state was understood as the public goods of the people (remin 人民). ${ }^{67}$

63 Du Tong Jian Lun, p. 1048.

64 Townsend pointed out a salient feature of modern nationalism: that all the subjects of the state were citizens, 'holding formally equal rights and obligations within it' (1996, p. 24). The essential link of nationalism to the idea of popular sovereignty was noted by Hobsbawn (1990, p. 18-19). The first anti-Manchu revolutionary propaganda journal Guo Min Bao 國民報 (founded in 1901 in Tokyo) had as its English: 'The Chinese National'.

65 Kuo (2014, pp. 174-175). It should be noted that such a claim was cautiously avoided in Chang (2009b).

66 I would like to thank one of the reviewers of this chapter for raising the question of 'popular sovereignty' as a way to examine the difference of Wang's ethnocentric thought from Chinese nationalism.

67 Liang (1899, p. 309). 
The difference in conceptions about the nature of the state, Liang argued, led to the difference in political outcomes. In guojia, members of the people or the subjects did not identify with the state (since it was someone else's private property), thus the strength of the state lay merely in its ruling house. In contrast, members of the people or the subjects in guomin strongly identified with the state (since it was their own property), and the strength of the people formed the strength of the state. Since the Darwinist competition between China and other countries in his day was that between guojia and guomin, Liang warned anxiously that China as a guojia was doomed to be overwhelmed by other guomin. ${ }^{68}$

Liang's distinction between guojia and guomin was later rephrased, with a somewhat confusing use of terms, as that between guojia (i.e.guomin) and tianxia (all under heaven), chaotin 朝廷 (dynastic regime), respectively. In his 1900 essay On the Causes of China's Perennial Weakness (zhongguoji ro su yuan lun 中國積弱溯源論), Liang argued that the primary cause of China's current problems was the lack of idea of guojia (i.e. guomin), which had resulted in the erroneous attitude in foreign affairs, the mistaken devotion of political loyalty to the dynastic regime rather than to China as a nation (guojia, i.e. guomin), and the non-existence of an essential identification of the people (in this essay, Liang confusingly called them guomin) with the state. ${ }^{69}$

In Liang's 1901 essay On the Change of the Idea of Nation and the Similarity and Difference among them (Guojia si xiang bian qian yi tung lun 國家 思想變遷異同論), he continued to upheld the guojia-guomin opposition proposed in 1899, but restated it as that between the 'complete state' (wan quan guojia 完全國家, i.e. guomin in his 1899 essay) and incomplete state, respectively.$^{70}$ Classified under the category of the incomplete state were states formed according to the principles of patriarchy, chieftainship, and imperial rule. This category stood for the initial stage of evolution in political organizations, and was followed by the stage marked by the category of 'complete state'. Included in this latter category were states characterized by the principles of nationalism (minzu zhuyi 民族主義) and national imperialism (minzu diguo zhuyi 民族帝國主義). The next stage which superseded the stage of complete state would be the one characterized by cosmopolitanism (wanguo datong zhuyi 萬國大同主義). ${ }^{71}$ 
If, instead of being preoccupied by Liang's confusing use of terms like goujia and guomin, one focused on the idea he endeavored to articulate behind these terms, one might conclude that the conception he eagerly advocated was to reimagine China as a 'nation' which would consider the Chinese state as their own property. For Liang, the key to realizing such a state was democracy, the political institution characterized, according to Liang's depiction, by people's rights and power (minquan 民權). $7^{2}$

It is noteworthy that in Liang's discourse about guomin (nation) and minzu zhuyi (nationalism), the former was viewed by him as the foundation of the latter:

Since guojia (i.e. the complete state - CS) is built by the contract of consent of the people, the people should be entitled to unlimited power, and the government cannot but obey the will of the people. This is the driving force of $\min z u z h u y i .^{73}$

Such a view might explain why Liang oddly summarized, in a misleading if not twisted way, the core idea of the Declaration of the Rights of Man and of the Citizen as the principle of national unity and independence:

A guomin (i.e. nation) which by their own will wishes to live under the same law must not be under a foreigner's jurisdiction. Moreover, this nation, either in whole or in part, must not be ceded to foreign countries, since guomin is independent and indivisible. ${ }^{74}$

In other words, the idea of nation proposed by Liang as the model image for a new Chinese state was characterized by its civic nature.

In contrast to the civic concept of guomin, Liang discussed the concept of minzu 民族, presenting the latter as an ethnic concept. In his 1903 essay Teachings of the Master Political Scientist Bluntschli (Zheng zhi xue Daj ia Bo lun zhi li zhi Xueshuo 政治學大家伯倫知理之學說), he emphatically maintained the distinction between the concept of guomin and that of

72 The term 'minquan' had already appeared in Liang's 1899 essay 'On Patriotism' (aiguo lun 愛 國論), in which he made the following contentions: 'What is guo? The conglomeration of people. What is the governance of guo? The people govern their own affairs. What is patriotism? The people love themselves. Therefore, the rise of minquan (people's rights and power) would be followed by the establishment of guoquan 國權, (the state's rights and power). Accordingly, any discussion of patriotism must start from promoting people's rights and power' (1899a, p. 273).

73 Liang (1901, pp. 30-31).

74 Liang (1901, p. 31). 
minzu. Referring to Bluntschli's definitions, Liang claimed that guomin was both a political personality and a legal corporate, ${ }^{75}$ whereas minzu was a people with common territory, blood, physical appearance, spoken and written language, religion, customs, and economy ${ }^{76}$ In his vision of a future Chinese state, it was guomin (or guojia as its equivalent) rather than minzu which served as her model image. By imagining China as guomin, Liang pleaded with 'great nationalism' (da minzu zhuyi 大民族主義; uniting several minzu within a state into one guomin) and dismissed 'small nationalism' (xiao minzu zhuyi 小民族主義; opposing one minzu against another minzu within a state). ${ }^{77}$

The lineage as well as legacies of Wang's ethnic thought for modern China seem to have remained an under-researched topic. In the historical context of the political separation of Manchu from the ethnic Han imposed by the Qing government, Wang's ethnocentrism seems to serve the ethnic Han revolutionaries well in fanning the hatred among the ethnic Han against the Manchu, as the ethnic Chinese in Wang's discourse were automatically understood as ethnic Han and the 'barbarians' the Manchu in the Qing context. In an essay Clarifying the Meaning of Hatred against the Manchu (zhen cho man lun 正仇滿論) published in 1901 (probably the first public utterance of anti-Manchuism in the late Qing period), Zhang Binlin made a direct rebuttal against Liang's On the Causes ofChina's Perennial Weakness, in which, as mentioned above, Liang attributed the primary cause of China's current problems to the lack of an idea of 'nation'. It is interesting to note that, instead of discrediting Liang's argument with a frontal attack, Zhang quietly left it unchallenged and adopted a strategy of spinning it around: making an alternative claim to account for the lack of identification of the Chinese subjects with the state. According to Zhang, this lack was due to the state of the ethnic Han being ruled by aliens. Upon close examination, this claim does not succeed in discrediting Laing's, as Liang argues that the people could not identify themselves with a state which was not their own property, and this lack of identification was found in Chinese history not only in the periods of alien rule, but also in the periods of ethnic Chinese rule. In this debate, if Liang had the Western idea of nation as his theoretical source, Zhang seemed to rely on nothing but an ethnocentrism with Wang Fuzhi as its most recent source.

75 Liang (1903, p. 1068).

76 Liang (1903, pp. 1067, 1069).

77 Liang (1903, pp. 1069-1070). On this issue, see the second section of Professor Julia Schneider's article in this volume. 
History shows that it was Zhang's ethnocentric appeal that eventually triumphed over Liang's discourse of nation among the revolutionaries, which seemed to give Wang Fuzhi's ethnic thought the upper hand in the solution of the Alien Rule Question. Nevertheless, history also shows that the same ethnic thought was considered unfit for an ethnic Han state established by the 1911 Revolution. From the Republican period onwards, Wang's theory of geographical ether and the demand of ethnic self-rule as its corollary were quietly ignored, as it would make the Chinese government's sovereignty or territorial claims over Manchuria, Mongolia, Xinjiang, Tibet, Taiwan, and the South China Sea unfounded (not to mention his proclamation that Vietnam shares the same geographical ether with geographical China, and thus should be annexed by China).

The immediate impact caused by Wang's ethnic thought after its diffusion in the mid-nineteenth century remains another under-researched topic. To end this chapter, I shall deal with one aspect of this topic in a very brief way.

In 1842, Wang's Huan Shu was already listed among his known works, and Du Tong Jian Lun was already in limited circulation in $1858 .^{8}$ Both works were prominent in delivering Wang's urge for an ethnic self-government. After the publication of Wang's major works in 1865 by Zeng Guochuan 曾 國荃 (金陵節署本 Jin Lin high Commission edition), Huan Shu and Du Tong Jian Lun became accessible to a wider public.

It is noteworthy that, from 1865 to 1895 , the ethnocentric hostility against barbarian rule and the strong urge for ethnic self-government expressed in these two works seemed to arouse little resonance in their literati readers and little concern in the Manchu government. A diary entry in 1867 by Zhoa Liewen 趙烈文 summarized the main theme of Huan Shu with comments which showed an understanding but no agreement. ${ }^{79}$

In 1876, Guo Songtau 郭嵩壽 asked the government to grant Wang a ritual position of "subordinate worship' (congsi 從祀) in the Confucian temple. The reason upheld by Guo was that Wang was distinguished in his Classics studies, Li shue 理學 and virtues. The suggestion was turned down by the Ministry of Rites, not because of Wang's hostility against the barbarians (including Manchu) but, to Guo's surprise and disappointment, because of his Hunan country fellow Li Huan 李桓, who maintained that Wang was underqualified and disapproved such an honor. ${ }^{80}$ In 1895 , another similar 
attempt was made by Kong Xianglin 孔祥霖. ${ }^{81}$ In his memorial, Kong praised Wang's Du Tong Jian Lun for the following merits:

As for his discourses on political history, they contained insights and knowledge on affairs from antiquity to the recent times. In these discourses, he analyzed the causes of success and decline, good governance and corruptions of polities. Apart from that, he also emphasized the supremacy of kingship and the importance of expulsing the 'barbarians', and condemned the factional politics. His opinions were so profound and incisive that they made readers of them thrilled and take them as reminders. Thus they could be regarded as valuable teachings for endless generations. That was why during the periods of Xianfeng and Tungzhi, half of the military leaders who ended the Taiping Rebellion were literati from Hunan, ${ }^{82}$ which must be largely attributed to the teachings of Wang's posthumous works ... The Hunanese earnestly followed the teachings from his works, so most of them were well-informed in the art of warfare and capable of military affairs, which eventually led to their success in ending the great disaster of the Taiping Rebellion ... Thus judged, Wang was indeed a senior loyalist of the Ming Dynasty, but he was also a contributive subject to our dynasty. ${ }^{83}$

Kong's eulogy of Wang is noteworthy in at least three aspects. First, it raises questions regarding to what extent and in what way the leaders of the Hunanese army were influenced by Wang's Du Tong Jian Lun. As mentioned above, Zeng Guochuan's consultant Zhoa Leiwen had already read this work in 1858, and Zeng Guofang 曾國藩 might have received a copy of the work in $1861 .^{84}$ According to Zeng Guofang's diary, he seems to start reading $D u$ Tong Jian Lun in 1862 for two months, and did not resume reading it until 1866, after the Taiping Rebellion had been ended in $1864 .^{85}$

It is well known that the Taiping Rebellion made an ethnocentric appeal to the Chinese against the 'Manchu barbarian monsters' in 1852, and the ethnocentric ideas contained in it, despite being similar to those of Wang Fuzhi, more likely may have come from the influence of Tiandi Association

81 He (1996, p. 82).

82 Hunan was Wang's home province.

83 Chuan Shan Quan shu 16, p. 686.

84 Zeng Guofang 曾國藩 started his campaign against the Taiping Rebellion in 1854, see Guo Tingyi (1969, p. 113); Chuan Shan Quan shu 16, p. 579.

85 Chuan shan quan shu 16, pp. 564-569. 
(天地會). ${ }^{86}$ However, there seems to be no evidence indicating that Wang's ethnocentrism made any visible impact on either Zhoa Liewen or Zeng Guofang from 1858 to 1862 .

Second, if Taiping Rebellion's ethnocentric appeal was similar to that of Wang Fuzhi, Zeng Guofang's effort in crushing it was utterly contrary to Wang's ethnocentric urge. Taking this into account, Kong's eulogy appeared to be hilariously ironical in attributing the Zeng brothers' success in suppressing an anti-Manchu regime to Wang's teachings on the one hand, and calling Wang 'a contributive subject' to the Manchu regime on the other.

Third, the fact that Kong, in his memorial submitted to the Manchu emperor, dared to list Wang's emphasis on the expulsion of the 'barbarians' among the valuable parts of his discourses seems rather curious. What was equally curious was that his memorial seems not to have been reprimanded by the court, despite his suggestion being turned down. ${ }^{87}$ These facts strongly suggest that Wang's ethnocentric statements might have been received with little concern by the Chinese literati and the Manchu ruler, at least before 1895 . How his ethnocentric thought was used to facilitate the revolutionary propaganda in the first few years of the twentieth century will be the subject of a more extensive research.

\section{Bibliography}

Balazs, Etienne. 1965. Political Theory and Administrative Reality in Traditional China. London: School of Oriental and African Studies, University of London. De Bary, W.T. and Irene Bloom ed. 1999. Sources of Chinese Tradition, 2nd edition. New York, NY: Columbia University Press.

Chang, Chishen 張其賢. 2015. 正統論、中國性與中國認同 (Orthodoxy, Chineseness, and Chinese Identity) Taiwanese Journal of Political Science 政治科學論 叢, 64: 1-44.

Chang, Chishen 張其賢. 2011. 'Tianxia System on a Snail's horns', Inter-Asia Cultural Studies, 12(1): 28-42.

Chang, Chishen 張其賢. 2009a.「中國」與「天下」概念探源 ('The Formation of Two Key Concepts: “Zhongguo" and “Tianxia”). 東吳政治學報 (Soochow Journal of Political Science), 27(3): 169-257.

86 Guo Tingyi (1969, pp. 94, 88-90).

$87 \mathrm{He}(1996$, p. 83). Qin (2008, p. 86) claimed that it was turned down by the Minister of Rites Li Hongzao 李鴻藻 and other officials, but no relevant record could be found in the source she quoted. 
Chang, Chishen 張其賢. 200gb. 「中國」概念與「華夷」之辨的歷史探討 (The Concept of Zhongguo and the Distinction of 'Hua' 'Yi' - a Historical Survey). Ph.D. dissertation in Political Science, National Taiwan University 國立臺灣大學政 治學系博士論文.

Chang, Chishen 張其賢. 2009c. 春秋時期族群概念新探 (A New Study on the Chinese Ethnic Thought during the Spring and Autumn Period). 政治科學論叢 Taiwanese Journal of Political Science 39: 85-158.

Chu, Suiliang 褚遂良. 諫戌高昌疏( 'Pleading against the Stationing of Troops in Gaochang') in Writings of Chu Suiliang 褚遂良集. Taipei:Yi Wen Tu Shu Guan. Deng, Xianhe 鄧顯鶴. 1842. Ed. by Editorial Board of Chuan Shan Quan Shu船 山全書編輯委員會. 1988. Chuan Shan Zhu Xu Mu Lu 船山著述目錄 (List of Wang Fuzhi's known works) in Chuan Shan Quan Shu vol.16, 船山全書第十六 冊. Chansha: Yuelu Publisher, pp. 408-412.

Dikötter, Frank. 1992. The Discourse of Race in Modern China. Stanford, CA: Stanford University Press.

Duara, Prasenjit. 1995. Rescuing History from the Nation - Questioning Narratives of Modern China. Chicago and London: The University of Chicago Press.

Guo, Tingyi 郭廷以. 1969.Jing Dai Zhongguo Shi Gang 近代中國史綱 (An Outline of the History of Modern China). Hong Kong:The Chinese University of Hong Kong. Han Yu 韓愈. 2004. Yuan Dao 原道 (On the Authentic Dao). Annotated by Yen Qi 閻琦 in 韓昌黎文集注釋上冊 (Annotated Works of Han Chanli,), vol.1. Xian: San Qin Chu Ban She, pp. 15-26.

He, Guanbiao 何冠彪. 1996. Ming Qing Ren Wu yu Zhu Shu 明清人物與著述 (Studies of Historical Figures and Works in the Ming and Qing periods). Taipei: Taiwan Commercial Press.

Hobsbawn, Eric. 1990. Nations and Nationalism since 1780 - Programme, Myth, Reality. Cambridge: Cambridge University Press.

Hsu, Cho-yun and Katheryn M. Linduff. 1988. Western Chou Civilization. New Haven and London: Yale University Press.

Kuo, Cheng-tian 郭承天. 2014.Guozu Shenxue de Minzhuhua: Taiwan yu Zhongguodaliu 國族神學的民主化: 臺灣與中國大陸 (Democratizing National Theology: Taiwan and Mainland China). Taipei: Chengchi University Press.

Ming Shi Lu. (1984). Scripta Sinica database. Taipei: Institute of History and Philology, Academia Sinica.

Legge, James. 1935/200o. The Chinese Classics, Vol. III, The Shoo King, or The Book of Historical Documents. Taipei: SMC Publishing Inc.

Levenson, Joseph. 1958/1968.Confucian China and its Modern Fate: A Trilogy. Berkeley and Los Angeles: University of California Press.

Zhang, Pinxing 張品興 ed. 1999. Liang Qichao Quan Ji.1-10 梁啟超全集全十冊. Beijing: Beijing Publisher. 
Liang, Qichao 梁啟超. Collected in Zhang Pinxing 張品興 ed. 1903. Zheng Zhi Xue Da jia Bo Lun Zhi Li Zhi Xueshuo 政治學大家伯倫知理之學說 (Teachings of the Master Political Scientist Bluntschli). 梁啟超全集第二冊 Liang Qichao Quan Ji, vol. 2, pp. 1065-1076.

Liang, Qichao 梁啟超. 1901. Collected in Zhang, Nan and Wang Renzhi 張柛, 王 忍之 ed. 1977-78. Guojia SiXiang Bian Qian Yi Tung Lun 國家思想變遷異同論 (On the Change of the Idea of Nation and the Similarity and Difference among them).Xin Hai Ge Ming Qian Shi Nian Jian Shi Lun Xuan Ji 辛亥革命前十年間 時論選集 vol. 1. Book 1. Beijing: San Lien Shu Dian, pp. 26-34.

Liang, Qichao 梁啟超. Collected in Zhang Pinxing 張品興 ed. 190o. Zhongguo Ji Ro Su Yuan Lun 中國積弱溯源論 (On the Causes of China's Perennial Weakness). Liang Qichao Quan Ji. vol. 1 梁啟超全集第一冊, pp. 412-427.

Liang, Qichao 梁啟超. Collected in Zhang Pinxing 張品興ed. 1899b. Lun Jin Shi Guomin Jin Zheng Zhi Da Shi Ji Zhongguo Qian Tu 論近世國民競爭之大勢及 中國前途 (On the General Picture of Competition among the Nations and the Future ofChina). Liang Qichao Quan Ji, vol. 1 梁啟超全集第一冊, pp. 309-311.

Liang, Qichao 梁啟超. Collected in Zhang Pinxing 張品興 ed.1899a. Ai Guo Lun 愛國論 (On Patriotism). Liang Qichao Quan Ji, vol. 1 梁啟超全集第一冊, pp. 270-276.

Lin, Yü-Sheng. 1979. The Crisis of Chinese Consciousness - Radical Antitraditionalism in the May Fourth Era. Madison: University of Wisconsin Press.

Lodén, Torbjörn. 'Nationalism Transcending the State: Changing Conceptions of Chinese Identity’ in Stein Tønnesson and Hans Antlöv, eds. Asian Forms of the Nation. Surrey: Curzon Press, pp. 270-297.

Lü Shi Chun Qiu Xin Jiao Shi 呂氏春秋新校釋 (New Annotations of Mr Lü’s Spring and Autumn). Annotated by Chen Qiyou 陳奇猷, 2 vols. Shanghai: Shanghai Guji chu ban she.

McMorran, Ian. 1968. Wang Fu-chih and his Political Thought, PhD thesis, University of Oxford.

Qin, Yanchun 秦燕春. 2008. Qing Mo Ming Chu de Wan Ming Xiang Xiang 清末民 初的晚明想像 (Imagining the Late Ming in the late Qing and Early Republican period). Beijing: Beijing University Press.

Rao, Zongyi 饒宗頣. 2003 (1977). Guo Shi Shang Zhi Zheng Tong Lun 國史上之正 統論 (Discourses on Orthodoxy in Chinese History), in Rao Zongyi's Collected Academic Works in the Twentieth Century, 20 vols., ed. by Editorial Board of Rao Zongyi's Collected Academic Works in the Twentieth Century 饒宗頣二十世紀 學術文集編輯委員會. Taipei: Xin Wen Feng Publisher.

Shi Jie 石介. Ed. by Chen Zhie 陳植鍔. 1984. 怪說上 'Deviant Creeds (first essay)'. 徂 徠石先生文集 in Writings of Mr Shi of Zulai.Beijing: Zhonghua Book Company, pp. 6o-61. 
Song Lien 宋濂.Yu Zhong Yuan Xi 諭中原檄 in Ming Shi Lu 明實錄. Scripta Sinica database, Institute of History and Philology, Academia Sinica), 26, pp. 401-404.

Townsend, James. 'Chinese Nationalism', in Jonathan Unger ed. Chinese Nationalism. Armonk and London: M.E. Sharpe Inc., pp. 1-30.

Schwartz, Benjamin. 1972. 'The Limits of "Tradition versus Modernity": The Case of the Chinese Intellectuals' in Benjamin Schwartz. 1996. China and Other Matters. Cambridge and London: Harvard University Press, pp. 45-64.

Vierheller, Ernstjoachim. 1968. Nation und Elite im Denken von Wang Fuzhi (16191692). Hamburg: Mitteilungen der Gesellschaft für Natur- und Völkerkunde Ostasiens, Band XLIX.

Editorial Board of Chuan Shan Quan Shu 船山全書編輯委員會 ed. 1988. Chuan Shan Quan Shu 船山全書, 16 volumes. Chansha: Yuelu Publisher.

Editorial Board of Chuan Shan Quan Shu 船山全書編輯委員會, ed. 1988. Zhuan Ji, Nian Pu, Za Lu, Chuan Shan Quan Shu Bian Ji Ji Shi 傳記, 年譜, 雜錄, 船 山全書編輯記事 (Biographies, List of Life, Miscellaneous, Editorial notes of Chuan Shan Quan Shu) in Chuan Shan Quan Shu,vol.16. 船山全書, 第十六冊. Chansha:Yuelu Publisher.

Wang, Fuzhi 王夫之. 1687. Ed. by Editorial Board of Chuan Shan Quan Shu 船山 全書編輯委員會. 1988. 讀通鑑論 Du Tong Jian Lun (Discourses on The General Mirrors) in Chuan Shan Quan Shu, vol. 10. 船山全書第十冊. Chansha: Yuelu Publisher.

Wang, Fuzhi 王夫之. 1685. Ed. by Editorial Board of Chuan Shan Quan Shu 船山 全書編輯委員會. Zhang Zi Zheng Mong Zhu 張子正蒙注 (Explanatory Commentaries on Zhang Zai's Correct Introduction to Knowledge) in Chuan Shan Quan Shu, vol.12. 船山全書第十二冊.Chansha: Yuelu Publisher, 1988, pp. 7-397. Wang, Fuzhi 王夫之. 1656. Ed. by Editorial Board of Chuan Shan Quan Shu 船山 全書編輯委員會. 1988. Huan Shu 黃書 (Book of Yellow) in Chuan Shan Quan Shu vol.12. 船山全書第十二冊. Chansha: Yuelu Publisher, pp. 499-545.

Wang, Ming-ke 王明珂. 2006. Ying Xiong Zu Xian Yu Di Xiong Ming Zu 英雄祖先 與弟兄民族 (Heroic Ancestors and Ethnic Brothers). Taipei: Asian Culture Press. Wang Zhi 王制. 1989. (Sagacious King's institutions) in Li Ji 禮記 (Book of Rite), book 12, pp. 212-277.

Yang, Shao-yun 楊劭允. 2014. Reinventing the Barbarian: Rhetorical and Philosophical Uses of the Yi-Di in Mid-Imperial China, 600-1300. PhD dissertation in History, University of California, Berkeley.

Zhang, Binlin 章炳麟. 1901. Zhen Cho Man Lun 正仇滿論 (Clarifying the Meaning of Hatred against the Manchu) collected in Zhang, Nan and Wang Renzhi 張 柚, 王忍之 ed. 1977-1978. Xin Hai Ge Ming Qian Shi Nian Jian Shi Lun Xuan Ji. Volume 1. Book 1. 辛亥革命前十年間時論選集第一卷上冊. Beijing: San Lien Shu Dian, pp. 94-99. 
Zhan guo zong heng jia shu 戰國縱橫家書 in Changsha Mawandui Han Mu Jian Bo Ji Chen 長沙馬王堆漢墓簡帛集成, ed. by Qiu Xigui 表錫圭, pp. 201-266. Beijing: Zhonghua Book Company.

Zhan guo Ce Jian Zheng 戰國策䇝證, Compiled by Liu Xiang 劉向集 and Annotated by Fan Xiangyong 范祥雍. Shanghai: Shanghai Guji chu ban she.

About the author

Chang, Chi-shen. Assistant Professor of Chinese Political Thought, Political Science Department, National Chengchi University, Taiwan.

Email: cschang@nccu.edu.tw 


\title{
3 Missionizing, Civilizing, and Nationizing
}

\author{
Linked Concepts of Compelled Change
}

Julia C. Schneider

\begin{abstract}
This chapter tries to clarify two sets of conceptual connections. On the one hand, Chinese discourses of compelled change, i.e. civilizing, and practices of conquest and colonialism are compared to the European discourses on missionizing, and their conceptual similarities are demonstrated. On the other hand, connections between Chinese ideas of a 'Confucian civilizing mission' as change of moral, cultural, and ethnic identity from the Ming and Qing dynasties are linked to later Chinese ideas of 'nationizing', i.e. integration of non-Chinese people into the Chinese nation by assimilation of language, script, way of living, and other cultural and ethnic markers.
\end{abstract}

Keywords: Confucian civilizing mission, Christian missionizing, internal colonialism, southern and southwestern China, Ming and Qing Dynasties

\section{Introduction}

This chapter aims at drawing connections between the three sets of discourses on the colonial integration of others into the self and its legitimation: first, the Chinese nationalist discourse on 'China's assimilative power', second, its pre-discursive root or dispositif, the 'Confucian civilizing mission', and, third, European Christian missionizing. The chapter is divided into two main parts. In the first part, I will go into detail about the post-19oo nationalist discourse and highlight how the idea of 'China's assimilative power' was developed due to the demands of Chinese nation-building. In the second part, I will argue why I see a theoretical connection between the ideas of 'Confucian civilizing', assimilation or 'sinicization', and Christian missionizing, particularly in the context of colonialism and imperialism.

Chinese scholars and historians began to write 'general histories' (tongshi 通史) and 'history textbooks' (lishi jiaokeshu 歷史教科書), as well as essays 
and articles, shedding light on certain aspects and eras of history and historiography in a nationalist style since the 19oos. At that time, nationalism, that is, the theory that nation and state should be congruent and that every nation should have a state, became known among Chinese reformist political thinkers and quickly gained popularity. Ernest Renan's question 'Qu'est-ce qu'une nation?' ('What is a nation') ${ }^{1}$ in its particular Chinese form - 'What is the Chinese nation?' - was indeed an urgent question at the beginning of the twentieth century. Nationalism had originated in Europe and, as stressed by Benedict Anderson, in Creole Middle America, and it became more and more popular all over the world in the course of the nineteenth century. ${ }^{2}$ Since the 1890 s, Chinese thinkers learned of its theories, mostly filtered through Japanese translations and adaptations of Western works on politics, history, and society.

The question of how to define one's own nation was by no means limited to the Chinese experience, but was posed by political thinkers around the globe since they came to support nationalism. This is an expression of a paradox of nationalism detected by Anderson: nationalism is a universal concept, but at the same time it is irremediably particular in its concrete manifestations. ${ }^{3}$ Although many political and scholarly elites asked themselves what defined their nations, their answers to this question were necessarily different. Furthermore, differences not only existed between, for example, definitions of the French and the Chinese nations, but also within the discourse on the Chinese nation opinions differed on how to define this particular nation.

When I refer to Chinese scholars and thinkers in late imperial and early republican times, I refer to people who spoke one of the Chinese languages or dialects, who mostly grew up in traditional elite environments with regard to their education during childhood and adolescence, in families of some fortune, rich enough to allow their sons to learn and study for a rather long time. Until the abrogation of the imperial examinations in the course of New Policies (xinzheng 新政) in 1905, Chinese education had had the ultimate objective of participating in the examinations and of gaining access to a career as an official. However, also after 1905, it provided the opportunity to a career, for example in politics, academia, press, and media.

At the end of the nineteenth century, it was from the ranks of these scholars and thinkers that the bold political attempt was made to reform the 
Qing Dynasty (1636/1644-1912) and change it into a constitutional monarchy. Reform-minded scholars like Kang Youwei 康有為 (1858-1927), his disciple Liang Qichao 梁啓超 (1873-1929), and several others persuaded the young Guangxu 光緒 Emperor Dezong 德宗 (1871-1908) to go against his aunt, Empress Dowager Cixi 慈禧 (1835-1908). However, their Hundred Days' Reform (wuxu bianfa 戊戌變法) failed due to the intervention of the conservative circles in the government backed up by the Empress Dowager. Kang, Liang, and others who had directly participated in the reformist attempt or had supported it publicly like Zhang Taiyan 章太炎 and Zhang Binglin 章炳 麟 (1868-1936), had to emigrate. Those who wanted to or had to remain in the Qing Empire, i.e. Tan Sitong 譚嗣同 (1865-1898), were put to death. Most of the escapees went to Japan where reformist Japanese politicians and political parties offered them shelter and the opportunity to continue their political work. From their Japanese exile, Liang Qichao and Zhang Taiyan continued their struggle for reform by publishing extensively. Their interest in nationalist theories grew due to the fact that they gained better access to Japanese translations, adaptations, and analyses of Western works on politics, history, and society on the one hand, and on the other hand, could study the outcome of the Japanese Meiji Reforms which had been implemented by the Meiji 明治 Emperor (1852-1912) since the beginning of his reign in 1868 .

\section{China's assimilative power}

\section{Liang Qichao's nationalism}

In his Japanese exile, Liang Qichao published several famous essays, among them Teachings of the Great Political Scientist Bluntschli (Zhengzhixue Dajia Bolunzhili zhi Xueshuo 政治學大家伯倫知理之學說) on the Swiss political theorist Johann Caspar Bluntschli (1808-1881). ${ }^{4}$ Bluntschli was well known among Japanese scholars, because his works had been translated into Japanese by the political scientist Kato Hiroyuki 加藤弘之 (1836-1916) already in the 1870s. Liang, however, copied large parts from a more recent translation of Bluntschli's German Political Science for the Educated Public ('Deutsche Staatslehre für Gebildete', 1874) by Azuma Heiji 吾妻兵治 (dates of life unknown), Science of the Nation (Kokkagaku 国家学 1899). ${ }^{5}$ Crucial 
for my analysis here, however, are passages which Liang added to Azuma's translation of Bluntschli's text. They refer to the particular situation of the Qing Empire and question the validity of Bluntschli's theories for the case of the Chinese nation.

Based on Bluntschli's approach to the different ways in which states, nations, and ethnicities could be linked, Liang developed his well-known theory of 'greater nationalism' (da minzuzhuyi 大民族主義) opposed to 'lesser nationalism' (xiao minzuzhuyi 小民族主義). ${ }^{6}$ 'Greater nationalism' meant that what 'all ethnicities, aboriginals and those originating from other places, who are united in the [Qing] Empire, [feel] regarding all ethnicities outside the empire' 合國內本部屬部之諸族以對於國外之諸 族.7 'Lesser nationalism', on the other hand, was what 'the Han [Chinese] ethnicity [feels] regarding other ethnicities within the [borders of the Qing] Empire' 漢族對於國內他族. ${ }^{8}$ Geographically, 'greater nationalism' thus referred to the whole Qing Empire, 'lesser nationalism' only to the Chinese inhabited regions within the Qing Empire, also called 'China proper' (benbu 本部; guannei 關內). In confronting 'greater' with 'lesser' nationalisms and taking a stance against the latter, Liang gave his answer to the question, what the Chinese nation was. However, his comparison between 'greater' and 'lesser' nationalisms shows that the answer was a matter of debate and did not come naturally.

Accordingly, two different conclusions were drawn from the Qing situation. One conclusion was that the existing Qing state defined the nation. This was the basis of Liang's 'greater nationalism'. The 'greater nation' was based on political and territorial considerations, which meant that those living within certain (political) borders were part of the Chinese nation. One could say that this idea equated the Qing Empire with 'China' (zhongguo 中 國) and that this was the basis for defining the Qing Empire as a 'Zhonghua [Chinese] nation' (zhonghua minzu 中華民族). The other conclusion was that the Chinese or Han ethnicity (Hanzu 漢族) defined the nation. The 'lesser nation' was based on a mixture of language, culture, tradition, place of residence, in short, ethnic markers, which meant that the Chinese nations were only those who were Han (漢) in the Qing Empires rendering. This clearly was a narrower understanding of the nation. Lesser nationalism diminished the territory of a future nation-state in comparison with the

8 Liang (1903/1983, p. 75). 
first option. For diverse reasons, most political thinkers and scholars opted for the first idea of the Qing Empire as the nation-state.

Liang Qichao's definition of the Chinese term minzu 民族 in his essay on Bluntschli (or rather, that of Azuma Heiji) was a translation of Bluntschli's German Nation. The German Nation, however, was defined by Bluntschli himself as the English 'people' and the French peuple. (The German Volk was defined as 'nation' in English and nation in French.) Based on Bluntschli, Liang also defined what conditions were needed in order to form one minzu. He gave the following list:

Same place, same blood relation, same physical appearance, same language, same script, same religion, same tradition, same way of living. Language, script, and tradition, however, are the most important [criteria] among them. ${ }^{9}$

How does Liang's definition of minzu inform the term 'nationalism' (minzuzhuyi 民族主義), or, in other words, how do Liang's two definitions of the nation come together: nation with regard to people (as underlying the term minzu) and nation in geographical terms (as underlying his idea of 'greater nationalism')? On the one hand, Liang assumed that a feeling of national unity within the borders of the Qing Empire (guonei 國內) was not only possible, but desirable. On the other hand, he defined minzu in a rather narrow way: ethnicities or identity groups which are genealogically linked and share a place of living, blood relation, physical appearance, language, script, religion, tradition, and way of living. Would not this latter definition of minzu as the basis of the nation-state exclude those 'other ethnicities within the [borders of the Qing] Empire' (guonei tazu 國內他族) ${ }^{10}$ from the minzu of a Chinese nation-state which according to the concept of 'greater nationalism' was supposed to include many non-Chinese peoples?

Liang justified his idea of a Chinese nation-state within the borders of the Qing Empire with the efficacy of an 'assimilative power' (tonghuali 同化 力), which the Chinese possessed and which he called 'China's assimilative power' (zhongguo tonghuali 中國同化力). ${ }^{11}$ With the unconscious efficacy or conscious application of this power, the ethnic definition of minzu could become congruent with the territorial definition of 'greater nationalism'. 
Liang had discussed the theory of 'assimilative power' already in 1902 in the essay About the General Tendency of Ethnic Struggles (Lun Minzu Jingzheng Zhi Dashi 論民族競爭之大勢). ${ }^{12}$ Its validity was based on the assumption that there were 'superior ethnicities' (youqiang minzu 優 强民族) which could 'swallow inferior, weak ethnicities and erase their frontiers'. ${ }^{13}$ In 1903, Liang identified the Chinese ethnicity as one of these superior ethnicities. The assumption that their superiority enabled them to change other people's identity was based on older Chinese culturalist assumptions, such as the late imperial reading of the Mengzi 孟子, (372-289 $\mathrm{BC}$ ) motto 'using the Xia [Chinese] to change the Yi [barbarians]' (yong Xia bian $Y i$ 用夏變夷), and on social Darwinist ideas of people being divided in superior ones and inferior ones, with the former having the natural right to rule and dominate the latter. Already Bluntschli had used social Darwinist classifications of people and had followed the general idea of dominant or superior people being able to assimilate and to change others especially in order to unify the people of a nation, and at the same time to withstand change by others. ${ }^{14}$ Bluntschli particularly referred to several people who possessed such power, the Romans and the Greeks in antiquity, and the contemporary United States of America (as a nation) as well as the French and the Russians. ${ }^{15}$ One important precondition according to Bluntschli was that this kind of assimilation 'only succeeds where the dominant people are decidedly superior to the rest in education, mind, and power. ${ }^{16}$ Liang did not fully accept this precondition. Although he agreed that superiority in power was useful, he assumed that only superiority of education and mind was indispensable. ${ }^{17}$

Consequently, Liang meant by 'China's assimilative power' that the Chinese, which by his definition were the Hanzu 漢族, were capable to transform everyone, groups as well as individuals, and assimilate them into Chinese (Han) culture and ethnicity. According to Liang, irrespective of the Chinese political, social, and military situation, their culture would always put them in the superior position and enable them to assimilate others under all circumstances.

Liang applied the theory within two fields, historiography and political strategy. As a political strategy, Liang used the theory of 'China's assimilative

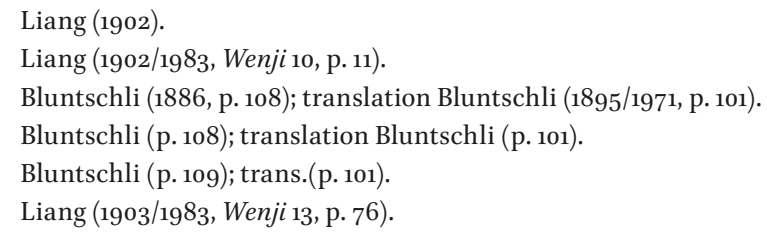


power' to argue for the possibility of integrating non-Chinese peoples into the Chinese nation and nation-state in his contemporary times. As a historiographical theory, Liang used 'China's assimilative power' as a basis to evaluate all kinds of contacts between Chinese and non-Chinese in all periods of time. Rather than analyzing these contacts in detail, he claimed that all had the same outcome: the non-Chinese peoples could not help but assimilate into the Chinese. His strongest argument was his interpretation of the histories of dynastic empires founded by non-Chinese peoples who conquered Chinese-inhabited regions, later called 'foreign conquest dynasties'. (The label 'conquest dynasties' of course only holds true from a limited perspective and otherwise strengthens the 'monolithic assumption that there were "Chinese" dynasties that were somehow not conquest dynasties.' ${ }^{18}$ ) This argument was particularly strong, because, according to Liang, although non-Chinese conquerors were politically, socially, and militarily superior, even they could not avoid their assimilation into the Chinese culture and people. The assumption of their assimilation thus meant that in the end every people, irrespective of their position with regard to politics, military, or social stratification, could be assimilated into the Chinese due to the Chinese superior culture and identity as an ethnicity or people.

The application of the theory of 'China's assimilative power' in the field of historiography was in fact based on the necessity to prove its validity as a political strategy. With selected examples from history, Liang tried to provide evidence for the applicability and successful prospects of assimilation into the Chinese when 'China's assimilative power' was used strategically to build and to unify the Chinese nation. Since the 1920s, the terms Hanhua 漢化 or Huahua 華化 (sinicization, or Sinification) became to be used to refer to the specific processes of (assumed) assimilation into Chinese culture and people.

\section{Chinese political thinkers and nationalisms}

Like Liang Qichao, most Chinese political thinkers accepted the idea that states with a homogenous nation were more likely to be strong and successful in the contemporary situation. Their approach towards nationalism was thus closely linked to the wish to withstand imperialist threats especially of the United Kingdom, France, Germany, Russia, and Japan. Based on his reading of Bluntschli, Liang had defined the unifying aspects 
of a people based on place, blood relation, physical appearance, language, script, religion, tradition, and way of living, emphasizing language, script, and tradition. Liang's strategy was to claim that the assimilation of most of the non-Chinese people in the Qing Empire had already happened in the past without revealing substantial proof for this claim. Based on older sinocentric approaches to other cultures and peoples, Liang's claim was generally accepted. This is reflected in the new genres of history textbooks and general histories published since the 19oos. History books of these genres had the purpose to educate and from the start they had strong nationalist tendencies, not only in the Qing Empire or the Republic of China but also in Japan and in the countries of their origin in Central and Western Europe.

Zhang Taiyan offered an alternative approach. He accepted the existence of 'China's assimilative power', but doubted that the Tibetans, Mongols, and Turkic Muslims (later called Uyghurs) were in fact already assimilated. He thus accepted the possibility of a contemporary, but not so much historical effectiveness of 'China's assimilative power'. Like Liang, he found language and script important aspects of national unity. He stressed a second aspect, '[way of] living, eating, and occupation' (jushi zhiye 居食職業), which might be comparable to Liang's aspect of 'tradition' ( fengsu 風俗). However, there is no detailed description, neither by Liang of 'tradition' nor by Zhang of 'living, eating, and occupation', so it remains unclear what they meant by these terms. Zhang moreover added a third aspect, 'laws and orders' ( falü fuling 法律符令). ${ }^{19}$ He found Tibetans, Mongols, and Turkic Muslims all lacking particularly with regard to one of these three aspects. If they were to become part of the Chinese nation-state, meaning political participation, it would be necessary for them to adjust to Chinese ways. ${ }^{20}$ Although Zhang stated that every people should decide on their own if they wanted to found a nation-state or become part of another, he left no doubt that he found the integration of all three peoples, Tibetans, Mongols, and Turkic Muslims, highly desirable and expected them to be sensible enough to see how unwise a separation from the Chinese would be. ${ }^{21}$

According to Zhang, the processes of assimilating Tibetans, Mongols, and Turkic Muslims could be finalized within twenty years, given that there was a concrete state program providing education in Chinese language and culture, promoting Chinese ways of living, eating, and occupation, especially 
in the field of agriculture, and implementing a Chinese legal system. ${ }^{22}$ In contrast to Liang, he did not find it necessary to refer to history to prove that people living in the Qing Empire had already been assimilated into the Chinese people and culture in the past. Zhang's argument was based on the simple power-political equation that the larger a state's territory was, the more powerful the state would be. At the same time, he assumed that the people in this state's territory had to be unified as a nation, because the size of the state was only an advantage when it was based on national unification. He did not base his acceptance of the possibility of sinicization on historical arguments like Liang did, but on the sheer necessity of unification - what had to be possible, was possible.

\section{Nationalism as religion: Nationizing as missionizing?}

I find the theory of 'China's assimilative power', as used in early Chinese nationalist discourse, close to religious concepts of missionizing. To approach Chinese nationalism based on the suggestion that nationalisms are like or are religions, as done by several scholars, means that it might be reasonable to apply concepts of missionizing to the theory of 'China's assimilative power' and the idea of sinicization..$^{23}$ To what extent does the idea of sinicization resemble certain aspects of religious missionizing as transformation and change of a peoples' identity in discourse and in reality?

Scholars such as Frank Wright write that 'nationalisms are not merely "like" religions - they are religions,', ${ }^{24}$ and Joseph R. Llobera claims that 'nationalism has become a religion - a secular religion where god is the nation'. ${ }^{25}$ Both statements are about western European nationalisms and they both refer to the fact that these appeared at a time when religious identities - Christianity and Judaism alike - were losing their attractiveness to people in Europe and North America. This crisis of religion happened due to the Enlightenment and scientific findings and inventions.

In the Western context, changes of identities due to cultural assimilation and changes due to processes of religious missionizing seem not to have been analyzed in parallel so far. In the Chinese discourse on national assimilation, its drawing on earlier ideas of Confucian civilizational assimilation

Wright (1988); Llobera (1994, p. 143); Anderson (2006, p. 5).

Wright (1988, pp. 128-148).

5 Llobera (1994, p. 143). 
are much more evident. By revealing its roots in earlier ideas of civilizational assimilation, the Chinese nationalist discourse reveals that the mechanics and underlying discourses, both on Confucian civilizational assimilation in Ming and Qing dynasties and on Chinese national assimilation in late Qing and Republican eras, are built on one another.

By this understanding of Chinese discourses on assimilation, linking pre-nationalist discourses with those after the idea of nation-building became part of these discourses, it becomes obvious that also in Europe two discourses which have not been interpreted as being related, might be more closely related than previously thought: Christian missionizing or Christian religious assimilation on the one hand, and on the other hand, processes of active or passive 'nationizing' in the course of nation- and state-building, nationizing being understood as imagined and real processes of integrating people into a nation and nation-state who have so far not been part. Whereas the connection between Western discourses on Christian missionizing and nationizing cannot be discussed within the frame of this essay, parallels between the Chinese and the Western discourses are analyzed further below.

\section{The superiority of the Chinese as a people and a culture}

In the Western context, nationalism and Enlightenment developed in parallel. Similarly, in parallel to the development of theories of Chinese nationalism since the late nineteenth century, Chinese thinkers became frustrated with traditional Chinese philosophies, ethics, and morals. This refers to several layers with regard to the wish for reforms which developed chronologically in parallel to political and historical events. Like in the Western context, the idea of identity shifted from one based on general ethics and moral to a nationalist idea of identity based on a specific ethnic belonging.

In the late nineteenth century, Chinese reformers wished for a strong Qing Empire. It was not considered to be a major obstacle that the Qing emperors were of Manchu ethnic background, as long as a reform towards constitutionalism was possible. However, the Hundred Days' Reform proved unsuccessful and important reformist thinkers like Kang Youwei, Liang Qichao, and Zhang Taiyan had to leave the Qing Empire. In their Japanese exile and based on their discussions of nationalism, more and more came to believe that the problem was exactly the non-Chinese identity of the Qing emperors and ruling elites. It came to be understood that the Qing Empire's desolate situation was the fault of the Manchu emperors, of whom 
the Chinese thinkers now thought as conquerors or even as colonizers. ${ }^{26}$ Chinese nationalist reformers and revolutionaries alike argued that due to the Manchus' assumed ethnic and cultural inferiority, imperialist powers had been able to overrun the Empire in the nineteenth century. (They also blamed their Chinese fellow subjects for their passivity in letting themselves be ruled by non-Chinese conquerors). Under the preconditions of a growing anti-Manchuism, it was claimed that the Chinese as a cultural and ethnic group were superior to non-Chinese, especially to non-Chinese within the Qing Empire. Therefore, they did not aim at a constitutional monarchy with Manchu emperors anymore, but at a republic with a Chinese ruling elite who would lead the non-Chinese inferior people towards their integration into a Chinese nation-state. This integration would be based on 'China's assimilative power' which the Chinese possessed because of their cultural and ethnic superiority.

When the Republic of China (ROC), the first Chinese nation-state, was finally founded in 1911, it became obvious that 'China's assimilative power' and the attraction to be part of a powerful, united nation-state under Chinese dominance were obviously not as appealing as previously thought. Non-Chinese peoples, especially Tibetans and Mongols, later also Turkic Muslims, who began to call themselves 'Uyghurs' under Soviet rule in the 1920s, developed their own ideas of nation-building or at least of state-building. They aimed at independent (nation-) states and did not want to be part of a Chinese dominated nation-state. Liang Qichao and Zhang Taiyan had assumed that non-Chinese would be naturally inclined to remain part of a Chinese successor state of the Qing Dynasty before 1911. Now, their hopes were proven incorrect. In the 1920s, Liang Qichao nevertheless worked even harder on this theory of 'China's assimilative power', renaming it 'assimilative power of the Zhonghua [Chinese] ethnicity' (Zhonghua minzu tonghuali 中華民族同化力). ${ }^{27}$ Instead of asking why the Chinese people and culture were not as attractive as assumed, he concentrated on showing that at least in the past, the 'assimilative power of the Zhonghua [Chinese] ethnicity' had worked indeed as smoothly as he had claimed in the 1900 s.

Others, however, paid more attention to the process of weakening of the Chinese nation-state. Nearly from the start, the ROC had been in a complicated situation, because of the influence of Yuan Shikai 袁世凱 (1859-1916) and his Beiyang Army clique, who jeopardized the Republican 
government and ruled the ROC more and more autocratically. Already before the Paris Peace Conference in 1919, when the allied powers of World War I gave the German concessions in China to Japan, Chinese thinkers, especially the younger ones, had become disappointed by the Western states, which for them lost their model character to some degree. They became engaged in the May Fourth Movement (1915-1925), whose aim was to reform Chinese culture and enable it to resist imperialism. One part was that they wanted to lessen the influence of Chinese traditional ideology, often called 'Confucianism' in English.

Traditional ideology, which was the moral and ethnic basis of government and ruling, of social organization and hierarchy in general, embraced in fact more than Confucian ideology based on the Four Books and the Five Classics (Sishu Wujing 四書五經). It also contained legalist, Neo-Confucian, and even Mongol and Manchu ways of government and ruling. However, (Neo-) Confucian ideology certainly was its decisive part. By critically judging traditional ideology and aiming at abrogating certain parts of it, the participants of the May Forth Movement not only wanted to reform Chinese culture, but they also aimed at changing and reforming the whole Chinese way of life with regard to society and politics.

The point I want to make here is, that like Christian ethics and morals were criticized in the context of Enlightenment and then nationalism, traditional ways of ethics and morals also were criticized in the Chinese nationalist and reformist discourses. The triggers for turning away from traditional ideologies differed from those in the West. In the West, scientific and technical developments and thus a new way of looking at the world played a great role. Among Chinese thinkers, however, the political, economic, and social decline since the beginning of the nineteenth century shook the belief in Confucian ethics and finally resulted in a general disappointment of Chinese traditional ethics and values in the late 1910 s. Although I am not sure if one can label traditional Chinese ideology, or rather ideologies as 'religion', I nevertheless find the parallelism of the developments, which ultimately lead to nationalism and a new way of narrating identities in Western and in Chinese contexts striking. In both settings, the older traditional/religious and younger enlightened/national, identities were based on, first, certain ways of behavior linked on the one hand to social rules of ethics and moral and on the other hand to cultural markers, such as language, dress, way of living and eating, occupations, etc., and second, an imagined genealogical connection and the idea of same descent. However, the emphasis of the markers shifted, and social rules, language, dress, way of living and eating, occupations, and particularly the 
idea of descent changed. New ways of imagining identity were embedded into the framework of a national identity.

Did nationalism offer a new 'religious' way of identification? Can nationalism be described as a new 'religion' in the Chinese context, too, as claimed by scholars working on West European nationalisms? And can the wish to assimilate non-Chinese peoples into the Chinese nation, their 'nationalization', be seen as a way of missionizing, as 'an organized effort for the propagation ${ }^{28}$ of Chinese nationality?

\section{Assimilation as missionizing in the context of Ming and Qing colonialism}

In a pre-19oo context, general concepts of Chinese-Confucian civilizing and change of identity indeed seem to resemble the idea of Western-Christian missionizing. Rites, rules, and morals based on the respective traditions, whether Confucianism or Christianity, were considered to be ultimately true, correct, and infallible by the bearers of the respective tradition. The assimilation of non-Confucians into the Confucian community, their adoption of Confucian rites, and the acceptance of certain rules and morals, in connection with the ability to read Chinese (at least among the upper social strata) are similar to Christianization and the Christian mission, the process of becoming part of the Christian community, based on education not only with regard to Christian ideology, but also to language and other subjects considered necessary knowledge in the context of Christian missionizing.

The similarities increase, if Chinese concepts and realities of pre-19oo 'Confucian civilizing missions' and its legacy in post-19oo assimilation and nationizing by 'China's assimilative power' are compared to approaches to Christian missionizing in the context of colonialism, especially since the nineteenth century, when ideas of racial inequality were brought into the debate. It is undeniable that the process of Christian missionizing has run parallel to that of colonization with regard to time and space since the first seafarers, financed by and supported by European powers, left Portugal and Spain for new continents in the fifteenth century. ${ }^{29}$ Colonial rule and the "Christian "conquest of the world" ${ }^{\circ}$ went hand in hand, and European Christian churches declared that European expansionism was 'God's plan'

28 I use a modified definition of 'mission' given in the Encyclopedia Britannica: 'in Christianity, an organized effort for the propagation of the Christian faith', www.Britannica.com.)

29 Gründer (2004, p. 7).

30 Gründer (p. 7). 
to propagate the 'Kingdom of God' in the world. They thus readily used the protection of the colonial states for their missions..$^{31}$ At the same time, colonial states often transferred the task of pacification of the colonies to the missionaries, who consequently became central to colonial power. Missionaries and colonial powers worked together in order to achieve the embedding of the colonized into the colonial system and structure with regard to rites, rules, and morals, which were to provide the base for a political, administrative, economical, and also linguistic integration. This integration would, however, not be an integration on eye level, but one resulting in the economical exploitation of the colonies. The pacification of the colonies managed by missionaries was thus especially based on an education of the conquered and colonized people which supported obedience and labor. ${ }^{32}$ Christianity consequently was the ideological and ritual accompaniment of Western imperialism'.33

Processes of enforced change and assimilation based on education, together with the seizure of power from local power holders and often with a displacement of the local populations, such as happened in the colonies of European imperial powers, are comparable to the processes of change in Guangdong, Guangxi, Guizhou, Yunnan, and Sichuan since the Ming Dynasty (1368-1644), when the growth of population in the Chinese (Han) inhabited regions caused increasing migration of Chinese people into these areas. Ming colonization was linked to a claim of a 'Confucian civilizing mission' ${ }^{34}$ or 'civilizing project' ${ }^{35}$ whereby 'civilizing' actually meant assimilation of the local non-Chinese/non-Confucian population into Chinese ways of living with regard to rites, rules, and morals, but also with regard to politics, administration, economy, and language. As described by John E. Herman, the official slogan of a 'Confucian civilizing mission' in fact concealed the Ming's military role in this conquest, which was an 'uninterrupted campaign of state-sponsored violence' ${ }^{36}$ In the case of European colonialism, missionaries came together with or shortly after

32 Gründer (p. 9).

33 Gründer (p. 11).

34 Herman (2007, p. 13).

35 With regard to China, Stevan Harrell uses the term 'civilizing projects' to describe 'a series of attempts by dominant powers to transform them ["peripheral peoples" or "minorities"], to make them more like the transformers, or, in the parlance of the transformers themselves, to "civilize" them'. He especially refers to 'at least four such civilizing projects', conducted by the three 'Chinese governments' as well as by 'Western missionaries' between 1842 and today: the Confucian, Christian, and Communist projects. See Harrell (1995, p. 3 and p. 17).

36 Herman (2007, p. 13). 
the armies of the colonial powers. Similarly, the 'missionaries' of ChineseConfucian culture, military officials, and civil servants, who engaged in the building of schools and temples to educate, civilize, and 'missionize' the locals, followed the military conquest immediately.

In the case of European colonialism, the purpose of educating and missionizing the colonized was based on the assumption that they were inferior to the Europeans and generally lacked culture, civilization, and, of course, the correct faith. Since the introduction of social Darwinism and Lamarckism into the discourse on colonizing and missionizing, the colonized peoples' alleged inferiority was additionally explained by their racial condition and also by their environments, which were now understood as the causes of their cultural and civilizational inferiority. Christian missionaries would compare local people, whom they perceived of as less gifted' races, to children in need of a fatherly education. Stevan Harrell argues that the 'child' metaphor demonstrates not only the inferiority of the other, but also their 'civilizability', thus giving further legitimacy to Christian or any other civilizing mission. ${ }^{37}$ The integration and dominance of colonies was furthermore justified by an evolutionary progressing image of history and culture, which argued that these people, as long as they were inferior, had to be dependent on and lead by the superior colonial power, like children were dependent on and lead by their parents (or rather, fathers).

A similar narrative can be found among Chinese scholar-officials in the Ming and Qing dynasties. They, too, argued that the non-Chinese people in the south and southwest were uncivilized and thus in need of guidance. This guidance would naturally be that of the Chinese people, who had achieved a superior culture. It was thus the duty of the respective central state to support the civilizing of these 'barbarians' in order to pacify the regions..$^{38}$ At the basis of both, the Christian and the Confucian missions, lay the assumption of European ${ }^{39}$ respectively Chinese superiority. One outcome was a depiction of non-Europeans/non-Chinese peoples as inferior, uncultivated, barbarian, even as inhuman and beastlike. In both contexts, the outsiders' group was portrayed in contrast to the insiders' group, thereby creating a highly simplified dichotomy between self and other.

37 Harrell (1995, p. 13).

38 Herman (2007, p. 230).

39 I use the term 'Europe' in a broad general sense here. It has to be mentioned, that 'Europe' did not necessarily refer to everyone on the continent of Europe, because especially in imperialist contexts, only peoples in the imperialist states were perceived as truly civilized, whereas other people in Europe were only seen as partly civilized. 
Stevan Harrell gives three different sets of metaphors, which are used in Chinese discourses to refer to the non-Chinese people until today, especially in the south and southwest, and have been in use at least since late Qing times and in some cases much longer. These three metaphors reveal the Chinese imagination of a hierarchical, but also dichotomous relationship of themselves with the non-Chinese, by positioning themselves and the non-Chinese in certain hierarchical settings with regard to family relations (father-child), gender relations (male-female), and temporal relations (contemporary-ancient).

The first metaphor, which resembles how Christian missionaries viewed their colonized 'flocks', is that of the non-Chinese as 'children'. In Chinese discourses, the child metaphor as a reference to non-Chinese people is, in fact, still in use in the People's Republic of China (PRC) today for certain 'minority nationalities' (shaoshu minzu 少數民族). Its function is to mark a clear position of the non-Chinese as children in relation to the Chinese as fathers, a relationship today also reformulated as that of 'older brother/ younger brother nationalities' (xiongdi minzu 兄弟民族). ${ }^{40}$ Like in the context of Christian missions, the 'child' metaphor refers to a patriarchal relation between family members and moreover stands for educability and civilizability.

The second metaphor Harrell mentions, identifies the non-Chinese as inferior, too, but adds another connotation. It is the metaphor of nonChinese as women. ${ }^{41}$ As Harrell points out,

sexual relations, seen as a man doing something to a woman, are a pervasive metaphor for a variety of relations of domination in many cultures, but they are particularly noteworthy in the imagery of civilizing projects. $^{42}$

Basically, uncivilized people are imagined as erotic, but also as promiscuous due to their inferior level of civilization. This image has several aspects. First, in both contexts, Christian missionizing and Confucian civilizing, rules of sexual propriety and of sexual repression, but also a high degree of hypocrisy are obvious. In the Chinese context, this imagining of nonChinese peoples as erotic and as demonstrating improper sexual behavior has been continued under Communist rule. Second, the non-Chinese 
peoples are imagined as erotic and as sexually desirable in their feminized version. This is an aspect not found in the discourse on the 'uncivilized people' in the context of Christian missions, however, it is a trope found in a Western Orientalist approach were the 'Orientals' frequently appear as erotic and female. Third, particularly in pictorial representations, many non-Chinese people are depicted as women, who wear colorful, 'exotic' clothes (or, in fact, do not wear many clothes at all). In such pictures, nonChinese women do not only function as the carriers of non-Chinese culture, but the reductionist tendencies of this portrayal deny the non-Chinese people 'in a male-dominated society, [...] full male status'. ${ }^{43}$

The third metaphor mentioned by Harrell is that of non-Chinese peoples as 'ancient'. ${ }^{44}$ Although this metaphor was sometimes used in the pre-1949 Chinese context, it gained prominence in the Communist state on the basis of historical materialism, but it has also been and still is prominent not only in the Christian missionizing context, but also in Western discourses on 'aboriginal', 'natural', or 'primitive people'. The 'ancient' metaphor serves to explain why uncivilized people indeed have no civilization, but are at the same time civilizable. This metaphor gained acceptance when racial arguments fell short. The latter could be used to explain why people were uncivilized, but they could not satisfyingly explain why these people then could be civilized, because according to racial theories savagery was inborn. Therefore, another explanation was needed. With historicism, that is, the idea of a universal pattern of linear progressive history, interpreted as a cultural, material, political, and social progress, different stages of civilizational development could be explained. At the same time, civilizability was ensured.

Until late imperial times, an often-used metaphor for non-Chinese people in the Chinese discourse similar to the 'ancient' metaphor was not that of a temporal but a spatial distance from the Chinese people and thus the civilizational center of the world. This spatiality was as symbolical as the temporality of the 'ancient' metaphor, because it did not mean that by coming closer to the civilizational center physically the 'far-away' status of the non-Chinese could be changed. Only if they approached the civilizational center with regard to morals, behavior, ethics, etc. could they come closer to civilization in the end.

The metaphors given by Harrell can be supplemented by the important 'animal' metaphor, which is a reinforced 'hierarchization'. Horst Gründer 
mentions e.g. Manoel da Nóbrega (1517-1570), a Jesuit, who equated Brazilian Indians with 'dogs' and 'pigs'. ${ }^{45}$ According to Frantz Fanon, the colonized subject 'is reduced to the state of an animal. And consequently, when the colonist speaks of the colonized he uses zoological terms'. ${ }^{46}$ Indeed, 'describing colonized people as animals who lack the ability to reason is a long-standing tradition in colonial texts', states Deborah Root. ${ }^{47}$

Within Chinese thinking, the equation of non-Chinese peoples with animals, based on the categorization of the Explaining Simple and Analyzing Compound Characters (Shuowen Jiezi 說文解字, $121 \mathrm{AD}$ ), was indeed a very old one, and groups of non-Chinese people were regarded as stemming from dogs, pigs, and other animals, symbolically or in reality, until the twentieth century. ${ }^{48}$ Although on first view the functions of the 'animal' metaphor seem to resemble that of the 'children', 'woman', and 'ancient' metaphors as it equally creates a strong hierarchy, an important difference lies in the factor of 'civilizability', which in case of the 'animal' metaphor cannot be ensured. Thus, in both, the Christian missionizing and the Confucian and Chinese contexts this metaphor could not be used to show the possibility of civilizing, missionizing, or assimilating the other, but rather that 'natural' borders between the human self and the 'animal' other had to be obtained. Therefore, the 'animal' metaphor seems not to have been part of the wider discourse on civilizing and missionizing, but rather of a different, although related discourse on the violence against the 'other' and its justification.

Another noteworthy parallel is the ideal of the 'noble savage' in the European context with its Chinese counterpart in the assumption of the non-Chinese being 'pure' in their 'simplicity'. In both cases, however, the image of the other in the end serves to criticize the culture of the self. The characterization of the 'noble savage' as pure and naturally good or human opposes the Europeans, who were corrupted despite their civilization. In the Chinese context, the non-Chinese barbarians' simplicity can on the one hand aim at deploring that the Chinese people are too soft in contrast to the barbarians, who are able to endure extreme hardship and thus be military more successful. On the other hand, the succession of chieftainship among tribal people was represented in the Chinese discourse as quasi-democratic. These representations could serve as criticism of autocratic and centralized forms of government like that of the Ming and Qing dynasties. 
In the discourse on nationalism and the integration of non-Chinese people into the Chinese nation-state these metaphors come to the surface only rarely, although they certainly informed Chinese thinkers and provided a background for their image of non-Chinese peoples. Indeed, they were influenced by many different ways of imagining the non-Chinese 'other', based on older concepts of culturalism, social Darwinism, and pseudoscientific racism, personal experience, and the assessment of the Manchu emperors and regents, etc. However, the ultimate aim of most of these thinkers was an inclusion of the non-Chinese people and territories and thus the acceptance of the possibility to assimilate them. This acceptance was again based on older narratives of the effectiveness of the Ming and Qing 'Confucian civilizing missions' (and also on the historical interpretation of non-Chinese conquest dynasties as assimilated by their Chinese subjects, a topic which I discuss elsewhere), ${ }^{49}$ which were thought to have contributed significantly to the integration of the southern and southwestern regions.

Herman argues, that a 'Confucian civilizing mission' could only really have been successful, if the Chinese social and state institutions would truly have been open to non-Chinese people, which they were not in the case of non-Chinese people in the south and the southwest. ${ }^{50}$ Based on Michael Hechter's study, Internal Colonialism: The Celtic Fringe in British National Development, $1536-1966,{ }^{51}$ which focuses on the UK and Ireland, Herman claims that the Ming government in fact created a 'cultural division of labor', instead of allowing or even supporting real inclusion and integration by their acclaimed 'Confucian civilizing mission'.

The term 'cultural division of labor' was originally introduced by Hechter to describe attempts to 'stabilize and monopolize [a superordinate group's] advantages through policies aiming at the institutionalization and perpetuation of the existing stratification system..$^{2}$ Herman uses the term to describe a certain situation in the preindustrial Ming Empire, whereas Hechter originally used the term to describe how cleavages between 'advanced and less advanced groups', or 'core and peripheral groups' developed due to the 'uneven wave of industrialization' in the UK and Ireland in particular. Nevertheless, Herman's use of the phrase for the situation in the southern and southwestern provinces of the Ming Empire makes sense, because the 
precondition for this kind of division of labor was an 'internal colonialism', which Hechter equally describes for the case of the UK and Ireland.

\section{Ming and Qing expansionisms as colonialisms}

The migration of Chinese settlers to the south, which had begun before 1368, but was institutionalized and officially supported, also by military action, under Ming rule and further professionalized under the Qing, has been labeled 'colonialism' by scholars of China's history since less than two decades. According to Emma Jinhua Teng, Peter Perdue, and others who contributed to a special issue of The International History Review titled 'Manchu colonialism' were the first scholars who used the term 'colonialism' for Qing expansionism. ${ }^{53}$ Since then it has been used especially for the Qing Empire's administration of conquered regions, but in recent times it has also been applied to the Ming Empire's inclusion of southern and southwestern regions into its provincial administration. With regard to Ming and Qing expansionism into the south and southwest, the term 'internal colonialism' has been applied as a specification of 'colonialism'.

Teng criticizes the use of the adjective 'internal' for Qing colonialism. ${ }^{54}$ According to her, the term 'internal colonialism' seems to imply that Qing colonization, for example of Taiwan and Tibet, was somehow domestic, which strengthens 'the ahistorical conception of the Qing frontiers as essentially "Chinese". ${ }^{55}$ The application of the term 'internal colonialism' to the Ming and Qing cases can make sense, however, if one differentiates between two meanings of colonialism based on two different processes. First, colonialism refers to the process of conquering territories, depriving local rulers of their power, and establishing a rudimentary colonial administration with certain instruments of military, political, and economic dominance. This process is concluded shortly after the conquest. Generally speaking, in this process, the conquerors and colonial powers are the main actors, whereas the conquered and colonized people are often forced to react. Second, colonialism also refers to a process, which begins with the conquest, continues long afterwards, and is at the same time more irreversible than the first. This is the process of enforcing and increasing the

53 Perdue (1998); Teng (2005, p. 253).

54 The term 'internal colonialism' has been in use at least since the 1950s, but became only influential since the mid-196os through Pablo Gonzalez Casanova's article 'Internal colonialism and national development'. See Casanova (1965).

55 Teng (2005, p. 254). 
colonizers' social, cultural, and mental dominance. In this second process, the colonized people are not only as active as the colonizers, cooperating unconsciously or consciously in order to achieve their respective aims in the colonial system by accepting exactly this system, they are moreover decisive to this process. ${ }^{5}$

The term 'internal colonialism' as used by Hechter referred explicitly to the second process in a specific setting. This setting was that of a colonial power, England, which integrated immediately adjacent regions as colonies: Scotland, Wales, and Ireland. The term 'internal' was maybe an unfortunate choice, and Teng is right to point to the fact that it seems to imply that the colonies were somehow domestic even before they were colonized in the first process. However, Hechter's main point, I think, was to differentiate between processes of colonialism in 'external' colonies, which are on another continent and governed in a set of administration, military, economy, and also culture and education largely different from the colonial state, from 'internal' colonies, which are not only spatially close, but which also seem to be fully integrated with regard to politics, administration, military, economy, culture, and education. Hechter argues that due to the closeness to England, the Irish, Welsh, and Scots should long ago have been absorbed into the English nation. That this has not happened, Hechter argues, is because of structures of 'internal colonialism' and the resulting 'cultural division of labor'. Against this background of Hechter's explanations, the term 'internal colonialism' becomes at least partly meaningful for the Ming and Qing cases. However, one important difference between 'internal colonialism' on the British Isles and Ming-Qing colonialism in the south and southwest are the differences between colonizers and colonized with regard to customs, language, religious beliefs, way of living, etc., which in the case of China's south and southwest are much bigger than in the case of the British Isles. In this respect, Ming-Qing colonialism comes closer to European overseas colonialism and distances itself from British 'internal colonialism'.

Teng's second critique of the term 'internal colonialism' is that it implies a fundamental difference between Qing colonialism and Western colonialism in that the former was 'only' the colonization of 'fellow Orientals'. ${ }^{57}$ Instead, Teng argues that the colonization and integration of the southern and southwestern regions into the Qing Empire functioned according to the same logics as European imperial colonialism. Her conclusion is that the study of Qing colonialism 
is important precisely because it destabilizes the dichotomy between the West/colonizers and the non-West/colonized, a dichotomy that has largely continued to structure our common sense perception of global power configurations and cultural differences well past the end of formal imperial rule..$^{8}$

Whereas I have just shown that by using the term 'internal colonialism' it is not necessarily implied that Asian colonialism is 'fundamentally different' from Western colonialism as the term has in fact been created for a European case, I agree that, indeed, not only Ming and Qing expansionism, but non-European processes of expansion and conquest in general have not been discussed under terms of colonialism and under the impression of post-colonial discourses on a general level. Only very recently a postcolonial discourse has been set into motion with regard to the Ming and Qing expansions and conquests. Among others, one reason for that, I think, lies in the fact that colonialist structures are still in existence in today's PRC, as Shu-mei Shih claims for the Tibetan, Mongol, and Uyghur inhabited regions. ${ }^{59}$ One might add to that list the southern and southwestern regions of the PRC, and the regions inhabited by the 'original inhabitants' (yuanzhumin 原住民) in Taiwan (which originally was, of course, the whole island of Taiwan). The PRC and the Republic of China (Taiwan) are the successors of the Qing Empire, also with regard to the territories which the Qing conquered militarily and integrated colonially, or took over from the Ming, 'Outer Mongolia' being the only larger conquered region which effectively broke apart.

\section{Confucian civilizing mission and Christian missionizing}

Not only the notion of a 'Confucian civilizing mission', but also the history of military conquest and political integration of the southern and southwestern regions supports the assumption that Ming and Qing expansionism can be interpreted as colonialism and can thus be analyzed based on similar theories and methods as Western colonialism. For some regions this has been done already, for example by Emma Jinhua Teng, ${ }^{60}$ who analyzes the images of Taiwan during the Qing Dynasty, and by John E. Herman, ${ }^{61}$ 
who provides a history of Guizhou's colonization from late Song until early Qing times.

With regard to the question to what extent and on what level Christian missionizing and Confucian civilizing can be compared, I first would like to point out differences, in order to clarify if they can weaken the abovementioned conclusion that European and Ming and Qing expansionisms and their accompanying civilizing projects are similar. One difference seems to lie in the spatial characters of the Christian and the Confucian communities. They are not only of different size and dispersion, but the Christian community seems to be transcultural and trans-ethnic from the start, presenting itself as non-ethnic due to its allegedly unlimited validity, whereas the Confucian community seems to be more closely linked to a certain group of people, the Chinese, who are defined and define themselves based on characteristics which are usually linked to ethnicity, that is, culture, language, genealogy, traditions, etc. Today, the perception of Confucianism as 'nationally Chinese' is further supported by the foundation of 'Confucius Institutes' as a means of transporting Chinese culture into the world outside the PRC. Confucius and the philosophy based on his teachings, Confucianism, thus appear as something 'Chinese'. However, Chinese and other Asian peoples of pre-190o or pre-nationalist times would not necessarily have agreed with this representation of Confucianism as Chinese, although the relations were strong.

An important Christian idea which accompanied colonialist and imperialist expansions was that mission as part of colonialism was the propagation of the 'Kingdom of God' or 'Kingdom of Heaven' in the whole world, whereby this godly kingdom was the realm where God's will prevailed. Similar to the Christian 'Kingdom of God' was the fundamental Confucian belief in the 'Way of [Benevolent] Kings' (wangdao 王道) to govern 'all under heaven' (tianxia 天下), that is, the whole world, whereby similar to the Christian idea, this government was transcendental and indirect. The respective missionizing or civilizing only reinforced these godly rights, which according to both were already there. Like Christians, Confucians too perceived of the Confucian philosophy as unlimitedly valid and thus trans- or non-ethnic. Therein, in fact, lies the most important reason for the idea of the missionizing or civilizing of others, so that they also become part of and accept the universality of the respective worldview. Like Christians thought and think of their ethics and morals as universal, the followers of the Confucian world view believed the same premise. Nevertheless, despite these universal claims, both, the Christian worldview underlying colonialist Christian missions and the Confucian worldview underlying the 'Confucian civilizing 
mission', are irremediably particular (and thereby resemble nationalism as described by Benedict Anderson, see above). Like Christianity 'could be de facto classified as the religion of Europe' ('faktisch als die Religion Europas gelten konnte' $)^{62}$, a 'white man's Church' ${ }^{63}$, especially when its entanglement with colonialism and imperialism became inextricable, Confucianism was an explicitly Chinese worldview, 'Chinese' here being understood as a cultural space, not a political one. This became obvious when the 'Confucian civilizing mission' was used to justify the Ming and Qing conquests and colonialism in the south and southwest and thus Confucianism became closely linked to Ming and Qing expansionism.

\section{Conclusion}

In the post-19oo political discourses, the question of how to build a Chinese nation-state was a dominant one. The idea of a successful 'Confucian civilizing mission', which was thought to work via superior ethics and morals, implemented by force if necessary, was reformulated and reformed as the idea of 'China's assimilative power'. Liang Qichao assumed this power would work unconsciously, in contrast to Zhang Taiyan, who thought that it had to be supported by official educational and political measures. The belief in its effectiveness became a basis for Chinese approaches to nation-building within the borders of the Qing Empire.

Before 1900, the discourses on civilizing and assimilation of non-Chinese people did not link this process to ethnic identity, but connected it to universally valid morals, rites, and a spiritual identity. At the beginning of the Qing Dynasty, however, there were theories of a Chinese identity based on ethnicity, for example by philosophers like Wang Fuzhi 王夫之 (1619-1692), which implied that 'Confucian civilizing' was not possible after all. However, these theories disappeared into (officially supported) oblivion. Only in the late Qing Dynasty, the works of early Qing philosophers were reprinted and became widely read among political reformers and nationalist thinkers. At the same time, Chinese identity became connected to an ethnic affiliation in a way it had not been before. Confucianism at first remained part of this identity, but was not the most important part of the 'civilizing mission' anymore, which became rather a 'nationizing mission'. In the course of the May Fourth Movement, Confucianism was even supposed to be removed 
from Chinese identity altogether. ${ }^{64}$ Based on the fact that different thinkers imagined the nation differently, the content of this 'nationizing mission' necessarily differed accordingly. However, education of the non-Chinese in Chinese ways, whatever these ways were, was usually an important part. This was based on similar assumptions, such as the belief in the legitimacy of a 'Confucian civilizing mission'. In the same way as Confucianism had been considered to be superior to other worldviews and approaches to ethnic and morals, Chinese culture and ethnicity were considered to be superior to non-Chinese cultures and ethnicities. And like in the setting of a 'Confucian civilizing mission' it was also thought to be the duty of superior people to help inferior ones to gain a 'higher' level with regard to culture and ethnicity. In the Ming and Qing dynasties, the court and officials referred to the ideal of a 'Confucian civilizing mission' in order to justify the violence of the colonization of the southern and southwestern regions for a Confucian audience. The real cause for the mission, - the acquisition of land and settlement areas at the expense of non-Chinese people - was downplayed. Against the background of the Chinese nation-building project, the ideal of a national and cultural superiority of the Chinese people was understood to inform a duty to guide others towards this superiority and thus include them in the nation-state. It was put forward to equally justify the military and political violence needed for this 'nationizing project' and to conceal the real cause for it, which was the strong belief in power politics based on the size of a state and its unity.

As described, seemingly different discourses and approaches resemble each other and are linked to each other over time and space. In the Chinese discourses, the late imperial idea of 'nationizing' is closely linked to the Ming and early Qing approaches of 'Confucian civilizing'. 'Confucian civilizing' and its link to the conquest and colonization of non-Chinese regions, on the other hand, resembles European Christian missions in Europeandominated colonies on other continents, especially South Asia, Africa, and South and Central America. All attempts to integrate the other through a change of identity with regard to ethics, morals, and other markers of the self within the framework of Christian missionizing, 'Confucian civilizing,' or Chinese nationizing are linked by a general assumption of the superiority of the self, versus the inferiority of the other, an understanding which seems to be a universal link between discourses on identity and integration. 


\section{Bibliography}

Anderson, Benedict. 2006. Imagined Communities: Reflections on the Origin and Spread of Nationalism. Rev. ed. London/New York, NY: Verso.

Atwill, David G. 2005. The Chinese Sultanate: Islam, Ethnicity, and the Panthay Rebellion in Southwest China, 1856-1873. Stanford, CA: Stanford University Press.

Bastid-Bruguière, Mariann. 2004. 'The Japanese-induced German Connection of Modern Chinese Ideas of the State: Liang Qichao and the Guojia lun of J.K. Bluntschli'. In Joshua A. Fogel, ed. The Role ofJapan in Liang Qichao's Introduction of Modern Western Civilization to China. Berkeley, CA: Institute of East Asian Studies, University of California Berkeley, Center for Chinese Studies, pp.105-124.

Bhabha, Homi K. 2004 [1994]. The Location of Culture. London/New York, NY: Routledge.

Bluntschli, Johann Caspar. 1886. Allgemeine Staatslehre. Stuttgart: Verlag der J.G. Cotta'schen Buchhandlung.

—, 1886/1971 [Engl. Trans. 1895]. The Theory of the State. Freeport, NY: Books for Libraries Press.

Casanova, Pablo Gonzalez.1965. 'Internal Colonialism and National Development'. Studies in Comparative International Development, 1(4): 27-37.

Crossley, Pamela. 1999. A Translucent Mirror: History and Identity in Qing Imperial Ideology. Berkeley, CA: University of California Press.

Fanon, Frantz. 2004 [1961]. The Wretched of the Earth. New York, NY: Grove Press. Gründer, Horst. 2004. Christliche Heilsbotschaft und weltliche Macht: Studien zum Verhältnisvon Mission und Kolonialismus. Gesammelte Aufsätze. In Franz-Joseph Post, Thomas Küster, and Clemens Sorgenfrey, eds. Europa- ̈̈bersee: Historische Studien, 14. Münster: LIT Verlag.

Harrell, Stevan, ed. 1995. CulturalEncounters on China's Ethnic Frontiers. In Studies on Ethnic Groups in China. London/Seattle, WA: University of Washington Press.

Hechter, Michael. 1975. Internal Colonialism: The Celtic Fringe in British National Development, 1536-1966. Berkeley, CA/Los Angeles, CA: University of California Press.

Herman, John E. 2007. Amid the Clouds and Mist: China's Colonization of Guizhou, 1200-1700. London/Cambridge, MA: Harvard University Asia Center.

Karl, Rebecca E. 2002. Staging the World: Chinese Nationalism at the Turn of the Twentieth Century. London/Durham, NC: Duke University Press.

Liang, Qichao 梁啟超. 1983. Yinbingshi Heji. 12 vols. Vols. 1-5: Wenji; vols. 6-12: Zhuanji. 飲冰室合集. 12 卷. 1-5 卷: 文集; 6-12 卷: 專集. Beijing: Zhonghua Press.

一, 1902/1983. 'Lun Minzu Jingzheng Zhi Dashi' 論民族競爭之大勢. In Xinmin Congbao, 2-5. 新民叢報, 2-5. Collected in Liang Qichao. Wenji 10, pp. 10-35. 梁 啟超文集 10 , 第 10-35 頁. 
一, 1903/1983. 'Zhengzhixue Dajia BolunzhiliZhiXueshuo'政治大家伯倫知理之學 說. In Xinmin Congbao, 38-39. 新民叢, 38-39. Collected in Liang Qichao. Wenji 13,pp. 67-89. 梁啟超文集 13 , 第67-89頁.

一, 1922/1983. 'Zhongguo Lishishang Minzu Zhi Yanjiu' 中國歷史上民族之研究. In Shidi Congkan, 2.2-3. 史地叢刊, 2.2-3. Collected in Liang Qichao. Zhuanji 42, pp. 1-34. 梁啟超專集 42, 第 1-34 頁.

Liu, Shipei 劉師培. 1903/1997. Rangshu. In Liu Shipei. Liu Shipei Quanji. 4 vols. vol. 2, pp. 1-17. 攘書, 劉師培全集. 四卷. II, 第 1-17 頁. Beijing: Zhonggong Zhongyang Dangxiao Press.

Llobera, Joseph R. 1994. The God of Modernity: The Development of Nationalism in Western Europe. Oxford/Providence, RI: Berg.

Millward, James A. 1998. Beyond the Pass: Economy, Ethnicity, and Empire in Qing Central Asia, 1759-1864. Stanford, CA: Stanford University Press.

Perdue, Peter. 1998. 'Comparing Empires: Manchu Colonialism'. The International History Review, 20 (2): 255-262.

Renan, Ernest. 1882/1947-1961. 'Qu'est-ce Qu'une Nation?'. In Ernest Renan, Oeuvres Complètes. Paris: Calmann-Lévy, vol. 1, pp. 887-906.

-,1882/2008. 'What is a Nation?' ('Qu'est-ce Qu'une Nation?'). In Homi K. Bhabha, ed., Martin Thom. trans. Nation and Narration. London/New York, NY: Routledge, pp.8-22.

Root, Deborah. 1996. Cannibal Culture:Art, Appropriation, and the Commodification of Difference. Boulder, CO: Westview Press.

Schneider, Julia C. 2017. Nation and Ethnicity: Chinese Discourses on History, Historiography, and Nationalism (19oos-1920s). Leiden: Brill.

Shih, Shu-mei. 2011. 'The Concept of the Sinophone'. Publications of the Modern Language Association of America (PMLA), 126(3): 709-718.

Teng, Emma Jinhua. 2005 [2004]. Taiwan's Imagined Geography: Chinese Colonial Travel Writing and Pictures, 1683-1895. Taipei: SMC Publishing. Origin in Harvard East Asian Monographs 230, Cambridge, MA: Harvard University Press.

Wright, Frank. 1988. 'Reconciling the Histories of Protestant and Catholic in Northern Ireland'. In Alan D. Falconer, ed. Reconciling Memories. Blackrock: Columba, pp.128-148.

Zhang, Taiyan. 1984. Zhang Taiyan Quanji. 6 vols. 章太炎全集. 六卷. Shanghai: Shanghai Renmin Press.

-, 1900/1984. Qiushu Chuke Ben. In Zhang Taiyan. Zhang Taiyan Quanji, III, pp. 1-106. 訄書初刻本, 章太炎全集, III, 第 1-106 頁.

—, 1907/1984. Zhonghua Minguo Jie. In Zhang Taiyan. Zhang Taiyan Quanji, IV, pp. 252-262. 中華民國解, 章太炎全集, IV, 第 252-262 頁.

Zarrow, Peter. 2005. China in War and Revolution, 1895-1949. London/New York, NY: Routledge. 


\section{About the author}

Schneider, Julia C. Assistant Professor, Department of East Asian Studies, University of Göttingen, Germany.

Email: julia.schneider@phil.uni-goettingen.de 


\title{
4 The Nation in Religion and Religion in the Nation
}

\author{
Adam Yuet Chau
}

\begin{abstract}
Two very different yet related phenomena in China's transition from a dynastic regime to a modern nation will help us better understand how the modern Chinese nation impacted on and was in turn impacted by religion. The first case is about how a rising consciousness of the nation and its impending peril allowed some grassroots literati in the early twentieth century to assign added religious significance to a traditional, primarily literati-oriented practice thus justifying, reformulating and accentuating certain religious practices (hence 'the nation in religion'). The second case is about how the nation provided the sociopolitical frame for religion while the nation itself was constituted by the 'religion sphere' (zongjiaojie 宗教界) (hence 'religion in the nation').
\end{abstract}

Keywords: religion sphere, religious sovereignty, cherishing lettered paper, script fundamentalism

\section{Introduction}

In this chapter I will attempt to look at two very different yet related phenomena in China's transition from a dynastic regime to a modern nation that are relevant to our understanding of how the modern Chinese nation impacts and is in turn impacted by religion (were it not to sound too cumbersome I would have subtitled this chapter 'How the Modern Chinese Nation Made Religion and Was at the Same Time Made by Religion'). The chapter consists of two parts. The first part is about the revaluing of a traditional religious practice at a time when Chinese civilization and the Chinese nation faced grave danger at the end of the nineteenth century and the beginning of the twentieth century. This case study reveals how a rising consciousness of the nation and its impending peril allowed some grassroots literati in the early twentieth century to assign added religious significance to a traditional literati practice thus justifying, reformulating and accentuating certain religious practices (hence 'the nation in religion'). 
The second part of the chapter is about how the newly-founded modern Chinese nation was constituted in crucial ways by various 'spheres' (jie 界), including the 'religion sphere' (zongjiaojie 宗教界). It shows how the nation provides the sociopolitical frame for religion while the nation itself is constituted by religion and other 'spheres' (hence 'religion in the nation').

\section{The nation in religion: Civilizational/national crisis and the cherishing of Chinese characters ${ }^{1}$}

In the late Qing period, China as an empire was under assault from Western imperialist powers. At the same time Chinese civilization was under assault from Western Learning (xixue 西學). In a very short time the cultural and civilizational foundations of China were questioned and the majority of grassroots literati trained in the now-useless Confucian classics faced the challenge of a new cultural-political order, one in which they could not see a viable role for themselves. At this crucial moment one religious practice came to the fore as a possible solution to dampen the process of wholesale conversion to Western culture and to reassert the primacy of Chinese civilization. In fact, the fate of the Chinese nation seemed to rest upon this religious practice. This religious practice is the 'cherishing of written characters' (xizizhi 惜字紙), which involves the reverence for the written word, especially the peculiar practice of picking up any scrap paper with any writing on it (i.e. 'lettered paper' 字紙) and burning it respectfully in a special furnace, usually located in the grounds of a temple dedicated to Lord Wenchang (Wenchang dijun 文昌帝君), the patron deity of the traditional literati. ${ }^{2}$

\section{Merits and demerits, rewards and punishments: Cherishing written characters in its earlier forms}

Cherishing written characters as a practice probably began during the Song Dynasty and became more popular during the Ming and Qing dynasties. ${ }^{3}$ $X i z i$ 惜字 practices were originally largely confined to the literati class. Scholars revered writing and worshipped Lord Wenchang in the hope of excelling in the civil service examination. Exam candidates were known

\footnotetext{
1 This section is drawn and excerpted from Chau (2013).

2 For a study on Wenchang see Kleeman (1994).

3 See Leung (1994) and McDermott (2006).
} 
to sleep overnight at a Wenchang temple hoping that Lord Wenchang would reveal the exam topics to them in a dream. Some literati members kept 'ledgers of merits and demerits' (gongguoge 功過格) that included items relating to $x i z i$ practices. ${ }^{4}$ However, the connection between $x i z i$ and Wenchang seemed to be a rather late invention; the autobiography of Wenchang supposedly written through spirit-writing in the late twelfth century, which Kleeman translated and studied, did not mention xizizhi practices at all, though it did mention at the end of the autobiographical narrative that he (i.e. Wenchang) was put in charge of the examination results and officialdom prospects (danguiji 丹桂籍). The practice of xizizhi has almost completely died out in all Chinese communities, except in a few communities in Taiwan (especially among some Hakka communities, e.g. in Meinong 美濃 county). ${ }^{5}$ But it is worth noting that some older people still hold deep reverence for lettered paper.

In the Ming and Qing dynasties as well as in the twentieth century, spirit-writing was one of the most common ways new scriptures and divine messages were produced. ${ }^{6}$ Many of the xizizhi texts indicated that they were produced by spirit-writing, almost invariably through possession by Lord Wenchang. For example, in order to help people concretize the merits of cherishing lettered paper, Lord Wenchang announced through spirit-writing the different levels (or more accurately, quantities) of rewards for those who cherish lettered paper and punishments for those who do not cherish lettered paper. The following schema is translated from Examples of Merits and Demerits Relating to Cherishing Written Characters Sent by the Lord Wenchang through Spirit-Writing (文昌帝君降乩惜字功過例).

Spending all one's life buying lettered paper and bringing it home, washing it with fragrant water and burning it: ten thousand merits; additional twelve years added to life; will enjoy prosperity and honor for a long time; descendants (sons and grandsons) will be honored and illustrious. Spending all one's life collecting lettered paper, washing it and burning it: five thousand merits; twelve additional years added to life; will attain prosperity and honor; descendants will all be virtuous and filial. Spending one's life collecting much lettered paper, washing and burning it; sending the ashes far away in clean creeks, big rivers, or the ocean: one thousand merits; descendants will be many and prosperous. 
Print and publish $x i z i$-related books and pamphlets and distribute them widely in the world: five hundred merits; many sons.

Copying and writing xizi-related books and instructions; the entire household cherishing lettered paper: three hundred merits; descendants will be rich.

When ones sees a text advocating cherishing letter paper, one keeps it so as to show one's descendants while at the same time oneself believing and respecting the practice and spreading it to others: one hundred merits; leads a peaceful life with no misfortunes. ${ }^{7}$

There is an equal number of items for demerits warning the reader of the dangers of not respecting and cherishing lettered paper.

Because of the society-wide reverence for learning and literacy, the general populace was also exhorted to cherish written characters, though in ways that were different from those practiced by the literati. For example, in one xizi-related morality 'book' (pamphlet; shanshu 善書) published in the late Qing entitled Perfected Interpretation on Cherishing Written Characters by Lord Wenchang (Wenchang dijun xizi zhenquan 文昌帝君惜字真詮) (probably composed by spirit-writing), there are twelve practices targeting the literati and eighteen practices targeting the humble folk.

For those who could read and write and were therefore in positions of power and could potentially abuse the power of the written word, their way of cherishing characters primarily involved being aware of the power of writing and therefore being extremely careful when committing words to paper. One was advised to 'cherish' writing (i.e. be extremely careful to the point of not writing at all) in the following situations: when someone's life is at stake; when someone's reputation is at stake; when someone's civil service exam results are at stake; when involving someone's private life or causing divorce; when causing the alienation and separation of family members; when causing harm to others to benefit oneself or robbing someone's livelihood; when bullying those who are weak and young; when deliberately ruining someone's plans as a result of personal vengeance; when

7 This schema is found in an anthology of miscellaneous morality tracts entitled Jiutian kaihua zhuzai yuanhuang silu Hongren Wenchang dijun yinzhiwen zhu'an 《九天開化主宰元皇司錄 宏仁文昌帝君陰騭文註案》 (Morrison Collection catalogue info: (明) 顏正註釋, (明) 顏文瑞 補案, (明) 顏章敬校刊, (清) 趙松一校; 清嘉慶二十一年 (1816) 刻本, [粤東省城] 心簡齋藏版; 版心題《丹桂籍》), which the author consulted in the Robert Morrison Collection of Chinese Books (馬禮遜藏書), collected by Robert Morrison (a missionary for the London Missionary Society between 1807 and 1834), now held in the Special Collections of the library of the School of Oriental and African Studies. 
causing people to have grievances against each other and when writing suits for others; when deliberately reversing right and wrong and harming innocent people; when writing erotic poems and songs or poking fun at others; when revealing someone's secret and causing him dishonor and a lifetime of regret. ${ }^{8}$

For members of the general public (including the literate) who did not wield the powerful brush there were eighteen don'ts or 'taboos' (jie 戒) to observe regarding lettered paper: selling torn books to others; throwing lettered paper in the dirt; stepping or stomping on lettered paper; covering windows and walls with lettered paper; covering vats with lettered paper; using lettered paper to hold up paintings; using lettered paper to wipe desks and ink stones; using lettered paper to wipe dirt; using lettered paper to make a torch at night; using lettered paper to wrap things; using lettered paper to light cigarettes/the pipe; cutting lettered paper with a knife or a pair of scissors; tearing up lettered paper while in a rage; using books as pillows; giving books/lettered paper to women to hold needles and threads; chewing lettered paper into a paste and spitting it out; sticking lettered paper into cracks in the wall; burning lettered paper into ashes and throwing them on the ground.

The Confucian elite in late imperial China had a theory about 'moral teaching' (jiaohua 教化). They believed that for the educated one needed to persuade them with reason, but for the uneducated masses one needed to use stories of 'divine retribution' (yinguo baoying 因果報應) to lure them with rewards and scare them with punishments. Most of the xizizhi literature included stories of divine retribution. It seemed that they were targeting the lower end of the literati and the masses (including the merchant class). (Apparently the so-called 'grand literati' [tongru 通儒] needed no such silly stories or indeed wanted to have nothing to do with the more vulgar forms of xizizhi.) For example, the Perfected Interpretation on Cherishing Written Characters by Lord Wenchang mentioned above included a few such stories as vivid illustrations. Such narrative format of 'proof' (zhengyan, 證驗) of the efficacy of cherishing (and not cherishing) lettered paper became standardized for later xizizhi literature; in fact, some of the earlier stories

$8 \quad$ Perfected Interpretation on Cherishing Written Characters by Lord Wenchang ('Wenchang dijun xizi zhenquan', 文昌帝君惜字真詮. This is one of the miscellaneous morality tracts collected in an anthology entitled 'Selections from the Three Teachings' 《三教擇錄》 (Morrison Collection catalogue info: (清) 陸逢泰擇錄; 清嘉慶十一年 (1806) 陸逢泰等刻本, [粤東省城] 合璧齊藏版), which the author consulted in the Robert Morrison Collection of Chinese Books (馬禮遜藏書) at the School of Oriental and African Studies. Unfortunately I do not have more detailed publication information on the original morality tract. 
were even reused and recycled (sometimes with modifications and embellishments) in later compilations.

\section{Xizizhi becoming a single-issue practice}

While in earlier times xizizhi might have been a virtuous practice among many other practices that a person could engage in with a view to accruing merits, towards the late Qing and the early twentieth century it became what might be called a single-issue practice, meaning engaging in this practice alone was supposed to bring good rewards. The analogy can be made using a modern example: it is as if simply engaging in recycling is enough to make one a good environmentalist and good eco-conscious citizen. Thus, xizizhi was advocated as a self-cultivational practice involving a single-minded devotion to written characters in the belief that such devotion will bring life-transforming benefits. The most common form of the practice in the late Qing period and the early twentieth century was to either personally do the rounds in the streets or to hire people to collect stray lettered paper. These lettered papers were collected in bamboo baskets and then brought to be burned at a specially designed 'pagoda-shaped furnace' (shengjiting 聖蹟亭 or jingziting 敬字亭), usually in a Wenchang temple. The ashes would be collected regularly and either buried in clean soil or scattered in rivers or the sea. It was believed that the long-term effects of cherishing written characters in this way included examination success (also for modern schools and universities), longevity, good fortune, good health, blessings, numerous and successful sons, etc. On the other hand, if one did not respect and cherish written characters, one would suffer ill health, poverty, misfortunes, early death, early death of one's family members and children, etc.

\section{The nation's fate lies in writing: Xizi zhengyanlu 惜字徵驗錄 and script fundamentalism}

One of my current projects is a study and translation of a morality book entitled Xizizhengyanlu 惜字徵驗錄 (Cherishing Written Characters: Stories of Evidence of Its Effects). Besides a number of introductory materials, the bulk of the book consists of eighty illustrated stories of xizi-related divine retributions that were published in 1934 by Mingshan Publishers (Mingshan shuju 明善書局) in Shanghai. (However, some of the stories seem to have been culled from earlier works, which is a quite common practice among compilers of morality books.) The version I am working with is a slightly 
augmented 1967 reprint edition of this earlier work that was published in Taiwan by Ruicheng Publishers/Bookstore (Ruicheng shuju 瑞成書局) in Taizhong 台中, a bookstore specialized in publishing and selling religionrelated books, including a large number of morality books.

The introductory materials preceding the illustrated stories included short essays explaining why one should cherish lettered paper. Judging from the rhetoric of these essays, we can tell that the xizi practice received renewed impetus during China's transition into the modern era, as modern printing technologies, journalism, and advertising were perceived to have cheapened the written word, and Western imperialism and social Darwinian discourse posed grave threats to China's civilizational superiority. Updated and reissued in the early twentieth century, the Xizi zhengyanlu blended new nationalist discourse with traditional moral values and provides a unique window into the aspirations and anxieties of the last generation of the traditional, grassroots Confucian elite. Below are excerpts from the introductory essay that give a flavor of the compiler's ideological orientation, especially how he thought that the fate of the Chinese nation is intertwined with that of the Chinese writing system:

After having done extensive surveys I have come to the conclusion that over the tens of thousands years of human history and across the hundred thousand miles of human territories, there has been no occasion when writing (literally 'characters', $z i$ 字) was not essential, and there has been no place where writing was not at the foundation of lives. In primeval times people knotted ropes to help them govern their lives: knots on big ropes for big matters and knots on small ropes for small matters. It was an age without writing, and people were ignorant and unenlightened, so even if records were inadequate there was not much they could do, until one stroke (of character) revealed the secrets of heaven and earth, and the shapes of characters were formed by observing the configurations (of stars). It was then that the usefulness of writing became abundant. Characters gave rise to writing (wen 文; composition) and writing became a vehicle for the Way (dao 道). This one [i.e. first] character opened the window to rites, music, government, and law; this one character brought about the transformations of morality and social order; this one character influenced the shape of material civilization; this one character set the guidelines for the five constants (relationships) and eight virtues; this one character created the ancient classics; the one character judged between the loyal and the treacherous, praised the good and condemned the bad. 
That is to say there was writing first and then there was a country and a society; there was writing first and then there was the relationship between father and son, husband and wife; there was writing first and then there were agriculture, craftsmanship, commerce, and learning. In addition, no social interaction does not make use of writing as its means, and no transmission of knowledge from the past to the present does not depend on writing as a treasure. How great has writing been to the human world! Alas, ever since the menacing storm of Europe and America [literally 'European wind and American rain'; oufeng meiyu 歐風美雨] blew hard on our country, the fortune of our writing has gone down precipitously. All over the country lettered papers are strewn about in a mess, being stepped on by whomever. The situation [for lettered paper] has become so dire that not a year passes without droughts, floods, epidemics, locust plagues, wars, earthquakes, and landslides. Of course one cannot say that not cherishing lettered paper alone has caused all these disasters, but writing results from the hard work of sages and virtuous men; it is the essence of heaven and earth; it is what our national treasures depend on; and it determines the fate of our culture. If we look down upon writing, it not only will not be allowed by the sages and virtuous forebears but it will also not be tolerated by heaven and earth [...].

Whether or not writing is valued or debased affects the rise and fall of the national fortune in critical ways; whether or not writing is treated well determines our lives' fortunes. I have long wanted to make everyone aware of the necessity of respecting and cherishing writing in order to recover from degeneracy and to cultivate our vitality. ${ }^{9}$ [italics added]

9 Here is the original Chinese text: 閒嘗旰衡, 古今數萬年, 縱横十萬里, 無時而不以字為 要需, 無地而不以字為命脈。上古結繩為治, 大事結大繩, 小事結小繩。無字時代, 草昧未 開, 記載關然, 此亦無可如何者也。逮至一劃開天地之祕, 觀象造文字之形, 則字之效用於 焉丕備。字以成文, 文以載道, 禮樂政刑一字之所啟符也, 彝倫做序一字之所開化也, 物質 文明一字之所薰陶也, 五常八德一字之所繩墨也, 邱墳典索一字之所創造也, 忠奸臓否一字 之所襄貶也.......是以有文字而後有國家社會, 有文字而後有父子夫婦, 有文字而後有農工商 學, 甚至往來交際無不以文字為鉒蹄, 今古流傳靡不以文字為珍寶, 夫其有益於人世不亦重 且大哉.......慨自歐風美雨咄咄逼人, 文字之景運頓遭挫折, 而字紙之狼藉, 大地皆然, 任情踐 踏, 日趨日下, 以致旱潦瘟蝗, 兵戈水火, 地震山崩, 無年不現, 雖不僅為不惜字之一端, 而文字 為聖賢之心血, 天地之精英, 國粹所賴, 文化做關, 苟其卑視, 固為聖賢所不許, 亦為天地所不 容......字之貴賤, 國運之興衰荍關; 字之藏否, 人生之休各所繫。予欲家喻戶曉俾人盡知所敬 惜有以挽頽風而培養元氣宣示久矣....... Excerpted from introductory essays written by Tang Guangxian 唐光先 and Shugu laoren 述古老人 in Cherishing Written Characters: Stories of Evidence of Its Effects ('Xizi Zhengyan Lu', 惜字徵驗錄), pp. 1-2. (Highlighting added) 
The first thing one notices about this rhetoric that differs from the earlier $x i z i$ literature is that the author does not claim to be Lord Wenchang, which is to say that this is no longer composed through spirit-writing. The second, and the most prominent feature of this rhetoric, is the connection of Chinese writing with the fate of the Chinese nation, which was perceived to be under threat from Euro-American imperialism (both cultural and military). It seems that there was an effort to enshrine Chinese writing as the foundation of Chinese civilization, which is why I call this effort (maybe even movement?) script fundamentalism. China's traditional Confucian literati were faced with the gravest challenges to their identity and ways of life in the early twentieth century, when the 'civil examination' ( $k e j u$ 科舉) system was abolished in 1905, China's national sovereignty was challenged by foreign powers, Western Learning became de rigueur for an emerging new educated class, and both state and private rituals - many of which had involved the active participation of the literati elite - were either abolished or their legitimacy and necessity questioned. It is in the context of such momentous transformations that grassroots literati in many parts of China renewed and revamped the practice of xizizhi.

Looking at the illustrated stories in the Xizi zhengyanlu, one notices some shifts in the intended audience as well as the emphasis on the benefits and harms relating to the xizi practices compared to late imperial versions of morality books of the same genre. In the Xizi zhengyanlu there are many stories of poor and even illiterate individuals who were rewarded with good fortune as a result of their devotion to xizizhi. There are also many stories in which the protagonists were merchants and small traders and shopkeepers. One may say that there was a democratization of the xizizhi practice as all members of society were thought to be capable of benefiting from the practice, and that indeed all members of society should be engaged in the practice.

This downward spread of the practice - at least in ideological terms if not necessarily in actual practice, i.e. targeting the lower segments of society rather than demonstrating that they actually adopted this practice - began in the Qing period, but became more insistent in the late Qing and the Republican period. Both Angela Leung and Joseph McDermott suggest that this downward spread of the practice reflected an effort to 'Confucianize' society, to galvanize an otherwise increasingly immoral/amoral society around a concrete practice that would yield concrete results..$^{10}$ However, if we look at the stories in the Xizi zhengyanlu, we will see that there is 
much emphasis on the magical qualities of xizi practice, which is quite unConfucian. In fact, the whole xizi practice is heavily indebted to Buddhism (the core notion of karmic retribution) and Daoism (the magical and exorcist qualities of the zizhi ashes). These karmic reward and retribution stories are a continuation of a long tradition of Confucian elites using them to cajole and scare the lower classes into line while not necessarily believing these stories themselves. ${ }^{11}$

Here is a sample story from the Xizi zhengyanlu about a company manager who, because of his practices of disrespecting writing, became a dog in the US after he died. The loss of face for the family is made to parallel the humiliation of China by the West (Westerners, Americans) as well as Japan (which invaded China and caused the destruction of the shop with writing-disrespecting practices). Below is a translation of the text:

\section{Story 22. An advocate of cigarette cards turned into a dog}

There was a certain manager of a certain tobacco company in Zhabei of Shanghai County of Jiangsu Province. He was the first to promote cigarette cards, putting as cover titles the ancient characters from books such as The Journey to the West, The Story of the Three Kingdoms, The Enfeoffment of the Gods, The Story of Jigong, The Red Lotus Monastery, The Water Margins, The Legends of Yue Fei, Seven Swords and Thirteen Knights-Errant, The Story of the West Chamber, The Dreams of the Red Chamber, etc. On the back of these cards were written, in standard script tiny as the heads of flies, the stories of these characters. As soon as people finished smoking the cigarettes, these cigarette cards mostly got thrown away. One cannot have cases of disrespecting and dirtying writing worse than this! When this manager died, he went to the United States and became a foreign-breed dog. On its belly there was writing indicating the name of this manager of such and such company. When people called its name the dog would wag its tail and shake its head as if responding to the call. They then named the dog with the name of the manager. This manager's brothers and nephews caught wind of this story. In order to protect and save their family's face they spent a lot of money buying the

11 What is interesting is that sometimes the elites did not mind admitting this strategy openly. For example, an apparently spirit-written preface to a morality book produced in Taiwan in 1937 has the following passage: 'One should talk about the wondrous with superior people, morality with middling people, and stories of karmic retribution with inferior people' (與上等人談玄妙, 與中等人語道德, 與下等人說因果). The morality book is entitled Golden Needle that Awakens ('HuanxingJinzhen', 喚醒金針), produced in the Venerate Virtue Hall of the Deng'an Society in Penghu (澎湖文澳登岸社禮善堂), see Li (2008, pp. 285-286). See also Leung (1994, pp. 112-113). 
dog, brought it back home, and tied it in a room. In year twenty-one of the Republican era (1932),Japan forcefully occupied Shanghai.Just as soon as the war broke out, this company burnt down. Those people who were in the know recognized that it was divine punishment for the manager's having initiated using cigarette cards. We plead that other companies will quickly change their ways and not follow his bad example. Then they will earn many karmic merits, benefiting themselves and society at large. [italics added]

\section{The nation, language ideologies, and religious efficacy}

Imagine that you are an early twentieth-century literatus in China, having spent years, even decades studying and memorizing passages from the Confucian classics in preparation for the civil service examinations and suddenly the examination system is abolished and everything you have learned so far has become completely useless. Not only are your chances of upward social mobility ruined, but your entire sense of identity and personhood is put under serious threat. What will you do? What will millions of other people caught in the same situation do? Of course many late-Qing literati were reform-minded and eager to jettison the old system for an entirely new educational system so as to strengthen the nation and to expel the foreign imperialists. But the majority of the literati, especially the vast number of grassroots literati whose livelihood and social standing depended so much on their being embedded in the Confucian social and moral order, were deeply conservative. Therefore it is not surprising that many of these conservative literati, when faced with such grave challenges and threats, became reactionary and searched desperately for some straw to hang on to. The 'cherishing-lettered-paper' practice seemed to be a perfect tool for these civilizational preservationists to elaborate on and to advocate as a practice, because even if they had lost the Confucian tradition as an anchor, they could still hope to hold on to the Chinese writing system as something that would never falter or fail them. ${ }^{12}$ Little did they realize that at around the

12 Constructing one's language as the foundation of a nation's identity has a long pedigree. During the so-called Romantic period and afterwards, when many nations in Europe were in the process of formation, one crucial ingredient of their nationalist striving was language, i.e. the genius of one's mother tongue. However, such nationalist linguistic ideology was primarily based on the national vernacular language as a system of spoken sounds, while the script or orthographic system was rarely mobilized as a key idiom of difference and differentiation. After all, very few European languages possessed a writing system entirely their own. The newly elaborated early twentieth-century Chinese nationalist linguistic ideology, on the other hand, 
same time there were radical reformers who were calling for the abolition of the Chinese writing system and to adopt an alphabetic system based on Latin letters, and that also around the same time the Chinese language was being 'trans-lingualized' by Japanese-invented expressions under the cloak of Chinese characters. ${ }^{13}$

In the minds of the early twentieth-century conservative literati who advocated 'cherishing lettered paper,' it was a meritorious practice not just for some select segments of society (e.g. the educated) but for the whole of the Chinese people. It is as if while the British taught the Manchu Qing some 'English lessons' (as James Hevia has characterized the British 'pedagogy of imperialism' $)^{14}$ with the Opium Wars and the siege and looting of Beijing in the wake of the suppression of the Boxers, these grassroots literati were busying themselves teaching the Chinese people another lesson, the lesson of civilizational self-preservation via the practice of 'cherishing lettered paper.' Here we have an example of the fusion of the Chinese nation with Chinese civilization, both being conceived as resting upon the Chinese writing system, which could only be saved by the practice of cherishing lettered paper, a traditional practice now endowed with nation-centric valences and heightened religious efficacy.

\section{Religion in the nation: The religion sphere in Modern China}

\section{The constitution of modern society through 'sphere-ization' and the rise of the 'religion sphere' in modern China}

In the political constitution of the modern Chinese state (from the republican times through the Maoist times to the current era), a process emerged that was very much driven by a desire to conform to international (i.e. Western) standards and practices. This process involved the recognition and production of different functional spheres in society that are similar to (or rather imitative of?) the functional constituencies or interest groups in Western

was based entirely on the writing system (and had nothing to do with the spoken language[s]), which is why this cultural movement could be labeled script fundamentalism. Such script fundamentalism was later found in Korea, whose two regimes after the Korean War both attempted to rid written Korean of Chinese characters altogether and enshrine the Korean alphabet system hangul (and of course King Sejong who invented hangul) as the genius of the Korean nation.

13 Liu (1995) and Liu (2004).

14 Hevia (2003). 
liberal states. These spheres included the education sphere (jiaoyujie 教 育界), health and medicine sphere (yiliaojie 醫療界), the manufacture and commerce sphere (gongshangjie 工商界), the labor sphere (laogongjie 勞工界), the intellectual sphere (zhishijie 知識界), the scholarly sphere (xueshujie 學術界), the women's sphere (funüjie 婦女界), the minoritynationalities sphere (minzujie), the overseas-Chinese sphere (qiaojie), the Taiwanese compatriots sphere (taibaojie), the arts sphere (yishujie), the science sphere (kexuejie 科學界), the sports sphere (tiyujie 體育界), the political sphere (dangzhengjie 黨政界), etc. ${ }^{15}$ And of course, along with these spheres one finds the 'religion sphere' (zongjiaojie 宗教界). ${ }^{16}$ I have opted to translate zongjiaojie into 'religion' sphere rather than 'religious' sphere because I want to avoid any inadvertent misunderstanding of the nature of the sphere itself as religious, which it clearly is not (see below for a discussion on how the religion sphere presumes and helps constitute the secular state).

The political utility of the concept of the religion sphere in contemporary China is manifest in its frequent appearances in the speeches of the PRC top leaders as well as official press. For example, in recent years there have been debates within the CCP about whether or not the Party can welcome religious leaders into its membership (e.g. allowing a number of religious leaders and religious elites into the Party ${ }^{17}$ ) despite the fact that in the Party constitution it says explicitly that a Communist Party member must be an atheist. And in a recent United Front speech President Xi Jinping spoke of the importance of mobilizing the religion-sphere leaders for building socialism.

Surprisingly there has not been any scholarly attention on the emergence, constitution, and transformation of these spheres in China, or indeed how

15 In more recent years new spheres have emerged, e.g. the law sphere ('falüjie', 法律界), the qigong sphere ('qigongjie', 氣功界), the stocks and securities sphere ('zhengquanjie', 證卷界), the charity sphere ('cishanjie', 慈善界), the classical learning sphere ('guoxuejie', 國學界), the NGO sphere (NGO' jie', NGO界), and even the internet sphere ('wangjie', 網界).

16 I am still trying to determine the earliest appearance of the term zongjiaojie in the Chinese context. It is possible that this was one of the 'translingualized' terms that originated in Meiji Japan (see Liu 1995) or was coined in late-Qing China by translators and writers connected to missionaries. It seems that the term was already common usage as early as 1910. For example, an article in the Chinese-language missionary periodical The True Light Monthly ('Zhenguangbao', 真光報) in 1910 (volume 9) was entitled 'On the Shortcomings of China's Religion Sphere' (論中 國宗教界之缺點). [I thank Ya-pei Kuo for bringing my attention to this article.] The True Light Monthly was a periodical published by the Guangzhou-based China Baptist Publication Society (美華浸信會印書局). (See http://www.zsbeike.com/cd/40736491.html).

17 The Chinese original is: 允许一部分宗教界的领袖人物和精英入党. 
China as a sociopolitical space has been constituted by these spheres. One main reason why this 'sphere-ization' of Chinese society has not been studied is due to the fact that 'spheres' (jie 界) as a term does not have any legal or institutional existence (though it certainly has implications for the legal management of affairs within different 'spheres,' and spheres in fact contribute to the production of institutions). In fact, I am prepared to argue that this 'sphere-ization' of Chinese society is one of the most interesting and exciting topics to study if one wants to understand how Chinese society works, especially relating to state-society relations.

A sphere is a relatively fuzzy, semi-formal sociopolitical domain comprising certain politically recognized social actors accompanied by related institutions and activities..$^{18}$ Each sphere is comprised of social actors who, consciously or unconsciously, construct and help maintain the sphere so that they can gain from their membership, or association with, the sphere. Some of these social actors have been assigned or appointed to occupy their positions within this sphere by the authorities (not always the government) while some others self-appoint or have fought their way into it. Many other social actors not operating within a sphere can also exert considerable influence over the development and shape of that sphere. For example, journalists, scholars, and bloggers can have discussions on the activities within a sphere and thus contribute to the overall construction of this sphere (e.g. witness the recent controversy in China over the improper management of NGOs in China). Sometimes particular individuals or a group of individuals outside the sphere can have more power than some of those actors inside the sphere in influencing the sphere's development. To the extent that the different spheres are constructed by actors and forces from both official and civil realms they might be said to constitute what Philip Huang calls 'the third realm', a realm of negotiation between formal state power and local elites wielding informal power. ${ }^{19}$ However, the spheres seem to have much greater conceptual concreteness than 'the third realm'.

18 A big dilemma for this study is how to translate the word jie 界. This character denotes boundaries and the area marked out by these boundaries (as in, e.g. 法界, 三界, 世界, 疆界, 邊 界, 界限, 界分, 界定, 租界, 界外, 境界, 界畫, 動物界, 劃分界線). Depending on the context and intended usage the character denotes a sector, a community, a constituency, a sphere, a circle, a realm, a field, a zone, a world, a commons, a public, etc.? It is interesting to note that the word jie has a heavy Buddhist connotative baggage since it is used to refer to the different 'planes of existence' in the Buddhist conception of the 'universe' (trailokya). See Liu (2004).

19 See Huang (1993). I thank Kuo Cheng-tian for having alerted me to the relationship between the spheres and 'the third realm'. I shall explore this relationship in more detail in future publications. 
The shape, size, and configuration of each sphere are always in flux (hence its inherent fuzziness). It is usually inchoate in the beginning of its formation (inchoate because there was great confusion or disagreement over what this sphere should consist of), but as more and more people and institutions become interested in building this sphere, it will take a more definitive and seemingly solid shape. Over time the 'rules of the game' might also become more stabilized and clear (though of course always subject to change). Since each sphere is supposed to be the structural-functional equivalent of other spheres, those spheres that were formed earlier will serve as models for the new sphere to emulate or, if necessary and expedient, to modify. This explains why the overall shapes of these spheres are quite similar to one another. On the other hand, since all spheres are supposed to be functionally different, each sphere also engages in a constant process of differentiation from the other spheres for fear of possible mergers, hostile takeovers or elimination. But this differentiation is often about the contents within, rather than the form of, these spheres (i.e. they remain more or less structurally isomorphic). Sometimes spheres do disappear, as a result of a decline in societal interest or by force (for example, the qigong sphere cum sphere disappeared in the wake of the forceful suppression by the government of Falungong and many other qigong denominations in the late 1990s). ${ }^{20}$

In theory the totality of the nation-state is to be composed of the seamless working-together of these various spheres as structural-functionalist components, together forming the nation-state's socio-taxonomical order (though admittedly this taxonomy is not as explicitly articulated as, for example, the taxonomy on minority nationalities in the PRC). Each sphere is a structural-functional equivalent of all the other spheres, while within each sphere there are sub-spheres which are in turn structural-functional equivalents of one another. For example, within the religion sphere in China today one finds, based on the five officially recognised religions, the Buddhism sphere (fojiaojie 佛教界), the Daoism sphere (daojiaojie 道 教界), the Protestantism sphere (jidujiaojie 基督教界), the Catholicism sphere (tianzhujiaojie 天主教界), and the Islam sphere (yisilanjiaojie 伊斯 蘭教界). Of course the different spheres did not emerge all at once; some spheres were invented earlier than others. Nor did the various spheres follow the same logic; for example, some constitute themselves along the lines of professions (e.g. educators, health professionals) while others by assigned sociopolitical status (e.g. women, minority nationalities) or by a 
recognized set of specialized activities (e.g. sports, arts, religion). In other words, even though these spheres bear structural and organizational similarities, they are in fact characterized by heterogeneous constitutive logics (e.g. depending on the sphere's degree of legitimacy within the polity, e.g. formal education versus religion; the degree of fuzziness of the boundaries around spheres).

The way in which Chinese society is constituted by this multitude of spheres has its origins in the transition of China from a dynastic polity to the modern nation-state form it assumed in the early twentieth century (around 1910 s to 1930s). This transition saw the flourishing of civil-society organizations in a climate of enthusiastic embrace of a modern liberal nation-state in which different social groups scrambled to be recognized by the state and be given voices in an exuberant social field (accompanied by the rise of mass print media, heightened commercialism, the penetration of imperialist and colonial influences, the import of Western models of social and political forms, etc.). The first 'spheres' emerged during this time, including the religion sphere. In fact, the religion sphere during this time was so vibrant that dozens of new sects were founded (what the historian Prasenjit Duara has called 'redemptive societies').

This effervescence of social-organizational mobilization was interrupted by the long war resisting Japan's invasion of China (from 1937 to 1945) and the civil war between the Nationalists and the Communists (1945-1949). The newly emergent spheres did not disappear during these war years; instead, they consolidated themselves and often made themselves useful for the war efforts. One may say that the national emergencies during the war years were beneficial to the formation and consolidation of these spheres since the different regimes at war needed to mobilize these social forces for their respective purposes (this was true as well for Japan at the time). Notably, for example, the (patriotic) religion sphere in war-time China came together as one voice when they conducted memorial rituals for the Chinese war dead, especially the fallen soldiers. ${ }^{21}$ After the Communist victory in 1949, the Nationalists fled to Taiwan, but both regimes, being at their core Leninist, became more authoritarian and suppressed the growth of civil society. In mainland China during the Maoist era the Communist party-state took the initiative to form and mold certain spheres, but these spheres were little more than instruments in the state's effort to mobilize society for building socialism. However, the construction of these spheres did contribute crucially to the perceived legitimacy of the new regime since 
the party-state wanted to form alliances with all useful elements of society (as part of the United Front strategy). For example, the historian Thomas Mullaney has detailed how the urgent need for representatives of minority nationalities to participate in the first People's Congress in the early 1950s formed the impetus for the Nationalities Identification (minzu shibie 民 族識別) project, ${ }^{22}$ which was essential to the further consolidation of the 'minority nationalities sphere.' In Taiwan, various spheres were subjected to a similar fate, to help the Nationalist regime prepare for fighting back to retake the mainland.

\section{Becoming 'persons of the religion sphere' (zongjiaojie renshi} 宗教界人士)

As mentioned above, within the religion sphere in the PRC one finds the Buddhism sphere, the Daoism sphere, the Protestantism sphere, the Catholicism sphere, and the Islam sphere. [In fact there is also the so-called 'sphere of the religions of the minority nationalities' (minzuzongjiaojie 民族宗 教界) but this sphere is primarily managed by the Nationalities Affairs Commission, though of course it has multiple links to the religion sphere proper as well and therefore can be included in the religion sphere.] Even though in theory the religion sphere should include all citizens practicing these different religions, but in practice and in official and common understanding when the religion sphere is mentioned it usually refers to the top representatives who represent their respective religions in the officially approved religious associations and in the media. These people are referred to as 'persons of the religion sphere' (zongjiaojie renshi 宗教界人 士). These representatives (sometimes self-appointed, often appointed by the authorities, but almost all needing to be consecrated by the state and the broader religion sphere) do have the power to speak on behalf of the religious constituencies they represent (or they are made to represent). On the one hand they are supposed to fight for the collective interests of their sphere; on the other hand they understandably engage in maneuvers that advance their own personal political ambitions or expand the influence of their own particular religious orders. To survive in the sphere requires astute political sensibilities and willingness to engage in protracted negotiations with state authorities and one's political rivals. Sometimes to protect one's religion the representatives need to make significant compromises. For example, during the Maoist period, when all religions faced extremely unfavorable 
conditions, the leaders of the major religions voluntarily submitted their religions to forms of socialist institutionalization, e.g. by becoming a work unit (danwei 單位) just like other state-run organizations. ${ }^{23}$ While those designated representatives of the religion sphere are given a voice in the public sociopolitical realm, those other members of the religion sphere are deliberately or by default silenced. For example, leaders of the underground Christian churches are never considered legitimate representatives of the Protestantism or Catholicism spheres. However, given how common and popular unofficial media has become in recent years, we might soon see the emergence of an unofficial religion sphere that is parallel to, and often against, the officially approved religion sphere.

Let us briefly look at an example of how a particular sphere, in this case the Protestantism sphere, was formed through the efforts of activists and through the construction of a unified, national ecumenical body. Beside the explosion of social forces relating to the formation of civil society during the dynastic-Republican transition, the emergence of the religion sphere was also a direct product of political activism and mobilization in response to the formidable threats from the modernist regimes (late Qing, Republican as well as Communist) and other social forces (e.g. grassroots reformers) that not only encroached upon the considerable assets of the numerous temples and shrines but even intended to eliminate religion completely as a social institution. One of the consequences of these threats was the coming-toconsciousness (at least among the religious leaders and elites) of the need to unify religious adherents under the banner of collective self-defense (against often militant secularist tendencies) and the formation of nation-wide, faith-based organizations. ${ }^{24}$ For example, in 1906, when Presbyterian pastor and Protestant leader Yu Guozhen 俞國楨 and his colleagues formed the Chinese Protestant Autonomous Association (Zhongguo Yesujiao zilihui 中 國耶穌教自立會) in Shanghai, their manifesto included statements such as: 'Chinese co-religionists of all (Protestant) denominations will not differentiate between one another by denomination or geographical region and will hopefully connect with one another (through this organization) and form one unified body." ${ }^{25}$ It is clear that this unification effort was meant for ethnically-Chinese Protestants (huajiaoyou 華教友) in China only, excluding Protestant brethren outside of China and excluding as well non-Chinese

23 See Li (2006b, pp. 652-54); Palmer (2009).

24 See Goossaert and Palmer (2011).

25 The original Chinese is: ‘各會華教友無分彼此, 不限區域. 庶幾聯絡同志, 合而為一.'(Zhang 2015: 192) 
foreign Protestants in China. This was one of the first efforts to make the Chinese Protestant community independent from their originating foreign denominational authorities. This was the moment when the Protestant sphere in China emerged despite the fact that Yu Guozhen and his colleagues did not evoke such a concept at that time. The urgency of such an initiative has also to be situated in the immediately post-Boxers Rebellion broader context.

The construction of every sphere needed activists (what are usually called 好事者, literally 'persons who love engaging in social activities and rallying support for a cause' or 社會活動家, literally 'social activists'), who are often self-appointed representatives of the emerging constituency (sphere) (such as Yu Guozhen for the Protestant sphere and Taixu 太虛 for the Buddhist sphere). Some of them managed to become recognized by both state authorities and the broader society (but never without contest or struggle) (e.g. Zhao Puchu, 趙樸初, for the Buddhism sphere during the Maoist and reform eras). Here is what Bourdieu has to say about these individuals or representative institutions, especially their artificiality:

Without being completely artificial (if it were, the building would not have been completely successful), each of these representational bodies, which give existence to represented bodies endowed with a known, recognized social identity, exists by virtue of a set of institutions that are so many historical inventions - a 'logo' (sigle in French), sigillum authenticum, as the canonists put it, a seal or rubber stamp, an office and a secretariat having a monopoly over the corporate signature and plena potentia agendi et loquendi, etc. ${ }^{26}$

What Bourdieu is referring to is precisely the kind of 'representational bodies' such as the Chinese Protestant Autonomous Association founded by Yu Guozhen and his colleagues that 'pretended' (in the sense of asserting a claim) to represent all 'two hundred and sixty thousand domestic Protestants ${ }^{27}$ as a collective body. The different regimes in modern China also prefer to endorse the formation of such representational bodies (e.g. the officially endorsed national religious associations) because these bodies and their leaders help make religious communities and their practices more 'legible' to the state and therefore more amenable to control and potential mobilization..$^{28}$ It is not a surprise that 'persons of the religion 
sphere' (zongjiaojie renshi 宗教界人士) as an expression most often refers to the leaders within these officially endorsed national-religious associations.

\section{The liberalization of society and the religion sphere in the reform era ${ }^{29}$}

Both mainland China and Taiwan became much more liberalized from the 1980 s onward. In China during the reform period (in the past thirty years), civil-society forces have grown considerably, coupled with the differentiation of societal interests along diverse lines. The liberalization of the media and the leaps in the sophistication in communications technologies have all contributed to the bourgeoning of a multitude of spheres because it has become much easier to identify a potential sphere, name it and then formalize it (with institutions, personnel, money, and other resources, activities, symbols, and discourses, etc.). The state still plays a major role in recognizing and consecrating these spheres, but it sometimes plays catch-up when new spheres are forming faster than it anticipates.

At this point it is worth noting that the Chinese conception of the religion sphere is very different from Pierre Bourdieu's analytical concept of the 'religious field' (see Bourdieu 1971). For Bourdieu, the religious field is a relatively autonomous social field with relatively clear 'rules of the game' about the value of symbolic goods. His case study is the Catholic Church in France, which, in addition to being a centralized religious body with clear boundaries, has benefited from a long history of relatively stable development and consolidation (including during periods of relative suppression under French republicanism), resulting in a condition amenable to the kind of analysis Bourdieu deploys. ${ }^{30}$ The religion sphere in China, on the other hand, is much messier and in much greater flux.

The (officially sanctioned) religion sphere proper as it stands today in the PRC-but note that this is only a portion of the overall religion sphere, which consists of a lot of persons and institutions that are merely tolerated by the state but not officially recognized - has three key components: 'persons of the religion sphere' (zongjiaojie renshi 宗教界人士), religious organizations (zongjiao tuanti 宗教團體), and 'venues for religious activities' (zongjiao huodong changsuo 宗教活動場所). In other words, in order to become an institutional player in the religion sphere (i.e. in order to register to be

29 A much fuller treatment of the rise of the religion sphere in modern China and how it works in contemporary China (including the recent emergence of a 'popular religion sphere') can be found in Chau (forthcoming).

30 See Dianteill (2003). 
recognized as a legitimate religious entity) one has to have these elements. This presents some problems for popular religious temples, which usually do not have any proper 'religious personnel' (shenzhi renyuan 神職人員) to speak of; but this requirement might urge local communities to find proper religious personnel to man their temples (or at least present themselves as if they had such personnel). All temples must also register to become 'venues for religious activities,' though in reality the vast majority of local temples in rural China go under the label 'superstition' and are not granted such privilege. In other words, the religious activities that take place at these unregistered temples are considered by Chinese law to be illegal. ${ }^{31}$ People who conduct religious activities in places not designated as venues for religious activities run the risk of getting arrested by the police and jailed. For example, Buddhist monks and nuns are allowed to conduct Buddhist rituals within the confines of their registered temples, but they are not allowed to conduct the exact same rituals outside the temples. In other words, religion is literally put in its proper 'place'. Of course a vast amount of rituals do take place outside of the limited number of officially approved venues for religious activities. The local authorities have simply chosen to turn a blind eye.

\section{The religion sphere, the nation, and state secularism}

One of the most revealing aspects about the religion sphere (as well as all the other spheres) is how it fills up the sociopolitical space of the nation. Precisely because the religion sphere has to be coextensive with the nation (in its institutional and imaginary reach), it is as much an 'imagined community' (Anderson 1991) as the nation: a lay Buddhist practitioner or a Protestant church-goer is led to imagine himself or herself as a member of the Buddhism sphere or Protestant sphere of China. In theory a nation can have only one religion sphere (even if underneath this umbrella sphere there can be a multitude of local spheres or a number of sub-spheres, e.g. the Shanghai religion sphere is a local religion sphere subordinate to the national religion sphere), and each sphere can only occupy one nation. The very act of the sphere-ization of society is to accentuate and solidify the boundaries of the nation. We may even go as far as saying that the formation of the spheres is necessary to the construction and maintenance of the sovereignty of the nation (hence 'religion in the nation' in the title of this chapter). Each nation has its own spheres. One nation's sphere of a

31 See Chau (2006) for a case study of how a popular religious temple came to be registered as a Daoist temple, thus gaining official protection. 
certain kind (e.g. religion) can interact with its analogous bodies in other nations but they do so based on the principle of nation-based, 'sphere-ized' autonomy. The religion sector in China should never be invaded by foreign bodies. This is one of the conceptual-structural reasons why the Chinese state is so wary and intolerant of any foreign interference with affairs within its own religion sphere; the nation's 'religious sovereignty' (i.e. the inviolability of the [imagined] borders of the nation's religion sphere) is coextensive with the nation's political sovereignty and neither is to be violated. ${ }^{32}$

Another revealing aspect of the religion sphere is that it is constitutive of the overall construction of secularity (the very existence of the religion sphere as a discrete social category attests to the efficacy of state secularism); i.e. the existence of the religion sphere qua sphere presumes secularity. In fact, China's state secularism stands out as an exception amongst many Asian nations. In contrast, most other Asian countries have placed far more emphasis on the nation's religious identity: modern Japan from the Meiji era to the end of World War II, with Shinto enshrined as the state's spiritual foundation; post-colonial/Independence India, with the nation considered fundamentally Hindu; post-colonial/Independence Indonesia, with the requirement that all citizens must believe in God and belong to one of five officially recognized religions: Islam, Protestantism, Catholicism, Hinduism, and Buddhism; post-colonial/Independence Malaysia, with Islam as the 'religion of the Federation'; modern Thailand, with Theravada Buddhism as quasi state religion; not to mention Pakistan and Bangladesh, with Islam as state religion, or Nepal up to 2006, with Hinduism as official religion. ${ }^{33}$

\section{Conclusion}

Religion and nation have had a complicated relationship in history. Religious adherence (especially the exclusivist, confessional kind) was often the foundation of ethnic group identity, which could serve as the foundation of

\footnotetext{
32 This 'religious sovereignty' should not be confused with any sense of autonomy which is the goal of some religious practitioners; the latter refers to autonomy from state interference. Autonomy is an important attribute of religious sovereignty but it is about the religion sphere as a key-constituting element of the nation being autonomous from foreign influence.

33 One of the manuscript reviewers pointed out that PRC secularism 'was/is based on its monopoly power or control over cosmological truth'. I think such a monopoly was only true during the high Maoist era but is no longer true today. The considerable liberalization in the religion sphere has produced a plethora of cosmological truths, the monitoring of which by the reform-era state is nearly impossible.
} 
nationhood (especially in early modern Europe). The nation, once formed, often served as the territorial and institutional basis for fostering and elaborating a nation-centric religiosity and religious identity (from Henry VIII's Church of England to Emperor Meiji's state Shinto, Ghandi's Hinduism, and even Taiwan's island-wide Mazu cult). Though not historically inevitable, such nation-centric religiosity and religious identity often led to more explicit forms of religious nationalism in which religious actors and institutions engaged in explicitly pro-home-nation, patriotic practices.

Neither of the two cases presented in this chapter are about religious nationalism per se but they demonstrate that the relationship between religion and nation in modernity is much more complicated than the notion of religious nationalism can capture.

\section{Bibliography}

Anderson, Benedict. 1991. Imagined Communities: Reflections on the Origin and Spread of Nationalism. London: Verso Books.

Bourdieu, Pierre. 1971. 'Genèse et structure du champ religieux'. Revue Française de sociologie, 12(2): 295-334.

-.1985. 'The Social Space and the Genesis of Groups'. Theory and Society, 14(6): 723-744.

Brokaw, Cynthia J. 1991. The Ledgers of Merit and Demerit: Social Change and Moral Order in Late Imperial China. Princeton, NJ: Princeton University Press.

Chau, Adam Yuet. 20o6. Miraculous Response: Doing Popular Religion in Contemporary China. Stanford, CA: Stanford University Press.

—. 2013. 'Script Fundamentalism: The Practice of Cherishing Written Characters (Lettered Paper) (惜字紙) in the Age of Literati Decline and Commercial Revolution'. In Philip Clart, ed., New Approaches to Studying Chinese Popular Religion and Sectarianism 中國民間宗教民間信仰研究之中歐視角. Taipei: Boyang Publishers, pp. 129-167.

—. Forthcoming. “The "Religion Sphere” (zongjiaojie 宗教界) in the Construction of Modern China'. In Stefania Travagnin and Gregory A. Scott, eds., Critical Concepts and Methods for the Study of Chinese Religions II: Intellectual History of Key Concepts. Berlin: Walter de Gruyter.

Clart, Philip A. 1996. 'The Ritual Context of Morality Books: A Case-Study of a Taiwanese Spirit-Writing Cult'. Ph.D. dissertation, University of British Columbia, 1996.

—. 2003. 'Chinese Tradition and Taiwanese Modernity: Morality Books as Social Commentary and Critique'. In Philip Clart and Charles B. Jones, eds., Religion 
in Modern Taiwan: Tradition and Innovation in a Changing Society. Honolulu, HI: University of Hawaii Press, pp. 84-97.

Dianteill, Erwan. 2003. 'Pierre Bourdieu and the Sociology of Religion: A Central and Peripheral Concern', Theory and Society, $32(5 / 6)$ (Special Issue on the Sociology of Symbolic Power: A Special Issue in Memory of Pierre Bourdieu): 529-549. Goossaert, Vincent. 2006. '1898: The Beginning of the End for Chinese Religion?' Journal of Asian Studies, 65(2): 307-336.

-. 2008. 'Republican Church Engineering. The National Religious Associations in 1912 China', in Mayfair M.-H. Yang, ed., Chinese Religiosities: Afflictions of Modernity and State Formation, Berkeley, CA: University of California Press, pp. 209-232.

Goossaert, Vincent and David A. Palmer. 2011. The Religious Question in Modern China. Chicago, IL: University of Chicago Press.

Hevia, James L. 2003. English Lessons: The Pedagogy of Imperialism in NineteenthCentury China. Durham, NC: Duke University Press.

Huang, Philip C.C. 1993. "Public Sphere”/“Civil Society” in China?: The Third Realm between State and Society'. Modern China, 19 (2): 216-240.

Jordan, David K. and Daniel L. Overmyer. 1986. The Flying Phoenix: Aspects of Chinese Sectarianism in Taiwan. Princeton, NJ: Princeton University Press.

Kleeman, Terry F. 1994. God's Own Tale: The Book of Transformations of Wenchang, the Divine Lord of Zitong. Albany, NY: State University of New York Press.

-, trans. 1996. Commentary on Lord Wen[chang's] Text of Hidden Administration (Wendi yinzhiwen zhu 文帝陰鴜文註). In Donald S. Lopez, Jr., ed., Religions of China in Practice. Princeton, NJ: Princeton University Press, pp. 64-71.

Leung Ki Che, Angela 梁其姿. 1994. Qingdai de xizizhihui 清代的惜字紙會 (Associations for Cherishing Written Characters during the Qing). Xinshixue 新 史學, 5(2): 83-115.

Li Shiwei (Li Shi-Wei) 李世偉. 2008. Rizhi shiqi luantang de rujia jiaohua .In Li Shiwei, Taiwan fojiao, rujiao yu minjian xinyang: Li Shiwei zixuanji 日治時期 鸞堂的儒家教化. 台灣佛教,儒教與民間信仰: 李世偉自選集. Taipei: Boyang wenhua, pp. 269-290.

Li Xiangping. 2006a. Zhongguo dangdai zongjiao de shehuixue xuanshi (The Sociological Analysis of Contemporary Chinese Religion). Shanghai: Shanghai renmin chubanshe.

-. 2006b. Xinyang, geming yu xuanli zhixu: zhongguo zongjiao shehuixue yanjiu (Beliefs, Revolution and Power Structure: Sociological Studies on Chinese Religion). Shanghai: Shanghai renmin chubanshe.

Liu, Lydia H. 1995. Translingual Practice: Literature, National Culture, and Translated Modernity - China 19oo-1937. Stanford, CA: Stanford University Press.

-. 2004. The Clash of Empires: The Invention of China in Modern World Making. Cambridge, MA: Harvard University Press. 
McDermott, Joseph P. 2006. 'Sacred Books and Sacred Trash'. In Colloquies on Art and Archaeology in Asia. No. 23: The Art of the Book in China. London: Percival David Foundation of Chinese Art, School of Oriental and African Studies, University of London, pp. 207-218.

Mullaney, Thomas S. 2011. Coming to Terms with the Nation: Ethnic Classification in Modern China. Berkeley, CA: University of California Press.

Nedostup, Rebecca. 2010. Superstitious Regimes: Religion and the Politics ofChinese Modernity. Cambridge, MA: Harvard University Asia Center.

Palmer, David A. 2007. Qigong Fever: Body, Science, and Utopia in China. New York, NY: Columbia University Press.

—. 2008. 'Heretical Doctrines, Reactionary Secret Societies, Evil Cults: Labelling Heterodoxy in twentieth Century China', in Mayfair Yang, ed., Chinese Religiosities: the Vicissitudes of Modernity and State Formation. Berkeley, CA: University of California Press, pp. 113-134.

—. 2009. 'China's Religious Danwei: Institutionalising Religion in the People's Republic', China Perspectives, 4: 17-30.

Scott, James L. 1998. Seeing Like a State:How Certain Schemes to Improve the Human Condition Have Failed. New Haven, CT: Yale University Press.

Watson, James L. 1985. 'Standardizing the Gods: The Promotion of T'ien Hou ('Empress of Heaven') along the South China Coast, 960-196o'. In David Johnson, ed., Popular Culture in Late Imperial China. Berkeley, CA: University of California Press, pp. 292-324.

$\mathrm{Wu}$ Yanghe (Wu Yang-ho) 吳煬和. 2010. Wenjiao, xinyang yu wenhua jian'gou Taiwan liudui jingzi fengsu yanjiu 文教、信仰與文化建構一台灣六堆敬字風 俗研究. Ph.D. dissertation, National Donghua University.

Yang, Fenggang. 2006. 'The Red, Black, and Gray Markets of Religion in China'. The Sociological Quarterly, 47: 93-122.

Yang, Mayfair Mei-hui, ed. 2008. Chinese Religiosities: Afflictions of Modernity and State Formation. Berkeley, CA: University of California Press.

Zhang Hua 張化. 2015. Shehui zhong de zongjiao: guancha yu yanjiu 社會中的宗 教: 觀察與研究. Shanghai: Shanghai Renmin Press.

Zhang Zhiyuan (Chang Chi-Yuan) 張志遠. 2006. Taiwan de jingziting 台灣的敬 字亭. Taipei: Yuanzu wenhua.

\section{About the author}

Chau, Adam Yuet. University Senior Lecturer in the Anthropology of Modern China, Department of East Asian Studies, University of Cambridge, United Kingdom. Email:ayc25@cam.ac.uk 



\title{
$5 \quad$ History and Legitimacy in Contemporary China
}

\author{
Towards Competing Nationalisms
}

Robert D. Weatherley and Qiang Zhang

\begin{abstract}
This chapter examines how the Chinese Communist Party is using Chinese history to bolster its nationalist legitimacy. Drawing on two case studies - the Anglo-French destruction of the Old Summer Palace (1860) and the legacy of the Republican era (1912-49) - we identify two different types of nationalism. The first is a confrontational form of nationalism, emphasizing the trauma associated with the Old Summer Palace incident and intended to incite public resentment towards 'hostile' foreign powers. The second is more consensual, emphasizing common ties with the KMT and intended to demonstrate a commitment to peaceful reunification with Taiwan. However, in both cases, an energetic public debate has arisen in which critics have accused the CCP of inadequately safeguarding Chinese sovereignty.
\end{abstract}

Keywords: China, history, legitimacy, nationalism

\section{Introduction}

The use of historical memory to stimulate popular nationalist sentiment is second nature to the Chinese Communist Party (CCP). The harrowing and often bitter memories associated with the First Opium War, ${ }^{1}$ the Second Sino-Japanese $\mathrm{War}^{2}$ and the Korean War ${ }^{3}$ are comprehensively documented in the annals of CCP history and frequently articulated by the state-controlled media. Sometimes the trigger for an official reminder is to commemorate the anniversary of an event epitomizing China's subjugation by foreign powers or to mark the end of an imperialist war, be it Japanese,

$1 \quad$ Lovell (2011).

2 Mitter (2000).

3 Hays Gries et al. (2009). 
Korean or otherwise. Sometimes the reminder is precipitated by a perceived act of foreign aggression or a diplomatic slight against China. On other occasions, there is no obvious reason. The aim is just to keep the memory fresh in Chinese minds.

The first part of this article examines a particularly traumatic event in China's historical memory - the destruction of the Old Summer Palace (Yuanmingyuan 圓明園) by British and French forces in 1860 in retaliation for the kidnap, torture, and in some cases murder of a small delegation of Anglo-French representatives who had arrived in Beijing to enforce the terms of the 1858 Treaty of Tianjin. ${ }^{4}$ Since the early 1990s, there have been increased reminders of this incident in an effort to whip up a sense of public indignation not only towards Britain and France, but towards other former imperialist powers for the wrongs that they inflicted on China during the Century of Humiliation. This in turn enables the CCP to highlight the success with which it liberated China from that traumatic era and transformed the country into a major international power. We refer to this approach as confrontational nationalism.

The second part of this article examines a more conciliatory nationalist position adopted by the CCP in relation specifically to the Nationalist Party (KMT 國民黨) and Taiwan. Here again, the emphasis is on China's recent history, but rather than concentrating on humiliation, the focus is more upbeat and optimistic, looking at the achievements of the Republican era when the KMT intermittently ruled China. In contrast to Yuanmingyuan, the CCP has not taken the lead in articulating a clear official line on the era. Rather it has relaxed the parameters of permissible debate to allow the public to do so. But the broad objectives are equally as nationalistic with the party seeking to present itself as flexible, tolerant, and with the interests of national unity and reunification with Taiwan as its core interest.

However, these attempts by the CCP to fortify its nationalist credibility are not proving to be altogether successful because in both of our examples the party has precipitated a response from members of the scholarly, media and online (or 'netizen') communities that is critical of the party and has even questioned its nationalist credentials. On Yuanmingyuan, some sceptics have accused the party of deliberately fabricating the official narrative of the incident for political purposes, of wasting time and public

4 Twenty members of the group died in captivity, including a correspondent for the London Times. The other sixteen, including the British envoys Henry Loch and Harry Parkes, were released after surviving for almost two weeks in the infamous Board of Punishments. For more information on the prelude to the Yuanmingyuan incident see Wolseley (1862) and BBC (2015a). 
money on the restoration of the site and ultimately of failing to protect China against foreign domination despite more than 6o years of party rule, drawing parallels with China's weakness under the Qing Dynasty. Critics have been even more vocal on the Republican era debate, accusing the CCP of with holding basic civil freedoms in contrast to those enjoyed during the Republic, of holding the country back economically and of inadequately safeguarding Chinese sovereignty after the establishment of the People's Republic of China (PRC) in 1949 in comparison to the KMT's pre-liberation record. Ironically, instead of augmenting its nationalist legitimacy, the CCP has set in motion a process that is serving to erode its legitimacy.

\section{Confrontational nationalism - Yuanmingyuan}

Despite the often anti-Western rhetoric of the Mao regime, official denunciations of the Yuanmingyuan incident were surprisingly rare under Mao. The apparent lack of significance attached to this incident was further reflected in the physical neglect of the site, with little effort being made to protect it, despite the area being declared a municipal park at the request of Zhou Enlai 周恩來. This led one disgruntled observer to comment that:

This sacred site - 'the garden of all gardens' - has now become a festering ground crowded with garbage heaps, vegetable plots, pigsties, and bean curd presses! Motley groups of peasant and migrant families have converged here in the thousands to make a living and to multiply in a disorderly and slipshod manner, generating pollution at a shocking speed and hastening the final deterioration of Yuanmingyuan. ${ }^{5}$

It was only during the 1980 s that the CCP began to turn its attention to Yuanmingyuan. A government bureau and a scholarly committee was formed, symposia and writing forums were held and the party reclaimed Yuanmingyuan as a historical site, authorizing the creation of the Yuanmingyuan Ruins Park which has been open to tourists for some time. ${ }^{6}$ The west side of Yuanmingyuan was moderately renovated in 2005, several small temples have been rebuilt and there are a number of tourist attractions including a museum, a small funfair, countless souvenir shops and even Jet-Ski rides on one of the main lakes. Tourists are allowed to trample around

5 Wang (1999, p. 80o).

6 Lee (2009, p. 156). 
and touch the ruins with no apparent restrictions placed on photography. Julia Lovell believes that the CCP is finally capitalizing on the propaganda value of the Yuanmingyuan ruins, 'replacing the pigsties and piles of rubbish with new signs littered across the gardens reminding visitors of what would have been there, if the British and French had not burnt or stolen it first'. ${ }^{7}$ But taken as a whole, the site remains largely untouched as the CCP contemplates what to do with it.

\section{Constructing a historical legacy}

In contrast to the current uncertainty over the physical fate of the site, the party has acted much more decisively over its historical legacy, placing the Yuanmingyuan incident firmly on the Chinese political agenda by keeping it in the public memory. This was first apparent with the launching of the Patriotic Education Campaign in the early 1990s. For example, the 1991 Circular on Fully Using Cultural Relics to Conduct Education in Patriotism and Revolutionary Traditions made direct reference to the destruction of Yuanmingyuan and stressed the importance of retrieving the stolen antiques, describing this as the 'patriotic duty' of all Chinese citizens. As the campaign spread into the education sector, school children, including those at primary school level, were (and still are) taught in detail about the indignity of Yuanmingyuan within the wider context of the Century of Humiliation and students of all ages are required to visit the site, officially designated as one of several 'patriotic education bases'. ${ }^{8}$ Anecdotal evidence suggests that students are encouraged to articulate their feelings of disgust towards Western states both at the site and back in the classroom. In addition, numerous signs have been erected in and around Yuanmingyuan reminding visitors of the incident and there is even a 'Never Forget National Humiliation' memorial wall on which details are inscribed of 'the sordid history of European and American incursions into China, of opium dealing, and the imposition of unequal treaties that made up the century of humiliation'. 9

Another way that the party has sought to preserve the traumatic memory of Yuanmingyuan is to recall the incident whenever it believes that foreign powers are still acting aggressively towards China, using the state-controlled media to articulate its views. So, for example, following the 
US-led NATO bombing of the Chinese Embassy in Belgrade in May 1999, an article published in the People's Daily made a direct comparison between the bombing and the destruction of Yuanmingyuan, stating dramatically that 'through the Embassy riddled with bullet holes covering the charred building, I can see reflected the destroyed ruins of the Yuanmingyuan'. ${ }^{10}$ Another People's Daily article angrily insisted that China would never again be downtrodden by Western powers, citing the burning of Yuanmingyuan as one in a series of past humiliations that must never be repeated:

This is not a period when Western forces can plunder the imperial palace at will, burn down the Yuanmingyuan and snatch Hong Kong and Macao, nor is it the same period as when the corrupt Qing government or Jiang Jieshi 蔣介石(or Chiang Kaishek) ruled. China has already stood up. ${ }^{11}$

Similar impassioned analogies to the Yuanmingyuan incident were made to mark the tenth and fifteenth anniversaries of the US attack.

The hosting of international events in China has also been used by the CCP to resurrect the memory of Yuanmingyuan. This was first apparent during the 1990 Asian Games in Beijing when a number of newspaper articles made reference to the incident. One article suggested that China was much stronger in 1990 than it was in 1860 and was in a much better position on the world stage as it moved towards the 21st century. ${ }^{12}$

There were even more references to Yuanmingyuan in the build-up to the 2008 Beijing Olympics. The Xinhua News Agency used the Olympics to draw a symbolic and rather exaggerated comparison between the ruins of Olympia and the ruins of Yuanmingyuan and an even more exaggerated comparison was made between the flames of the Olympic torch and the flames that engulfed the palaces. ${ }^{13}$ The state media's tone became confrontational in reports about overseas demonstrators disrupting the Olympic torch relay in protest at China's human-rights record in Tibet. Particular venom was directed towards French protestors and the perceived support given to them by the French government and media, who were accused of gross hypocrisy in the context of Yuanmingyuan. As the People's Daily put it 'if France wants to talk to China about human rights, they first need to apologize for what they did to Yuanmingyuan and then return the great 
quantity of Chinese relics that they stole'. ${ }^{14}$ Following this, opinion polls in China (cited gleefully in the People's Daily) showed a sharp decline in positive feelings towards France ${ }^{15}$ and a sudden increase in the public boycotting of French goods, suggesting that the media campaign against France was succeeding. ${ }^{16}$

The media often publishes dramatic personal accounts made by visitors to the site. One article claims that 'in Yuanmingyuan's scorched ruins, I see a pool of blood'. ${ }^{17}$ Another article laments Yuanmingyuan's 'former imperial glory that has been reduced to a royal scar' ${ }^{18}$ A report in China Aviation News describes the ruins as like a bleeding wound, still tingling in each Chinese descendant'. ${ }^{19}$ Even articles which refer fleetingly to Yuanmingyuan rarely fail to make mention of its destruction. For example, a seemingly innocuous article about the completion of the Beijing Number 4 subway line observes how the new line passes through Yuanmingyuan and then automatically defaults to anguished and protracted descriptions of its annihilation, completely changing the original focus of the article. ${ }^{20}$

The media interest in Yuanmingyuan reached its peak in the build-up to the 150th anniversary of its destruction on 17 October 2010. The first commemorative articles started appearing as early as January 2010, with the Wenhui Bao suggesting (somewhat controversially as it turned out) that China was considering inviting an Anglo-French delegation to attend the anniversary ceremony. ${ }^{21}$ This was followed by a plethora of other articles and new reports about, for example, the month-long schedule of events prior to the anniversary date culminating in a live performance by Jackie Chan $^{22}$ and a salt sculpture exhibit in Taipei replicating the looted and muchheralded twelve 'zodiac animals', thereby emphasizing the cross-straits significance of the anniversary. ${ }^{23}$ These zodiac animals were removed after the Democratic Progressive Party took over the Taiwan government in 2016.

\footnotetext{
Renmin Ribao (2008a).

Renmin Ribao (2008b).

Xinhua Wang (2008).

Renmin Ribao (2009).

Renmin Ribao (2010a).

Zhongguo Hangtian Bao (2010).

Guangzhou Ribao (2009).

Wenhui Bao (2010).

2 Xinhuashe Zhongwen Xinwen (2010a).

3 Zhongguo Xinwenshe (2010).
} 


\section{The nationalist rationale}

The rationale for resurrecting the memory of Yuanmingyuan in such a deliberate and concerted manner draws directly on the CCP's quest for nationalist legitimacy. Following the crisis of economic legitimacy that led to mass nationwide demonstrations in spring 1989, particularly in Tiananmen Square, the CCP was forced to diversify the basis of its popular legitimacy to include nationalism. As overseas governments lined up to criticize the party for using military force to disperse the Tiananmen protestors, the party looked to position itself as the sole defender of Chinese national interests in the face of a seemingly hostile West. A key aspect of this approach has been to utilize the legacy of Yuanmingyuan which it has done in two interrelated ways. Firstly, Yuanmingyuan reminds the Chinese people of just how 'bad' life was during the Century of Humiliation. The destruction of the palaces, with their ruins still visible today, is ideal for these purposes, carefully depicted as the living epitome of a terrible period in China's history. By the same token, Yuanmingyuan is a reminder of just how 'good' life is under the CCP. After 'liberating' China from foreign imperialism in 1949, the CCP is guiding China single-handedly towards superpower status and restoring China to its rightful place in the world. So the dual objective is to create public antagonism towards the West and public gratitude towards the CCP.

Much of the party's rhetoric bears this out. We noted earlier a reference in the People's Daily to the West no longer being able to 'plunder the imperial palace at will, burn down the Yuanmingyuan and snatch Hong Kong and Macao'. The message is clear: the Century of Humiliation is now over and the CCP ended it. Similarly, the claim that 'China has already stood up', drawing conveniently on Mao's words at the Gate of Heavenly Peace on 1 October 1949, strongly implies that the CCP is responsible for this. Likewise, the references to Yuanmingyuan when China hosts major international events such as the Beijing Olympics is intended to contrast the humiliations of the past with the triumphs of the present, again brought about by the CCP. The Olympics was depicted as a prime example of national rejuvenation, proof that China, under the CCP, is no longer the 'sick man of Asia'.

\section{Returning the antiques}

One of the key areas of controversy surrounding the Yuanmingyuan incident is the current location of the antiques that were stolen by the British and French in 186o. The precise number is difficult to quantify. UNESCO has estimated that of the 1.6 million Chinese antiques stored in more than 200 
museums across 47 countries, approximately one million were taken from Yuanmingyuan. These include a two-metre high Buddhist stupa currently housed at the Chinese pavilion in the Fontainebleau Palace near Paris and a painting of one of the 'forty scenic sites' of Yuanmingyuan displayed in the Paris National Library. ${ }^{24}$

With this in mind, the official Chinese media has campaigned hard for the return of the stolen antiques. Although there were sporadic efforts during the 1990s, ${ }^{25} 2009$ saw a considerable rise in media-influenced public support for the campaign after a group of Chinese lawyers working overseas formed a 'patriotic alliance', seeking to apply international law in order to facilitate the return of the antiques. ${ }^{26}$ The CCP has also funded teams of experts to travel across the world and make contact with foreign museums in an effort to bring back the stolen items. ${ }^{27}$

The nationalist symbolism associated with the stolen Yuanmingyuan treasures is palpable and has been enthusiastically developed and exploited by the CCP in its quest to whip up a nationalist zeal against former imperialist powers. For example, the theft of the treasures is depicted as a devastating wound struck at the very heart of the Chinese nation whilst their return is portrayed as part of 'a long and arduous road towards national salvation'. ${ }^{28}$ Each time Yuanmingyuan antiques are returned to China this is seized upon as a great victory for the Chinese nation. ${ }^{29}$ But it is depicted only as a partial victory given that many treasures remain scattered throughout the world thereby constituting a continued humiliation for China. ${ }^{30}$

As noted above, the return of Yuanmingyuan antiques (often by Chinese bidders) is welcomed in the Chinese media. However, sometimes reports on foreign auctions of the antiques are designed to generate resentment and anger amongst the Chinese people, especially when Chinese bidders pay a fortune to buy back what was stolen from China in the first place. The Liberation Army Daily described these auctions as an affront to China's national dignity 'going against the spirit of international conventions and inflicting serious harm on China's cultural rights and national emotions'.$^{11}$ A People's Daily article described foreign claims that there was nothing

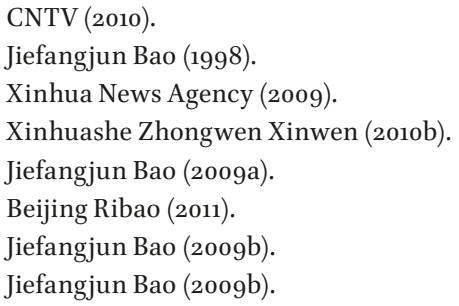


wrong in auctioning the antiques as an example of the continuing 'undisguised gangster logic' and 'cultural hegemony' of Western nations. ${ }^{32}$

The most high-profile foreign auction of Yuanmingyuan antiques took place in Paris in 2009. When Christie's tried to sell the rat and rabbit 'zodiac' heads collection owned by the late fashion designer Yves Saint Laurent and his business partner Pierre Berge, there was widespread condemnation in China and demands that the statues be given back to China free of charge. Particular outrage was sparked when Berge said that he would happily return the antiques if China promised to improve its human-rights record, return Tibet to the Tibetans and authorize the safe return of the exiled Dalai Lama. ${ }^{33}$ In response, there were numerous public protests in China and a number of petitions were signed demanding that the antiques be handed back immediately, not sold at auction. In addition, a group of 81 Chinese lawyers filed a suit in France in an attempt to halt the proposed auction. ${ }^{34}$ Meanwhile, Chinese Foreign Ministry spokesman Ma Zhouxu condemned the apparent hypocrisy of Western states on the question of human rights and noted that 'Western imperial powers have looted a lot of Chinese cultural relics. These cultural relics should be returned' ${ }^{35}$

In the end, the auction went ahead but ended in farce. Although the antiques were 'sold' to Cai Mingchao, an established Chinese collector and adviser to China's National Treasures Fund for 15 million Euros each, Cai refused to pay, claiming, in what can only have been a publicity stunt approved by the party, that his bid was made purely 'on patriotic grounds' ${ }^{36}$ Cai was hailed as a national hero back in China, but Christie's declared his actions unlawful and threatened to bring a suit against him. Ownership of the two heads reverted back to Pierre Berge. However, in April 2013 they were returned to China by the family of the French billionaire FrançoisHenri Pinault who now owns Christie's. Neither Christie's nor the family office would confirm whether or not the Pinaults had purchased the heads from Berge prior to their return, but the gesture was a clear attempt at strengthening economic ties between France and China. This is because it coincided with an official visit to China by President François Hollande, accompanied by François-Henri Pinault. ${ }^{37}$ 


\section{Dissenting voices}

In his book entitled What Does China Think?, Mark Leonard has described the destruction of Yuanmingyuan 'as an open wound that can be salted whenever citizens need to be mobilized or reminded of how the Communist Party saved China from foreign defeat'. ${ }^{8}$ To some degree, Leonard's analysis is accurate. In response to the frequent official reminders of the incident, some people have duly expressed their outrage at the incident. The ultra-nationalist blogger Wei Yahua who is active on the pro-CCP website Utopia proclaimed in a blog entitled 'Is the Humiliation of the Burning of Yuanmingyuan Repeating Itself?' that 'the imperialists entered the territory unhindered, like a wolf entering a flock of sheep. This was not a war, it was a slaughter' ${ }^{99}$ One frequently made observation is that although China is on the rise as an international power, the Chinese people must remain vigilant against Western powers and must never forget Yuanmingyuan otherwise something analogous may happen in the future. In a blog entitled 'The Regret of the Yuanmingyuan', the writer Jia Chenxi warns that 'we cannot forget our past history, otherwise the nightmare will repeat itself!"40 This resonates closely with the CCP's approach, especially when it feels under threat by a perceived act of foreign aggression.

But not everyone automatically rallies behind the CCP at the mere mention of the Yuanmingyuan incident. Some people have accused the CCP of deliberately doctoring the official narrative on the incident to suit its own political purposes. A particularly vocal critic known as Dai35408 has dismissed the official narrative as being riddled with 'politically motivated biases and inaccuracies' which have culminated in 'more than half a century of patriotic education brainwashing'. ${ }^{41}$ The basis of this accusation derives from the convenient paucity of information in Chinese textbooks and media coverage about the maltreatment of the Anglo-French delegation prior to the burning and looting of the palaces.

The Shenzhen-based writer Yan Changhai has also accused the CCP of an unbalanced historical portrayal of the Yuanmingyuan incident. In a blog entitled 'Why Don't You Ask Why Yuanmingyuan Was Burnt', Yan blames the destruction of the palaces (and indeed the start of the Second Opium War) on what he describes as the provocative actions of the Qing 
government under Emperor Xianfeng, presumably a reference to the mistreatment of the Anglo-French delegation. Yan argues that the convenient omission of key facts about the incident from the CCP narrative is because 'corrupt CCP officials' are trying to use nationalism for their own political purposes as 'a tool to fan up populism'. ${ }^{42}$ Yan has also been critical of the CCP in relation to the Republican era, as we will see later.

Just as doubts have been raised about the historical accuracy of the official narrative on Yuanmingyuan, so there are doubts about the appropriateness of resuscitating the memory of the incident. Some critics note that the very existence of Yuanmingyuan reflected a shameful era of elitism and inequality. It was, after all, an inordinately expensive complex of palaces and gardens inhabited by an imperial royal family, built on the back of slave labor and yet completely inaccessible to the impoverished general public. As Tong Shujie puts it, Yuanmingyuan was 'nothing but a place for the Qing Dynasty emperors to live a luxurious life. It's a symbol of a waste of money and resources and the then imperial family's greediness'. ${ }^{43}$

One blogger using the name Zhexuejia Gua Le (which translates as 'The Philosopher is Dead') has suggested on Weibo that the common people deeply resented the greed and luxury associated with Yuanmingyuan, so much so that when it was attacked by Anglo-French forces 'they did not feel a thing and many even clapped and helped [the Anglo-French forces]'. It has only been in recent years, to suit the CCP's nationalist purposes, that Yuanmingyuan 'has been elevated to a national event. But actually burning it made ordinary people feel avenged'. ${ }^{44}$ Another blogger with the name Li Xiongwei's Own Garden (Zijia Yuanzi Li Xiongwei) has insisted that 'for a dynasty that did not consider the welfare of its people, the more beautiful and spectacular their buildings were, the worse their crimes'. This blogger even asserts that 'the Western powers did not do enough by burning these buildings. They should have burnt their owners too'. ${ }^{45}$ Yan Changhai suggests that if Yuanmingyuan had not been burned down, it would remain inaccessible to the Chinese public, asking, in a clear dig at the continued secretiveness of the CCP, 'would it not have turned into today's Zhongnanhai [the central headquarters of the CCP]'? He continues, 'as a

\footnotetext{
42 Yan (2014).

43 Beijing Review (2011).

44 Zhexuejia Gua Le (2014).

45 Zijia Yuanzi Li Xiongwei (2013).
} 
forbidden area, it is better for it [Yuanmingyuan] to have been burnt. At least ordinary people are able to see the ruins'. ${ }^{4}$

Other people express misgivings about the continued relevance of the incident and the amount of column space devoted to it by the Chinese media in light of current social pressures, such as passing exams, finding work, and raising a family. ${ }^{47} \mathrm{~A}$ first-hand example of this is captured by Julia Lovell in conversation with a visitor to Yuanmingyuan, who in one breath expressed his outrage at the destruction of the site, but in the next breath asked about opportunities to study at law school in England. ${ }^{8}$

Leading on from this, there is a feeling amongst some people that the CCP should not be wasting its time and public money on setting up delegations to scour the world for lost Yuanmingyuan treasures or on rebuilding the old site, albeit only partially at this stage. Instead, there are much more important issues to contend with, such as environmental degradation, spiralling unemployment, and official corruption, and it is these issues which 'shame' the nation. Wang Feng of the Qilu Evening News insists that, 'it's more meaningful to build more quality schools than to spend so much money on the reconstruction program'. ${ }^{49}$

Similarly, as another blogger poignantly remarks:

What is national humiliation? It is when government buildings are extravagant in the extreme and village schools are shabby and leaking, this is national humiliation. When we believe that building the Birds Nest, constructing arenas and rebuilding the Yuanmingyuan are able to 'restore the nation's glory' and the dignity of the Chinese people, to take ignorance and treat it as honor, that is the biggest national humiliation..$^{\circ}$

But if some people only imply that the CCP is too tentative in its dealings with foreigners in the context of the Yuanmingyuan incident, others are much more forthright in this assertion. One impassioned blogger known as PLANavy insists that Western imperialists are still trying to degrade and embarrass China as they did during the Yuanmingyuan incident and calls on the CCP to finally 'wake the sleeping Chinese dragon'. ${ }^{51}$ This blogger has also called for the CCP to be more assertive in its stance towards Japan

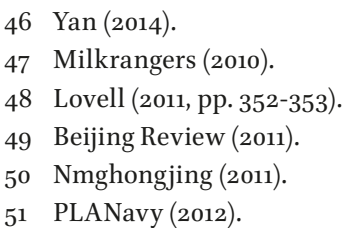


over the disputed Diaoyu islands (Senkaku islands). Similarly, Zui Huayin in a blog entitled 'Forgotten Memories' insists that 'China must wake up! We cannot again lag behind, we cannot be weak again! We cannot allow a tragedy like Yuanmingyuan to happen again!'52 In addition, there were reports of widespread internet anger over suggestions that the CCP was considering inviting British and French officials to the commemorative events marking the 15oth anniversary of the Yuanmingyuan incident, with angry claims that China was putting 'salt in the wounds's3 by 'inviting the invading forces' ${ }^{54}$ The scale of opposition on this issue forced the party to back down on its original plans.

The US presence in the South China Sea has triggered online criticism of China's lack of national assertiveness via historical references to Yuanmingyuan. In October 2015, a US aircraft carrier sailed inside the twelve nautical-mile radius that China claims as its territorial waters around one of its recently reclaimed islands, followed shortly afterwards by a visit from the US Defense Secretary Ash Carter whose helicopter landed on the aircraft carrier. If this caused irritation within the Chinese Foreign Ministry, it was nothing compared to the outrage expressed by the Weibo user with the blog name Yike de Weibo (Stranger's Weibo):

Having slapped the left side of your face [by sailing into Chinese territory], they [the US] are coming to slap the right side of your face. Let us see how the CCP leadership will explain this to the people. Today, it is the South China Sea, tomorrow it will be Tianjin Port. Yuanmingyuan has been burnt, Yiheyuan will be next. ${ }^{55}$

A similar level of anger was expressed following comments made by the former commander of the US Pacific Fleet Gary Roughead who made it clear that the US would stand by its treaty with Japan, no matter what. According to a blogger known only as dgc5 if in its negotiations with foreign powers, 'China fails to make any progress, it would not be strange at all if the Eight-Nation Alliance burns Yuanmingyuan again'. ${ }^{56}$ In referring to Eight-Nation Alliance, the blogger means the Anglo-French Alliance, a common mistake made by bloggers on this subject. 


\section{Consensual nationalism: The Republican era}

Turning now to the debate about the Republican era, under Mao there was no debate. According to the exaggerated party line, the Republican economy was on the verge of collapse after inefficient governmental handling and corruption led to massive unemployment, gross under-production and unprecedented high levels of inflation. Chinese society was portrayed as impoverished, fragmented, and disenfranchised and the KMT as impotent in the face of warlordism and highly oppressive under the auspices of the ruthlessly dictatorial and fascistic Jiang Jieshi. 'Old China', it was argued, was ripe for liberation and this duly came with the victory of the CCP in 1949. After retreating to Taiwan in 1949, Jiang and the KMT remained at the forefront of CCP hostility as the Mao regime pursued an uncompromising, confrontational stance on reunification with Taiwan.

The political ascent of Deng Xiaoping in the late 1970s led to a gradual and deliberate repudiation of this grim official depiction of the Republic and the KMT. This was partly linked to the implementation of economic reform. In an effort to legitimize his radical change of direction in economic policy, Deng actively encouraged PRC scholars to embark on a positive reassessment of the Republic's economic system. As Wright has pointed out, the intention was to demonstrate to the bourgeoning number of PRC entrepreneurs that they could learn something useful from the business practices and entrepreneurial acumen of Republican entrepreneurs. ${ }^{57}$ It was also thought that PRC entrepreneurs may feel inspired to 'take up' where their Republican predecessors had left off several decades earlier. As Bergere has suggested:

There was a growing feeling that Deng Xiaoping and the reformists were taking up the job that had been left unfinished in 1949. The Republican era was more and more perceived as the starting point of a forceful modernization drive, as a time of economic and cultural innovation and creativity to which contemporaries should turn for inspiration..$^{8}$

The relaxation of political controls that accompanied Deng's ascent allowed for academic research to be conducted on other aspects of the Republican era as archival materials from Taiwan and further abroad became increasingly available to PRC historians. One particular area of activity focused on 
discovering what had happened to certain high-profile KMT figures who had received a cursory mention in PRC history books, but then had vanished without a trace from the written page. Hu Hanmin 胡漢民 (1879-1936) is one such example. Head of the KMT's Legislative Yuan in Nanjing from 1927-1931 and an important ally of Sun Yatsen, Hu's career up until about February 1931 was documented in PRC history texts. It was at this point that Hu was placed under house arrest following disagreements with Jiang over the drafting of the new provisional constitution. Intrigued by Hu's subsequent absence from PRC texts despite living for another five years, historian Chen Hongmin set about completing the picture as part of his master's dissertation at Nanjing University which he wrote during the early 1980s. Chen's research showed that Hu had been airbrushed from the CCP's official historiography after 1931 because he consistently maintained an anti-communist political stance. But Chen rightly noted that Hu was equally opposed to the Jiang Jieshi regime and to Japan's military aggression, a fact that was conveniently ignored by the CCP. Chen later argued that party censors had acted unfairly and that $\mathrm{Hu}$ should be posthumously credited for his staunch anti-Japanese position. ${ }^{59}$

Another sign that the party was being more positive about the legacy of the KMT during the Republic was the official recognition of the KMT's contribution during the Second Sino-Japanese War, a contribution previously overlooked or denied by the CCP. For example, high-profile KMT generals who had fought in the war were formally acknowledged. Zhang Zizhong 張自忠, the most senior general to die in the war, was posthumously awarded the title of 'revolutionary martyr' in $1982 .{ }^{60}$ Li Zongren 李宗仁, later Vice-President of Taiwan, was also recognized by the CCP for the leading role he played in the 1938 Battle of Taierzhuang 台兒莊 in Shandong, the first major Chinese victory of the war. ${ }^{61}$ Both Zhang and Li were estranged from Jiang Jieshi. Although Zhang participated in the 1927-1928 Northern Expedition, he never acknowledged the Jiang regime that came to power as a result of that campaign and repeatedly tried to displace it. Li was also a long-established political opponent of Jiang and after fleeing to the US at the end of the civil war, Li returned to China in 1965 in support of Zhou Enlai amidst much fanfare. ${ }^{62}$ Zhang and Li's opposition to Jiang explains why they were singled out for praise and honor by the CCP. Jiang was still

$61 \quad \operatorname{Li}(1979)$.

62 Bonavia (1995) 
public-enemy-number-one in China at this time, so there was little risk to the CCP in recognizing Jiang's enemies as the party's friends. Nevertheless, the recognition of Zhang and Li still represented a significant change in official attitude towards the KMT and its role in the war against Japan.

A broader public interest in the Republican era has been apparent since the early 1980 s. This is partly because of the Republic's chronological proximity to the present, making it more relevant to everyday life in China. It is also because of the scarcely believable official narrative on the period, espoused for so long by the CCP. Whilst KMT figures such as Jiang were well known during the Mao era of the PRC, they were only known by their derisory ideological labels such as 'counter-revolutionary' or 'national traitor'. Similarly negative labels were applied to the Republic. However, as Deng moved to ease domestic political tensions, a public demand emerged for TV programs, books, and magazine articles offering a less politicized assessment of the Republican era. This led to the screening in 1984 of a Hong Kong television drama entitled 'The Bund' based on the criminal activities of the 1920s Shanghai triads, which quickly became a hit with the Chinese public. ${ }^{63}$

At around this time, a number of books began to appear on Chinese bookshelves in what was known as 'Republican exposé'. These were cheaply produced and low-quality books which focused on the criminal underworld and the lives of notorious historical figures, such as spy chiefs and military officers from the KMT's Huangpu 黃埔 Military Academy. The book titles were often sensationalist, such as 'Dai Li: King of Spies', 'Chen Guofu: The KMT Godfather' and 'Jiang Jieshi and the Three Heroes of Huangpu'. The books portrayed the Republic as an era characterized by corruption, internecine gangland warfare, and high-level assassinations. ${ }^{64}$

\section{The emergence of Republican fever}

During the mid-199os, as relations between the CCP and KMT became strained (particularly during the Taiwan Strait missile crisis of 1995-1996) Beijing took a few steps back from its KMT charm offensive. However, the election of the pro-independence Chen Shuibian as Taiwan's president in 2000 precipitated an abrupt recovery in relations between the CCP and the KMT relations, both of whom were erstwhile opponents of Taiwanese independence. This, together with the deaths in 2001 of KMT General

63 Xianfeng Guojia Lishi (2008).

64 Ibid. 
Zhang Xueliang 張學良 (instigator of the 1936 Xian incident) and in 2003 of Song Mayling 宋美玲 (Madame Jiang Jieshi), served to intensify the mainland Chinese interest in the Republican era and by 2006 references to a new phenomenon called 'Republican fever' (minguo re 民國熱) began to appear in the PRC media. According to Zhou Weijun, the fever emerged following the successful launch of a series of scholarly and non-specialist books on the Republic including titles such as 'The Bad Temper of History' and 'Waves under the Pen'. ${ }^{65}$ What differentiated these books from previous publications on the subject was the more optimistic portrayal of the Republic. Whereas previously the emphasis had been on the allegedly shady, dangerous and corrupt features of the Republic, these new books depicted an era of diversity, sophistication, and unrealized potential, as we will discuss in more detail shortly.

But Republican fever is not the exclusive domain of the publishing industry. Since 2000, a large number of Republican-based period dramas have been screened on Chinese TV to massive popular appeal. ${ }^{66}$ One such drama was called 'The Grand Mansion Gate' based on the real-life experience of the family who owned the renowned Chinese pharmaceutical company Tongrentang 同仁堂. Another was entitled 'Like Mist, Like Rain and Like Wind', a love story set in 1930 s Shanghai. Some of these dramas still followed the conventional CCP view of history and depicted Republican society as oppressive. Others have adhered to the model set out in 'The Bund' by focusing on the chaos and corruptions of the Republican era. But, as a whole, the image of Republican society as represented in these dramas has become much more diverse, colorful and modern. Furthermore, the viewing public are often attracted to the unique elegance of the styles and temperament which subtly combined Chinese traditions with Western influences.

Those infused with Republican fever express themselves in a number of different ways, as we will see below. One notable example is the nationalist rituals commemorating KMT soldiers who died during the Second SinoJapanese War. This can be usefully linked to religion because commemoration is an act of transaction with the dead. According to the research of Lin Zhenru carried out in Hunan Province, these rituals usually take place at locations where KMT soldiers are believed to have fought and perished, often in desolate areas such as overgrown fields, hillsides or discarded 
wasteland ${ }^{67}$ This enhances the symbolism of the occasion representing the fate of the dead KMT soldiers, largely forgotten in official Chinese history books in stark contrast to their CCP counterparts. The rituals are very similar to traditional Chinese funeral rites and include the reading of a funeral oration by a preordained 'master of ceremonies', the burning of incense and paper money, the offering of symbolic gits such as fruit and vegetables and a period of silent reflection and kneeling. Some participants or volunteers (sometimes even referred to as 'mourners') wear T-shirts bearing the flag of the KMT (blue sky and white sun) or Taiwan (blue sky, white sun and red background). Makeshift banners are often prepared and erected honoring the KMT war dead.

The creation of a more relaxed political environment that has allowed Republican fever to emerge can again be linked to the CCP's quest for nationalist legitimacy through the utilization of history. In contrast to the confrontational mode of nationalism linked to Yuanmingyuan, the party's positive assessment of the Republican era and forbearance of Republican fever reflects a more consensual mode of nationalism, with the party seeking to present itself as flexible, tolerant, and with the wider national interest as its core interest. This effort to cultivate an image of national unity and harmony is part of a broader policy on reunification with Taiwan.

\section{Rights and freedoms during the Republic}

Academic excellence. But as with Yuanmingyuan, some people have used the open forum on the Republic to criticize the CCP on a number of counts, including its failings as a nationalist entity. One of the most commonplace claims made by those infused with Republican fever is that intellectual scholarship during the Republic was remarkably sophisticated, much more so than previously thought and much more so than PRC levels of scholarship. Writing in the Guangzhou-based Southern Window magazine, the historian Tang Xiaobing of Shanghai's East China Normal University identifies numerous best-selling books and periodicals published in the PRC about the democratic principles championed by Republican-era intellectuals, primarily as a reaction to some of the undemocratic features of contemporary China. In particular, Tang identifies a growing aversion towards China's 'authoritarian political culture and rising tide of consumerism and cynicism'. According to Tang, this also explains why modern-day Chinese intellectuals tend

67 Lin (2016). For an analogous discussion of the 'religious' commemoration of the war dead at the Nanjing Massacre Memorial Hall see Miyamoto (2012). 
to identify themselves with their liberal-minded counterparts from the Republic (e.g. Hu Shi 胡適), whilst left-wing intellectuals associated with the current regime (e.g. the CCP founding members Chen Duxiu 陳獨秀and Li Dazhao 李大釗) are often ignored or even criticized. This nostalgia for liberal-minded Republican intellectuals is linked to a desire amongst contemporary intellectuals to 'inherit their spiritual legacy' according to Tang, as well as a wish to reestablish the concepts of democracy, freedom, and human rights that were openly discussed by many Republican intellectuals and intermittently practiced during the Republican era. Indeed, the legacy of the Republic's liberals and their 'unfinished mission of enlightenment' has become the starting point for many modern-day Chinese thinkers who want to resurrect and take forward this enlightenment, in Tang's view. ${ }^{68}$

In an article published on the CCP's very own People's Daily website, historian Zhang Lifan suggested that post-1949 Chinese intellectuals are some considerable distance behind their Republican-era predecessors in terms of the quality of their scholarship suggesting that: 'we have still not surpassed them, nor have we reached their intellectual heights' ${ }^{69}$ Sun Yu, curator of the Lu Xun Museum in Beijing and author of the book 'In the Republic' is particularly forthright, claiming that 'the academic brilliance created by Republican intellectuals in very difficult times puts present-day intellectuals to shame'.$^{70}$ Xie Yong, a professor of Chinese literature at Xiamen University, asserts that China's most prominent intellectuals either emerged during the Republican era or received their education during that era, especially in the field of humanities and literature when 'it was definitely better before $1949^{\prime} .^{1}$

The education system. The admiration for Republic-of-China intellectuals has also led to praise for the education system that produced them and this has simultaneously given rise to doubts about the quality of education after 1949. The Gansu-based writer Xue Linrong has asserted that the contemporary Chinese education system has a long way to go before it can reach the level attained during the Republic. According to Xue, the KMT was genuinely committed to improving education standards, as manifested by the financial investments that it made, such as unusually high salaries for teaching staff. Even during the socioeconomic chaos that beset China 
during the Second Sino-Japanese War, free education was available in KMTcontrolled areas. ${ }^{72}$

Zhang Lifan broadly agrees with Xue, identifying at least two reasons why so many reputable intellectuals were produced during the Republican era. Firstly, people at that time received a solid educational grounding in both traditional Chinese culture and Western ideas, encouraging a more diverse and open-minded intellectual development. Secondly, the education system was characterized by a free and inclusive academic atmosphere which was highly conducive to scholarly excellence, something not experienced after $1949 \cdot{ }^{73}$

Much of the praise for the Republic's education system tends to focus on the quality of its universities. In his article in Southern People Weekly commemorating the centennial of Beijing's prestigious Qinghua University, Zhang Lifan insisted that 'the Chinese higher education institutions that rose in the first half of the twentieth century were steeped in European and American influences and enjoyed academic freedom'. Aiming a direct attack on the CCP, Zhang argued that the same is not true for the post-1949 university sector. According to Zhang, the PRC's university reforms of $195^{2}$ were an 'unprecedented educational disaster' mainly because the Westernoriented education system was replaced by the Soviet model which was designed to produce 'instruments' that would work for the system at the expense of independent thinking. ${ }^{74}$

The post-Mao era has fared little better, in Zhang's opinion. Although the Soviet model has gradually been phased out with the ascent of Deng Xiaoping, Chinese universities are still under CCP control and are increasingly subject to commercial pressure. Zhang concluded with a rather damning observation that on losing the independent spirit and freedom of thought that characterized the Republican era, China lost the potential to have great thinkers: 'once the independent and free thinking spirit disappeared from the campus, we can only lament that there will be no more great masters after they left us'.75

Zhang's positive assessment of the Republican university system is shared by other thinkers. In an article published in Beijing News, Hebei scholar Xie Zhihao noted that many contemporary Chinese intellectuals, especially education historians, have great respect for the way in which

72 Xue (2010).

73 Zhang (2010).

74 Zhang, Lifan (2011).

75 Ibid. 
university education flourished in Republican times. By contrast 'contemporary Chinese universities are such a let-down. Republican universities, no matter how unsatisfactory, at least maintained a minimum standard of education' $7^{6}$

The Phoenix TV website published an online special report about the post-imperial history of the Chinese university system. The report was extremely complimentary about Republican universities, describing them as having an 'independent character and free spirit'. By contrast, universities during the Mao era were described as being forced to endure 'collective reformation and ideological unification'. Things were not much better after the death of Mao, according to the report. Due to political and commercial pressure, universities have become 'floating duckweed without roots and instruments without souls'.77

Media freedom. Turning to freedom of expression during the Republic, a number of Chinese commentators have commented on the considerable autonomy of the media under the Republic, despite the CCP line suggesting otherwise. Zhang Ming, a professor of political science at Renmin University, believes that the highpoint of media freedom in China was from 1911 to 1927 during the experimental period of constitutional democracy known as the Beiyang 北洋 era. At this time, Zhang notes, there was little if any official censorship of the media. In general, journalists were able to write or say what they wanted. Official censorship of the media did start to creep in after the Northern Expedition brought the KMT to power in 1928 under a single-party authoritarian system of government. In response to this, Zhang continues, some newspapers deliberately left blank spaces where paragraphs or pages had been removed by KMT censors to make it clear to the reading public that some words had been taken out. But this was nothing compared to the censorship that the media has been subjected to since 1949, Zhang argues. In a direct attack on the CCP, Zhang notes that in contrast to the practice of leaving blanks to show that the press had been censored, the press after 1949 'did not even have the courage to leave a blank' ${ }^{78}$

Notwithstanding the media censorship enforced by the KMT after 1928, Xin Lijian, president of a private education company called Xinfu Education Group, believes that there was still a considerable degree of media freedom back then. According to Xin, despite its overtly anti-KMT

76 Xie (2008).

77 Fenghuang Wang (2010).

78 Zhang, Ming (2011). 
rhetoric, the CCP-controlled Xinhua Daily was still permitted to operate in KMT-controlled areas between 1938 and 1947, relatively free from KMT intervention. This autonomy extended to 'calling on workers and peasants to rise up and overthrow the KMT' and even to 'encouraging the KMT army to turn their guns on the government'. In light of this, Xin praises the media freedom of the Republican era and laments the fact that 'this valuable legacy was cut off in 1949 and has not been reconnected since'.79

The democratic legacy. Closely related to this frank discussion of media freedom during the Republic is a much broader debate about the democratic legacy of the era, particularly the democratic ideas articulated by intellectuals during that period. Chinese thinkers are even more enthusiastic about the democratic legacy of the Republic, particularly during the Beiyang era. One such enthusiast is the Tianjin-based media commentator Li Shumin who argues that Beiyang was unquestionably the most democratic period of China's entire history. In an article published in the liberal magazine Yanhuang Chunqiu, Li acknowledged that there were deep flaws in the Beiyang democratic process, but insisted that 'the separation of powers was formally adopted and political power was contained, people's rights and freedoms were to some extent respected and guaranteed, an independent judiciary was established and the freedom of speech was to some extent protected'. For Li, 'the Beiyang era occupies an important position in the history and development of modern democratic politics in China during the twentieth century'. Li concluded pointedly that the CCP has much to learn from this period. ${ }^{80}$

This positive view of Beiyang democracy spread to a much wider public audience, partly (and ironically) because of the release of the official PRC film commemorating the goth anniversary of the founding of the CCP entitled 'Beginning of the Great Revival'. Although the objective of the film was to bolster CCP credibility, what really captured public attention was the depiction of Beiyang as an era of political dynamism. After watching the film, the blogger Yang Hengjun wrote of his nostalgia at seeing how 'Chinese citizens enjoyed freedom of association, demonstration and protest at a time when many countries in the world were not very free, ${ }^{81}$ Likewise, a widely circulated online post at a Republic of China-themed seminar, commended 
the film for 'using vivid scenes, brilliant examples and heart-warming details' and listed a number of freedoms enjoyed during the era. ${ }^{82}$

But it is not only Beiyang that has received praise in China. The singleparty system established by Jiang Jieshi during the Nanjing Decade (19271937) has also been more favorably reassessed. Writing in Southern Weekend, Qin Hui from Qinghua University stated that 'although the Republic did not succeed in building a constitutional political system, it did sow the seeds. The progress of democratization in contemporary Taiwan cannot be said to have nothing to do with this, ${ }^{8}{ }^{8}$ Others have praised Jiang more directly. Hu Xingdou, an economist at the Beijing Institute of Technology, wrote that 'Jiang Jieshi was the greatest man in modern China'. As well as leading China to victory in the war against Japan and establishing China's status as a respected international power (see immediately below), Jiang 'formulated a first-rate constitution that was comparable to American and European constitutions'. ${ }^{84}$

\section{The Republic's nationalist credentials}

China's international status. Perhaps the most vociferous claims made by exponents of Republican fever relate to the diplomatic achievements of the Republic and China's rising international status during this time. According to the official PRC view, the encroachment of foreign imperialist powers during the nineteenth-century Qing Dynasty reduced China to a 'semicolonial society'. It was not until 1949, under the leadership of the CCP, that China was finally liberated from foreign oppression and China's sovereignty was finally restored after the Century of Humiliation. Conspicuous by its absence, however, is any acknowledgement of the diplomatic successes made by the KMT during the Republican period, something which has been duly noted by some thinkers. According to Qin Hui of Qinghua University writing in Southern Weekend, Republican governments were actually 'quite successful in their diplomacy and international political activities' and it was during the Republican era that China genuinely 'stood up' on the world stage. Qin specifically praised the wartime diplomacy of the era when 'China chose the right international alignments and became one of the victorious nations. These were great successes for Republican diplomacy

82 Yang et al. (2011).

83 Nanfang Zhoumo (2011).

$84 \mathrm{Hu}(2011)$. 
and had a huge significance in enabling China to stand up'. ${ }^{85} \mathrm{~A}$ month later, Qin published another article in Southern Weekend directly refuting the claim that the CCP was solely responsible for freeing China from imperialist subjugation. Qin insisted that the 'unequal treaties' were actually abolished in 1942, at which point 'China's sovereignty and independence had undoubtedly been established'. ${ }^{86}$

Another supporter of this position is the veteran liberal-economist Mao Yushi. In an article entitled 'When Did the Chinese People Stand Up?' published by Yanhuang Chunqiu, Mao suggests that China emerged from its Century of Humiliation not in 1949 as the CCP has consistently maintained, but on defeating Japan in 1945, following which China retrieved Manchuria and Taiwan from Japanese occupation and became a permanent member of the UN Security Council. According to Mao, 'it was upon winning the War of Resistance that China truly ended national humiliation and, as Sun Yatsen had hoped, began to be treated fairly as a nation'. ${ }^{87}$ Mao reiterated this position a few years later:

Retrieving the three northeastern provinces and Taiwan, taking back the sovereignty over the foreign concessions in China, becoming a founding member state of the United Nations and a permanent member of the Security Council, eliminating the century-long humiliation, were done by Jiang Jieshi, and were the results of the Chinese people's arduous eight-year long resistance. ${ }^{88}$

Just as Republican governments have been increasingly praised for wresting control of Chinese sovereignty from foreign powers, so questions have been asked about whether the CCP can be credited with any international successes in 1949. In a speech which was widely circulated on the internet, Qin Hui asked in a forthright manner 'which unequal treaty was abolished in 1949 and what economic rights, such as customs rights, however big or small, were obtained in 1949? I believe no one can answer that. Indeed, nothing can be found' ${ }^{89}$ Yan Changhai has accused the CCP of failing to safeguard Chinese sovereignty in the post-revolutionary era. In a blog carried by the Phoenix TV website, Yan listed the numerous 'traitorous pacts' that Mao

\footnotetext{
85 Qin (2012a).

86 Qin (2012b).

87 Mao (2010).

88 BBC (2015b).

89 Qin (2010).
} 
Zedong made with the Soviet Union when signing, amongst other things, the $195^{\circ}$ Treaty of Friendship, Alliance, and Mutual Assistance. Under this Treaty, Yan argued, the CCP 'sold out Chinese territories and sovereignty', such as the maintenance of Soviet control over China's Eastern Railway in Manchuria and Port Arthur in Dalian. Referring to the CCP as a collection of 'vested interest groups', Yan accused them of 'shamelessly claiming to be the "protector" of the Chinese nation, so that they can deceive the Chinese people into supporting them. But in fact, they have never really defended the country or the nation. On the contrary, countless facts have proved that they are traitors through and through'.9 ${ }^{\circ}$

Economic development. One of the most commonplace assertions about the Republic relates to the allegedly ruinous state of the Chinese economy. For many years the CCP line insisted that China's economy under the KMT was in disarray and only after 1949 did China genuinely industrialize its base. A number of Chinese commentators have disputed this. For example, the Guangzhou-based newspaper New Express published a full-page feature rejecting the version of history contained in some PRC school textbooks that the economy was so weak during the Republic that China 'could not even produce matches or nails'. Instead, the article argued that the roots of China's industrialization can be traced back to the late Qing period and that during the Republican period many factories were not only producing matches and nails, but also cars, modern weaponry, gunboats, and even airplanes. ${ }^{91}$ Yuan Weishi, a historian at the Sun Yatsen University in Guangzhou, has insisted that China enjoyed rapid economic expansion during the Republic, with average industrial growth at 13.8 percent per annum in the decade after $1912 . .^{92}$ Xin Lijian agrees with this perspective. Describing the Nanjing Decade as a 'golden decade', Xin claims that the KMT oversaw an 'economic miracle' with annual industrial growth rates averaging 9.3 percent from 1931 to 1936 . From this Xin concludes that 'without the foundation laid during the Nanjing decade, China could not have won victory in the eight year-long war of resistance against Japan. Therefore, it was a decade that should not be forgotten'.93

Some Chinese scholars have suggested that the Republican economy was actually more successful than the PRC economy in certain areas. Qin Hui 
claims that industrial growth prior to 1937 was certainly no slower than industrial growth during the entire Mao era and was significantly faster than in the twenty years from the Anti-Rightist Campaign to the end of the Cultural Revolution (1957-1976). Although the post-Mao reform era has seen rapid economic expansion, some commentators have attributed this to the undoing of Maoist practices and a resumption of where the economy left off in $1949 .{ }^{94}$ According to Yuan Weishi, 'what has been achieved in the last 30 years has been nothing more than returning to history'. Yan Changhai openly commended Jiang Jieshi's record in modernizing China, whilst accusing the CCP of holding China back. It was circulated so widely that it attracted the attention of the then Taiwan President Ma Yingjiu. Yan argued that 'Jiang's defeat was not just his personal failure, but can also be seen as a major setback in the modernization of China.' ${ }^{95}$

A Republican national identity. Another notable aspect of Republican fever has been the assertion of a Republican national identity, often as an alternative to the PRC's own national identity. The most daring espousal of this was made by a group of mainly young internet users called the Union of Chinese Nationalists (UOCN) now banned in the PRC. The group identified itself with Sun Yatsen's Three Principles of the People (nationalism, democracy, and people's livelihood) and described its supporters as 'spiritual members' of the KMT, claiming to have more than thousands of online registered members. The UOCN's nationalist stance was manifested mainly in its opposition to Taiwanese independence which is why the group was also known as the China Pan-Blue Alliance and pledged to 'work with the KMT for national reunification'. The group organized specific events that commemorated the KMT's war effort during the Second Sino-Japanese War and publicly exhibited Taiwan and KMT flags in cities such as Wuhan and Chongqing. ${ }^{6}$

In addition to its nationalist activities, the UOCN openly advocated a representative form of multi-party democracy and respect for human rights. Some members attempted to stand for election to local People's Congresses and participated in the democracy-oriented Rights Defense Movement, offering help to protesting workers at the Chongqing Special Steel Group. The group also voiced its support for the human-rights protection of the Falungong and other persecuted religious and minority groups. However, 
the CCP shut down the UOCN describing it as an 'illegal organization' following which it is believed that many of UOCN members were jailed. ${ }^{97}$

Despite this crackdown on the UOCN, a Republican identity narrative continues to be propagated online as popular interest in the Republican era has increased and as social networking and micro-blogging websites have enabled netizens to express themselves more easily. Supporters of the Republic are active on social media sites such as Renren.com (China's equivalent to Facebook) and on the micro-blogging platform Weibo (similar to Twitter). They often use Republic and KMT flags as their profile pictures and have the KMT emblem as part of their online monikers, all of which is in open defiance of official Chinese web censors.

Proponents of a Republican national identity frequently assert their views on significant dates in China's modern history. The Hong Kong magazine Asia Weekly noted how on 1 October 2011, some people posted images of the Republic's flag on the internet and announced that they were boycotting the PRC National Day in preference for the Republic's centennial on 10 October $2011 .{ }^{98}$ Taipei's China Times newspaper reported that 'Republican fans' in the PRC had celebrated the Republic of China National Day by posting the Republic's flag on Weibo and disseminating the official national day address of Ma Yingjiu. An unnamed mainland netizen was quoted in jest as saying, 'when I logged onto Weibo, my computer screen was filled with images of a Blue Sky with a White Sun [the KMT emblem], which almost made me think the mainland had been recovered [by Taiwan] overnight!'99

\section{Challenging CCP legitimacy?}

Having examined some of the dissenting views on Yuanmingyuan and the Republican era, it remains for us to assess the wider significance of these counter-narratives, particularly for the authority of the CCP. Certainly, it is not our contention that the CCP is somehow tottering on the brink of collapse against the backdrop of these dissenting views. It is not even clear that the public backlash (if you can call it that) against the CCP forms a majority position in China. Although critics of the party are widespread, including academics, journalists, and bloggers, there are plenty of pro-CCP voices to be heard in the media, online, and in person. Anne-Marie Brady notes the 
success with which the CCP generated a broad base of public support during the build-up to the Beijing Olympics as part of what she calls a 'campaign of mass distraction' away from pressing domestic issues. ${ }^{100}$ Similarly, Nyiri, Zhang and Varrall have illustrated the high level of support that existed for China's Tibet policy amongst overseas Chinese students at around that time, as well as anger towards overseas pro-Tibetan demonstrators and the pro-Tibetan international media. ${ }^{101}$

That said, the public discord towards the CCP identified in this article should not be underestimated. There are at least three reasons for this. Firstly, such discord shows no obvious signs of subsiding in light of the growing number of people in China with access to the internet, the remote likelihood of being caught (particularly those who use barely decipherable blogs names) and the sophisticated methods that the netizens are employing to side-step the efforts of official online censors, despite the tighter political controls being applied by Xi Jinping following his insistence that state-run media outlets 'are propaganda fronts and must have the party as their family name'. ${ }^{102}$ China's 'blogosphere' comprises hundreds of millions of participants and with its increasingly vociferous demands for a more assertive China on important issues of national interest, the internet is fast becoming what Friedman has described as 'the de facto voice of the people. ${ }^{103}$

Secondly, leading on from Friedman's point, some of those people who have doubted the party's nationalist credentials in the context of Yuanmingyuan and the Republican era have also done so on other issues of national concern. We noted earlier how some of the Yuanmingyuan critics have been critical of the party over the Diaoyu islands fallout with Japan and China's alleged lack of assertion against the US in the South China Sea. Similarly, Republican fever activists have also criticized the extent of CCP nationalism regarding the Second Sino-Japanese War. Following the party's more positive reassessment of the role played by the KMT in winning this war (again as part of a more conciliatory nationalism), public anger has been directed toward the CCP on a number of related issues. Some people have accused the party of covering up the truth behind the war and for mistreating KMT war veterans after 1949. Others have even accused the CCP of betraying the Chinese nation by allowing the KMT to over-extend

100 Brady (2009).

101 Zhang and Varrall (2010).

102 Guardian (2016).

103 Friedman (2010, p. 25). 
itself in fighting the Japanese with minimal communist assistance and ordering communist soldiers to fire on their nationalist counterparts. ${ }^{104}$

Thirdly, it should be noted that the CCP is certainly taking the views of its detractors seriously, as manifested by the often indignant official response to the views of these detractors. For example, on the assertion noted earlier that the Qing Dynasty was actually to blame for the Yuanmingyuan incident, the party-controlled Chinese Social Sciences Today responded by dismissing this as 'a typical manifestation of historical nihilism' and 'nothing but a Chinese version of the West's defense for its looting and burning of Yuanmingyuan'. ${ }^{105}$ Exponents of Republican fever have also met with criticism. An editorial in the state-run Global Times attacked exponents of Republican fever for, amongst other things, engaging in 'brazen acts of lying' and 'an out-and-out historical falsification'. ${ }^{106}$ Similarly, in a 10 October 2014 article (the anniversary of Taiwan's National Day), the newspaper derided the 'morbid nostalgia' for the era, suggesting that a small number of 'fanatics' are 'fixated on beautifying that historical period, claiming that it was a time of "democracy, freedom and respect for wisdom". ${ }^{107}$

Taken as a whole, the hostility towards the CCP as identified in this article represents a real challenge to the CCP's authority. Ironically, given the original objectives of CCP nationalism, such hostility is serving to weaken rather than fortify the party's legitimacy at a time when it needs all the support it can get.

\section{Bibliography}

BBC. 2009. 'China "Patriot" Sabotages Auction'. http://news.bbc.co.uk, 2 March.

BBC. 2015a. 'The Palace of Shame That Makes China Angry'. http://www.bbc. co.uk, 2 February.

BBC. 2015b. 'Zhongguo Xuezhe Mao Yushi Jiaru Kangzhan Lishi Lunzhan Yin Reyi' (Chinese Scholar Mao Yushi Joins Debate on War History Sparking Heated Discussions), http://www.bbc.com, 9 September.

Beijing Review. 2011. 'Is it Necessary to Reconstruct the Yuanmingyuan?' http:// www.bjreview.com 15 December.

104 Zhang and Weatherley (2013).

105 Zhongguo Shehui Kexue Bao (2010).

106 Huanqiu Shibao (2012).

107 Global Times (2014). 
Beijing Ribao. 2011. 'Si Jian Yuanmingyuan Shou Shou Jiang “Jushou” Wuhan' (Four Old Summer Palace Animal Head Statues Will 'Meet' in Wuhan). Beijing Daily, http://www.bjd.com, 14 June.

Bloomberg. 2013. 'Pinault Family Gives China \$40 Million Disputed Bronze'. http:// www.bloomberg.com, 27 April.

Bonavia, D. 1995. China's Warlords. New York, NY: Oxford University Press.

Brady, A-M. 2009. 'The Beijing Olympics as a Campaign of Mass Distraction'. China Quarterly, 197: 1-24.

Chen, Hongmin. 2011. 'Mao Xiansheng Zhidao Wo Xie Lunwen' (Mr Mao's Guidance in the Writing of My Thesis). Minguo Chunqiu (Spring and Autumn Republic), http://img.mg1912.com, 16 September.

China Beat. 2009. 'James Hevia on Summer Palace Relics'. http://thechinabeat. blogspot.com, 24 February.

China News Service. 2007. 'State Council Taiwan Affairs Office: The So-Called Union of Chinese Nationalists Organization is Not Legally Registered', http:// www.chinanews.com, 25 April.

CNTV. 2010. '1.6 Million Chinese Relics Held by 47 Museums Worldwide', http:// english.cntv.cn, 20 October.

Dai35408. 2010. 'Du Junli: Fang bu xia de Yuanmingyuan Qingjie' (Unable to Let Go of the Yuanmingyuan Complex). Xinlang Boke (Sina Blog), http://blog.sina. com, 23 October.

dgc5. 2015. http://www.weibo.com, 26 January.

Dongfang Ribao. 2010. 'Huoshao Yuanmingyuan 150 Nian Yao Qinlue Guo Chuxi Jinian' (Invitation to the Invading Countries to Attend the Commemoration of the 15 oth Anniversary of the Burning of the Yuanmingyuan). Oriental Daily News, http://global.factiva.com, 15 January.

Fenghuang Wang. 2010. 'Daxue Zhidao' (Dao of University Education). Phoenix TV Website, http://news.ifeng.com, 3 February.

Friedman, T. 2010. 'Power to the (Blogging) People'. New York Times, 15 September, p. 25 .

Global Times. 2014. 'Double Ten Day Fervor Humiliates History', http://www. globaltimes.cn, 10 October.

Guangzhou Ribao. 2009. 'Yanzhe Beijing Si Hao Xian Chihe Wanle' (Food and Amusements Along the Beijing Number 4 Line). Guangzhou Daily, http://gzdaily. dayoo.com, 3 November.

Guardian. 2016. 'Xi Jinping asks for “Absolute Loyalty” from Chinese State Media', https://www.theguardian.com, 19 February.

Hays Gries, P., J. Prewitt-Freilino, L.-E. Cox-Fuenzalida, and Qingmin Zhang. 2009. 'Contentious Histories and the Perception of Threat: China, the United States, 
and the Korean War - An Experimental Analysis'.Journal of East Asian Studies, 9: $433-465$.

Hu, Xingdou. 2011. 'Jiang Jieshi shi Zhongguo Xiandai Diyi Weiren' (Jiang Jieshi was the Greatest Man in Modern China), http://blog.ifeng.com, 13 November.

Huanqiu Shibao. 2012. 'Meihua Dangnian Guomindang Zhengquan shi Gongran Sahuang' (It is a Brazen Act of Lying to Embellish the KMT Regime of the Past). Global Times, http://opinion.huanqiu.com, 11 October.

Jia, Chenxi. 2011. 'Yuanmingyuan de Wanxi' (The Regret of the Yuanmingyuan). Xinlang Boke (Sina Blog), http://blog.sina.com, 17 November.

Jiefangjun Bao. 1990. 'Zhongguo: Zouxiang 21 Shiji' (China: Moving Towards the 21st Century). People's Liberation Army Daily, http://dlib.eastview.com, 23 September.

Jiefangjun Bao. 1998. 'Dangdai Zibenzhuyi Guojia Gongren Jieji de Bianhua Deng' (Working Class Changes in a Contemporary Capitalist Country). People's Liberation Army Daily, http://dlib.eastview.com, 9 February.

Jiefangjun Bao. 2009a. 'Guobao Huigui Lu Manman' (The Road to Returning the National Treasures is Very Slow). People's Liberation Army Daily, http://dlib. eastview.com, 28 February.

Jiefangjun Bao. 20ogb. 'Yi Renquan wei Qihao Qinfan Zhongguo Renmin de Jiben Wenhua Quanli shi Huangmiu de' (To Use the Banner of Human Rights to Infringe on the Chinese People's Basic Cultural Rights is Absurd). People's Liberation Army Daily, http://dlib.eastview.com, 25 February.

Lee, Haiyan. 2009. 'The Ruins of Yuanmingyuan or How to Enjoy a National Wound'. Modern China, 35(4): 155-190.

Leonard, M. 2008. What Does China Think? London: Fourth Estate.

Li, Shumin. 2005. 'Beiyang Junfa Shiqi Weihe Ye You Minzhu?' (Why Was There Also Democracy During the Beiyang Warlord Era?). Yanhuang Chunqiu (Yanhuang Annals), http://www.yhcqw.com.

Li, Zongren. 1979. The Memoirs of Li Tsung-jen, Te-kong Tong and Li Tsung-jen. Boulder, CO: Westview.

Lin, Zhenru. 2016. 'Ritualized Remembrance in Post-Socialist China' (Unpublished paper).

Lovell, J. 2011. The Opium War: Drugs, Dreams and the Making of China. London: Picador.

Mao, Yushi. 2010. 'Zhongguo Renmin shi Shenme Shihou Zhan Qilai de?' (When Did the Chinese People Stand Up?) Zhongguo Gaige Luntan (China Reform Website), http://www.yhcqw.com, 1 November.

Milkrangers. 2010. 'Bu Neng Wangque de Jinian' (Cannot Forget to Commemorate), Xinlang Boke (Sina Blog), http://blog.sina.com, 15 November. 
Mitter, R. 2000. 'Behind the Scenes at the Museum: Nationalism, History and Memory in the Beijing War of Resistance Museum, 1987-1997'. China Quarterly, 161: 279-293.

Miyamoto, Yuki. 2012. 'The Ethics of Commemoration: Religion and Politics in Nanjing, Hiroshima, and Nagasaki'.Journal of the American Academy of Religion, 8o(1): 34-63.

Nanfang Zhoumo. 2011. 'Minguo Lishi de Di Er Mianxiang: Luanshi zhong de Xiandaihua Bufa' (The Second Aspect of Republican History: Steps Towards Modernization in a Chaotic World). Southern Weekend, http://www.infzm. com, 4 November.

New York Times. 2009. 'China Fails to Halt Sale of Looted Relics at Paris Auction', http://www.nytimes.com, 26 February.

Nmghongjing. 2011. 'Shenme shi Guochi?' (What is National Humiliation?) Xinlang Boke (Sina Blog), http://blog.sina.com, 20 November.

Nyiri, P., J. Zhang, and M. Varrall. 2010. 'China's Cosmopolitan Nationalists: "Heroes and Traitors" of the 2008 Olympics'. The China Journal, 63: 25-55.

PLANavy. 2012. 'Nandao Yao Muyi Tianxia, Zhongguo Cai Hui Suxing Ma?' (Is it Possible to Be the Mother Under Heaven and Earth, Until China is Able to Wake Up?) Xinlang Boke (Sina Blog), http://blog.sina.com, 29 March.

Qin, Hui. 2005. 'Zhongguo Gaige Qian Jiu Tizhi Xia Jingji Fazhan Jixiao Chuyi' (Comments on China's Economic Development Performance Under the Old System Before Reform) Yunnan Daxue Xuebao Sheke Ban (Journal of Yunnan University, Social Sciences Edition), 2, http://www.chinareform.

Qin, Hui. 2010. 'Zhongguo Lishi de Yanxu yu Duanlie' (The Continuity and Fracture of Chinese History) Chuanzhixing Xueshu Tongxun (Academic Newsletter of the Transition Institute), 8, http://blog.caijing.com.

Qin, Hui. 2012a. 'Minzu Zhuyi de Shijian: Zhongguo Zhan Qilai le de Licheng' (The Practice of Nationalism: The Process of China Standing Up) Nanfang Zhoumo (Southern Weekend), http://www.infzm.com, 19 January.

Qin, Hui. 2012b. 'Ban Zhimindi Zhuangtai de Zhongjie: Zaitan Zhongguo Zhan Qilai le de Licheng' (The End of Semi-Colonial Status: More on the Process of China Standing Up). Nanfang Zhoumo (Southern Weekend), http://www.infzm. com, 23 February.

Renmin Ribao. 1999a. 'Zhongguo bu shi Yibai Jiujiu' (China is not 1899). People's Daily, http://huylpd.twinbridge.com, 12 May.

Renmin Ribao. 1999b. 'Zhengyi de Nahan' (Righteous Cry). People’s Daily, http:// huylpd.twinbridge.com, 25 May.

Renmin Ribao. 2008a. 'Wangmin Reyi de Xinwen: Aoyun Shenghuo Chuandi Zao Xirao' (Netizens Hot News: Olympic Torch Relay Disrupted). People's Daily, http://news.xinhuanet.com, 11 April. 
Renmin Ribao. 2008b. 'Cong Faguo Kan Xifang Minzhu yu Guojia Liyi de Beilun' (From France We See a Western Democracy and National Interest Paradox). People's Daily, http://world.people.com, 17 May.

Renmin Ribao. 2009. 'Jiu zai Nin de Xingxiang Li' (Only in Your Image). People's Daily, http://huylpd.twinbridge.com, 13 January.

Renmin Ribao. 2010a. 'Daguo Mianzi:Yuanmingyuan 150 Nian Jiachou yu Guochi' (Great Power Honor: Yuanmingyuan's 15oth Anniversary of Animosity and Humiliation). People’s Daily, http://www.people.com, 18 October.

Renmin Ribao. 2010b. 'Wenwu Zhuisuo Shi bu Wo Dai' (Cultural Relic Recourse Waits for No-one). People's Daily, http://huylpd.twinbridge.com, 19 November. Sun, Yu. 2008. Zai Minguo (In the Republic) (Zhejiang Renmin Chubanshe), http:// cul.cn.yahoo.com.

Tang, Xiaobing. 2008. 'Toushi Minguo Zhishi Fenzi Shi Re' (The Essence of Republican-Era Intellectual History Fever). Nanfengchuang Zazhi (Southern Window Magazine), http://www.nfcmag.com, 5 May.

Waldron, A. 1996. 'China's New Remembering of World War II: The Case of Zhang Zizhong'. Modern Asian Studies, 30(4): 945-978.

Wang, Dancheng. 1999. Yuanmingyuan: Lishi, Xianzhang, Lunzheng (Yuanmingyuan: Debates Past and Present). Beijing: Beijing Chubanshe.

Wang, Zheng. 2008. 'National Humiliation, History Education, and the Politics of Historical Memory: Patriotic Education Campaign in China'. International Studies Quarterly, 52(4):783-806.

Wei, Yahua. 2012. 'Huoshao Yuanmingyuan de Guochi Hai Hui Zhongyan Ma?' (Is the Humiliation of the Burning of Yuanmingyuan Repeating Itself?), Xinlang Boke (Sina Blog), http://blog.sina.com, 3 April.

Weil, R. 2013. 'Yuanmingyuan Revisited: The Confrontation of China and the West'. Socialism and Democracy, 27(1): 99-135.

Wenhui Bao. 2010. 'Yuanmingyuan Linan 15o Zhounian Huo Yao Yingfa Zhengyao Chuxi' (British and French Officials Might be Invited to Attend the 15oth Anniversary of the Yuanmingyuan). Wenhui Daily, http://global.factiva.com, 15 January.

Wolseley, J. 1862. Narrative of the War with China in 1860; to Which is Added the Account of a Short Residence with the Tai-ping Rebels at Nanking and a Voyage from Thence to Hankow. London: Longman.

Xianfeng Guojia Lishi. 2008. 'Jiefeng Minguo' (Unwrapping the Republic).Xianfeng National History, http://news.sohu.com, 29 April.

Xie, Yong. 2010. 'Chen Danqing vs Xie Yong: Jintian Weishenme Tanlun Minguo'? (Chen Danqing vs Xie Yong: Why Discuss the Republic Today?) Fenghuang Wang (Phoenix TV Network), http://book.ifeng.com, 30 September. 
Xie, Zhihao. 2008. 'Ganhuai Minguo Daxue de Dixian' (Thoughts on the Minimum Standard of Republican Universities).Xinjing Bao (Beijing News), http://epaper. bjnews.com, 23 January.

Xin, Lijian. 2009a. 'Minguo Shiqi de Xinwen Ziyou' (Media Freedom in the Republican Era), http://blog.ifeng.com, 2 November.

Xin, Lijian. 2009b. 'Jiemi Minguo Huangjin Shinian' (Revealing the Secrets of the Golden Decade During the Republican Era), http://blog.ifeng.com, 2 November. Xin Zhoukan. 2010. 'Niandai Ju: Zui Ju Yule Xiaoguo de Dianshiju Leixing' (Period Dramas: The Most Entertaining Television Genre). New Weekly, http://www/ neweekly.com, 1 September.

Xinhua News Agency. 2009. 'Lawyers Abroad Form Alliance for Return of Lost Cultural Relics', http://toolkit.dialog.com, 4 March.

Xinhua Wang. 2008. 'Aoyun Huoju Chuandi Bali Shouzu Wangmin Zhenglun Dizhi Faguo Huo' (Olympic Torch Relay in Paris Blocked, Internet Users Argue for French Goods Boycott). Xinhua Network, http://news.xinhuanet.com, 14 April. Xinhuashe Zhongwen Xinwen. 2008. 'Aoyun Shenghuo Caiji yu Chuandi Quwen' (Olympic Torch Lighting and the Relay Story). Xinhua News Agency, http:// global.factiva.com, 4 March.

Xinhuashe Zhongwen Xinwen. 2010a. 'Yuanmingyuan Jiang Qidong Lijie 150 Zhounian Xilie Jinianhuodong' (Yuanmingyuan is Launching 150th Anniversary Commemoration Events).Xinhua News Agency, http://global.factiva.com, 25 September.

Xinhuashe Zhongwen Xinwen. 2010b. 'Zhongguo Zhuanjia Cheng Haiwai Faxian Xin de Yuanmingyuan Liushi Wenwu' (China Expert Goes Abroad to Discover New Lost Yuanmingyuan Relics). Xinhua News Agency, http://global.factiva. com, 18 January.

Xinkuai Bao. 2011. 'Lishi Jizai Zhong de Jiu Zhongguo: Feiji Dapao Dou Neng Zao' (Old China According to Historical Records: Even Aeroplanes and Big Cannons Were Being Built). New Express, http://www.ycwb.com, 8 May.

Xue, Linrong. 2010. 'Minguo Jiaoyu Gei Women de Jiejan' (What We Can Learn From Republican-Era Education). Fenghuang Wang (Phoenix TV Website), http://news.ifeng.com, 3 February.

Yan, Changhai. 2011a. 'Minguo Zhihou Zhongguo Jiujing Diushi Duoshao Tudi?' (How Much Land Did China Lose After the Republic?) Fenghuang Wang (Phoenix TV Network), http://blog.ifeng.com, 22 August.

Yan, Changhai. 2011b. 'Ma Yingjiu Cheng Lejian Dalu Gaibian dui Jiang Jieshi Pingjia' (Ma Yingjiu Says He is Glad to See the Mainland Changing its Assessment of Jiang Jieshi). Zhongguo Pinglun Xinwen Wang (China Review News), http://www.chinareviewnews.com, 8 April. 
Yan, Changhai. 2014. 'Why Don't You Ask Why Yuanmingyuan Was Burnt?', http:// yanchh.blogchina.com, 22 July.

Yang, Hengjun. 2011. 'Kan Jian Dang Wei Ye de Yidian Ganxiang' (Some Thoughts After Watching the Beginning of the Great Revival), http://yanghengjunbk. blog.163.com, 17 June.

Yang, Kuisong, Chen Danqing et al. 2011. 'Minguo shi Lishi Haishi Xianshi?' (Is the Republic History or Reality?), http://www.21ccom.net ${ }_{2} 13$ September.

Yazhou Zhoukan. 2008. 'Jiang Xun, Xunhui Sun Zhongshan: Zhongguo Fanlan Lianmeng Xianxiang Beihou' (Finding Sun Yatsen: Behind the UOCN Phenomenon). Asia Weekly, http://www.yzzk.com, 11 May.

Yazhou Zhoukan. 2011. 'Zhongguo Dalu “Minguo Rechao” Beihou' (Behind Republican Fever in Mainland China). Asia Weekly, http://www.yzzk.com, 16 October. Yike de Weibo. 2015. http://www.weibo.com, 5 November.

Yuan, Weishi. 2010. 'Mao Yushi Deng: Huishou Xinhai Bainian, (Mao Yushi et al.: Reviewing the Century Since the 1911 Revolution). Zhongguo Gaige Luntan (China Reform Website), http://www.chinareform.org, 1 November.

Zhang, Lifan. 2010. 'Minguo Sixiangjie de Lishi Gaodu' (The Historical Height of the Republican-Era Intellectual Circle). Renmin Wang (People's Network), http:// history.people.com, 14 December.

Zhang, Lifan. 2011. 'Minguo Xuemai: Bainian Qinghua de Lingyi Daotong' (The Republican Legacy: Another Intellectual Origin of the One Hundred Year-Old Qinghua University).Nanfang Renwu Zhoukan (Southern People Weekly), http:// nf.nfdaily.cn, 16 May.

Zhang, Ming. 2011. 'Minguo Shiqi de Meiti' (The Media in the Republican Era). http://zhangmingbk.blog.163.com, 11 January.

Zhang, Qiang, and R. Weatherley. 2013. 'Owning up to the Past: The KMT's Role in the War Against Japan and the Impact on CCP Legitimacy'. Pacific Review, 24(3): 221-42.

Zhexuejia Gua Le. 2014. http://www.weibo.com, 10 June.

Zhongguo Hangtian Bao. 2010. 'Xuannao de Zhong Cai Wusheng De Baimiao:Xie Zai Yuanmingyuan Lijie 150 Zhounian Zhiji' (Noisy Colouring, Silent Lines: Written During the 15oth Anniversary of the Destruction of the Yuanmingyuan). China Aviation News, http://global.factiva.com, 27 May.

Zhongguo Shehui Kexue Bao. 2010. 'Mingji Lishi, Mianxiang Weilai' (Remember History, Face the Future). Chinese Social Sciences Today, http://news.ifeng.com, 2 November.

Zhongguo Xinwenshe. 2010. 'Taiwan Zhanchu Yong Yan Diaosu de Yuanmingyuan shi Er Shou Shou' (Taiwan Exhibit Uses Salt Statues of Yuanmingyuan's Twelve Zodiac Animals). China News Service, http://global.factiva.com, 26 February. 
Zhongshi Dianzi Bao. 2012. '“Guofen” Qing Shuang Shi, Wo Guoqi Weibo Piaoyang' (Republican Fans Celebrate Double Ten, Our National Flag Waves on Weibo). China Times, http://news.chinatimes.com, 11 October.

Zhongyangshe Zhongwen Xinwen. 2010. 'Shangkou Sayan? Yuanmingyuan Mengnan 150 Zhounian Ban “Huodong Zaopi' (Salt in the Wound? The 15oth Anniversary Activities of the Destruction of the Yuanmingyuan Meets with Criticism). Central News Agency, http://global.factiva.com, 19 January.

Zhou, Weijun. 2008. 'Minguo Re Zhixia de Weiyan Dayi' (The Hidden Meaning Behind Republican Fever). Nanfang Dushi Bao (Southern Metropolis Daily), http://epaper.oeeee.com, 20 January.

Zijia Yuanzi Li Xiongwei. 2013. http://www.weibo.com, 7 December.

Zui, Huayin. 2010. 'Weile Wangque de Jiyi' (For Forgotten Memories). Wo de Souhu (Sohu Blog), http://guguzgz.blog.sohu.com, 6 November.

\section{About the authors}

Weatherley, Robert D. Affiliated Lecturer of Chinese International Relations, Department of Politics and International Studies, University of Cambridge, UK/ Head Lawyer of China Group, Mills \& Reeve, United Kingdoms.

Email: robert.weatherley@mills-reeve.com

Zhang, Qiang. Ph.D. candidate in Politics, Department of Politics and International Relations, University of Oxford, United Kingdom.

Email: qzhanguk@gmail.com 


\title{
$6 \quad$ Pilgrimage and Hui Muslim Identity in the Republican Era
}

\author{
Yuan-lin Tsai
}

\begin{abstract}
Pilgrimage (hajj) is the fifth pillar of Islam and the most important symbol of unity of the Muslim 'Community' ('Ummah'). When panIslamism and Chinese nationalism met in the early twentieth century, it is interesting to see how the Chinese pilgrims, and the Chinese Muslims as a whole, understood and responded to the Islamic revivalist call to the unity of the Community and the Chinese nationalist voice to build a new nation-state. This chapter explores the relationships between these two forces by researching original official documents, news reports, memoirs, and other biographical materials regarding the Hui Muslims' pilgrimage experience. It concludes that Hui Muslim pilgrims' choice is not an either/or question, but a mixture of pan-Islamism and Hui patriotism.
\end{abstract}

Keywords: pilgrimage, Mecca, Hui, Uighur, pan-Islamism, Wahhabi

\section{Introduction}

Islam in China has not yet been a well-explored field despite some groundbreaking books and articles that have been published in Chinese, Japanese, and various Western languages during the last two decades. The scholars in this field have usually made their own efforts in an isolated fashion and have not integrated into the academic communities of either Islamic studies or Chinese studies. This is also true for the studies of the Chinese Muslims' pilgrimage (hajj). In the two most comprehensive historical works on the pilgrimage - Peters' The Hajj: The Muslim Pilgrimage to Mecca and the Holy Places (1994) and Wolfe's One Thousand Roads to Mecca: Ten Centuries of Travelers Writing about the Muslim Pilgrimage (1997) - there is no mention of the Chinese Muslims' pilgrimage journey. Recently, Tagliacozzo's ambitious book, The Longest Journey: Southeast Asians and the Pilgrimage to Mecca (2013), tries to investigate the Southeast Asian Muslims' pilgrimage in the context of global history and elevates the pilgrimage studies to a new level. 
But the title of his book is a little misleading. The Chinese Muslims' journey to Mecca is even longer than the Southeast Asian Muslims' 'longest journey'. Certainly, this omission is reasonable since China is usually not included in the Muslim world and Islam has never been part of the mainstream of Chinese religions despite Muslims having settled in China for more than a thousand years and the Muslim population of China being more than two million, as much as the whole population of Malaysia. However, it is worth exploring how the Chinese Muslims living in the far eastern margin of the Muslim world have overcome so many physical, economic, psychological, social, and cultural difficulties because of the pilgrimage before air travel became commonplace.

The pilgrimage is the fifth pillar of Islam and the most important symbol of the unity of the Muslim 'Community' ('Ummah'). The pilgrims who return to Mecca and observe the mandated rituals at the holy sites would have a profound feeling of having gone through a life-transforming spiritual experience and belonging to a global community that shares the same religious beliefs. My research will focus on the relationship between the awakening of the Chinese Muslim identity and the pilgrimage in the Republican Era on the basis of a large amount of original official documents, news reports, memoirs, and other biographical materials, as regards to the Chinese pilgrims' responses to Islamic revivalism and Chinese nationalism.

\section{The Chinese Muslim communities in the Republican era (1911- 1949)}

After the fall of the Qing Dynasty, the founding father of the Republic of China, Sun Yatsen, immediately proclaimed that the new country belonged equally to the five nationalities, including Han, Manchu, Mongol, Hui (including Uighur Muslim), and Tibetan. But according to Sun's first People's Principle, Nationalism, all ethnic nationalities in China should eventually be assimilated into a new Chinese nationality. The nationalist government followed Sun's nationalism and tried to implement the assimilation policy to the ethnic minorities. In the new historical context of pan-Islamism and Chinese nationalism, it is interesting to see how the Chinese pilgrims, and the Chinese Muslims as a whole, understood and responded to the Islamic revivalist call for the unity of the Community and the Chinese nationalist voice to build up a new nation-state. 
Hui 回 is the traditional name for all Muslim peoples in China. Although the PRC government has changed it as an ethnic term, ${ }^{1}$ exclusively for the Muslims who have scattered in every province and are more acculturated to the Han Chinese societies. In Taiwan and overseas Chinese communities Hui still refers to all Muslim peoples in China and even other countries, and the 'Hui religion' (Huijiao 回教) is another name for Islam. In the Republican era, most official documents and personal writings roughly made a difference between the Uighur Muslims, mainly in Xinjiang, and the sinicized Muslims in almost every other province. The latter are the descendants of Muslim traders, envoys, and soldiers who migrated from the Middle East and Central Asia via the 'Silk Road' on land and sea, and eventually settled in China. They were more inclined to accept a new Chinese nationality based on the model of Sun's nationalist ideal than the Uighur Muslims, for geographical, cultural, and historical reasons. Due to the late integration of Xinjiang into the Qing imperial political system and the Uighur Muslims' exposure to their Turkish Muslim brothers in the neighboring Central Asian region, they kept their Persian-Turkish Islamic tradition intact up to the Republican era. Indeed, the majority of the Uighur Muslims could not speak Chinese, and far less adopted Han Chinese customs, read Confucian Classics or took up any position in the Han-dominant bureaucratic system. But the sinicized Muslim elites could master all of these matters, far better than the elites of other ethnic minorities. The nationalist government was aware of the problem of the Uighur Muslims but had never been able to build up a strong political mechanism to integrate them until the communists took over mainland China in 1949. The fate of the Uighur Muslims had been at the mercy of local warlords in Xinjiang during the Republican era. Therefore, their pilgrimage experience was very different from the rest of the Chinese Muslims. My research on the Chinese pilgrimage literature only focuses on the group of the sinicized (Hui) Muslim elites, although some of their works contain important information on Uighur Muslims' pilgrimage.

Perhaps for most Hui Muslims, Sun's claim to give equal rights to the five nationalities was an ideal, not a reality. Under the shadow of the massacre of the Hui communities in the northwestern and southwestern regions in the late Qing era, they doubted that the Han majority would treat them

1 The PRC government classifies all Muslim peoples in China in ten ethnic groups based upon the Stalinist ethnology. The Hui is one of them. The other nine Muslim ethnic groups are Uighurs, Tartar, Kirgiz, Kazak, Tajiks, Uzbeks, Dongxiang, Salar and Bonan, and all of them, besides Hui, are highly concentrated in the northwestern provinces where the Han majority has relatively less influence on the ethnic minorities than in the eastern provinces. 
as equals. But some of them might have thought that it would be worth a struggle to build up a liberal, democratic, and modern China. None of the Hui Muslims looked back at the monarchy system. They welcomed the new republican system in which they no longer had to perform ancestral rituals, 'prostrate'(ketou 吒頭) to the emperor and government officials, or follow various sophisticated customs against Islamic tenets. Therefore, some Hui Muslim intellectuals joined Sun's revolutionary party and took part in the general effort to reform China. They held the view that Islamic modernization should be part of a national effort to modernize China. ${ }^{2} \mathrm{~A}$ new wave of Islamic revivalist movements combining the ideology of Chinese nationalism were carried out by a new generation of foreign-educated Hui Muslim elites in the Republican era.

A group of such new Hui Muslim elites expressed their progressive ideas through the new media, such as newspapers, journals, and pamphlets, and organized themselves into local, provincial, and national voluntary organizations. The new instruments of communication transformed the general Chinese public sphere at that time, and also created a new Muslim public sphere. By the 1930s, more than a hundred Muslim newspapers and periodicals were coming out in almost every province of China. ${ }^{3}$ One of the most influential periodicals was Crescent China (Yue Hua 月華), issued every ten days from 1929 until the Japanese invasion of North China in 1937. Crescent China's approach was global and frequently included news about worldwide subjects, particularly from the Muslim countries. It also regularly published translated essays on a variety of topics from the Al-Manar (The Beacon) journal and other Egyptian Islamic modernist periodicals. ${ }^{4}$ Through the introduction of Crescent China and other new presses, the Hui Muslim intellectuals were familiar with Muhammad Abduh's (1849-1905) and Rashid Rida's (1865-1935) ideas of Islamic reform. These new ideas motivated some young Muslims to go overseas to study in order to learn new knowledge to build up a new China. In the context of this new nationalism and internationalism, the Chinese Muslim communities cultivated their first generation of Azhari graduates and modernist 'religious leaders' ('imams'), and brought forth a new wave of the pilgrimage movement in the 1920s and 1930s. The most well-known leaders with an Azhari diploma included Wang Jingzai 王靜齋 (1879-1949), Ma Songting 馬松亭 (1895-1992),

2 Gelvin and Green (2014, p. 251).

3 Ibid., p. 253 .

4 For the brief history of Islamic modernism in the late nineteenth and early twentieth centuries, see Hourani (1995, pp. 130-244). 
Pang Shiqing 龐士謙 (1902-1958). During his nine-year stay at Al-Azhar University (1937-1946), Pang was requested by his Azhari colleagues to write an Arabic book to introduce the Chinese Islamic tradition, which came out in 1945, entitled China and Islam. The publication of this book was the first time that the Arabic-speaking Muslim world received first-hand knowledge of Chinese Islam from a Chinese Muslim scholar. ${ }^{5}$ The founder of the Muslim Brotherhood, Hassan al-Banna (1906-1949), wrote the preface for the first Arabic edition of Pang's China and Islam. In his memoir, Pang mentioned that the Muslim Brothers asked for his help to build up the Chinese branch of their organization. Pang told them that China already had similar Islamic reform organizations, but he was willing to cooperate more in Egyptian and Chinese Muslim reformist movements in the future. ${ }^{6}$ Pang's polite objection to Hassan al-Banna's suggestion was a sign of the limitation of the Hui Muslims' to take part in the transnational Islamic revivalism in the Republican era.

The first generation of Azhari graduates initiated the earliest formal contacts between China and Egypt in sharing the strong sense of comradeship under the same yoke of Western colonialism. In this context, King Fu'ad (1868-1936) donated money to build up an Islamic library in Beijing and financed the travel and lodging of Chinese students in Cairo through the aforementioned leader Ma Songting's request. ${ }^{7}$ From then onward, the nationalist government saw the political value of Hui Muslims as a bridge between China and the Muslim world and developed diplomatic relations with Muslim countries through the Hui Muslim elites. Although the Republic of China government in Taiwan lost all official diplomatic relations with the Middle Eastern countries after the 199os, the Hui Muslims in Taiwan have still been the most important agents for the ROC in Taiwan by maintaining some unofficial relations with the Muslim world by way of the pilgrimage, studying at Muslim universities, and by doing halal business, and so on.

In the Republican era, the Hui Muslim intellectuals saw the connections with the Middle East as a renewal of traditional Chinese Islam's ties with the Muslim world and a return to their Islamic origin. In this regard, the Hui Muslims were like their Arab Muslim brothers in the early twentieth century, believing that the modernization of Islam meant a return to its

5 http://www.islam.org.hk/e15/e/action/ShowInfo.php?classid=32\&id=6710, accessed ${ }_{15}$ April 2016.

6 Pang (2005, pp. 373-374).

7 Ibid., p. 370. 
original form, the true and pure Islam in the Prophet Muhammad's time. Therefore, the identity of Chinese nationalism was not contradictory to the global unity of the Islamic Community at all; these two identities complemented and reinforced each other. The convergence of religious and political identities was especially embodied in the Hui pilgrims' experience.

\section{Hui pilgrims' road to Mecca}

Before the mid-nineteenth century, few people in the far eastern part of the Muslim world were able to make their way to Mecca for the pilgrimage, especially the Chinese Muslims, who had lived far from the center of the Muslim world and had to dedicate a year or more to the pilgrimage journey via the difficult 'Silk Road' on land or by sea, which was a risky trip that did not guarantee a safe return.

The 'Silk Road' consisted of several routes. As it extended westwards from the ancient commercial centers of China, the 'Silk Road' on land was divided into the northern and southern routes. ${ }^{8}$ The 'Silk Road' oversea began from the port cities of South China, mainly Guangzhou and Quanzhou, through Champa, Java, Palembang or Malacca, Ceylon, Calicut, the Persian Gulf or the coast of Yemen. ${ }^{9}$ The first Hui pilgrim writing about his journey to Mecca was Ma Huan 馬歡 (1380-1460), who joined Zheng He's great seven voyages (1405-1433) as scribe and translator, taking this route to Southeast Asia, South Asia, Western Asia, and East Africa. On the last voyage (14311433), Zheng He's fleets started their journey from Fujian, through Champa, Bengal, Laccadive and Maldives Islands, Aden, to the East African coast. During his return journey to China, Zheng He died off the Malabar Coast near Calicut. He had apparently never found time for the pilgrimage but did send Ma Huan and a group of Muslim sailors to Mecca. Ma Huan's work, the General Survey of the Ocean Shores (Yin Ya Sheng Lan 瀛涯勝覽) composed in 1416, gave a brief account of his observations of people's lives and customs in Mecca and most of the ports they visited. He called Mecca 'the Country of the House of Heaven' (Tianfang Guo 天方國), an official name for Mecca and Arabia in imperial China. Ma admired the Muslims in Mecca who followed the Islamic law in a strict way, but did not provide much detail regarding their lifestyle and customs. His narrative focused on the splendid Masjid al-Haram, the Grand Mosque of Mecca, but did not 
describe the rituals performed by the pilgrims. Ma's writing style is similar to that of the local gazetteers written by imperial officials, and his feelings and personal comments about the holy city don't show up in his narrative. ${ }^{10}$

After the Western colonial powers reopened the door to China after the Opium War (1840-1842) and used firearms and steamships to control the sea routes, it was easier for the Chinese Muslims to perform the pilgrimage. Many researches have already related the first global wave of Islamic revival to the pilgrimage at the time of Western imperialism from the midnineteenth to early twentieth century, but few of them are concerned with the impact of the renewed possibilities for the Chinese Muslim communities to go on the pilgrimage to Mecca. Indeed, the second earliest eyewitness narrative by a Hui pilgrim came out in the new context of Western colonialism, in which the pilgrims from all over the Muslim world no longer took the traditional route along the 'Silk Road' to Mecca.

The Yunnanese Hui leader Ma Dexin (1794-1874) wrote his Record of pilgrimage (Chao Jin TuJi 朝覲途記) following his return to China in 1848 . Ma's journey began in 1841, which signified the beginning of a new era in the Chinese Muslim pilgrimage history. Unable to sail from Guangzhou during the Opium War, Ma followed an overland path through Burma and boarded a ship in Rangoon, sailing directly to Arabia. Ma Dexin's narrative on the holy city, like Ma Huan's, merely focused on the Grand Mosque without any description of the pilgrimage rituals or the Meccans' customs. ${ }^{11}$

After performing the pilgrimage, Ma spent eight years studying at AlAzhar University. He was the first Hui leader to study in the Muslim world and initiated a new learning model for the new Hui 'scholars' (ulama) in the Republican era by combining the pilgrimage with studying at Al-Azhar. Regrettably, Ma mentioned nothing about what he had seen and learned at Al-Azhar, which Pang did a century later. By the end of the nineteenth century, regular steamships sailing from the East Asian ports to the Middle East and Europe completely reorganized the economy of the pilgrimage. ${ }^{12}$

In the 1920s, Shanghai became the main departure port for the Chinese pilgrims to go to Mecca via the sea route through the South China Sea and the Indian Ocean which was then under British control. This journey to Mecca had been standardized in the most efficient and fast way. ${ }^{13}$ The Uighur pilgrims took a different route due to the long distance between 
Xinjiang and Shanghai. They kept taking the traditional 'Silk Road' on land for the first half of the pilgrimage, during which their Turkish Muslim brothers in Central Asia could help them to overcome their physical and psychological hardships, until they arrived in Bombay or Karachi to take a steamship for the rest of their journey to Mecca.

From 1930 onward, the Chinese Muslim pilgrims from almost every province besides Xinjiang did business with a British company, the Blue Chimney Co., to arrange the steamship to Mecca but only after time-consuming negotiations with a travel agency in Shanghai. The Blue Chimney Co.'s monopoly of the Chinese pilgrimage journey continued until 1940, cut short by the Second World War. ${ }^{14}$ The Chinese pilgrims departed from Shanghai, traveled through Hong Kong, Singapore, Colombo, Bombay, disembarked in Jeddah, and then rode to Mecca on camels. It only took about four or five weeks to make the one-way trip from Shanghai to Mecca. Besides applying for a passport from the Ministry of Foreign Affairs of the ROC government, getting a visa from the British embassy, exchanging foreign currency at the bank, and buying the ticket through the travel agency, every pilgrim had to be vaccinated against epidemic diseases at the quarantine station of Shanghai. According to Tagliacozzo the 'aggressive European powers sought to manage the pilgrimage on the grounds of global epidemiological survival. ${ }^{15}$

Blue Chimney Co. provided halal food for the Chinese pilgrim during their voyage, but they were often offended by the other travelers' customs and behavior, for example the Europeans' strange dress and - in their eyes licentious interaction between men and women. At every port on the route to Mecca, the Chinese pilgrims witnessed their Muslim brothers, including Malay, Indian, and Arab, 'enslaved' by the British colonial power and in their hearts a sense of sympathy arose, humiliation and responsibility towards the Muslim unity. ${ }^{16}$ The Chinese pilgrims' life-transforming experience was very similar to that of the pilgrims in the rest of the Muslim world. This journey reinforced their solidarity with other Muslim peoples and generated revivalist movements in their home countries. This was not much different in the Chinese Muslim case in spite of their status as a minority in their homeland.

14 My reconstruction of the standard procedure of the pilgrimage in the 1930s departing from Shanghai is based on the following original sources: eight Hui-run journals, including Crescent China, and two Shanghai-based journals, Hai Shi (海事) and the most popular and influential newspapers in the Republican era, Shun Pao (申報).

15 Tagliacozzo (2013, p. 134).

16 Zhao (2oo8, pp. 29-43, 48-59); Tang (2008, pp. 61-68, 73-108, 239-243). 


\section{The pilgrimage experience and the reconstruction of Hui Muslim identity}

The shift in the model of performing the pilgrimage from the pre-colonial to colonial era had a great impact on both the material and spiritual aspects of the Muslim world as Tagliacozzo shows. The rise of the European colonial states and technological progress enabled more pilgrims to perform the pilgrimage. Therefore, paradoxically, the Pan-Islamic consciousness was awakened in more Muslims doing the pilgrimage in the easy, economical, and efficient way under the domination of Western colonialism. Tagliacozzo demonstrates this paradoxical fact by his comprehensive study on the Southeast Asian case, especially in regard to epidemiological, financial, and geopolitical aspects. He explains how the pilgrimage grew in importance among Malays and how Southeast Asia was brought into the religious and intellectual worlds of Arabia and the surrounding Muslim countries. The Southeast Asian situation has some parallels with the Chinese case.

In the 1930s, the Hui pilgrims witnessed the historical turning point of Arabia and the neighboring Arab countries. After the collapse of the Ottoman Empire following the World War I, France and Britain partitioned the Arab territory of the Ottoman Empire into the five new political entities of Transjordan, Iraq, Syria, Lebanon, and Palestine. Furthermore, the British continued their policy of 'divide and rule' in the Arabian Peninsula and pitted the two most powerful Arab leaders, Sharif Husayn ibn Ali of Mecca and Abd al-Aziz Ibn Sa ud of Najd, against each other. But the latter, as the inheritor of the Wahhabi ideology and less reliant on the Western powers than Sharif Husayn, gathered an indigenous force of resurgent Wahhabi tribesmen from the Najd. Ibn Sa'ud leading his enthusiastic Ikhwan (the brotherhood order) wanted to restore Islam among the Bedouin people, and to break their allegiance to local chiefs and shaykhs (elders). Their influence had penetrated into the Hijaz surrounding Mecca, so Sharif Husayn was gradually isolated within the holy city. The British support merely made him more unpopular among his Arab subjects. In September 1924, three thousand Wahhabi warriors invaded Ta if and forced Husayn to abdicate his Sharifate and leave Mecca. The century-long cold war between the Sharifs and the Saudis was about to be decisively concluded, and Ibn Sa'ud's army peacefully entered Mecca. The following year Ibn Sa'ud was crowned the King of the Hijaz and reunified Arabia under the banner of Islam. With the abdication of Sharif Husayn and the collapse of the Ottoman caliphate, the Muslim peoples were left without a symbolic 
head for the first time in history. The Middle East was ready for the new tide of Arab nationalism. ${ }^{17}$

In November 1926, Ibn Saud issued a decree setting out the first comprehensive pilgrimage regulations, granting his regime the right to license and oversee all pilgrim guilds. Fixed rates for the pilgrimage services were published and distributed among the Muslim countries. Meanwhile, Europeans could not but accept Ibn Sa'ud's sovereignty in the holy city in exchange for maintaining their profitable business of furnishing the pilgrims' material needs. ${ }^{18}$

The dramatic political change of Mecca and the early stage of Arab nationalism were witnessed by the Hui pilgrims in the 1930s. The two most detailed memoirs in this critical period were written by two Hui pilgrims from Beijing: Zhao Zhen wu's Diary of the Westward Journey (Xi Xing Ri Ji 西行日記) and Tang Yichen's 唐易塵 Record of the Pilgrimage to Mecca (Mai Jia Xun Li Ji 麥加巡禮記). These two memoirs describe their interesting pilgrimage experiences right after Ibn Sa udi issued the Wahhabi order of Mecca, following the strict rules of Shari'ah.

Zhao Zhenwu 趙振武 (1895-1937), a Hui scholar from Beijing, who was educated in both traditional religious school and modern secular university, contributed the last half of his life to build up a modern Islamic education in China. Zhao performed the pilgrimage in the company of Ma Songting's educational mission group to Al-Azhar in 1933 when he was the editor-inchief of Crescent China. Zhao, Ma, and their Beijing Hui colleagues, made Crescent China the major voice of Islamic modernism in China. Zhao and Ma went to Mecca after they had finished their mission at Al-Azhar and a tour around Jerusalem.

Perhaps Zhao was not very impressed by Ibn Sa'ud's rule of Mecca due to Zhao's modernist view on Islam, so his narrative about the pilgrimage and the holy city was very brief in comparison to those of Al-Azhar and the old city of Jerusalem, yet King Sa ud did have a meeting with him and the Hui pilgrim group. Zhao arrived in Jerusalem two years after the first General Islamic Congress in 1931 and three years before the Palestinian Arab revolt in 1936. He was well informed about the escalating conflict between Palestinian Arabs and Jewish Zionists. Zhao and other Hui pilgrims stayed at the Naqshbandiyyah Sufi order of the Indian Muslims in Jerusalem and had a chance to visit the Palestinian Muslim Leader and Grand Judge

17 For the political change of Mecca in the 1920s, see Peters (1994, pp. 331-354); Wolfe (1997, pp. 323-326); for its context of Arab nationalism, see Hourani (1995, pp. 294-305).

18 Peters (1994, pp. 358-362); Wolfe (1997, p. 326). 
('Mufti') of Jerusalem, Mohammed Amin al-Husseini (1897-1974). Zhao mentioned that there were merely twenty thousand Muslims living in the old city of Jerusalem compared to seventy-five thousand Jews. He was very sympathetic to the miserable situation of the Palestinian Muslims and asserted that the large wave of Jewish immigration was a conspiracy of British imperialism to ruin the Muslim world. ${ }^{19}$ This was a common view held among the Palestinian people during the British mandate (1922-1947). ${ }^{20}$

In contrast to Zhao's detailed narratives of Al-Azhar and Jerusalem, his narrative of Mecca was brief and not very exciting. The Meccan Arabs were portrayed as under-developed and less educated. He was offended by the high official of the Sàdi government, assigned by King Sàd to receive the Hui pilgrims, and made harsh comments on the Wahhabi Islam:

We had a long talk with him, and realized his personality and the nature of Wahhabism very well. He thought that to be a good Muslim, one should only recite the Witness creed ('Shahadah'). This is absolutely not enough! Although I should not regard him as disbeliever ('kafeier', 'kafir'), he does not understand that true Islam includes observing the five pillars, pursuing the good, prohibiting the evil, faithfulness, filial piety, benevolence, and kindness. All of them are Islamic pillars. If without these pillars, how will the religious house be built? Every stranger could be caught and commanded to recite the Witness creed. The key difference between Muslim and non-Muslim is always upon whether one can practice those pillars or not. ${ }^{21}$

Zhao concluded his memoir by emphasizing the importance of education for the revival of an Islamic civilization. ${ }^{22}$ Obviously, Zhao's pilgrimage experience shows that the pilgrim's spiritual union with the Community does not necessarily result in political solidarity with his Muslim brothers and sisters. Zhao's political identity belonged to his motherland, and his nationalist imagination was about a modern Hui community and a new China through the modernist educational reform. This was the Azhari way of Islamic revivalism, not the Wahhabi one.

Tang Yichen's memoir is probably the most interesting pilgrim writing of the Republican era, although his pilgrimage might be the most 
controversial one. Tang, a Japanese-educated Hui intellectual also from Beijing but without the credentials of religious scholars like Zhao and Ma, performed his pilgrimage in 1938 during the Japanese occupation of North China (1937-1945). In spite of being educated at a secular university and not being a religious scholar, Tang expressed his religious passion and political stance in his memoir in a very straightforward way. He was inspired by reading Zhao's memoir and enthusiastic about fulfilling his pilgrimage duty. During the difficult time of the Sino-Japanese war, Tang applied for permission from the Japanese colonial authority. As a key member of the Japanese-backed Muslim association of North China, he easily obtained the permission to leave for Mecca. But this gift sent by the Japanese enemy gave him the dishonorable name of Hui traitor (Huijian) forever. As soon as Tang and his four fellow pilgrims were ready to depart from Beijing to Shanghai, the news (or more precisely, the rumor) of Tang's pilgrim group ordered by the Japanese authority to go on a 'diplomatic' pilgrimage to the Muslim world reached to the nationalist government in Chungking, Sichuan. The nationalist government immediately ordered the Hui scholars and students in Al-Azhar to organize a pilgrim group to monitor Tang's activities in Mecca and make anti-Japanese propaganda among the other pilgrims from all over the Muslim world. Tang knew this horrible situation and was afraid of talking to any Chinese stranger during his anxious journey to Mecca. His sadness and depression became heavier at seeing the British flags at every port on the route to Arabia, from Hong Kong, through Singapore, Colombo, to Bombay. His depression was not relieved until he arrived in Jeddah and saw the Sa udi flag. He was very excited to get to know the holy land ruled by an indigenous Muslim regime and admired the Sa'udi rule as an 'Arabic Monroeism', a good model to be followed by other Muslim peoples. ${ }^{23}$

But Tang's admiration for the Sa udi Kingdom was only for her independence, not for her Wahhabi ideology. After arriving in Mecca, Tang had an official meeting with King Sa ud. Once he met the pilgrim group sent by the nationalist government, Tang tried very hard to explain to them that his pilgrimage trip was not ordered by the Japanese authority and had nothing to do with politics. ${ }^{24}$ In the spiritual atmosphere of the holy city, their political differences were soon overcome through their spiritual union with the faithful Community. Tang and the Hui Azhari students, led by the respected Pang Shiqing, made an agreement and shook hands to totally dissolve their distrust. Obviously, Pang did not doubt Tang's explanation 
and they shared their sense of the Muslim unity and anti-imperialism. They also agreed that both Hui and Uighur Muslims had to work together to build up a new China. ${ }^{25}$ Tang could not speak Arabic, so an Azhari student translated and read his public letter to King Sa'ud in Arabic when they met with the King. ${ }^{26}$

Tang's narrative of the pilgrimage rituals was more detailed and expressed more religious passion than Zhao's. His words demonstrated a great sense of belonging to the faithful Community and the bliss of the spiritual journey. Nevertheless, like Zhao's modernist viewpoint, he was very uncomfortable with the extreme measures to regulate the pilgrimage by King Saud and the Arabs' 'uncivilized' condition. Tang frankly ridiculed the Arabs' 'low intelligence' and the Africans' 'poor religious performance. ${ }^{.27} \mathrm{His}$ comments on his fellow Muslims were not at all moderated by his sympathy for their 'enslaved' condition under British imperialism.

In Tang's mind, there were three approaches to Islamic reform in the Muslim world: Turkish secularism, Sàdi Wahhabism, and Egyptian Islamic modernism. He strongly condemned Mustafa Kemal Atatürk's secularist policy and labeled the founding father of modern Turkey as 'the destructor of the Muslim world', claiming that he had 'no sense of conscience', and that he was 'the devil bringing disorder on earth'. ${ }^{28}$ The Wahhabi approach of the Sàdi Kingdom was also disappointing from Tang's modernist standpoint. The luxurious life of the royal family was in sharp contrast to the poverty of the Arab tribesmen. Furthermore, Tang saw that the British hegemonic power still overshadowed the Arabian Peninsula and that the Saudi Kingdom was not really independent of the Pax Britannica dominion. ${ }^{29}$ Therefore, the Egyptian modernist approach was Tang's only hope for Islamic revival and the Muslim national liberation.

In the concluding section of his memoir, Tang constructed a peculiar conspiracy theory to justify his political stance of anti-Western imperialism:

In recent years, many Hui people have proclaimed, 'We have to struggle for religion, not for the state.' They want to keep away from politics (...) In fact, this is the omen of the extinction of Islam (...) Due to their misunderstanding, they think a good Muslim should only seek the spiritual

26 Tang, (2008, pp. 167-170).

27 Ibid., pp. 89-108, 172-174.

28 Ibid., pp. 30-31.

29 Ibid., pp. 239-243. 
path and not be involved in secular matters. Thus our great statesmen also talk about the necessity of the separation between religion and politics (...) Englishmen realize the apolitical mentality of the Muslim peoples and try to abuse it. They do their best to satisfy Muslims' religious needs and take away Muslims' political power. But most Muslims are ignorant and mistakenly regard Englishmen as their good friends. They do not know the heartless Englishmen have already sucked their blood dry but still keep a smile on their faces. Their maliciousness cannot be exceeded by other peoples..$^{30}$

Tang took Palestine as the proof of his conspiracy theory and asserted the British imperialists had been behind the Palestinian-Jewish conflicts. Moreover, he also claimed the interracial marriage between Indian men and British women was another British conspiracy to exterminate the Indian national liberation movement. Tang raised the question: If the young generation of Indians born in such an interracial family have British mothers, how can they fight against their mothers' home country? He concluded Britain was the most malicious country on earth..$^{11}$ Tang's racist words, anti-secularist ideology, and Third-Worldism have been common themes among contemporary religious extremists or right-wing circles. Seemingly, many post-colonial peoples have not yet recovered from their colonial trauma.

Indeed, Tang's memoir was deemed a negative textbook of a Hui traitor by both the nationalist and Communist historians due to his taking part in the Japanese-backed Muslim association of North China. But Tang was still a Chinese nationalist when he considered the British imperialists more evil than the Japanese enemies. The label of Hui traitor might have been unfair to Tang and those Hui people who merely wanted to 'struggle for religion, not for the state' while their home country was occupied. Tang did not mention how he viewed the Japanese occupation of North China. His memoir was published in 1943 when the Japanese army still occupied North China. It would have been better for him not to say anything negative about the Japanese authority. Tang's case reveals a little-known aspect of Hui nationalism, different from the two official versions of the nationalist and Communist regimes. We need more historical materials, in addition to the pilgrimage literature, to illuminate the complex Hui nationalist politics in the Republic era. 


\section{Conclusion}

Both China and the Arab world encountered historical turning points in the 1920 and 1930s. Although these two Asian peoples reconstructed their national identities under the enormous challenge of Western colonialism and moved into the new historical phase of post-colonialism, they followed a dramatically different trajectory of nation-building. The Sa'udi Wahhabism is a certain kind of religious nationalism which resulted in the theocratic nation-state, Saudi Arabia. This model has inspired many Islamic revival movements up to now. No matter which approach an Islamic movement takes, either moderate or extreme, secular-oriented nationalism has been an unpopular alternative, and religion is usually mixed with politics in the Arab countries. The Chinese nationalists chose the opposite way. The Hui people have been caught up between these two different worldviews and ideologies. However, for the Hui Muslim pilgrims in the historical context of Republican China, their choice would not simply be the choice between pan-Islamism and Hui patriotism, but a mixture of the two. Which approach a certain group of Hui intellectuals has taken depends on the context of this group's local, national, and global problems. Although for the Hui intellectuals in the Republican era, the pilgrimage to their spiritual homeland provided a new chance and an alternative to create a religious nationalism going beyond the boundaries of ethnicity and nationality and overcoming the dichotomy of the material and the spiritual, such a religious nationalism did not appear due to the minority status of the Hui Muslims and the political and ideological limitations of Chinese nationalism. Chinese nationalism has been the Han-dominant ideology for the last hundred years, and mostly geared to the Western model of secular nationalism at the expense of religious traditions. The Hui Muslims cannot but accommodate themselves with such a dominant ideology and discourse under the Han Chinese political and cultural hegemony. Their religious freedom could be fully respected by the public authority but limited in their own social spaces. Religious nationalism, in the sense of building an independent Hui Muslim state, would never have been a legitimate alternative under either the democratic or socialist regime; both of them are secularist.

Nevertheless, the pilgrimage is a good way to see the dialectical relationship between religious practice and Muslim nationalism, and also between global and local Islamic politics. In the Hui Muslim case, these two sides have positively reinforced each other, although their transnational identity has not yet gone beyond the delimitation of the 
nation-state. Therefore, the spiritual unity of the Community cannot be materialized in a secular world. At least, the spiritual identity of the Hui people is still in harmony with the national identity of their motherland, and the sacred/secular conflict has not yet occurred there. To some extent, the Hui experience is unique in comparison with the contemporary situation of the Muslim minorities in the European and American countries. In the early 21st century, Global Islamism is seemingly antithetical to the national identity of these countries. I think this difference is quite understandable considering the geographical and historical conditions of the Hui people.

\section{Bibliography}

Gelvin, James L. and Nile Green, eds. 2014. Global Muslims in the Age of Steam and Print. Berkeley, CA: University of California Press.

Hourani, Albert. 1995. Arabic Thought in the Liberal Age, 1798-1939. Cambridge: Cambridge University Press.

Ladjal, Tarek, et al. 2o13. 'Asian Hajj Routes: The Reflection of History and Geography,' Middle-East Journal of Scientific Research, 14(12): 1691-1699.

Ma, Dexin 馬德新. 2008. Chao Jin TuJi 朝覲途記 (Record of Pilgrimage). Lanzhou: Gansu Wenhua Press/Yinchuan: Ningxia Renmin Press.

Ma, Huan 馬歡. 2005. Yín Ya Sheng Lan 瀛涯勝覽 (General Survey of the Ocean Shores). Beijing: Haiyang.

Mols, Luitgard, and Marjo Buitelaar, eds. 2014. Hajj: Global Interactions through Pilgrimage. Leiden: Sidestone Press.

Pang, Shiqing 龐士謙. 2005. Ai Ji Jiu Nian 埃及九年 (My Nine Years in Egypt). Hefei: Huangshan Shushe.

Peters, F.E. 1994. The Hajj: The Muslim Pilgrimage to Mecca and the Holy Places. Princeton, NJ: Princeton University Press.

Peters, F.E. 1994. Mecca: A Literary History of the Muslim Holy Land. Princeton, NJ: Princeton University Press.

Tagliacozzo, Eric. 2013. The Longest Journey: Southeast Asians and the Pilgrimage to Mecca. Oxford/New York: Oxford University Press.

Tang ,Yichen 唐易塵. 2008. Mai Jia Xun Li Ji 麥加巡禮記 (Record of the Pilgrimage to Mecca). Lanzhou: Gansu Wenhua Press/Yinchuan: Ningxia Renmin Press.

Wolfe, Michael, ed. 1997. One Thousand Roads to Mecca: Ten Centuries of Travelers Writing about the Muslim Pilgrimage. New York, NY: Grove Press.

Zhao, Zhenwu 趙振武. 2008.XiXing RiJi 西行日記 (Diary of the WestwardJourney). Lanzhou: Gansu Wenhua Press/Yinchuan: Ningxia Renmin Press. 


\section{About the author}

Tsai, Yuan-lin. Associate Professor of Islamic Studies and Religion-Politics Relationship, Graduate Institute of Religious Studies, National Chengchi University, Taiwan. Email: yltsai@nccu.edu.tw 



\section{Part II}

Religion and Nationalism in Contemporary China 



\title{
$7 \quad$ Religion and the Nation
}

\author{
Confucian and New Confucian Religious Nationalism
}

\author{
Bart Dessein
}

\begin{abstract}
For Confucian rulers, maintenance of the unified empire they had inherited from the Qin in 206 BCE was not only seen as a political task, but also had religious ramifications. Confucian state ritual determined the position of other philosophies and religions in Chinese society, and was given a political interpretation.

This contribution shows how the republican zeal to reestablish a unified nation after the collapse of the Qing Empire was - in its radical decline of Confucianism - fundamentally religious, and how also Maoism was shaped within the traditional politico-religious paradigm. This contribution also argues that, in its dynamic relation with a growing religious adherence, contemporary CCP-supported New Confucianism has become a religious component of the CCP nation-state.
\end{abstract}

Keywords: Confucianism, New Confucianism, imperial China, Republican China, People's Republic of China

\section{Origins of Chinese politico-religious self-identity ${ }^{1}$}

China's so-called 'period of regional development' (1700-771 BCE) is characterized by a series of developments that would determine the country's further history: ${ }^{2}(1)$ bronze started to be used in the production of agricultural tools, which made it possible to both increase the area of agricultural land that could be tilled and the efficiency with which this could be done; ${ }^{3}$ (2) society became hierarchically organized with the formation of different communities (Weber's 'Gemeinschaften') within the layer of popular culture;

1 The following paragraphs summarize some of the elements I addressed in previous publications. See Dessein (2011; 2012; 2014).

2 This term was coined by Stover (1974, pp. 42ff).

3 The Chinese most likely learned the casting of bronze from the northern Eurasian mobile pastoralists around 1700 BCE. See Fitzgerald-Huber (1995, p. 67). 
and (3) political power became increasingly concentrated in the hands of a proto-bureaucratic elite that formed a separate social and ideological community ('Gemeinschaft'). ${ }^{4}$ An increased agricultural output may have made it possible to feed a larger number of people, this growing population, in its turn, necessitated a continuous expansion of the agricultural land. As directly available farmland was limited to the central plain (zhongyuan 中原) of the Yellow River (Huanghe 黃河) and its tributaries, the point necessarily came where expansion of the farmland of one of the many different feudal domains that constituted 'China' at that time, was only possible to the detriment of the neighboring domains. The economic and political crisis that thus ensued gave rise to the formulation of different 'philosophies' in the subsequent periods of 'Spring-and-Autumn' (Chunqiu' 春秋, 722-481) and 'Warring States' (Zhanguo 戰國, 481-221). These 'philosophies' are basically analyses of and suggestions for solving the crisis. This period that is also known as the period of the 'One Hundred Philosophical Schools' in Chinese intellectual history, has therefore been of major importance for Chinese state building, and for the establishment of the peculiar and intricate relationship between 'philosophy' and 'politics' in Chinese culture. ${ }^{5}$ The existence of a so-called Jixia Academy (jixia xuegong 稷下學宮), an assembly of political advisors founded in ca 360 BCE by Duke Huan, ruler of the feudal 'state' Qi 齊, points to it that this period of Chinese history was, indeed, characterized by politically inspired intellectual debate. ${ }^{6}$ The 'philosophies' that were formulated in this period are strikingly similar in their aim to reinstall an imagined 'golden era'. Chinese 'philosophies' are hence not only oriented towards the Diesseits, but they are also fundamentally oriented towards the past. ${ }^{7}$

The magnitude of the unification of all the different feudal states under one central leadership in 221 BCE by the ruler of the Qin state was such that he no longer referred to himself as 'king' (wang 王) - the name that had been used to refer to central authority in the previous period - but as Qin shi huangdi 秦始皇帝: the first 'august emperor' of Qin. ${ }^{8}$ The first

\footnotetext{
4 See Weber (1978, pp. 40-41).

5 See in this respect Dessein (2001).

6 Lloyd and Sivin (2000, pp. 30-35), remark that this Jixia Academy is not a meeting place for intellectuals, comparable to a contemporary research center. For the interpretation of the Jixia Academy as a center of learning: see Makeham (1994). See also Sivin (1995, chapter 40); Lee (2000, pp. 44-46).

7 Bauer (2006, p. 37). This also explains why, in China, it was not the authority of demonstration that determined the validity of a saying, but its philosophical origin.

8 See Bodde (1986, p. 53).
} 
'august emperor' also manifested the major break with the past he had achieved in his choice to govern his country through applying the Legalist doctrine, the only political doctrine that did not take a eulogized historical period as example. This choice was undoubtedly also given in through the Legalist doctrine's focus on law and punishment as policy guidelines, a characteristic that added to the practical usefulness of this doctrine to also effectively unify the country. ${ }^{9}$

The fall of the Qin Dynasty after having ruled for only fifteen years was the chance for the former feudal lords, who had been deprived of their privileges by the first emperor, to return to the political scene. Now that the short-lived Qin Dynasty had proven the unsuitability of Legalism as guideline for practical politics, this gave room for other philosophies to come to the forefront in the Han Dynasty (206 BCE-22o CE). Many hypotheses have been formulated as to why it has been Confucianism - in its 'New Text School' interpretation - that could establish itself as the new political doctrine. One of the elements that may have been conducive to this effect may be that the founders of the Han Dynasty who were of non-noble descent saw in the Confucian focus on the concept of 'governing through humaneness' (ren 仁) - as opposed to governing through hereditary right - an excellent instrument to legitimate their rule.

The transition from the Qin to the Han has been of a threefold political importance. Firstly, with the return to power of the former feudal lords, the hierarchical social structures that had existed in pre-imperial times were reinstalled. Secondly, after its promulgation as only orthodoxy in $136 \mathrm{BCE}$, Confucianism was crafted into these inherited hierarchical structures and a Confucian bureaucracy was installed to administer the Chinese 'body politic'. ${ }^{10}$ In order to uphold the Confucian political, moral, and divine order, functionaries were selected on the basis of their knowledge of the Confucian

9 See Bauer (2006, p. 37). Katz (2009, p. 43), remarks that in the Qin-Han era, 'written legal texts began to be used in place of oaths in order to command assent and obedience', and that this era further witnesses an increasing prevalence of state-sanctioned violence.

10 Schwartz (1985, p. 377) calls Emperor Han Wudi the 'Constantine of Confucianism', who followed the momentous advice of the New Text School ideologue Dong Zhongshu (ca 179- ca 104 BCE) and others to establish the 'five classics' of Confucianism as the foundation of all official education and to proscribe all 'unorthodox' doctrines. Dull (1994, p. 3) remarks that the reign of Emperor Wu (140-87 BCE) of the Han Dynasty is the period in which Confucianism for the first time was recognized as the 'ism', 'to the exclusion of all others, that was to be acceptable to the state and was to become the object of study for those who hoped for an official career'. See also Schmidt-Glintzer (1999, p. 18). 
'canon' of examination materials. ${ }^{11} \mathrm{~A}$ third consequence was that China's typical economic landscape of hydraulic cultivation of small plots of land an ecotype that was fundamentally different from the economic landscape of the surrounding regions, combined with its unique political structure, fundamentally shaped Chinese 'self-identity'. ${ }^{12}$

That the Confucian literati saw themselves as the 'natural' inheritors of a 'national' and 'divine' historical lineage is evident from the 'Prefaces' to the Maoshi 毛詩 version of the Songs (Shijing 詩經). While the songs that are included in the Shijing themselves go back to the tenth to sixth centuries BCE and depict the Chinese people as born through divine intervention, ${ }^{13}$ and as ensuring themselves of continued divine support through ritual offerings, the extant 'Prefaces' to the songs are most likely written around the beginning of the Common Era and present the 'history of China' as one single development from the eleventh century BCE up to 599 BCE. This presentation importantly implies that the secular realm, which is referred to as 'All-under-Heaven' (tianxia 天下), is connected to the spiritual realm. ${ }^{14}$

The connection between the secular and the spiritual realm is also evident in the Luxuriant Gems of the Spring and Autumn Annals (Chunqiu fanlu), the major work of the Han-Dynasty Confucian scholar and ideologue Dong Zhongshu 董仲書 (ca 179-ca 104 BCE). Through developing analogies between heaven - the collective of deceased ancestors, earth, and man, this work that is conceived as a commentary on the Confucian Classic Chunqiu (Spring and Autumn Annals), presents 'All-under-Heaven' as a holistic 'organism' in which every part is interrelated with every other part. ${ }^{15}$ It is the task of Confucian rule to preserve harmony (hexie 和諧) - that is, to uphold the existing social order - in this organism. As Dong Zhongshu explains:

When the ancients invented writing, they drew three [horizontal] lines which they connected through the centre [by a vertical stroke], and then

11 See Bauer (2006, p.119); van Ess (2003, p. 42). Seiwert (1994, p. 532) remarks that 'In knappster Form: Orthodoxie war die Voraussetzung für den Zugang zur Elitenkultur und damit die Voraussetzung für die Teilhabe an der institutionellen Macht, für Prestige und legalen Reichtum'.

12 See Wolf (1966, pp. 25-30).

13 Schwartz (1985, p. 30) remarks that the God (di 帝) to which the first stanza of the ode Sheng min refers is 'the nonhuman high god who engendered the dynasty'.

$14 \mathrm{Yu}(2005, \mathrm{p} .34)$ remarks that the politico-religious narrative of Confucianism, in fact, builds on the system that was developed already in the Shang Dynasty (traditionally 1766-1122 BCE), when ancestors were transformed from kin to symbols of divine power.

15 Schwartz (1985, p. 364) has characterized this 'cosmological Confucianism' as a kind of 'phenomenalist philosophy'. 'Phenomenalism' is hereby understood as a belief that governmental and social irregularities can lead to vast dislocations in nature. 
called this wang (ruler/king). These three lines represent heaven, earth, and man; the connecting of them through the centre represents the way (dao 道) of [the ruler]. Who, if not a wang, could take the central position between heaven, earth, and man, so as to connect and council them? Therefore, a wang models himself on heaven. [...] He models himself on its dao and thereby brings his administration into operation. He models himself on its will and, with it, attaches himself to humaneness (ren 仁). ${ }^{16}$

An important implication of the idea that the ruler mirrors his moral behavior on heaven and can therefore be a model to emulate in his own right is that a 'universalizing' potential was attributed to Confucianism, that is, it was thought that 'barbarians' could become part of the Confucian 'All-under-Heaven' through education and emulation. ${ }^{17}$

\section{Religion and Confucian nationalism}

According to Pierre Bourdieu, when political or ecclesiastical elites elevate one religious system over another, the displaced beliefs and practices become stigmatized as 'magic', 'sorcery', and 'superstition', and are associated with the vulgarity of the common people. When, in this way, a body of knowledge is centralized and systematized by a class of specialists, this creates a field of power between those who hold religious authority and those who do not. ${ }^{18}$ This is precisely what happened with the sole recognition of New Text School Confucianism as official orthodoxy in the Han Dynasty. Although Confucianism may not be a 'full-fledged religion', the religious ramifications of the Confucian politico-religious construct described above transformed Confucianism - at least for the elite - into a 'civil religion' with its proper symbols, rules of behavior, and ritual prescripts. These rituals further had the possibility to bestow on the commoners 'a sense of belonging

16 Dong (1988, p. 794b). This interpretation of the role of politics can also be read in Xu Shen's (ca 58-ca 147) Shuo wen jie zi (Explanation of Single Graphs and Analysis of Compound Graphs), the oldest extant etymological dictionary of the Chinese language (Xu, [1981] 1988, p. 7b). The intricate connection between the realm of secular governance and the realm of the divine is also reflected in the references to the Shijing (Songs) in the Confucian Lunyu (Analects). For the significance of the fact that the Lunyu refers to the Shijing: see Shryock (1966, p. 4).

17 See Levenson (1964), and Dessein (2016). Note that such a 'model role' is also present in the way the People's Republic of China presented itself as the leader of the Communist World.

18 Bourdieu (1971, pp. 304-305, 308-309). Also see Goossaert and Palmer (2011, p. 10). 
to an "imagined community" of supremely civilized subjects of the realm.' ${ }^{19}$ In this light, Clifford Geertz's statement that religion is 'a system of symbols which acts to establish powerful, pervasive, and long-lasting moods and motivations in men by formulating conceptions of a general order of existence and clothing these conceptions with such an aura of factuality that the moods and motivations seem uniquely realistic', gains an extra meaning when religion and politics form an interconnected whole. ${ }^{20}$ In Confucian China, where religious symbols and rituals necessarily also had a political meaning, upholding harmony in 'All-under-Heaven' was as much a divine as a 'national' political mission.

That Confucianism became the only sanctioned doctrine does not mean that 'China' became philosophically or religiously homogenous. Analyzing the religious world in market terms, Yang Fenggang claimed that religious regulation leads to the development of a tripartite religious market: a 'red' market of officially recognized religions, a black market of forbidden religious organizations, and a grey market of those religions that are not forbidden but are not orthodox either. ${ }^{21}$ Applying this model to imperial China, the practical outcome of the recognition of Confucianism as only orthodoxy to the exclusion of all other ideologies, was that Daoism, Buddhism, and popular religions were displaced to the 'grey zone' of the religious market - in imperial China, there was no systematic prohibition of religious cults. Hubert Seiwert has described this situation as follows:

As soon as we leave the domain of the ideological homogenous elite culture, it becomes clear that the cognitive and normative orientations of the elite claimed to possess universal value, but did actually not do so. Chinese history (not only the pre-modern one) is full of examples of attempts to control society ideologically, to eliminate 'false' (heterodox) doctrines and writings, and to render the correct interpretation of the world universal validity. ${ }^{22}$

19 Nylan, ([2008] 2009, p. 61). Yu (2005, p. 51) states that: 'Just as the state's recognition of Confucius and its continual process of canonizing his descendants were indicative of its own moral discernment and enlightenment, so the designated descendants's fulfilment of their ritual duties on behalf of the state betokened their acknowledgement of the regime's legitimacy'. For the term 'imagined community': see Anderson (1991). On the religion sphere being a kind of imagined community as much as the nation is: see Chapter 4.

20 Geertz (1966, p. 4). Note that this phenomenon is also true for Marxism-Leninism in the People's Republic of China.

21 Yang (2012, p. 85).

22 Seiwert (1994, pp. 531-532). Schmidt-Glintzer (2009, p. 27) described this as 'die Einbindung des Einzelnen in die Gemeinschaft [als] Grundfärbung aller politischen Philosophie Chinas'. 
A practical outcome of the concentration of politico-religious power in the hands of the Confucian elite, the displacement of non-Confucian faiths to the grey market, and the absence of an institutionalized system of political opposition was that political opposition - by definition a threat to the preservation of a Confucian harmonious 'All-under-Heaven'- often canalized itself in religiously inspired movements. It can therefore be called a Confucian paradox that it is precisely because Buddhism, Daoism, and popular religions had been displaced to the grey zone of the religious market that they had become more difficult to control. ${ }^{23}$ It was, on the other hand, also their position in the volatile zone of the grey market that, to the degree that they were (thought to be) favorable for political unity and could thus serve a nationalist aim, religion and religious cults were (1) appealed on by the political elite, and (2) could and were taken up by the Confucian elite themselves. ${ }^{24}$ Indeed, the elevation of Confucianism to the status of 'civil religion' did not even mean that the elite became homogeneously Confucian. The division of the spiritual world in Confucianism, Daoism, Buddhism, and popular religion and local cults remained far more complex than the simple socioeconomic default lines of elite vs. popular socioeconomic groups. ${ }^{25}$ Non-Confucian concepts may, in themselves, not have been conducive to maintain social harmony, they could - and were - integrated in elite philosophy in so far as they did not infringe on or threaten the maintenance of harmony in 'All-under-Heaven'. Hubert Seiwert has, in this respect, differentiated 'orthodoxy' from 'orthopraxy':

The orthodoxy, i.e., elements of the world view that could bring social cohesion, did not belong to one of these three traditions (i.e., Confucianism, Daoism, and Buddhism) exclusively, but were shared by all - in any case, in so far as they were integrated in elite culture. [...] What was expected of the members of the elite culture was not necessarily that they confessed to Confucianism, but rather that they confessed to the

23 See Weggel (1980, pp. 127-128). This is reflected in the traditional Chinese concept of law. Chinese law is occupied with infringements on morality and criminal cases because these are seen as infringements against the Confucian cosmological harmony. See Bodde and Morris $(1967$, p. 4).

24 Goossaert and Palmer (2011, p. 22) remark that the function of the lay followers of Confucianism, Daoism, and Buddhism was to 'transmit their tradition of practice and to serve the entire society'.

25 See Goossaert and Palmer (2011, p. 23). Also see Chapter 1. 
basic cognitive and normative orientations of civil religion. Here we touch upon the meaning of orthopraxy $[\ldots] .{ }^{26}$

In a situation in which the dividing lines between the red and the grey religious market were the product of a continued negotiation, non-Confucian belief systems had to accept varying degrees of political restrictions. ${ }^{27}$

\section{The nineteenth century: Redefining Confucianism as 'religion'}

The Manchu Qing Dynasty was characterized by the flourishing of a variety of - especially non-Chinese - religions. The newly conquered region of Xinjiang was dominantly Muslim, Tibet and Mongolia were dominantly Vajrayana Buddhist, and in the Eastern and Central parts of China, Roman Catholicism and Protestantism were proliferating. These religions, along with traditional Daoism, sinicized Buddhism, and local cults, made Qing China a multireligious place. ${ }^{28}$ To administer this diversified religious empire, the Qing court had implemented a policy of religious pluralism, whereby the government, according to tradition, maintained the right to judge which religions were orthodox and which were not.

The incursions of European forces in China that started in the nineteenth century not only brought about economic and political consequences, but they also had a major effect on the way the spiritual world was perceived and organized. To qualify this change, it is necessary to first devote some space to the issue of 'religion' understood as zongjiao 宗教, a term that, as many 'modern' terms, was introduced in nineteenth-century China through Japan. ${ }^{29}$ Typical for the age of modernization in which not only political authorities, but also scholars and believers develop to be major social forces

26 Seiwert (1994, pp. 531-532). For general reflections on the processes of interactions in the making of modern religion in China: see Ashiwa and Wank (2009, pp. 6-8).

27 In theory, the emperor had absolute religious authority. He had the right to intervene in religious matters as he saw fit. In this, he could decide on the basis of his own judgment. See Goossaert and Palmer (2011, pp. 27-28).

28 See Rawski (1998).

29 Coining the term 'zongjiao' was, in Japan (where the term is pronounced shükyō), related to the adoption of religious freedom in its 1889 constitution. In this way, Shintō as national cult was distinguished from 'religions' that were, under Western influence, allowed to develop. While all Japanese citizens had to participate in Shintō, participation in 'religion' was an individual choice. As outlined by Hardacre (1989), religions were encouraged to modernize by adopting a nationalist and rational discourse. See also Goossaert and Palmer (2011, p. 210); Brook (2009, pp. 38-39). 
in the process of defining religion, the Western presence in China also meant that the traditional Chinese spiritual realm started to be redefined in terms of the Western concept of 'religion' (zongjiao) - a term that was not surprisingly first used in its reference to European Christianity. ${ }^{30}$ As a logical consequence, the traditional division between the Confucian 'civil religion' and the large grey zone of all other ideologies and faiths that had prevailed in imperial history, was interchanged for a new 'European' division between 'orthodox religion' (Christianity) and 'superstition' (mixin 迷 信). That is to say that the new category zongjiao also displaced Confucianism to the grey zone of the religious market, ${ }^{31}$ thus showing, as expressed by Yoshiko Ashiwa and David L. Wank "the fluidity and contextuality of the boundary between superstition and religion. ${ }^{32}$ This displacement was also the result of the following: the traditional interpretation of Confucian rule, i.e., the conviction that there is an intricate connection between the spiritual and the political world, necessarily implies that any change in the political structure of China has to lead to a change in its religious make-up. That is to say, when the nineteenth and early twentieth-century intellectuals strove to create a Chinese nation-state after Western model, this could not but have its ramifications for the position of Confucianism - the backbone of traditional elite culture. ${ }^{33}$ It may for the great majority of these intellectuals have proven to be almost impossible to settle with a displaced Confucianism - an intellectual struggle for modernity set in.

This observation puts into perspective the general assumption that in its confrontation with European dominance, the Chinese elite increasingly saw the creation of a Chinese nation-state (guojia 國家) after Western model as the only possible political alternative for China to survive. ${ }^{34} \mathrm{~A}$ more qualified statement would indeed be that while some of the intellectuals of the final decades of the empire wanted to do away with Confucianism once and for all - it may be reminded here that Sun Yatsen (孫逸仙, 18661925) and Jiang Jieshi (蔣介石, or Chiang Kaishek, 1887-1975) were Christian

$30 \quad$ See Yang (2012, p. 27).

31 See Duara (1991, p. 76).

32 Ashiwa and Wank (2009, p. 9).

33 See Goossaert and Palmer (2011, p. 43).

34 This nineteenth-century Chinese nationalism can be defined as 'reactive nationalism', i.e. nationalism, the coming to consciousness, of a group that suffered mistreatment, discrimination, and abuse at the hands of another group. Such a 'reactive nationalism' is different from 'organic nationalism' that arises naturally as a result of time, inbreeding, and geographic isolation, and is still different from 'constructed (or artificial) nationalism' that is a deliberate and conscious creation by the state from above, via the systematic mass dissemination and inculcation of a nationalist ideology. See Chang (2001, p. 24). 
converts $^{35}$ - the political visions of what may be the majority of them reveal a lingering belief in the values of (a redefined) Confucianism. As Helwig Schmidt-Glintzer observed:

China wanted to completely throw away its past, a young generation wanted to open a new page in history, and yet, getting free from the past was not successful, and this was seen as the core problem of China by many. ${ }^{36}$

When scholars such as Wei Yuan 魏源 (1794-1857) claimed that there was no Western knowledge worth to be studied except for military technology and knowledge of weaponry, and that, therefore, it would be sufficient for China to master this military knowledge in order to be able to defend itself against the West, this reveals a maintained conviction in the value of Confucianism in its connection to national unity. ${ }^{37}$ This conviction was also visible in the 'Self Strengthening Movement' (ziqiang yundong 自強運動) of the 1860 s - an attempt to make China materially so strong that it would be better able to defend itself against the West, as well as in the works of Wang Tao 王韜 (1828-1897). Contrary to Wei Yuan, Wang Tao had travelled to Europe and had discerned in Europe a peculiar cultural tradition. He therefore claimed that it was necessary to study European culture in order to become acquainted with the basis of its superior technology. Knowledge and the use of Western technology would, in practice, lead to it that Chinese (Confucian) culture as 'essence' ( $t i$ 體) would embrace Western technology as 'function' (yong 用)..$^{8}$ The final outcome of this would be that the different national histories would fuse into an era of universal peace in which the world would become one 'great unity' (datong 大同). The choice of the term datong, a term borrowed from the seventh chapter Liyun 禮運of the Han Dynasty Confucian work Liji 禮記, echoes the age-old Confucian claim

35 Sun Yatsen in this respect claimed that it was due to Christianity that America was more prosperous, stronger and had a higher civilization than China had. It would therefore be Christianity that could give China back its dignity. See Goossaert and Palmer (2011, p. 69).

36 Schmidt-Glintzer (2009, p. 33). According to Metzger (2012, p. 228), 'From this normative standpoint, modern Chinese history essentially is the story of a troubled progression toward increasing discontinuity with the Chinese tradition and increasing convergence with Western modernity'.

37 Wei (1852).

38 See Wang (2001, pp. 41-42). For an evaluation of the Fairbankian interpretation of China's modernization process from first understanding only the superiority of Western weapons, then grasping that of Western institutions, and finally appreciating Western values: see Metzger (2012, p. 238). 
that in this unified world, the right to rule 'All-under-Heaven' would remain a Confucian prerogative.

A lingering faith in the value of Confucianism as the 'essence' of the Chinese tradition was most obvious in the writings of the so-called 'Radical Confucians'. For the 'Radical Confucians', it was 'State Confucianism' (guoxue 國學) that was to be blamed for the decline of the Chinese empire. The 'State Confucians' had been in power ever since the Han Dynasty and the main aim of their policies had been to legitimize and to uphold political power in the hands of the ruling elite. This had resulted in authoritarianism and a centralization of imperial power. 'State Confucianism' therefore had to be replaced by 'Radical Confucianism' (junxue 君學), a moral teaching that is critical for all political and social injustice and is aimed at the well-being of the Chinese people..$^{39} \mathrm{An}$ analysis of the publications of the 'Radical Confucians' in the journals Journal of National Essence ('Guocui xuebao' 國 粹學報, published between 1905 and 1911) and People's Tribune ('Minbao' 民報, published between 1905 and 1910) shows that they saw the period of China's history before the unification under the first empire as the 'golden age' of Chinese history, characterized by philosophical debate free from the direct control of the government - we can, again, refer to the so-called Jixia Academy here, and in which knowledge was disseminated among all men of letters. Since the unification of the empire under the Qin Dynasty and the rise of Confucianism to the status of state orthodoxy in the Han Dynasty, China had glided into the 'dark ages'. The 'Radical Confucians' claimed that a Renaissance of China - in this explicitly referring to European history - did not mean that one had to do away with the Confucian tradition, but, on the contrary, that such a Renaissance was only possible through returning to the 'essence' of Confucianism as formulated in the 'Spring-and-Autumn' period..$^{40}$ Radical Confucians thus tried to establish a genealogy of the Chinese nation that goes back to the Yellow Emperor. ${ }^{41}$ This illustrates what was remarked by Martin Kern: "Through remembrance, history turns into myth', whereby 'it does not become unreal but, on the contrary, and only then, reality in the sense of a continual normative and formative force'. ${ }^{42}$ In their endeavour to return to the essence of Chinese culture, the 'Radical

39 As remarked by Kuehner (2015, p. 25), in ancient usage, the term 'guoxue' referred to an institution, not to a field of learning. In its early twentieth-century usage, the term was reintroduced from Japan where it, as kokugaku, was used to denote those nineteenth-century Japanese scholars who rejected all foreign intellectual influence, specifically Chinese Neo-Confucianism.

40 See Hon (2014, p. 31); Zarrow (2007, pp. 23f).

41 See Kuehner (2015, p. 31).

$42 \operatorname{Kern}([2008]$ 2009, p. 226). 
Confucians' were also profoundly anticlerical - a position that can be interpreted as a reaction towards Roman Catholic and Protestant clergy. ${ }^{43}$

A still very different reaction to the degrading of Confucianism as a result of the new religious paradigm can be seen in the figure of Kang Youwei 康有為 (1858-1927). He advocated to redefine Confucianism within the new 'religious' paradigm, that is as a religion (zongjiao) in its own right. In order to transform Confucianism into a 'national religion' (guojiao 國教) - and the only possible one for that matter, he proposed to ban all religious institutions and transform the Confucian temples that had begun to be confiscated starting in 1901 into schools for instruction in what he called Kongjiao 孔教, the Confucian religion. ${ }^{44}$ A 'modernized' Confucianism would thus have to become the Chinese 'orthodox religion', in the same way as an 'orthodox' Christianity was perceived as 'orthodox religion' in many modern nineteenth century European countries. ${ }^{45}$ Reshaping Confucianism as a national religion may have meant that elements of local cults that had traditionally been integrated in 'State Confucianism' would now have to be avoided, thus completely severing local cults from the realm of official 'religion', ${ }^{46}$ it, on the other hand, would also mean that Confucianism would no longer be a dividing factor between the elite and the common people, but that Confucius would become a symbol for all and to be honoured by all in the nation-state - a guojiao indeed. ${ }^{47}$ The parliamentarians of the early Republic saw the proposal to elevate Confucianism to 'national religion' as against the freedom of religion and it was voted down in 1913 and again in $1916 .{ }^{48}$ With Confucianism dismissed as vehicle to rally the collective feelings of all people, Sun Yatsen brought in the Kuomindang (KMT, the Nationalist Party) and the concept 'party state' (dangguo 黨國)

43 See Goossaert and Palmer (2011, pp. 35-36).

44 See Goossaert and Palmer (2011, pp. 45-47); Ashiwa and Wank (2009, p. 7 and p. 9).

45 This shows that Kang Youwei was not so much driven by 'intellectual rationality' as by an inspiration to modernize tradition. See Goossaert and Palmer (2011, p. 52). In his zeal for a spiritual Confucian renewal and unification of the Chinese race and nation along with a social reform, Kang Youwei and his disciples were followed by the Guangxu Emperor. See Goossaert and Palmer (2011, p. 207).

46 See Goossaert and Palmer (2011, pp. 55-56).

47 See Kuo (2008, p. 67).

48 See Goossaert and Palmer (2011, p. 56). This may partly be explained by the fact that among the 274 members elected (indirectly, through colleges of local elites) to the first national parliament between December 1912 and January 1913, sixty were Christians, a proportion that was totally out of measure when we consider that Christians accounted for less than 1 percent of the population. See Goossaert and Palmer (2001, p. 70). On the concept of 'modern' separation of state from religion: see Ashiwa and Wank (2009, p. 2). 
- nationalist feelings for the state were identified with the KMT that came to be regarded as the incarnation of the new state. ${ }^{49}$ According to Sun Yatsen, it was necessary to first deconstruct the Chinese 'cultural state' in order to create the Chinese 'nation-state'. In his inaugural speech on the first congress of the KMT in January 1912, he therefore declared that he no longer wanted to 'govern' the state through the Party (yidang zhiguo 以黨治國), but to 'establish' it through the Party (yidangjianguo 以黨建國).50 The only way for the citizens to respond to the nationalist appeal and to contribute to the 'establishment of the state' was hence to become member of the Party - much in the same way as they, in imperial times, had to become part of the Confucian bureaucracy.

Although, in a context in which traditional religions, including Confucianism, had been displaced, the focus on nation-building through the KMT may have made Chinese nationalism an overall non-religious phenomenon, ${ }^{51}$ the identification of the KMT with the nation-state that was to be created through the Party made both the KMT as instrument and the modern nation-state as final political aim 'sacred' institutions. ${ }^{52}$

\section{Maoist China and Confucianized communist nationalism}

The Japanese invasion of China in the 1930 os and the way the KMT government reacted to this event raised support among different social groups for the Chinese Communist Party (CCP), established in Shanghai in 1921. In his article 'On the people's democratic dictatorship', published in June 1949, a few months before he proclaimed the establishment of the People's Republic of China from Tiananmen - the place also Chinese emperors had used to announce major political decisions, Mao Zedong 毛澤東 alluded to the leading role of the CCP in its historical mission of modernizing the Chinese peasants and workers in the following words:

49 See Harrison (2001, pp. 190-193). This move would also prove important for presenting the Chinese Communist Party as incarnation of the unified (datong) nation-state. See further.

50 See Fitzgerald (1996, p. 185).

51 See Cohen (2005).

52 Goossaert and Palmer (2011, p. 175) remark that Chiang Kai-shek appealed on the citizens with such watchwords as 'orderliness, cleanliness, simplicity, frugality, promptness, precision, harmony, and dignity - ideals encapsulated in the four traditional virtues of propriety, rectitude, honesty, and sensitivity to shame - drawn from Confucian tradition but given a modern meaning within the framework of loyalty to the state'. 
$[\mathrm{U}]$ nder the leadership of the working class and the Communist Party, from an agricultural into an industrial country, and from a new-democratic into a socialist and communist society, abolish classes and realize the Great Harmony [大同].53

This statement can be seen as a development of an earlier statement Kang Youwei had made in his History of Chinese Philosophy (Zhongguo Zhexue $S h i$ 中國哲學史):

In the world of the 'great unity' (datong 大同), there will be no difference between classes and races. There will be no inferior people nor religious leaders. Everyone will be equal and 'All-under-Heaven' will enjoy equal rights. ${ }^{54}$

While we may expect that Kang Youwei must have exempted Confucianism, the doctrine he wanted to have recognized as 'state religion' (guojiao), from the religions referred to in this statement, for Mao Zedong and the CCP, loyal to the Marxist militant atheist interpretation of 'religion' as 'opium for the people', also Confucianism had to be discarded as 'superstition'. Hence the campaign to 'smash the four olds' (po sijiu 破四舊).55 However, when Mao Zedong stated that: '[T]here are some things which need not have any national style, such as trains, airplanes and big guns. Politics and art should have a national style, ${ }^{6} 6$ this shows that also he was not free from the idea that the Chinese political tradition had its particular value and should

53 Mao (1961, pp. 418-419). See also Schram (2002, pp. 411-412).

54 Kang (2002, p. 716). Goossaert and Palmer (2011, p. 170) note that also Hong Xiuquan had promised to, through the Taiping rebellious movement, create a proto-communist peaceful society on earth. Apocalyptic revolution, Christian influence, and communist utopianism, so they claim (2011, p. 39) are the three elements that, throughout the next century, never cease to interact. For the CCP's explicit claim of filiation to the Taiping movement: see Cohen (1997, pp. 292-293).

55 The 'four olds' are ideas, culture, customs, and habits. Yang (2012, p. 46) defines 'militant atheism' as a type of atheism that 'treats religion as the dangerous opium and narcotic of the people, a wrong political ideology serving the interests of the exploiting classes and the antirevolutionary elements', whereby 'political forces are necessary to control and eliminate religion'.

56 Quoted through Schram (2002, p. 437), who interprets this saying of Mao's as an expression of the conviction that 'a revolutionary transformation guided by Marxist theory [...] did not mean turning the country into a carbon copy of the Soviet Union', and of Mao's conviction that "the assimilation of the past provides not only raw material but also a "method" for elaborating a correct line today'. 
continue to exert its influence on contemporary politics. ${ }^{57}$ Very different from the 'elite orthopraxy' that had characterized the Confucian society, but in the same way as Kang Youwei's concept of a Confucian guojiao and Sun Yatsen's KMT had contained the possibility to rally all people for a 'national' cause, also the organization of the Communist state had the potential and possibilities to penetrate all layers of society.

In the same way as the Confucian emperors had been conceived to be models for 'All-under-Heaven' through their moral superiority, the adoption of Marxism-Leninism gave China the possibility to reshape itself as a model for other developing and underdeveloped countries in a communist 'All-under-Heaven'. ${ }^{8}$ Zhou Enlai's 周恩來 (1898-1976) claim that 'socialist patriotism is not a narrow nationalism, but a patriotism aimed to strengthen national pride under the guidance of internationalism,',59 is also reminiscent of the distinction Liang Qichao 梁啟超 made between 'small nationalism' (xiao minzu zhuyi 小民族主義) and 'great nationalism' (da minzu zhuyi 大民族主義): while ‘small nationalism' was, according to Liang Qichao, the feeling of the Han for the other ethnic groups within the borders of the former Qing empire (guonei國內), 'great nationalism' was the sentiment of all people towards all people beyond the borders of the former Qing empire (guowai 國外). ${ }^{60}$ This homeland concept was visible in the CCP policies that were formulated during the 1930s, when it was attempted to gain the support of all Chinese citizens through deemphasizing ethnic difference. Such policies were implemented during the famous Long March (Chang zheng 長征) of 1934-1936. ${ }^{61}$

Mao Zedong's veiled admiration for Confucian political concepts notwithstanding, the official religious policy meant that, in contradistinction to the Republican period in which religions were displaced to the grey zone of the religious market, the CCP's militant atheism meant that religion was

57 For Mao's indebtedness to Confucian thinking, Guo Moruo's 郭沫若 (1892-1978) Makesi jin wenmiao 馬克思進文廟 (Marx Visits a Confucian Temple), a text written in 1925, is revealing. In this text, Guo Moruo, a friend of Mao Zedong, places the following statement in the mouth of Confucius in response to Marx's description of the ideal Communist society: "Yes, truly (...) your ideal society and my world of 'great unity' are completely the same without us having deliberated over it. Let me cite a part of an old text of mine for you!", after which Confucius starts to recite the part of the Liji on datong. (Guo in Liu 1953). See also Dessein (2017).

$5^{8}$ For the rivalry between the PRC and the Soviet Union over leadership in the communist world: see Näth (1975, pp. 259-268, p. 284, and p. 307); Chen (2005, p. 43).

59 Quoted through Chen (2005, p. 41).

6 Liang ([1903] 1983, p. 75). Zarrow (2004, p. 47) suggests that Liang's 'deepest inspiration [...] came from what we can loosely call the Confucian tradition'. Also see Chapter 3 .

61 See Gladney (2009, p. 156). 
further degraded to the black zone of the religious sphere, i.e., the zone of forbidden religious organizations that work in the underground and arises to cater to religious needs that cannot be expressed in the open market. ${ }^{62}$ A suppression of religion does not, however, eradicate religious feelings. Rather, other forms of religiosity will develop. As most people fear the consequences of acting in the black market, they will redirect their religious needs in innovative ways, thus negotiating, as it were, a new grey market with the authorities. In Maoist China, this possibility was facilitated through the integration of secularized medicine, martial arts, and body cultivation techniques placed under the new category of qigong' 氣功 into the new state. ${ }^{6_{3}}$ The grey religious market that was thus created would flourish in an innovative way during the period of the Great Leap Forward (Da yue jin 大躍進, 1958-1960).

Although Buddhism, Islam, Catholicism, Protestantism, and Daoism had been protected under the principle of religious freedom in the beginning years of the PRC and the leaders of these five recognized religions were even given political acknowledgment - they had to help with the construction of the new state ${ }^{64}$ - since 1953 and especially with the Anti-Rightist Campaign (1957) and the Great Leap Forward, religious freedom became severely restricted and religious festivities, traditional clothing, etc. were forbidden because they would have obstructed economic production. ${ }^{65}$ As

62 The CCP's antireligious stance was also inspired by the fact that many redemptive societies had sided with the Guomindang during the civil war because of their fear for atheist communism. See Goossaert and Palmer (2011, p. 141). These societies were intellectually often linked to the 'national essence' (guocui 國粹) movement. See Goossaert and Palmer (2011, p. 108).

63 The Nationalist project of the martial arts that were claimed to be able to restore the original purity of the 'national essence' was thus continued in the PRC. Also qigong and traditional Chinese medicine that were made 'scientific' (kexuehua 科學化) in the Nationalist project were continued. See Goossaert and Palmer (2011, pp. 92, 110, 116-117). Also ordinary superstition, which was not to be automatically confused with organized counterrevolutionary activity was allowed. See Goossaert and Palmer (2011, p. 149).

64 'As long as a part of mankind is technologically backward', so was stated in a Renmin ribao editorial of 1950, 'any idea about taking coercive action is useless and positively harmful. This is the reason why we advocate protecting freedom of religious belief, just as we advocate protecting freedom to reject religious belief'. Quoted through Welch (1972, p. 4). While the CCP called for the systematic confiscation of Han temples and denied political rights to their priests and 'superstitious' specialists, the temples, monasteries, and mosques of the minorities were to be protected, and their leaders could be appointed to political positions. See Goossaert and Palmer (2011, p. 144). Zhang Chengzhi 張承志 (b. 1948), a Chinese Muslim novelist and essayist, is even credited with having coined the term 'red guards' (hong weibing 紅衛兵). See Fisac (2003, p. 163).

65 See MacInnis (1972). Also see Chapter 1. 
in the Great Leap Forward movement, rural China had been reorganized in communities (Weber's Gemeinschaften) that resemble traditional kinship groups, the disastrous outcome of this economic experience paradoxically strengthened the old community loyalties. The main difference with the imperial period in this was that the leaders of the new communities in the aftermath of the Great Leap Forward were no longer lineage elders, but rural CCP cadres. Many people reverted to such old pre-revolutionary religious activities as worshipping deities, divination, or fortune-telling, and violence between enemy lineages and communities was often accompanied by religious rituals that served to express kinship and community solidarity. ${ }^{66}$ Communist policies that had aimed at building a nation-state in which loyalty would be to the nation-state through establishing CCP cells as substitute for the local temples that had been the traditional places of symbolic power where local unities and disunities had been settled, had clearly failed. ${ }^{67}$

It is for the development of religious nationalism in communist China important to note that communism shares three important features with religions: (1) a certain conviction about life and the world, (2) a set of rituals that give expression to this conviction, and (3) a peculiar social organization of a moral community of adepts and practitioners. The only characteristic that communism does not share with religions is that it does not believe in the supernatural. This 'supernatural' aspect was, however, substituted with the State, the CCP, and Mao Zedong as divine trinity ${ }^{68}$ Communism further shares characteristics (1) and (2), and to a certain extent also (3) with Confucianism. ${ }^{69}$ It is therefore fairly easy to redirect one's religious feelings from religion (or Confucianism) towards the 'communist utopia'. This became obvious in the period of the Cultural Revolution (1966-1976). This period in which religion was seen as one of the 'four olds' (si jiu 四 舊) that had to be eradicated, was simultaneously, as labelled by Vincent Goossaert and David A. Palmer, the 'apotheosis' of political sacralisation..$^{70}$

66 See Perry (2001, pp. 288-294). As remarked by Goossaert and Palmer (2011, p. 225), 'Family practices and values can be considered the sanctuary of traditional religion, especially in times of repression and change'.

67 See Goossaert and Palmer (2011, p. 55).

68 See Chapter 1.

69 See Yang (2012, pp. 36-37) who therefore calls communism a 'pseudo-religion'.

70 Goossaert and Palmer (2011, p. 167). We can also refer here to the famous poster Mao Zhuxiqu Anyuan 毛主席去安源 (President Mao goes to Anyuan), first published in 1968 and perhaps the most important painting of the Cultural Revolution period, on which Mao Zedong is portrayed in classical attire. Also see note \#55. 
In the same way as religion had, in traditional China, always been interpreted as conducive to maintaining the holistic world, also devotion to the communist ideal was to serve the sacred nation - and, for that matter, Mao as incarnation of the Party and thus of the nation-state. ${ }^{71}$ As much as the Cultural Revolution was the denouncement of tradition and of Confucianism it is generally claimed to be, it is, I would therefore claim, paradoxically also fundamentally Confucian in its aspect of, after the chaos caused by the Great Leap Forward, projecting the Party and Mao Zedong - the 'Great Saviour of the People' (renmin de dajiuxing 人民的大救星) - as moral examples and only guarantee to overcome the chaos. The CCP directed Mao cult that supplied to the religious market, functioned in the same way as Confucian rituals had done in the veneration of the emperor and 'All-under-Heaven'.72 The Red Book (Mao zhuxiyulu 毛主席語錄) became the sacred canon of this 'political religion' and statues of the 'Red Sun' (hong taiyang 紅太陽) of Chinese communism were erected and venerated. ${ }^{73}$ For the hundreds of millions of sincere worshippers engaging in Mao worship, the feelings they experienced were almost religious. ${ }^{74}$

Communist self-cultivation was advocated by Liu Shaoqi in his essay On Self-cultivation of the Members of the CCP (Lun gongchandangyuande xiuyang 論共產黨員的修養). This essay that, as stated by Vincent Goossaert and David A. Palmer is 'riddled with quotes from Confucius's Analects and the Great Learning and from neo-Confucian philosophers' explains how 'self-cultivation was necessary for keeping one's faults and ideals before one's consciousness. [...] the Communist needed to conduct a class struggle within his own mind [...] the Party member was to become aware of and eradicate every trace of selfishness in his mind; otherwise, it would gradually corrupt his mind and body, and lead him to lose sight of objective reality and of his true self'.75 In the 'political religiosity' of the Cultural Revolution era, communist study and ritual replaced Neo-Confucian self-cultivation,

71 See Duara (2008, p. 64). According to Goossaert and Palmer (2011, p. 189), another explanation for the dedication with which the Chinese engaged in the Mao cult is that it was simply too dangerous to be suspected of not engaging in the cult. Zealous enthusiasm was often the only way to demonstrate sincerity and avoid being struggled against.

72 See Aijmer (1996, p. 227).

73 See Yang (2012, p. 91). See also Zuo (1991).

74 See Yang (2012, p. 139). For the Mao cult: see Myers (1972) and Zuo (1991).

75 Goossaert and Palmer (2011, p. 178). For Liu Shaoqi's position vis-à-vis Confucianism: see Weber (2015, p. 181). For a discussion of religio-political mobilization in relation to self-cultivation: see Apter and Saich (1994). 
and the CCP and Mao Zedong as incarnations of the moral norm had to bind the people - and thus the nation - together. ${ }^{76}$

\section{The post-Mao era: Communist new Confucian nationalism}

The realities of Maoist China that became increasingly visible after the death of the 'Great Saviour of the People' on 9 September 1976 had major ramifications for the Party's legitimation. The patronage and corruption that raged in the Party stood in stark contrast with the role of 'moral example' Mao Zedong had attributed to himself and to the Party. Deng Xiaoping's policies that focused on market principles also undermined the communist adagio of the Party as consumerism provided the Chinese citizens with a new ideal: 'becoming rich' was the new maxim. The identification of the Party with the Chinese nation-state further meant that decline of the Party's credibility contained a threat for the possibility of the nation-state to rally the commitment of the Chinese citizens.

The decline of moral authority of the Party at first instance led to a spiritual void. ${ }^{77}$ It is in this void that the post-Mao era has witnessed a gradual grow th of religious adherence, including a reemergence of qigong. ${ }^{78}$ It is therefore important to note that a consumerist modernity as introduced by Deng Xiaoping also has important ramifications for the 'religious market'. ${ }^{79}$ It is characteristic for consumerist modernity that all social relations - including religious and ideological ones - are patterned after the 'consumerist syndrome'. ${ }^{80}$ Free choice on the commodities' market encroaches on religion in the sense that religion is transformed to be a commodity in its own right. This means that (1) the religious customer seeks self-realization (no longer support for the state) in religion, and (2) religions become flexible in their search for the approval of the religious customer. ${ }^{81}$ Andrew Dawson in this respect speaks of 'prosumption', a

76 See Thornton (2007). Remark that not only Confucianism knows the practice of self-cultivation, but that Buddhism and Daoism also do. In practice, the Cultural Revolution antagonized different sub-groups of Chinese society. However, the class struggle had to, ultimately, 'make the people one'.

77 See Goossaert and Palmer (2011, p. 191).

78 For an evaluation of the nature of this reemergence: see Otehode (2009, pp. 250-261).

79 Simmel (2004), stated that consumerism is a worthy replacement for religion, because, like religion, it enacts a dream world with material objects.

8 o See Bauman (2005, p. 84); Speck (2013, p. 28).

81 See Speck (2013, p. 30). 
neoliberal process 'to collapse the acts of production and consumption into a singular process through which commodity value is both extracted and generated at one and the same time. ${ }^{8_{2}}$ In contradistinction to traditional religious life that focuses on the weakness of human beings as a species, in the individualized consumerist religious market, religion focuses on the weakness of one individual as against the omnipotent species of human beings. ${ }^{8}$ This new function of religion explains why, on a 'religious market' that caters to the wishes of the consumerist religious customer who has become convinced that there is nothing that cannot be purchased, setbacks in life - the encounter with the insufficiency of human life and the impossibility of state policies and science to overcome these setbacks - may lead to religious fundamentalism - a form of religious individuality that allows no relativism. ${ }^{84}$ Religion thus becomes a means with which the effect of state policies and of science can be criticized from an individual standpoint. ${ }^{85}$ This attitude, it has been claimed, is especially true for those who are more vulnerable to the shortages of life - in China these typically are ethnic minorities and the workers and farmers who were the first advocates of the CCP but have seen their economic and social position deteriorating in the Deng Xiaoping era - that is, those left behind in the scramble for the entry tickets to the consumers' party. ${ }^{86}$ With religious affinity no longer directed towards upholding the state, or, as Vincent Goossaert and David A. Palmer phrased it, with a "Middle Kingdom" that has lost its Middle', the PRC government has been in search of something to give the Chinese 'All-under-Heaven' a spiritual center again. ${ }^{87}$

In a politico-cultural context in which religion has traditionally been seen as a potential threat for the ruling (Confucian/communist) class, the contemporary steep increase of religious adherence and the potential for growing religious fundamentalism make a resort to religion as ideological alternative for communism impossible. This explains why the government is now increasingly promoting age-old Confucianism - a doctrine that is

82 Dawson (2013, p. 137). See also Zwick, Bonsu, and Darmody (2008). Dawson (2013, pp. 137-138) remarks: 'Such is the case because the notion of the prosumer is paradigmatically late modern in that its merger of producer and consumer plays to the contemporary valorization of the individual as the central axis around which all else is held to revolve'.

83 See Bauman (2005, p. 183); Speck (2013, pp. 31-31); Gaenssbauer (2015, p. 46); Meng (2012, p. 33).

84 See Bauman (2005, p. 182).

85 See Beck (2010).

86 See Speck (2013, p. 30).

87 Goossaert and Palmer (2011, p. 3). 
not categorized as 'religion' in the so-called 'Document 19' of 1982 that supplements the 1982 Constitution - as ideological alternative. ${ }^{88}$ In its renewed function as instrument to uphold national unity under CCP rule, Confucianism (now called 'New Confucianism' (dangdai xin ruxue 當 代新儒學) has thus been reshaped to function as a doctrinal backbone to 'communist New Confucian Nationalism'. ${ }^{89}$ On the religious market, Confucianism thus finds itself in a dynamic relation with religions that are - as was the case in Confucian China - tolerated to the extent that they foster national unity..$^{90}$ It is in this respect also more than noteworthy that guoxue has been reintroduced by the CCP government, that is, not as a parallel to junxue Confucianism which criticized 'state Confucianism', but, on the contrary, as a type of learning that is to be advocated in order

88 This 'Document 19' ('On the Basic Viewpoint and Policy on the Religious Question during Our Country's Socialist Period') is an exponent of so-called enlightenment atheism: a form of atheism that regards religion as 'an illusory or false consciousness, being both nonscientific and backward' and therefore as making propaganda necessary in order 'to expunge the misleading religious ideas'. See Yang (2012, p. 46). The perceived threat for national unity the CCP state feels religion is exerting, is also evident from Xi Jinping's speech delivered at the 'Working Meeting for Religion' on 23 April 2016. In this speech, he calls upon all religious people to unite in order to realize the 'double one hundred' and the 'China Dream' of the grand revival (fuxing 復興) of the Chinese people, to take their responsibility for the 'harmonious society' (shehui hexie 社 會和諧 ), to deeply love their country, and to persevere in the 'sinicization' of religion. See 'Xi Jinping zai quanguo zongjiao gongzuohui shang fabiao zhongyao jianghua' 習近平在全國宗教 工作會上發表重要講話 http://www.sara.gov.cn/xwzx/tplb/333676.htm, accessed 12 May 2016. Also see note \#64.

89 It is, in this respect, important that, as noted by Yang (2012, pp. x-xi), 'Since the May Fourth and New Culture Movements around 1919, Chinese elite intellectuals, influenced by European Enlightenment discourses, have become critical of and despising toward religion. The received wisdom has been that the Chinese as a whole have never been religious'. Promoting Confucianism may also divert attention away from 'foreign' religions and popular cults. See in this respect Yang (2012, p. 179); Goossaert and Palmer (2011, p. 260). Gaenssbauer (2015, p. 54) remarks that 'According to He Guanghu, in the PRC Marxism and Communism had been turned into a religion of the political community (guojiao 國教)', but that 'in a society marked by materialism and corruption there are not many people left nowadays who still believe in Marxism and Communism, [...]. Chinese people are instead called now to show patriotism (aiguo zhuyi 愛國 主義). He Guanghu describes patriotism in China as a ‘quasi-religion' (zhun zongjiao 準宗教) or 'pseudo-religion' (wei zongjiao 偽宗教), since patriotism implies belief in the state and the worship of human power'. See He (2012, pp. 220, 230).

9o We can here again refer to the speech Xi Jinping delivered at the 'Working Meeting for Religion' on 23 April 2016: 'Xi Jinping zai quanguo zongjiao gongzuohui shang fabiao zhongyao jianghua' http://www.sara.gov.cn/xwzx/tplb/333676.htm, accessed 12 May 2016. Also see Brook (2009, p. 22). 
to sustain CCP rule. ${ }^{91}$ We may, in the same vein, also mention the renewed attention for the cult of the Yellow Emperor..$^{92}$ It is in all this, and very similar to the practices in imperial China, remarkable how in the CCP's use of Confucianism, only those elements of this traditional ideology that do not infringe on the (communist) nation-state are selected. Selectiveness is also evident from the Chinese leadership's gradual revaluation of the function of religion. Chinese communist leadership has meanwhile abandoned the slogan that religion is 'opium for the people', and has resorted to a policy of what it calls 'mutual accommodation' - that is, conducive to the creation of a 'harmonious society' (hexie shehui 和諧社會). ${ }^{93}$ This policy, further, also allows the CCP to continue its policy of propagating atheism.

The revaluation of Confucianism in mainland China that, actually, already started in the 1980 s when Li Zehou voiced his admiration for the 'pragmatic rationality' (shiyong lixing 實用理性) of Confucius and his influence on Mao's thought, ${ }^{94}$ was boosted when, following the economic rise of Japan, Korea, Taiwan, Hong Kong, and Singapore, a similar economic rise also occurred in the PRC. Confucianism was no longer, as had been the case in the late nineteenth and early twentieth century, condemned as the cause of China's misfortune but, on the contrary, as an important factor of economic progress. Consequently, the pragmatist attitude of the late nineteenth and early twentieth century in which the Chinese tradition was redefined in European terms, was exchanged for a reinterpretation of the European tradition in Chinese terms. ${ }^{95}$ Wang Bo, professor of philosophy at Peking University formulated this attitude as follows in 1999: 'We are

91 See Kuehner (2015, pp. 36-38), who refers to Liu Dong's claim that 'I have no hesitation asserting that if Chinese civilization is to survive, Chinese tradition deserves to be popularized and traditional guoxue, especially Ruxue, must reach even greater constituencies'. See Liu (2011, p. 46). We may also refer here to the fact that many universities in the PRC have recently established a guoxue institute, and that there is a guoxue website: guoxue.com.

92 See Goossaert and Palmer (2011, p. 260). The turn to Confucianism can also be interpreted as an attempt to 'anchor' CCP rule in more than only economic growth. See Weber (2015, pp. 186-187)..

93 Goossaert and Palmer (2011, pp. 2, 316-317, 322, 325-327); Gaenssbauer (2015, pp.25, 33); Mou (2009, p. 171); Rošker (2016, p. 216). Rosker (2016, pp. 218-219) remarks that where 'in the Analects (Lun yu), Confucius makes a radical distinction between sameness (in the sense of uniformity, tong) and harmony or harmonization (he), and criticizes the former in the following terms: 'The nobleman creates harmony, not sameness. Ordinary men, on the contrary, are all the same and cannot create harmony', in the contemporary period 'harmony' is rather conceived of as 'conformity'.

94 See Metzger (2012, p. 232). Weber (2015, p. 173) dates the academic revival of Confucianism back to the 1970 s.

95 See in this respect Gaenssbauer (2015, p. 10). 
confronted with the following dilemma: What do we wish? That the object of our study would be "Chinese", or that it would be "philosophical" ?96 This is reminiscent of He Bingsong who, in the late 1930 s and the 1940s, claimed that it was not China that had to learn from the West, but the other way round. For this, he referred to such eighteenth-century intellectuals as Voltaire and Leibniz who were admirers of Chinese culture ${ }^{97}$ Zhuo Xinping also gives expression to the revaluation of a Chinese uniqueness:

We recognize in the 'Chinese dream' the potential for a great development and blossoming of Chinese culture. [...] but in order to bring this 'Chinese dream' to realization we must unite the entire Chinese people by means of this cultural belief and must mobilize all forces which it is possible to mobilize. [...] This means that we must, of course, allow to unfold, in the course of the economic and social development aspired to, also those positive effects contributed by adherents to religions. Any [...] manner of proceeding which might tend to construct a contradiction between the broad majority of adherents to religious beliefs and ourselves is a manner of proceeding which we must decidedly oppose [...] The 'Chinese dream' and the building of a 'beautiful China' [...] both belong to the cultural belief of our Chinese nation. At the same time this is the cultural belief of every individual person in China. This is our spiritual home. ${ }^{98}$

A revaluation of Confucian values is not restricted to the philosophical and academic milieu. Also in the PRC's political rhetoric, a reconnection to Confucian philosophy is visible. Former Premier Wen Jiabao said the following:

From Confucius to Sun Yatsen, the traditional culture of the Chinese nation has had valuable elements, many positive aspects concerning the nature of human beings, and democracy. In this way, it emphasizes love and compassion, sense of community, harmony between different viewpoints, and the sharing of the world. ${ }^{99}$

96 Wang (1999, p. 30).

97 See Wang (2001, p. 157).

98 Zhuo (2013, p. 37). Quoted through Gaenssbauer (2015, pp. 50-51). Note that Zhuo Xinping, in another publication, calls for the elevation of Confucianism to the status of 'religion', much in the same way that Kang Youwei did in the nineteenth century. Personal communication Philip Clart.

99 Quoted through Weber (2013). 
This strand of thought is also visible in the 'cultural nationalism' of Kang Xiaoguang, important New Confucian theoretician and advisor to former Premier Zhu Rongji:

In the following 20 to 50 years, Confucianism will fight a decisive battle with Western culture. This will be a battle on life and death, since it concerns the future of the Chinese nation. I am firmly convinced that democracy will doom the future of China, while Confucianism or Confucianizing can best serve the interests of the Chinese nation. This is my fundamental opinion. [...] The hegemony of Confucian culture first has to be established. One has to realize that it will take continuous efforts for Confucianism to beat the West. ${ }^{100}$

The age-old aura of moral superiority of the junzi 君子 that was once used by Mao Zedong is now used by Xi Jinping to boost CCP and his authority. ${ }^{101}$ $\mathrm{Xi}$ Jinping's message is that a further modernization of the Chinese nationstate is only possible under CCP rule and in combination with the Chinese cultural tradition. By referring to Confucianism, the CCP is accentuating the compatibility between the two and is, in this way, presenting communism as the natural continuator of the Confucian Chinese tradition. ${ }^{102}$ President Xi Jinping formulated it thus during his visit to Qufu, the birth place of Confucius:

That I come here, to Qufu, to the Institute for Confucian Research, shows that the Central Committee of the Chinese Communist Party enhances traditional culture. [...] The Institute for Confucian Research [...] incarnates the conviction of the Party and the State. [...] Many viewpoints of Confucius and of Confucianism were a great contribution to the intellectual richness of humanity, and provide a lot of fundamental concepts of which some are common with the thought of other countries, while others - such as 'humanity' (ren) and 'do not do to another what you do

100 Kang (2006, pp. 113-114). Quoted through Weber (2013).

101 Kallio (2015, p. 76) quotes Michael Schuman (2014) in this respect: 'Xi also apparently believes that Confucius can bolster his own standing in the country. Confucius' ideal government was topped by a "sage-king" [...] By combining one-man rule with the morality of Chinese antiquity, (Xi) appears to be painting himself up as some newfangled communist/Confucian sage-king - an all-commanding figure who will usher in a new epoch of prestige and prosperity'.

102 See Zlotea (2015, p. 162). In Chapter 5 of this volume, Robert D. Weatherley remarks that ' $[t]$ he use of historical memory to stimulate popular nationalist sentiment is second nature to the Chinese Communist Party'. 
not wish others would do to you' (ji suo buyu, wu shiyu ren 已所不欲, 勿 施於人) - are unique. We may not cut off history. We have to summarize it and to adopt the valuable heritage of Confucius to Sun Zhongshan. [...] Comrade Mao Zedong has used a lot of quotations of Confucius and Confucian ideas in his speeches. [...] In my speeches, I also use a lot of words of Confucius. [...] Now we see the value of Confucian thinking much more clearly. [...] If we want to bring China's case to a good end, then it is necessary that we are in accordance with the method of China's national situation. ${ }^{103}$

Jyrki Kallio therefore summarized the recent development as follows:

If Confucius is the new figurehead for China, then President Xi Jinping is the figurehead for the project to revive traditional schools of thought in China. The beginnings of the Party's project were noticeable as far back as the 1980s, and it was during Hu Jintao's era (2002-2012) that the 'harmonious society' became the catchphrase for the Party's goals. [...] Xi Jinping has since widened the scope and has been talking about China's desire to build a 'harmonious world'. ${ }^{104}$

Or, how with the revaluation of Confucianism for a national agenda, also the age-old 'All-under-Heaven' ideal has returned to the fore.

\section{Conclusion}

The development of the practical use of Confucianism in China since the Han Dynasty perfectly illustrates the claim by Anthony Kemp that: "(a) sense of time is fundamental to human thought to the extent that the past must be invoked in order to establish any present ideology, even one that involves a discounting of the past. All ideologies are fundamentally descriptions not of a present state, but of a past history'. ${ }^{105}$

This observation suggests that, in twentieth-century China, no radical rupture occurred when the culturalist concept made place for a 'national'

103 Xi Jinping zhuxi dao Qufu Kongzi ruxue yanjiuyuan canguan bing fabiao yanjiang' 習近 平主席到曲阜 孔子儒學研究院參觀並演講 http://www.hytxe.com/info/361.html, accessed 16 May 2014.

104 Kallio (2015, p. 76).

$105 \operatorname{Kemp}$ (1992, p. 106). Emphasis added. 
identity. Rather on the contrary. The very fact that Chinese nationalism and communism grew from a humiliated culturalism has continued to shape the way the country perceives itself and presents itself to the world. As defined by Prasenjit Duara:

The shape and content of national identities in the modern era are a product of negotiation between remembered historical narratives of community and the institutionalized discourses of the modern nation-state-system. ${ }^{106}$

\section{Bibliography}

Aijmer, Göran. 1996. 'Political Ritual: Aspects of the Mao Cult during the Cultural Revolution', China Information, 11: 215-231.

Anderson, Benedict. 1991. Imagined Communities: Reflections on the Origin and Spread of Nationalism. 2nd edition. London: Verso.

Apter, Daved E. and Saich, Tony. 1994. Revolutionary Discourse in Mao's Republic. Cambridge, MA/London: Harvard University Press.

Ashiwa, Yoshiko and David L. Wank. 20og. 'Making religion, Making the State in Modern China: An Introductory Essay'. In Making Religion, Making the State. The Politics of Religion in Modern China, ed. by Yoshiko Ashiwa and David L. Wank. Stanford, CA: Stanford University Press, pp.1-21.

Bauer, Wolfgang. 2006. Geschichte der chinesischen Philosophie. München: Verlag C.H. Beck.

Bauman, Zygmunt. 2005. Liquid Life. Cambridge: Polity.

Beck, Ulrick. 2010. A God of One's Own: Religion's Capacity for Peace and Potential for Violence, trans. Rodney Livingstone. Cambridge: Polity.

Bodde, Derk. 1986. 'The state and empire of Ch'in'. In Cambridge History of China. Volume 1. The Ch'in and Han Empires 221 B.C.-A.D. 220, ed. by Denis Twitchett and Michael Loewe. Cambridge: Cambridge University Press, pp. 20-102.

Bodde, Derk and Morris, Clarence. 1967. Law in Imperial China. Exemplified by 190 Ch'ing Dynasty Cases (Translated from the Hsing-an hui-lan). With Historical, Social, and Juridical Commentaries. Cambridge, MA: Harvard University Press.

Bourdieu, Pierre. 1971. 'Genèse et structure du champ religieux', Revue française de sociologie, 12: 295-334.

Brook, Timothy. 2009. 'The Politics of Religion: Late-Imperial Origins of the Regulatory State'. In Making Religion, Making the State. The Politics of Religion 
in Modern China, ed. by Yoshiko Ashiwa and David L. Wank. Stanford, CA: Stanford University Press, pp. 22-42.

Chang, Marie H. 2001. Return of the Dragon. China's Wounded Nationalism. Boulder, CO: Westview Press.

Chen, Zhimin. 2005. 'Nationalism, Internationalism, and Chinese Foreign Policy', Journal of Contemporary China, 14(41): 35-53.

Cohen, Myron, L. 2005. 'Being Chinese: The Peripheralization of Traditional Identity'. In Kinship, Contract, Community, and State: Anthropological Perspectives on China, ed. by Myron L. Cohen. Stanford, CA: Stanford University Press, pp. 39-59.

Cohen, Paul A. 1997. History in Three Keys: The Boxers as Event, Experience, and Myth. New York, NY: Columbia University Press.

Dawson, Andrew. 2013. 'Entangled Modernity and Commodified Religion: Alternative Spirituality and the "New Middle Class"'. In Religion in Consumer Society. Brands, Consumers and Markets, ed. by François Gauthier and Tuomas Martikainen. Ashgate AHRC/ESRC Religion and Society Series. Surrey: Ashgate, pp. 127-142.

Dessein, Bart. 2001. 'Climbing a Tree to Catch Fish: Some Reflections on Plato, Aristotle, and China'. In La Rationalité en Asie / Rationality in Asia, ed. by Johannes Bronkhorst. Études de Lettres 2001/3, Lausanne, pp. 97-125.

Dessein, Bart. 2011. 'Cultural and political nationalism, and the creation of a "harmonious society"', Zhongguo Yanjiu, 7: 41-67.

Dessein, Bart. 2012. 'Beyond Modernity: Chinese Self-identification in the Era of Globalisation', Zhongguo Yanjiu, 8: 23-41.

Dessein, Bart. 2014. 'Faith and Politics: (New) Confucianism as Civil Religion', Asian Studies, 18(1): 39-64.

Dessein, Bart. 2016. 'Historical narrative, remembrance, and the ordering of the world: a historical assessment of China's international relations'. In China's International Roles: Challenging or Supporting International Order? ed. by Sebastian Harnisch, Sebastian Bersick, and Jörn-Carsten Gottwald. New York, NY: Routledge, pp. 22-37.

Dessein, Bart. 2017. 'Yearning for the Lost Paradise: The "Great Unity" (datong) and its Philosophical Interpretations', Asian Studies 5/1: 83-102.

Dong Zhongshu 董仲舒. 1988. Chunqiu fanlu 春秋繁露. In Ershi'er $z i$ 二十二子. Shanghai: Shanghai guji chubanshe.

Duara, Prasenjit. 1991. 'Knowledge and Power in the Discourse of Modernity: The Campaigns against Popular Religion in Early Twentieth-Century China',Journal of Asian Studies, 50(1): 67-83.

Duara, Prasenjit. 1993. 'Provincial Narratives of the Nation: Centralism and Federalism in Republican China'. In Cultural Nationalism in East Asia-Representation 
and Identity, ed. by H. Befu. Research Papers and Policy Studies 39. Institute of East Asian Studies: Berkeley, CA: University of California Press.

Duara, Prasenjit. 2008. 'Religion and Citizenship in China and the Diaspora'. In Chinese Religiosities: Afflictions of Modernity and State Formation, ed. by Mayfair Mei-hui Yang. Berkeley, CA/Los Angeles, CA: University of California Press, 2008, pp. 43-64.

Dull, Jack L. 1994. 'Determining Orthodoxy: Imperial Roles'. In Imperial Rulership and Cultural Change in Traditional China, ed. by Frederick P. Brandauer and Chün-chieh Huang. Seattle, WA: University of Washington Press, pp. 3-27.

Ess, Hans van. 2003. Der Konfuzianismus. München: Verlag C.H. Beck.

Fisac, Taciana. 2003. 'Social Anomie and Political Discourse in Contemporary China'. In China Today: Economic reforms, Social Cohesion, and Collective Identities, ed. by Taciana Fisac and Leila Fernández-Stembridge. London: RoutledgeCurzon, pp. 149-172.

Fitzgerald,John. 1996. Awakening China. Politics, Culture, and Class in the Nationalist Revolution. Stanford, CA: Stanford University Press.

Fitzgerald-Huber, Louisa G. 1995. 'Qijia and Erlitou: The Question of Contacts with Distant Cultures', Early China, 20: 46-77.

Gaenssbauer, Monika. 2015. Popular Belief in Contemporary China. A Discourse Analysis. Bochum/Freiburg: Project Verlag Edition Cathay 69.

Geertz, Clifford. 1966. 'Religion as a Cultural System'. In Anthropological Approaches to the Study of Religion, ed. by Michael Banton. New York, NY: Praeger, pp. 1-46.

Gladney, Dru C. 2009. 'Islam in China: State Policing and Identity Politics'. In Making Religion, Making the State. The Politics of Religion in Modern China, ed. by Yoshiko Ashiwa and David L. Wank. Stanford, CA: Stanford University Press, pp. 151-178.

Goossaert, Vincent and Palmer, David A. 2011. The Religious Question in Modern China. Chicago, IL/London: The University of Chicago Press.

Hardacre, Helen. 1989. Shintô and the State, 1868-1988. Princeton, NJ: Princeton University Press.

Harrison, Henrietta. 2001. China. Inventing the Nation. London: Arnold.

$\mathrm{He}$, Guanghu 何光滬. 2012.Zhongguo de guojia xinyang yu zongjiao xinyang中國 的國家信仰與宗教信仰 (The State-Faith and the Religious Faith in Contemporary China), Daofeng: Hanyu shenxue xuekan 道風: 漢語神學學刊 (Logos \& Pneuma. Chinese Journal of Theology), 37: 317-333.

Hon, Tze-ki. 2014. 'Radical Confucianism: The Critique of Imperial Orthodoxy in Guocui xuebao (1905-1911)'. In Interpreting China as a Regional and Global Power, ed. by Bart Dessein. Nationalism and Historical Consciousness in World Politics. Politics and Development of Contemporary China. Basingstoke: PalgraveMacMillan, pp. 30-43. 
Kallio, Jyrki. 2015. 'Carving Out a Role for a Confucian China on the World Stage'. In Contemporary East Asia and the Confucian Revival, ed. by Jana S. Rošker and Nataša Visočnik. Newcastle upon Tyne: Cambridge Scholars Publishing, pp. 75-97.

Kang, Xiaoguang. 2006. 'Confucianization: A Future in the Tradition', Social Research: An International Quarterly for the Social Sciences, 73(1):112-114.

Kang, Youwei 康有為.2002.Zhongguo zhexue shi 中國哲學史 (History of Chinese Philosophy), ed. by Liu Wenying. 2 vols. Tianjin: Nankai daxue chubanshe.

Katz, Paul R. 2009. Divine Justice. Religion and the development of Chinese legal culture. London/New York, NY: Routledge.

Kemp, Anthony. 1992. The Estrangement of the Past: A Study in the Origins of Modern Historical Consciousness. New York, NY: Oxford University Press.

Kern, Martin. [2008] 2009. 'Announcements from the Mountains: The Stele Inscriptions of the Qin First Emperor'. In Conceiving the Empire. China and Rome Compared, ed. by Fritz-Heinz Mutschler and Achim Mittag. Oxford: Oxford University Press, pp. 217-240.

Kuehner, Hans. 2015. 'Zhang Taiyan and "National Studies"'. In Contemporary East Asia and the Confucian Revival, ed. by Jana S. Rošker and Nataša Visočnik. Newcastle upon Tyne: Cambridge Scholars Publishing, pp. 23-42.

Kuo, Ya-pei. 2008. 'Redeploying Confucius: The Imperial State Dreams of the Nation, 1902-1911'. In Chinese Religiosities: Afflictions of Modernity and State Formation, ed. by Mayfair Mei-hui Yang. Berkeley, CA/Los Angeles, CA: University of California Press, pp. 65-84.

Lee, Thomas H.C. 2000. Education in Traditional China, a history. Handbuch der Orientalistik, Section 4, China. Vol. 13. Leiden: Brill.

Levenson, Joseph R. 1964. Modern China and its Confucian Past: The Problem of Intellectual Continuity. Berkeley, CA: University of California Press.

Liang, Qichao 梁啟超. [1903] 1983. Zhengzhixue dajia Bolunzhili zhi xueshuo 政治學大家伯倫知理之學說 (The Theory of Bluntschli's Understanding of Politics), Yinbingshi heji 飲冰室合集 (Collection of the Storehouse for Drinks), Wenji 13: 67-89.

Liu, Dong. 2011. 'National Learning (Guoxue): Six Perspectives and Six Definitions', China Perspectives, 1: 46-54.

Liu, Wuji, ed. 1953. 'Introduction'. In Readings in Contemporary Chinese Literature. Far Eastern Publications. New Haven, CN: Yale University Press, pp. 7-17.

Lloyd, Geoffrey E.R. and Sivin, Nathan. 2000. The Way and the Word. Science and Medicine in Early China and Greece. New Haven, CN/London: Yale University Press.

MacInnis, Donald E., ed. 1972. Religious Policy and Practice in Communist China. London: Hodder and Stoughton. 
Makeham, John. 1994. Name and Actuality in Early Chinese Thought, SUNY Series in Chinese Philosophy and Culture. Albany, NY: State University of New York Press. Mao, Zedong. 1961. Selected Works of Mao Zedong, vol. 4. Beijing: Foreign Languages Press.

Meng, Xianxia 孟憲霞 . 2012. Shehuizhuyi guojia chuli zongjiao wenti de jingyan jiaoxun 社會主義國家處理宗教問題的經驗教訓 (Experiences acquired and lessons to be learnt from the socialist states' manner of dealing with religious questions). Beijing: Zhongguo shehui kexue chubanshe.

Metzger, Thomas A. 2012. The Ivory Tower and the Marble Citadel. Essays on Political Philosophy in Our Modern Era of Interacting Cultures. Hong Kong: The Chinese University Press.

Mou, Zhongjian 牟鐘鑒.2009. Duizhongguo minjian zongjiao yao you yi gexin de renshi 對中國民間宗教要有一個新的認識 (We need new Knowledge regarding Chinese Popular Religion). In Zongjiao yu minzu 宗教與民族 (Religion and ethnicity), ed. by Mou Zhongjian, vol.6, Beijing: Zongjiao wenhu chubanshe, pp. 166-188.

Myers, James. 1972. 'Religious Aspects of the Cult of Mao Tse-Tung'. Current Scene $20(3): 3-11$.

Näth, Marie-Luise. 1975. 'Die Aussenpolitik der VR China: Talleyrand Redivivus?' In China nach der Kulturrevolution, ed. by Jürgen Domes. München: Wilhelm Finck Verlag, pp. 259-331.

Nylan, Michael. [2008] 2009. "The Rhetoric of "Empire" in the Classical Era in China'. In Conceiving the Empire. China and Rome Compared, ed. by Fritz-Heinz Mutschler and Achim Mittag. Oxford: Oxford University Press, pp. 39-64.

Otehode, Utiraruto. 2009. 'The Creation and Reemergence of Qigong in China', In Making Religion, Making the State. The Politics of Religion in Modern China, ed. by Yoshiko Ashiwa and David L. Wank. Stanford, CA: Stanford University Press, pp. 241-265.

Perry, Elizabeth J. 2001. Challenging the Mandate of Heaven: Social Protest and State Power in China. Armonk: M.E. Sharpe.

Rawski, Evelyn S. 1998. The Last Emperors: A Social History of Qing Imperial Institutions. Berkeley, CA/Los Angeles, CA: University of California Press.

Rošker, Jana S. 2016. The Rebirth of the Moral Self. The Second Generation of Modern Confucians and their Modernization Discourses. Honolulu, HI: University of Hawai'i Press.

Schmidt-Glintzer, Helwig. 1999. Geschichte Chinas bis zur Mongolischen Eroberung. Oldenbourg Grundriss der Geschichte. München: R. Oldenbourg Verlag.

Schmidt-Glintzer, Helwig. 2009. Chinas Angst vor der Freiheit. Der lange Weg in die Moderne. München: Verlag Beck. 
Schram, Stuart. 2002. 'Mao Tse-Tung's Thought from 1949-1976'. In An Intellectual History of Modern China, ed. by Merle Goldman and Leo Ou-fan Lee. Cambridge: Cambridge University Press, pp. 267-348.

Schuman, Michael. 2014. 'The Chinese President's Love Affair with Confucius Could Backfire on Him', Time.com, 30 October 2014.

Schwartz, Benjamin. 1985. The World of Thought in Ancient China. Cambridge, MA: Harvard University Press.

Seiwert, Hubert. 1994. 'Orthodoxie, Orthographie und Zivilreligion im vorneuzeitlichen China'. In Gnosisforschung und Religionsgeschichte. Festschrift für Kurt Rudolph zum 65. Geburtstag, ed. By Holger Preißler, Hubert Seiwert, and Heinz Mürmel. Marburg: Diagonal-Verlag, pp. 529-541.

Shryock, John K. 1966. The Origin and Development of the State Cult of Confucius. An Introductory Study. New York, NY: Paragon Book.

Simmel, Georg. [1900] 2004. Philosophy of Money. 3rd enlarged edition. London: Routledge.

Sivin, Nathan. 1995. Medicine, Philosophy and Religion in Ancient China. Researches and Reflections. Variorum Collected Studies Series. Aldershot: Variorum.

Speck, Simon. 2013. 'Religion, Individualisation and Consumerism: Constructions of Religiosity in "Liquid" and "Reflexive" Modernity'. In Religion in Consumer Society. Brands, Consumers and Markets, ed. by François Gauthier and Tuomas Martikainen. Ashgate AHRC/ESRC Religion and Society Series. Surrey: Ashgate, pp. 27-42.

Stover, Leon. 1974. The Cultural Ecology of Chinese Civilization. New York, NY: The New American Library.

Thornton, Patricia, M. 2007. Disciplining the State: Virtue, Violence and StateMaking in Modern China. Cambridge, MA: East Asia Center, Harvard University. Wang, Bo. 1999. 'What Did the Ancient Chinese Philosophers Discuss? Zhuangzi as an Example', Contemporary Chinese Thought, 40(4): 28-40.

Wang, Edward Q. 2001. Inventing China Through History. The May Fourth Approach to Historiography. New York, NY: State University of New York Press.

Weber, Max. 1978. Economy and Society, ed. by Guenther Roth and Claus Wittich. Berkeley, CA/Los Angeles, CA: UCLA Press.

Weber, Ralph. 2013. 'The Politics of 'Confucian Political Philosophy', Warp, Weft, and Way. Chinese and Comparative Philosophy. http://warpweftandway.com/ weber-the-politics-of-confucian-political-philosophy. English version of 'Politik, Konfuzianismus und konfuzianische politische Philosophie in der VR China heute', Widerspruch - Münchner Zeitschrift für Philosophie 56.

Weber, Ralph. 2015. 'In Search of Numbers and Substance: On the Current Confucian Revival in the PRC'. In Contemporary East Asia and the Confucian Revival, 
ed. by Jana S. Rošker and Nataša Visočnik. Newcastle upon Tyne: Cambridge Scholars Publishing, pp. 171-190.

Weggel, Oskar. 1980. Chinesische Rechtsgeschichte. Handbuch der Orientalistik. 4. Abteilung, China. 6. Leiden/Cologne: E.J. Brill.

Wei, Yuan 魏源. 1852. Haiguo tuzhi 海國圖志 (Illustrated Treatise on the Countries in the Sea). Yangzhou: Guweitang.

Welch, Holmes. 1972. Buddhism under Mao. Harvard East Asian Series 69. Cambridge, MA: Harvard University Press.

Wolf, Eric R. 1966. Peasants. Foundations of Modern Anthropology Series. Englewood Cliffs: Prentice-Hall.

Xi Jinping zhuxi dao Qufu Kongzi ruxue yanjiuyuan canguan bing fabiao yanjiang 習近平主席到曲阜 孔子儒學研究院參觀並演講 http://www.hytxe.com/ info/361.html, accessed 14 June 2016

Xi Jinping zai quanguo zongjiao gongzuohui shang fabiao zhongyao jianghua 習近平在全國宗教工作會上發表重要講話 http://www.sara.gov.cn/xwzx/ tplb/333676.htm, accessed 12 May 2016.

Xu, Shen許慎 . [1981] 1988. Shuo wen jie zi 說文解字. Shanghai: Shanghai guji chubanshe.

Yang, Fenggang. 2012. Religion in China. Survival \& Revival under Communist Rule. Oxford: Oxford University Press.

Yu, Anthony C. 2005. State and Religion in China. Historical and Textual Perspectives. Chicago, IL/La Salle, IL: Open Court.

Zarrow, Peter. 2004. 'Late-Qing Reformism and the Meiji Model: Kang Youwei, Liang Qichao, and the Japanese Emperor'. In The Role ofJapan in Liang Qichao's Introduction of Modern Western Civilization to China, ed. by Joshua A. Fogel. China Research Monographs 57. Berkeley, CA: Institute of East Asian Studies, pp. 40-67.

Zarrow, Peter. 2007. 'The New Schools and National Identity: Chinese History Textbooks in the Late Qing'. In The Politics of Historical Production in Late Qing and Republican China, ed. by Tze-ki Hon and Robert J. Culp. Leiden: Brill, pp. 21-54.

Zhuo, Xinping 卓新平. 2013. Zhongguo zongjiao yu wenhua zhanlüe 中國宗教與 文化戰略 (The Religions in China and the Strategy of Culture). Beijing: Shehui kexue wenxian chubanshe.

Zlotea, Mugur. 2015. 'Weaving Confucianism into the Official Party Discourse: From Hu Jintao's “Harmonious Society”, to Xi Jinping's Communist Junzi'. In Contemporary East Asia and the Confucian Revival, ed. by Jana S. Rošker and Nataša Visočnik. Newcastle upon Tyne: Cambridge Scholars Publishing, pp. 149-170. 
Zuo, Jiping. 1991. 'Political Religions: The Case of the Cultural Revolution in China', Sociological Analysis, 52(1): 99-110.

Zwick, Detlev, Samuel Bonsu, and Aron Darmody. 2008. 'Putting Consumers to Work: “Co-creation" and New Marketing Governmentality',Journal of Consumer Culture, 8(2): 163-196.

\section{About the author}

Dessein, Bart. Professor in Ghent Center for Buddhist Studies, Ghent University / European Institute for Asian Studies, Brussels, Belgium.

Email: Bart.Dessein@UGent.be 



\title{
8 Yiguandao under the Shadow of Nationalism
}

\author{
Traitors, Conspirators, Traditionalists, or Loyalists?
}

Ching-chih Lin

\begin{abstract}
In the name of nationalism, Yiguandao has been portrayed as double-faced by different political authorities since the 1930s: traitors, conspirators, loyalists, and traditionalists. To strengthen its legitimacy, Yiguandao has emphasized Confucian teaching and proclaimed its orthodox status as a successor to Chinese cultural heritage since the 1970s. However, Yiguandao faces another predicament between its Chinese national identity and rising Taiwanese nationalism, particularly after the 2000s. The modern fate and face of Yiguandao are closely entangled in the political struggles of nationalism. Revolving nationalism can be a double-edged sword because it can be reconstructed or manipulated by the state, political parties, or even religions to meet their own interests over time.
\end{abstract}

Keywords: Yiguandao, Chinese nationalism, Taiwanese nationalism, traitor, sectarianism

\section{Introduction: Labeling religious sectarianism in the name of nationalism}

In the name of nationalism, Yiguandao 一貫道 (I-Kuan Tao, the Unity Sect $)^{1}$ has been politically portrayed as having various contradictory faces by different political authorities and even the Yiguandao itself, since Zhang Tianran 張天然 (1889-1947) succeeded the patriarch in the 1930s and made the religious sect one of the most influential religions in twentieth-century China. Unlike the modern Daoism considered as a part of national identity

1 I-Kuan Tao is the English romanization and translation of ‘一貫道' by the religious organization itself. Literally it means 'Way of Penetrating Unity', a quote from Analect, in which Confucius dialogues with his students, 'My Way is penetrated by a universal unity' (wu dao yi yi guan zhi 吾道一以貫之). 
in Hsieh Shu-wei's chapter in this book, Yiguandao followers were deemed traitors of the nation or the people, in line with the sentiment of the antiJapanese campaign after World War II, because of their connection with Japanese rule and the leadership of Wang Jingwei's government from 19401945. Moreover, members of Yiguandao were accused of being conspirators and Kuomintang (KMT) spies or American imperialist accomplices soon after the People's Republic of China was established in 1949. Ironically, the KMT in Taiwan also viewed Yiguandao members as conspirators and Communist spies, and hence suppressed the religion's organization and spread for more than three decades.

Yiguandao followers turned into loyalists three decades later. After the KMT government in Taiwan recognized Yiguandao's legal status and rehabilitated its reputation in the late 1980 s, its masses of adherents became sought-after voters for different political parties to win over in the process of democratization. To strengthen its legitimacy, Yiguandao emphasized Confucian teaching and proclaimed its orthodox status by succeeding in the tradition of promoting Chinese cultural heritage, working in concert with the KMT's traditionalist ideology of politicized Confucianism - a tool of legitimacy used against the Cultural Revolution of the Communist Party.

Since the 1980 , Yiguandao has successfully propelled Confucian teaching forward and has helped preserve Chinese tradition by promoting the children's movement of reciting Chinese classics and poets in Taiwan. This movement resonated also with the recent nationalist trend of restoring Chinese tradition in general education in mainland China. From the 1990s, Yiguandao members became traditionalists preserving cultural heritage in mainland China. Some Taiwanese Yiguandao educators were discreetly invited to return to the mainland and help promote Chinese tradition, in order to slow down the rapid growth of Christian churches and sectarianism in rural areas.

However, in Taiwan today, Yiguandao has a new crisis of nationalist legitimacy. It has had to face the predicament of its Chinese national identity encountering the rise of Taiwanese nationalism, particularly since Chen Shuibian's presidency in the 2000 s.

Yiguandao's modern fate and face are thus closely entangled with political struggles under the shadow of nationalism. Dynamic nationalism can be a double-edged sword, as it can be reconstructed or manipulated by the state, political parties, or even religions themselves to meet their own needs over time. In the following pages, I unveil how in different periods Yiguandao members were portrayed as traitors, conspirators, loyalists, and traditionalists in the name of nationalism by different political authorities and by Yiguandao itself. 
As John Lagerwey has pointed out, China has been a 'religious state', and the religious dimension of the Chinese state and society were and are inseparable from each other, past and present. ${ }^{2}$ Not only has the state tried to control or intervene in religious affairs, but religions have also utilized political symbols and resources as social, political, economic, and cultural capital. Nationalism became a new political symbol in the modern period, used by both the state and religious organizations. This essay endeavors to explain why Yiguandao has a multifaceted image, due to nationalist manipulation, whether by the state, political parties, or the religion itself. To borrow Prasenjit Duara's phrase, ${ }^{3}$ the author here tries to rescue Yiguandao from nationalist narratives and political manipulation. Like the history of the Boxers in 1900, historians can reconstruct the past in at least three dimensions - as event, experience, and myth. ${ }^{4}$

Nationalism has never been fixed; instead, it has been reimagined, reinvented or reconstructed at all times. ${ }^{5}$ Nationalism was a symbol or tool used by different state governments or political parties to manipulate the relationship between state and religion in China and Taiwan in the twentieth century and this continues even today. ${ }^{6}$ This chapter deals with both state-led nationalism and popular nationalism, ${ }^{7}$ and various types of cultural nationalism launched by either the state, political parties, or Yiguandao itself are explored in the following pages. Considering the partystate nature of both KMT's Republic of China and the People's Republic of China led by the Chinese Communist Party (CCP), ${ }^{8}$ this chapter treats the party-centered nationalist discourse and strategies as part of state nationalism. The history of Yiguandao needs to be restored in the context of competing nationalist narratives in modern and contemporary China. Among those multifaceted images bearing the name of nationalism, we need to clarify whether they are autonyms, pseudo-autonyms, labels, or stereotypes, using the analytical categories inspired by B.J. ter Haar. ${ }^{9}$ In the following sections, this essay tries to answer these questions: How were

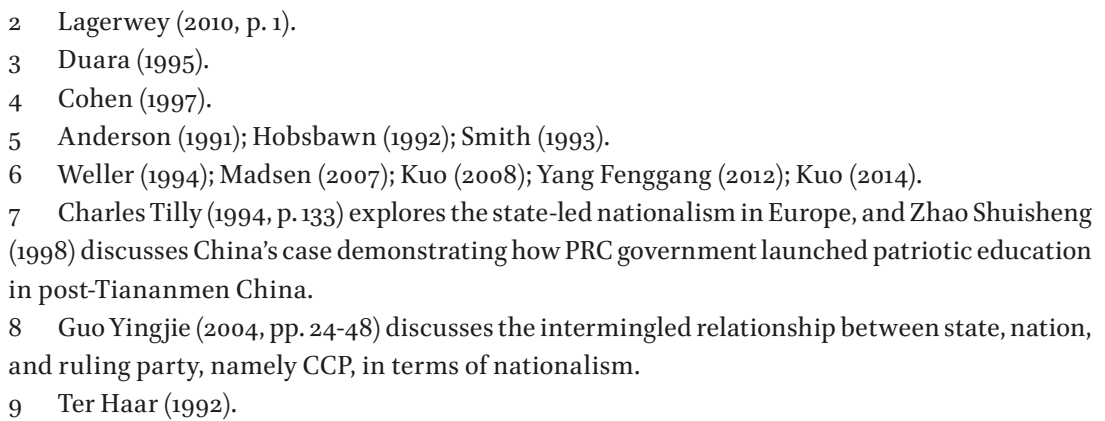


these contradictory labels or stereotypes made? By whom and for what purposes were they constructed?

\section{Ambivalent faces of Yiguandao}

Under the shadow of nationalism, Yiguandao has been portrayed with ambivalent, contradictory faces by various political entities, from the state to ruling parties, and Yiguandao itself in different periods and for dissimilar purposes. Each label has had varying consequences, from the suspension or revival of religious activities, to the sacrifice of lives.

\section{Traitor}

Some leaders of Yiguandao were viewed as traitors during and after the Anti-Japanese War (1937-1945). Yiguandao rapidly expanded during this period, particularly in the areas occupied by the Japanese army or the puppet government led by Wang Jingwei 汪精衛 (1883-1944). The religion's boom under Japanese occupation may have had different causes, such as its charitable activities and the promise of religious salvation offered by Yiguandao believers, yet this boom also earned the group the label of traitor (hanjian 漢奸) and political suppression afterwards. Some religious leaders of Yiguandao were individually labeled traitors, especially those high-ranked officials in Wang Jingwei's government, such as Li Lijiu 李麗 久, Sun Xiangfu 孫祥夫, Chu Minyi 褚民誼, Zhou Fohai 周佛海 and Zhou Xuechang 周學昌. ${ }^{10}$ The modern founder of Yiguandao, Zhang Tianran, was once appointed a Councilor in Wang Jingwei's administration, in order to facilitate passing through military checkpoints to preach in different areas. This connection with Japan and the puppet administration resulted in the traitor label.

This traitor label led to an official dismissal order from the Social Department on 31 January 1946, with the court accusing Yiguandao of treason. ${ }^{11}$ The headquarters and branches in Nanjing, then the national capital, were seized by the government. Yiguandao ceased public activities and had to use its social and political connections to regain its property and reputation. Eventually the court could not find significant evidence to accuse the group of treason, and Yiguandao won the lawsuit and regained its property and 
reputation..$^{12}$ On 1 August 1947, the major leaders of Yiguandao officially established a new charitable organization, the Association of Chinese Morality and Charity (Zhonghua Daode Cishan Hui 中華道德慈善會), ${ }^{13}$ in order to avoid the negative traitor label.

The trials against traitors were abundant and controversial after the end of World War II. Scholarly research has proved that a great number of the accused in traitor trials were actually innocent. ${ }^{14}$ The struggle between the Kuomintang (KMT) and the Chinese Communist Party caused mutual accusations of treason during this period. Nationalism was manipulated by both political parties to instigate nationalist sentiment against the Japanese by labeling the other side as collaborators and traitors. ${ }^{5}$ Yiguandao's rapid and nationwide boom had threatened the political authorities. Nationalism thus became a convenient label and tool to weaken the legality and legitimacy of Yiguandao. Compared to conventional accusations against sectarian groups in the late Imperial dynasties, such as rebellion, swindling of money, rape of young girls and married wives, nationalism was a new charge during the twentieth century.

\section{Conspirators}

Both KMT and CCP governments still applied conventional labels to sectarian groups in the twentieth century. Both political parties accused Yiguandao of conspiracy and being enemies of the state, although using different terminologies. After the political separation of 1949, the KMT in Taiwan labeled some Yiguandao leaders from mainland China as Taiwan CCP spies and conspirators (feidie 罒諜) who were scheming to overthrow the government and jeopardize the survival of the state - the Republic of China which KMT claimed the authentic orthodox nation representing 'the only Chinese nation'. Meanwhile, the CCP government, claiming the only orthodoxy as well, also suspected the leaders of Yiguandao of being KMT spies and conspirators (guote 國特 or guomindang tewu 國民黨 特務) who were spreading rumors of the end of the People's Republic of China (PRC) and scheming to organize guerrilla warfare supported by the KMT or American imperialist accomplices. The latter charge involved the manipulation of nationalism also. Rumors in North China in the early 
1950s were that Yiguandao followers, as KMT conspirators or American imperialist accomplices, plotted to cut off women's breasts and steal boys' testicles. The other version of the rumor said that the KMT accused CCP cadres of cutting off men's testicles and women's breasts and removing wombs to make new weapons against America's atom bombs. ${ }^{16}$ All these rumors refer to the consequence of having no offspring, which would result in the death of the Chinese nation. Both the KMT government in Taiwan and the CCP government in mainland China launched campaigns against the Yiguandao after 1949.

Both KMT and CCP rulers claimed the orthodoxy (zhengtong 正統) of the Chinese nation and therefore considered spies and conspirators of the other to be major enemies. The Yiguandao became the scapegoat in the struggle between the two sides of the Taiwan Strait. This is a different level of nationalism: the competition between two ruling governments claiming the orthodoxy of China as a nation. Both governments launched campaigns against the Yiguandao as being an 'evil cult' (xiejiao 邪教) although using different terminologies.

The CCP government launched a regional campaign against the Yiguandao in the areas occupied by the CCP's army before 1949, and soon accelerated the nationwide eradication of Yiguandao personnel and organizations after the establishment of the PRC. The alleged crimes of Yiguandao members were collaboration with the Japanese, conspiracy with the KMT and American imperialist accomplices, counter-revolutionary behavior, the status of gangsters and landlords, and 'feudal superstition. ${ }^{17}$ The accusation of feudal superstition was the contemporary 'evil cult' under the rule of the CCP along with animism. Central and local governments executed brutal suppression between $195^{\circ}$ and 1953 and fundamentally eradicated most of the organizations of Yiguandao. ${ }^{18}$

The KMT government considered Yiguandao members potential conspirators even before the Anti-Japanese War. Zhang Tianran was arrested by secret police in the spring of 1936 for his suspected conspiracy and collaboration with the Japanese and was finally released without conviction in January $1937 \cdot{ }^{19}$ The KMT government arrested some Yiguandao leaders in the course of investigating CCP spies in the early 1950s, and then used

16 Lu (1998, pp. 192-195).

17 'Editorial: Firmly Prohibiting I-Kuan Tao', People's Daily (Renmin Ribao 人民日報), 20 December $195^{\circ}$.

18 Lu (1998, p. 200); Yang Liuchang (2011, pp. 37-40).

19 Lin Jung-tse (2010, p. 513); Lu (2002, p. 255). 
the Regulation of Prohibiting Unhealthy Popular Customs (Chajin Minjian Buliang Xisu 查禁民間不良習俗) to categorize Yiguandao as evil cult in $1951 .^{20}$ The Ministry of the Interior reiterated the prohibition in 1958. After that, newspapers, magazines, and radio stations began to cooperate with KMT propaganda and reported the alleged crimes of Yiguandao. Buddhist associations were also mobilized by the Taiwan Garrison Command (Taiwan Jingbei Zongbu 台灣警備總部) to attack Yiguandao. ${ }^{21}$ Some leaders and followers of Yiguandao were arrested and tortured in prisons. In 1963, the Chief of Office of Police Affairs, Zhang Guoqiang (張國德), strengthened the suppression, although no clear evidence could be found to link it to conspiracy. ${ }^{22}$ As a result, two top leaders of Yiguandao, Chen Wenxiang (陳 文祥) and Zhang Peicheng (張培成) had to publicly announce the dismissal of Yiguandao in nationwide newspapers on 13 March $1963 .{ }^{23}$ Thereafter, Yiguandao activities became clandestine, and some branches joined Buddhist or Daoist associations, in order to maintain their legitimacy and legality. ${ }^{24}$ The Provincial Association of Daoism in Taiwan welcomed Yiguandao believers to join its membership, according to a newspaper published by the KMT. The top leader Zhang Peicheng joined Daoism and eventually became the deputy chairman. ${ }^{25}$ Two leaders of the Andong Branch of Yiguandao, Gao Binkai (高斌凱), and Liu Renhan (柳人漢), learned Zen meditation in Buddhist temples. ${ }^{26}$ Some branches emphasized Confucian teaching in order to fashion the orthodoxy of Confucianism which was officially sponsored by the KMT government in Taiwan, and which will be discussed in detail in the following sections. After the government's crackdown in the 1960s, most Yiguandao leaders and followers transformed into clandestine organizations and activities and promoted charities and moral teaching to demonstrate their loyalty to the 'Liberal China', the KMT government in Taiwan. Most of the books they published during this period had loyal phrases on the covers, such as 'restoring traditional culture', being 'patriotic to the nation', and 'loyal to the state leader'. 


\section{Loyalist and traditionalist in Taiwan}

Leaders and followers of Yiguandao emphasize loyalty (zhong 忠) as one of the most important virtues, because they highlight Confucian teaching as the core element in traditional Chinese culture. Yiguandao members thus view themselves as the successors to Chinese orthodox culture. ${ }^{27}$ The roles of loyalists and traditionalists are two sides of the same coin. Loyalty to the state or ruler has been the most significant ethic among all social relations in Confucianism. Yiguandao emphasizes Confucian teaching, along with other teachings from Daoism and Buddhism. In Provisional Etiquette (Zhanding Fogui 暫訂佛規) published in 1939, Zhang Tianran emphasized that all Yiguandao followers should follow the Eight Virtues of Confucianism, among which loyalty is the foremost. ${ }^{28}$ During the political crackdown, Yiguandao followers did not choose to resist. Zhang Tianran constantly stressed that Yiguandao followers, including himself, should not be involved in politics. ${ }^{29}$ Instead, Yiguandao emphasized Confucian teaching even harder, in order to favor the 'Movement of Renaissance of Traditional Chinese Culture' (Zhonghua Wenhua Fuxing Yundong 中華 文化復興運動) which was initiated by the KMT government during the Cultural Revolution (1966-1976). Due to the destruction and eradication of traditional Chinese culture during the CCP-led Cultural Revolution, the KMT stressed its respect for traditional culture and highlighted Confucianism in particular, since Confucius had been seriously attacked by the Red Guards and CCP elites. Confucianism became the critical symbol of the Chinese nation. Regarding the competition of orthodoxy between the KMT and CCP governments, the attitude toward Confucianism became the critical value and criterion. Since Yiguandao had taught its followers the importance of Confucianism for decades, it found a niche in the KMT's rule to rebuild the religion's legitimacy. Yiguandao thus became one of the most influential movements promoting Confucian teaching outside the official educational system, including the movement of reciting Confucian texts and classical poems..$^{30}$ The state-led nationalism and its popular counterpart converged at this point and mutually strengthened the legitimacy of each other. Song Guangyu 宋光宇 identifies Yiguandao 
as 'non-official Promotion Committee of the "Movement of Renaissance of Traditional Chinese Culture". ${ }^{31}$ In the 199os and afterwards, Yiguandao members presided many times at the official Memorial Ceremony for Confucius in different Confucian Temples in Taiwan.

Yiguandao stressed orthodoxy by reconstructing the Confucian genealogy from ancient emperors and sages through the KMT's founder Sun Yatsen and contemporary rulers, Jiang Jieshi and Jiang Jingguo, and then connected Yiguandao with orthodoxy. Before and after the crackdown, Yiguandao members tried to communicate with KMT rulers and high-ranked elites via intermediate personnel to the effect that Yiguandao would be very loyal to the government if legal status were granted. Within the preaching and spirit-writing rituals, loyalty and filial piety were often highlighted as the most important virtues. ${ }^{32}$ Yiguandao promoted traditional culture by organizing children reading Confucian classics and the politeness movement. ${ }^{33}$ Moreover, Yiguandao groups also organized various charities, from refuges for disasters, orphanages, preschools, social assistance for the poor and the elders, to health care and hospitals, and thus earned awards and honors from the government even before they were legalized. ${ }^{34}$ All these efforts to strengthen the civilized dimensions perfectly fit the modern category of 'institutionalized religion' demonstrated by authors of Making Religion, Making the State: The Politics of Religion in Modern China. ${ }^{35}$ Yiguandao endeavored to present itself as a civilized modern religion to fulfill the expectations toward all religions of the modern state. In addition, Yiguandao stressed moral teaching as the foundation for social stability and organized numerous workshops and camps for students and teenagers. ${ }^{36}$ The former Interior Minister, Wu Boxion 吳伯雄, once remarked admiringly that wherever there is one more Yiguandao follower, the society would need one less police officer. ${ }^{37}$ The roles of loyalist and traditionalist were recognized positively by the state after the mid-1980s. Yiguandao's emphasis on popular nationalism won the tolerance of the state and created the partnership between the religious association and KMT.

In the process of democratization in Taiwan in the mid-1980s, KMT elites found a new way to ask Yiguandao followers to demonstrate their

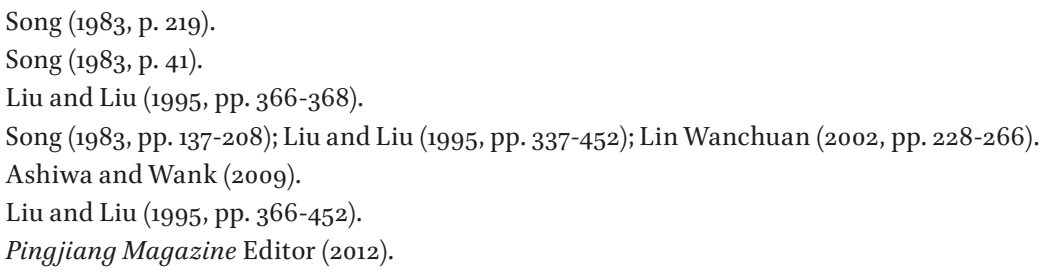


loyalty: by collecting votes to elect KMT's candidates. To earn its legal status, Yiguandao cooperated with the KMT in various elections to help the candidates of the ruling party defeat the opposition party, ${ }^{38}$ the rising camp in favor of Taiwanese nationalism. By cooperating with the rulers, Yiguandao successfully removed their demonizing label and eventually earned legal status in 1987 when the Ministry of the Interior accepted the application for a national association of Yiguandao. The Republic of China Yiguandao Association was officially established and registered in 1988.

Both the KMT government and Yiguandao itself stressed the role of loyalty to the state and the ruling party from different perspectives and for distinct purposes. The party-state rulers wanted votes to win elections, while Yiguandao members desired legalization. However, as democratization proceeded, Yiguandao members had to face the predicament of how to interact with the rising opposition political party. Unfortunately, the predicament deteriorated as the opposition party tended to be more and more 'pro-Independence' in the 1990s and 200os, the period of the expansion of Taiwanese nationalism. As Robert D. Weatherley points out in this book, nationalism is a double-edged sword. Yiguandao's emphasis on Chinese nationalism might have helped the religion earn legitimacy and legality in the 1980s, but it also undermined the religion's legitimacy and social support when Taiwanese cultural nationalism gradually inflated in the 199os and 2000s. ${ }^{39}$ In fact, the Taiwan Affairs Office of the State Council (Guowuyuan Taiwan Shiwu Bangongshi 國務院台灣事務辦公室), had already noticed the value of Yiguandao in the competition between Chinese and Taiwanese nationalist narratives ${ }^{40}$ something which will be discussed further in the next section.

Another traditionalist's predicament concerns Yiguandao's global spread. The fact that the religion highlights traditional Chinese culture as its core element has hindered its reception by potential non-Chinese followers, although Yiguandao's highlighting of Chinese nationalism has been helpful for the religion's transmission among overseas Chinese communities. ${ }^{41}$ In some Southeast Asian countries, several branches have become successfully indigenized in non-Chinese cultural communities. Local ritual masters use local languages and concepts to preach and practice the rituals. Globalized transmission is the ultimate goal that Yiguandao has pursued 
for decades, but it requires more global adaptation to reduce the religion's China-centered doctrine, which in some ways contradicts its emphasis on Chinese nationalism.

\section{Loyalist and traditionalist in mainland China}

There has been no legal status for Yiguandao as loyalist or traditionalist under the PRC's rule. Yiguandao has been categorized an evil cult since the very beginning of the PRC. In order to be considered good citizens, followers of Yiguandao had to relinquish their membership and publicly denounce the religion and its leaders and followers. Traditional culture was disregarded and massively destroyed before the end of the Cultural Revolution. By then, there was no social or cultural space in which Yiguandao could survive. However, the situation changed in the mid-1980s.

The call for restoring traditional culture gave space for the reading of classics and the restoration of Confucius' status. Taiwan's experiences in promoting the movement of reciting classics and poems were then demanded in mainland China also. The PRC needed traditional culture to restore national glory and strengthen its national identity. The 'National Studies Fever' (guoxuere 國學熱) began in 1993 in the universities, gradually spreading to the public and becoming popular in the 2000s..$^{42}$ Scholars, educators, and parents were devoted to the trend, while the state invested national resources to construct infrastructure and to promote the movement. The establishment of Confucius Institutes abroad represents the crystallization of the National Studies Fever. There are now 500 branches offering 1000 courses in 134 countries, educating in the Chinese language and propelling Chinese culture into the world. ${ }^{43}$ This can be considered a revitalization movement that the state and society use to try to restore the missing traditional culture, ${ }^{44}$ though Yiguandao also tries to syncretize Buddhism, Daoism, Christianity, and Islam with Chinese culture, mainly Confucianism. ${ }^{45}$ Yiguandao has thus participated in the trend. Some branches of Yiguandao sent followers back to China to set up preschools and extracurricular schools with specialization in reading Chinese classics and poems, plus highlighting moral teaching, which differentiates them from

\footnotetext{
42 Dong (2014, p. 33).

43 See official website of Confucius Institute: http://www.hanban.edu.cn/confuciousinstitutes/ node_10961.htm. Last accessed on 22 March 2016.

44 Chiu (1989); Li Yih-Yuan (1999, pp. 41-74); Ting (2004, pp. 123-124).

45 Ting (2009, p. 313-366).
} 
their regular competitors. In the 21st century, Yiguandao has been afforded a very promising opportunity to return to mainland China as part of the National Studies Fever. In fact, Yiguandao's return was tacitly connived at by the PRC for multiple purposes: to promote the grassroots organizations of National Studies Fever, to win over the Taiwanese and overseas Chinese, and to stop the rapid growth of Christian churches and sects in rural areas.

Out of concern for Chinese nationalism, the PRC government has worried about the boom of Christian churches as discussed in this book by Tsai Yen-zen and Kuo Cheng-tian as regards to the relationship between state and church in China. One of the main under-the-table concerns is the foreign connection behind Christian churches and missionaries who can propel democratization and challenge the legitimacy of the PRC. To harness the rapid expansion of Christianity, the PRC government would rather give space to native religious organizations, even sectarianism. In fact, the backroom communication between the PRC and Yiguandao representatives started in the 1990s, and the public interactions began in the mid-200os. In the first stage, the PRC government sent scholars with special backgrounds, such as retired police officers or officials of the Taiwan Affairs Office or the United Front Work Department to contact Yiguandao in Taiwan and abroad. ${ }^{46}$ Yang Liuchang (楊流昌), an official of the Taiwan Affairs Office, earned a PhD in Beijing investigating the history of Yiguandao and its development in Taiwan and published his dissertation in Hong Kong. This book suggests that the PRC government is seeking a way to allow Yiguandao to return to mainland China as it concentrates on the process of legalization and negotiations between the KMT and the religion. The PRC government is facing a similar situation that its KMT counterpart experienced three decades ago: after criticizing and suppressing Yiguandao for decades, how does it now legalize the religion and reinterpret that past criticism and suppression? One potential discourse explains that Yiguandao in Taiwan has fundamentally transformed its conspiratorial tendencies into a patriotic and philanthropic religious association. The PRC government needs a reasonable discourse to legitimate the return of Yiguandao.

Nationalism can be invoked to legitimate the return of Yiguandao to compete with the rapid expansion of Christianity. In the Annual Report on China's Religions of 2009, published by the state think-tank Institute of World Religions, Chinese Academy of Social Science, the authors clearly suggest mobilizing formerly prohibited sectarian religions, such as Yiguandao or Dejiao (德教), to form a team to spread Chinese culture globally, appeal to 
overseas Chinese, enhance the nation's 'cultural soft power' and maintain the 'security of national culture'. ${ }^{47}$ Time will heal the wound. From feudal superstition and counter-revolutionaries to protectors and missionaries of national culture, followers of Yiguandao are now expected to be loyal to the PRC by playing the traditionalist role against Christianity. On the list of evil cults announced in 2000 and 2005, Yiguandao was no longer categorized as an evil cult. Some branches were tacitly connived with to return to mainland China, as long as they did not cross over the 'red line' and preach religion in public. In the past, most activities of Yiguandao in mainland China were under surveillance; some religious leaders were even arrested or exiled. ${ }^{4}$ Now Yiguandao shifts its status in China from 'red zone' to 'gray zone', to borrow Yang Fenggang's concept. ${ }^{49}$ It took more than five decades to overturn the relationship between Yiguandao and the PRC government.

Mutual understanding began in the early 199os when Yiguandao associations made donations to assist victims of several natural disasters. Yiguandao leaders entrusted messages to scholars to communicate with the think-tank Institute of World Religions, Chinese Academy of Social Science in 1996, and also invited the Institute's faculty members to visit branches of Yiguandao and attend academic forums organized by the religion in Taiwan from 1997 onwards.$^{50}$ Yiguandao leaders were also invited to visit mainland China by various bureaucratic administrations from 2006 onwards. The United Front Work Department even invited several top leaders of Yiguandao branches to visit several historical sites of the religion and the hometowns of the religion's modern founders, Zhang Tianran and Sun Huiming (孫慧明). Former KMT Chair ,Wu Boxion, helped pass the Yiguandao organization's message to former CCP Chair and PRC President $\mathrm{Hu}$ Jintao (胡錦濤)with the suggestion of legalizing Yiguandao in mainland China on 26 May 2008..$^{1}$

Being loyal to the PRC might earn legal space for Yiguandao in mainland China, but might also backlash in Taiwan. When the President of the Association for Relations Across the Taiwan Straits, Chen Yunlin (陳 雲林), led delegates to attend the first meeting with the Straits Exchange Foundation in Taiwan in December 2008, and encountered protests led by

47 Jin and Qiu (2009, p. 16; p. 228).

48 Lin Wanchuan (2010, pp. 80-81).

49 Yang Fenggang (2012).

50 Li Yu-zhu (2011, p. 229).

$5^{1}$ Li Yu-zhu (2011, p. 230). 
the pro-Independence camp, Yiguandao leaders mobilized hundreds of supporters to welcome and escort the PRC delegates..$^{2}$ According to one of the organizers, they wanted to demonstrate the voice of Chinese national identity and show friendly intentions towards the PRC government. ${ }^{53}$ Later, in early 2009, the messenger from PRC contacted Yiguandao and inquired why they had organized the mobilization. The friendly intentions received a positive response. Top officials of the State Administration for Religious Affairs (SARA), Ye Xiaowen (葉小文) and Jiang Jianyong (蔣堅永), also met Yiguandao leaders in Taiwan in 2009. ${ }^{54}$ Several top officials, along with scholars, visited Yiguandao's branches in Thailand, Malaysia, Singapore, the Philippines, and Hong Kong in March 2009; then other delegate groups visited branches of Yiguandao in Taiwan in May and June 2009. In August 2009, delegates of scholars and officials from the PRC attended an academic conference and visited the most significant branches all over Taiwan. By showing classes of National Studies, children reciting Chinese classics and poems, and charities for social minorities and disaster victims, Yiguandao endeavored to persuade PRC officials that Yiguandao means no harm to the rule of PRC. Using the roles of loyalist and traditionalist again became the strategy for the religion to cooperate with the state, but this time the nation was the PRC.

Chinese nationalism is a double-edged sword for Yiguandao followers. On the one hand, it has helped Yiguandao earn trust from the PRC leaders. On the other hand, Yiguandao may risk losing social support in Taiwan as the Indigenization Movement launched by President Li Denghui 李登輝 (Lee Teng-hui) in the 1990s, and followed by President Chen Shuibian (陳 水扁) in the 2000s, has educated a new generation of students with more Taiwanese national identity than their Chinese counterparts. Yiguandao voters no longer favor the KMT in elections. To attract the young generation to join Yiguandao, the religion needs to adjust the policy of highlighting Chinese nationalism and orthodoxy, which worked successfully in Taiwan in the 1980 s and works well in mainland China in the 2010s, but could fail in Taiwan the future. If Yiguandao favors Chinese nationalism in order to obtain legalization in mainland China, it might offend Taiwanese nationalism and lose social support. As a result, the religion's adherents might be considered traitors once again.

53 Personal communication with the top leader. To protect the person's privacy, identity is anonymous here.

54 Li Yu-zhu (2011, p. 231). 


\section{Concluding remarks}

Under the shadow of nationalism, the images of Yiguandao have been manipulated by different parties, including the religion itself. The state and political parties have used nationalist narratives to control religious sectarianism; meanwhile, religions have their own autonomy and know how to utilize nationalist narratives to create social and political space and earn more resources. However, nationalism as a double-edged sword is essentially fluid and may change over time. Religion, nonetheless, is supposed to pursue ultimate, eternal concerns. When a religion tries to use nationalism as an expedient means of obtaining something, it can easily lose that thing or eventually even lose itself.

The image of religious sectarianism can be manipulated by governments or political leaders according to their needs, and nationalism has served as a useful and convenient mobilizing tool. Under the shadow of nationalism, Yiguandao has been portrayed with ambivalent and conflicting faces since its modern rising in the 1930s.

Religion cannot be free from politics, past and present; but that does not mean it has to serve politics or nationalist identity. Religions have their own autonomy, goals and significance.

Yiguandao has used nationalist narratives and labels to legitimate its orthodoxy and legality and to appeal to overseas Chinese in the past decades. However, it could also have undermined its social basis as the indigenization of political-cultural national identity has gradually increased in Taiwan in the past two decades. The 'China-centered' discourses and terminology in the teachings and rituals of Yiguandao might also be a barrier to its teaching to non-Chinese people and to spreading its religion across the globe.

Nationalism is a double-edged sword for religion. As nationalism can be reconstructed and manipulated for different communities for various purposes over time, the changing dynamics of nationalist discourses and labels can jeopardize the social and cultural basis of religion, which is usually expected to be 'eternal through time'. If Yiguandao desires to become a world religion in the future, it needs to create advanced theologies and religious concerns that transcend China-centered nationalism.

\section{Bibliography}

Jianjue Qudi Yiguandao 堅決取締一貫道 (Editorial: Firmly Prohibiting Yiguandao), Renmin Ribao (People's Daily), 20 December 1950. 
Anderson, Benedict. 1991. Imagined Communities: Reflections on the Origin and Spread of Nationalism, 2nd ed. London: Verso.

Ashiwa, Yoshiko, and David L. Wank, eds. 20o9. Making Religion, Making the State: The Politics of Religion in Modern China. Stanford, CA: Stanford University Press. Brook, Timothy. 2005. Collaboration:Japanese Agents and Local Elites in Wartime China. Cambridge, MA: Harvard University Press

Chang, Shih-ying 張世瑛. 2001. CongJige Zhanhou Shenjian de Anli laikan Hanjian de Shenfen Rending Wenti 從幾個戰後審奸的案例來看漢奸的身份認定問題 (A Few Cases Reflecting the Issue of Identity of Hanjian [Traitor] in Postwar China).Guoshiguan XueshuJikan 國史館學術集刊 (Academia Historica), 1:1-25. Cohn, Paul A. 1997. History in Three Keys: The Boxer as Event, Experience, and Myth. New York, NY: Columbia University Press.

Chiu, Hei-yuan 篗海源. 1989.Jiexi Xinxing Zongjiao Xianxiang 解析新興宗教現 象(Analysis of Phenomena of New Religions). In Hsu Cheng-Kuang and Soong Wen-li, eds. 收於徐正光,宋文里編, Taiwan Xinxing Shehui Yundong 台灣新 興社會運動 (New Social Movements in Taiwan). Taipei:Juliu.

Dong, Enlin 董恩林. 2014. Dalu ‘Guoxuere’Xianzhuang de Fenxiyu Pingjia 大陸「 國學熱」現狀的分析與評價 (Analysis and Evaluation of the 'National Studies Fever' in China Today).Zhongguo Wenzhe Yanjiu Tongxun 中國文哲研究通訊 (Newsletter of the Institute of Chinese Literature and Philosophy) . 24(1):33-54.

Duara, Prasenjit. 1995. Rescuing History from the Nation: Questioning Narratives of Modern China. Chicago, IL: University of Chicago Press.

Guo Yingjie. 2004. Cultural Nationalism in Contemporary China: The Search for National Identity under Reform. London/New York, NY: RoutledgeCurzon.

Haar, B.J. ter. 1992. The White Lotus Teachings in Chinese Religious History. Leiden: E.J. Brill.

Ho, Fang-Jiau 何鳳嬌. 1996. Taiwan sheng Jingwu Dangan Huibian: Minsu Zongjiao pian 台灣省警務檔案彙編: 民俗宗教篇(Documentary Collection on Taiwan's Police Administration). Taipei: Academia Historica.

Hobsbawm, E.J. 1992. Nations and Nationalism since 1780:Programme, Myth, Reality, 2nd ed. New York, NY: Cambridge University Press.

Hsiau A-chin 蕭阿勤. 2012. Conggou Taiwan: Dangdai Minzu Zhuyi de Wenhua Zhengzhi 重構台灣: 當代民族主義的文化政治 (Reconstructing Taiwan: The Cultural Politics of Contemporary Nationalism). Taipei: Lianjing.

Jin Ze and Qiu Yonghui 金澤、邱永輝, eds. 2009. Zongjiao Lanpishu: Zhongguo Zongjiao Baogao (2009) 宗教藍皮書: 中國宗教報告 (2009)(Annual Reporton China's Religions (20og)). Beijing: Zhongguo Shehui Kexue Wenxian Chubanshe. Jordan, David K. and Daniel L. Overmyer. 1986. The Flying Phoenix: Aspects of Sectarianism in Taiwan. Princeton, NJ: Princeton University Press. 
Kuo, Cheng-tian. 2008. Religion and Democracy in Taiwan. Albany, NY: State University of New York Press.

Kuo, Cheng-tian 郭承天. 2014. Guozu Shenxue de Minzhuhua: Taiwan yu Zhongguodalu 國族神學的民主化: 臺灣與中國大陸 (The Democratization of National Theologies: Taiwan and Mainland China). Taipei: Chengchi University Press.

Lagerwey, John. 2010. China: A Religious State. Hong Kong: Hong Kong University Press.

Lee, Fong-mao 李豐柕. 2013. Tuoxie yu Hezuo: Yiguandao Laoqianren Zhang Peicheng Canyu Daojiao Zonghui de Jingyan - Yi Daozong 1966 1983 Nianjian Lijianshi Huiyi Jilu wei Zhuyao de Kaocha 妥協與合作: 一貫道老前人張培 成參與道教總會的經驗--以道總 1966 1983 年間理監事會議紀錄為主的 考察 (Compromise and Cooperation: The Previous Yiguandao Leader Zhang Peicheng's Participation in the Council of Daoism, 1966 1983). Huaren Zongjiao Yanjiu 華人宗教研究 (Studies in Chinese Religions) 2: 135-172.

Lee, Li-liang 李麗涼. 2012. Yidai Tianshi: Chang En-puyu Taiwan Daojiao 式代天 師: 張恩溥與台灣道教 (The Great Master: Chang En-pu T'ien Shih and Taoism in Taiwan). Taipei: Academia Historica.

Li, Yih-Yuan 李亦園. 1999. Tianye Tuxiang: Wode Renleixue Shengya 田野圖像—— 我的人類學生涯 (Pictures of Fieldwork: My Career in Anthropology). Taipei: Lixu Wenhua.

Li, Yu-zhu 李玉柱. 2011. Yiguandao de Taiwan Jingyan yu Quanqiu Fazhan 一貫 道的台灣經驗與全球發展 (Yiguandao's Experiences in Taiwan and Global Development). Presented at the Conference on the Trend of New Religions held by Institute of World Religions, Chinese Academy of Social Sciences in December, 2010. In Yang Liuchang, Tiandao Chuanqi: Yiguandao zai Taiwan de Chuanboyu Yingxiang 2010年12月發表於中國社會科學院世界宗教研究所主 辦, 新興宗教發展趨勢學術研討會,收於楊流昌,天道傳奇:一貫道在台灣的傳 播與影 (響The Miracle of the Heavenly Way: The Transmission and Influence of Yiguandao in Taiwan). Hong Kong: Zhongguo Pinglun Xueshu Chubanshe.

Lin, Pen-hsuan 林本炫. 1990. Taiwan de Zhengjiao Chongtu 台灣的政教衝突 (Conflicts between Politics and Religion in Taiwan). Banqiao: Daoxiang.

Lin,Jung-tse 林榮澤. 2010. Shizun Zhang Tianran Zhuan 師尊張天然傳 (Biography of Reverend Master Zhang Tianran). New Taipei: I-Kuan Yili Bianjiyuan.

Lin, Wanchuan 林萬傳.2002. Yiguandao Gaiyao 一貫道概要 (General Introduction of Yiguandao). Tainan: Qiju Shuju.

- 2010. Bayang Daomai Xinchuanlu 白陽道脈薪傳錄 (Genealogy and History of Yiguandao). Taipei: Mingde Chubanshe.

Liu Hsin-te and Liu Hsin-yu 劉心德, 劉心玉. 1995. I-Kuan Weizhong 一貫維中 (History and Contemporary Activities of Yiguandao). Taipei County: Sanyang Printing. 
Liu Ping 劉平. 2013. Guanyu Yiguandao (1937-1987) de Lishi Pingjia Wenti 關於一 貫道 (1937-1987) 的歷史評價問題 (On the Historical Review of Yiguandao). In Cheng Gongrang 程恭讓 and Chung Yun-ying 鍾雲鶯, eds. Dao zi Minjian: Zhonghua Minjian Zongjiao Wenhua Luntan Lunwenji 道在民間: 中華民間宗 教文化論壇論文集 (The Way among the Lay People: Proceedings of Forum on Chinese Popular Religious Culture). New Taipei: Zhonghua Wenha Guoji Jialiu Cujinhui , pp. 258-274.

Lo, Jiu-jung 羅久蓉. 1994. Kangzhan Shengli hou Zhonggong Chengshen Hanjian Chutan 抗戰勝利後中共懲審漢奸初探 (Preliminary Investigation of Chinese Communist Party's Punishment and Trials of Traitors after the Victory of AntiJapanese War). Zhongyang Yanjiuyuan Jindaishi Yanjiusuo Jikan 中央研究院近 代史研究所集刊 (Bulletin of the Institute ofModern History, Academia Sinica), 23: 267-291.

—.1995. Lishi Qingjingyu Kangzhan Shiqi Hanjian de Xingcheng 歷史情境與抗戰 時期漢奸的形成 (Historical Context and the Formation of Traitors during the Anti-Japanese War). Zhongyang Yanjiuyuan Jindaishi Yanjiusuo Jikan 中央研 究院近代史研究所集刊 (Bulletin of the Institute of Modern History, Academia Sinica), 24: 815-841.

-. 2013. Ta de Shenpan: Jindai Zhongguo Guozu yu Xingbie Yiyi xia de Zhongjianzhibian 她的審判: 近代中國國族與性別意義下的忠奸之辨 (Her Trials: Contextualizing Loyalty and Disloyalty in Modern China from the Gendered Nationalist Perspective). Taipei: Institute of Modern History, Academia Sinica. Lu, Zhongwei 陸仲偉. 1998. Yiguandao Neimu 一貫道的內幕 (Inside Stories of Yiguandao). Nanjing: Jiangsu Renmin Chubanshe.

-.2002.Minguo Huidaomen 民國會道門 (Sectarianism in Republican China), ed. by Tan Songlin 譚松林, Zhongguo Mimi Shehui 中國秘密社會 (Chinese Secret Societies), 7 vols. Fuzhou: Fujian Renmin Chubanshe, V.

Madsen, Richard. 2007. Democracy's Dharma: Religious Renaissance and Political Development in Taiwan. Berkeley, CA: University of California Press.

Pan, Min 潘敏. 2010. Ershi Shiji Bashi Niandai Yilai Chengzhi Hanjian Yanjiu Zongshu20世紀80年代以來懲治漢奸研究綜述 (Comprehensive Review of the Studies of Punishing Traitors since the 1980s). Kangri Zhanzheng Yanjiu 抗 日戰爭研究 (Studies of Anti-Japanese War), 2010(3):147-152.

Pingjiang Magazine. 2012. 'Yuanxin Yuanxing' (Vows and Fulfillment of Vows). Pingjiang Magazine 134. 萍江竹刊編輯部. 2012. “愿心、愿行”。萍江竹刊 134 期. http://www.andong.org.tw/index.php/2009-09-30-07-23-17/2011-04-19-0705-39/63-134.html, last accessed on 21 March 2016.

The Second Historical Archives of China, ed. 1999. 'Shehuibu Zhi Neizhengbu Gonghan 1947/5/7' (Government Document from Social Ministry to Ministry of the Interior on 5 May 1947). In Zhonghua Minguoshi Dangan Ziliao Huibian 
Diwuji Disanbian.Wenhua (Documentary Collection of Archives of the Republic of China, Volume 5 Book 3: Culture). Nanjing: Jiangsu Guji Chubanshe. 中國第 二歷史檔案館. 1999. 社會部致內政部公函 (1947 年5月7日)’.中華民國史檔案 資料彙編第5輯第3編·文化.

Smith, Anthony D. 1993. 'The Nation: Invented, Imagined, Reconstructed?' In Majorie Ringrose and Adam J. Lerner, eds., Reimaging the Nation. Buckingham: Open University Press.

Song, Guangyu 宋光宇. 1983. 天道鈎沉 Tiandao gouchen (Thorough Investigation of the Heavenly Way).Taipei: Song Guangyu.

—.1996. Tiandao Chuandeng: Yiguandao yu Xiandai Shehui 天道傳燈: 一貫道與 現代社會 (Passing the Light of Heavenly Way: Yiguandao and Modern Society). Taipei: Sanyang Press.

Tilly, Charles. 1994. 'States and Nationalism in Europe 1492-1992'. Theory and Society 23(1): 131-146.

Ting, Jen-chieh 丁仁傑. 2004. Shehui Fenhuayu Zongjiao Zhidu Bianqian:Dangdai Taiwan Xinxing Zongjiao Xianxiang de Shehuixue Kaocha 社會分化與宗教制 度變遷: 當代台灣新興宗教現象的社會學考察 (Social Differentiation and the Change of Religious Institutions: A Sociological Investigation of Contemporary New Religious Movement in Taiwan). Taipei: Lianjing.

-. 2009. Dangdai Hanren Minzhong Zongjiao Yanjiu: Lunshu, Rentong yu Shehui Zaishengchan 當代漢人民眾宗教研究: 論述、認同與社會再生產 (Studies in Contemporary Chinese Popular Religion:Discourse, Identity and Social Reproduction). Taipei: Lianjing.

Wakeman, Frederic, Jr. 魏斐德. 2003. Hanjian! - Zhanshi Shanghai de Tongdi yu Chujian Huodong 漢奸! 戰時上海的通敵與鋤奸活動 (Traitor! - Collaborationism and Anti- espionage Activities in Shanghai During the War). Shilin 史 林 (Historical Review), 2003(4): 1-22.

Wang, Chien-chuan 王見川. 2008. Cong Xinziliao kan Yiguandao de Lishi 從新 資料看一貫道的歷史 (Reading the History if Yiguandao from New Historical Materials). Hanren Zongjiao, Minjian Xinyang yu Yuyanshu de Tansuo 漢人 宗教、民間信仰與預言書的探索 (The Exploration of Han Chinese Religion, Popular Religion and Prophecies). New Taipei: Boyang.

Weller, Robert. 1994. Resistance, Chaos and Control in China: Taiping Rebels, Taiwanese Ghosts and Tiananmen. Seattle, WA: University of Washington Press. Xuan Yi 宣儀. 2003. Rekao Budao de Dayuan Xingzhe 任考不倒的大願行者 (The Grand Master Who would Never be Challenged Down). Hsinchu: Hongzong Shengtang Daoxueyuan.

Yang, Fenggang. 2012. Religion in China: Survival and Revival under Communist Rule. New York, NY: Oxford University Press. 
Yang, Liuchang 楊流昌. 2011. Tiandao Chuanqi: Yiguandao zai Taiwan de Chuanbo yu Yingxiang 天道傳奇: 一貫道在台灣的傳播與影響 (The Miracle of the Heavenly Way: The Transmission and Influence of Yiguandao in Taiwan). Hong Kong: Zhongguo Pinglun Xueshu Chubanshe.

Zhang, Tianran 張天然. 1939. Zhanding Fogui 暫訂佛規 (Provisional Etiquette). Jinan: Chonghua tang.

Zhao Suisheng. 1998. 'A State-Led Nationalism: The Patriotic Education Campaign in Post-Tiananmen China'. Communist and Post-Communist Studies 33(3): 287-302.

\section{About the author}

Lin, Ching-chih. Assistant Professor in Chinese Religions Studies, Graduate Institute of Religious Studies, National Chengchi University, Taiwan.

Email: cclin52@gmail.com 


\title{
9 Daoism and Nationalism in Modern and Contemporary China
}

\author{
Shu-wei Hsieh
}

\begin{abstract}
This chapter explores the Daoist encounter with modernity in twentiethcentury China. It focuses on nationalism and Daoist resilience, reinvigoration, and revival. Since both nationalism and Daoism are transformations of premodern traditions and identities, the emergence of the modern category of 'Daoism' is a product of the encounter with the West. Daoism was nationalized in early twentieth century and Daoism was made a part of national identity. The efforts to renew and reform Daoism became deeply engaged with nationalism, science, the religious reform movements, as well as other movements of modernity. According to these Daoist leaders, promoting Daoism has a positive impact on modern China, including building a sense of community, forging cultural self-identity, and strengthening the nation.
\end{abstract}

Keywords: Daoism, Chinese religion, nationalism, modernity, patriotism

\section{Introduction: Religion and superstition}

The Chinese intellectual elite regarded religion with skepticism in the early twentieth century, partially due to the reason-based approach taken by traditional Confucian scholars toward the issues of ghosts and gods. Historically, religion played only a supporting role in the moral education of the populace and in the continued survival of the state. With the dawn of scientific-rational thinking embraced by the May Fourth movement, religion and science were considered opposing concepts. These historical factors, in conjunction with the emergence of the NonChristian Movement and Non-Religious Alliance in the 1920s, have meant that modern intellectuals and the modern state have not made religion a major priority. The religious policy of the modern Chinese state has gone further to re-delineate the realm of religion, drawing a border between legal religion and superstition. This policy is aimed at achieving the goal of modernizing the state, so that China can become a secular modern 
country. ${ }^{1}$ As China's national religion, Daoism must be made compatible with the process of modernization. In this context, Daoism underwent a reshaping to make it a suitable national religion for a modern state. This reshaping process is closely tied with the concept of what makes a religion.

The modern Chinese word for 'religion' (zongjiao 宗教, literally ‘sect teaching') represents a concept that is relatively new to China. The acceptance of the concept of religion, and the assessment of its meaning and value, are closely intertwined with modern cultural thought and political movements. In other words, religion was an important part of the discussion in intellectual circles regarding how traditional China could be shaped into a modern country. Prior to the twentieth century, China had no concept of religion. The new word zongjiao was borrowed from Japanese shūkyō, which was coined as a translation for the Western concept of religion. After Japan signed trade and maritime treaties with the North German Federation in 1869, the word shükyo began appearing in translation of the word religion. Fumio Murata, in his Record of Things Seen and Heard in the West ('Seiyo bunken roku'), discussed the various sects of Western belief under the heading Shūkyō. Yukichi Fukuzawa experimented with several other translations of the word religion, but after Mori Arinori published the essay 'Shükyō' in the journal Miroku zasshi in 1874, shükyō became the word of choice for the concept of religion. ${ }^{2}$

In China, though the combination of the characters zong and jiao has been in use from documents ranging from Southern-dynasty documents to Song-Dynasty Buddhist writings and local annals in the Ming and Qing Dynasties, the combination usually referred to the teachings or tenets of a certain sect or school of thought, instead of its modern definition that can encompass all belief systems. The word zongjiao did not appear in the cultural discourse of China's intellectual circles until the late nineteenth century. The first use of the word in its modern definition in Chinese writing was in Huang Zunxian's Chronicle of Japan ('Riben guo zhi', 日本國志), published in 1895. Liang Qichao also began to use the word zongjiao after he fled to Japan in the wake of the failure of the Hundred Days' Reform in 1898. From then on, the concept of religion became increasingly part of China's intellectual discourse. In his Discourse on the Boundary of Rights

1 Ashiwa and Wank, eds. (2009); Chau (2006); Duara (1991, pp. 67-83); DuBois (2005); Goossaert (2006, pp. 307-336); Palmer and Goosaert (2011); Poon (潘淑華), (2010); Mayfair Mei-hui Yang (2008).

2 Chen (1999); Smith (1998, pp. 269-284); Gaenssbauer (2015, pp. 10-13). 
Between the Collective and the Self (Qunji quanjie lun 群己權界論), Yan Fu 嚴復 used the word zongjiao to correspond to the English word religion. This correspondence became widely accepted and formalized in the twentieth century, and the traditional definition of 'teaching tenet' gradually gave way to the modern definition of 'religion'. The establishment of the word also gave rise to modern scholarly discussion of the topic of religion. ${ }^{3}$

The borrowing of the Japanese word shükyō in order to translate the word religion heralded the emergence of religion studies in its modern form: the study of religion in a rational, objective, and interdisciplinary manner. This represented a major change in the approach to religion for Chinese scholars. However, there is no concept equivalent to the Western conception of 'religion' in Chinese cultural and academic contexts. The word is only a symbol to represent the Western concept of religion, and can only be understood from a Western perspective using Western definitions. When we analyze Daoism through the lens of 'religion' we inevitably view the various aspects of Daoism from a Western context and using Western approaches. This leads to an analysis of Daoism through its classics, its tenets, and its organization. Certainly, this research approach has proven fruitful for modern Daoism studies around the world, opening up avenues of research that had not been explored. However, on some level, this approach also molds or interprets Daoism as a 'religion' as defined through the Western lens, overlooking some core aspects of Daoism. This has led to an imbalance in Daoism studies that has in turn weakened or damaged the value of Daoism as a subject of research.

The concept of religion stands in opposition to the concept of superstition (mixin 迷信). The word mixin does occur in Chinese contexts, but in its modern meaning it must once again be traced back to a borrowing from the Japanese meishin. In the mid-1880s, meishin was used in Japanese in opposition to science. In A Japanese and English Dictionary (1886), meishin was given as the Japanese word corresponding to the English superstition. Chinese media sources began using the word mixin in 1897, mostly connecting it with zongjiao in opposition to 'science' (kexue 科學) in a continuation of the Japanese usage of the word. An English-Chinese Standard Dictionary (1908) was the first English-Chinese dictionary to explicitly give mixin as the equivalent of superstition. Starting at the end of the Qing Dynasty, the opposition between 'superstition' and 'science' fueled many debates. The May Fourth movement espoused the Enlightenment ideals of science and reason, opposing traditional beliefs including the Confucian teachings 
of putting family first, worshipping ancestors, and emphasizing sexual purity. Religion and feudal traditions were considered 'superstitions'. It was not until Liang Qichao 梁啟超 conducted an in-depth exploration of religion, superstition, and belief in the journal Xinmin Congbao 新民 叢報, and similar debates took place on the pages of the Xin Qingnian 新 青年 and Lingxue Congzhi 靈學叢誌, that religion was decoupled from superstition. In the 1920 s and after, both the Nationalist and Communist regimes launched major campaigns against religion and superstition under various names: 'destroying temples to build schools', 'improving customs', and the final culmination in the Cultural Revolution. All of these efforts show the profound influence of the concept of superstition. ${ }^{4}$

Under the Western conception of religion, Daoism was reshaped based on its tenets and its classics. Daoism was considered one of the major world religions in China, comparable to Judaism, Christianity, Islam, Hinduism, and Buddhism. In the early twentieth century, the Nationalist government officially recognized Catholicism, Protestantism, Islam, Buddhism, and Daoism as the 'five major religions', subject to government regulations but also government protection as long as they conformed to governmentimposed standards for being a 'religion'. However, the classification of Daoism as a world religion necessarily emphasizes certain aspects that are more compatible with the Western framework of religion, while overlooking or marginalizing other essential aspects. This process, known as the religionization of Daoism, has been underway for a century, and it is now time to look back and reflect on how religionization has shaped Daoism.

At the end of the Qing Dynasty, 'Daoism' was a wide-ranging field that included the systemic organizations of temples, local Daoist altars and Daoist clerics living secular lives, the tradition of self-guided practitioners, and various other outlets that provided Daoist-related services. All of the elements listed above have some level of connection with folk beliefs, particularly the secular-living clerics. Daoism and folk beliefs formed a complex and intricate web of faith. ${ }^{5}$

Influenced by the religion-related policies of Western nation-states, modern China adopted the secularization model and redefined the realm of religion, establishing a dichotomy between 'legal' and 'illegal' religion. ${ }^{6}$ Under this state-led process undertaken by the intellectual elite, Daoism was reshaped: the elements that were deemed appropriate by the state 
became the core of modern Daoism, while the elements that were excluded faded into the periphery, deprecated and sometimes even suppressed and destroyed. The dichotomy of 'religion' and 'superstition' was the framework on which the twentieth-century state and intelligentsia based their efforts to reshape Daoism.

National policy separated religion and the state, making religion an object of state governance. Under this system, the state provides legal status to certain Daoist institutions, allowing them to establish organizations of clerics, temples, and Daoist academies. This model is an obvious imitation of the Western approach to religion (mainly Christianity), an approach that has reshaped modern Daoism.

First, this approach emphasizes tenets and theology. However, the focus of Daoism has never been on its teachings. Historically, Daoism encountered many challenges in terms of what it teaches, some from Buddhism and some from Confucianism; Daoism has seldom gained the upper hand in these debates. The modern state's effort to define Daoism in the way Western religions are defined have led to a focus on classics, tenets, and organization, yet such an approach is limiting because it overlooks the practice of Daoism and how it manifests in daily life and in the various levels of society, which is where the core of Daoism lies. ${ }^{7}$

I believe that the most important aspects of the practice of Daoism include individual cultivation and study, rituals, talismans, and the performance of spells. However, individual cultivation and study is the only aspect that remains in the realm of modern Daoism. The remaining elements have become watered down, or rationalized as part of the 'national culture' or 'cultural heritage'. At the same time, Daoism has been closely connected with folk beliefs since the Song and Yuan dynasties, as part of the same network of faith. This has been a key link between Daoism and daily life. But after the founding of the Republic, the link has been gradually severed and Daoism isolated from the wider context of the general population's beliefs. This reshaping and re-delineation of Daoism has occurred because of the modern state's view of Daoism through the lens of religion. As China's national religion, Daoism must adhere to the state's standard for a 'legal' (hefa 合法) religion. The state has therefore overlooked or belittled the practice of Daoism, believing that these elements are unworthy of a major world religion. At worst, these elements have been railed against as superstition; at best, they are separated from their cultural context with attempts to explain them using 'science-like' or 'semi-scientific' approaches, 
rationalizing these practices through the academic disciplines of medicine, psychology, or anthropology. ${ }^{8}$

This chapter will explore the religionization of Daoism under the context of secularization theory. The works of Robert Weller, Vincent Goossaert, David Palmer, Paul Katz, and Liu Xun will form the basis of these explorations. ${ }^{9}$ From the works of these scholars, we can see the hidden influence of Christianity as the modern intellectuals and the state have reshaped Daoism. The influence is felt on different levels including politics, education, religious publishing, organization, and the gaining of adherents. This Christian-influenced model has given rise to the new form of modern Daoism. Here, we must understand how the concept of religion has changed and the background for these changes, then explore more deeply the historical background of modern Daoism and how the Western conception of religion has reshaped Daoism. Against this historical context, I will analyze the structure and content of the Daoist Textbook of Patriotism to understand how contemporary China sees and defines Daoism, and observe the relationship between the state and Daoism from the government's perspective. Finally, the model for constructing a national Daoism will be discussed, as well as how this model has influenced our understanding of Daoism.

\section{The historical background of modern Daoism}

In the twentieth century, China experienced a series of political upheavals and social movements including the fall of the Qing Dynasty, the establishment of the Republic, and the founding of the People's Republic of China in 1949. All of these events shaped and influenced the development and practice of Daoism in China. National policy and discourse played a major role in determining the form and content of Daoism. The rise and eventual suppression of Daoist temples, and their revival in recent years, is emblematic of how the relationship between the state and Daoism has changed over time.

After the Hundred Days' Reform of 1898, China underwent a profound change in intellectual thought as well as an accompanying change in religious policy. Between 1898 and the Communists' rise to power in 1949, intellectuals began discussing the ideals of religion and superstition in

$8 \quad \mathrm{Lu}$ (2012, pp. 228-250); Palmer (2011, pp. 87-106).

9 Szonyi (2013, pp. 339-358); Katz (2014); Palmer, Shive, and Wickeri (2011). 
their works, and the state bureaucracy underwent a thorough reform of its religious features. State-led worship was abolished, and governmentsupported local temples and ceremonies lost their official status. Initiatives to break superstitions and replace temples with schools were launched across China. ${ }^{10}$ However, religion-based 'redemptive societies', such as the Unity Sect (Yiguandao 一貫道, also see Chapter 8) and the Red Swastika Society (Shijie hongwan zihui 世界紅过字會), remained legal and highly influential. Many prominent members of the Nationalist Party, business tycoons, and industrialists were devoutly religious. They practiced 'internal alchemy' (neidan 內丹) in pursuit of a long life, becoming at-home clerics. Many studied under prominent Daoist masters. Traditional religious groups emulated Christian churches in their mass communication efforts, leading to a rise in the number of religious publishing houses, record companies, and radio stations. ${ }^{11}$ During this period, the movement to found schools using temple resources, the transformation of religious knowledge, and the religious life of the urban elite all shaped the substance of modern Daoism.

In the first half of the twentieth century, Daoism gradually became part of the global culture as it underwent modernization and came into contact with modernity. This transformation can be seen in three aspects:

First, local folk beliefs underwent a transformation. The biggest influence on this transformation was the 'found schools using temple resources movement' (miaochan banxue 廟產辦學), which was accompanied by efforts to abolish superstitions and improve customs, as well as the New Life Movement. These state-driven reform efforts reached their peak when the Standards for Preserving and Abolishing Temples was promulgated in November $1928 .{ }^{12}$ The reforms broke apart the folk-belief networks centered on local temples, severely affecting the livelihood of secular-living local clerics. The gradual disintegration of the intricate network of local altars, temples, and adherents completely changed the face of local Daoism, a transformation that represents national religious policy and the changing relationship between local society and Daoism. ${ }^{13}$ From a historical perspective, the movement to replace temples with schools is conceptually different from traditional efforts against 'debauched worship'. Later, the Great Leap Forward and the Cultural Revolution would further the destruction of this faith network.

Duara (1991, pp. 67-83); Goosaert (2006, pp. 307-336); Lo (2010).

Katz (2014).

Nedostup (2010); Goosaert and Palmer (2011, pp. 123-138); Duara (1995).

Goosaert (2013, pp. 569-604). 
Second, Daoist organizations and activities, centered on the 'spiritwriting' ( fuji 扶乩or fuluan 扶鸞) ceremonies, took place mostly in Daoist altars and halls. Some altars were part of 'spirit-division' (fenling 分靈) networks, in which multiple altars or temples worshipped the divided spirit of the same god. Clerics were the members of these organizations, but adherents and lay worshippers often played an even more important role. The gods worshipped by these groups mainly included Lu Dongbin 呂洞賓, Guangong 關公, and Jigong 濟公. Adherents communicated with these gods through spirit-writing ceremonies. Activities such as reading the classics, cultivating good health, inner alchemy, curing sickness, banishing evil, and charity works were important to many adherents. ${ }^{14}$ Many spiritwriting halls produced religious texts through spirit-writing, and these texts became an important way in which Daoism was spread. ${ }^{15}$ These Daoist organizations were very common in the Jiangnan region, which included major cities such as Shanghai and Hangzhou. Some of the organizations were connected to salvation groups. Most traditional scholar-gentlemen were involved in the religious practices of spirit-writing and charity work by salvation groups. Meanwhile, in the face of the war and upheaval of the period, Daoist institutions, salvation groups, and spirit-writing halls all operated with the ideal of helping the world, becoming places of refuge for ordinary people. These organizations played an important role in the religionization of Daoism in the early twentieth century, with their charity work, publishing of religious texts, and spreading of their teachings. After 1949, however, this type of Daoist organization gradually disappeared as the state adopted ever-broader definitions of 'feudal superstition'. The loss of these organizations greatly weakened the spread of Daoism.

Third, the faith and practice of the urban elite, and the way Daoism manifested in their lives, reshaped the face of Daoism. The changes in modern Chinese society were most profound and significant in the cities. A key to understanding Daoism in modern and contemporary China is the changing role that Daoist clerics played in urban life, particularly the interaction between Daoist temples, urban adherents, and professional clerics. In the colorful religious life of China's modern and contemporary cities, clerics and the intellectual elite are influenced by both national and local

14 Goosaert (2007, pp. 308-319); Goosaert (2004, pp. 699-771, esp. pp.741- 748); See also Esposito (2000, pp. 623-658, esp. pp. 645-650); Esposito (2001, pp. l91-231); Yuria 森由利亞 (2002, pp. 165184); Ichiko 志賀市子 (2002, pp. 185-209).

15 Goosaert (2004, pp. 706-707, 735-740, 744-751); Monica Esposito (2004, pp. 630, 638, 643); Goosaert and Palmer (2011, pp. 91-122). 
forces. ${ }^{16}$ The shaping of Daoism in modern Chinese cities is closely linked to the shaping of the religion itself; it is a form of Daoism that preserves traditional cultural elements while adapting to unprecedented challenges and even developing new innovations. ${ }^{17}$ Shanghai in the Republican period was home to a flourishing religious publishing industry, as well as many prominent religious figures. ${ }^{18}$ Other smaller cities had Daoist organizations, and the practice of neidan and qigong was popular.

Chen Yingning 陳摆寧 (1880-1969) is a good example of the Daoist lifestyle of China's urban elite, and how the urban elite in turn shaped modern Daoism by devoting themselves to Daoist practice, publishing Daoist magazines, and participating in new ways to practice Daoism. Chen's lifestyle shows that Daoist groups and masters were extremely active in modern Chinese cities. His example shows that the interaction between Daoism and modern ideas extended beyond simple secularization; in particular, the Shanghai elite were innovative in their practice of Daoism. The Chen example demonstrates that the religious and secular were not a dichotomy. For the urban elite of which Chen was a member, religion was a cultural realm that was closely tied to daily life. He accepted and participated in the Christian concept of kindness, the charitable works of Daoist groups, at-home practice of Daoism, spirit-writing activities, and all kinds of Daoist organizations. Chen participated mostly in volunteer groups, which were important in modern China as a personalized form of religious activity. This type of religious practice was a result of personal decisions and choices to cultivate a person's own interior life and health. Chen also noticed that women were consciously creating a female form of Daoist practice. ${ }^{19}$

Chen promoted his ideas of 'learning of the gods' (xianxue 仙學) through the Yihuatang publishing house, founded by Zhang Zhuming (1904-2004). In 1933, Zhang founded the semi-monthly Yangshan banyuekan in Shanghai and invited Chen to be one of the chief writers for the publication. Chen used this platform to advocate for learning of the gods and connect with Daoism enthusiasts; the publication became a major hub for Daoists across China. In 1939, Zhang founded the monthly Xiandao Yuebao, again with Chen as chief writer.

16 See Papers in 'The Modern History of Urban Daoism' International Conference, Southern Taiwan University, 13-14 November 2010; Susan Naquin (2000).

17 Goosaert (2007); Liu (2009).

18 Kiely (2011, pp. 4-22); Jessup (2010); Scott (2014).

19 Liu (2009). 
Through these platforms, Chen constructed and refined his ideas of learning of the gods. He set himself in opposition to the basic ideal of 'quiet inaction' (qingjing wuwei 清靜無為) in Daoism, framing learning of the gods as an active, empirical science that could be verified. He believed that the Chinese nation was facing a crucial test for its survival, and that Daoism should take a healthy, confident, and worldly approach in resistance to the intrusion of foreign countries. Therefore, Chen billed learning of the gods as a form of bodily cultivation that was scientifically valid, and said of Daoism: 'from the smaller perspective it can strengthen your body; from the greater perspective it can strengthen our race'. He tied Daoism with the strength of the nation, believing that Daoism was the way to make China and the Chinese people stronger and better able to fight off foreign invaders. He also called on his fellow believers to collect and organize texts on neidan, establishing the Association for Printing Classics on the Way of Alchemy (Dandao Kejing Hui 丹道刻經會) to publish and circulate classics and newly collected texts on inner alchemy. His intent was to strengthen the Chinese people physically, fundamentally changing the Chinese nation through the physical cultivation of Daoism. In effect, Chen's efforts provided a way for people to reacquaint themselves with Daoism and experience the richness of Daoism practice.

Chen wrote the Declaration of the Chinese Daoist Association (Zhonghua Daojiao Hui Xuanyan 中華道教會宣言) in 1936, providing an in-depth analysis of the nationalistic advantage of Daoism:

Other religions often despise the world, hoping for greater blessings in the afterlife. This makes for a pessimistic atmosphere for our nation and our affairs. The ideas of Daoism focus on this life only, and place physical health as the first priority, making for a better real life. Other religions speak of peace, yet once the weak nations share the religion of the strong nations, the strong nations invade and cause trouble. Daoism is based on our nation. If the nation is willing to work hard, then heaven will be in front of our eyes. Ah! What else but Daoism can take on the mission of bringing together all schools of thought, of filling the deficiencies of Confucianism, of taking on the best of Chinese learning, and of ensuring the correctness of new ideas? If we have the Dao (way), then we must not lack in teaching it; if we do not teach it, then how can we spread the Dao? If we teach it, then we must not lack in an organization; if we do not have an organization, then how can we ensure that the Dao remains correct and consistent? We are all children of the Yellow Emperor, born on the land of China with its wonderful rivers and mountains. We think 
back on our forbearers and martyrs, and we see the heretics fighting for our land and the decline of our national religion. Therefore we have gathered our comrades to form this association. On the basis of current law, we have formulated our rules and presented them to the party and government seeking permission to found this association. The great way may join together with the eight virtues; Daoism and Confucianism may collaborate, focusing equally on changes and constants, and letting the usual and unique work together. If that can be, China will be able to coordinate toward its purpose. The heavens and man will be in harmony, danger will turn to safety, and the ominous will become auspicious. The spirit of our nation relies on this. ${ }^{20}$

Here, Chen treats Daoism as the national religion, part of the heritage of the children of the Yellow Emperor. It is the only legal faith, while other belief systems are heresies. He criticizes Buddhism for its disdain of the world and its passive yearning for reward in the next life, while also criticizing Christianity for being the religion of foreign invaders who have no place to speak of peace. Daoism's focus on the cultivation of health and the pursuit of bodily strength is proactive and worldly; Daoism is also the embodiment of the national spirit, allows China to solve the problems posed by Confucianism by bringing together the various schools of Chinese philosophy, and is able to change with the times. Chen said: 'When we speak of Daoism today, we must trace it back to the Yellow Emperor and Laozi, while taking into account all of the different schools of thought in China's history. Then we can see that Daoism is the spiritual refuge of the Chinese nation'. He also said: 'When one believes in Daoism, one can save one's self; when one spreads the word of Daoism, one can save the nation'. ${ }^{21}$ Used in service of one's self, Daoism can strengthen the body so that it does not decay; used in service of others, Daoism can bring the rule of the saintly kings. Based on this nationalistic consciousness, Chen wanted the party and government to approve the formation of the Chinese Daoist Association in order to spread the Dao of the nation.

Chen Yingning 陳損寧 is an emblematic example of how the intellectuals of his time thought of the relationship Daoism and the Chinese nation, offering a view of the nationalistic attitudes of Daoist supporters. Chen's conception of Daoism as an essentially worldly school of thought, as well as his nationalistic fervor, meant that his ideas were supported by the state. 
When the Chinese Daoist Association was founded in 1957, Chen was elected vice president and general secretary; he was then elected as president of the association in 1961. He was also a member of the National Committee of the Second and Third Chinese People's Political Consultative Conference.

\section{A textual analysis of the Daoist Textbook of Patriotism}

In November 1956, Daoist representatives in China began preparing to form a Daoist association in Beijing, publishing the Formation Declaration of the Chinese Daoist Association (Zhongguo daojiaohuifaqishu 中國道教會發起 書), which expressed their patriotic sentiment toward the new China. In April 1957, the Chinese Daoist Association was officially founded in Beijing. The Charter of the Chinese Daoist Association (Zhongguo daojiao xiehui zhangcheng 中國道教會章程) highlighted the need to 'bring together Daoists across the nation in solidarity, continue and develop the superior traditions of Daoism, love and protect the fatherland under the leadership of the People's Government, actively participate in the nation's socialist construction work and movement to protect world peace, and assist the government in implementing religious freedom policies'. In March 1992, the Chinese Daoist Association amended the charter and emphasized that it would 'bring together Daoists across the nation under the leadership of the People's Government, love the nation and the religion, and adhere to the nation's constitution, laws, regulations, and constitution'. Therefore, the charter of the Chinese Daoist Association has always made patriotism one of its highest priorities. ${ }^{22}$

On the basis of the historical analysis above, we can now turn our attention to the structure and content of the Daoist Textbook of Patriotism (Daojiao Aiguo Zhuyi Jiaocheng 道教愛國主義教程, 'Textbook' afterwards). This text was produced by the Chinese Daoist Association, reviewed by Daoist scholars in research institutions, re-reviewed by researchers at the State Administration for Religious Affairs, and published by China Religious Culture Publisher in 2011. Instruction based on the Textbook is required for students in Daoist schools, and the leaders of Daoist organizations must also teach the Textbook to their believers. ${ }^{23}$ The Textbook represents the official viewpoints of the state, the government, and academia, as well as how the state seeks to educate its populace on Daoism. The Textbook thus 
offers us a window into the official view on Daoism and how the modern state sees the connection between Daoism and patriotism. Studying the Textbook allows us to explore how Daoism has been linked with patriotic thought to form a system of values.

The Daoist Textbook of Patriotism gives this definition for patriotism: 'Patriotism refers to the thoughts and emotions that drive people to stay loyal to, love, and give to their fatherland, as well as the moral norms that arise from these thoughts and emotions. It is a political principle and moral standard for how one treats the people of one's fatherland'. ${ }^{24}$ Under the moral rubric of patriotism, the Textbook constructs an official political theology of Daoism and a viewpoint on Daoism and the nation.

The understanding and definition of Daoism in the Textbook maintains the Western, Christian understanding of religion. Key elements include teachings, classics, organizations, rules, rituals, and sites. In such a framework, the Textbook defines the theological teachings of Daoism as being contained in its founding classic, the Daodejing 道德經. It claims that the over 1,00o Daoist classics collected in the Daoist Canon (Daozang 道 藏) are derived or developed from the basic ideals of the Daodejing. In truth, in the 'three caverns and four supplements' (sandong sifu 三洞四 輔) structure of Daoist classics, the Daodejing is placed on a fundamental but peripheral position. Analyses from within Daoism, such as The Origin of Daoism (Daojiao Suoqi 道教所起) hold that the classics stem from the divinely inspired Perfect Writing (zhenwen 真文). ${ }^{25}$

Therefore, the designation of the Daodejing as Daoism's foundational text corresponds with both the official view over the centuries as well as the Western Christian-influenced viewpoint in the modern context. The Daodejing symbolizes the most primal, unaltered, and pure ideas of Daoism, and all other classics derive from this original text. That is why the Textbook holds that the teachings of Daoism are all contained in the foundational text of the Daodejing. This perspective also matches the Protestant Christian understanding of religious teachings. The Protestants of the seventeenth century reacted against the liberal humanism of the Renaissance, claiming to be in pursuit of truth. The Protestants debated the 'pure essence' of Christianity under the standard of 'orthodoxy', rejecting all hybridized, integrated, and untrue religious phenomena. ${ }^{26}$ 
Next, the Textbook is essentially theistic. It includes the following: 'To love Daoism is to exalt the gods of Daoism, respect the gods of Daoism, and worship the gods of Daoism'. Even so, the Textbook does not expound further on the Daoist gods, only mentioning the seven-level hierarchy of Daoist divinities in Tao Hongjing's 陶弘景 Dongxuan Lingbao Zhenling Weiye Tu 洞玄靈寶真靈位業圖. In its theological discourse, the Textbook returns to 'morals' as its core. ${ }^{27}$ From the perspective of a secular state, the cosmology and divine hierarchy of Daoism are not matters that deserve pressing attention.

Third, Daoism has an organization and leaders. Its organization starts with individual temples and includes local, provincial/municipal, and national groups. This structure matches that of the contemporary Daoist Association, and also forms the organizational network that the state uses to administer Daoism. Old religious power structures centered on major mountain-monasteries such as Longhu Mountain, Gezao Mountain, and Wudang Mountain are essentially excluded from this power structure, as are the networks between local altars and temples, as well as local centers for spreading Daoism such as spirit-writing halls. Under the modern Daoist organizational structure, these three types of Daoist institution must be incorporated into the organizational network of the modern Daoist Association before they can be considered 'orthodox' and 'legal'.

Fourth, the Textbook defines Daoism as a religion with rules. The rules are embodied by the 'commandments and taboos' (qinggui jielu 清規戒 律), which fit with modern views on religious ethics. However, Daoism actually places more importance on the 'granting of runes' (shoulu 受筡) and associated rituals than on the 'commandments and taboos'. 'Granting of runes' is very closely connected to one's place in the hierarchy and self-identity in Daoism. Taboos are one element of the 'granting-of-runes' system, which must be considered as a whole. However, the study of religious ethics and world religions have often overlooked the importance of the 'granting-of-runes' system and focused solely on the normative effects of the 'commandments and taboos'.

Fifth, the Textbook states that '[t]o pursue purity and cleanliness, and help the living and put the dead to rest, Daoism has over the past two thousand years accumulated a great amount of methods and techniques to perform rituals and make for a long life'. ${ }^{28}$ The Textbook defines the teachings for purification and internal alchemy across the vast collection 
of Daoist classics as 'rituals' and 'methods for a longer life'. The former is a tool for the serving adherent, i.e. the social service dimension of religion; the latter is a method of self-control on the mental and physical levels, i.e. religious morals and practice.

Sixth, the Textbook points out that 'the temples of Daoism are places for Daoists to learn and practice the religion, as well as places for Daoist clerics to stay in contact with lay adherents. Daoists conduct religious activities and collect contributions from adherents in temples, allowing Daoism to be passed down through the generations. ${ }^{29}$ Here, temples are considered to fulfill the same function as churches, as a place to conduct religious activities and for adherents to gather. However, this view overlooks the complex relationship between temples and folk-belief networks. Since the Song and Yuan dynasties, Daoist temples have been connected on many levels with the state-worship system, as well as with other temples devoted to folk beliefs. ${ }^{30}$ Daoist temples were part of a hierarchy together with mountain temples, temples for Confucius and Guan Yu 關羽, city-god temples, and land-god temples. This hierarchy was the dominating force in the beliefs of the Chinese people, but gradually disintegrated in the twentieth century. In modern times, Daoist temples are isolated religious spaces that sometimes become tourist traps, maintaining their existence only through visitor ticket sales.

The six dimensions of Daoism in the Textbook, as described above, are all the product of an understanding of Daoism based on Christian models and ideas. This is the result of the re-delineation of Daoism using the framework of 'religion' in the wave of modernization and secularization of modern times. This viewpoint is also how the state defines and understands Daoism. Yet in this model, the traditional secular-living clerics, priests of folk beliefs, spirit-writing halls and altars, and self-guided practitioners and scholars all struggle to find a place. They seem to be left out of this framework.

The Daoist Textbook of Patriotism is divided into nine chapters, each on a different topic. The first chapter is titled 'Fighting for the Equality of the Heavenly Way and the Independence of the Nation'. This chapter discusses the Daoist ideal of peace and how it coincides with the goals of a socialist country. With this ideal in mind, the Textbook uses the examples of various historical figures to explain how Daoists sacrificed themselves for their country and society, protecting the independence of the nation. 
The second chapter, 'The Flesh and Blood of the Chinese People', establishes the Yellow Emperor and Laozi as the sources of Daoism, and as the ancestors of the Chinese nation. To connect the Yellow Emperor 黃帝 to Laozi 老子 is to link the sources of Daoism and the Chinese nation. Within a religion, this kind of tracing back to a 'pure' source is often based on a process of delineation and differentiation, making clear the difference between that which is primal, pure, legal, central, and authoritative, and that which is late-coming, counterfeit, additional, superstitious, hybridized, and ritualized. The goal is to establish a pure legitimacy in heritage, history, or politics. Such a differentiation and determination can also be discussed within the framework of Daoism and the Chinese nation. ${ }^{31}$

The third chapter is 'The Shared Spiritual Force and Behavioral Rules for the Chinese Nation'. This chapter uses the examples of Guan Yu and other Daoist divinities such as Lu Mi, Xin Ya, and Li Qing to explain that these divinities, who were only made gods after dying as mortals, were all loyal to the country, responsible protectors of the people, diligent in their duties, devoted to their morals, and great contributors to the Chinese nation before they died. The chapter then goes on to discuss that the ideal for interpersonal relationships in Daoism is harmony and concordance (hehe 和合). The Textbook uses classics such as the Lingbao Wuliangduren Shangpin Miaojing 靈寶無量度人上品妙經, the Taipingjing 太平經, and the Daodejing 道德經 to discuss Daoism's pursuit of interpersonal and societal harmony. Finally, the chapter connects the rules and taboos of Daoism with the rules of Chinese ethics, holding that Daoism's rules regarding morals and ethics are consistent with those of Chinese traditions. The Textbook extols these ethical views as having contributed greatly to the order and stability of Chinese society.

The fourth chapter is 'An Important Part of China's Philosophical Treasures'. In this chapter, the Textbook defines the Daoist school of thought in the Eastern Zhou Dynasty, as embodied by the Daodejing, as the source and core of Daoist philosophy. Ideas contained in the Daodejing, such as 'morals' (daode 道德), 'pure quiet' (qingjing 清淨), and 'inaction' (wuwei 無為) are also explored. The tracing of words and ideas in this chapter establishes a linear understanding of the development of Daoism, from purity to complexity. The chapter carries a subtextual viewpoint that Daoism developed from a primal, pure spiritualism to a more religious, ceremonial form through additions, misunderstandings, and hybridization throughout the ages. The pursuit of a return to the supposedly pure past 
is common across all religions in the modern world. This phenomenon shows the complex and multifaceted relationship between religious studies and religious movements..$^{32}$ The Textbook divides the history of the Daoist School and Daoism into four stages which also represent a shift from the philosophical and spiritual toward the religious, ceremonial, and mystical. To avoid this association with superstition, the Textbook takes care to always link the teachings and theology of Daoism back to the philosophical concept of 'morals'. This is a perspective worth examining. ${ }^{33}$

The fifth chapter, 'A Wondrous Flower in the Glory of Chinese Culture', and the sixth, 'The Contributions of Daoism to Chinese Culture', discuss Daoist literature, music, art, and architecture. Why would a text such as this, whose purpose is to instill a proper sense of patriotism in learners, incorporate literature and art in its Textbook? Why devote so much time to these historical works of art, and what do these artworks have to do with patriotism? These two chapters are written with two main goals. First, the rich religious essence of Daoism, including practices such as rituals, meditation, runes, and spells, are transformed and reduced to 'art' in these chapters. Not only does this allow the text to avoid the tricky boundary between religion and superstition, it also uproots religious practice from the realm of the sacred to the secular realm of literature and art. Second, using the same logic that made Daoism China's national religion, Daoism's associated literature, music, art, and architecture are incorporated into the spiritual heritage of the Chinese people. The richness of Daoist religious practice is thus turned into a cultural resource shared by the entire Chinese nation. To discuss these works of art and literature is to prove that Daoism directly contributed to Chinese culture, and acts as evidence that Daoists love the nation and the country. This is a process of secularization: turning 'superstitions' into 'cultural heritage' or 'intangible heritage', so that they become cultural relics of the secular world.

The seventh chapter is 'For the Health and Survival of the Chinese People' and the eighth is 'Building an Environment Where Man Is in Harmony with Nature'. These two chapters begin with an introductory history of medicine in China, then describe the contributions that Daoism made to Chinese medicine. Next, the text discusses Daoism's contributions to China's health culture. The eighth chapter describes Daoism's ideas on environmental protection and how Daoism contributed to science. These two chapters emphasize the state's shaping of Daoism as a religion. As China's national 
religion, Daoism must meet the standards of a 'legal' religion in the state's eyes. This means that when it comes to the physical practice of Daoism, including external alchemy, internal alchemy, guidance, and consumption of potions, the text overlooks and reduces the religious sensibility and ultimate aim of salvation of these practices. The 'superstitious' aspect of these practices are removed, replaced with a 'rational science' wrapping. The practices are plucked from their religious concepts and explained as 'semi-science' or 'science-adjacent'. They are placed into the history of science, so that they can be rationalized and legitimatized in a medical, psychological, or anthropological context.

The ninth chapter is 'Daoism and Socialism Must Continuously Adapt to Each Other'. This chapter focuses on the service aspect of Daoism. The practices and rituals of Daoism must always have the ultimate aim of serving the people. This chapter enlarges and glorifies the ideal of helping the world and other people in Daoist texts, placing the ideal in the framework of contemporary socialism. The chapter emphasizes the need to discover the parts of Daoist culture that are useful to modern society, and to promote and spread these elements. It also demands a 'correction' of traditional rituals and spells, and a 'modernization' of traditional Daoist organizations. These calls for reform are an echo of Daoism's modernization process.

The image of Daoism established by the state is the product of Daoistrelated discourse since China began modernizing. It is impossible to separate the social, political, and religious ideologies contained therein. From the perspective of social and cultural history, we can better understand the power plays behind the construction of Daoism. The Daoist Textbook of Patriotism is a self-shaping of a national Daoism, with the debate on legitimatization and the goals of such a construction embedded within. Analyzing the Textbook allows us to observe how myths are considered and used. ${ }^{34}$

Based on the state's official position and the rubric of patriotism, the Textbook provides an overview of Daoism with a unique perspective and method. The Textbook is not a promulgation of Daoism's teachings from the point of view of the religion itself, nor is it critical of Daoism on any ideological basis. Rather, its perspective is one that is rooted in the nation and its culture. When Daoism is constructed using this perspective, it becomes a national form of 'Daoism'. 35 
Of course, the Textbook is only one prescriptive text. Prescriptive texts usually present a religion, ethical system, or system of rules as the writer wishes them to be, rather than as they are. In contrast, descriptive materials can reveal how people understand and use prescriptive texts. To treat a prescriptive text as if it were descriptive would undoubtedly be a significant blind spot, treating religious documents specifying rules and commandments as textual embodiments of actual religious practice. As many scholars have pointed out, religious practice in real life is often the opposite of what is presented in prescriptive texts. Jonathan Z. Smith has pointed out the gulf between systemic religious discourse and the social practice of religion. ${ }^{36}$ In other words, while the Textbook does reflect historical fact on some level as a prescriptive text, the text ultimately represents the state's viewpoint. Exactly how closely this 'Daoism' as defined by the state and the intellectual elite corresponds to the real world is worth thinking about. We have reflected on modern Daoism on the level of a national symbol and of a metaphor. The state-constructed Daoism is an entity imagined in the process of modernization. Due to the modern concept of religion, Daoism is often seen, consciously or unconsciously, as a metaphorical self-contained whole, or as an organism with teleological characteristics. On one hand, such a view would see religion as a subject and overlook its more abstract and complicated aspects; on the other, this view would see Daoism as a fixed and unchanging system, overlooking its historical framework and social context. When the state makes a religion a subject and treats it as an objectively existent entity, the important role played by adherents will be ignored. This viewpoint stems from the Western conception of religion as a self-contained whole. When religion is considered an entity, it becomes a vessel, an exclusive and rigid phenomenon. In this view, people only belong to a religion - the agency, inclusivity, and changing nature of the adherents are entirely ignored. We must treat Daoism as a loose set of resources and observe how adherents use, transform, and ignore these resources in response to different situations. ${ }^{37}$

We can rely on prescriptive texts like the Textbook to understand and analyze the state's position; in the future, we can explore more limited personal writings and oral material, then bring in religious discourse to clarify the engagement and mutual creation that takes place between individuals and religious discourse. In doing so, we can present a more diverse view of the dynamism of contemporary Daoism. We can begin by exploring 
the personal interactions between Daoists, then bring in the discourse of Daoist groups in order to clarify the engagement and mutual creation that takes place between individuals and religious discourse. In doing so, we can present a more diverse and finely graduated view of the dynamism of contemporary Daoism..$^{8}$ We can treat the daily lives of adherents as the central topic of Daoism, then explore adherents' lives and inner activities and how they connect and interact with Daoist discourses. This is also a way to explore through adherents the link between state discourse on Daoism and the interior thoughts of individuals. ${ }^{39}$ In short, our work cannot be limited to the philosophical and prescriptive levels. We must also include in our study how groups on different levels of the hierarchy, as well as individuals, interact with each other and practice Daoism. Only when we view Daoism through these interactions and mutually creative activities can we better understand the construction of modern Daoist culture and religious imagery, so that our depiction of Daoism is more nuanced and a better representation of the dynamic phenomenon in Daoist states and societies.

\section{Conclusion}

Daoism underwent a shift over the past century from traditional to modern. The concept of religion, previously non-existent, was imported into China and subsequently applied to Daoism, shaping the modern form of the faith. Using the concept of religion as a starting point, this chapter explored how the state established and shaped Daoism, and observed modern and contemporary Daoism from the state's perspective to elaborate how the template of a 'religion' influenced the contemporary view of Daoism. A new model for contemporary Chinese Daoism was molded by modernization and state regulation; this new model is not only manifest in many Daoist writings, but is also an inescapable part of popular ideas and conceptions. This chapter rethinks the essence and value of Daoism based on the reflective framework outlined above, exploring the essence and content of China's national religion.

This chapter examines the shaping of Daoism in China over the past century, as the landscape of temples changed and religious activities gained in popularity among the elite. The complex relationship between the state 
and modern Daoism is recontextualized by reflecting on the dichotomy of religion and superstition.

Daoism continues to play an important role in China, but modern Daoism was indubitably the product of the influence of Western religions. This 'religionization' process was a phenomenon that took place under the influence of Christianity and the Western idea of religion. The traditional form of Daoism was, in modern times, 'replaced' by the new modern form of Daoism. Therefore, the history of Daoism is fragmented and non-continuous, as the new cultural form replaced the old, creating a rift in the middle. However, the break is not total; the new form appeared in part to solve the difficulties and problems inherited from the past, and to seek a new form of legitimization and authority. ${ }^{40}$

In fact, Daoism underwent multiple major shifts in its tenets and its form of worship in its history, but all of those forms were incorporated under the umbrella of 'Daoism'. This caused scholars to think of Daoism as a tradition passed down through the generations. Meanwhile, Daoism devoted much effort to constructing such a history for itself, in an attempt to establish its legitimacy and authority and to situate itself as the 'legal' Daoism passed down through history. Historically, Daoism was always a loose category of multiple lineages. ${ }^{41}$ It is a cluster term incorporating many complex traditions, which multiplied and changed with time ${ }^{42}$ fitting in with local traditions and creating new ones as new ideas emerged. Daoism also maintained an interactive relationship with the state.

The establishment of legitimacy is a historical process that is continually redefined..$^{43}$ Daoism is not a comprehensive and closed system that can be controlled and understood by the state; from the perspective of the faithful, every person has a different understanding and interpretation of the relationship. However, as defined by the state, Daoism must be limited in its scope; it must be 'legal' and comply with laws. The less clearly defined Daoist traditions are marginalized. The clerics and priests living secular lives may have the richest knowledge of Daoist rituals and spells to ward off evil, but their knowledge is considered part of 'local customs' or intangible cultural traditions. The spirit-writing tradition, so important in the spread of Daoism, also struggles to find its proper position in this framework. 
Although modern Daoism is undergoing a revival in many places, the renaissance conceals a crisis. As Daoism gradually loses its rich and diverse elements in the process of modernization, how can it reconnect and revitalize itself through th connection with local cultures within the state framework? How can it rebuild its link with folk beliefs while pursuing innovative developments in modern urban civilization, so that it is no longer just a 'state religion' protected by the state or a part of the 'cultural heritage' for tourists to experience? The answers will decide whether Daoism can compete with Buddhism and Christianity in China, as well as whether Daoists can develop their religion into a universal religion that is part of the spiritual heritage of humanity in general.

\section{Bibliography}

Ashiwa, Yoshiko, and David L. Wank, eds. 2009. Making Religion, Making the State: The Politics of Religion in Modern China. Stanford, CA: Stanford University press. Bokenkamp, Stephen R. 2001. 'Lu Xiujing, Buddhism, and the First Daoist canon'. In Scott Pearce, Audrey Spiro and Patrica Ebrey, eds. Culture and Power in the reconstruction of the Chinese realm, 200-6oo. Cambridge, MA: Harvard University Asian Center, pp. 191-99.

Bokenkamp, Stephen R. 2004. 'The Silkworm and Bodhi Tree: The Lingbao Attempt to Replace Buddhism in China and Our Attempt to Place Lingbao Daoism'. In John Lagerwey, ed. Religion and Chinese Society: Volume I, Ancient and Medieval China. Hong Kong/Paris: Chinese University of Hong Kong, École française d'Extrême-Orient, pp. 317-139.

Brown, Peter. 1996. The Rise of Western Christendom: Triumph and Diversity, $A D$ 200-100o. Oxford: B.H. Blackwell.

Burke, Peter. 1992. History and Social Theory. Ithaca, NY: Cornell University Press. Campany, Robert. 2003. 'On the Very Idea of Religions: in the Modern West and in Early Medieval China'. History of Religions, 42(4): 215-253.

Chau, Adam Yuet. 2006. Miraculous Response: Doing Popular Religion in Contemporary China. Stanford, CA: Stanford University Press.

Chen, Hsi-yuan. 1999. 'Confucianism Encounters Religion: The Formation of Religious Discourse and the Confucian Movement in Modern China', Ph.D. dissertation, Harvard University.

Chen, Yingning 陳椇寧. 1934. Zhonguo daojiao yuanliou gailun 中國道教源流概 論. Yanshan banyuekan 揚善半月刊, 14:1. 
Chinese Daoist Association 中國道教協會. 2011. Daojiao Aiguo Zhuyi Jiaocheng 道教愛國主義教程 (Daoist Textbook of Patriotism). Beijing: Zongjiao Wenhua Chubanshe.

Davis, Edward. 2011. Society and the Supernatural in Song China. Honolulu, HI: University of Hawaii press.

Duara, Presenjit. 1991. 'Knowledge and Power in the Discourse of Modernity: The Campaign against Popular Religion in Early Twentieth-Century China', The Journal of Asian Studies, 50: 67-83.

Duara, Prasenjit. 1995. Rescuing History from the Nation: Questioning Narratives of Modern China. Chicago, IL: University of Chicago Press.

DuBois, Thomas David. 2005. The Sacred Village: Social Change and Religious Life in Rural North China. Honolulu, HI: University of Hawaii Press.

Ehrman, Bart. 2003. Lost Christianities: The Battles for Scripture and the Faiths We Never Knew. New York, NY: Oxford University Press.

Esposito, Monica. 2001. 'Longmen 龍門 Taoism in Qing China: Doctrinal Ideal and Local Reality'. Journal of Chinese Religions, 29: lg1-231.

Esposito, Monica. 2004. 'Daoism in the Qing'. In Livia Kohn, ed. Daoism Handbook. Leiden: E.J. Brill, pp. 623-658.

Faure, Barnard. 1991. The Rhetoric of Immediacy: A Cultural Critique of Chan/Zen Buddhism. Princeton, NJ: Princeton University Press.

Gaenssbauer, Monika. 2015. Popular Belief in Contemporary China: A Discourse Analysis. Bochum: Projekt Verlag.

Goossaert, Vincent. 2004. 'The Quanzhen Clergy, 1700-1950'. In John Lagerwey, ed. Religion and Chinese Society: The Transformation of a Field. Hong Kong/ Paris: École Française d'Extrême Orient, Chinese University of Hong Kong Press, pp. 699-771.

Goossaert, Vincent. 2006. '1898: The Beginning of the End for Chinese Religion?' The Journal of Asian Studies, 65: 307-336.

Goossaert, Vincent. 2007. The Taoists of Peking, 1800-1949. A Social History of Urban Clerics. Cambridge, MA: Harvard University Press, pp. 308-319.

Goossaert, Vincent. 2010. 'Daoist Bureaucratic Structures: Central Temples in modern Jiangnan', 'The Modern History of Urban Daoism' International Conference, Southern Taiwan University, 13-14 November 2010, pp. 39-80.

Goossaert, Vincent. 2011. 'The Social Organization of Religious Communities'. In David Palmer, Glenn Shive, and Philip Wickeri, eds. Chinese Religious Life. Oxford: Oxford University Press, pp. 172-19o.

Goossaert, Vincent. 2012. 'Daoist and Local Cults in Modern Suzhou: A Case Study of Qionglongshan'. In Philip Clart, ed. Chinese and Enropean Perspectives on the Study ofChinese Popular Religions 中國民間宗教、民間信仰研究之中歐視角. Taipei: Boy Yang Press, pp. 200-228. 
Goossaert, Vincent. 2013. 'A Question of Control: Licensing Local Ritual Specialists, 1850-1950'. In Paul Katz and Shu-fen Liu, eds. Belief, Practice and Cultural Adaption 信仰、實践與文化調適. Taipei: Academia Sinica, pp. 569-604.

Goossaert, Vincent, and Palmer, David. 2011. The Religious Question in Modern China. Chicago, IL: University of Chicago Press, pp. 123-138.

Gregory Adam Scott. 2014. 'Conversion by the Book: Buddhist Print Culture in Early Republican China'. Ph.D. dissertation, Columbia University.

Herrou, Adeline. 2010. 'A Day in the Life of Ren Faqiu at the Louguantai: The memory of old Taoist Monks in China today'. In 'The Modern History of Urban Daoism' International Conference, Southern Taiwan University, 13-14 November 2010, pp. 355-400.

Herrou, Adeline. 2012. 'Daoist Monasticism at the Turn of Twenty-First Century'. In David A. Palmer and Xun Liu, eds. Daoism in the Twentieth Century. Berkeley, CA: University of California Press, pp. 82-107.

Jessup, J. Brooks. 2010. 'The Householder Elite: Buddhist Activism in Shanghai, 1920-1956'. Ph.D. dissertation, UC Berkeley.

Katz, Paul. 2013. 'Superstition and its Discontents: On the Impact of Temple Destruction Campaigns in China, 1898-9148'. In Paul Katz and Shu-fen Liu, eds. Belief, Practice and Cultural Adaption 信仰、實踐與文化調適. Taipei: Academia Sinica, pp. 605-682.

-. 2012. Religion in China and Its Modern Fate. Waltham, MA: Brandeis University Press.

Kiely, Jan. 2011. 'Shanghai Public Moralist Nie Qijie (聶其杰, 1880-1953) and Morality Book Publication Projects in Republican China'. Twentieth-Century China, 36(1): 4-22.

Lai, Chi Tim. 2003. 'Daoism in China Today, 1980-2002'. In Daniel Overmyer, ed. Religion in China Today. Cambridge: Cambridge University Press, pp. 107-121. Laliberté, André. 2011. 'Contemporary Issues in State-Religion Relations'. In David Palmer, Glenn Shive, and Philip Wickeri, eds. Chinese Religious Life Oxford: Oxford University Press, pp. 191-208.

Lipner, Julius. 2005. 'Ancient Banyan: An Inquiry into the Meaning of 'Hinduness'. In J. E. Llewellyn, ed. Defining Hinduism. New York, NY: Routledge, pp. 30-49.

Liu, Xun. 2009. Daoist Modern: Innovation, Lay practice, and the Community of Inner Alchemy in Republican Shanghai. Cambridge, MA: Harvard University Asia Center.

Lo, Shih-chich. 2010. 'The Order of Local Things: Popular Politics and Religion in Modern Wenzhou (1840-1940)'. Ph.D. dissertation, Brown University.

Lu, Xichen. 2012. 'Yuanjidao', In David A. Palmer and Xun Liu, eds. Daoism in the Twentieth Century. Berkeley, CA: University of California Press, pp. 228-250. 
McRae, John. 1986. The Northern School and the Formation of Early Ch'an Buddhism. Honolulu, HI: University of Hawai'i Press.

McRae, John. 2003. Seeing through Zen: Encounter, Transformation, and Genealogy in Chinese Chan Buddhism. Berkeley, CA: University of California Press.

Meulenbeld, Mark. 2015. Demonic Warfare: Daoism, Territorial Networks, and the History of a Ming Novel. Honolulu, HI: University of Hawai'i Press.

Mori Yuria 森由利亞. 2002. 'Identity and Lineage: The Taiyi jinhua zongzhi 太一 金華宗旨 and the Spirit-writing Cult to Patriarch Lü in Qing China'. In Livia Kohn and Harold D. Roth, eds. Daoist Identity. History, Lineage, and Ritual. Honolulu, HI: University of Hawai'i Press, pp. 165-184.

Naquin, Susan. 2000. Peking: Temples and City Life, 1400-1900. Berkeley, CA: University of California Press.

Nedostup, Rebecca. 2010. Superstitious Regimes: Religion and the Politics of Chinese Modernity. Cambridge, MA: Harvard University Asia Center.

Needham, Rodney. 1975. 'Polythetic Classification: Convergence and Consequences'. Man 10(3): 349-369.

Orsi, Robert. 1997. 'Everyday Miracles: The Study of Lived Religion'. In David D. Hall, ed. Lived Religion in America: Towards a History of Practice. Princeton, NJ: Princeton University Press, pp. 3-64.

Overmyer, Daniel. 1990. 'Buddhism in the Trenches: Attitudes toward Popular Religion in Indigenous Scriptures from Tun-huang'. Harvard Journal of Asiatic Studies, 50(1): 197-222.

Palmer, David. 2011. 'The Body: Health, Nation, and Transcendence'. In David Palmer, Glenn Shive, and Philip Wickeri, eds. Chinese Religious Life. Oxford: Oxford University Press, pp. 87-106.

Palmer, David, Glenn Shive, and PhilipWickeri, eds. 2011. Chinese Religious Life. Oxford: Oxford University Press.

Pelikan, Jaroslav. 1984. The Christian Tradition: A History of the Development of Doctrine, Vol. 4: Reformation of Church and Dogma (1300-1700). Chicago, IL: Chicago University Press.

Potter, Pitman. 2003. 'Belief in Control: Regulation of Religion in China'. In Daniel Overmyer, ed. Religion in China Today. Cambridge: Cambridge University Press, pp. 11-31.

Raz, Gil. 2015. 'What is Daoism and who is its founder?' In Patrick Gray, ed. Varieties of Religious Inventions. Oxford: Oxford University Press, pp. 83-111.

Raz, Gil. 2012. Emergence of Daoism. London/New York, NY: Routledge.

Schlutter, Mprten. 1998. 'Chan Buddhism in Song Dynasty (960-1279): The Rise of the Caodong Tradition and the Formation of the Chan School'. Ph.D. dissertation, Yale University. 
Sharf, Robert. 2002. Coming to Terms with Chinese Buddhism. Honolulu, HI: University of Hawai'i Press, pp. 13-15.

Shiga Ichiko 志賀市子. 2002. 'The Manifestations of Lüzu 呂祖 in Modern Guangdong and Hong Kong: The Rise of Spirit-writing Cults'. In Livia Kohn and Harold Roth, eds. Daoist Identity: History, Lineage, and Ritual. Honolulu, HI: University of Hawai'i Press, pp. 185-209.

Smith, Jonathan. 1982. Imagining Religion: From Babylon to Jonestown. Chicago, IL: University of Chicago Press.

Szonyi, Michael. 2013. 'Secularization Theories and the Study of Chinese Religions'. In Vincent Goossaert, ed. Critical Readings on Chinese Religions. Leiden: Brill, pp. 339-358.

Tam, Wailun. 2011. 'Communal Worship and Festivals in Chinese Villages'. In David Palmer, Glenn Shive, and Philip Wickeri, eds. Chinese Religious Life. Oxford: Oxford University Press, pp. 30-49.

Tambiah, Stanley J. 1984. The Buddhist Saints of the Forest and the Cult of Amulets. Cambridge: Cambridge University Press.

$\mathrm{Wu}$, Guozhong 武國忠, ed.Zhonghuaxianxue yangshen zonshu 中華仙學飬生全 書. Beijing: Huaxia chubanshe.

Yang, Der-Ruey. 2012. 'Revolution of Temporality'. In David A. Palmer and Xun Liu, eds. Daoism in the Twentieth Century. Berkeley, CA: University of California Press, pp. 47-81.

\section{About the author}

Hsieh, Shu-wei. Professor of Buddho-Daoist Interactions and Chinese Religions Studies, Graduate Institute of Religious Studies, National Chengchi University, Taiwan.

Email: hsiehben@hotmail.com 


\title{
$10 \quad$ Nationalism Matters
}

\author{
Among Mystics and Martyrs of Tibet
}

\author{
Antonio Terrone
}

\begin{abstract}
This chapter looks at two strategies employed by Tibetans to preserve their values, culture, and religion thus advancing nationalistic concerns. The 'Buddhist encampments' of the Nyingma School are a form of 'soft nationalism' adapting traditional religious culture to a modern Buddhism. The wave of self-immolations spearheaded in 2009 by monks from the Gelukpa school of Buddhism, exemplifies, instead, what I call 'hard nationalism'. As a violent form of nationalism, self-immolators call for radical political change in Chinese-controlled areas of eastern Tibet, autonomy, and the return of the Fourteenth Dalai Lama. Nationalism, is thus seen not as a monolithic phenomenon but as a movement taking different shapes even within the same community and among individuals sharing the same values.
\end{abstract}

Keywords: Nationalism, fundamentalism, Tibetan Buddhism, Buddhist encampments (chögar), self-immolations

\section{Introduction}

Three decades ago Chinese scholars, just like most scholars in international relations, understood religion more as a private human activity than one relevant to domestic and global politics. Nowadays, however, religion has become centrally important when it comes to democratic initiatives, peacebuilding programs, economic growth, international relations, and terrorism prevention. ${ }^{1}$ According to recent statistics, despite different public perceptions about the relevance of religion in society and politics, religion continues to be prominent in human life, and as a consequence, subject to more restrictions across the world. ${ }^{2}$ Religious groups and organizations have flourished and become creative, adaptive, and increasingly engaged

\footnotetext{
1 Toft et al. (2011).

2 Pew (2014; 2015a; 2015b).
} 
both socially and politically. In Asia, large-scale surveys demonstrate that religions are highly diverse in numerous countries, thus showing that the map of the global religious landscape does not grow consistently everywhere. ${ }^{3}$

In the case of China, while it scores in the top six Asian countries in terms of religious diversity next to Vietnam, Hong Kong, Taiwan, Singapore, and South Korea, in 2013 it also had the highest number of governmentimposed restrictions on religious practice in the world. ${ }^{4}$ China amended its Constitution in 1982 to include laws on the protection of religious freedom and 'normal' religious activities, and is committed to atheist governance and a separation between religion and politics. Ironically, however, Chinese government officials have declared themselves in charge of selecting and electing spiritual leaders in the Tibetan Buddhist tradition including the Panchen Lama and the Dalai Lama, the two highest ecclesiastic hierarchs in Tibet. ${ }^{5}$ Religion is also centrally important in the territorial and cultural claims of national minorities in China, and figures centrally in what we may consider ethno-religious nationalism. Since the foundation of the PRC, Xinjiang and Tibetan-inhabited provinces in China have witnessed several cycles of ethnic protests. Since 2008, violent urban riots erupted in Lhasa and across various Tibetan regions of western China resulting in numerous casualties among both Tibetans and Han Chinese. To date, 147 Tibetans have self-immolated in eastern Tibet, calling for self-determination, the return of their leader the Dalai Lama, the preservation of the Tibetan language, and freedom of religion.

This essay discusses two major religious phenomena in Tibetan society that have emerged as new responses to Chinese religious and ethnic policies in the past three decades. My essential concern is that although these two are different from each other, they are both expressions of the nationalist concerns and agenda of a substantial portion of Tibetans in contemporary China struggling to safeguard their cultural identity. The first phenomenon that I discuss in this essay is the rise and development of an unprecedented form of religious congregation called chögar in Tibetan and that in English can be glossed as 'Buddhist encampment'. The modern form of these religious congregations began during the 1980s' revival of Buddhism in Tibet in the wake of Deng Xiaoping's 'reforms and opening' (gaige kaifang 改革 開放). The identity of these establishments as hybrid institutions lay at the 
intersection between formal Buddhist monasteries and informal meditation hermitages. Their founders employed historical and religious means to foster faith and reeducate devotees in the fundamentals of Tibetan Buddhism, in so doing rejuvenating a sense of nationalist identity in their following through invoking Tibet's past glories. The second phenomenon I look at is the striking wave of self-immolations in eastern areas of Tibet in the PRC. These began in 2009 with protesters initially coming predominantly from the monastic ranks but later from the Tibetan laity as well. The numbers of lay self-immolators now outnumber that of Buddhist monastics. This phenomenon too, like that of the chögars, is rooted in reappropriating Tibetans' control of their society, their language, and their cultural and religious values.

This essay argues that not only has ethno-religious nationalism not declined among Tibetans against most secularist theories' odds (especially Marxist-Leninism), but rather the two phenomena I analyze here show that ethno-religious nationalism still matters for a minority struggling for relevance in an increasingly contentious and globalized world. I suggest that these phenomena can be analyzed and understood as expressions of soft nationalism (in the case of Buddhist encampments) and hard nationalism (in the case of self-immolation), both of which have emerged in Tibet in response to long decades of complex political, economic, and social transformations that have affected Tibetan communities in the PRC.

When it comes to expressions of nationalism, different Tibetan Buddhist congregations have employed diverse strategies and agendas. In particular, we can distinguish between types of strategies utilized within Nyingma and Gelukpa religious institutions; although both communities share common goals, they also have specific individual interests. Whereas the large-scale efflorescence of Buddhist encampments is exclusively a Nyingma phenomenon, self-immolations have occurred with greater frequency in Gelukpa monastic centers. Considering the long history of Tibetans' controversial relationship with the Chinese state, this essay concludes by arguing that ethno-religious nationalism is not only an unremitting force within the Tibetan community in China, but is ongoing and will likely deepen in the foreseeable future.

\section{Nationalisms and religions}

In the past three decades, scholarship in the field of political science and religious studies has refined our understanding of the elusive nature of 
nationalism. From characterizing it as a sentimental state of mind to an imagined community, many have attempted to pin down the essence of nationalism. Beginning in the 1990s, nationalism was understood as a political doctrine and an ideal essentially of two types: an ethnic nationalism, also referred to as 'genealogical' nationalism, which predominantly locates itself in the inherited legacy of a people's culture as the cement of a given community; and a civic nationalism, or 'territorial' nationalism, which transcends ethnicity as a marker of community to incorporate all those willing to submit to the sociopolitical creed of a given nation. ${ }^{6}$ For some, civic nationalism is the one generated by some sort of 'rational attachment' and is more socially realistic whereas for territorial nationalism, ethnicity is not the sine qua non of identity claims, but just one of several factors conducive to community formation. Ethnicity, instead, when advocated on nationalistic terms, enacts a spirit of genealogical belonging that takes over other potential identity factors, thus tending to border on racism and authoritarian rule. ${ }^{7}$ So strong is the sense of a nation and national identity in people that even without a state as a political entity, a national community can succeed in maintaining faith and loyalty to its values, beliefs, traditions, language, and culture. This is what warrants a nation's work to protect and disseminate its traditional value system and culture (including language and religion) as well as to value its people's sacrifice on behalf of the nation. ${ }^{8}$ According to Robert Pape, suicide terrorism has roots in nationalism, which he defines as 'the belief among members of a community that they share a distinct set of ethnic, linguistic, and historical characteristics and are entitled to govern their national homeland without interference from foreigners. ${ }^{9}$

As Michael Ignatieff comments, resistance to historical truth or protection of historical myths is fundamental to a people's group identity. ${ }^{10}$ To guarantee individuality, a nation tends to build and manipulate its historical memory based on its need to represent itself as unique and distinctive, and to those ends nations emphasize myths of origins, myths of their liberation from oppression, and accounts of their group formation. ${ }^{.1}$ This nurtured belief in one unique origin, the myth of its formation, and the liberation from various calamities not only contributes to their group identity but also

6 Ignatieff (1995, pp. 5-7); Smith (1993, p. 15).

7 Ignatieff (1995, pp. 7-8).

8 Ignatieff (1995, p. 10); Smith (1993, pp. 162-163).

9 Pape (2005/2006, p.7 9).

10 Ignatieff $(1997$, p. 185).

11 Smith (1981, p. 65). 
sustains other factors essential to a community including language, culture, and religion. ${ }^{12}$ Memory is essential to a people's nationalistic claims. Umberto Eco (1932-2016), for instance, believed that collective memory represents collective identity. Memory is used differently by people with different political agendas. Reactionary groups tend to preserve memories based on what they consider useful and meaningful to their cause. Revolutionary groups, instead, tend to erase memories in the interest of forgetting everything that existed before their rise in order to start from scratch. ${ }^{13}$

Despite being at odds with other forms of political ideology (secularism, democracy, Communism, pluralism), religion is a cohesive force in nationalistic claims especially when it comes to national minorities. The common practice of liturgies and the sentiment of brotherhood and sisterhood that emerges through religion have the power to generate cohesion among people. ${ }^{14}$ Sacred imagery, or holy icons as Hobsbawm calls them, exemplify the emblematic role that religious feelings and shared beliefs have on communities that claim national identity. Hobsbawm's research on holy icons, which corroborates this essay's argument, suggests that the most successful forms of religious symbols that sustain an idea of a 'state' at a proto-nationalistic phase of a people's history are those germane to a 'divine or divinely imbued king or emperor whose realm happens to coincide with a future nation'. Theocracies, for instance, like the system of government in Tibet ('ganden podrang') ruled by the lineage of the Dalai Lamas until the 1950 s are a case in point as the Tibetan rulers were themselves understood to be emanations of buddhas and bodhisattvas. According to Hobsbawm, there is hardly anything more crucial and successful in a people's claim to statehood in a proto-nationalistic phase than 'the consciousness of belonging or having belonged to a lasting political entity', or being a 'historical nation. ${ }^{15}$ Like Ernest Gellner, he agrees that proto-nationalism alone (a term used by Georges Dreyfus to characterize the Tibetans' sense of national identity during the Imperial period, seventh to ninth centuries) is a desirable ideological determinant for further developing mature nationalistic claims, but insufficient in itself to concretize a people's state-forming aspirations. ${ }^{16}$ Both phenomena discussed in this essay exemplify attempts to foster and concretize national identity and unity. However, one of them, the rise 
of Buddhist encampments, focuses on constructive building blocks of a people's cultural legitimacy such as cultivating moral values, education, and the safeguarding of culture, religion, and language. The other, Buddhist monastics and laypeople's self-immolations attempt to realize the modern idea of political legitimacy and self-determination by engaging in political protest and violent self-sacrifice through auto-cremation, calling on the return of the Tibetan leader (the Fourteenth Dalai Lama, Tenzin Gyatso), Tibetan independence, and national unity.

While on the one hand, Tibetan religious leaders realize that selfpreservation is necessary and essential, they also understand that staunch conservatism and traditionalism can be counter-productive strategies in authoritative regimes like the Chinese Communist government, if not self-destructive. In my experience, based on observation in the field and empirical analysis, I believe that a moderate radicalization phenomenon has emerged in Tibet due to the perceived disregard of Chinese policy makers for Tibetans' sociopolitical and cultural discontent. Far from being satisfied with recent Chinese economic, educational, demographic, employment, and social change brought in by the government in the past three decades since the launch of the 'reform and opening' campaign, Tibetans persist in perceiving their religion, mostly Buddhism, as one of the most important bastions of defense against the tensions and the chaos of the time. Some scholars have commented on how the societal turbulence, perceived injustice, and suffering can easily stimulate new ideas and creative responses. ${ }^{17}$ I see both the rise of mass Buddhist encampments and self-immolations as examples of such creative responses, emerging in or after moments of crisis. The impact of globalization is far-reached and has had wide-spread repercussions. In the case of Tibetans in China these include but are not limited to the opportunity to disseminate faith and religious ideas (mostly Tibetan Buddhism), more opportunities for traveling and meeting other people and ethnic groups, the rethinking of traditional systems and the embrace of modernization, increased use of the Internet, and growth of interconnectedness. While traditionally Tibet Buddhism virtually governed every aspect of life including education, culture, and even politics, under the Chinese Communist regime, Tibetans had to accept and adapt to a new worldview, new policies, and pervading interference in their society and culture. Therefore, while on the one hand Tibet's integration into a secular state caused enormous changes, on the other hand this very same event also stimulated new interests and challenges with the appropriation among 
Tibetans of new understandings of religious renewal, new formulations of the relationship between religion and society, and new uses of the body as an instrument for political and religious activism.

\section{Buddhist encampments}

Although Tibetan society has faced numerous challenges and changes in its modern history, most Tibetans both inside and outside of Tibet continue to look at their national history through religious symbols and holy icons. In the early 1980s, responding to the opening encouraged by Deng Xiaoping's and Hu Yaobang 胡耀邦's liberalization policies, most monasteries in Tibet reopened their gates, rebuilt their premises, and revived their theological curricula. In the first decade up to the late 1980s, these policies of religious tolerance and mild encouragement to reopen religious centers under the auspices of major economic reforms instigated large-scale responses by Tibetans, who eagerly rebuilt their Buddhist institutions. Though many monasteries reopened and started their activities with relative freedom, particularly Gelukpa monasteries known for their historical ties to both the Dalai Lama and the political authority of the country were penalized by coercive state policies whose ultimate goal was to dilute their relevance in Tibetan social life.

However, monasteries were not the only form of institutional religion to respond to the new socioeconomic and political atmosphere. A small number of Buddhist masters in the Nyingma school of Tibetan Buddhism established new religious centers in eastern Tibet that became known as chögar, 'Buddhist encampments'. These were not monasteries in the traditional sense of the word; they were loosely organized, democratic, multiethnic, and more liberal with regard to gender inclusivity. Both monks and nuns could join, as well as lay people including Han Chinese, each with their own living quarters. Importantly they refrained from openly demonstrating loyalty to the Dalai Lama, thus avoiding the charged issue of Tibet's political leadership. They also employed traditional forms of Buddhist doctrinal transmission, with a focus on providing a comprehensive and solid monastic education emphasizing philosophy, commentarial traditions, and debate. Khenpo Jikmé Püntsok (1933-2004) founded the first modern Tibetan Buddhist encampment in 1980 called Larung Gar, now the largest Buddhist institution in the world, located in Sichuan Province, PRC. At the root of his institution-building effort was his conviction of the need to solidify the validity of the Vinaya code of monastic discipline 
for both monks and nuns, which had been damaged during previous decades of social hardship and religious suppression. At the same time he also progressively adopted a more modern educational approach, thus in a way adapting his vision to the secular interests of the PRC, for whom religious freedom is contingent on religious organizations' commitment to the interests of the state, such as safeguarding a 'harmonious society' (hexie shehui 和諧社會), upholding the authority of the Chinese Communist Party, and incorporating elements of a modern scientific education. Larung Gar and the other modern Buddhist encampments that followed its model are known for supporting an egalitarian system of monastic life, education, and service opportunities, minimal leadership and hierarchical structures, as well as an interest in social engagement and religious education for the laity. Since their onset, most of the Buddhist encampments operated on a leadership based on types of executive committees constituted by educated monastics headed by the spiritual guidance of the original founders of the institutions. Larung Gar, for instance, had an executive committee of up to seven 'reincarnate lamas' ('tülkus') and 'seminary teachers' ('khenpos') who responded directly to Khenpo Jikmé Püntsok. After his passing, the place continues to run this way and its leaders are at the same time Buddhist masters and scholars with an increasingly international reputation gained by regular tours around China and the world to give speeches about Buddhism, modernity, and science.

Khenpo Jikmé Püntsok's Larung Gar mountain hermitage was later formally established and registered as Larung Five Sciences Buddhist Academy (Larong wuxing foxueyuan 喇榮五形佛學院) in 1987 under the auspices and active mentorship of the Tenth Panchen Lama Chökyi Gyeltsen (19381989). It rapidly became a large, ecumenical, and internationally oriented institute that promoted an innovative Tibetan Buddhist education for a younger generation of monks and nuns. This education consisted of offering degrees as 'seminary teacher' ('khenpo'), open to both monks and nuns, upon completion of one of two fundamental classical curricula: a scholarly one focused on exoteric as well as esoteric learning, including Madhyamaka philosophy, canonical Mahāyāna literature, and so forth, and a meditation track aimed at the deepening of the study and practices of contemplation systems, including the pinnacle contemplative techniques of the Nyingma and Kagyu Schools of Tibetan Buddhism, the Great Perfection ('dzokchen') and Great Seal ('chakchen') systems.

Larung Gar quickly rose to prominence in the late 1980s and 1990s not only for the traditional scholastic and contemplative Buddhist education it offered, but for the modern approach to learning that Khenpo Jikmé 
Püntsok and his closest assistants spearheaded, including the incorporation of computer science and history in the context of a multicultural and multilinguistic environment influenced by large numbers of Han Chinese devotees. When I visited Larung Gar for the first time in August 2001, in the very first few hours after my arrival, I was introduced to Khenpo Sodargyé, at that time already a leading authority at the encampment whom I found in a newly arranged computer room containing at least half a dozen desktop computers that he announced would be used to train young monastics in typesetting and other skills.

Another emphasis in the newly modernized form of Buddhism at religious encampments beyond education was a heightened involvement in social welfare concerns outside monastic life, including environmentalism, animal protection, vegetarianism, philanthropy, vocational training, healthcare, and disaster relief. These centers became immediately popular and, due to the relative paucity of good monastic education, they attracted monastics as well as lay devotees by the thousands both from Tibetan regions and, interestingly, from mainland China and other Chinese societies. Therefore, these centers have been able to maintain a strong adherence to traditional Buddhist ethics and Tibetan cultural values, while also adapting to the changing needs of the contemporary world.

However, I would argue that Khenpo Jikmé Püntsok's success benefited greatly from the visions and wisdom of other prominent figures of his time. In designing his Larung Five Sciences Buddhist Academy, he received the endorsement from two of the highest hierarchs in the Tibetan religiopolitical world. One was the Tenth Panchen Lama, Chökyi Gyeltsen (19381989), whom he met in 1980 and who fully supported and contributed to the founding of his Buddhist Academy. Another was the Fourteenth Dalai Lama Tenzin Gyatso, whom he met during a visit in India in 1992. Khenpo Jikmé Püntsok was believed to be a reincarnation of an earlier well-known Buddhist master, Tertön Sogyal Lerab Lingpa (1856-1926), himself a visionary who established a strong connection with the Thirteenth Dalai Lama Tupten Gyatso (1876-1933). Conceptually, the Larung Five Sciences Buddhist Academy evokes the modern 'Buddhist colleges' or academies (foxueyuan 佛學院) popularized by the Chinese master Taixu (1890-1947) in the early twentieth century and reconceptualized in the post-Cultural Revolution wave of Buddhist revival in China. Just like Taixu, Khenpo Jikmé Püntsok, and especially his successors adapted the Buddhist teachings, envisioning a new and modern platform to educate monastics and propagate the doctrine among Tibetans, Chinese, and internationally. In so doing they opened the doors to discussions of Buddhism and science and encouraged a more 
active social engagement among devotees. I would argue that by adopting this model, Khenpo Jikmé Püntsok effectively transnationalized Buddhism, thus attracting not only Tibetans, but thousands of Chinese devotees as well. In this he became a model for other Tibetan religious encampments across eastern Tibet.

We can understand the rise of Tibetan religious encampments as an instantiation of modern Buddhism in that they are ecumenical; environmentally, philanthropically, and socially engaged; and geared as much toward laity as monastics. At the same time, Buddhist encampment leaders such as Khenpo Jikmé Püntsok, Drupwang Lungtok Gyeltsen, Orgyen Kusum Lingpa, and Namtrül Jikmé Püntsok drew their charisma from traditional Tibetan conceptions of their national history. In particular, through their identities as Nyingma visionaries, or Treasure revealers ('tertön'), they evoked Tibet's ancient past during its era of imperial glory and Buddhist virtue from the seventh to ninth centuries. Their emphases on the golden age of Imperial Tibet gained particular resonance with some Tibetan Buddhists in the aftermath of the assimilation of Tibet into China and concomitant harsh socioeconomic policies started in the 1960 s followed by the devastating events of the Cultural Revolution. The connection between the historic height of Tibet's imperial power and Buddhist encampment leaders lies in the religious roots of their identity as Treasure revealers, or those who retrieve sacred scriptures and artifacts through a process of visionary revelation.

At the heart of the Treasure tradition are the epic narratives of the obscure and probably mythic eighth-century Indian Tantric master Padmasambhava, whom Nyingma supporters as well as many other Tibetans worship as a 'second Buddha' and a major contributor to the establishment of Buddhism in Tibet. ${ }^{18}$ By virtue of their connection to his prophetic and thaumaturgic skills, present-day Treasure revealers can receive Padmasambhava's Buddhist teachings, supernatural powers, charismatic gifts, and sacred relics through their mystic powers. These serve to reconnect Tibetans with a strongly autochthonous vision of their past and thereby reaffirming their sense of Tibetan identity. Through the process of discovering these sacred missives in the Tibetan landscape, Treasure revealers have resacralized Tibet's Buddhist legacy and reinvigorated Tibetans' memory of ancient sacred sites that have been and continue to be pilgrimage destinations relevant as localities of national memory as well as foci of religious identity 
for thousands of devotees. ${ }^{19}$ This emphasis within the Treasure tradition on sacred places supports a particularly strong ritual construction of a symbolic boundary according to which individuals (the personal self) reconnect with the cosmic unity or divine genesis (the other) essential to their sense of community. ${ }^{20}$

The narratives of Padmasambhava are also interesting for another reason pertaining to nationalism in Tibet. In traditional Tibetan sources, mostly Nyingma, but several of them recognized on a national level as well, Padmasambhava contained and tamed the negative unruly and chaotic energies of local Tibetan chthonic spirits that resisted the introduction of an alien religion (Buddhism) on Tibetan soil. A vast number of Tibetans, therefore, imagine the role of pious early historical Tibetan kings and especially Padmasambhava as founders of a Buddhicized and civilized Tibet, associating this with proto-nationalism, institutionalized religion and Tibetan unity. The 'compassionate forces' of Buddhism religiously subjugated and consecrated the land of Tibet through the potent means of Tantric rituals and thus transformed the restive gods, demons, and spirits of the Tibetan land into pacified protective lords of the Buddhist doctrine. This popular mythic narrative of Tibetan national history is central to the way in which centuries of Tibetans have thought of Tibet, presenting it as a land that since the embrace of Buddhism during the seventh to ninth centuries turned its harsh nature and rough people into a sophisticated and spiritual nation, with a distinctive language, culture, and religion.

By virtue of the reenactment of divine revelation, the reopening and recreation of sacred sites and pilgrimage routes, and the activation of visionary charisma, all potent 'holy icons' of Tibetan identity, Tibetan Buddhist visionaries helped Tibetans reconnect with the idea of belonging to a land defined in terms of shared memories. ${ }^{21}$ These ideas, traditions, and narratives contribute to a Tibetan sacred geography through idealized and mythicized landscapes populated by powerful entities and human beings whose genesis is connected to highly realized bodhisattvas, pious kings, and compassionate Buddhist masters.

It is appropriate to point out here the role of pacification and violation intrinsic to the missionary task attributed to Padmasambhava. The histories of early Tantric Buddhism in Tibet portray the soteriological power that Buddhism emanates both as a compassionate benevolence 
and a violent and wrathful attitude toward human life and nature. The myth of Padmasambhava's use of pacifying as well as violent means to enforce a new faith system on Tibetans is one instance of the prevalence of violence in religion, but also and even more interestingly of the influence that religion often imposes on the sociopolitical and cultural identity of a people. Jacob Dalton confirms from his analysis of numerous early Tibetan Buddhist manuscripts dating from the eighth to the twelfth centuries that certain types of ritual technologies in Tibet at this time involved the use of compassionate violence to tame chthonic spirits to achieve spiritual goals. The classic trope of the heroic bodhisattva who engages in compassionate killing or even self-sacrifice/suicide for a higher cause with the altruistic intent of reducing suffering among all beings is well-known not only in Tibetan literature but also in earlier Mahāyāna sūtric scriptures..$^{22}$ This ideal, although already doctrinally explicit, was further intensified and complicated in the specific Tibetan ritual and literary context by Tantric literature and practice with the emergence of narratives that addressed not only violence in the form of the subjugation of restive sprits impeding the conversion of Tibetan to the new faith (Buddhism), but also a controversial discussion of killing, often linguistically disguised as righteous and morally upright rituals of 'liberation' ('drölwa').

The use of legitimate and state-sanctioned violence in the context of Buddhism in Tibet evokes Weberian motifs of state monopoly on the use of force and violence as legitimate means of government and in maintaining law and order in a country. ${ }^{23}$ The Tibetan motif of subjugating and taming the restive chthonic forces opposing the construction of the first monastery in Samyé and the ordination of the first Tibetans as Buddhist monks as planned by the then king Tri Songdetsen (755-ca 804) evokes similar cosmic wars featuring good versus evil epics in numerous religious traditions from Judeo-Christian to Asian. The very same technologies were also transposed into the realm of Tibetan border defense from potential or real aggressors, thus adding a stronger political and historic relevance to these doctrines. Therefore, I argue that since the very beginning of the genesis of Buddhism in Tibet, not only were politics and governance intimately tied with religion, but this latter was itself in some instances tightly interconnected with violence. This history can help the relationship between religion and nationalism in Tibet today as demonstrated in the examples featured in this essay. 


\section{Buddhist encampments as Tibetan soft nationalism}

The vast popularity of the Buddhist encampments, enhanced by the religious literature they disseminate featuring mytho-histories of Tibet, is a main reason why the Nyingma visionaries who are their founders have garnered a wider following among Tibetans as well as Han Chinese devotees than other Tibetan Buddhist masters. By 'religious literature' I refer to their prolific production of revealed Buddhist scriptures known as Treasures ('terma'). The Treasure tradition is a system of scriptural and artifact revelations developed in the tenth and eleventh centuries by ritual specialists within the Nyingma School of Tibetan Buddhism, although it is important to point out that such a system of scriptural transmission exists with equal relevance in the Bön tradition as well. Many of these scriptures reproduce narratives of the mythic history of the Tibetan race, the introduction of Buddhism in Tibet, and the divine nature of the Tibetan imperial lineage. This is the case, for instance, of the Manikabum (Mani bka' bum), a text that was revealed between the twelfth and the thirteenth century. ${ }^{24}$ Several elements of the terma tradition are narrated in this scripture that factor into the formation of a nationalist consciousness in Tibet. These include, the narrative of the origins of how Buddhism entered Tibet, the deeds of the eighth-century Indian Buddhist master Padmasambhava, especially his subjugation of the land and the conversion of Tibetans to Buddhism, and the rise of pious Buddhist kings incarnating the divine virtues of the Bodhisattva Avalokisteśvara. ${ }^{25}$

While these narratives justify the retrieval of ancient artifacts and scriptures specifically intended to address and fulfill the spiritual needs of the contemporary times, interestingly, they also incarnate a moderate form of nationalism or soft nationalism. The Buddhist visionaries who founded the encampments employed myths and histories related to Tibet's mythicized and idealized past to legitimize a revival of Nyingma doctrinal and liturgical practices, an emphasis on monastic discipline, and a return to Buddhist moral values from which Tibetans went astray especially due to decades of hardships. By virtue of a nostalgic idealized golden past when Buddhism was established and growing, when Buddhist communities dominated the Tibetan cultural and political world where the society was autonomous and in charge of its cultural, spiritual, and political life, the founders of the Buddhist encampments did not aim to recreate the past through reshaping 
an ancient political and social order. Rather, they used the past in order to orient themselves toward the future, selecting various elements from traditional values and modern opportunities for self-preservation and for the reactivation of a Buddhist order. The Buddhist encampments accommodate some of the requirements promulgated by the Chinese state in terms of administration, performance of religious activities, and a more up-to-date education. ${ }^{26}$ At the same time, however, the leaders, especially in the case of Larung Gar, continue to hold on to a strong nationalist agenda of safeguarding traditional culture, monastic codes of discipline, strict scholastic learning, and Buddhist ethics together with an unremitting commitment to develop the study and dissemination of the Tibetan language.

Although it is admittedly difficult at this stage to quantify the impact and influence these sacred Treasure texts and the narratives they produce have on their audience in contemporary Tibet, it is quite safe to infer that it is substantial. This is especially true considering the vast popularity of these institutions among Tibetan monastics and laity in the past 40 years and the continuous turbulent relationship they entertain with the Chinese government. Additionally, as briefly mentioned above, Buddhist encampments, unlike most Tibetan Buddhist monasteries, promote an ecumenical attitude toward education thus attracting and welcoming monastics not just from Nyingma congregations, but from monasteries and nunneries adhering to other Tibetan Buddhist denominations as well. The role of noncanonical literature with strong indigenous content on fostering sentiments of fundamentalist nationalism has been attested in many traditions. ${ }^{27}$ The example of Buddhist nationalism in Sri Lanka is a case in point. Donald Swearer's study of the Mahāvaimsa, the ancient Sinhalese non-canonical Buddhist scripture, shows how its narrative attributes the development of Buddhism on the island to the Buddha himself, grounding the plot on Sri Lankan soil with Sinhalese actors. Therefore, it connects the development of Buddhism there to the Sinhalese subjugation of Tamil people considered the enemies and usurpers of Sri Lankan territory and contributed significantly to the rise of fundamentalist Sinhalese Buddhist nationalism. ${ }^{28}$

Based on my ethnographic research in Tibet during frequent fieldwork trips and long-term sojourns between 1998 and 2011, I can confirm the vast popularity of religious encampment leaders, particularly Khenpo Jikmé Püntsok, Drupwang Lungtok Gyeltsen, Orgyen Kusum Lingpa, Namtrül Jikmé 
Püntsok and Tāré Lhamo. Virtually in every town or village in eastern regions of Tibet, in people's houses or on stands at the local market, it was possible to find photos and photo collages of them, pamphlets with short biographies and photos of their revealed items, VCDs, VCRs, and music cassettes of their teachings, documentaries, and even recorded discoveries of their terma/ treasure items. Collections of devotional folksongs and poems were composed for them, portrait pictures of the most famous Buddhist visionaries such as Khenpo Jikmé Püntsok and Drupwang Lungtog Gyeltsen could be easily found on the souvenir stands on the Bharkhor circular road around the Jokhang Temple in Lhasa, and pilgrimage to their Buddhist encampments was very common among many Tibetans even from as far away as Lhasa. ${ }^{29}$

An example of this focus on traditional values is Khenpo Jikmé Püntsok's well-known attention to the Buddhist doctrine of virtuous and meritorious behavior. During his lifetime, he reiterated the relevance of strict monastic discipline, good conduct, moral rectitude, and outstanding ethics during large-scale public and private speeches in the main 'college hall' ('shedra') at his Buddhist academy. A selection of his speeches was published under the title The Radiant Lamp that Discriminates Between the Two Systems, ${ }^{30}$ which collects some of Khenpo Jigmé Püntsok's most representative thoughts on these topics. There we can detect an interest in rejuvenating a form of Buddhism that accentuates morality and ethics and critiques deceit and falsehood among Buddhist professionals with the intent of providing guidance in a period of the decay of ethical values and fast-paced modernization. A similar text is the Heartfelt Advice to Tibetans for the Twenty-first Century that also includes Khenpo Jikmé Püntsok's attention to the importance of ethical behavior, harmony, and the preservation of Tibetan culture in the face of a rapidly changing world.$^{31}$ The short and privately published booklet was widely distributed among his devotees and copies could be found in several households across eastern Tibet. A local nun gave me a copy of the booklet when I was living in a remote mountain hermitage near Sharda in Nangchen County in Qinghai in 1998. She had recently returned from Serta Larung Gar for a break from her studies and meditation training there. She was adamant about the importance of the Khenpo Jikmé Püntsok's words and strongly advised me to read it if I wanted to understand his work.

Just like the Tenth Panchen Lama Chökyi Gyeltsen's aim in the 1980s, Khenpo Jikmé Püntsok's priority in helping Tibetan religious traditions 
to resurge was education, which became one of the main features of his mission. Seeing the young generation of Tibetans as the future leadership of the religious and secular worlds,,$^{32}$ he reiterated the relevance of correct study. Within this background, he addressed committed Buddhists, stressing several key points including the need that they entrust themselves fully in the three jewels, the importance of pure intentions, sincere and honest behavior, correct speech, dismissing evil actions and sins, and ultimately living in accordance with the ten virtues. He does this by invoking authorities of the past such as the nineteenth-century Tibetan Buddhist polymath Ju Mipham, whose commentary to Nagarjuna's 'Drop of Nourishment for the People' (Skt. nitasastra-jantuposanabindu), a short collection of didactic metaphors, he employs to strengthen his ideological legitimacy. ${ }^{33}$

Additionally, Khenpo Jikmé Püntsok skillfully interspersed his authority grounded in the formal knowledge of the scriptural tradition with classic Treasure revelation-inspired prophetic rhetoric. He announced numerous times that only by committing to the teachings on ten virtues can one see through the pitch-dark night of the current degenerate times. He considered the practice of virtues as a fundamental aspect of self-control. ${ }^{34}$ Addressing then more specifically the monastic sangha, The Radiant Lamp advises that it is important for monks to completely renounce possessions, one's household, and the accumulation of wealth. Invoking the pratimokșa vows of individual liberation for monastics, he often embraced a paternalistic attitude admonishing against the dangers of impure conduct/having sex, theft, killing, and lying as the major four actions to avoid. ${ }^{35}$ Beyond this, however, Khenpo Jigmé Püntsok's nationalist message can be found also in his calling for a more thorough study and use of the Tibetan language, and the active preservation of Tibetan knowledge, customs, and costume. ${ }^{36}$

The new Buddhist centers like Larung Gar and other mass Buddhist encampments command increasing respect among devotees in China and reached out to supporters in Euro-American societies as well. They function as catalysts of 'Tibetanness' for Tibetans, while also acting as centers of modern Buddhism for many Chinese. Their focus on education, training, and maintaining Buddhist virtue is emblematic of the fundamentalist intent of the leaders behind these institutions. Many Tibetans could not

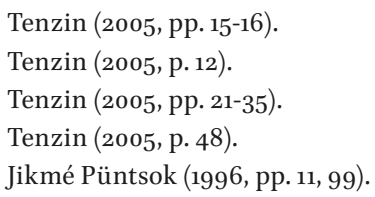


appreciate the increasing loss of traditional Tibetans religious culture and the changed nature of Buddhist monasteries in Tibet, where curricula have been weakened and authority diluted. The establishment of religious educational institutions such as the Buddhist-encampments-turned-colleges is a clear sign of fundamentalist trends that emerged in the 1980 s and continued until the early 2000s. ${ }^{37}$

While the conservative and Tibetan nationalist orientation of the Buddhist encampments is highly problematic for the Chinese authorities (hence the years of crackdown and relaxation over the past three decades), the positioning of many leaders of Buddhist encampments within the Chinese state's discursive institutions of religion, modernity, and science offer at the same time the opportunity for some accommodation. Their hybrid nature and modern orientation with a culturally conservative Tibetan flavor, therefore, can be mutually beneficial to Tibetans and the Chinese state. They were born and grew up around Buddhist teachers who by virtue of their visionary-based charisma were able to attract thousands of followers in just over a decade. For many Tibetans, they promoted a strong nationalist ideology which emphasizes their connection to the glorious part of the Tibetan empire, the reinforcement of a type of Buddhism with strong Tibetan characteristics, and the promise of salvation as prophesied by Padmasambhava, emanated in the prophecies and visions that they claim to receive as part of their spiritual connection to their ancestral teacher, Padmasambhava. Their vision, however, did not stop there as Khenpo Jikmé Püntsok inspired this new approach by combining charismatic leadership and a modern approach to teaching Buddhism (always with some traditional elements), thus adapting to the new sociopolitical circumstances.

What he and many other leaders of Buddhist encampments promote is a sort of 'soft nationalism' that is not so much aimed at claiming political self-determination but rather at protecting the cultural, linguistic, and religious legacy of Tibet while also accepting some level of adaptation to the changing world. The Buddhist centers they have founded are rarely engaged in assertive forms of 'hard' nationalism aimed at political confrontation and self-determination. They are aimed at revamping religious education, remapping the Buddhist landscape with sacred places and powerful spaces of worship, promoting ecumenism as a path to a united front against the dangers of globalization and Chinese dilution of Tibetan traditional culture and values. Unlike the once-powerful and politically influential mega monasteries of the Gelukpa school, these new mass semi-monastic centers do not 
promote the worship of the Dalai Lama nor try to fight for his return, and do not engage in confrontations with local authorities for more freedom in the practice of religion. They focus on combining modern education and a strong ecumenical outreach, instilling the relevance of social engagement in the formation of Buddhist monastics, while at the same time not resisting but adapting to and experimenting with the new ideas promoted by the Chinese government through the State Administration for Religious Affairs including the work that religious organizations should endorse such as peaceful and harmonious coexistence, charity, relief work, and promotion of environmental protection.

The persistence of nationalism in eastern Tibet is a consequence of various interdependent factors including the historical demise of the theocratic polity led by the Dalai Lama and other high hierarchs in the Buddhist world, the collapse of the mass monastic system predominantly led by the Gelukpa school and which was virtually in control of the production of knowledge, education, and culture, as well as the impact of the vast sociopolitical, economic, and cultural influence which resulted from Tibetans' conflicted interaction with the modern Chinese world. By virtue of its claimed link to the Tibetan Empire, the role of Padmasambhava in the introduction of Buddhism in Tibet, and the activities of the early Tibetan Buddhist communities, the scriptures of the Nyingma school root Tibetan identity in that early phase of Buddhism on Tibetan soil, therefore gaining heightened significance as an antidote to the threat of modern circumstances. The Buddhist encampment leaders with their focus on meditation, scholastic study, multi-year curricula, and social engagement represent the complexities of what I see as a fundamentalist movement within the Tibetan society. It is especially Khenpo Jikmé Püntsok's modern attention to the relevance of traditional canonical and non-canonical scriptures, the safeguarding of Vinaya, the monastic code of discipline, his emphasis on morality, ethics, and virtuous actions based on various Buddhist doctrines such as the 'ten virtues' as a guiding principle for both monastics and the laity, as well as his active participation in prophetic and visionary movements across Tibet through the treasure revelation tradition in the service of the twenty-first century that encapsulates this new Tibetan national identity.

\section{Self-immolations as hard nationalism}

Beyond the role of the Buddhist encampments in revamping Tibetan nationalism, recently Tibetans are also employing more assertive and harder 
expressions of nationhood and political awareness that resonate with types of nationalism found in Europe since the nineteenth century. This latest phase of Tibetan nationalism is being expressed among the young and disenfranchised through a form typical of ethno-nationalist conflicts, that of martyrdom. This is manifest, nowadays, in the wave of self-immolations that occurred particularly in eastern Tibet between 2009 and 2015, and continue to claim victims in the present. As of March 2017, 147 Tibetans have voluntarily set their bodies ablaze as a form of protest against the Chinese government. ${ }^{3}$ While many were Buddhist monastics or ex-monastics, both monks and nuns especially in the first two years, the vast majority of self-immolators have been lay people. Approximately one-third of the total self-immolated protesters left behind either written or recorded messages before their ultimate act. ${ }^{39}$ Based on these records, it seems that religion per se is not the main reason for their violent act. Only in the first years were monastics, almost uniquely from Gelukpa monasteries, the majority of self-immolators. Starting in 2011, more and more lay people joined the lethal protests and by 2013 they outnumbered monastics in areas such as Amdo (Qinghai and Sichuan Province) with a majority of ethnic Tibetans, which scholars believe are typically more prone to unrest and resistance. ${ }^{40}$ In these areas ethnic Tibetans have displayed increasing frustration at several circumstances perceived as unjust and unfair including a sense of desperation for lack of employment, more state-imposed control and interference with religious activities, unbalanced education, and exclusion from political, and economic opportunities. ${ }^{41}$ Lack of freedom of religious practice seems to be a major concern for the self-immolators, especially among monastics, but it is only one of several other motivations. Other desiderata include self-determination, the return of the Dalai Lama, the release of the Eleventh Panchen Lama originally recognized by the Fourteenth Dalai Lama named Gendün Chökyi Nyima (b. 1989), more equality and justice in education and employment opportunities, and the promotion of Tibetan language and cultural education. For many Tibetans, these issues together with requests for more authentic religious freedom are all core ingredients of their perception of Tibetan national and cultural identity. ${ }^{42}$ 
The spate of self-immolations began in Ngaba in February 2009 just a few months after local security forces brutally put an end to the violent uprising in 2008. Monasteries there as well as in other parts of eastern Tibet including Rebkong, for instance, were put under strict monitoring, religious practices were tightly controlled as were rituals and education, and patriotic reeducation intensified. A network of CCTV surveillance video-cameras monitored monastics' as well lay peoples' movements in strategic places across the urban area. Additionally massive deployments of military and paramilitary personnel fostered an atmosphere of intimidation and fear. ${ }^{43}$ Under these conditions, many monks radicalized out of frustration. To date the self-immolators' demands have not been adequately met. The Chinese government's refusal to recognize Tibetans' yearning for increased self-determination and their unwillingness to offer any solutions or dialogue, but only harsh suppression, is further fueling the rise of Tibetan self-immolations. Self-immolation is the new Tibetan form of communication to convey their despair, taking Tibetans' nationalist response to the Chinese government's hard line to a higher level. ${ }^{44}$ Reports indicate that prior to their dramatic self-sacrifice; many self-immolators show signs of anger, frustration, and confrontation with local authorities and military personnel in their local areas, often just days before committing themselves to fire. ${ }^{45}$

Although the PRC and its media sources have extensively accused Tibetan self-immolators of being not only terrorists engaging in separatist activities, but also religious zealots backed by the Dalai Lama, self-immolation can hardly be considered a form of terrorism. ${ }^{46}$ While self-immolation is a violent expression of anger, resentment, and hopelessness, auto-cremation speaks more to the non-hostile commitment to political activism than any form of terrorism, including suicide bombing, with which it shares some features. The two forms of political violence, self-immolation and terrorism, share several characteristics including a central communicative component, political radicalism, a fundamentalist agenda, and being an extreme last resort which includes the death of the activist in tune with ancient Mahāyāna scriptures. However, the non-hostile nature of self-immolations, despite the extreme violence to their own bodies, should 
not be confused with criminals who unleash indiscriminate harm to others for political goals. ${ }^{47}$

Within the Tibetan community in exile in India, self-immolators are being celebrated and immortalized as martyrs and national heroes, as exemplified by their identification as pawó, a word that in Tibetan refers to both 'hero' and 'martyr'. ${ }^{48}$ It is to these martyrs that the Tibetan community in exile, based in Dharamsala, India, has erected a monument to commemorate their gestures as acts of selfless patriotism ('gyelché'). The self-immolators are not only patriots, but also specifically Tibetan which on the stele ('doring') are referred to not by the ubiquitous term bö/bod for Tibet, but chölsum bö or 'Tibet of the three provinces', a traditional political term used in reference to the political unity of the Tibetan regions of the $\mathrm{U}$ Tsang, Kham, and Amdo provinces. As much as self-immolation is political, however, it is also religious, given that from a Buddhist perspective the martyr's intent to sacrifice her body to communicate the anguish of her people is an act of generosity; it is an imitation of the extreme gesture of the Buddha to sacrifice his life for the wellbeing of another living creature. ${ }^{49}$ This has an important place in the phenomenon of self-immolations in Tibet and in Asia in general. The act, however, is then also appropriated by the nation it represents and controlled, manipulated, and sacralized to become the emblem of the heroic struggle of the Tibetan nation. Here the politics of martyrdom in both its altruistic sacrificial sense stemming from the Buddhist legacy as well as extreme political activism merge with the interdependent concepts of 'memory', 'identity', and 'heroism', reinforcing a radicalized sense of Tibetan national unity. ${ }^{50}$ Tibetans, like all societies, are psychologically invested in their heroes and especially the monastic sangha, as these not only represent Tibet, its struggle for freedom, and the knowledge of more than a thousand years of Buddhist history, but they also function as the pure truth of a nation's past..$^{51}$ Whereas martyrdom suggests union with one's spiritual achievements, heroism invokes union with one's homeland, a mystical union with the spirit of a nation. The militant and violent nature of self-immolations cannot be understated as they represent a hard-line assertion of values and a confrontation with perceived threats to individual, communal, and national rights and values. A vast number 
of self-immolators show signs of radicalization exacerbated by decades of policies that have diluted religious culture, impoverished the relevance of Tibetan languages, and weakened the Tibetan sociopolitical identity by precluding Tibetans from having self-chosen leaders. Some self-immolators wrote about acting to 'lead others to Buddhahood' and modeling their actions on 'the Buddha who gave his body to a hungry tigress', while others addressed the needs to offer their burning bodies as lamps that dispel the darkness of the land of snows'..$^{2}$ While the lyricism contained in such testimonies draws on religious fervor as well as scriptural and doctrinal sources typical of the Mahāyāna tradition, it nevertheless contributes to an estheticization of violent sacrifice as a modern form of identity. They are reminiscent of certain postmodern interpretations of the consumption of images, signs, and actions representative of contemporary Western societies, where so much becomes a spectacle..$^{53}$ And therefore everything overlaps including politics, religion, culture, as well as violence and the power of media technologies. Considering the visual media through which the vast majority of the world population is exposed to the images of Tibetans dying ablaze for their nationalist struggle, it is hardly possible to ignore the shocking elements of these stylized performances so critical in this esthetics of death especially in popular culture. ${ }^{54}$ The graphic signs of auto-cremations have now likely entered the houses of millions of people around the world and its audiences have consumed these images as signs and symbols now referring to the specific struggle for justice and equality in Tibet.

This kind of fundamentalism that emerged in Tibet in the past few years is not unique among Asian societies. Similar episodes of Buddhist leadership and monastic engagements in nationalist activities have been documented in many modern South Asian countries including Sri Lanka, Vietnam, Thailand, and Myanmar. Although these cases are all characterized by their own historical circumstances and thus are not directly comparable, this confluence of Buddhist insurgencies around the Asian world shows that despite their stereotype as nonviolent, compassionate, and altruistic, there is strong potential for Buddhist supporters to rise and join forces to fight against what they perceive as a dangerous threat to national interests and their sense of identity as a people.

Central to the cohesion of a nation is its 'rich legacies of memories', since 'the nation, like the individual, is the culmination of a long past of 
endeavors, sacrifice and devotion'.55 The glory of a heroic past is therefore the capital upon which a nation builds its imagined community, to use the well-known term coined by Benedict Anderson. A nation's imagined political community is heightened by the solidarity expressed toward those who died for that very same idea of nationhood. ${ }^{56}$ Ernest Renan would have agreed with this point as he believed that a nation is 'a large scale solidarity, constituted by the feeling of the sacrifices one has made in the past and those one is prepared to make in the future' ${ }^{57}$ For him shared suffering is more important than shared joy, and grief is more valuable than triumph. Nothing could be truer in the case of self-immolators in Tibet, for in the micro-politics of self-immolations, sacrifice, suffering, and grief are at the heart of building national identity. Supreme sacrifice therefore justifies the transcendent character of the nation and the Buddhist altruistic act of a bodhisattva. It is above all the 'official memory' of these experiences as passed down to posterity that will contribute to the reinforcement of a national spirit. Therefore, the figure of the martyr is particularly useful in the construction of national memory, especially in moments of crisis. It creates a sacred aura around an already victimized and much idealized imagined nation. Individual victims become national heroes by taking upon themselves the task of denouncing perceived human-rights violations and memorializing their sacrifice through enacting heroic death.

\section{Conclusion}

With the Communist Party's self-fashioning as a multireligious and multiethnic China - albeit strictly controlled and regulated - several religious traditions sprang back to life. The Marxist narrative of the decline of religion in China not only did not work, but by tolerating religion PRC policy has allowed it to flourish and crystallize..$^{8}$ In the case of Tibetans, for whom religious life constitutes a fundamental part of national and cultural identity, not only has Buddhism reemerged strongly, but it supports even stronger Tibetan nationalistic claims. In its modern emphasis, religion, next to language and ethnicity, can be used to transform the community into a nation. 
The two cases presented here demonstrate two ways in which Tibetans are promoting and consolidating their national identity. The power of history and myth at the core of the success of large religious institutes, like the Buddhist encampments, and the promotion of martyrdom and heroic sacrifice to protest for self-determination are two aspects of modern Tibetan collective identity that are unlikely to dissipate any time soon. Buddhist encampments like Larung Gar capitalize on religion, modern education, language, and social engagement as a source of anti-secular nationalist revival. This phenomenon seems to encourage some openness for discussion with authorities and accommodation of China policies and state institutions. The same cannot be said of the self-immolators, who do not give the impression of being interested in compromises. As the government in China tends to turn a blind eye to the issues for which they advocate, the international media seems the only one to be actually acknowledging their message. This can be evinced by the essential role that digital technology, especially the Internet, emailing, text messaging, and social media has in the phenomenon of self-immolations. Communication to the outside world is essential. The martyrdom and heroism of the self-immolators are equally balanced in their sacrificial activities: the former stemming from personal dedication and religious identification (the desire to imitate the supreme generosity of the Buddha); the latter valorized by the myths of personal transformation by virtue of violent processes and typically identified and bestowed by community valorization and evaluation. In the economy of sacrifice, Tibetans who commit themselves to the blazing flames of altruism and patriotic heroism enjoy great admiration and are rewarded with honor and status in the memory of the community.

This essay suggests that Tibetans continue to cultivate and give voice to Tibetan national sentiments through diverse strategies. Buddhist encampments are a platform for local communities to focus on education, language, ethics, and religious values as priorities in safeguarding Tibetan culture, thus promoting a form of 'soft nationalism'. The attention on Buddhist education, culture, and modernization of most of the Tibetan Buddhist encampments and institutes resonates with China's post-socialist modernization project and its promotion not only of economic development, but also of poverty reduction, openness, and stability. What the Buddhist encampments also feed into is China's move toward a multicultural, cosmopolitan, and controlled religious pluralism, contributing to its new image via the 'soft-power' strategy of promoting certain modern forms of religion, including Tibetan Buddhism. 
On the other hand, self-immolators use the hard currency of self-sacrifice and self-chosen martyrdom through violent death to call on Tibetans to unite and simultaneously influence the national and international communities' perceptions of Tibet in the hope of hastening a response. Unlike the mass Buddhist encampments, the phenomenon of self-immolation with its religion-infused political intent speak of a more assertive nationalism, one of resistance to integration, political violence, and martyrdom. The crisis of Tibetan self-immolation indicates a widespread and growing sense of malaise and impotence in the face of aggressive market-based homogenization throughout China. It condemns the loss of cultural values and local traditions in the rush for global economic competition. The predominant and overarching role played by Gelukpa monks in Ngawa and other towns such as Rebkong in the self-immolation crisis suggests their frustration for not being able to freely worship the Dalai Lama as a centrally important religious figure in their tradition, which is not shared in the same way by other Buddhist schools in Tibet, especially the Nyingma. We can understand these differences as examples of how nationalism in a postindustrial globalized world and the rise of politicized religion in the international political economy are not uniform and monolithic phenomena, but are shaped and represented differently by different people and diverse agencies even within the same community that shares the same values. However, I believe that both soft and hard nationalisms in the form of religious encampments and self-immolation, respectively, operate at the microlevel of a developing society lacking the ability to trigger an effective nationalist rebellion to achieve its goals. In the larger picture, this study understands nationalistic developments among Tibetans in China not as emblematic of a flaw in Buddhism, but as a characteristic sign of the interconnection between religion and nationalism.

Central Tibetan authoritative leadership is lacking in Tibet since the departure of the Dalai Lama for India in 1959 and the passing of the Tenth Panchen Lama in 1989. Since then, the religious enthusiasm that a number of influential religious figures, such as the highly charismatic Nyingma Buddhist teachers and visionaries of the encampments, have been able to rekindle among large sections of the population in eastern Tibet and mainland China has been largely unrivaled by other Buddhist monastic communities. Therefore, I characterize this movement as soft nationalism, whose actors have established new institutions with the intent to combine traditional values and symbols with modern systems of thought. By contrast, however, there is also pervasive resentment and frustration among many other Tibetans in the very same regions who react to China's 
repressive policies on religion, language, and territory with anger and a harder nationalist, if not fundamentalist, attitude. Radicalized by years of harsh control and perceived sociopolitical ostracism, Tibetans opting for self-immolation represent this alternative strategy of political protest and violence with the desperate intent to unite Tibetans in the struggle for self-determination, the call to return the Dalai Lama to Tibet, and to draw attention to their plea from various audiences, including the international media. Considering their lackluster results, self-immolations may gradually decline in frequency, but political protests of some sort will be unlikely to stop. Nevertheless, both soft and hard nationalist groups have shown themselves to be innovative and resourceful. They have proven that nationalism matters in Tibet on a global religious level as well as a local activist level.

\section{Bibliography}

Ashiwa, Yoshiko and David L. Wank, eds. 2009. Making Religion, Making the State: The Politics of Religion in Modern China. Stanford, CA: Stanford University Press. Anderson, Benedict. 1993/2006. Imagined Communities: Reflections on the Origin and Spread of Nationalism. New York, NY: Verso.

Bhuchung K. Tsering. 2012. 'Man on Fire'. Himal. 1o February. http://himalmag. com/man-on-fire/, last accessed on 20 April 2016.

Bogardus, Emory S. 196o. The Development of Social Thought. New York, NY: Longman's Green and Co., Inc.

Baudrillard, Jean. 1993. The Transparency of Evil. London: Verso.

Bruder, Margaret Ervin. 2004. 'Aestheticizing Violence, or How To Do Things with Style'. http://gradnet.de/papers/pomoz.archives/pomog8.papers/mtbruder 98.htm, last accessed on 20 April 2016.

Cabezón, José. 2013. 'On the Ethics of the Tibetan Self-Immolations'. Religion Dispatchs, 13 June. http://religiondispatches.org/?s=On+the+Ethics+of+the+T ibetan+Self-Immolations, last accessed on 20 April 2016.

Biggs, Michael. 2012. 'Ultimate Sacrifice: What's the Difference between SelfImmolators and Suicide Bombers?' Foreign Policy. 3 December. http://foreignpolicy.com/2012/12/03/ultimate-sacrifice/, last accessed on 20 April 2016.

Dalton, Jacob P. 2011. The Taming of the Demons: Violence and Liberation in Tibetan Buddhism. New Haven, CT: Yale University Press.

Dreyfus, Richard. 1994. 'Proto-nationalism in Tibet'. In Per Kvaerne, ed. Tibetan Studies: Proceedings of the 6th Seminar of the International Association of Tibetan Studies (Fagernes 1992), vol. 1. Oslo: Institute for Comparative Research, pp. 205-218. 
—, 2005. 'Are We Prisoners of Shangrila?' Journal of the International Association of Tibetan Studies, 1: 10-14.

Enze, Han and Christopher Paik. 2014. 'Dynamics of Political Resistance in Tibet: Religious Repression and Controversies of Demographic Change'. The China Quarterly, 217: 69-98.

Ferrario, Davide. 2015. Umberto Eco sulla Memoria: Una Conversazione in Tre Parti. https://www.youtube.com/watch?v=Hq66Xgf-zgc, last accessed on 20 April 2016.

Fields, Rona M. 2004. Martyrdom: The Psychology, Theology, and Politics of SelfSacrifice. Westport, CT: Praeger Publishers.

Fine, Jonathan. 2015. Political Violence in Judaism, Christianity, and Islam: from Holy War to Modern Terror. Lanham, MD: Rowman and Littlefield.

Fischer, Andrew M. 2009. 'Educating for exclusion in western China: structural and institutional dimensions of conflict in the Tibetan areas of Qinghai and Tibet'. Working Paper 69. Center for Research on Inequality, Human Security and Ethnicity.

Gellner, Ernest. 1983. Nations and Nationalism. Oxford: Basil Blackwell Publisher Limited.

Germano, David. 1998. 'Re-membering the Dismembered Body of Tibet: Contemporary Tibetan Visionary Movements in the People's Republic of China'. In Melvin Goldstein and Matthew T. Kapstein, eds. Buddhism in Contemporary Tibet: Religious Revival and Cultural Identity. Berkeley, CA: University of California Press, pp. 53-94.

Hobsbawm, Eric J. 1992. Nations and Nationalism since 1780: Programme, Myth, Reality. Cambridge/New York: Cambridge University Press.

ICT (International Campaign for Tibet). 2017 [2009]. 'Self-immolations by Tibetans.' www.savetibet.org/resources/fact-sheets/self-immolations-by-tibetans/, last accessed 30 March 2017.

Ignatieff, Michael. 1995. Blood and Belonging:Journeys into the New Nationalism. New York, NY: Farrar, Straus and Giroux.

—, 1997. The Warrior's Honor: Ethnic War and the Modern Conscience. New York, NY: Henry Holt and Company, Inc.

International Campaign for Tibet (ICT). 2012. 'Harrowing images and last message from Tibet of first lama to self-immolate'. www.savetibet.org/harrowing-imagesand-last-message-from-tibet-of-first-lama-to-self-immolate/, last accessed on 20 April 2016.

Jigmé Püntsok, Khenpo. 1996. Dus rabs nyer gcig pa'igangs can pa rnams la phul ba’i snying gtam sprin gyi rolmo. Taipei: Ningmaba larong sancheng falin foxuehui. 'Jam bzod (dbyangs bzod pa); Li thang. 2014. Rang lus mer sreg-Self-Immolation. New Delhi: Tibetan Parliamentary and Policy Research Centre.

Kapstein, Matthew T. 20o6. The Tibetans. Hoboken, NJ: Wiley-Blackwell. 
—, 1992. 'Remarks on the Maṇi bka'-'bum and the Cult of Āvalokiteśara in Tibet'. In Steven D. Goodman and Ronald M. Davidson, eds. Tibetan Buddhism: Reason and Revelation. New York, NY: State University of New York Press, pp. 79-93.

Kolas, Ashild, and Monika P. Thowsen. 2005. On the Margins of Tibet: Cultural Survival on the Sino-Tibetan Frontier. Seattle, WA: University of Washington Press.

Kuhn, Robert Lawrence. 2016. “Asymmetric Harmony” for US-China Ties'. Chinadaily.com. 31 March. http://europe.chinadaily.com.cn/opinion/2016-03/31/ content_24199450.htm, last accessed on 20 April 2016.

Kuriakose, Karikottuchira K. 2011. 'Globalization, Religion, and Nonviolence'. In Brandon J. Sherman, ed. Globalization Policies and Issues. New York, NY: Nova Science Publishers, pp. 155-175.

Lee, Peter. 2011. 'Will Aba be the CCP's Waterloo?' Asia Times. 11 November. www. atimes. com/atimes/China/MK11Ado1.html, last accessed on 20 April 2016.

Lhamokyab, Noyontsang. 2013. Dpa' bo me 'bar las mched pa'i snyan dngags kyi me lce (The Flames of Poetry Spreading from the Fire of Heroes). Revue d'Etudes Tibétaines, 25: 113-122.

Martin, Dan. 1997. Tibetan Histories: A Bibliography of Tibetan-Language Historical Works. London: Serindia Publications.

Marty, Martin E. and R. Scott Appleby, eds. 1993. Fundamentalisms and Society: Reclaiming the Sciences, the Family, and Education. Chicago, IL: University of Chicago Press.

—, 1991. Fundamentalisms Observed. Chicago, IL: University of Chicago Press.

Pape, Robert A. 2005/2006. Dying to Win: The Strategic Logic of Suicide Terrorism. New York, NY: Random House.

Pew Research Center. 2014. 'Global Religious Diversity. Pew Research Center: Religion and Public Life’. 4 April. www.pewforum.org/2014/04/04/globalreligious-diversity/, last accessed on 20 April 2016.

-, 2015a. 'Latest Trends in Religious Restrictions and Hostilities'. In Restriction on Religion. 26 February. www.pewforum.org/2015/o2/ 26/religious -hostilities/, last accessed on 20 April 2016.

—, 2015b. 'The Future of World Religions: Population Growth Projections, 20102050'. In Demographic Study. 2 April. www.pewforum.org/2015/04/02/religiousprojections-2010-2050/, last accessed on 20 April 2016.

Pittman, Don A. 2001. Toward a Modern Chinese Buddhism: Taixu's Reforms. Honolulu, HI: Hawai'i University Press.

SARA (State Administration for Religious Affairs of P.R.C. 國家宗教事務局). 2007. The Management of Reincarnate Lamas in Tibetan Buddhism (Zangchuan Fojiao Huofo Zhuanshi Guanli Banfa 藏傳佛教活佛轉世管理辦法). www.sara.gov.cn. 
—, '870 Reincarnate Lamas Inquired as the Reincarnate Lama Buddha Query System is Officially Opened' (Huofo Chaxun Xitong Zhengshi Qiyong, Shoupi Kecha 870 Ming Huofo 活佛查詢系統正式啟用 首批可查870名活佛). www. sara.gov.cn.

Shakya, Tsering. 1999. The Dragon in the Land of Snows: A History of Modern Tibet since 1947. London: Pimlico.

—, 2012. 'Self-Immolation: the Changing Language of Protest in Tibet'. In Katia Buffetrille and Françoise Robin, eds. Tibet is Burning. Self-Immolation: Ritual or Political Protest? Revue d'Etudes Tibétaines, 25:19-39.

Schmid, Alex P. 2011. 'The Definition of Terrorism'. In Alex P. Schmid, ed. The Routledge Handbook of Terrorism Research. London/New York, NY: Routledge, pp. 39-157.

Sisk, Timothy D., ed. 2011. Between Terror and Tolerance: Religious Leaders, Conflict, and Peacemaking. Washington D.C.: Georgetown University Press.

—, 2011. 'Religious Leaders, Conflict, and Peacemaking'. In Timothy D. Sick, ed. Between Terror and Tolerance: Religious Leaders, Conflict, and Peacemaking. Washington D.C.: Georgetown University Press, pp. 1-27.

Smith, D. Anthony. 1993. National Identity. Reno, NV: University of Nevada Press. —, 1981. The Ethnic Revival in the Modern World. Cambridge/New York, NY: Cambridge University Press.

State Council Information Office of the People's Republic of China. 2015. 'China's Military Strategy'. Chinadaily.com. 26 May. http://usa.chinadaily.com.cn/ china/2015-05/26/content_20820640.htm, last accessed on 20 April 2016.

Swearer, Donald K. 1991/1994. 'Fundamentalistic Movements in Theravada Buddhism'. In Martin E. Marty and R. Scott Appleby, eds. Fundamentalisms Observed. Chicago, IL: University of Chicago Press, pp. 628-69o.

Tenzin Gyatso (bstan'dzin rgya mtsho). 2005. Chos rje dam pa 'jigs med phun tshogs 'byung gnas dpal bzang po mchog gi mjug mtha'i zhal gdams rang tshugs ma shor/gzhan sems ma dkrugs zhes pa'i 'grel ba lugs gnyis blang dor gsal ba'i sgron me (The radiant lamp that discriminates between the two systems: A comment on the undisturbed minds of others, or the sublime and excellent lord of the Dharma 'Jigs med phun tshogs 'byung gnas dpal bzang po's ultimate stable and unerring advice). Serta, Sichuan: Bla rung lnga rig slob gling.

Terrone, Antonio. 2010. Bya rog prog zhu: The Raven Crest. The Life and Teachings of bDe chen 'od gsal rdo rje, Treasure Revealer in Contemporary Tibet. PhD Dissertation. Leiden: Leiden University.

—, Forthcoming. 'Burning for a Cause: Self-immolations, Human Security, and the Violence of Nonviolence in Tibet'. Journal of Buddhist Ethics.

—, 2008. 'Tibetan Buddhism Beyond the Monastery: Revelation and Identity in rNying ma Communities of Present-day Kham'. In Monica Esposito, ed.Images 
of Tibet in the 1gth and 2oth Centuries, vol. 2. Paris: École Française d'ExtrêmeOrient, pp. 746-779.

Toft, Monica Duffy. 2003. The Geography of Ethnic Violence: Identity, Interests, and the Indivisibility of Territory. Princeton, NJ: Princeton University Press.

—, 2011. Daniel Philpott, and Timothy Samuel Shah. God's Century: Resurgent Religion and Global Politics. New York, NY: W.W. Norton \& Company.

Van der Veer, Peter. 1994. Religious Nationalism: Hindus and Muslims in India. Berkeley, CA: University of California Press.

—, 2013. 'Nationalism and Religion'. In John Breuilly, ed. The Oxford Handbook of the History of Nationalism. Oxford: Oxford University Press, pp. 655-676.

Wang, Lixiong. 2012. 'Last-words analysis - Why Tibetans Self-immolate?' Phayul. com. 27 December. www.phayul.com/news/article.aspx?id=32726, last accessed on 20 April 2016.

Weber, Max. 2004. 'Science as Vocation'; 'Politics as Vocation'. In David Owen and Tracy B. Strong, eds. translation Rodney Livingstone. Indianapolis, IN: Hackett Publishing Company Inc.

Woeser, Tsering. 2013. Immolations au Tibet: La Honte du Monde. Montpellier: Indigène éditions.

—, 2014. 'Why Do Tibetans Self-Immolate?' Radio Free Asia. 6 June. www.rfa.org/ english/, last accessed on 20 April 2016.

Wong, Edward. 2012. 'In Occupied Tibetan Monastery, a Reason for Fiery Deaths'. The New York Times. 2 June. www.nytimes.com/2012/o6/o3/world/asia/wave-oftibet-self-immolations-challenges-chinese-rule.html, last accessed on 20 April 2016.

\section{About the author}

Terrone, Antonio. Assistant Professor of Tibetan Buddhist Studies, Graduate Institute of Religious Studies, National Chengchi University, Taiwan; American Theological Library Association, Chicago, USA.

Email: terrone@lycos.com 


\title{
11 'We Are Good Citizens'
}

Tension between Protestants and the State in Contemporary China

Yen-zen Tsai

\begin{abstract}
The Chinese Communist Party (CCP) sets up rules that restrict religious group's activities. Since Xi Jinping became the president of the People's Republic of China in 2012, suppression of the Chinese Protestant churches has intensified. In this chapter, I approach this church-state tension by examining key official documents about CCP's religious policy and regulations as the context in which the tension arises. I also analyze important manifestos, petitions or theses recently produced by unregistered Protestant communities or individuals as responses to the state's oppression. I argue that both CCP and the unregistered Protestants subscribe to a notion of religious nationalism but emphasize this notion differently and that this difference is a key factor underlying their present antagonistic relationship.
\end{abstract}

Keywords: Chinese Christianity, CCP, TSPM, house church, apologetics

\section{Introduction}

Benefiting from China's Reform-and-Open policy implemented in 1978, Chinese Christians have in general enjoyed more religious freedom in the post-Mao era than before. This relative freedom, however, is fragile and precarious. The Chinese Communist Party (CCP), based upon its atheist ideology, sets up rules and regulations that restrict the religious group's activities. Violators or non-conformists are easily arrested and sentenced to imprisonment. ${ }^{1}$ Since Xi Jinping became the president of the People's Republic of China (PRC) in 2012, suppression of the Protestant churches has intensified. This is especially marked by two kinds of repressive measure: the removal of the cross from the chapel roof or demolition of the church building and the arrest of human-rights lawyers, many of whom 
are Protestants. ${ }^{2}$ During the national conference on managing religion held from 22 to 23 April 2016, Xi reaffirmed the correctness of the CCP's theory about religion and its restrictive policy, insisting upon embracing a 'socialism with Chinese characteristics'. ${ }^{3}$ Against observers who are optimistic about the irreversible progress of the opening up of religious policy in China, this sharp turn should alert us to the inveterate conflict between church and the Communist party-state. ${ }^{4}$

Interactions between Chinese Protestants and CCP are complicated, and there are ways by which we can investigate them. In this chapter, I propose to approach the tension issue by examining two groups of literature. The first one is related to key official documents that stipulate CCP's religious policy and rules and regulations. They tell the government's basic position toward religious belief and religious activities. On one level, they reveal how CCP defines religion and where its core interest lies. On another level, they make clear the standard on the basis of which the government deals with the religious groups. The second one contains manifestos, petitions or theses produced by Chinese Protestant communities or individuals as responses to the party-state's afflictions upon their faith. These apologetic writings are highly relevant and useful to our understanding of the subject because, as a 'genre of testimony', they show the 'fundamentals of religious belief' of a church community. They are salient markers that indicate this community's boundary and 'act as a membrane for the exchange of ideas'. ${ }^{5}$ By juxtaposing these two sets of writings, one should be able to detect key elements surrounding the tension, to contrast their differences and similarities, and to explain the antagonism between them.

My chapter consists of three major parts. I start with introducing CCP's religious policy and revealing its gist found in key official documents as the context in which the Chinese church-state tension arises. In the second section, I analyze some of the important Chinese apologetic writings generated in the recent decades, making clear where and why they oppose the official policy. In the last section, I discuss, on the basis of my findings, the fundamental stances of CCP and Chinese Protestants, and argue that both of them subscribe to a notion of religious nationalism. I further point out

2 BBC (2016); Economist (2014); Los Angeles Times (2014); McKenzie (2014); Melchior (2016); UCA News (2016); Van Sant (2016).

3 Xi's speech can be read at http://politics.people.com.cn/BIG5/n1/2016/0423/c1001-28299513. htm, last accessed 17 June 2016.

4 Kindopp (2004); Lambert (2009); F. Yang (2012); Wielander (2009).

5 Bernabeo (1987, pp. 349-352). 
that their emphasis upon this notion diverges and that this divergence is a key factor underlying their antagonistic relationship.

\section{CCP's religious policy}

On the national level, there are three important documents that spell out CCP's definition of religion and prescribe how a religious group should act accordingly. 'The Basic Viewpoint and Policy on the Religious Question during Our Country's Socialist Period', first presented during the Third Plenum of the Eleventh Party Congress in 1978 and publicized in 1982, and commonly named Document 19, sets the basic tone of CCP's religious policy that has exerted a great influence in the following decades. ${ }^{6}$ Brought about immediately after the Cultural Revolution, the document repudiates the leftist extremism against religion in the previous years. Instead, it asserts the importance of coping with religion pragmatically with scientific theories. Based upon Marxist materialism, it regards religious manifestations, including religious beliefs, feelings, rites, and organizations, as social and historical products. They are destined to vanish, it affirms, once human development advances into socialism and communism. Before this happens, one has to deal with religion meticulously as it possesses protracted nature, complexity, and mass nature, three characteristics that may cause contradictions among the people.

According to Document 19, CCP's basic policy 'toward religious question is that of respect for and protection of the freedom of religious belief' 7 This seemingly positive attitude, however, is circumscribed by many subordinate clauses. Document 19 confirms people's freedom to religious belief, but, at the same time, it advocates people's right to reject religion and propagate atheism and anti-superstition. Further, it thus stipulates:

Religion will not be permitted to meddle in administrative or juridical affairs of state, nor to intervene in the schools or public education. It will be absolutely forbidden to force anyone, particularly people under eighteen years of age, to become a member of a church, to become a Buddhist monk

6 MacInnis (1989, p. 7). For more detailed historical background about Document 19, see Dunch (2008, pp. 160-165). The Chinese original of this document can be obtained at www.kxwsl. com/ReadNews.asp?NewsID=755, last accessed 20 February 2016. For its English translation, MacInnis (1989, pp. 7-26).

7 MacInnis (1989, p. 14). 
or nun, or to go to temples or monasteries to study Buddhist scripture. Religion will not be permitted to recover in any way those special feudal privileges which have been abolished or to return to an exploitative and oppressive religious system. Nor will religion be permitted to make use in any way of religious pretexts to oppose the Party's leadership or the Socialist system, or to destroy national or ethnic unity. ${ }^{8}$

What the document aims at is to instruct the religious believers, both clergy and laity alike, to be patriotic, observe the law, support socialism, and uphold national and ethnic unity, the strengthening of which contributes to the establishment of the united front. To achieve this purpose, it requires that religious groups follow CCP's leadership; objection to this demand is deemed being disloyal to the party-state.

With respect to religious activities, Document 19 states that religious groups should act only at a site, either a temple, a chapel, or a mosque, licensed by the government. Activities conducted outside the designated area are in principle not allowed. All religious groups, based upon their respective religious tradition, should be associated with or incorporated into one of the eight national religious organizations that represent the five state-approved religions: ${ }^{9}$ the Chinese Buddhist Association, the Chinese Daoist Association, the Chinese Islamic Association, the Chinese Catholic Patriotic Association, the Chinese Catholic Religious Affairs Committee, the Chinese Catholic Bishops' Conference, the Chinese Protestant Three-self Patriotic Movement, and the China Christian Council. The party-state in this way consolidates different religious groups into authorized associations so that they, within the limit of constitution and law, can perform a positive function for the country.

It is significant to note that Document 19 defines religion in distinction from three areas that may cause confusion or overlapping. It first distinguishes religion from culture and custom, arguing that for the CCP members, to join the former is forbidden whereas to follow the latter as a traditional, social practice is conducive to ethnic unity. The document also differentiates between 'normal religion' (zhengchang zonjiao 正常宗教)

8 MacInnis (1989, p. 15).

9 It is true that some provincial governments might, in consideration of their respective needs or situations, admit religions not within these five to be officially acceptable. For example, Russian Orthodoxy can be practiced in Heilongjiang and folk religion is permitted in Fujian. But it should be noted that they are not authorized on the national level and that to be practically admissible does not always mean they are legally guaranteed. See SARA (20oob, p. 41); Hsun Chang (chapter 13 of this volume). 
and 'abnormal religion' (buzhengchang zonjiao 不正常宗教). By 'abnormal religion', it refers to criminal and anti-revolutionary groups and their activities in the guise of 'religion'. Included in this category are sects branching off from popular religions and sorcerers and witches who capitalize on people's ignorance for material gains. The document further stipulates that even for the five authorized religions, conducting activities on the principle of self-government, self-support, and self-propagation only is permitted. To cut foreign connections, either financial or organizational, and resist infiltration of hostile power from abroad makes clear an area where the domestic religions should stand; it simultaneously reveals how CCP defines religion out of political consideration.

The State Department of PRC issued the 'Announcement Regarding Some Questions on Further Improving Work on Religion', alternatively called Document 6, in February $1991 .^{10}$ The document was formulated in the aftermath of and as a response to the June Fourth Incident in 1989 that had generated tremendous upheavals throughout China. Social stability was at the top of the PRC government's agenda. As far as its attitude toward religion is concerned, the government set as its primary goal to persistently implement the policy of religious freedom, on the one hand, and, on the other, to more harshly control illegal religious activities. ${ }^{11}$ On the surface, Document 6 adds nothing but reiterates the main gist of Document 19. However, the tone it raises and the content it frames underline its importance in shaping the operation of the official religious administration. In view of some confusions, such as competing for leadership in the temple, mosque, and church and establishing unauthorized Buddhist and Christian seminaries to recruit students in local areas, this document calls for a clear-up in order to maintain continuity and stability of CCP's religious policy.

Document 6 lays out its announcement in the order of six subtitles, all imperative sentences: (1) comprehensively and accurately implement the policy of religious freedom; (2) manage religious affairs according to the law; (3) fully expand the function of patriotic religious organizations; (4) resolutely strike down criminal activities in the name of religion; (5) strengthen work units and establish work teams of religious affairs; (6) strengthen CCP's leadership in religious affairs. Under each subtitle, the document elaborates what to rectify and how to improve it with respect to

10 The Chinese original of this document can be obtained at http://CCP.people.com.cn/ GB/64184/64186/66704/4495639.html, last accessed 20 February 2016.

11 For an excellent exposition of the June Fourth Incident in relation to Document 6, see Ying (1999, pp. 36-44). 
chaos among religious groups. For example, regarding implementing the policy of religious freedom, it affirms a citizen's right to religious belief and demands rectification of abuses, if any. The purpose of this instruction, as explicitly stated, is to more conveniently unite the mass and enhance social stability. But when coming to the second instruction, 'manage religious affairs according to the law', it stresses the necessity of strictly supervising religious organizations and their activities and guarding against any illegal encroachments from either within or without. It is therefore obvious that the intention of Document 6, with a succinct frame of expression, is to bring religious believers or communities into alignment, a task CCP is highly concerned with in the process of social liberalization.

In line with the aforementioned religious policy and for the purpose of effectively realizing it in society, the State Administration for Religious Affairs (SARA) of PRC issued the 'Regulations on Religious Affairs' (RRA) on 1 March $2005 .{ }^{12}$ This document, in place of the simpler 'Rules of Management for Religious Sites, ${ }^{13}$ was originally intended to transcribe the instruction on religious policy by Jiang Zemin, then CCP's general secretary, into concrete guidelines for the religious groups. SARA would have to make sure that Jiang's 'three sentences', that is, 'to thoroughly implement CCP's religious policy, to tighten management of religious affairs according to the law, and to actively guide religion to adapt to socialist society', could be observed and practiced. ${ }^{14}$ Now the RRA is comprehensive in content and thematic in presentation. ${ }^{15}$ There are forty-eight articles in total, divided into seven chapters. Chapter 1 'General Provisions' translates the main ideas of Document 19 and Document 6 into five articles, emphasizing the citizens' constitutional right of religious freedom and the importance for them to abide by the law, uphold national and ethnic unity, and maintain social stability. It also makes clear that religious groups, on the basis of self-governing, should not be dominated by foreign power, and that local governments of all levels have the administrative duty to supervise them.

Chapter 2 'Religious Organization' stipulates how religious groups should register with the local governments and conduct their activities, such as publication and establishment of school, according to regulations respectively specified. Likewise, Chapter 3 'Religious Site' details where religious

\footnotetext{
12 The Chinese original of this document can be obtained at www.sara.gov.cn/zcfg/xzfg/531. htm, last accessed 22 February 2016.

13 For the Chinese original of this text, SARA (1996, pp. 46-49).

14 SARA (2000a, pp. 18-19); Dunch (2008, pp. 169-174).

15 For a discussion of this document against religious legislation in contemporary China, see Ying (2006).
} 
groups can or cannot act and how the religious buildings should receive the government's approval before construction and should be subject to regular inspection afterwards. Chapter 4 'Religious Personnel' intends to identify the clergy and prescribe the contents of their activities, whereas Chapter 5 'Religious Property' details the rules that govern the transaction of real estate of religious groups. Most restrictive of all the articles are those contained in Chapter 6 'Legal Responsibility'. They pertain to various possible conditions in which violators of rules are to be prosecuted by the court or penalized by the government's supervisory offices. They thus pose much pressure on the religious groups, causing them to weigh the result carefully when engaging in religious activities. Chapter 7 'Appendix' specifies how religious groups in the mainland should interact with their counterparts in Hong Kong, Macau, and Taiwan.

The three documents introduced above demonstrate a relationship of continuity. Document 19 lays the ideological foundation of religion for postMao CCP, Document 6 strengthens it, and RRA transcribes it into rules and regulations that can be practically referenced in society. In addition to these documents, many other materials, officially promulgated in the form of talks, collections of reading, or textbooks, also serve to inform the religious believers about what religion is and how they should behave as practitioners. ${ }^{16}$ The explicit intention on the part of CCP is to highlight its official boundary from which it can interact with its religious citizens legally and practically.

\section{Chinese apologetic writings}

Document 19 and Document 6 might be landmarks that reflected CCP's willingness to loosen up its control over religious groups in the post-Mao China. Their relative liberating effect, however, was not favorably received. Many Christians, particularly those affiliated with the unregistered 'house churches', stood up to resist the party-state's religious policy and voiced against its concomitant rules and regulations. As Christian churches, notably those of the Protestant evangelical sort, expanded very rapidly, how to respond to their needs, such as recognizing their group status, finding proper meeting sites for their congregation, and training qualified theological students as prospective ministers, has become a thorny problem that often resulted in conflicts and discontents. It was common that local 
governments treated the recalcitrant church members with physical coercion, and this ignited more protests and resentments in return. Against this background, leaders of four branches of Protestant house churches in north China together published two manifestos in November 1998, to make known their grievances: 'Confessions of China House Churches ${ }^{17}$ and 'Attitude of China House Churches toward the Government, Religious Policy, and the Three-Self Patriotic Movement (TSPM) ${ }^{\prime}{ }^{18}$ The first manifesto concisely expresses their fundamental belief, and the second one, based upon this belief, speaks out their common stance vis-à-vis the secular authority. The two literary pieces are thus intimately related and should be evaluated as two sides of one entity.

The 'Confessions of China House Churches' reveals that unregistered Protestants in north China are theologically very conservative. They believe biblical inerrancy, affirming that as it was divinely inspired, the Bible should be literally understood and is the ultimate criterion and guidance for the Christian's life. Their exposition of the Trinity and Christology basically follows the Nicaean Creed. In an appendix, they vehemently oppose the heretic' proclamation that Christ has returned in his second incarnation. To be reborn and saved, they assert, one has to repent, believe in Jesus as the Son of God who died for humanity's sins on the cross and was resurrected from the dead, and receive the promised Holy Spirit. The Confessions indicates that these unregistered Protestants tend to be Pentecostal-charismatic, as they believe that receiving the Holy Spirit is the assurance of salvation and that speaking in tongues and working miracles are testimonies to God's mighty acts.

More relevant to our interest is the ecclesiology elaborated in the Confessions. According to this literary piece, the church is composed of members called by Christ from various places, both domestic and international. It is thus the body of Christ and, as well, God's house. All Christians worldwide belong to the same body, and they should be united in truth and in Christ. To manage the church, Christians should follow the biblical principles and should not be controlled and manipulated by any secular power, although, the Confessions adds, they should obey the constitution so far as legal

17 The Chinese original of this text can be obtained at www.chinesetheology.com/ChinaReligiousPolicy/ChinaHouseChurchConfession.htm, last accessed 22 February 2016.

18 The Chinese original of this text can be obtained at http://edenho.info/wp-content/uploa ds/2015/o6/\%E4 \%B8 \%AD\%E5 \%9C\%8B\%E5 \%AE\%B6 \%E5 \%BA\%AD\%E6 \%95 \%99 \%E6 $\%{ }_{9} \mathrm{C} \% 83 \% \mathrm{E} 8 \% 81$ \%B2 \%E6 \%98 \%8E.pdf, last accessed 22 February 2016. 
aspects are concerned. In three strong sentences, the section on ecclesiology ends in a high voice:

We oppose alliance or intermingling of church and politics; we oppose dependence on domestic and international political power for the development of the church; we object to the church's involvement in activities that destroy ethnic and national unity.

That a church's proclamation of its biblical doctrine would also include elements from the current political scene is unusual, but that is exactly what the unregistered Chinese Protestants purport to convey, in view of the highly politicized environment in which they live. To profess that they are politically unambitious at least precludes their being suspected of unpatriotic and, in a positive way, makes their religious purposes more salient. The second manifesto 'Attitude of China House Churches toward the Government, Religious Policy, and the Three-Self Patriotic Movement', reinforces the Confessions and straightforwardly cast their opinions against the secular authority. This apologetic writing begins with four statements as a prelude. They serve as an important premise upon which the Chinese Protestants assume they could engage in an effective dialogue with the government institutionally and ideologically. The unregistered churches, the statements proclaim, verify that they love the people and the country as they do the Lord and the church; they also uphold national unity and ethnic consolidation. They honor the constitution of PRC, political leaders, and the government as ordained by God. In an askew tone, they assert that they never betrayed any national interests and only did things beneficial to the people. Moreover, although misunderstood and persecuted, they never fought back either in attitude or in action.

The manifesto immediately turns to raise the first rhetorical question: 'Why do we refuse to register with the government?' It then presents five reasons as the answer, contending that the government's current religious regulations contravene the biblical principles. It specifically pinpoints the so-called 'three-fixeds' (sanding 三定) policy as unbiblical: fixed site, fixed personnel, and fixed district. Countering these restrictions, it argues that to conduct activities at the designated site only clashes with the Lord's teaching to hold fellowships anywhere in his name. To the rule that ministers licensed by the Religious Affairs Bureau exclusively are permitted to deliver sermons from the pulpit, it retorts that anyone called by God and authorized or commissioned by the church is entitled to preach. And with respect to the rule that a church minister is not allowed to conduct activities beyond 
the boundary of a village or a province, it alludes to the Bible's instruction that Christians should go to the end of the world to evangelize people and to establish churches.

The second reason why the house churches turn their back on the government is because the official policy forbids them to preach to people under eighteen. According to the Bible, the manifesto contends, Jesus commands his disciples to receive the little ones. CCP's religious policy also forbids church ministers to pray for spiritual healing or practice exorcism, but this obviously denies the similar acts that Jesus performed. As to the rule that forbids the church to receive other church members from afar, it is against the biblical teaching that the church elders should not treat visitors coming from remote places with hospitality and kindness. The last reason why the house churches refuse to register is because the religious policy bans foreign connections. Against this, the manifesto answers that the church should be ecumenical; no distinction should be made among people of different ethnic backgrounds because Christ redeems all humans and calls them into one unity.

The manifesto proceeds to ask the second rhetorical question: 'Why do we refuse to join the Three-self Patriotic Movement?' To this question, it responds from five ideological and practical aspects, arguing in the oppositional mode of expression. The unregistered house churches accuse that TSPM is headed by the government and administers to the official religious policy, whereas they themselves respect Christ as their head and manage the church according to the biblical principles. This contrastive fact also applies to the different formations of clergy in the two camps. As TSPM was founded by Wu Yaozong 吳耀宗 and followed the liberal theology of social gospel, it has departed from the orthodox biblical teachings. The unregistered house churches, in contrast, build their foundation upon the Bible and inherit the fundamentalist and evangelical traditions. Henceforth the two organizations have treaded on two different paths: one, subject to the government, engages itself in political movements, whereas the other, maintaining the principle of separation between church and state, submits itself to God. In this context, TSPM sets tending the congregation inside the church as its main task, but the unregistered house churches take evangelical expansion as their great mission.

The manifesto admits that the Bible-centered orientation in theology and action may have to pay a high price, therefore it brings out into the open its attitude of being persecuted. In a nutshell, the unregistered house churches contend that it is not ethical and political problems that should cause the government's suppression of them; by all accounts their members 
are patriotic and morally upright. Rather, it is simply because they refuse to register with the local government and join TSPM that they have received such an ill treatment. Even under persecution, the manifesto continues, they would persist in their faith as well as, without any grudges, continue to make supplication to God on behalf of the country and the government.

Along this line of attitude, the manifesto ends with an appeal to the government for true understanding. It requests that the latter recognize the unregistered house churches' innocent motivation and stop imputing the name of heretics or 'evil cult' to their group. It also sincerely calls on the government to implement the policy of religious freedom, without resorting to means of physical violence such as beating, confiscation, detention, fine, or reeducation through labor. For those Christians imprisoned for the sake of preaching the gospel, they ask for earlier release. In conclusion, the manifesto claims that if Christian believers increase, they will bring about wider social stability and higher spiritual civility, and this is the blessing they can contribute to the country.

In contrast to these two manifestos produced from the unregistered house churches that disclose their general theological belief and religious attitude toward the government, a petition expressly for a church or an event deserves our attention. On 10 May 2011, seventeen Protestant church ministers or leaders, all unaffiliated with TSPM, wrote to Wu Bangguo 吳 邦國, chairman of the Standing Committee of China's National People's Congress, and asked for the citizen's true religious freedom. In a concerted effort, they spoke for Shouwang Church 守望教會, an unregistered Protestant house church in Beijing which had been barred from worship gathering.

The public letter, titled 'We Stand for Our Faith: Some Citizens' Petition to the National People's Congress with Respect to the Church-State Conflict', echoes the letter of protest under the same title (women shiweile xinyang 我 們是為了信仰) which Wang Mingdao 王明道, one of the spiritual progenitors of the house churches, wrote in 1955 against TSPM as a secularized and politicized organization. In a stout tone, the 2011 letter opens with lines affirming that the undersigned are Chinese citizens who love their country, care about the people's wellbeing, and obey the government's administrative authority to secure social order. After this confession of being patriotic, they add in tandem that they are also part of the ecumenical Christian church, revealing themselves as an integral part of world Christianity. Then they describe the Shouwang case by highlighting that the members of this church, over one thousand and coming primarily from the intellectual class, have been forced out of their meeting site. Without a permanent place for worship, they had no choice but to gather outdoors on Sundays. This kind 
of mass meeting in the public area has incurred the police's intervention, with the result of many members' detention and the church leaders' house arrest. The petition mentions that the Shouwang Church is by no means an isolated case; similar crackdowns have taken place in many cities across the country. And, as far as the church leaders can see, the cause of the tension lies in the problematic bureaucracy of religious management.

The petition refers to three sources of constitutional or human-rights documents, all of which pertain to religious freedom, to buttress their struggle: Article 36 of PRC's Constitution, Article 18 of the Universal Declaration of Human Rights, and Article 18 of the International Covenant on Civil and Political Rights. Of the last two, PRC is one of the signatories. In particular, Article 18 of the Universal Declaration of Human Rights is purposefully cited:

Everyone has the right to freedom of thought, conscience and religion; this right includes freedom to change his religion or belief, and freedom, either alone or in community with others and in public or private, to manifest this religion or belief in teaching, practice, worship and observance. ${ }^{19}$

On the basis of this conviction, Christians in most nations of the world, the petition continues to argue, enjoy religious freedom that includes the right to worship, meeting, speech, education, and evangelism.

The petition protests that Protestants in China, unless they join TSPM which is politically manipulated, have been deprived of their religious freedom; restrictions and suppressions by many of the government's supervisory departments are widely seen. To rectify the abuses, the church leaders request that a special investigation committee be formed to probe into the Shouwang case and urge Beijing City Government to settle it, review whether or not SARA's 'Regulations of Religious Affairs' is unconstitutional, and draft a 'Protection Law for PRC's Religious Freedom'.

Toward the end, the church leaders argue that religious freedom is a universal value in the world community. It is the foundation upon which other kinds of human rights, such as the political right and the property right, are built. Without it, a multiethnic country with plural religions is not able to generate a civil society or bring about social stability and national unity and prosperity. The petitioners hope that by way of forming a special committee, the government could adhere to the principle of ruling by the law and serving the people and henceforth initiate a new phase of

19 This original text can be obtained at www.un.org/en/universal-declaration-human-rights/, last accessed 23 February 2016. 
productive church-state relation. To conclude their petition, they claim that, as Christians and patriotic citizens, they will continuously pray for their compatriots and the government as well; they will ask God to bestow peace, harmony, and stability upon China that is presently rising and, at the same time, to fill Chinese society with righteousness, benevolence, and tolerance.

A group of ministers and elders of the Early Rain Reformed Church 秋雨 之福教會 in Chengdu, headed by Wang Yi 王怡, formulated a theological statement, titled 'Reiteration of Our House Church's Position' and parenthetically called Ninety-Five Theses, on 18 August, to defend their faith. ${ }^{20}$ Apparently modeling their apologetic writing on Martin Luther's namesake, they in this piece of literature expound their political theology with numerous biblical quotes but in a systematic and concise way. In the preamble, they express their wish to unite themselves with Christians who share their viewpoints and to launch dialogue with governments of all levels. They outline their theses in six thematic sections, capping each of them with a subtitle that summarizes the central meaning of that particular section.

Theses 1-17 of the Ninety-Five Theses lay out the theological presupposition that asserts God's supreme sovereignty on the one hand and, on the other, relate it to Chinese people and Chinese government. They state that as God is the creator of all, Chinese territory, history, and cultural products are necessarily part of God's creation. And since God creates human beings according to his image, every Chinese, along with other peoples, are descendants of Adam; hence equal human dignity and value between the Chinese and other races. Based upon this understanding, no one is allowed to enslave or oppress others, and unless God permits, no one is allowed to rule over others. In Chinese society, all types of authority come from God the ultimate source, and submission to the official authority is justified only with respect to this recognition. Those in power, then, are accountable to God for their political, judicial, or moral decisions. As an innate, universal faculty, human conscience serves as the seat of judgment that dictates our conducts in society. People, the rulers and the ruled alike, have to obey their conscience, which equally means that they have to obey God. Because conscience may vary according to different individuals, the Bible in this connection is the criterion that checks people's quality of conscience and, concomitantly, their deeds. Government officials who exercise their power in contradiction to the biblical principles while asking the people to obey therefore ruin human conscience and challenge God's sovereignty. And

20 The Chinese original of this text can be obtained at www.cclifefl.org/View/Article/4248, last accessed 25 February 2016. 
people who submit themselves to rules or commands that are unbiblical simply betray their conscience and live an enslaved life inimical to God.

The second section, from Thesis 18 to Thesis 31 , is an exposition of the authors' soteriology and Christology. The Theses argue that as God intervened in the Israelites' history to save them from slavery in the past, he would do the same whenever and wherever he deems necessary. Jesus the Messiah comes to save humanity who are enslaved in sins. Chinese, past and present, are also sinners, and none of them can save himself or herself. It is God's will to save all, Chinese included. This saving grace, the core of the gospel, purports the presence of the Kingdom of God to which all nations, rulers, and peoples, China and its inhabitants included, are supposed to turn.

Theses 32-39, the third section, assert that although God's bestowal of human conscience and his saving grace are universal, Chinese culture, with its emphasis on benevolence and righteousness as the ultimate virtue, does not provide the way to salvation. Instead, Chinese people have for long lived in idolatry, worshipped the emperor and his autocratic institution, and relied upon one's power for self-perfection. These wrongdoings are unmistakable components of the sins that other peoples have similarly committed and the Bible severely castigates. In this sense, anyone who advocates or seeks for sinicization of Christianity with the purpose to alter the Bible's fundamental teachings denies Jesus Christ; as such he or she is anti-Christ and will fall under God's judgment. The sinicization of Christianity includes proclaiming that Chinese culture contains the revelation of the one true God, that there are special Chinese ways to salvation unspecified in the Bible, and that the ecumenical Christian doctrines should be adapted to Chinese social and political realities. The church may have to respect Chinese culture and people in terms of practicing the truth and preaching the gospel, but it stands against distorting the gospel through culture and binding faith with political means, both under the pretext of sinicization of Christianity.

Theses 40-44, the fourth section, deal with ecclesiology. They opine that Christ redeems people across the world, including Chinese, through his blood to form a church. As this resurrected Christ has gained the power to rule over the whole world, all that exist, China and its government included, are subject to his dominion. This means that no matter how many Chinese Christians there are and whatever polity the Chinese government may adopt, Christ reigns supreme; it is not the earthly kings, political parties, cultures, and wealth that control history or the human heart. Therefore the church of Christ may be situated in any place, but it does not belong to any country; it may be regarded as a worldly organization, but it pays its loyalty only to Christ. 
On the basis of this interpretation, the fifth section, Theses 45-72, proceeds to elaborate the theology of two kingdoms. These Theses claim that the 'city of God' and 'the city of earth', one spiritual and the other worldly, are two kingdoms qualitatively different from each other. Christ's kingdom is superior to the earthly kingdom, although before the Last Judgment, Christ does not materialize his dominion by physical means. Rather, he tolerates the earthly kingdom with love and magnanimity and allows it, supported by arms, to temporarily exist. In the Chinese context, when questioned about their attitude toward the Chinese government, Christians would thus answer in three ways. First, the kingdom of God has come to China, which cannot be withstood by swords or other physical means. Since the church is the body of Christ, every persecution of it only empowers it to grow. Second, the church does not belong to any worldly government. It does not resist the present government by force nor does it resort to administrative privileges to influence society. However, when Christians are deprived of civil rights that are their due, they are entitled to defend themselves against the illegal encroachments through legal means. Third, similar to the case that the worldly government has the authority to regulate human society, the church takes it as its mission to preach the gospel and call for assembly of those who listen to God's words. If any government or organization impedes the church's evangelical work, this amounts to resisting God. And the church, in this circumstance, has the duty to reproach this sinful act either in private or in public, with the aim to bring the offender to repentance. In sum, the government is not justified to interfere with or discriminate against the church's activities, such as gathering for worship, sending missionaries to different local areas, and publishing religious works, unless the secular authority exercises its power for the sake of maintaining social order and does it on the principle of universality and equality. The relationship between church and the state is one that is mutually independent. On the part of the Christians, they regard things that belong to God above those that belong to Caesar; based upon their conscience, they would defend this faith even to the point of losing their life.

Theses 73-95, the last section, strongly express the church's position against TSPM. They point out that this organization, nominally established by and composed of Christians, is supported and controlled by the government. It is a betrayal of one's faith, the theses sharply accuse, to accept an atheist government's manipulation of the church's management. The past history of TSPM shows that this organization has actually launched an anti-Christ movement in close cooperation with the atheist regime. What it has helped to establish, a nationalist church, denies Christ's sovereignty 
that stands above all nations. TSPM, as a matter of fact, is a religious guild and a vicar of the secular political power. What is urgent today for Chinese Christians is to proclaim the true faith, reelect the clergy, and recount the church's property and membership in order to establish a truly independent church. That is, religious affairs are not China's possessions; rather, they belong to Christ and every Christian's conscience. As long as the Chinese government gives up its control of the church's beliefs, personnel, and evangelical activities, the church, in consideration of social order and public benefit, is glad to register as an independent, civil group.

In addition to the preceding manifestos, letter, and theses we analyzed, there are many more apologetic writings that deserve our consideration. For example, He Guanghu 何光滬, eminent professor of Renmin University, wrote an open letter, titled 'Stop Persecution, Redeem Conscience, Reduce Conflict, Establish Harmony', to former President Hu Jintao, Prime Minister Wen Jiabao, and other PRC leaders and spoke for the oppressed Shouwang Church and other Christians of similar fate (9 April 2011). ${ }^{21}$ Over one hundred leaders of the unregistered Chinese house churches attended the rally of the Lausanne Movement held in Seoul (25-28 June 2013). They collectively signed the Seoul Commitment in which they, as part of the ecumenical evangelical movement, promised to preach the gospel all over China. ${ }^{22} \mathrm{~A}$ church-minister couple publicized a petition for the Christians arrested in Liuzhou, Guangxi, in which they protested against the local government's power abuse and insisted upon reclaiming their civil right to religious freedom (18 February 2014). ${ }^{23}$ Mother of Zhang Kai, renowned Protestant human-rights lawyer, publicly appealed to President Xi Jinping for her detained son, asking for objective investigation of the case and abiding by the law on the part of the government (15 October 2015). ${ }^{24}$ In all, these writings, explicitly or implicitly, touch upon the religious ideology, law, policy, and regulations of the party-state on the one hand, and upon the church's responses to them on the other. In particular, they reveal how Chinese Protestants define themselves by spelling out their fundamental beliefs. Confronting the secular authority, they make clear their boundary

21 The Chinese original of this text can be obtained at www.chinaaid.net/2011/o4/blog-post_9. html, last accessed 26 February 2016.

22 The text of the Seoul Commitment can be obtained at www.lausanne.org/lang/c16o-chinesesimplified/documents-zh/seoul-commitment, last accessed 26 February 2016.

23 The Chinese original if this text can be obtained at www.chinaaid.net/2014/02/218.html, last accessed 2 March 2016.

24 The Chinese original of this text can be obtained at http://xgmyd.com/archives/22088, last accessed 2 March 2016. 
that enables us to see where their tension against the party-state lies. In the following pages, I will expound this tension and highlight ideological insistencies on both sides that make their relationship intractable.

\section{Comparative discussion and critique}

The CCP adheres to Marxist atheism and, as such, approaches religion with a presupposition that implicitly or explicitly negates its legitimacy. Article 36 of PRC's Constitution ensures that 'citizens of the People's Republic of China enjoy freedom of religious belief' and, it immediately adds, that 'No State organ, public organization or individual may compel citizens to believe in, or not to believe in, any religion; nor may they discriminate against citizens who believe in, or do not believe in, any religion.' ${ }^{25}$ This article candidly divides people into two kinds, religious believers and non-believers, and bestows upon them an equal right to repudiate each other's claim. Respect for or protection of religious freedom in the Chinese context, therefore, takes on overtones of a dialectic relationship; it protects people's right to religious freedom, but it also puts this freedom in a hazardous position that it may be readily challenged. What was originally a positive constitutional support for the religious groups thus becomes an excuse for the party-state to scheme against its realization, as it also becomes the same source for the non-believers to guarantee their anti-religious position. Document 19 and Document 6 , as we have shown, elaborate Article 36 with an eye to favoring the party-state's ideological preference on the one hand and, on the other, reducing religious believers' freedom to a minimum extent. The 48 articles of the 2005 RRA concretize CCP's interpretation of religion, further setting up restrictions of various aspects on the religious groups' activities. These steps of linkage, from the ideological or theoretical to the practical, are programmatic in design. They are constructed by a party-state who is 'a circumspect and shrewd monopolist as far as organization and ideology are concerned', although nominally they are meant to help establish a socialist harmonious society. ${ }^{26}$

The CCP's approach to religion is fundamentally different from that adopted by the unregistered Protestant house churches, and this difference catalyzed the latter's antagonistic reactions as we have witnessed in

25 The English version of PRC's Constitution can be obtained at www.npc.gov.cn/englishnpc/ Constitution/2007-11/15/content_1372964.htm, last accessed 2 March 2016.

26 Lai (2006, p. 57); Kuo (2011). 
their apologetic writings. One can detect at least three aspects in CCP's understanding of religion and implementation of religious policy, and they are closely interrelated. First, CCP is not interested in what religion means to the religious believers but, instead, in what it can achieve for its goal to accomplish national unity and social stability. This functionalist stance, in contrast to the substantivist one, as William E. Arnal's insightful classification of approaches to religion suggests, treats religion as a means to an end. ${ }^{27}$ Quite a few scholars have pointed out this feature of CCP's instrumental rationality when analyzing China's religious policy in the post-Mao era. ${ }^{28}$ Second, CCP recognizes only five institutional religions, while relegating the 'diffused religion', in which most Chinese' life is embedded, to the negligible background. ${ }^{29}$ This 'purist' cognition, on the one hand, discriminates against popular culture that may involve or mix with 'religion', treating it as non-religion or, worse, 'superstition'. On the other hand, it excludes sectarian groups that may have a long history of transmission and new religious movements that may grow into mature organizational forms. Narrowing religion down to a limited boundary is thus easier to define and more expedient to control. That CCP supports TSPM and demands all the Christian churches to register with it for official recognition is the corollary of this position. However, whether or not one can define religion without taking cultural, historical, and social contexts into consideration is subject to serious inquiry. ${ }^{30}$ Third, on the level of administrative management, CCP strategically devises the rule of 'threefixeds' and ask the Christian churches to observe it. This rule is obviously meant to restrict the expansion of the church. More than that, it is set up to bar different local churches from organizing themselves into a united whole, which may pose as a competitor to or a formidable rival against the secular regime. In this connection, CCP's advocacy of the separation of church and state is also called into question. With regard to this policy, what CCP intends is to keep religion from interfering with secular affairs so that its domain of influence would not be impinged upon. But now it presents itself as a 'state religion' which collapses the sacred and the secular or church and state and, consequently, creates more and graver conflicts with the defiant Protestant communities..$^{31}$

28 Fällman (2010); Lai (2006); Leung (2005); Storch (2011).

29 Yang (1961).

30 Asad (1993); Geertz (1973).

31 Evans (2002, pp. 770-771); Yu (2005, p. 3). 
By contrast, the unregistered Protestant house churches base their faith upon the Bible, the ultimate source of reference. As they believe that it is divinely inspired, it is totally credible and trustworthy. And because it is revealed to the whole of humanity, the central messages it conveys such as the supreme authority of God, death and resurrection of Christ, powerful movement of the holy spirit, Jesus' second coming, salvation through God's grace, love toward God and human fellows, etc., are applicable to peoples all over the world. This fundamentalist faith urges them to be Christian according to the dictate of their conscience. Against the conventional understanding that since religion belongs to the private area and so therein should one's conscience exercise itself, the unregistered Chinese Protestants extend their conscience to the public sphere where they confront the secular authority..$^{32}$ Thus their approach to religion is substantivist in nature, with an emphasis on relating one's innate true self to what one says and behaves, in private as well as in public. This reflexive and internalist feature stands in opposition to CCP's externalist religious outlook.

The unregistered Protestant house churches repeatedly express that they are good citizens. In their apologetic writings, they never forget to mention that they love the country, care about the people, espouse national and ethnic unity, and are very willing to contribute their efforts to the advancement of society. Indeed the Christian virtues they promote are compatible with the socialist morality which CCP would like to see practiced in Chinese society. ${ }^{33}$ Rarely have accusations occurred with reference to Chinese Christians' moral corruptions or offenses against public moral tastes, in contrast to their counterparts in the early centuries of the Roman Empire who were, besides being 'atheists', reportedly perpetrators of incest and cannibalism. ${ }^{34}$ Scholars who have researched different Christian communities in various places of China agreed that Christians in general place high emphasis on moral integrity and have played a significant role in helping to construct a civil society. ${ }^{35}$ However, this moral or ethical confession, coming sincerely from their conscience, seems unsatisfactory both to themselves and to the party-state. To the unregistered Protestants, if they are content with being called good citizens, their choice to stay away from TSPM would not make sense because the latter exactly takes 
this feature as its utmost concern. ${ }^{36}$ On the part of CCP, it does not want to let go of the unregistered house churches simply because they are morally good. To the party-state, morality is only auxiliary to behavioral conformity circumscribed by rules and regulations, and transgression of them easily brings one's morality into suspicion; it prefers politically good citizens to morally good citizens.

The CCP's definition of religion is intertwined with its insistence on Chinese nationalism. The unregistered Protestant house churches, although claiming that they are patriotic, find this nationalism narrow and restrictive. Many of the apologetic writings assert that as Christ is the Lord of all human races, those who are called by him are naturally fellow members of the same spiritual family. Signatories of the Seoul Commitment, for example, joined the ecumenical Protestant Christianity in defiance of CCP and TSPM and avowedly committed themselves to world evangelism. What the party-state is sensitive about foremost is, through this type of connection, infiltration by foreign power that may result in Western domination, a historical and national nightmare that it has endeavored for decades to terminate. But the unregistered Protestants see the foreign connection as a fulfillment of the biblical teaching and as part and parcel of their faith. To them, Christianity should be one and undivided; to modify it with any national or racial adjectives contradict their self-understanding.

At this point, one sees a crucial cause underlying the tension between the unregistered house churches and the party-state. The defiant Chinese Protestants intend to affiliate themselves with or incorporate their churches into the world Christianity. They henceforth oppose TSPM which, at the behest of CCP, separates Chinese Protestants from this spiritual tie in the name of self-government, self-support, and self-propagation. To them, TSPM then is secular in nature and political in practice; its nationalist but separatist vision is unacceptable. And to register with this organization and obey its leadership simply violates against the genuine Christian faith. Further, the unregistered house churches stand against the movement of sinicization of Christianity, regarding it similarly as an act of breaching the ecumenical Christian community. On the contrary, they assemble full enthusiasm to Christianize China, its people, culture, and society included. This is not a betrayal of their Chinese citizenship, according to them. Rather, it is a patriotic act because by Christianizing China, this country and its people are to be redeemed out of their present moral and political predicaments. 
If they are requested to love their country more, they would bring forth a nationalism of this sort to fulfill their religious belief.

As mentioned, CCP finds it expedient to maintain the principle of oneway 'separation of church and state' (zhengjiao fenli 政教分離) in order to keep religious groups from meddling in the secular affairs. The unregistered house churches, however, find this principle detrimental to their existence because the party-state often utilizes it as a pretext to control their development. If they subscribe to this separation principle, they would have to withdraw from many secular engagements. One is reminded that the partystate has the power to circumscribe the secular domain, just as it is up to it to define what religion is. In lieu of this principle, the unregistered church leaders in the Ninety-Five Theses counter with that of 'mutual autonomy of church and state' (zhengjiao fenli 政教分立), emphasizing two distinct domains that stand separated from but equal to each other. ${ }^{37}$ The keywords, 'autonomy', 'separation', and 'equality', are indicative; combined together, they allow us to understand more deeply the unregistered Protestant house churches' true intention as well as the goal of their struggle. It is significant to note that the two camps have come to a new confrontational stalemate. Here one sees that CCP starts with political interest and proceeds to take up the religious as its sphere of control. By contrast, the unregistered Protestant house churches, motivated by spiritual zeal, establish their religious domain and expand it to cover the secular territory. The demarcation between the sacred and the secular or church and the state becomes blurred through their mutual interactions, yet, paradoxically, it also becomes more distinct whenever conflicts occur.

Based upon the preceding exposition, it is apt to coin 'religious nationalism' as a useful interpretive term for the tension between CCP and the unregistered Protestant house churches. Scholars have argued that such key concepts as religion, modernity, and the nation have entered into the public discourse in China since the early stages of the twentieth century and still remained important points of disputation..$^{38}$ Our examination of this tension issue has shown that for CCP, religion should serve the nation. For the interest of the party-state, all religious groups, TSPM and unregistered Protestant house churches included, are supposed to follow the guidelines promulgated through successive official documents. PRC's constitution guarantees religious freedom to its citizens, but this can be

37 'Separation' (li) and 'independence' (li) are pronounced in different tonal accents in Mandarin Chinese, although when transcribed into Romanization, they appear the same.

38 Ashwa and Wank (2009); Dunch (2008). 
realized only on the condition of the latter's being submissively patriotic. Religion in this sense is subsumed under the nation, and thus 'religious nationalism' here puts its emphasis on 'nationalism'. For the unregistered Protestant house churches, the nation should not reign above religion. Their Christian religiosity consists of fundamentalist faith and ecumenical spirit, and this serves as the basis upon which they perceive the world and conduct their activities. They assure the party-state that they are patriotic, but this patriotism is a derivative of their religious faith. They would follow the government's religious policy and observe its rules and regulations so long as they do not contradict their biblical teachings and Christian conscience; to them, religion precedes the nation. 'Religious nationalism' here, then, should lay its emphasis on 'religious'. Whichever aspect both sides of the tension may stress, 'religious nationalism' cogently leads us to frame the issue. More importantly, it challenges us to rethink the thorny question of the nature of religion and the ideology that lies beneath and, as well, hover over the church-state tension.

\section{Conclusion}

Karrie J. Koesel in her recent study of the relationship between religion and authoritarian states, China and Russia in particular, observed that, based upon each side's interests, religious groups and the state have begun to develop cooperative partnerships. As she put it:

Across the authoritarian world, a dynamic process of exchange is at play such that innovative government officials and active religious leaders negotiate the rules that govern their relationship. Conflict can certainly emerge from this interaction, but there is also ample room for cooperation. ${ }^{39}$

This general trend impressed her to propose an 'interests-based theory' that, in place of the old 'domination-resistance' model, emphasizes negotiation and mutual benefiting. ${ }^{40}$ In China's case, her thesis could invite echoes from quite a few scholars. ${ }^{41}$ While the converging tendency through negotiation and mutual engagement might have taken place in many parts of China,

Kindopp (2004); Liu (2010); F. Yang (2006); Wielander (2009). 
one has to be careful about making too quick a conclusion. My examination of CCP's documents on religion and the unregistered Protestant house churches' apologetic writings is a good case that supports a more reserved appraisal. SARA's publication of the 'Draft for Revision of Regulations on Religious Affairs' on 7 September 2016, further confirmed my position..$^{42}$ This new official document, although soliciting feedbacks from the public, is intended to manage and control religious groups and their activities even down to the minute levels. That broader chaos and fiercer conflicts between the Protestant community and the party-state would occur seems foreseeable. ${ }^{43}$

It is true that local governments may negotiate with the Christians for the sake of better management or for maintaining a 'harmonious society'. But compromise on the local and bureaucratic level should not be interpreted as the government's change of religious policy and its regulations. The fundamental interest of CCP is rooted in its ideological belief and inscribed in PRC's constitution. Challenge of this core interest is often met with suppression.

The unregistered Protestant house churches which we discussed in this chapter represent a substantial portion of Christian population in present-day China. They may come from the rural areas in northern China or from the metropolitan Beijing, yet they share some common features among themselves. Most salient of all is that they all stick to the Bible as the ultimate source of inspiration, espouse an ecumenical Christianity, and harbor an aggressive evangelical spirit. This fundamentalist theology easily clashes with the party-state's ideology, as both of them appear to insist upon their respective 'interests'. Suppression of the unflinching Christians only erupts into more reactions and consolidates them into a firmer group. Historians of Christianity who study the phenomenon of persecution and martyrdom have already demonstrated ample precedents in the early history of this religion. ${ }^{44}$

The observation that Christians have enjoyed more or less religious freedom in post-Mao China is generally correct, but, as my chapter has argued, this should not be taken as something stable. The repressive measures $\mathrm{Xi}$

42 The Chinese original of this text can be obtained athttp://rufodao.qq.com/a/20160909/020526. htm, last accessed 10 January 2017.

43 Scholars and church leaders have heatedly commented on the Draft since its publication. Many of them explicitly pointed out the possible dire consequences if it would be implemented, whereas others were reserved about it. For a collection of these public opinions, visit the following website: www.chinesetheology.com/ChineseChurches.htm, last accessed 10 January 2017. 44 Frend (1984, 1987); Ehrman (1999, pp. 25-50). 
Jinping launched against the Protestant churches, registered or not, reveal what CCP would do when its real interests are challenged. On the other hand, some scholars have noted a few Chinese Protestant intellectuals who either publicly defended the persecuted fellow Christians or engaged in helping establish a civil society. ${ }^{45}$ Based upon these contributions, they thus hoped for the emergence of a 'democratic China'. ${ }^{6}$ This expectation is unrealistic because the grip Xi Jinping's government has recently laid upon Chinese society does not allow this kind of development to happen, at least, so far. Moreover, whether or not church leaders like those who composed the Ninety-Five Theses could create a democracy similar to that in the West is subject to serious doubt. For one thing, their exclusivist Protestant stance conflicts with the phenomenon of religious pluralism that has existed in Chinese society for thousands of years, and the staunch attempt to Christianize China easily turns 'a harmonious socialist society' into rifts and disunity. At present and at most, what one can conclude is that the relationship between Protestants and the party-state in contemporary China is maintained along the line of 'an uneasy equilibrium'. ${ }^{47}$

\section{Bibliography}

Arnal, William E. 2000. 'Definition'. In Guide to the Study of Religion, Willi Braun and Russell T. McCutcheon, eds. London/New York, NY: Cassell, pp. 21-34.

Asad, Talal. 1993. Genealogies of Religion:Discipline and Reasons of Power in Christianity and Islam. Baltimore, MD/London: The Johns Hopkins University Press. Ashwa, Yoshiko and David L. Wank, eds. 2009. Making Religion, Making the State: The Politics of Religion in Modern China. Stanford, CA: Stanford University Press.

Bays, Daniel H. 2003. 'Chinese Protestant Christianity Today'. China Quarterly, 174(2): 488-504.

Bernabeo, Paul. 1987. 'Apologetics'. In The Encyclopedia of Religion, vol. 1, Mircea Eliade, ed. New York, NY: Macmillan, pp.345-359.

BBC. 2016. 'US Condemns Zhang Kai “Confession” on Chinese TV'. 27 February. www.bbc.com/news/world-asia-china-35676223

Cao, Nanlai. 2011. Constructing China's Jerusalem: Christians, Power, and Place in Contemporary Wenzhou. Stanford, CA: Stanford University Press. 
Duara, Prsenjit. 2008. 'Religion and Citizenship in China and the Diaspora'. In Chinese Religiosities: Afflictions and Modernity and State Formation, Mayfair Mei-hui Yang, ed. Berkeley, CA: University of California Press, pp. 43-64.

De Ste. Croix, G.E.M. 2006. Christian Persecution, Martyrdom, and Orthodoxy. New York, NY/Oxford: Oxford University Press.

Dunch, Ryan F. 2001. 'Protestant Christianity in China Today: Fragile, Fragmented, Flourishing'. In China and Christianity: Burdened Past, Hopeful Future, Stephen Jr. Uhalley and Xiaoxin Wu, eds. Armonk, NY: ME Sharp, pp. 195-216.

—. 2008. 'Christianity and "Adaptation to Socialism"'. In Chinese Religiosities: Afflictions and Modernity and State Formation, Mayfair Mei-hui Yang, ed. Berkeley, CA: University of California Press, pp.155-178.

China Road. 2014. 'Cracks in the Atheist Edifice'. Economist. 1 November.

Ehrman, Bart D. 1999. After the New Testament: A Reader in Early Christianity. New York, NY/Oxford: Oxford University Press.

Evans, Carolyn. 2002. 'Chinese Law and the International Protection of Religious Freedom'. Journal of Church and State, 44: 749-774.

Fällman, Fredrik. 2010. 'Useful Opium? "Adapted Religion" and "Harmony" in Contemporary China'.Journal of Contemporary China, 19(67): 949-969.

—. 2013. 'Calvin, Culture and Christ? Developments of Faith among Chinese Intellectuals'. In Christianity in Contemporary China, Francis Khek Gee Lim, ed. London/New York, NY: Routledge, pp. 153-168.

Frend, W.H.C. 1984. The Rise of Christianity. Philadelphia: Fortress Press.

- 1987. 'Persecution: Christian Experience'. In The Encyclopedia of Religion, vol. 11, Mircea Eliade, ed. New York, NY: Macmillan, pp. 251-256.

Geertz, Clifford. 1973. The Interpretation of Cultures. New York, NY: Basic Books. Kindopp, Jason. 2004. 'Fragmented yet Defiant: Protestant Resilience under Chinese Communist Party'. In God and Caesar in China: Implications of ChurchState Tensions, Jason Kindopp and Carol Lee Hamrin, eds. Washington, D.C.: Brookings Institute Press, pp. 122-145.

Kuo, Cheng-tian. 2011. 'Chinese Religious Reform: The Christian Patriotic Education Campaign'. Asian Survey, 51(6): 1042-1064.

Lai, H.H. 2006. 'Religious Policies in Post-Totalitarian China: Maintaining Political Monopoly over a Reviving Society'. Journal of Chinese Political Science, 11(1): 55-77.

Lambert, Tony. 2009. 'Church and the State in China: A Sixty-year Saga'. Connections, 8(3) (Feature Articles; n.p.).

Leung, Beatrice. 2005. 'China's Religious Freedom Policy: the Art of Managing Religious Activity'. The China Quarterly, 184: 894-913. 
Liu, Yi. 2010. 'From Christian Aliens to Chinese Citizens: The National Identity of Chinese Christians in the Twentieth Century'. Studies in World Christianity, 16(2): 145-163.

Los Angeles Times. 2014. 'China Demolition of Church in Wenzhou Leaves Christians Uneasy'. 5 May.

MacInnis, Donald E. 1989. Religion in China Today: Policy and Practice. Maryknoll, NY: Orbis.

McKenzie, William. 2014. 'China's Latest Crackdown Target: Religion'. CNN. 2 June. Melchior, Jillian Kay. 2016. 'China's New Crackdown on Christians: Xi Jinping Attacks the "Patriotic" Church that Has Long Co-existed with the Government'. Wall Street Journal, 4 February.

SARA. 1996. Zongjiao Huodong Changsuo Niandu Jiancha Gongzuo Shouce宗教活 動場所年度檢查工作手冊 (Manual for Annual Inspection of Religious Sties). Beijing: Religious Culture Press.

SARA. 2000a. Zhongguo Zongjiao Fagui Zhengce Duben 中國宗教法規政策讀本 (Readings on Chinese Religious Rules and Policy). Beijing: Religious Culture Press. SARA. 200ob. Quanguo Zongjiao Xingzheng Fagui Guizhang Huibian 全國宗教行 政法規規章匯編 (Collection of Administration Rules and Articles for Chinese Religion). Beijing: Religious Culture Press.

SARA. 2005. Aiguo zhuyijiaocheng 愛國主義教程(Textbook of Patriotism). Beijing: Religious Culture Press.

Storch, Tanya. 2011. 'Is Communism to Be Blamed for China's Religious Policy?' World History Connected, 8(1): 1. http://worldhistoryconnected.press.illinois. edu/8.1/storch.html, last accessed 19 December 2012.

Tong, Joy Kooi-chin. 2013. 'Christian Ethics and Business Life: an Ethnographic Account of Overseas Chinese Christian Entrepreneurs in China's Economic Transition'. In Christianity in Contemporary China, Francis Khek Gee Lim, ed. London/New York, NY: Routledge, pp. 169-182.

UCA News. 2016. 'China Parades Christian Lawyer in TV Confession: Critics Brand Zhang Kai Video, Accuse Beijing of "Flipping Truth on Its Head”'. 26 February.

Van Sant, Shannon. 2016. 'Spate of Arrests in China's Zhejiang Province'. Voice of America, 11 February.

Wielander, Gerda. 2009. 'Bridging the Gap? An Investigation of Beijing Intellectual House Church Activities and Their Publications for China's Democratization'. Journal of Contemporary China, 18(62): 849-864.

Yang, C.K. 1961. Religion in Chinese Society. Berkeley, CA/Los Angeles, CA: University of California Press.

Ying, Fuk-Tsang. 1999. Dangdai zhongguo zhengjiao guanxi 當代中國政教關係 (Church and State Relationship in Contemporary China). Hong Kong: Alliance Bible Seminary. 
-. 2006. 'New Wine in Old Wineskins: An Appraisal of Religious Legislation in China and the Regulations on Religious Affairs of 2005'. Religion, State \& Society, 34(4): 347-373.

Yu, Anthony C. 2005. State and Religion in China: Historical and Textual Perspectives. Chicago, IL/La Salle, IL: Open Court.

Yang, Fenggang. 2006. 'The Red, Black, and Gray Markets of Religion in China'. Sociological Quarterly, 47: 93-122.

-.2012. 'Religious Revival and Religious Deficit in China Today'. Chinese Law and Religion Monitor 8(1): 8-25.

Zhang, Shengzuo. ed. 1995.Zongjiao Zhengce Xuexi Gangyao 宗教政策學習綱要 (Study Guideline of Religious Policy). Beijing: Religious Culture Press.

\section{About the author}

Tsai, Yen-zen. Professor of Comparative Religions, Graduate Institute of Religious Studies, National Chengchi University, Taiwan.

Email:yztsai@nccu.edu.tw 



\section{Part III}

Religion and Nationalism in Taiwan and

Hong Kong 



\title{
12 Religion and National Identity in Taiwan
}

\author{
State Formation and Moral Sensibilities \\ Edmund Frettingham and Yih-Jye Hwang
}

\begin{abstract}
We propose in this chapter that the relationship between religion and nationalism in Taiwan has been mediated by two developments that pull in different directions. The first is state formation, which has erected barriers between religion and national identity. The second is a search for culturally authentic expressions of modernity, which has shaped both religion and nationalism in Taiwan, infusing them with a shared sensibility. The emergence of religious movements sharing important affinities with nationalism has reinforced the cultural sources of nationalist politics, but also motivated more direct forms of engagement with this politics. This is because the forms of religion that display this modernist sensibility tend to be this-worldly in their focus, and politically engaged.
\end{abstract}

Keywords: Religion, nationalism, Taiwan, Buddhism, Christianity

\section{Introduction}

Issues of identity and nationhood have combined as a pervasive organizing theme in democratic politics in Taiwan since the end of authoritarian rule. Political divisions have revolved around the question of whether the people of Taiwan, linked by co-residence or shared sociocultural characteristics, constitute a nation distinct from the Chinese nation. The rise of identity politics in Taiwan has also coincided with a newly vigorous religious scene, the main beneficiaries of which have been the reformed Buddhist sects, Daoism, Christianity, and popular religion. This chapter aims to explore the relationship between religion and processes of national identity formation in Taiwan.

Any account of how religion has intersected with nationalism in Taiwan must begin with an account of the sources of nationalist sentiment on the island and the location of political struggle over national identity. Some 
have suggested that nationalism has arisen within civil society in the post-democratization era to fill a relative void created by the weakness of the Taiwanese state: its retreat from society domestically, its ambivalent political situation in relation to the mainland, and its lack of recognition internationally. The state, in this view, has been incapable or unwilling to sustain a national project, and the retreat of the state has created space for new forms of identity politics or the emergence of Taiwanese nationalism. Religion, as a body of cultural practices that preexisted the development of the state, has once again adapted to become an important site for the construction of identity, with Taiwan's unique political situation and lack of full statehood giving it an importance that it otherwise would not have had. ${ }^{1}$ On this account, Taiwanese nationalism is formed in the social space occupied by religious groups and other non-state actors, suggesting that religious movements are in a powerful position to foster an 'ecumenical nationalism' (as Richard Madsen predicts) or cut across any attempt to foster a monolithic Taiwanese identity (as Robert Weller expects). ${ }^{2}$

In this chapter, we propose that the relationship between religion and nationalism in Taiwan is considerably more complex than the above account suggests because it is not only mediated by the loosely regulated processes of social negotiation in civil society, but also by the more restricted and tightly regulated processes associated with government and state formation. Whereas Madsen and Weller both suggest that nationalism in Taiwan is a post-democratization, civil society phenomenon arising recently in opposition to the faltering KMT-led project of state formation in Taiwan, ${ }^{3}$ we argue that the common 'high culture' promoted as an important tool in this state formation project was crucial to the later emergence of a Taiwanese national identity. Furthermore, the importance of the state as the protector and promoter of a shared national culture in modern societies suggests that the state and its institutions will remain an important battleground in the struggle to define the content of national identity on the island. Thus even if the retreat of the state and the development of civil society have undoubtedly created new opportunities for the social negotiation of national identity, it is also important to understand the relationship between religion-led and state-led processes of nation-building.

$1 \quad$ Weller (1987; 2000a; 200ob); Madsen (2007).

2 Madsen (2007, p. 137); Weller (2000, p. 231).

3 Madsen points to the KMTs opposition to Taiwanese nationalism, and its view of Taiwan as little more than a launchpad for the recovery of political control in China (2007, p.11). Weller similarly suggests that '[i]n a world organized by nation-states, Taiwan falls between all the boundaries' (2000, p. 479). 
We argue that these statist nation-building processes have, as a functional by-product, tended to separate religion from the sphere of politics and the state, and by extension inhibit religious involvement in the politics of national identity. At the same time, however, this differentiation of the religious and the political is never complete. The boundary between the sacred and the secular is frequently transgressed and redrawn by both political and religious actors on the surface level of public politics. Beyond this surface level, though, there is also a deeper discursive level at which the evolution of religion in Taiwan has been shaped by a distinctively modern moral sensibility, a concern with culturally authentic modernization, that has also been crucial in animating the politics of nationhood in Taiwan. This moral sensibility provides a mutually energizing point of contact between religion and nationalism on the island, but it also motivates a closer religious engagement with the politics of national identity.

The argument proceeds in four stages. In the following section, we provide an account of national identity formation in Taiwan as driven by both state formation processes and a moral concern with culturally authentic modernization. In the next section, we argue that the former process tended to separate religion from processes of national formation through differentiating the religious and political spheres, whereas the latter phenomena cut across these boundaries, creating affinities of moral sensibility and motivating greater religious engagement with the politics of nationhood. In the final sections, we illustrate our argument with a comparative discussion of the Foguangshan Buddhist Order (佛光山, FGS), and the Presbyterian Church in Taiwan (PCT), both of which have been actively concerned with the identity and political status of Taiwan.

\section{The development of national identity politics in Taiwan}

Ernest Gellner argued that nationalism can be viewed as a functional requirement of industrializing economies in modernity. ${ }^{4} \mathrm{~A}$ nation is not given in nature, or an intrinsic component of the human condition; but neither is it a historical accident or the contingent ideological invention of European thinkers. It is instead rooted in the structural requirements of a very particular kind of society. Specifically, it is an effect of efforts to create the educated workforce sharing a common means of communication that is vital for an industrial society. Economic growth in such a society is 
dependent on a mobile population whose members are able to communicate easily with one another, and this in turn demands a single culture and common medium of communication. Only with a homogenous culture can people in a particular society do business with one another across boundaries of family, ethnic group, region, and so on. The development of such common cultures over large geographical areas depended on the emergence of large and well-centralized states. The need for uniformity, and the magnitude of project, mean that the task of inculcating this shared culture can no longer be left to institutions such as the family and religious groups that had passed on high, literate cultures in premodern times. In modernity, the state therefore developed as provider and protector of the shared culture. The primary means through which ever-larger sections of the population are inculcated into the common high culture is the creation of mass public education systems, and to a lesser extent the promotion of a common language.

The universalization of the high culture within the state, transmitted by a national schooling system rather than through local and regional folk traditions, erodes the distinctive cultures of subnational communities. This makes the state increasingly dependent on the inculcation of a strong and homogenous shared culture to provide social cohesion and moral policing that had previously been supplied by more local forms of community. As a shared national culture begins to pervade the entire population and subgroupings are eroded, it also becomes natural to identify the shared national culture as the primary locus of political legitimacy. It is therefore in this social context that we see the formation of nationalism, understood by Gellner as the belief that the political boundaries of the state and the cultural boundaries of the nation should align. Gellner writes that

When general social conditions make for standardized, homogeneous, centrally sustained high cultures, pervading entire populations and not just elite minorities, a situation arises in which well-defined educationally sanctioned and unified cultures constitute very nearly the only kind of unit with which men willingly and often ardently identify. The cultures now seem to be the natural repositories of political legitimacy. Only then does it come to appear that any defiance of their boundaries by political units constitutes a scandal. ${ }^{5}$ (emphasis in original) 
One implication of Gellner's argument here is that 'nationalism is not the awakening of nations to self-consciousness; it invents nations where they do not exist. ${ }^{6}$ In other words, it is not nations that engender nationalism; rather, it is nationalism that invents nations. ${ }^{7}$ It is in the context of efforts to make political boundaries align with the boundaries of a linguistic or cultural unit that particular nations are invented as ethno-linguistic unities with a shared history and a set of folk traditions. The nation, as a coherent cultural unity, does not preexist nationalist projects to win political autonomy and the right of self-determination for a people. While nationalisms claim the warrant of the preexisting folk cultures they claim to be defending and revitalizing, they use these cultures selectively, transform them radically, and often invent entirely new traditions. They may be assembled from elements of dormant, oppressed or threatened low cultures, but rather than reviving these cultures they replace them with a high culture adapted for impersonal, industrial-bureaucratic societies, even if it claims continuity with local folk traditions. National identities are often given content by a process of arbitrary selection and invention, but the nationalism that drives this process is rooted in deep structural requirements of modern societies.

Gellner's account has been criticized for tying nationalism to state formation and industrialization. This means it has trouble accounting for nationalisms that developed before industrialization, and those that lack the aspirations to statehood that Gellner takes as definitive of the phenomenon. ${ }^{8}$ Neither of these criticisms apply in the case of Taiwan, however. Here Gellner's account provides a useful interpretive framework that points to two important aspects of the development of nationalism in Taiwan.

Firstly, Gellner's understanding of nationalisms as modern 'high cultures' that appropriate and selectively reconstruct elements of the folk cultures they putatively defend directs our attention to the ways in projects of national identity in Taiwan have never been the political expression of preexisting national units. Rather, they represent attempts to distill centralized, homogenous, and universal island-wide cultures from the extremely complex patchwork of locally sustained ethnic, regional, linguistic, and

6 Gellner (1964, p. 168). Gellner affirms this in his later work: 'It is nationalism which engenders nations, not the other way round' (1983, p. 55).

7 Gellner (1983, pp. 55-62).

8 Anthony D. Smith points to Serbia, Finland, Ireland, Mexico, Japan, and West African states as examples of preindustrial nationalism (1998, p. 36); Charles Taylor argues that early expressions of nationalism in Quebec promoted non-state institutions rather than seeking a statist outlet (2011, p. 85). 
religious cultures that have shaped Taiwan's history. In this first respect, then, Gellner's work draws our attention to the arbitrary content of nationalidentity projects in Taiwan, and their contingent and often distant relation to their source material.

In another respect, however, Gellner's theory suggests that the development of nationalism in Taiwan is intimately connected to state-building, and has deeper roots than a focus on recent articulations of Taiwanese national identity alone would suggest. Specifically, it highlights the significance of intensive efforts by the KMT government to inculcate a shared national culture through centralized education, language, and cultural policies after it retreated to Taiwan in 1949. While the emergence of a distinctively Taiwanese national identity is a much more recent development, taking Gellner's account seriously suggests that earlier KMT-led processes of state and national culture formation around a certain conception of Chinese-ness were crucial preconditions of the later emergence of Taiwanese national consciousness. The content of specific accounts of what it means to be Chinese and Taiwanese may be arbitrary and highly selective, but the movement towards nationalism-in-general is deeply rooted in functional requirements that follow from state-building and industrialization.

This combination of contingency and structure can be seen in the process through which a complex range of ethnicities and identities, and have increasingly been reduced to a simple set of alternatives: Taiwanese and Chinese, understood as mutually exclusive. When people in Taiwan now refer to the Taiwanese, they exclude people in mainland China from this identity. It was not always so; at times Taiwanese and Chinese have been compatible or even complementary categories. Both terms have historically meant different things to different people, connoting a variety of elements such as ethnic origin, language, culture, residency, citizenship, identification, and so on. The specific meanings of Taiwanese-ness and its significance vary, vertically across time, and horizontally across individuals and ethnic groups. The present constellation of meanings, in which Taiwanese refers to a national rather than an ethnic or provincial identity, has emerged since the 199 os and been enforced under Ma Yingjiu administration's forceful push to link up with China despite societal resistance to it, which represents both an expansion and a simplification of the category relative to earlier usage.

The difficulty of the identity question in Taiwan is partly a legacy of the island's complex history of occupation and settlement. The earliest Han settlers from China in the fourteenth century encountered an island already occupied by aborigines. After brief periods of Spanish and Dutch rule in the seventeenth century, the island fell under the control of the 
Qing Dynasty, under which large numbers of Han Chinese from the coastal provinces migrated to the island. Taiwan became a colony of Japan after the Sino-Japanese War of 1894 , until it once again became a province of China in 1945 following Japan's defeat in the World War II. Four years later, the KMT relocated the capital of the Republic of China to Taipei when the Chinese Communist Party (CCP) gained ascendancy in mainland China.

The complexity of Taiwan's history is reflected in its ethnic makeup. It has frequently been said since the 199os that Taiwan has four ethnic groups: the Hokkien, Hakka, Aboriginal people, and Mainlanders. None of these four ethnic groups formed naturally, however; they are all socially constructed. ${ }^{9}$ The aboriginal people are Taiwan's first inhabitants. Although they are discussed as a single group of people, the Aboriginals are in fact composed of at least nine tribes. Each tribe has its own language, custom, and kinship, and there was no common language among the aboriginals. ${ }^{10}$ The Aboriginals compose only 1.7 percent of the population of Taiwan. The Hokkien people (福建人), who constitute more than 73 percent of the population, are people whose ancestors were from southern Fujian and immigrated to Taiwan from the seventeenth century until the inception of Japanese colonization. The Hokkien ethnic group is not a perennial and homogeneous ethnicity either. Although they all came from southern Fujian, their language, customs, and culture diverged greatly among them since the region is mountainous. ${ }^{11}$ The Hakka people (客家人), making up 12 percent of the population, is a distinct ethnic group in China who has their own cultural identity, language, and customs. The Hakka immigrants in Taiwan came from different parts of China, mainly southern Fujian and northern Guangdong. 'The Mainlanders' is the label used by the native Taiwanese to describe ethnic Chinese who settled in Taiwan with Jiang Jieshi's KMT regime after 1945, and their descendants. However, there was no shared identity among those who immigrated at that time, as they came from different parts of China. Not until the early 199os did the Mainlanders form a collective identity and become a 'singular' and 'unitary' ethnic group. This group of people now makes up around 13 percent of the population.

Due to the complexity of its history and ethnicity, the connotations of the term 'Taiwanese' (taiwanren 臺灣人) differs across different historical periods. What it meant to be a Taiwanese in the nineteenth century is

9 Wang (2003).

10 Tribes, for example, used the Japanese language to communicate with one another under Japanese rule.

11 Wang (2003, pp. 25-42). 
different from what it meant in the twentieth century, and in the 1970s it was different from the 1990s. For instance, during the Japanese colonial period, the term 'taiwanjin' (臺灣人, lit., 'Taiwanese' in the Japanese language) was synonymous with the Japanese term 'hontojin' (本島人, lit., the islander) in Taiwan, in contrast to another Japanese term 'naichijin' (内地人, lit., people from Japan proper). While the term 'hontojin' referred to Aboriginals, Hokkien and Hakkas, 'naichijin' indicated the Japanese residents in Taiwan. At this time, there was no opposition between the categories of Chinese and Taiwanese. In his account of the political movement for a Taiwanese parliament during the Japanese occupation, the historian Wang Xiaopo (王 曉波) argues that the elites leading the campaign shared a consciousness of a common Han-Chinese identity that looked to the mainland, rather than any emergent sense of Taiwanese-ness. ${ }^{12}$

When it retreated to Taiwan in 1949, the KMT sought to integrate Taiwan into the modernizing Chinese nationalist project it had been pursuing on the mainland. This was initially a top-down, state-led project that focused on the creation of a nation through the generalization of standard Mandarin as the language of everyday and official communication, and the promotion of Confucian traditions of mainland elites as a shared culture of national unification, consistent with the KMT's position that Taiwan was an integral part of China. The term 'Taiwanese' became a regional or provincial affiliation. It was by then interchangeable with another Chinese term benshengren 本省人 (lit., people from within Taiwan Province), which referred to those Han-Chinese whose ancestors came to Taiwan before the colonization by Japan: Hokkien and Hakkas. ${ }^{13}$ The term was used in contrast to another term waishenren 外省人 (lit., people from outside the province), which refers to the Mainlanders. ${ }^{14}$

This nation-building process reached its high-water mark with the Cultural Renaissance movement that began in the mid-196os, a systematic program of moral and cultural education that aimed to develop a spiritual consciousness of Chinese-ness that could serve as the basis of national solidarity, and inculcate traditional values through socialization in schools, study groups, and neighborhood associations. ${ }^{15}$ Chinese culture was elevated over indigenous cultural forms, which were represented as crude

12 Wang (1988/1999).

13 Brown (2004, pp. 9-10).

14 The non-Han Aboriginals simply disappeared in this schema, as if they did not exist on the island. They were neither 'Taiwanese' nor 'non-Taiwanese'.

15 Chun (1994). 
and backward, and the use of languages other than Mandarin was banned in schools and public places.

The version of 'traditional Chinese culture' promoted by the KMT was, in Gellner's terms, a 'high-culture' invention of Chinese tradition as a conservative response to the threat of communism on the mainland, and a cultural ethos more compatible with the developing state than locally sustained folk cultures. As Chun argues, 'the crisis of culture in postwar Taiwan was one which was predicated by the government's attempt to nationalize Chinese culture... where no such culture (of the nation) previously existed. In concrete terms, it was driven by the perceived need to establish new foundations of spiritual consciousness, ideological rationality and moral behavior that could conform to the dictates of the modem polity or nationstate in ways that primordial notions of Chineseness could not'. ${ }^{16}$

When the term 'Taiwanese' changed its meaning again in the 199os, it reflected the new context created by the KMT's efforts to foster a shared high culture. It was now often used in Taiwan to speak of the ethnic majority, the Hokkien people, ${ }^{17}$ though this conception of the term was later, particularly after 2000, challenged by some Taiwanese politicians and scholars who have contended that 'Taiwanese' should incorporate 'the Four Ethnic Groups': the Aboriginals, Hokkien, Hakka, and Mainlander. For instance, Taiwan's former president Li Denghui promoted a new conception of being 'Taiwanese' - the so-called 'New-Era Taiwanese' (Xinshidai Taiwanren 新時代台灣 人). ${ }^{18} \mathrm{He}$ called for the residents of the island to look upon Taiwan as their shared home, unifying together, and establishing a shared future. Anyone who identifies with his appeal can then become a Taiwanese - a 'New-Era Taiwanese'. One could tentatively argue that this ostensibly all-inclusive discourse of 'Taiwanese' in effect signifies a formation of Taiwanese national identity; that is, the belief in the 'homogeneity' of the people residing in Taiwan and the pursuit of self-determination by all residents in Taiwan. ${ }^{19}$

By this time, ambiguity, interchangeability, and inclusiveness of these two concepts - 'Taiwanese' and 'Chinese' - had disappeared, and the people of Taiwan were accordingly compelled to 'become' either Taiwanese or Chinese; any other political possibilities in the middle ground or a gray area were ruled out. China was invoked as the 'Other', against whose image

16 Chun (1994, p. 54).

17 Brown (2004, p. 9).

18 ref. idem? (2005).

19 While this political rhetoric ostensibly includes all residents of Taiwan, it is not exactly all-inclusive. Some groups of people residing on the island are still excluded, e.g. foreign spouses. 
the Taiwanese 'Self' has been redefined and reconstructed. It is plausible to argue that there is no 'homogeneous' Taiwan due to the complexity of Taiwan's history and ethnicity as mentioned above, but that if such a 'homogeneous' Taiwan does exist, its precondition is that there is an existent China to encounter. No matter how people in Taiwan interpreted their own history, tradition and culture, the most important and fundamental task was now that of demonstrating how 'Taiwanese-ness' is different from 'Chinese-ness'. The presence/absence and specter of 'China' is a crucial aspect of the homogenization of Taiwanese national identity. China in fact is economically the greatest (potential) market for Taiwan; it is historically the source of its ethnicity, culture, and languages; it is politically a contestant or enemy; and it's one of Taiwan's deepest and most recurring images of 'the Other'. China, as Taiwan's contrasting image, has helped the Taiwanese to define what Taiwan is itself. In this sense, 'China' is not simply a physical site but a discursive space in which different forms of homogeneity, solidarity, affinity, and identity are constructed and contested. Indeed, when the Taiwanese people think of themselves as a people, they nowadays do so in contradistinction to the Chinese people; China is their main object of alienation/disassociation. The polarization of identities in Taiwan has been exacerbated by the rise of the politics of identity since the 1970s, and has become especially intense since democratization. Nevertheless, language, culture, and identity have been a consistent theme in Taiwanese politics at least since the KMT retreated to Taiwan in 1949. The emergence of a national Taiwanese identity defined in opposition to Chinese identity was made possible by the KMT's earlier state-building project, and specifically, by its attempt to stimulate national solidarity and loyal patriotism through the creation of an island-wide national culture in Taiwan.

The sinicization policies were relaxed in the 1980 s, with growing recognition and promotion of indigenous culture within a policy that was still oriented towards China overall. ${ }^{20}$ The reorientation towards Taiwan and indigenous culture gathered pace with the end of martial law and the beginning of democratization. A series of changes exemplified the new movement towards a national consciousness centered on Taiwan: most notably, the more inclusive rhetoric of the KMT under Li Denghui, and a liberalization of the education system introduced in 1968 at the height of the Cultural Renaissance, involving a revision of textbooks to increase representation of indigenous heritage. The KMT's effort to reorient national culture towards Taiwan, without giving up the cultural connection with China, was then 
challenged by the more radical discourse promoted by its main rival the Democratic Progressive Party (DPP), in which the distinctiveness of Taiwan in relation to China has been emphasized much more strongly.

The outcome has been the emergence of a de-sinicization/anti-China movement in Taiwan that seeks to define Taiwanese national identity and culture as opposed to Chinese, and opposes any move perceived as threatening the fragile autonomy of the emergent national community. This anti-China sentiment was further fortified under the President Ma Yingjiu administration from 2008 to 2016 , a period which saw the warming of cross-Strait relations and close political ties and economic integration between PRC and Taiwan. There were a number of social movements during Ma's presidency, wherein the participants - many of them overlapping explicitly protested against Ma's policy and disagreed with Taiwan's closer relationship with China. Those events include: (1) the Wild Strawberries Movement of 2008, which protested the visit of Chen Yunlin 陳雲林, the chairman of the Association for Relations Across the Taiwan Straits (ARATS) to Taiwan; (2) the protests against the Economic Cooperation Framework Agreement (ECFA) in 2010; (3) demonstrations launched by the 'Alliance Against Media Monsters' in 2012 to oppose the Next Media buyout, in which the Hong Kongnese owner of Next Media sold the Taiwan Division of the company to Wangwang China Times and its pro-China Taiwanese entrepreneur; (4) the Sunflower Movement (Taiyanghua Yundong 太陽花 運動), as well as (5) Anti-Black Box Curriculum Movement which sought to implement controversial changes to textbook education. ${ }^{21}$

The 'Sunflower Movement' is particularly significant as a group of Taiwanese students in March 2014 occupied Taiwan's parliament to protest legislation of a cross-strait trade pact - or Trade in Services Agreement (TiSA) - that would open Taiwan to further mainland investment. Ostensibly, Ma Yingjiu was criticized for failing to inform the public about the trade pact, and the issues of democratic governance, accountability, and public trust were at the forefront of the movement. More profoundly, the protests point to a deeper crisis as Ma sought to further integrate Taiwan's economy with China's. After Ma took office in 2008, he brought Taiwan closer to the mainland, signing 21 cross-strait trade agreements in the first six years of his presidency. His eventual goal was for Taiwan to participate in regional economic integration, increasing economic opportunities and cooperation with Taiwan's primary trading partners through participation in the Trans-Pacific Partnership (TPP), and the Regional Comprehensive 
Economic Partnership (RCEP). Nevertheless, Ma faced an angry backlash from voters over the improvement of the cross-Strait relationship. The Sunflower Movement demonstrated that there is a widespread fear of China among Taiwanese people, particularly the younger generation. The essence of this movement is not just about a trade agreement; it is rather about the risks of opening Taiwan to further economic and political dependence on China. Most Taiwanese who oppose the trade agreement do so mainly because they fear that such an agreement will further increase the mainland's political influence in Taiwan, thus gradually killing the independence movement in Taiwan. ${ }^{22}$

Likewise, more recently, the controversies surrounding curriculum guideline changes in 2015 channeled all of the themes that have been central to political disputes over identity in Taiwan. Taiwan's Ministry of Education under Ma's administration tried to do what it described as 'fine-tuning' textbooks used in the twelve-year compulsory education. Yet, this move stimulated a new wave of protests against Ma's government. Opposition groups have alleged that the High School Citizens and Society text redacted sections about the White Terror and illustrations of the $2 / 28$ Incident, and added content relating to Chinese tradition and culture. Some extremist protest groups such as the 'Taiwan-Centric Textbook Alliance' have even demanded the 'rejection of a Chinese colonial curriculum', and the 'creation of a Taiwan-centric curriculum'.

In its state-led and top-down nature (initially at least), the centrality of language and education as key battlegrounds, and the selective, almost arbitrary reductions of complex cultural histories into island-wide common identities, Taiwan has followed the path described by Gellner. What Gellner's theory cannot account for in the case of Taiwan is why the KMT's efforts to promote a high culture based on a version of Chinese traditional culture have not completely succeeded, and why increasing numbers of people have resisted assimilation into this cultural project. Why has a rival, 'Taiwanese' account of the shared culture of the island emerged in opposition to the 'Chinese' account? Gellner understands rival projects of nationalism as being generated by minority groups forced to assimilate into a high culture that is not their own, and where they face discrimination or systematic disadvantage that comes from working in a second language. ${ }^{23}$ The emergence of Taiwanese nationalism is not adequately explicable as the project of an economically and culturally excluded section of society, 
however, and Gellner's account cannot explain the sense amongst advocates of a Taiwanese national identity that asserting the distinctiveness of Taiwan is a moral imperative rather than simply a matter of material advantage.

Charles Taylor offers a way of explaining this development without falling back on assumptions about a primordial Taiwanese identity that has been frustrated and oppressed by mainland impositions. ${ }^{24}$ Taylor asks why some elites passionately resist assimilation into dominant national cultures, even when they share many of the values of these cultures, and assimilation would be the easiest option? His answer is that such resistance can be understood as driven by a desire for a locally distinctive process of modernization that builds on rather than obliterates valued local cultural traditions. Crucially though, achieving such a distinctive developmental path is more than a matter of preserving aspects of a valued folk culture; at stake is the dignity and self-worth of a people who desire recognition as the equals of other peoples.

A common elite response to modernization outside of the West has been a creative adaptation of modern Western social forms that draw on indigenous cultural resources. Modernization often engulfs and erodes traditional cultures, and where such cultures are not completely destroyed, elites have often understood their choice as being between an outright rejection of modernity, and finding resources in the traditional culture to sustain the best practices and institutions of other modern societies. This search for a culturally authentic path to modernity is driven not only by a concern to ensure the wellbeing of co-nationals while preserving familiar customs and traditions from erosion, but also by a desire for dignity and respect. Modernization has often taken place in the context of global and regional hierarchies, constituted by the presumption among members of successful and powerful societies that their way of life is superior to others they view as being in some way backward or inferior. These hierarchies are strongly evident in direct and neocolonial relationships, in which civilized is contrasted with savage, but they have come to also structure a world public sphere, in which peoples understand themselves and other societies through the categories of 'developed', 'developing', and 'underdeveloped'. Against this background, the search for different, locally authentic forms of modernity is an assertion of equality, and a bid for recognition of this equality by dominant societies. The emotive power of nationalism, Taylor suggests, and the frequency with which themes of pride and humiliation 
feature in nationalist discourse, become comprehensible when nationalism is understood through this connection between modernization and dignity.

Nationalism as a search for dignity is generated by experience of modernization against the background of the generalization and universalization of modern social, political and economic forms in a world of cultural difference. It is modern in another sense, however, for Taylor argues that modernity has transformed the conditions of dignity. In a hierarchical, network society, dignity and self-worth were grounded in kinship relations, lineage, clan, and so forth. In a horizontal, direct access society, by contrast, dignity is attached to a common categorical identity that can be threatened and humiliated. Nationalism involves the assertion of a particular categorical identity as the vehicle for the dignity desired. Taylor suggests that although nationalism is often generalized as a mass movement through a defensive politics of fear directed against a putative threat represented by another community, such mass movements often have their origins in a moral aspiration to recognition of equality in difference.

In Taiwan, the felt need for political difference in the context of modernization has arisen within a complex set of relationships. ${ }^{25}$ The incipient Han-Chinese-Taiwanese consciousness of the Japanese colonial period sought a more locally authentic adaptation of Japanese modernity (which was itself a project concerned in part with the dignity and equal standing of Japan alongside the Western powers). The KMT state on the mainland during the Republican era took on modernizing Western ideas while promoting Confucian values as a source of social stability and unity. ${ }^{26}$ It continued this project in Taiwan, where the model of modernity aspired to be that of the United States, but inflected by the identity of the Chinese that had developed on the mainland in the early twentieth century, and the Confucianism of the mainland. ${ }^{27}$ Since the 1970 s, the Mandarin-US high culture of the KMT has been increasingly challenged by the demand that Taiwan should find its own path, with a national project no longer based exclusively on the culture of the Mainlanders. The popularization of this challenge, which began as an elite discourse, was helped by the increasing divergence of Chinese and Taiwanese societies, fear of potential political domination or military threat from the PRC, and the ROC's indeterminate political status. After the loss of its UN seat in 1971, followed by the loss of US diplomatic recognition in 1979, Taiwan has been denied by all but a few 
states the recognition of statehood that is the formal condition of equality in international society.

Melissa Brown relates two anecdotal examples that illustrate some of the ways the emergent articulations of a distinct Taiwanese national identity have been bound up with these dynamics of dignity and equality. One concerns a Mainlander whose parents arrived with the nationalists in the 1940s. Brown describes how this woman recalled a visit to China in the 1980s:

After expressing shock at the standards of living, at the loss of Confucian civility and propriety in relationships, and at the apparent lack of work ethic which she found in China, she identified herself proudly as from Taiwan.

In the second anecdote, Brown describes meeting an academic in 1987 who wore a hat with a 'MIT' logo. She explained that the acronym, for her, stood not for the Massachusetts Institute for Technology but for 'Made in Taiwan'. In Brown's words,

[s]he had bought the hat on a recent visit to Boston, because she had been a student in the US during the 196os and 1970s, when 'Made in Taiwan' was on so many labels [...] and Taiwan was associated with cheap products - inexpensive and not very well made. She had been ashamed to have Americans associate her with such cheap products. She said that now that Taiwan was known for its economic success, she would wear her MIT hat proudly.

These examples illustrate the hierarchies associated with modernization China is represented as backward and regressive, while the US is a society to be caught up with. Also evident is the desire for recognition of equality by an Other who has achieved a standard of development aspired to (the US). The second informant's experiences of shame and pride, meanwhile, illustrate individual self-worth at stake in these relationships. ${ }^{28}$

We have proposed here an account of nationalist politics in Taiwan as arising out of two processes: a state-building and modernization process initiated by the KMT government, and a felt need for culturally authentic forms of modernity. While the former created and consolidated the space of shared universal high culture that is crucial for the development of 
nationalist projects in general, the content of this shared culture has been shaped by a desire for dignity and equality in the context of Taiwan's evolving social and political relationship with the mainland, and international isolation. This account of the forces shaping successive phases of identity politics in Taiwan provides a framework for understanding how religious movements have engaged with the politics of national identity. In the next section, we will argue that the former process tended to separate religion from the politics of national identity, while the latter pushed in the opposite direction, motivating greater religious involvement in the politics of nationhood and increasing the wider public appeal of such involvement. In the final two sections, we will illustrate the argument by showing how the Buddhist Foguangshan Order and the Christian Presbyterian Church in Taiwan have interpreted and responded to these constraints and influences in different ways conditioned by their own traditions of belief and practice.

\section{Religion and the politics of national identity}

Gellner conceived the rise of nationalism as an essentially secular phenomenon, in origins and nature. Like other modernization theorists, he tended to view nationalism as a replacement for religious modes of identity and community that had been eroded by the social changes associated with modernity, and religion tended to become socially marginal rather than adapting to a role in the new social forms. The rise of nationalism was a movement away from the cultural politics of agrarian societies, in which a shared high culture was maintained by religious institutions with power and authority extending over a patchwork of folk cultures and political units. The new nationalist culture required by industrializing economies could not be grounded in religion, for two reasons. Firstly, the dogmas of religion could not supply the level of sophistication required by a shared culture. ${ }^{29}$ And secondly, the protection and maintenance of this culture required a powerful state actively involved in society, rather than the relatively weak religious institutions that merely overlaid society. ${ }^{30}$

Following this perspective, it might be supposed that religion is only relevant to understanding nationalist politics in Taiwan as the substance of what preceded it - a cultural form that has been displaced in its public significance by the rise of a new, state-supported mode of social belonging. 
Modernization in Taiwan, as elsewhere, has not been associated with a decline in religion though..$^{31}$ Neither industrialization, state-building nor the emergence of nationalist projects have been associated with a collapse of religiosity or a decline in the social significance of religious institutions. Nationalism is significant as a secularizing movement in another respect, though. In Taiwan as in many other countries, the rise of a national imaginary as the focus for societal unity has a differentiating effect, separating politics and religion by defining citizenship as belonging to a separate realm of life with its own identity. As Charles Taylor points out,,$^{32}$ modern democratic states are horizontal, direct-access societies, which have a functional need for a shared identity. Citizens no longer stand in hierarchical relationships through which their access to the state is mediated; they stand as individuals, participating as equals in the public sphere, the market economy, and the state. Individual identity is no longer defined in networked terms, by a person's standing in a certain set of hierarchical relationships, but in categorical terms: identification with a set of impersonal entities, such as nations, ethnic groups, races, religions, or humanity in general. Social groupings began to be imagined as 'sets of equivalent persons', rather than 'webs of relationships among persons or hierarchies of positions.' ${ }^{33}$ This direct-access social imaginary is given political form in the modern state. Membership of these states cannot be mediated by membership of a religious community. Modern, and especially democratic states, depend for their survival and legitimacy on the mobilization of a committed citizenry who identify strongly with the polity, prioritizing their identity as citizens and thus their allegiance to the state before all other communities. In this context, appeal to a categorical national identity is an obvious way to unite a country, but it has the further effect of downgrading the public importance of identities - such as religious identities - that divide societies into subgroups.

In Taiwan, therefore, as elsewhere in Asia, modes of pious belief and practice that had formerly been deeply embedded in social, political, and economic life were detached to create a new religious realm that would be formally insulated from education, welfare, business, and politics. ${ }^{34} \mathrm{An}$

31 For influential critiques of models positing linear connections between modernization and secularization, see Casanova (1994); Berger (1999); Taylor (2007). For a recent defense of secularization theory, see Bruce (2002).

32 Taylor (2011, pp. 81-104).

33 Calhoun (1993, p. 230).

34 Baker (1997); Weller (2015). For an account of comparable processes in China, see Ashiwa and Wank (2009). 
important facet of this process was the extension of official recognition to significant religious traditions, a recognition that comes with autonomy, the protection of freedom to practice religion, and even permission for a more public role - in the provision of welfare, for example - within prescribed limits.

The differentiation of religion from other spheres of life is both enabling and constraining. It provides some measure of protection against state interference, but it also limits the political role that religious movements can legitimately take on. However, taking nationalism as a secular political form detached from religion risks neglect of the ways in which the boundaries of religion and nationalism are permeable and frequently breached from both sides. The differentiation of religion is never complete, for two reasons.

The first is that religion is often the object of secular regulation, to undermine or reform aspects or forms of religion viewed as incompatible with national culture. ${ }^{35} \mathrm{An}$ important part of the Nationalist regime's government of religion during the martial law period was the creation of large umbrella associations that could unify religious organizations belonging to particular traditions into manageable, state-regulated organizations. The Buddhist Association of the Republic of China (BAROC), for example, represented Buddhist groups to the government, and made it easier for the government to regulate and monitor them. ${ }^{36}$ It was one of many associations representing interest groups in the Nationalist state, and they were all expected to act as conduits for communications between their members and the government, mobilize political support for the regime, and help the government to implement its policies. ${ }^{37}$ During the early years of the martial law period, the KMT's concerns about espionage and infiltration by Communist agents led to the surveillance and infiltration of groups considered potentially seditious on account of socialist or pacifist leanings, as well as restrictions on the form religious organizations could take, and limitation of the power of temples. ${ }^{38}$ Indigenous Taiwanese religion came under particular suspicion as being incompatible with modernization and sinicization projects. Until the 1980 os, for example, the KMT actively tried to discourage the formation of island-wide cults that could serve as an alternative focus of cultural loyalty. During the Cultural Renaissance, the 
Nationalist government issued guidelines that aimed to rationalize local religious traditions it considered superstitious. ${ }^{39}$

The second reason for not overstating the division between secular national politics and religion is that the demarcation of a distinct religious sphere has never been stable or complete. The relaxation of state control over religion from the 1970 s onwards created an atmosphere of greater openness, contributing to the pluralization of the religious sphere and providing more opportunities for religious voices to be heard in public life. Added to this, many religious traditions in Taiwan have never been fully 'religionized', in the sense of differentiated from other spheres of life as a discrete spiritual practice with its own apolitical rationality. Many forms of religiosity have escaped the control of the state, and were never fully dis-embedded, and while others become re-embedded in everyday life. ${ }^{40}$ Religious rituals are often closely tied to understandings of political processes in local religious traditions, for example. ${ }^{41}$

To summarize then, the boundaries between sacred and secular exercise real normative constraints on the place and role of religion, and this is especially the case in the public political sphere, but this differentiation is never complete. The significance of religion for the politics of national identity in Taiwan resides not only in the formal public interventions of organized religious groups though. It can also be found at the deeper discursive level at which secularist language of differentiation and separation becomes increasingly misleading, suggesting a greater autonomy and self-sufficiency than either religious or political discourses can possess. Religious traditions are never hermetically sealed off from contextual influences, however many modern 'fundamentalist' movements may believe that they can be..$^{42}$ They are shaped and strengthened and undermined by historical processes in the societies in which they are always embedded. And nationalist imaginaries take up elements - symbols, myths, rituals, and narratives - from adjacent forms of cultural politics including religion..$^{43}$

Following William Connolly, these relationships need not be understood on the model of efficient causality: separating out religion and nationalism to show how one causes the other, or how they cause each other. He proposes

Katz (2003, pp. 401-402).

40 Weller (2015, p. 15).

41 Ahern (1981).

42 For an illustration, see Sami Zubaida's (1982) analysis of the modern, Western categories of thought, which Khomeini's ideas about government implicitly relied on, in spite of his desire to develop an Islamic politics untainted by Western corruptions.

43 Van der Veer (2015). 
instead a model involving the mutual constitution of discursive systems and relations of affinity and resonance between their core elements that can create intensities of solidarities between different social groups. ${ }^{44}$ For Connolly, the discursive elements that resonate are not only ideas and doctrines, but also identities and sensibilities. Affinities of sensibility can create powerful political assemblages even where social constituencies differ in their religious, political, and economic doctrines and identities. ${ }^{45}$

We want to suggest that the relationship between religion and nationalist politics in Taiwan not only should be understood in terms of the formal political interventions of religious groups, but also at a deeper level where religious discourses resonate with the moral sensibility that animates nationalist politics. Religious engagement has been mediated by the ways in which religion has been positioned and contained by the modernization and state-building processes associated with the rise of nationalism, but it has also been mediated by the same experience of the distinctive conditions of moral dignity in modernity. Experiences of shame and pride have been at the heart of many nationalist movements, but they have also shaped the evolution of religions in modernity. In some cases, the development of culturally authentic expressions of religious modernity has involved taking the 'best' formal elements of the rational religion of Western modernity Christianity - and discovering resources that support the same elements in one's own tradition, as Hindu revivalist movements such as the Arya Samaj in South Asia discovered in Hinduism 'modern' religious forms such as a monotheistic God, foundational scriptures, and congregational worship. ${ }^{46}$ It can also take the form of adopting more general themes characteristic of modernity: a greater humanitarian concern for this-worldly wellbeing; a preoccupation with reconciling the content of the religious tradition with the conclusions of modern science; a literalist and pseudoscientific rejection of metaphor and allegory in the interpretation of scriptures and traditions; or alternatively a thorough rejection of literalism, with the content of tradition relativized as a mythical framework for the affirmation of universal human goods. Whether they involve the emulation of modern Western religious forms or reforming religion on the basis of more generic modern cultural emphases, such efforts are driven by a felt need to create modern forms of religion worthy of equal recognition and respect in themselves, and able to serve as resources for culturally authentic developments of 
modernity more broadly. The influence of these cultural dynamics within the religious field can provide an impulse towards religious engagement with nationalist politics grounded in a similar sensibility, and serve as echoes and repositories of moral experience that provide a subtle reinforcement of nationalist politics in the wider society.

In the next two sections, we propose that these moral sensibilities are evident in the humanistic Buddhism of FGS and the Asian Christianity of the PCT respectively, creating a reservoir of moral impulses that motivate engagement with the politics of national identity in Taiwan, and strengthen this politics through cultivating in their members moral sensibilities that resonate with the moral sources of this politics of nationhood. At the same time, however, the formal and explicit engagement of these groups in this politics has been constrained by the boundaries between sacred and secular that are a by-product of modern state-formation. Yet each group interpreted and responded to these constraints and influences in different ways conditioned by their own traditions of belief and practice.

\section{Foguangshan}

FGS is one of the most prominent Buddhist organizations in Taiwan. It has played an important role in the revival of Buddhism on the island, and has expanded to establish more than 200 branch temples around the world. ${ }^{47}$ FGS's charismatic founder Xingyun 星雲 was born in Southern Jiangsu, and arrived in Taiwan with the Nationalist forces at the end of the civil war. He teaches a form of Buddhism with roots in the humanistic Buddhism developed in China by the monk Taixu in the early twentieth century. Humanistic Buddhism was a modernist reformulation of traditional Buddhist doctrine as a response to the influence of modernization and Westernization in China. Major themes in this reform have included: a greater concern with this-worldly wellbeing and the improvement of society; a narrative of Chinese Buddhism as having been in decline, overly focused on other-worldly rebirth, and weighed down with superstitious accretions; and finally, greater emphasis on lay involvement. ${ }^{48}$ Taixu and other reformers saw such changes as necessary not only to revitalize Buddhism to position it as a necessary response to the social and spiritual challenges of the twentieth century but also saw as a way to strengthen Chinese culture and 
society against the threat presented by foreign encroachment in China. ${ }^{49}$ Taixu sought to reform Chinese Buddhism away from a concern with the dead, ritual, and preparation for rebirth in a supra-mundane pure land, a realm in which unhindered study of the Buddhist dharma is possible. Buddhism was instead refocused on the living, and efforts to transform the human world into a mundane pure land..$^{\circ}$

These themes and emphases are all present in Foguangshan. Xingyun has sought to strengthen Chinese culture against the countervailing influences of Western modernity and globalization. While Western (US) presence in Taiwan has provided welcome protection from Communist domination, the popularity of Foguangshan and other humanistic Buddhist movements such as Ciji Charity Association (Ciji Gongde Hui 慈濟功德會) reflect an ambivalence about the cultural implications of this influence. Humanistic Buddhism combines what are believed to be the modern ideals of the West, such as this-worldly humanism, science, and a democratic elevation of 'ordinary life', with the traditional virtues and roles associated with Confucian notions of morality and human relationships. They provide a way for Taiwanese devotees to creatively adapt important facets of modernity in a non-Western, locally authentic way that can ground a claim for cultural equality.

The humanistic Buddhist concern with establishing a pure land in the human world tends to blur the boundaries between supra-mundane and mundane and between sacred and profane. In this, it extends the Buddhist idea of the interpenetration of all things to relativize boundaries between private life, civil society, and the state. Change in each is linked. This in turn has implications for practice: everyday activities such as work become legitimate, even exemplary forms of cultivation, lay, and monastic life converge, with lay members taking on a more active role in the order and monks and nuns active in society.

One expression of this is Xingyun's commitment to involvement in public affairs. He has a ceremonial role on the KMT's Central Advisory Committee, maintains close relations with prominent politicians, and endorses candidates during election periods. His close links with successive KMT governments and frequent appearances in the political sphere have generated a certain amount of opposition. As a Chinese monk, openly supportive of reunification, with a large following among native Taiwanese, he has been courted by the KMT as a symbol of unity and has accepted this role. He 
has engaged in informal diplomacy that furthered the agenda of the ROC government in cross-strait relations on a number of occasions..$^{51} \mathrm{He}$ has positioned himself as a mediator in cross-strait relations, headed a delegation visiting the PRC in 1989, given refuge to prominent Chinese dissidents, and has been instrumental in organizing a series of World Buddhist Forums that bring Chinese and Taiwanese Buddhists together. At the second of these, in 2009, he attracted criticism among supporters of Taiwanese independence for his comments insisting that the Taiwanese are Chinese, and for expressing the hope that more cross strait exchanges, like the Forum, will encourage unification through generating a sense of commonality between mainland Chinese and Taiwanese..$^{2}$ Recently, he returned the head of a sixth-century Buddha statue, stolen from a temple in northern China in 1996, and subsequently bought by a Taiwanese businessman and donated to Xingyun. The return was a symbolic gesture to promote good cross-strait relations as president-elect Cai Yingwen prepared to take office..$^{53}$

Xingyun's political activities have been constrained by the normative division between the religious and the secular. Crossing the boundary opened him up to criticism from both Buddhist and secular standpoints. He has been called in derogatory terms 'a political monk' by critics concerned about the religious neutrality of the political sphere, as well as Buddhist critics who charge him with trivializing the sacred by his worldly activities. ${ }^{54}$ He endorsed Chen Luan 陳履安, a prominent Foguangshan supporter, in the 1996 presidential election, and the flurry of criticism that resulted has been connected with the closure to visitors of the monastery in Kaohsiung county that serves as the movement's headquarters. The monastery had become one of Taiwan's premier tourist attractions, drawing thousands of tourists every weekend, until Xingyun announced in 1997 that it would close to visitors other than devotees. The previous year's political controversy is likely to have played a role in this decision, alongside a number of other economic and spiritual considerations. By recloistering the monastery, Xingyun would resacralize an important symbol of the Foguangshan movement and ward off criticism that it had strayed from its proper religious vocation. ${ }^{55}$ Xingyun's interventions in the politics of Taiwanese identity and cross-strait relations have been constrained by his location as a religious figure. 
Xingyun's explicit interventions in the public sphere are not the only way in which FGS blurs the boundaries between the religious and the political. Even more significant than FGS's forays into electoral politics have been FGS's less high-profile educational activities. These activities are oriented towards political change, not through direct intervention in the political sphere, but through drawing political figures, and potential political figures including ordinary democratic citizens, into deeper religious commitment. This is intentional, and has its roots in Xingyun's understanding of political change. He has argued that the proper political stance for a monk is to 'show concern' but without 'interfering'. This means acting as a moral guide, endorsing candidates with the moral character necessary for political leadership, and preparing lay Buddhists for political involvement - all with the ultimate end of creating the kind of ethical society best suited to Buddhist spiritual cultivation..$^{56}$ 'Personally', he has said, 'I do not think that monastics should engage in any political activities. But we can cultivate lay people to be involved in politics'.57 This is a pragmatic rather than a merely principled stance: for Xingyun, the long-term social and political change he seeks will not come about through exerting pressure on the state to pull the levers of government on particular issues. It will rather come about through remaking individual lives in ways that alter the social and political relations they are involved in: the focus of Foguangshan is accordingly on moral, intellectual, and spiritual education, and large campaigns encouraging individuals to commit to purifying their intentions and their actions..$^{8}$

The values promoted in Foguangshan's educational and spiritual outreach are those of a modern, humanistic, and this-worldly Buddhism. The 'purification of minds' that Xingyun regards as crucial to social and political change can be achieved through meditation, sutra recitation, retreats, and pilgrimages. ${ }^{59}$ There is also a strong Confucian element, however. Humanistic Buddhism is an enculturated form of Buddhism, as it belongs to the broader tradition of Chinese Buddhist practice that has always been infused with Confucian (as well as Daoist) sensibilities. While humanistic Buddhism has sought to purge Buddhism of 'superstitious' accretions, it has retained its Confucianized character, and this is a dimension of the tradition that Xingyun openly embraces. For Xingyun and many devotees of the order, Buddhism, and especially the Foguangshan movement, are the primary 
means through which Chinese Confucian culture is being preserved in a largely post-Confucian world. ${ }^{60}$ There are clear echoes here of the KMT government's postwar understanding of itself as a guardian of traditional Chinese culture. ${ }^{61}$ The KMT's appropriation of Confucian traditions was selective and symbolic though, intended to legitimize the regime and give substance to a nationalist myth of sacred origins and continuous history, and the ritual system that gave substance to Confucian values has mostly disappeared, leaving little trace of its significance in everyday life. ${ }^{62}$

Foguangshan presents itself as the primary means through which this traditional culture is being preserved. Clerics emphasize to devotees the importance of ritual acts, in the form of Buddhist etiquette, that sanctify every aspect of daily life. ${ }^{63}$ Foguangshan also encourages state involvement in rituals, recalling the role Confucian rites formerly played in Chinese society. State officials visiting Foguangshan monasteries are received with elaborate and carefully choreographed rituals that symbolically affirm the spirit and ethos of Confucianism as the basis of Taiwanese society ${ }^{64}$ This role, as a carrier of Confucian values, has been extended through even more public ceremonies such as the Buddha Tooth Welcoming Ceremony in $1998 .^{65}$ The event marked the arrival in Taiwan of one of the three Buddha teeth still in existence, which had been given to Xingyun by a group of Tibetan Buddhists no longer able to preserve it. The tooth traveled to Taiwan in a specially chartered plane, was welcomed at the airport by a crowd of thousands, driven in a cavalcade on a specially closed highway into Taipei, and received offerings by senior government officials, acting on behalf of the ten-thousand strong crowd, at a ceremony at the Jiang Jieshi Memorial Hall. Xingyun argued that the symbolic power of the tooth meant it could play a vital role in promoting social harmony. Chandler has noted that the significance of the ceremony exceeded the symbolic power of this particular relic, as it served as a reminder of the significance of all ritualized activity and its importance for social harmony.

Foguangshan presents itself as the primary vehicle for a BuddhistConfucian culture that should rightfully be at the center of Taiwanese public life, in the subjectivity and habits of lay devotees, and in the shared rituals of public life. In this regard, its most significant contribution to the politics

\footnotetext{
6 o Chandler (2004, p. 249).

61 Laliberté (2004, p. 40).

62 Chun (1994).

63 Chandler (2004, p. 251).

64 Chandler (2004, pp. 249-250).

65 Chandler (2004, pp. 250-251).
} 
of identity in Taiwan may be its 'religious' and educational outreach work. The practical embodiment of Confucian values may have been eroded in Taiwan, but the tradition itself still serves as a powerful signifier of cultural unity between Taiwan and mainland China, at a time when it seems to many Taiwanese that its long separation from the mainland has opened a gulf between the cultures and mentalities of the two societies. The program of Foguangshan resonates with many of those who want to stay in touch with their Chinese roots. ${ }^{66}$

FGS challenges the differentiation of religion and the secularity of the shared national culture, seeking to ground it in a Buddhist-Confucian culture by involving political actors in religious education and ritual. This response, conditioned by the emphasis on this-worldly social and political outreach characteristic of humanistic Buddhism, can be contrasted with the more confrontational approach of the PCT.

\section{Presbyterian Church in Taiwan}

The PCT is the largest Protestant denomination in Taiwan, with almost a quarter of a million members. ${ }^{67}$ It developed out of English and Canadian missions established in the mid-nineteenth century, but Calvinism had earlier been present in Taiwan under Dutch colonial rule in the midseventeenth century. With the expulsion of the Dutch, Christianity withered on the island until the return of the missionaries some two centuries later. By the time the KMT took control of Taiwan in 1945, the church was largely independent of the missionaries who had founded it, but continued the combination of practical, this-worldly religion combined with social welfare, education, and medical provision that had characterized the church since the earliest days of the mission. ${ }^{68}$

Under KMT rule, the PCT became increasingly political. Initially, conflict was generated by perceptions that aspects of the PCT's ordinary activities threatened the KMT's rule and state-building project. Presbyterian clergy were rounded up as part of the KMT's crackdown on the island's social and intellectual elites during the $2 / 28$ incident. ${ }^{69}$ The PCT also found itself in conflict with the government over the church's efforts to develop the

66 Chandler (2004, p. 254).

67 Presbyterian Church in Taiwan (2016).

68 Cheng (2009).

69 Rubinstein (2003, p. 215). 
Romanization of local languages and dialects as a practical shortcut to biblical literacy. The translation of bibles and hymnals into Taiwanese, Hakka, and tribal languages, and the use of these languages in services, conflicted with the KMT's policy of Mandarinization. Notwithstanding these conflicts, the PCT avoided open political engagement in the early years of KMT rule, focusing instead on church growth and welfare work. ${ }^{70}$

It was during the 1970s that the PCT came into open confrontation with the KMT regime, publishing a series of outspoken statements criticizing restrictions on religious freedom and human rights and calling for democratization and self-determination for the people of Taiwan. ${ }^{11}$ These statements were some of the earliest public attempts to reorient the KMT's project of national consolidation towards Taiwanese autonomy. They articulated a model of political community based not on ethnicity or religion, but on shared residency in Taiwan and common commitment to living there in peace, freedom, and justice. This ideal of civic nationalism, based on the right of peoples to self-determination, was affirmed not only by the UN Charter but ordained by God..$^{2}$

In 1972, the year after its initial statement, the PCT justified its intervention in political affairs with an exceptionalist argument. ${ }^{73}$ Under ordinary circumstances, the Church should not become involved in politics as in the Middle Ages, but individual Christians have a responsibility to work for the good in society and politics. The Church, as a corporate body, also has a responsibility to speak out when political authorities violate the life of the Church, or human rights and human dignity. In these circumstances though, any statement made by the Church will be a theological statement - 'a confession of faith' - not a political statement. Defense of human rights could also be a confession of faith, because they are given by God. The PCT thus acknowledged a boundary between religious and political affairs, but denied it was stepping over the boundary.

The image of political community that emerges from the PCT's public statements is one in which religion and politics, and religious community and political community, are separate things. In a 1994 response to a statement by the China Christian Council, the PCT argue that 'Christian community and national community are not equal terms' and that 'differences

70 Rubinstein (2003, pp. 215-223).

71 Presbyterian Church in Taiwan (1971); Presbyterian Church in Taiwan (1975); Presbyterian Church in Taiwan (1977).

72 Presbyterian Church in Taiwan (1971).

73 Presbyterian Church in Taiwan (1972). 
in national identity should not be an obstacle to Christian solidarity'.74 The PCT defends what might be described as a divinely ordained autonomy of the political: political community is not the same as religious community, but certain basic political principles - rights to a homeland, self-determination, human rights, and human dignity - are gifts from God that ought to be respected and defended. This argument has been developed over time into increasingly blunt statements that the 'the people' who have the right of self-determination are the people of Taiwan and its islands.75

The PCT may not have regarded their challenge to the KMT as political, but the government took a different view. The PCT's advocacy of selfdetermination and democracy, and support for the activist movement that later became the DPP, came at a considerable cost during the martial law period. ${ }^{76}$ Its challenge to the KMT's project of state-building accepted its basically secular civic nationalism and its distinctiveness from religion, while making arguments on religious grounds for reorienting it towards a project of Taiwanese nationalism.

The culturally authentic modernity of the PCT can be contrasted with that of FGS. Whereas Humanistic Buddhism reformed the religious tradition to introduce modern, Western-influenced emphases, the PCT has sought to enculturate Protestant Christianity - the paradigmatic religion of modernity - by creatively adapting it in a local idiom without sacrificing the essence of the tradition. The public statements of the PCT from the 1970s onwards can be understood as expressing the ideal of 'contextual theology', especially as developed by Taiwanese Presbyterian pastor Shoki Coe 黃彰 輝. This refers to the idea that theology should be open to the social, political, and religio-cultural circumstances of its construction as 'coordinating principles' that interact dialectically with the transcendent truths of the gospel. ${ }^{77}$ Theologian C.S. Song's 宋泉盛 influential development of this idea proposed that Asian Christians should articulate an Asian theology, on the basis that God works through all cultures, and not only Western culture within which most theology has thus far been done..$^{8}$ The PCT's concern with the historical experience of the Taiwanese people, its identification of the people of Taiwan with that of the people of ancient Israel, and the emphasis on God's concern for both, is in continuity with this tradition. 
The overall shape of the PCT's public engagement thus manifests a concern with developing a culturally authentic form of Christianity that reflects and responds to the Taiwanese context.

In putting that understanding into practice in its public witness, the PCT encountered the normative boundaries between the political and the religious, just as FGS had done. Rather than seeking to blur and erode these boundaries though, as FGS has through its educative and ritual activities, the PCT has accepted their basic legitimacy. Nevertheless, while it endorses the normative separation of the political and the religious, the PCT has also sought to define the boundaries between them in such a way that issues crucial to the politics of national identity and self-determination become religious issues. This puts these aspects of self-determination beyond the legitimate veto power of the state and justifies the PCT's involvement on these topics, while also framing efforts to restrict the PCT's interventions as being illegitimate restrictions on religious freedom.

\section{Conclusion}

In this chapter, we have argued that the relationship between religion and nationalism has been mediated by two processes that pull in different directions. The process of state formation, which has tended to separate religion and national identity, and the search for culturally authentic expressions of modernity, which has tended to draw them together. We proposed that the significance of religion in relation to nationalism in Taiwan has been qualified by powerful processes of modernization and state formation which have created barriers for religious involvement in politics that remain potent, in spite of the relaxation of state controls on religion. At the same time, however, religious traditions have been shaped by the same impulses towards culturally authentic modernity that animate nationalist projects. This affinity of sensibility provides a general reinforcement of the cultural sources of nationalism, but it also arguably motivates greater religious engagement with this politics. This is partly because the moral sensibility encountered in both the religious and political communities takes on the aura of common sense, but also because modern expressions of religion tend often to be more this-worldly and socially and politically engaged. 


\section{Bibliography}

Agné, Hans, Jens Bartelson, Eva Erman, Thomas Lindemann, Benjamin Herborth, Oliver Kessler, Christine Chwaszcza, Mikulas Fabry, and Stephen D. Krasner. 2013. 'Symposium “the Politics of International Recognition"'. International Theory, 5(1): 94-107.

Ahern, Emily Martin. 1981. Chinese Ritual and Politics. Cambridge: Cambridge University Press.

Asad, Talal. 2003. Formations of the Secular: Christianity, Islam, Modernity. Stanford, CA: Stanford University Press.

Asad, Talal. 2005. 'Trying to Understand French Secularism'. In Hent de Vries and Lawrence E. Sullivan, eds. Political Theologies. New York, NY: Fordham University Press, pp. 494-526.

Ashiwa, Yoshiko and David L. Wank, eds. 2009. Making Religion, Making the State: The Politics of Religion in Modern China. Stanford, CA: Stanford University Press.

Baker, Don. 1997. 'World Religions and National States: Competing Claims in East Asia'. In Susanne Hoeber Rudolph and James Piscatori, eds. Transnational Religion and Fading States. Boulder, CO: Westview Press, pp. 144-172.

Bartelson, Jens. 2013. 'Three Concepts of Recognition'. International Theory, 5(1): 107-129.

Berger, Peter L., ed. 1999. The Desecularization of the World:Resurgent Religion and World Politics. Grand Rapids, MI: William B. Eerdmans.

Brincat, Shannon. 2014. 'Recognition, Conflict and the Problem of Ethical Community'. Global Discourse, 4(4): 397-408.

Brown, Melissa J. 2004. Is Taiwan Chinese? The Impact of Culture, Power, and Migration on Changing Identities. Berkeley, CA: University of California Press.

Bruce, Steve. 2002. God Is Dead: Secularization in the West. Oxford: Blackwell.

Calhoun, Craig. 1997. Nationalism. Minneapolis, MN: University of Minnesota Press.

Calhoun, Craig. 1993. 'Nationalism and Ethnicity'. Annual Review of Sociology, 19: 211-239.

Casanova, José. 1994. Public Religions in the Modern World. Chicago, IL: University of Chicago Press.

Chandler, Stuart. 2004. Establishing a Pure Land on Earth: The Foguang Buddhist Perspective on Modernization and Globalization. Honolulu, HI: University of Hawai'i Press.

Chang, Bi-yu. 2004. 'From Taiwanisation to De-Sinification: Cultural Construction in Taiwan since the 1990s'. China Perspectives, 56: 34-44. 
Chang, Mau-kuei. 2003. 'On the Origins and Transformation of Taiwanese National Identity'. In Paul R. Katz and Murray A. Rubinstein, eds. Religion and the Formation of Taiwanese Identities. Basingstoke: Palgrave Macmillan, pp. 23-58.

Cheng, Yang-en. 2009. 'Calvinism and Taiwan'. Theology Today, 66: 184-202.

Chun, Allen. 1994. 'From Nationalism to Nationalizing: Cultural Imagination and State Formation in Postwar Taiwan'. The Australian Journal of Chinese Affairs, 31: 49-69.

Chwaszcza, Christine. 2013. "Recognition": Some Analytical Remarks'. International Theory, 5(1): 160-165.

Connolly, William. 2005. 'The Evangelical-Capitalist Resonance Machine'. Political Theory, 33(6): 869-886.

Daase, Christopher, Caroline Fehl, Anna Geis, and Georgios Kolliarakis, eds. 2015. Recognition in International Relations: Rethinking a Political Concept in a Global Context. Basingstoke: Palgrave Macmillan.

Erman, Eva. 2013. 'The Recognitive Practices of Declaring and Constituting Statehood'. International Theory, 5(1): 129-150.

Fan, J. 2014. 'The Economics of the Cross-Strait Services Agreement'. The Diplomat. http://www.brookings.edu/research/opinions/2014/04/18taiwancrossstraitservicesagreementfan, last accessed .

Fabry, Mikulas. 2013. 'Theorizing State Recognition'. International Theory, 5(1): 165-170.

Fo Guang Shan Monastery. 'Introduction to Fo Guang Shan'. https://www.fgs.org. tw/en/Organizations/Introduction/, last accessed .

Gellner, Ernest. 1964. Thought and Change. London: Weidenfield \& Nicolson.

Gellner, Ernest. 1983. Nations and Nationalism. New York, NY: Cornell University Press.

Greenhill, B. 2008. 'Recognition and Collective Identity Formation in International Politics'. European Journal of International Relations, 14(2): 343-368.

Gustafsson, Karl. 2014. 'Identity and Recognition: Remembering and Forgetting the Post-War in Sino-Japanese Relations'. The Pacific Review, 28(1): 117-138.

Gustafsson, Karl. 2015. 'Recognising Recognition through Thick and Thin: Insights from Sino-Japanese Relations'. Cooperation and Conflict, pp. 1-17. November 2. http://dx.doi.org/10.1177/0010836715610594, last accessed .

Haacke, Jürgen. 2005. 'The Frankfurt School and International Relations on the Centrality of Recognition'. Review of International Studies, 31(1).

Hechter, M. 200o. Containing Nationalism. Oxford: Oxford University Press.

Hechter, Michael. 1975. Internal Colonialism: The Celtic Fringe in British National Development, 1536-1966. Berkeley, CA: University of California Press.

Ho, Ming-sho. 2015. 'Occupy Congress in Taiwan: Political Opportunity, Threat, and the Sunflower Movement'. Journal of East Asian Studies, 15: 69-97. 
Hornby, Lucy, and Ben Bland. 2016. 'Buddha's Return Belies Tensions between Beijing and Taipei'. Financial Times. 11 March 2016.

Katz, Paul R. 2003. 'Religion and the State in Post-War Taiwan'. The China Quarterly, 174: 395-412.

Kessler, Oliver, and Benjamin Herborth. 2013. 'Recognition and the Constitution of Social Order'. International Theory, 5(1): 155-16o.

Krasner, Stephen D. 2013. 'Recognition: Organized Hypocrisy Once Again'. International Theory, 5(1): 170-176.

Laliberté, André. 2004. The Politics of Buddhist Organisations in Taiwan:1989-2003. Abingdon: Routledge.

Laliberté, André. 2009. 'The Regulation of Religious Affairs in Taiwan: From State Control to Laisser-Faire?' Journal of Current Chinese Affairs, 38(2): 53-83.

Lee, Archie Chi Chung. 2005. 'Contextual Theology in East Asia'. In David Ford and Rachel Muers, eds. The Modern Theologians. Oxford: Blackwell, pp. 518-534.

Lin, S. 2014. 'Bridging the Chinese National Identity Gap: Alternative Identities in Hong Kong and Taiwan'. Joint U.S.Korea Academic Studies, 25, pp. 114-132.

Lindemann, Thomas. 2013. 'The Case for an Empirical and Social-Psychological Study of Recognition in International Relations'. International Theory, 5(1): 150-155.

Lok-sin, Loa. 2009. 'Taiwan Buddhist Master: "No Taiwanese”. Taipei Times, 31 March 2009.

Madsen, Richard. 2007. Democracy's Dharma: Religious Renaissance and Political Development in Taiwan. Berkeley, CA: University of California Press.

Mahmood, Saba. 2006. 'Secularism, Hermeneutics, and Empire: The Politics of Islamic Reformation'. Public Culture, 18(2): 323-347.

Pacey, Scott. 2005. 'A Buddhism for the Human World: Interpretations of Renjian Fojiao in Contemporary Taiwan'. Asian Studies Review, 29(4): 445-461.

Presbyterian Church in Taiwan. 'A Declaration on Human Rights'. http://english. pct.org.tw/Article/enArticle_public_19770816.html, last accessed .

Presbyterian Church in Taiwan. 'Our Appeal'. http://english.pct.org.tw/Article/ enArticle_public_19751118.html, last accessed.

Presbyterian Church in Taiwan. 'Recommendations Concerning the Present Situation'. http://english.pct.org.tw/Article/enArticle_public_19900515.html, last accessed .

Presbyterian Church in Taiwan. 'Response to the China Christian Council Statement'. http://english.pct.org.tw/Article/enArticle_public_19941124.html, last accessed.

Presbyterian Church in Taiwan. 'A Statement on Our National Fate'. http://english. pct.org.tw/Article/enArticle_public_19711229.html, last accessed . 
Presbyterian Church in Taiwan. 'Statement on Our National Fate: Motivation Based on Faith and Theology'. http://english.pct.org.tw/Article/enArticle_public_19720500.html, last accessed .

Presbyterian Church in Taiwan. 'Structure and Statistics'. http://english.pct.org. tw/enWho_int_Sta.htm, last accessed .

Rubinstein, Murray A. 2003. 'Christianity and Democratization in Modern Taiwan: The Presbyterian Church and the Struggle for Minnan/Hakka Selfhood in the Republic of China'. In Philip Clart and Charles B. Jones, eds. Religion in Modern Taiwan: Tradition and Innovation in a Changing Society. Honolulu, HI: University of Hawaii Press, pp. 204-257.

Rubinstein, Murray A. 1991. The Protestant Community on Modern Taiwan:Mission, Seminary, and Church. Armonk, NY: M.E. Sharpe.

Smith, Anthony D. 1998. Nationalism and Modernism. London: Routledge.

Taylor, Charles. 2011. Dilemmas and Connections. Cambridge, MA: Harvard University Press.

Taylor, Charles. 2007. A Secular Age. Cambridge, MA: Belknap Press.

Tilly, Charles. 1990. Coercion, Capital, and European States, Ad 990-199o. Oxford: Basil Blackwell.

Van der Veer, Peter. 2002. 'Religion in South Asia'. Annual Review of Anthropology, 31: 173-187.

Van der Veer, Peter. 2015. 'Nation, Politics, Religion'.Journal of Religious and Political Practice 1(1): 7-21.

Wang, Fu-Chang 王甫昌. 2003. Dangdai Taiwan Shehui De Zuqun Xiangxiang 當代台灣社會的族群想像 (Ethnic Imagination in Contemporary Taiwan). Taipei: Qunxue.

Wang, Xiao-bo 王曉波. 1988/1999. Taiwanshi Yu Taiwanren 台灣史與台灣人 (Taiwan History and the Taiwanese). Taipei: Tungta.

Weller, Robert. 2015. 'Global Religious Changes and Civil Life in Two Chinese Societies'. The Review of Faith and International Affairs, 13(2): 13-24.

Weller, Robert. 2000a. 'Living at the Edge: Religion, Capitalism, and the End of the Nation-State in Taiwan'. Public Culture, 12(2): 477-498.

Weller, Robert P. 200ob. 'Religion and the New Taiwanese Identities - Some First Thoughts'. Harvard Studies on Taiwan: Papers of the Taiwan Workshop, 2:225-232. Weller, Robert. 1987. 'The Politics of Ritual Disguise: Repression and Response in Taiwanese Popular Religion'. Modern China, 13(1): 17-39.

Wheeler, Ray. 2002. 'The Legacy of Shoki Coe'. International Bulletin of Missionary Research, 26(2): 77-80.

Wolf, Reinhard. 2011. 'Respect and Disrespect in International Politics: The Significance of Status Recognition'. International Theory, 3(1): 105-142. 
Zubaida, Sami. 1982. 'The Ideological Conditions for Khomeini's Doctrine of Government'. Economy and Society, 11(2): 138-172.

\section{About the authors}

Frettingham, Edmund. Assistant Professor of International Relations, Leiden University College The Hague, the Netherlands.

Email: e.j.frettingham@luc.leidenuniv.nl

Hwang, Yih-jye. Assistant Professor of International Relations, Leiden University College The Hague, the Netherlands.

Email: jayhwang@live.co.uk 


\title{
13 Multiple Religious and National Identities
}

\author{
Mazu Pilgrimages across the Taiwan Strait after 1987
}

Hsun Chang

\begin{abstract}
After the lifting of Martial Law in 1987, pilgrimages to China have become a routine activity for many temples in Taiwan, especially in the case of the temples of Mazu. To most residents of Taiwan, Mazu is a symbol of Taiwanese identity; to the Chinese, Mazu is a symbol of peaceful unification between Taiwan and China. Thus, there are two nationalist interpretations of Mazu, and many tensions exist among Mazu believers. This chapter focuses on the cross-strait pilgrimage from Xingang Mazu Temple in Taiwan to Yongchun, Fujian in China in 2011, and the establishment of a Taiwanese branch temple in Fujian. In addition, the author shows that Taiwanese local politicians use Xingang Mazu Temple to attract tourists and as a platform for new religious nationalism.
\end{abstract}

Keywords: Taiwan, Mazu, pilgrimage, cross-strait, religious nationalism

\section{Pilgrimages across Taiwan Strait after 1987}

While there has been much research on folk religion in modern Taiwan after World War II, there have been relatively few studies on religious changes after the lifting of martial law in Taiwan in $1987 .{ }^{1}$ By comparison, we find rich documents of the religious revival and its related issues in China after $1987{ }^{2}$ The southeastern Chinese province of Fujian was the original homeland of most immigrants from China to Taiwan over the past two centuries, the majority of cross-strait religious contact has been between temples in Fujian and Taiwan. In the early history of Chinese settlement in Taiwan, many immigrants would annually return to their Chinese places of origin to worship their ancestors, and would often bring statues of deities

2 Yang (2008); Ashiwa and Wank (2009); Goossaert and Palmer (2011). 
back to their ancestral temples to strengthen the statues' power. Although Han Taiwanese no longer make annual trips back to their places of origin in China to worship their ancestors, they are still aware of their roots in Fujian and the fact that their deities were 'divided spirits' (fenlin 分靈) or 'divided incense' (fenxiang 分香) from their predecessors in Fujian. When the practice is allowed, believers will bring statues back to Fujian to be empowered, which is why there are so many pilgrimages across the Taiwan Strait every year. Among dozens of deities from Fujian, Mazu 媽祖, the sea goddess, has long been a favorite; Mazu ensured that immigrants crossed the Strait safely, brought rain to water crops, protected the safety of merchants going back and forth across the Strait, and sheltered the poor. Even nowadays, she is said to listen to all those who ask for her help. Among the hundreds of deities in the folk religion of Taiwan, Mazu has hundreds of thousands believers, and is often considered to be the patron deity of Taiwan. There are around one thousand temples in Taiwan dedicated to her, and roughly sixty of these temples send their members on regular pilgrimages to Meizhou (湄州), Fujian. ${ }^{3}$

Most group pilgrimages to China are organized by temple committees. A pilgrimage group is typically composed of the chief temple manager, other temple managers, pilgrims (also called 'incense-guests', xiangke 香 客), and entertainers hired by the temple. All these participants have to follow certain rules during the trip, such as wearing clean clothes, observing a vegetarian diet, maintaining sexual abstinence, and avoiding alcoholic beverages, betel nut, and cigarettes, etc. Some of the pilgrims bring their own statues of Mazu, and these pilgrims must burn incense throughout the trip and have their statue stay at the ancestral temple overnight once. Before the pilgrims leave the ancestral temple and start their journey back to Taiwan, all the statues are passed over the main giant censer of the ancestral temple in order to fill them with the deity's efficacious powers.

The Dajia 大甲 Mazu Temple undertook its first recent pilgrimage to Meizhou, Fujian in October 1987, which was before Taiwan's central government legalized direct religious contact with mainland China. The Dajia Mazu Temple gained a higher status in the hierarchical system of Mazu temples throughout Taiwan thanks to the cooperation it obtained from Fujian, and it thus earned the reputation of being the headquarters of

3 According to the Record of the Divine Feats of the Heavenly Imperial Consort (天妃顯聖錄), Mazu's maiden name was Moniang Lin, she was born in Xianliang Harbor in 96o AD, and died on Meizhou island, Fujian, in 987 AD. The Meizhou temple was subsequently granted the status of the ancestral temple (or mother temple) of Mazu. 
Meizhou Mazu in Taiwan and attracted more believers than before. ${ }^{4}$ This prompted other Mazu temples to undertake the pilgrimage to Meizhou and bring back new statues (fenshen 分身) from Meizhou. Eventually, after 199o, not only were Mazu believers busily crossing the strait, but other deities' believers were also making pilgrimages to their deities' ancestral temples in China in order to empower their temples and enhance their reputations. ${ }^{5}$

The returning believers from Taiwan have provided an opportunity for the revival of folk religion in China. Folk religion was severely repressed during the Cultural Revolution, and is still not a legal religion in China. ${ }^{6}$ Nevertheless, after the modernization and opening in 1987 , folk religion has been tolerated or permitted in some coastal areas, especially in Fujian. ${ }^{7}$ Folk religion is used as a tool for promoting cohesion with the Taiwanese by local governments in Fujian. More importantly, the belief and cult of Mazu was declared intangible cultural heritage by UNESCO in 2009, and this has provided stronger incentives for promotion of the Mazu cult by Fujian's local governments. Many Mazu temples have been rebuilt and rituals reinitiated as a token of friendship with people from Taiwan. My own observation is that some temples dedicated to other deities that have been rebuilt have added Mazu to their altars. According to my informants, when you have Taiwanese signatures in the petitions, permission to rebuild a temple will be granted faster. The revival of folk religion in Fujian has attracted not only people from Taiwan, but also overseas Chinese from Southeast Asia. ${ }^{8}$

In recent years, many believers from folk-religion temples in China have traveled to Taiwan as well. Some of these temples are the ancestral temples of various deities, including the Warrior God (Guansheng Dijun 關聖帝 君), Madam Linshui (Linshui Furen 臨水夫人), and the Universal Blessing Emperor (Guangze Zunwang 廣澤尊王). These trips are interpreted as visits by the deities to inspect their branch temples in Taiwan. ${ }^{9}$ Some of these trips are also made to learn how to run a temple using modern business methods. Furthermore, numerous academic conferences, seminars, and workshops have been held on both sides of the Strait concerning various relevant issues, such as hagiography, ritual, legend, myths of different deities, architecture, painting, sculpture of different temples, religious tourism, religious economy, and religious politics, etc. These meetings have resulted

4 Chang (2003).

5 Nyitray (1996); Rubinstein (2001); Hatfield (2010).

6 Yang $(2008$, p. 8).

7 Dean (2010); Kuo's chapter in this book.

8 Sangren (2003); DeBernardi (2013).

9 Mio (2003, p. 202); Ting (2012, p. 7). 
in the publication of many proceedings or books, which in turn give rise to more events, and induce more scholars to get involved in the study of folk religion.

\section{A cross-strait Mazu pilgrimage in 2011}

Mayfair Yang has studied the pilgrimage of Dajia Mazu to the Meizhou ancestral temple by ship in July $2000 .{ }^{10}$ In this section I will describe how Xingang 新港 Mazu and her followers took a plane to Fujian to establish a new branch temple at Yongchun County 永春縣. This was an extraordinary event. Usually an old temple establishes a branch temple in a newly developed frontier area. Historically, temples in Taiwan typically received images of deities from places of origin in China, and thereby became branch temples of mother temples in China. Why would a Chinese village accept an image from Taiwan and become a branch temple of a Taiwanese temple?

Originally a local temple in Jiayi County 嘉義縣, Xingang Mazu Temple later emerged as a regional temple by holding annual 'inspection-tour' processions through southern Taiwan. Along with fifteen temple committee members, I escorted two Mazu images, one large (about $180 \mathrm{~cm}$ ) and one small (about $45 \mathrm{~cm}$ ), on a flight from Taipei to Xiamen on 30 December 2011. After a careful inspection by the Xiamen airport customs, we took cars and trucks to Yongchun County. The two Mazu images, received amid the sound of firecrackers, gongs, drums, and other entertainment groups, made an inspection tour around the town, and were finally taken to Chenban Village (陳坂村), which is located in a mountainous area.

Chairman Ho (2008-present) of the Xingang Mazu Temple and other committee members had presented one small Mazu statue and two statues of guardian generals ('Thousand-Miles Eye' and 'With-the-Wind Ear' (qianliyan 千里眼; shunfenger 順風耳) to Chenban Village in 2010. The friendship between Xingang and Chenban started at an academic conference in May 2010, when Professor Chen of the Chinese Academy of Social Science in Beijing came to Xingang to present a paper at the first International Conference on Mazu Culture, which was held by Xingang Mazu Temple. After a week spent observing and enjoying the Mazu culture of Xingang, Professor Chen decided to recommend Xingang Mazu to his hometown, where an existing village temple was dedicated to Daoist Master Zhang (Zhang Tianshi 張天師). A compromise was found to build a new back hall 
for Mazu. Permission for the construction of the new back hall for Mazu was granted by the local government office quickly enough so that the statues that came from Taiwan in 2011 could be housed. Because this is the first Mazu in Yongchun county, she is respectfully called 'Kaiyong Mazu' - the 'first Mazu who helped develop Yongchun' (Kaiyung Mazu 開永媽祖) - by the village people.

A branch temple ranks lower than its mother temple. Why would Yongchun county office approve the construction of a back hall for the installation of Mazu from Xingang? Why would Chenban villagers accept donations and statues from Xingang? Why would this new Mazu in Yongchun be respectfully called 'The first Mazu in Yongchun'? Many local officials basically do not believe in folk religion. They do not care about the inferior or superior status of Mazu images and temples. If building a Mazu hall promotes unity with people from Taiwan, the local officials might even receive appreciation from higher levels of the government. And since the old village temple had lost believers for decades, the villagers did not believe any harm could come from adding a Mazu image. All the money and statues were donated by Xingang, so why not accept them? And in fact, after Mazu was installed in the temple, more villagers and outsiders came to worship, and even Daoist Master Zhang received more worship and donations.

Professor Chen and his mother, who still lives in the village, were invited to be consultants for the Chenban Temple (Chenban gong 陳坂宮). Professor Chen suggested that the new Mazu be taken on an annual inspection tour around Yongchun County in order to protect her new believers. From 2011 to 2016, we observed Kaiyong Mazu inspect her new territory, consisting of the villages of Yongchun County, during the Chinese New Year holiday. Increasing amounts of donations were collected from every village with each passing year. Chenban Temple will be able to distribute rice, oil and clothes to the poor, and set up a scholarship for middle-school students using these donations in 2016. As long as Chenban Temple is doing social welfare work, the local government is inclined to be tolerant of folk religion. Professor Chen told us that he runs the village temple in accordance with the management practices used at Xingang Temple, and is proud of naming the Mazu 'Kaiyong Mazu': 'No one ever heard of Chenban village before. But now, because of this Mazu, people all over Yongchun County welcome our New Year inspection tour and donate money to our temple'.

Why have the people of Xingang donated money and several divine images, and why do many travel to Yongchun every year to teach ritual techniques, management practices, and fiscal skills, and to maintain their relationship with Yongchun? By dividing power and dividing the spirit of 
Mazu with Yongchun, Xingang now sponsors a branch temple in China. In this way, Xingang Temple has increased its rank, as Dajia Temple did in 1988 using different means. The more branch temples one sponsors, the more powerful one's temple is. Most of the small Mazu temples in Taiwan are affiliated with a larger Mazu temple, and the rivalry between temples in Taiwan has nearly reached a deadlock. Ever since 1990, however, the competition among the larger Mazu temples in Taiwan has extended to China. Whichever temple has a stronger China connection and more believers, the higher its rank in the hierarchy of the Mazu cult. A higher rank means the more efficacious power the temple is able to command, and greater ability to attract believers and donations. No temple committee member will publicly admit to this competition, and they instead usually attribute their actions to the power of Mazu. It is Mazu's power that decides the rank of the order. There is nevertheless a strong sense of parochialism among Mazu's believers. If we compare Mazu and the Virgin Mary, we can imagine competition among Our Lady of Fatima, Our Lady of Guadalupe, and Our Lady of Lourdes. The Holy Spirit is personified, localized, and endorsed in conjunction with strong community identity.

Xianliang Harbor 賢良港, in the coastal area of Putian 苯田, Fujian, is Mazu's hometown, and apart from Meizhou Island, Xianliang Temple is the most sacred place for Mazu believers. Descendants of the Lin family still hold a memorial ceremony on the morning of the day of Mazu's death on the seashore at Xianliang Harbor. Members of the Xingang and Chenban temple committees attended the morning ceremony of 23 October 2012 to offer incense and bow to Mazu. In the afternoon, the Xingang and Chenban temple committee members were invited by the Meizhou Temple to offer incense and bow at the same memorial ceremony, but now held on the Shore of Meizhou Island. The members of the Chenban temple committee were invited by the Xingang temple committee members to the Xianliang and Meizhou Mazu temples. To the members of the Chenban temple committee, this was an unexpected honor and an acknowledgement of the status of Chenban Temple. But had there been no recommendation from Xingang, this mountain village temple could not be guest incense-offerer at the Xianliang or Meizhou temple. Likewise, if there had not been the unification promotion policy from the central government of China, Xingang Temple would not have had the prestige to be entertained by Xianliang or Meizhou temple. The Mazu temples at Meizhou Island and Xianliang Harbor can be likened to the imperial court. Mazu was granted the title of 'Empress of Heaven' (tianhou 天后) by the Kangxi Emperor in 1684, and was worshipped by local governors with subsidies from the state every spring and autumn 
afterwards. If one recalls that the celestial hierarchy of Chinese folk religion mirrors the Chinese imperial bureaucracy, ${ }^{11}$ one will understand that Mazu is the eternal-living empress to its believers. While Meizhou Ancestral Temple is the irreplaceable eternal-sacred court that houses the Empress Mazu, Xianliang Temple houses the Empress' parents.

There are thousands of Mazu temples in China, and even the Chinese communist government continues to acknowledge the supreme status of Meizhou Mazu, and seeks to develop the island into a national scenic area welcoming Mazu believers worldwide. Members of both Xingang and Chenban temples were proud of having the opportunity to offer incense and bow at the hitherto restricted ceremony. Thereafter, the believers of Chenban Temple were even more grateful to Xingang Temple. Kaiyong Mazu and the believers of Chenban Temple were invited to visit southern Taiwan in the spring of 2014, and were asked to take part in the Big Offering $(\text { jiao 醮) })^{12}$ of Xingang Temple in December 2015. It was felt that this would enable believers in Taiwan and in Fujian to communicate face to face, and also enhance the two temples' social capital.

\section{One Mazu, multiple political interpretations}

Associations between symbols and objects are arbitrary, conventional, and culturally determined. ${ }^{13}$ To the boat people in Hong Kong, Mazu promised mastery of the seas and protection from storms; to the land elites she symbolized territorial control and social stability. ${ }^{14}$ Mazu was 'Aunt Lin' (Lin gu 林姑) to the residents of Putian and was 'Empress of Heaven' to the state. Nowadays, Mazu symbolizes different things for people in Taiwan and people in China. Most believers in Taiwan venerate Mazu because she was a filial daughter, and she is merciful and responsive. In contrast, the few Mazu believers in China think that Mazu will bring fortune and good luck, otherwise why would the Taiwanese worship Mazu. For the local government of Fujian, Mazu is 'Goddess of Peace of the Taiwan Strait'

11 Wolf (1974, pp. 131-182).

12 Most Daoist scholars define this Big Offering of Daoism as a seeking of cosmic renewal (Saso 1972, p. 36). It is held only by temples, and not by individuals, when a temple has been constructed or renovated, or after a disaster, and expresses gratitude to the temple's deity (Dean 1993, pp. 45-47; Lagerwey 1987, p. 51; Schipper 1974, p. 313).

13 Firth (1975, p. 6o).

14 Watson (1987, p. 294). 
(Haixia Heping Nushen 海峽和平女神. ${ }^{5}$ This politically laden title implies that Fujian has been authorized to have broad links with Taiwan before other provinces.

The believers in Taiwan who escorted Mazu to Meizhou were not necessarily pro-unification, and saw the event simply as a religious pilgrimage. In the words of some believers, 'Mazu came from Fujian and she needs to enhance her power annually! We are settled in Taiwan. My parents and grandparents were born in Taiwan. I am a Taiwanese'. But religious contact will bring cultural and economic communication, and the cult of Mazu is the most mature platform that can be used by the government in Fujian. As a consequence, alliances and coalitions of different Mazu temples on both sides of the Taiwan Strait have been growing steadily since 1987. We can see that the titles of eighteen temples have been carved on the wall of Xianliang Temple. These temples, led by Dajia Temple, made donations for the remodeling of Xianliang Temple. Before the renewal of Xianliang Temple in 2002, every gate, pavilion, hall, room, tower on Meizhou Island that had been renovated in 1980-1990 bore the engraved title of a Taiwanese temple. All these donations and inscriptions are suggestive of the intimate relationships between the temples on both sides of the Taiwan Strait.

It is no secret which Taiwanese temples have alliances with or branch temples in China. Many, including Xingang Temple, are proud of having close relationships with Chinese temples. Another example is Songshang 松山 Mazu Temple in Taipei, which published a new version of its temple brochure in February 2012. In this new brochure, the story of a visit by a prestigious Chinese temple in Xianyou 仙遊, Fujian in August of 2011, receives great emphasis. The Xianyou temple in question is two-hundred years old, and has nine branch temples in Fujian area. It has nevertheless been searching for its ancestral temple for a long time, and finally, on the basis of matching historical tablets, Xianyou temple successfully traced its origin to Songshang Temple. In the pamphlet, the term 'acknowledge one's ancestor and return back to one's lineage' (renzhu gueizung 認祖歸 宗) is used. To celebrate this reunion, in April 2012, Songshang and Xianyou temple jointly visited temples in southern Taiwan to strengthen their relationships with these temples. Many other temples in Taiwan advertise their relationships with Chinese temples. Beigang Temple is allied with Meizhou Temple, and they have called each other sister temples since 1988; Dajia Temple established a branch temple in Macau in 2003, and one in

15 This term was coined around 1984 by some scholars in Fujian, and has finally been accepted by the central government of China. 
Tianjin in 2008. In addition to Yongchun, the Xingang Temple is also allied with a temple in Quanzhou. Lugang Temple in central Taiwan established a branch temple in Shanghai in 2010.

When discussing Chinese nationalism, there exists a certain degree of ambiguity. At the level of the state, the people of Taiwan like to quote the '1992 consensus' (jiuer gongshi 九二共識), which means both sides recognize there is only one China, but agree to differ on its definition. This consensus can also be applied to religious nationalism. For Taiwanese temples, 'to build a branch temple in China denotes to devour, to eat China,' whereas for Chinese temples, 'The Taiwanese have acknowledged us as ancestors and returned to us'. During the 2011 trip to Yongchun, friends and team members said, 'We are triumphantly fighting our way back into China!' Some Dajia pilgrims challenged the legitimacy of Meizhou by saying: 'All the images of Mazu in Meizhou were carved after Cultural Revolution, and they are younger than most of the statues in Taiwan'. These believers opposed going to China to enhance the power of Mazu. Instead, a small number of temples in southern Taiwan rely on shamanism as a localized source of power. For example, a Yunlin Mazu temple claims that their Mazu is Meiyun Lin 林美雲, instead of the traditional Lady Moniang Lin 林默娘.

We can see that complicated feelings arise when Taiwanese believers go to China. Once they have the opportunity to go to Fujian or China, no one refuses to take a look at their place of origin. The sense of being orphaned which some people in Taiwan feel disappears after one has got to know one's roots. ${ }^{16}$ Most believers visit their place of origin in Fujian after they finish their pilgrimage to Meizhou. Nevertheless, more than one hundred years' separation has decreased the emotional attachment, and increased differences in lifestyle. Temple-to-temple interactions can be linked with the production of different levels and types of identity. There exist multilevel and multifaceted forms of identity production, and these identities may be both spiritual and ethnic, as well as local, regional, provincial (Taiwancentered), interprovincial (Taiwan and Fujian), and even international (Taiwan and China) as Rubinstein also has observed. ${ }^{17}$

16 Taiwan was ceded to Japan by the Qing Dynasty and was a Japanese colony from 1895 to 1945, at which time the Japanese surrendered to Chiang Kai-shek's Kuomintang. Taiwanese singer Luo Dayou (羅大佑) dubbed Taiwan 'the orphan of Asia' in one of his most famous songs. 17 Rubinstein (2003, p. 182). 


\section{Community consciousness and temple competition}

Temples of folk religions have been allying as well as competing with each other to survive the political pressure they face in both Taiwan and China. As mentioned earlier, temple committee members of Dajia flew to Meizhou illegally in 1987 without the Taiwan government's permission. For selfprotection and for raising funds to rebuild Meizhou Temple, Dajia Temple organized a temple association called Taiwan Mazu Fellowship (Taiwan Mazu lienyihui 台灣媽祖聯誼會). Its membership increased gradually from eighteen temples in 1990 to sixty temples in 2010. Being the richest temple and having the widest connections in China, for the past twenty and more years, the vice-president of Dajia Temple, Mr Zheng, has won the chairmanship of the Taiwan Mazu Fellowship. Chairman Ho of the Xingang Temple has won the vice-chairmanship of the Taiwan Mazu Fellowship because of his generosity and willingness to serve. Mr Zheng and Mr Ho take turns at leading the Taiwan Mazu Fellowship members to visit China every year. Members of this association are friendly to China and are willing to invest in various items of infrastructure in Meizhou and Fujian.

There is another association organized by Lu-er-men 鹿耳門 Mazu Temples in southern Taiwan called Taiwan Golden Orchid Association of Temples (Taiwan Simiao Jinlanhui 台灣寺廟金蘭會, TGOAT). Membership of this TGOAT is not limited to Mazu temples and has risen to seventy. Their main purpose is in-island oriented social welfare for allied communities and to enhance inter-temple communication. Though a few temples have joined both the Taiwan Mazu Fellowship and the TGOAT, the two temple associations have different political stands. The former is more pro-Chinese nationalism and the latter is pro-Taiwan nationalism. When there are local elections for county mayors or representatives, we can see candidates of Kuomintang (KMT) approaching the Taiwan Mazu Fellowship for support while candidates of the Democratic Progressive Party (DPP) visit the TGOAT.

Temple alliances and competition can be observed in China as well. Adam Chau has shown that in northern China, temples of folk religions are constantly facing threats from the State. One of the strategies is to expand temples' secular functions. 'The temple's functional expansiveness and concerns of legitimacy necessarily draw in social forces beyond the village. These trans-local maneuvers include former inter-village alliances, securing support and protection from local state agencies, attracting media attention, and engaging with cosmopolitan and even foreign non-governmental 
organizations. ${ }^{18}$ In Mazu's case, we see that foreign social forces are from Taiwan and overseas Chinese communities. From Tianjin 天津 in northern China, to Shanghai in central China, to Quenzhou 泉州, Xiamen in Fujian, we see Mazu temples along the coastal China have statues from Taiwan and these are allied with different temples from Taiwan. All of these Mazu temples deliberately lower their status rank by receiving statues and donations from Taiwan to expand their foreign capital.

After securing approval from the Chinese Ministry of Culture 國家文化 部, the Chinese Mazu Cultural Exchange Association (CMCEA, Zhonghua Mazu Wenhua Jiauliou Xiehui 中華媽祖文化交流協會) was organized by the Fujian local government, Meizhou Ancestral Temple and CCP local members in October 2004. CMCEA supervises 150 Mazu temples and organizations in China; its chairman is Mr Zhang Kehui 張克輝, who is a Taiwanese who stayed on in China during the civil war between the Kuomintang and the Communist Party and has been elected as the vicechairman of the CPPCC (Chinese People's Political Consultative Conference 全國政協). ${ }^{19}$ CMCEA has represented the Chinese central government to arrange all possible cultural exchange activities with Taiwan and overseas Chinese communities. These exchange activities between various temples along the coastal cities in China and Taiwan were all approved by CMCEA. Even the Chenban village receiving statues from Xingang in 2010 and 2011 were permitted by CMCEA. I saw a red banner celebrating the alliance with Xingang hung on the wall of the Chenban Temple written by Zhang Kehui during my trip on 30 December 2011.

The cult of Mazu is not one of the five legally recognized religions in China and it is not controlled by the State Administration for Religion Affairs. It is regulated by the Ministry of Culture and the CPPCC. The CCP maintains its control over the rapidly expanding religious and cultural activities of the Mazu cult. CMCEA shares the CCP's enduring efforts to eliminate social and ideological competition. Ashiwa and Wank correctly pointed out that ' $[t]$ he Party eliminates competition by such measures as: co-opting clergy and believers into state-approved religious associations; confining religious activities to such registered sites as churches and temples; recognizing only clergy trained in state-approved seminaries; vetting sermons and monitoring foreign contacts of religions'. ${ }^{20}$ We can notice that the CMCEA is doing exactly the same thing. Putian University 
(Putian Xueyuan 莆田學院) established by the Putian City government is responsible for research and training scholars for the Mazu cult. The Committee Organization of Meizhou Ancestral Temple (Meizhou zumiao dongshihui 涺洲祖廟董事會) is the apex organization and no competition among Mazu temples in China is allowed by the CMCEA.

Knowing that Mazu temples in southern Taiwan and the TGOAT are more pro-Taiwan independence, CMCEA arranged for the statue of Meizhou Ancestral Temple to visit Taiwan and had an inspection tour around Taiwan in January 1997, in an attempt to earn southern Taiwanese' hearts. Unfortunately, CMCEA chose Tainan Big Tianhou Temple (Tainan da tianhou gong 台南大天后宮) to be its host and overruled Dajia, Beigang, or other allied temples. This irritated the allied temples and they refused to receive the Meizhou statue. Public opinion in Taiwan thus accused the Meizhou Temple's visit of being more a political event than a religious tour. Why did CMCEA choose the declining Tainan Big Tianhou Temple instead of other popular temples? Mass media suspected that it was because Tainan Big Tianhou Temple was remodeled from Koxinga's 國姓爺 or 鄭成功 official residence into a Mazu temple by General Shi Lang 施琅 after defeating Koxinga's grandson in 1683 and hence became the state temple in the Qing Dynasty. This officially favored temple bears the memory of Koxinga's failure and humiliation of Taiwan's return to China. Thus, during the onehundred-day tour in Taiwan, wherever the Meizhou statue stopped, there were protest groups. CMCEA or the Chinese Mazu was even more repelled in southern Taiwan.

Meizhou Island and Meizhou Ancestral Temple have been planned and designed by central government to be the only and the best place to host foreign believers and tourists since 1987 . Apart from the political considerations of isolation, and the ease with which it can be quarantined, Meizhou Island was religiously the destination of all pilgrimages for Mazu. Committee members of the Meizhou Ancestral Temple are selected from smaller Mazu temples on the island by throwing divine blocks (zhijiao 撙 笠). On the island there are fourteen smaller Mazu temples that belong to different villages but they are voiceless and are ignored by most visitors. This is deliberately arranged by the Meizhou Administration Bureau (Meizhou zumiao jingqu guanli chu 涺州祖廟景區管理處) to have better control of the island.

Within these state constraints various smaller Mazu temples still manage to thrive. They forge new networks and have activities outside of the state as mentioned earlier. Competition therefore is unavoidable but it is playing underground. Leave alone Quanzhou or Shanghai, just look at Mazu 
temples in Putian City, where we have heard of competition among Meizhou Ancestral Temple, Xianliang Harbor Temple, and the Wenfeng Temple 文 峰宮. The latter two temples dug up all the documents, sediments, cultural relics, and created legends to compete with Meizhou Ancestral Temple and thus attract believers and tourists from Taiwan and Southeast Asia.

Religious tourists coming from abroad need more sightseeing spots apart from Meizhou Ancestral Temple. Airplanes stop at Xiamen or Fuzhou, from where one takes a bus to Putian City and spend hours waiting for the boat to Meizhou. On their way back to the airport, again, some visit Putian City. Taiwanese pilgrims told me that most of the hotels in Putian City were built after 1987 to house hundreds of thousands of pilgrims in the third month of the lunar calendar each year. These pilgrims pay homage to Mazu in the Xianliang Harbor Temple, and the Wenfeng Temple before they continue their trip to Meizhou. I have witnessed a new building coming up in front of the Wenfeng Temple and a new hall behind the Xianliang Harbor Temple in 2012. Chairman Ho of Xingang Temple and we were entertained by these two temples with great hospitality showing that both temples had received large donations from Xingang/Taiwan Mazu Fellowship.

There were many conferences and forums held by the Meizhou Temple since 1987. All the proceedings or publications sponsored by Meizhou Temple favored Meizhou as the birthplace of Mazu. All the scholars and bureaucrats praise Meizhou Temple and no other temple dares to challenge its sacredness. Professor Ye of Fujian Normal University invited several scholars from both sides of the Strait (I was one of them) to conduct an ethnological investigation in Xianliang Harbor in April 2012 and held a conference in Xianliang Harbor in October 2012. This conference was, and had to be, sponsored by Xingang Temple (from Taiwan), or it would not have been permitted. Yet, these two events were initiated by the Xianliang temple committee members and the main purpose was to verify its sacredness: being the birthplace of Mazu. It was the first time temple committee members of the Xianliang Harbor openly gathered scholars of history, folklore, and ethnology to declare the temple's sacredness for them. Retired local cadres of Zhongmen town 忠門鎮 and Gangli village 港裡村 were invited to speak at the conference. They were more than pleased to see their hometown hosting so many scholars and becoming well known to the outside world.

One of the reasons why Xianliang Temple dared to openly hold this international conference, I believe, was the implementation of the Project of the North Shore Economic Development (湄州灣北岸經濟開發區計畫). 
This is a ten-year (2007-2017) project undertaken by the Fujian local state. ${ }^{21}$ The project plans to connect Xianliang harbor with Meizhou Island and build a bridge eventually to link these two areas. This huge project must have given local people confidence to compete with Meizhou Ancestral Temple. On the seashore of Xianliang harbor we saw construction vehicles busy reclaiming land from the sea, villagers were moved to inner-land areas, empty houses were abandoned, and shrines of earth gods were ruined. It is quite ironic that all this construction is for tourists/believers from outside. If there are no foreign worshippers and donations how can villagers sustain this newly built gorgeous Xianliang Harbor Temple?

To promote tourism in Putian city meant to help Xianliang Harbor Temple and Wenfeng Temple become famous, but that would have triggered competition and this obviously was not welcomed by the Fujian government or the state. Scholars of the Putian University were in a dilemma and were under pressure from the Meizhou Administration Bureau. Professor Ye from Fujian Normal University and scholars from Taiwan therefore were requested to strengthen their social forces. Thus, when we discern the relationship between state and religion, we might need to distinguish between local and central government and provincial government from the county office. Different levels of the state administration might have different positions. Furthermore, temple competition might just be superficial, what is deeply involved is community consciousness.

To conclude this section, we explicate that conflicts among Mazu temples in Taiwan mainly focus on which is the oldest temple in Taiwan, meaning which has the highest sacredness (ling 靈or efficacy). In reality, disputes among Mazu temples in Fujian have been mainly about which is the birthplace of Mazu, the accepted validation of sacredness. The logic for competition among temples on both sides of the Strait is about the sacredness or efficacy. But the logic of competition between Taiwan Mazu and Chinese Mazu is about the political legitimacy of unification. This is elaborated in the following sections.

\section{Localized resistance: Xingang Mazu Temple and local factions}

Variations in national identity can also be observed among Mazu temples, and among believers of one temple. Over the past ten years, Chairman

21 North Shore Management Committee (2007, p. 1), Putian Newsletter Editorial Board and North Shore Management Committee, eds. (2008). 
Ho and the committee members of Xingang Mazu Temple have shown enthusiasm for friendship with temples in China, and have developed new alliances in southern Taiwan. The price of this is that they have neglected the benefit of local people, which has given the opposing faction time to make its appearance.

Dr Chen is a well-reputed doctor in Xingang. An NGO organization, the Xingang Cultural Educational Foundation (XCEF), led by Dr Chen has been famous in Taiwan since the 1980s, which was a time when Taiwan was implementing a program of comprehensive community construction. Generally keeping a low profile, Dr Chen has been a public opinion leader in connection with many community projects. Politically speaking, Dr Chen has a strong Taiwanese identity. In Taiwan's political circles, doctors are typically advocators of modernization and democracy. No exception to this general rule, Dr Chen has long striven to create a progressive community from the poor, backward rural Xingang of the past. During the presidency of Chen Shuibian of the DPP, Dr Chen was appointed a state policy advisor. Dr Chen also recommended a performance group to design an event for Xingang Mazu's visit to New York. The DPP had been trying through many channels to secure Taiwan's admission to the United Nations. In 2007, believers from Xingang Temple flew to New York with their Mazu statue and palanquin. While this was nominally for the purpose of making an inspection tour to bless Taiwanese immigrants, the group also went to the headquarters of the UN to support Taiwanese demonstrators. Today, a tablet bearing the inscription 'UN for Taiwan' presented by President Chen Shuibian hangs from the roof of Xingang Temple.

The New York trip of Xingang Mazu was planned by a performance group, Paper Wind Mill Theatre Troupe (Zhifengche jutuan 紙風車劇團) and the Paper Wind Mill Cultural Educational Foundation (紙風車文教基金會), to be scheduled as part of an international cultural event on 15 September 2007 in New York. This project was supported by Chairman Lu of Xingang Temple at that time, and most importantly, by the Executive Yuan, and by President Chen Shuibian, as President Chen visited Xingang Temple to show his gratitude after the group had returned from New York. No doubt, Xingang Temple attracted the attention of the whole island and outweighed Dajia Temple for its boldness. Not only politicians but also Mazu temples were involved in this debate of Taiwanese identity. Mazu temples were forced to take a position on this issue which made the temple competition worse, and which also opened up the political struggle among Mazu temples. The DPP was planning to have a referendum on the issue of admission to the UN (入聯公投) in March 2008, and the DPP knew this 
would imply a change of 'Republic of China' to 'Taiwan'. In other words, Admission to the UN implied Taiwan's independence. This issue became the top debate of the presidential election at the end of December 2007 between the presidential candidate of KMT, Ma Yingjiu, and the candidate of DPP, Xie Changting 謝長廷.

The XCEF was established in 1987 by Dr Chen as a means for local elites to learn local politics and make contact with the government's bureaucratic system up to the central government of Taiwan. The chiefs of Xingang Township over the past twenty years or more were all members of the XCEF, which helped train them in modern political skills. The many projects and branch units run by the XCEF include a library, gallery, theater, and restaurant, and almost every knowledgeable local person has been recruited to hold a post. Xingang Temple is the richest temple in town, and is also supported by the XCEF. With the help of XCEF, Xingang Temple and its surrounding area has resurged from 1990 to be a new tourist spot and famous for its environmental protection..$^{22}$ There is a biweekly meeting of the members of XCEF, and many honorable guests or successful Xingang businessmen are invited from other parts of Taiwan to give talks and to share new information. By playing these roles, the XCEF serves as a pressure group for Xingang Temple and the whole town.

When the KMT instituted local elections for county mayors and representatives in the early 1950s, the KMT needed to work with local elites to win elections. Native politicians filled local factions of the KMT, especially during the presidency of Li Denghui. As a consequence, not just the members of the DPP have a Taiwanese identity, a large number of KMT members also have been localized and have a Taiwanese identity. The difference is that grassroots KMT members may not be pro-Taiwan independence.

Community temples have long comprised a public sphere in traditional Han Taiwanese society, and are still the most efficient organization for public-opinion formation. Both traditional elites and modern politicians commonly try to get involved in temple affairs in order to manipulate local communities. The localization of the KMT began with involvement in local religion. Despite the KMT's official hostility toward popular religion, its local politicians have used religion to build up support. Gradually, the higher levels of the KMT changed their attitude, and recognized that believers can be mobilized to vote. 'Connection' (guanxi 關係) and service are the most important means of getting elected and reelected in local politics. Most 
voters do not vote based on issues or the ideological positions of candidates. Instead, they vote for those who serve them. ${ }^{23}$

Although Chairman Ho of Xingang Temple is a KMT member, he nevertheless accepted Dr Chen and former Chairman Lu's arrangement to visit New York, and he also had Dr Chen's acquiescence for establishment of the branch temple in Yongchun. It was for the benefit of Xingang's development that Dr Chen and other local leaders tolerated Chairman Ho for such a long time. But ten years was long enough to accumulate many complaints. Local elites criticized Ho in these words: 'He didn't care about our feelings. He worked with outside scholars and enterprises too much. We are humiliated when outsiders think there are no talented persons in Xingang'. They disliked Ho's paying more attention to China than to Xingang, and wondered about the benefit to Xingang of constructing a branch temple in Chenban village. What they thought was urgent was to protest the building of an incinerator in Xingang, or to create more investment in Xingang. The Big Offering festival in December 2015 was the first victory for the opposing faction, which successfully replaced some of the temple committee members. And preventing the operation of the World Research Center for Mazu Culture, Fengtian Temple (奉天宮世界媽祖文化研究暨文獻中心) was their second attack. This faction planned to take over the presidency of the temple in 2016 but did not succeed. ${ }^{24}$ Chairman Ho won the election and he told us that the election of Xingang Temple became harder and harder. He had to put in more money and more personnel to run the temple. Friends of the temple are worried that Xingang might follow the step of the expensive election of Dajia Temple. ${ }^{25}$ We can see that, at the local level, all the elites and leading figures are relatives of each other, or are working together. Even when a member of KMT wins an election, he has to work with members of DPP. Resources have to be shared, and posts in the temple or township have to be shared as well.

After the first direct presidential election in 1996, the distance between local and national politics has drawn closer and closer in Taiwan. The very same group of voters can vote for temple chairman, town mayor, legislator, and the president of Taiwan. If the times of the elections for these different posts are close to each other, voters tend to vote for candidates belonging to

23 Bosco (1994, p. 118).

24 There are twenty members in the committee organization of Xingang temple. Some of them are pro-DPP and some are pro-KMT. Election of the temple presidency therefore overlapped and was influenced by local politics.

25 Local faction and gangsters have intervened in the election of Dajia Temple governing committee for the past twenty years (Santos 2007). 
the same faction. Ideological positions concerning unification with China are less clearly differentiated in the case of local KMT and DPP politicians. The benefit they can derive from a faction, the balance between factions, and services received from the candidates are the factors considered most by voters.

\section{Identity politics and new religious nationalism}

That Mazu may venture into political affairs is not a new thing. After the goddess arose from the coastal area of Putian, she was reputed as having helped defeat the northern barbarian army of Jin 金 in 1205. The eunuch General Zheng He 鄭和 of the Ming Dynasty went to Southeast Asia on seven diplomatic missions between 1405 and 1433. Every time he set sail, he first worshipped Mazu at the harbor of Fuzhou to seek a peaceful journey. It was Mazu who helped General Koxinga successfully land on Taiwan and defeat the Dutch at Tainan in 1662, after which he took over Taiwan as his base for fighting the Manchu invaders who founded the Qing Dynasty. Again, it was Mazu who assisted General Shi Lang to overcome the grandson of Koxinga in 1683 and hand over Taiwan to Qing Emperor Kangxi. This was also the reason why Emperor Kangxi granted Mazu the title of 'Empress of Heaven' which was the highest rank of a female deity in Chinese folk religion.

After immigrants from Fujian in China settled in Taiwan during the Qing Dynasty, Mazu was localized in Taiwan. During a battle between the French and Chinese in 1884 in Danshui, the Chinese general Liu Mingchuan 劉銘 傳 sought the blessing of Mazu and won a victory. Lastly, during World War II, Mazu was seen by many believers in southern Taiwan catching bombs with her skirt to save people. Luckily, Mazu has not appeared in the war between the KMT and the CCP after 1949. 'Mazu has no political stand. She protects and blesses whoever has a sincere heart', a believer explained. This provides free space for interpretation. To believers in Taiwan, Mazu is the patron goddess of Taiwan and a symbol of Taiwanese identity. ${ }^{26}$ Mio also argues that Mazu has intensified Taiwan's new nationalism. ${ }^{27}$ To the Fujianese, Taiwanese believers are their descendants, and cultural nationalism trumps political nationalism. 
In some way, Mazu reflects Hokkien cultural identity which in a way transcends both Taiwanese and Chinese identities. ${ }^{28}$ Many Taiwanese have invested in Fujian and lived in Fujian since 1980. The dialect spoken in Xiamen is exactly the same as in Taiwan. There is no gap between living in Xiamen or in Taiwan. Retired scholars moving to Xiamen and teaching in Xiamen University or students pursuing a Ph.D. degree in Xiamen University told us that direct flights make it easier to commune between Taiwan and Xiamen. Taiwanese who live in Kinmen 金門 spend their weekend in Xiamen which is cheaper than Taiwan. The first wave of Taiwan business migrants from 1980 to 1990 is now accompanied by highly educated elites who have attained Ph.D. degrees from Western universities. To these people, cultural and religious identities are far more realistic than political identity.

Mazu was mobilized to influence Taiwan's 2016 presidential election. A new giant statue of Mazu was consecrated in the main hall of Xianliang Temple on 31 December 2015. As many as 500 temples in Taiwan, Singapore, and Indonesia, etc. were invited to partake in the awesome ceremony. Twenty-seven statues of Mazu from Taiwan were brought back to receive worship in Xianliang Temple. 'This is an old trick Chinese Mazu temples will play whenever Taiwan holds an election', commented members of DPP in Xingang. To members of KMT '[t]his is an event to be celebrated'. It turned out that the DPP won the presidential election in 2016 and froze the official communication with China. Cross-strait policy moved backward to that of 2007. Many of the pro-KMT temples complained this new policy caused them trouble because the Chinese temples resumed the hostility upon them. They wonder if the pro-DPP Mazu temples will in any way assist the DPP to strengthen the Taiwan independent policy just as they did in 2007. Will new religious nationalism in Taiwan beat old Chinese cultural nationalism? Under the DPP regime we might anticipate stronger resistance and more boycotts to Chinese temples, but the result is hard to foretell.

\section{Conclusions}

The relationships between state and religion are far more complicated than just seeing their antagonism or conflict. Multiple actors and political processes need to be examined. ${ }^{29}$ In this chapter, I have shown that KMT or DPP have different attitudes toward Chinese Mazu, resulting in their 
involvement in different groups of Mazu temples, and different degrees of communication with Chinese temples. I also have revealed that the CMECA is the agent of the Chinese central state, and CMECA is consistent with Meizhou Administration Bureau in developing Meizhou Island into the homeland of Mazu believers from around the world. But the Fujian provincial government welcomes foreign religious tourists to visit Xiamen, Quanzhou or other Mazu temples. Putian City and Putian University have a different planning for Xianliang Harbor and its future.

Politics within the state are unavoidable, just as competition within Mazu temples. Debates among politicians and bureaucrats over the interpretation of the Mazu cult and its application to cross-strait relations occur in Taiwan and in China. To worship a Chinese Mazu symbolizes unification with China. The religious mirror reflection of the political system reminds people that Chinese Mazu tour-inspecting Taiwan in 1997, under the acquiescence of the KMT, denoted Chinese political leader tour-inspecting Taiwan. In order to balance the symbolic unification function of Mazu, the DDP and its agent, Xingang Temple, in 2007, carried a Mazu statue and joined the demonstration in front of the building of the United Nations, New York, to quest for Taiwan's independence.

Competition among Mazu temples used to dispute on the orthodox/ legitimacy of the history. After 1987, cross-strait relation has made the competition more complex. Competition within Taiwan has been extended to China. Pro-KMT temples try to ally with Chinese temples in different cities to uphold its status in Taiwan. Pro-DPP temples try to collaborate with each other to resist forces from China. Still, some temples will change their political preferences from KMT to DPP or vice versa. Xingang is one of these temples. Chairman Ho of Xingang Temple has changed the temple's political position from pro-independent to pro-unification. He is the vicechairman of the Taiwan Mazu Fellowship which has deep relations with Chinese temples. Nevertheless, he is facing more and more pressure from the local faction.

After the Cold War, ideology has no longer defined the difference between East and West. To most Taiwanese, the vital issue regarding China and Taiwan may not be the choice of unification or independence, or even economic development, but rather the difference in lifestyle and tastes. Taiwanese complain that Chinese tourists create noise and chaos wherever they stop. Chinese tourists don't follow traffic rules or maintain orderly conduct in public spaces. Chinese tourists haggle about everything they buy. Taiwanese merchants in China complain that bribery is necessary for the local Chinese government to get things done, as well as in hospitals if one 
wishes to receive decent medical treatment. Taiwanese pilgrims complain that Chinese worship Mazu without sincerity, have no accurate knowledge of ritual or liturgy, and all the Mazu images in China are too new and young.

Although, at the central-government level, there may be a debate concerning unification and independence, at the local-community level, when we look at the traditional public sphere, the community temple, Mazu is used as a symbol of peaceful unification across the Taiwan Strait, which is juxtaposed with a symbol of Taiwanese identity. We also see that local politicians are involved in the temple affairs and use temples as election resources, where believers are mobilized and transformed into voters. The very same Mazu temple can be at one time pro-unification, and at another time pro-independence. Because local KMT politicians and DPP politicians are interrelated and intertwined when it comes to temple affairs, they each take turns electing the president of the temple committee. Local community temples have thereby become a basic unit of local politics in Taiwan.

The ancestor veneration and temple-based deity cults of Taiwan's traditional popular religion inevitably have a different performance from those of their original places of origin in Fujian. After rapid political liberalization, economic expansion, modernization, and urbanization since 1987 , there are new forms of religious expression, and these have been accompanied by the spread of island-wide deity cults and politicization of temple organizations. Whereas the power of popular religion is often used as a symbolic lever in debates concerning 'Chinese' and 'Taiwanese' identity, ${ }^{30}$ Taiwanese identity is not necessarily equated with Taiwan independence. In Taiwan, the older generation is politically as well as religiously committed to the identification of Taiwanese and Chinese culture, while the younger generation has exclusively a Taiwanese identity. They are working on narrating the uniqueness of Taiwanese culture and religion.

The situation has been changing rapidly in the past two years. In the legislative election of 2016, a new political party, the New Power Party (shidai liliang 時代力量) organized by the younger generation won five seats in the Legislative Yuan. This new party helped the DPP win the presidential election in 2016. After DPP has regained its regime, for the next four years, we foresee more pro-independent young people trying to participate in the public sphere and to join the election to public office. 


\section{Bibliography}

Ashiwa, Yoshiko and David L. Wank, eds. 2009. Making Religion, Making the State: The Politics of Religion in Modern China. Stanford, CA: Stanford University Press.

Bosco, Joseph. 1994. 'Taiwan factions: guanxi, patronage, and the state in local politics'. In Murray A. Rubinstein, ed. The Other Taiwan: 1945 to the Present. New York, NY: M.E. Sharpe, pp. 114-144.

Chang, Hsun 張珣. 2003. Wenhua Mazu 文化媽祖(Constructing Mazu: Selected Papers on the Mazu Cult). Taipei: Institute of Ethnology, Academia Sinica.

Chang, Hsun 張珣. 2013. Cong Minjian Xinyang yu Defang Chanye kan Guojia yu Defang de Guanxi 從民間信仰與地方產業看國家與地方的關係: 以新港奉 天宮為例 ('State policy and local cultural industry: a case study of Xingang Fengtian Temple in Taiwan'). In Chang, Hsun 張珣 ed. Hanren Minzhong Zongjiao Yanjiu: Tianye yu Lilun de Jiehe 漢人民眾宗教研究:田野與理論的結 合 (Chinese Popular Religion: Linking Fieldwork and Theory). Taipei: Institute of Ethnology, Academia Sinica, pp. 115-16o.

Chau, Adam Yuet. 2009. 'Expanding the space of popular religion: local temple activism and the politics of legitimation in contemporary rural China.' In Ashiwa Yoshiko and David L. Wank, eds. Making Religion, Making the State. Stanford, CA: Stanford University Press, pp. 211-240.

Chen, Jian 陳劍. 2012. Zhonghua Mazu Wenhua Jiauliou Xiehui chenli zi 中華媽 祖文化交流協會成立記 ('The establishment of the Chinese Mazu Cultural Exchange Association). In Pengfei Yang 楊鵬飛 ed. Mazu Wenhua Sanshihnian 媽祖文化三十年 (Thirty Years of Mazu Culture). Fuzhou: Strait Art and Literature Publishing Company, pp. 92-95.

Clart, Philip, and Charles B. Jones, eds. 2003. Religion in Modern Taiwan. Honolulu, HI: University of Hawai'i Press.

Dean, Kenneth. 1993. Taoist Ritual and Popular Cults of South-EastChina.Princeton, NJ: Princeton University Press.

Dean, Kenneth. 2010. 'The return visits of overseas Chinese to ancestral villages in Putian, Fujian'. In Tim Oakes and D. Sutton, eds. Faiths on Display: Religion, Tourism, and the Chinese State. Lanham, MD: Rowman \& Littlefield Publishers, Inc., pp. 235-264.

DeBernardi, Jean. 2013. 'A northern god in the south: Xuantian Shangdi in Singapore'. In Hsun Chang, ed. Chinese Popular Religion: Linking Fieldwork and Theory. Taipei: Academia Sinica, pp. 49-72.

Firth, Raymond. 1975. Symbols: Public and Private. Ithaca, NY: Cornell University Press.

Goossaert, Vincent and David A. Palmer. 2011. The Religious Question in Modern China. Chicago, IL: The University of Chicago Press. 
Hatfield, D.J.W. 2010. Taiwanese Pilgrimage to China: Ritual, Complicity, Community. New York, NY: Palgrave MacMillan.

Jordan, David. 1994. 'Changes in postwar Taiwan and their impact on the popular practice of religion'. In Stevan Harrell and Huang Chun-chieh, eds. Cultural Change in Postwar Taiwan. Taipei: SMC Publishing INC, pp.137-160.

Katz, Paul, and M.A. Rubinstein, eds. 2003. Religion and the Formation of Taiwanese Identities. New York, NY: Palgrave.

Lagerwey, John. 1987. Taoist Ritual in Chinese Society and History. New York, NY: MacMillan Publishing Company.

Mio, Yoko 三尾裕子. 2003. Cong Liangan Mazumiao de Jiaoliu Laitan Taiwan de MinzuZhuyi 從兩岸媽祖廟的交流來談臺灣的民族主義 ('Taiwanese nationalism: Contact between Mazu temples across the Taiwan Strait'). In Mei-rong Lin and Hsun Chang 林美容、張珣, eds. Mazu Xinyang de Fazhan yu Bianqian 媽 祖信仰的發展與變遷 (Development and Changes of the Mazu Cult). Taipei: Taiwan Association for Religious Studies, pp. 193-204.

Nadeau, Randall, and Hsun Chang. 2003. 'Gods, ghosts and ancestors: religious studies and the question of "Taiwanese identity". In Philip Clart and Charles B. Jones, eds. Religion in Modern Taiwan. Honolulu, HI: University of Hawai'i Press, pp. 280-300.

North Shore Management Committee 福建省莆田市沸州灣北岸經濟開發區管 委會 ed. 2007. Touzi Zhinan 投資指南 ('Investment Guide'). Putian: Municipal Committee.

Nyitray, Vivian-Lee. 1996. 'The sea goddess and the goddess of democracy'. In Arvind Sharma and K.K. Young, eds. The Annual Review of Women in World religion, vol. IV. Albany, N.Y.: State University of New York Press, pp. 164-177.

Putian Newsletter Editorial Board and North Shore Management Committee 莆 田通訊編輯部, 北岸開發區綜合辦公室, eds. 2008. Meizhouwan Bei'an Jingji Kaifaqu 湄州灣北岸經濟開發區. Putian: Municipal Committee.

Rubinstein, Murry. 2001. 'Returning to roots, seeking the mediated center, and redefining traditions: Charting responses to modernity in Taiwan's religious community since the lifting of Martial Law'. In Taiwan Studies Promotion Committee of Academia Sinica, ed. Changes of An Authoritarian Regime: Taiwan in the Post-Martial Law Era. Taipei: Institute of Taiwan History, Academia Sinica, pp. 277-318.

Rubinstein, Murry. 2003. “Medium/message” in Taiwan's Mazu cult centers: using "time, space, and word" to foster island wide spiritual consciousness and local, regional, and national forms of institutional identity'. In Paul Katz and M.A. Rubinstein, eds. Religion and the Formation of Taiwanese Identities. New York, NY: Palgrave, pp. 181-218. 
Sangren, P. Steven. 1988. 'History and rhetoric of legitimacy: the Matsu cult of Taiwan'. Comparative Studies in Society and History, 30(4): 674-697.

Sangren, P. Steven. 2003. 'Anthropology and identity politics in Taiwan: The relevance of local religion'. In Paul Katz and M.A. Rubinstein, eds. Religion and The Formation of Taiwanese Identities. New York, NY: Palgrave, pp. 253-288.

Santos, Percival. 2007. 'Inventing the public enemy: the gangster in Taiwanese society, 1991-2006'. Ph.D. thesis. Anthropology Department. London School of Economic and Political Science. University of London.

Saso, Michael. 1972. Taoism and the Rite of Cosmic Renewal. Seattle, WA: Washington State University Press.

Schipper, Kristofer. 1974. 'The written memorial in Taoist ceremonies'. In Arthur P. Wolf, ed. Religion and Ritual in Chinese Society. Stanford, CA: Stanford University Press, pp. 309-324.

Ting, Jen-Chieh 丁仁傑. 2012. Guangzezunwang You Taiwan: Hanren Minjianxinyang Shenming Jiexujiegou yu Zhanyan 廣澤尊王遊臺灣: 漢人民間信仰神 明階序結構與展演 ('The inspection tour of Lord of Guangze in Taiwan: ritual performance and hierarchic structure of Chinese Deities').Min-Shu-Qu-Yi 民 俗曲藝 (Journal of Chinese Ritual, Theatre and Folklore), 177, pp. 1-61.

Watson, James. 1987. 'Standardizing the Gods: The Promotion of Tien Hou along the South China Coast'. In David Johnson, ed. Popular Culture in Late Imperial China. Berkeley, CA: University of California Press, pp. 292-324.

Wolf, Arthur. 1974. Religion and Ritual in Chinese Society. Stanford, CA: Stanford University Press.

Wolf, Arthur. 1974. 'Gods, ghosts, and ancestors'. In Arthur P. Wolf, ed. Religion and Ritual in Chinese Society. Stanford, CA: Stanford University Press, pp. 131-182.

Yang, Mayfair Mei-hui. 2004. 'Goddess across the Taiwan Strait: matrifocal ritual space, nation-state, and satellite television footprints'. Public Culture, 16(2): 209-238.

Yang, Mayfair Mei-hui. 20o8. 'Introduction'. In Mayfair Mei-hui Yang, ed. Chinese Religiosities: Afflictions of Modernity and State Formation. Berkeley, CA: University of California Press, pp. 1-40.

\section{About the author}

Chang, Hsun. Research Fellow of Cultural Anthropology, Institute of Ethnology, Academia Sinica, Taiwan.

Email: etch@gate.sinica.edu.tw 


\title{
14 Salvation and Rights in Hong Kong
}

\author{
Mariske Westendorp
}

\begin{abstract}
This chapter details narratives of individual Hong Kong Buddhists and their motivations for spiritual and/or activist engagement during the 2014 Umbrella Movement. I argue that religion as expressed by Buddhists indicates political engagement to be more about future salvation and personal considerations of how to act as 'good' Buddhists than about the relationship between religion and politics, and. From this main argument follow two observations. First, individual motivations for political engagement are engendered by personal perceptions which are not always compatible with official religious doctrines. Second, by emphasizing the links between various political struggles, events such as the Umbrella Movement take on an extra dimension, in this case reaching beyond the specific context of Hong Kong.
\end{abstract}

Keywords: Hong Kong Umbrella Movement, engaged Buddhism, civic engagement, salvation

\section{Introduction}

On Monday 22 September 2014, the Hong Kong Federation of Students (HKFS) and Scholarism organized a class boycott which was attended by students of different Hong Kong universities. The boycott was organized in response to the announcement of the National People's Congress Standing Committee (NPCSC) on 31 August, regarding the method of election of the Chief Executive (CE) of Hong Kong in 2017. Hong Kongese students were dissatisfied with the proposed method of the NPCSC, regarding it as advocating 'fake democracy' as it ensured only delegates approved by the Chinese Communist Party (CCP) could stand for election. Instead, the students demanded 'universal suffrage'. The following Friday, the students, forming a group of young pro-democracy activists 'who, unlike their predecessors, had little or no experience of a Hong Kong under colonial rule' gathered near the eastern entrance of the Central Government Offices in Admiralty (Hong 
Kong Island). ${ }^{1}$ The same evening, while trying to 'reclaim' the recently privatized Civic Square by climbing over its fences, they were surrounded by policemen. Early Saturday morning, and throughout the rest of that day, police used pepper spray and other forms of violence in an attempt to clear the site. Many activists were arrested, including Joshua Wong, the 17-year old Scholarism student leader. Tensions intensified, resulting in the police using more pepper spray and tear gas. The reaction to the perceived police force 'brutality' was intense, and resulted in many Hong Kongers joining the students in protest from that Saturday onwards. ${ }^{2}$ On Sunday 28 September, the Occupy Central with Love and Peace Movement (OCLP) also moved in support of the students. Together with the students they led the Umbrella Movement, named after the umbrellas used by protesters to ward off pepper spray.

The Umbrella Movement lasted 79 days, from 28 September to 15 December 2014. During the Movement, three areas of Hong Kong were occupied: Admiralty, the main occupation site; Causeway Bay, the off-shoot of Admiralty; and Mong Kok, often described as the lawless' occupation site, where the leaders of HKFS, Scholarism, and OCLP had no leadership and where power was in the hands of the people. It is estimated that approximately 1.2 million people took part in the protests at various times and in different forms, an astonishing number in a city of 7.2 million residents. ${ }^{3}$ Finally on 15 December, the Umbrella 'revolution' ended peacefully, albeit without concrete solutions, winners or any breakthroughs in the debate surrounding universal suffrage.

The 2014 Hong Kong Umbrella Movement was, most definitely, a historical incident, which brought particular issues in the Hong Kong Special Administrative Region (HKSAR) into sharp focus. At the basis of the Umbrella Movement was the ongoing debate surrounding the socioeconomic and political relationship between the HKSAR and the People's Republic of China (PRC) post-1997 Handover. This relationship is shaped by the 'one

\footnotetext{
$1 \quad$ Cheung (2015, p. 100).

2 Prior to the event, the Hong Kong police force was seen as a peaceful and stable form of modern governmentalism essential to the economic prosperity of the city (Constable, 2009). The only occasion in which the Hong Kong police had exercised strong physical force was during the 2006 anti-World Trade Organization protests when Korean farmers demanding free trade clashed violently with the police. However, the violence in those protests was directed towards the Koreans, not towards Hong Kong's own people. The violence used in September 2014 signaled for the residents of the city that the police and, by extension, the Hong Kong Government had turned against the Hong Kong populace (Kuah-Pearce, 2009).
}

3 Hui (2015, p. 111). 
country, two systems' policy (yiguo liangzhi一國兩制), a policy promising the HKSAR its own judicial, economic, social, and political systems, and a continuation of its capitalist way of life for at least 50 years until 2047. Regardless of the promises made in this policy, many local Hong Kongers feel the definite threat of an increasing encroachment of mainland China on their everyday lives through migration and tourism, investments, and political measures. The threat they feel formed the basis for the emergence of different localist groups and the Umbrella Movement.

\section{Politics and religion}

Although in essence the Umbrella Movement was a political movement, mainly joined by members of Hong Kong's middle class seeking universal suffrage, other narratives were present as well, both in the occupied areas as in other places. These were for instance the narratives of religious believers. Paying attention to these narratives indirectly highlights an aspect of Hong Kong life that is often overlooked or perceived to be irrelevant; i.e. the importance of religion in the everyday lives of Hong Kong middle-class residents. The relevance of religion is often overlooked in research into Hong Kong society. In the introduction to a recent special edition of Asian Anthropology, Chiara Formichi and Paul O'Connor note that:

Much scholarship has examined the Singapore and Malaysia contexts as laboratories par excellence of the multi-religious, multi-ethnic state, and due to recent tensions, Myanmar has been gaining increased attention; yet Hong Kong has remained at the margins, being generally perceived as having a rather homogenous population, for which religion plays hardly any role. ${ }^{4}$

This chapter is an attempt to correct this bias. As I will argue, religion informs the daily lives and experiences of many Hong Kongers. It also shapes their aspirations, both religious and non-religious. An examination of religion in the Umbrella Movement clearly indicates the porous boundaries between religion and seemingly 'secular' politics.

In addition, this chapter adds to the debate on state and religion in China, a growing topic amongst social scientists specialized in the country. Many studies concerning the Chinese state and religion regard these two subjects 
as dichotomous categories, operating separately and often in conflict with each other. ${ }^{5}$ However, as I argue in this chapter, the contemporary relation between the Chinese state and religion was not the main factor determining spiritual or activist engagement during the Hong Kong Umbrella Movement. Instead, it was the ideas regarding salvation, engagement, and rights of individuals. This case study indicates that religion is just as much an individual conduct, not always situated in the public domains of politics and/or religious institutions. ${ }^{6}$ Instead, it concerns individual actors who transcend the debate on state and religion through their individual considerations.

I elaborate on this argument by focusing on the civic engagement of Hong Kong Buddhist individuals during the Umbrella Movement, and by analyzing their theological and political responses to the Movement. Narratives of these Buddhist individuals were collected during fieldwork research in Hong Kong in the years prior to the Umbrella Movement (from July 2012 to July 2013, and March to August 2014), and via social media during the Movement. In my opinion, the Umbrella Movement not only occupied the streets of urban Hong Kong, but likewise occupied different (social) media and the conversations I had via these media with my Hong Kong informants. A scrutiny of different media channels during the Umbrella Movement, and continued conversations with my informants via WhatsApp, Facebook, and email afforded me insights into their religious reflections on the Movement and their levels of civic engagements, either actively or spiritually. In the highly digitalized city of Hong Kong, this research method proved extremely valuable.

The narratives presented are of individual Buddhist practitioners who do not necessarily feel represented by, nor represent a particular Buddhist organization or school. However, most of them do feel primarily attracted to Theravāda Buddhism. They attend dharma teachings and meditation classes organized by international Buddhist masters, mostly Theravādin. ${ }^{7}$ Moreover, most of my informants describe Buddhism as being a 'modern' religion, characterized by a wish to recover the original Buddhist tradition

5 Ashiwa \& Wank (2009).

6 Asad (2003).

7 In contemporary Hong Kong, as in virtually all Chinese contexts, Mahāyāna Buddhism (mainly Pure Land, but also Chan and Taintai) is the most popular form of Buddhism practiced. Theravāda Buddhism is the least popular. Although Theravāda Buddhism is the least popular stream of Buddhism practiced in Hong Kong, it is gaining popularity among the younger generation of Hong Kong Buddhists (Yeung and Chow, 2010). It has also become the most popular form of Buddhism among the Hong Kong middle class. 
as a reaction to 'the dominant problems and questions of modernity'. ${ }^{8} \mathrm{I}$ elaborate further on this in the next section.

In response to the outbreak of the Umbrella Movement and the rise of localism, these Buddhist individuals referred to personal religious values and notions to explain why and how they participated in the Movement as 'good' Buddhists. What their different narratives highlight is a preoccupation with not only questions of localism and politics, but also with questions of belonging and salvation. The encroachment of the PRC on everyday life in the HKSAR has given rise to a deeply felt perception among my informants that their Hong Kong identity is under threat. However, this was not the only meaning attributed to the Movement. The ways in which the threat was interpreted and the subsequent ways in which my informants have responded to the Hong Kong Umbrella Movement are in many and important ways related to their personal religious ideas and ideals. Some went out into the streets when circumstances allowed, some joined social media discussions, and others decided to stay away entirely, choosing inaction or private meditation as forms of civic engagement. By combining the fight for civic values, e.g. democracy and universal suffrage, with religious values the line between the religious and the secular has become blurred.

In the first part of this chapter, focus is on the civic engagement of Hong Kong Buddhist organizations during the Umbrella Movement. According to Hao Zhidong et al., civic engagement is composed of two parts: social services and civic activism. ${ }^{9}$ Below, I focus on the civic activism of Hong Kong Buddhist organizations and leaders during the Umbrella Movement which included 'such activities as protest rallies, demonstrations, and declarations of positions on various social and political issues'. ${ }^{10}$ In the second and most prominent section of this chapter, I detail the narratives of my Buddhist informants and their individual motivations for civic engagement. In this section, I define civic engagement as 'the ways in which citizens participate in the life of a community in order to improve conditions for others or to help shape the community's future'." I demonstrate two ways in which my informants became civically engaged with the Umbrella Movement; i.e. through spiritual engagement and/or through activist engagement. For them, the different positions of Buddhism in the PRC and the HKSAR are

o Ibid., p. $5^{0 .}$ 
not as important as for organizations; instead, their narratives highlight their attachment to perceived Buddhist notions of salvation.

Setting up this chapter in this two-tiered manner allows me to bring to the fore two interesting observations. First, I will indicate that individual motivations for participating in the Umbrella Movement were engendered by individual perceptions pertinent to the concept of salvation, a concept which is not always compatible with official doctrines dispensed by religious leaders (although they are in part shaped by them). Regardless of the teachings of Buddhist organizations and leaders, individuals often express their own perceptions of what should take priority within their faith and how to be a 'good' Buddhist. In many cases, Buddhist individuals choose their own trajectories. Second, by emphasizing the links between the Hong Kong Umbrella Movement and other iconic Buddhist struggles fought in other countries during different times, the Movement took on an extra dimension as a way of aspiring to societal and eventually personal salvation beyond the specific context of Hong Kong and its relation to the PRC. It was viewed as one of a host of other Buddhist movements, aspiring to the creation of just and equal societies. Knowledge of these companion uprisings made my informants reflect more actively upon salvation and enlightenment at very personal levels. As such, the Movement not only transcended the artificial boundaries between the religious and the secular, but also transcended temporality and spatiality. It became a Movement reflecting a larger temporal and spatial dimension than it might appear to have had at first sight.

\section{Modern Hong Kong Buddhism and salvation}

As Kuo (see Introduction, this volume) argues, the emerging civil society of Hong Kong is mainly constructed by Christian leaders and intellectuals. An increasing number of Hong Kong's Christians belong to an elite group that has been active in Hong Kong's political life from the early twentieth century onwards. These Christians are the ones that want to preserve the status quo in post-Handover Hong Kong, and are therefore most politically active. $^{12}$ In the next section of this chapter, I give some examples to support these arguments. During the Umbrella Movement, many Christian organizations and leaders were actively supporting the students and in some cases even fighting for universal suffrage themselves. In contrast, 
Buddhist organizations and leaders were less present during the Movement, perhaps because they are known to 'tilt more towards Chinese patriotism'. ${ }^{13}$ For this reason, studying the motivations for civic engagement of Buddhist individuals more prominently highlights the relationship between religion, politics, and belonging on personal levels.

As indicated, what characterizes most of the Buddhists I interviewed is a personal attraction to a 'modern Buddhism'. In this modern form of Buddhism various aspects of the religion are demythologized, psychologized, and rationalized, making it better adjusted to a 'modern' lifestyle. ${ }^{14}$ Other characteristics of modern Buddhism are: being more socially engaged, less ritualistic and hierarchical, and more focused on the individual instead of the deified Buddha. These features are reflected in the increasing importance attached to the role of the laity in modern Buddhist practices. ${ }^{15}$ Personal experience has become central. The aspiration to reach enlightenment is no longer merely associated with monastic vocation, but can equally be aspired to by the laity. There is also a heavy emphasis placed on the practice of meditation by the laity, which was originally only a practice of the clergy. ${ }^{16}$ Commenting on 'Reformist Buddhism' in contemporary Singapore, Kuah-Pearce Khun Eng concludes that members of a new generation of local Chinese Buddhists in the city

are not only interested in the functional aspects of religion, but rather are intent on seeking solutions to their individualized religious needs and personalized spiritual fulfilment. As with other modern religious trends, they see their religious needs as personal, no longer tied to religious needs of their families or community. ${ }^{17}$

As a result of these modern trends, the distance between clerical and lay Buddhists has become less; egalitarianism between the two has increased. It should therefore come as no surprise that many of my informants picture Buddhism as an individually practiced religion, highlighting their individual commitment to it, and their own responsibility to act as 'good' Buddhists. These notions feature in the narratives of most of my informants, also with 
regards to their individual motivations for civic engagement during the Umbrella Movement.

The main focus in this chapter is on my Buddhist informants' personal notions regarding salvation. Ideas of salvation (and damnation) feature prominently in most religions, including Buddhism. Salvation forms a central doctrine of this religion, stated in authoritative documents, describing ideas of a Nirvāna that can be accessed through the eradication of suffering. Rachel McCleary considers the effects of religious participation and beliefs on economic growth. She argues that

[s]alvation is a spiritual goal that may or may not be attained through human effort. If people believe in the possibility of salvation through their own efforts, it makes sense that they are likely to perform the actions that contribute to attaining such an end. Therefore, religious beliefs have implications for behavior, such as work effort, saving, and charity. ${ }^{18}$

This quote highlights the links between personal action and the aspiration to reach salvation. This link is also clearly visible in the narratives of my informants. However, contrary to McCleary (who has explored economic behavior) I look at the civically engaged behavior performed by my informants in response to the political Umbrella Movement.

Ideas centered on salvation feature prominently in the religious narratives of my informants: through living a spiritual life and sanctifying one's actions in the here and now (thus living as 'good' Buddhists), my informants aspire to attain salvation in the (near) future. As I will argue, their ideas are not necessarily the same as defined by religious doctrines, institutions, and leaders. Therefore, instead of focusing on the practices that my Buddhist informants should be performing and the beliefs they should observe according to doctrines or theologies, my focus in this chapter is on the practices they actually perform and, primarily, the beliefs and notions they actually hold. ${ }^{19}$ These beliefs and notions do not necessarily follow the particular doctrine prescribed by Buddhist leaders or texts, but are historically and culturally contextualized. Because all religion is lived, it is fluid and creative; and, by extension, it is adjustable to particular socioeconomic, political, and personal circumstances. ${ }^{20}$ 


\section{Buddhist presence in the Umbrella Movement}

In early November 2014, Winston, a Buddhist in his early 30s, sent me a message via WhatsApp. ${ }^{21}$ I had been in contact with Winston throughout the whole period during which the Umbrella Movement took place, reflecting on the daily happenings in the streets (he never joined them, but he read many articles online and heard stories from friends) and debating which steps should be taken next. Winston sent me the following message:

See the mess that Occupy has made. They're stuffed, they have no bargaining power left and they are fighting among themselves. It's because they had no spiritual guidance. Social activists fall into this trap of thinking that their cause is the highest one. They get burned out and bitter. Religious guidance helps them to see the longer term, and the bigger picture. $^{22}$

I found Winston's message remarkable, given that although he is Buddhist, he had never before mentioned the significance of religion for and in the protests. His words further intrigued me, as they alluded to the visible absence of Buddhist spiritual guidance in the streets. In Hong Kong, Buddhist masters are overall not directly involved with political activities, nor do they directly adhere to specific Buddhist political theologies. In fact, Buddhist presence from all Buddhist schools was mostly absent during the Umbrella Movement.

During the initial weeks of the Umbrella Movement, media were quick to emphasize the religious aspects of the protests, both the religious symbols present 'on the ground' and those that were absent from the occupied sites. English-language media sources of Hong Kong news providers and international sources mainly placed emphasis on the presence of (Protestant) Christian groups and leaders, and on the support churches provided to the protestors. Mention was made of how some churches opened their doors to protesters and police alike, offering first aid, snacks, and water, refuge, or simply a place for people to go to the bathroom. Other sources indicated the presence of prayer groups, crosses, and people reading their Bibles in the occupied areas. ${ }^{23}$ Particular attention was paid to Christian leaders, both

21 To ensure anonymity, I use pseudonyms throughout this chapter.

22 Personal communication via WhatsApp, Winston, 8 November 2014.

23 Sources: (1) Sarah Eekhoff Zylstra (13 October 2014). Hong Kong Christians Lead Protests for Democracy. Christianity Online. See http://www.christianitytoday.com/ct/2014/ 
clerical leaders of Christian groups and lay Christian leaders of different protest groups. For example, sources mentioned that the Occupy Central with Love and Peace Movement was led by, amongst others, Benny Tai, a committed Christian, and Reverend Chu Yiuming of the Chai Wan Baptist Church. And the student organization Scholarism is led by Joshua Wong, an evangelical Christian who had attended a Protestant private school and the United Christian College.

Emphasis was also placed on the position adopted by some Christian clergy members; for example, on the outspoken Catholic Cardinal Zen, who had supported the fight for democracy from its earliest moments (but later changed his position slightly). The media also singled out Anglican Archbishop Paul Kwong, who was heavily criticized following a sermon he delivered in early July 2014, in which he urged Anglicans to remain silent, just as Jesus remained silent when awaiting his crucifixion, like a lamb awaiting slaughter in silence.. ${ }^{24}$ The spotlight likewise fell on certain Protestant ministers, e.g. the Reverend Tin Yau Yuen of the Methodist Church who, in an open letter which he wrote in October 2014, seemed to suggest that the Christian faith supports the fight for democracy. He stated: 'The gospel we believe in is necessarily related to social and political issues. It's impossible to be politically neutral, as who can have no political view?'25

Only few English media sources noted the responses of Buddhist organizations and leaders in the protests. Reference was made to Buddhist symbols seen in the streets, the building of makeshift Buddhist shrines at the protest

october-web-only/hong-kong-christians-lead-protests-for-democracy-china-html. (2) JackJenkins (12 October 2014). Why Christians are Helping Lead Hong Kong's Pro-Democracy Movement. Think Progress. See http://thinkprogress.org/world/2014/10/12/3579154/why-christians-arehelping-lead-hong-kongs-pro-democracy-movement/. (3) Ned Levin (3 October 2014). Hong Kong Democracy Protests Carry a Christian Mission for Some. Wall Street Journal. See http://www.wsj. com/articles/hong-kong-democracy-protests-carry-a-christian-mission-for-some-1412255663. 24 The official explanation provided by the Reverend Peter Koon (Provincial Secretary General of the Hong Kong Anglican Church) was that Kwong was merely 'trying to remind fellow Christians of the church's role as a "facilitator of peace"'. Sources: (1) Oiwan Lam (12 July 2014). Hong Kong's Anglican Archbishop Says Pro-Democracy Protesters Should be Like Jesus and Keep Quiet. Global Voices Online. See http://globalvoicesonline.org/2014/07/12/hong-kongs-archbishop-tellsdemocracy-protesters-to-keep-quiet/. (2) Ernest Kao (9July 2014). Archbishop's Sermon on Occupy Central was 'Taken Out of Context'. Church says Controversial Remarks on Occupy were Meant as Humor, Not a Public Statement. South China Morning Post. See www.scmp.com/news/hong-kong/ article/1550314/church-defends-reverend-paul-kwong-who-told-pro-democracy-residents.

25 Source: Reverend Tin Yau Yuen (10 June 2014). Pastoral Letter From the President, Reverend Tin Yau Yuen to the Methodist Congregations of Hong Kong: A Church at Crossroads. Methodist Congregations of Hong Kong. See http://www.methodist.org.hk/media/filehotlink/2014/10/o6/ Pastoral_Letter_to_MCHK_congregationsEng.pdf. 
sites, and the gathering of Buddhists in occupied areas. ${ }^{26}$ Buddhist monks volunteered as first-aid workers, or wrote articles to express their concern about the protests. Nevertheless, as these media articles showed, these Buddhist efforts were minimal compared to the Christian presence. It could be argued that the relative absence of commentaries on Buddhist symbols during the Movement might be an artifact of the English languages sources writing about the protests. However, my Buddhist informants told me the same: there was almost no Buddhist presence in the streets. Moreover, in early October 2014, the Hong Kong Buddhist Association released an official statement which advocated 'that Buddhists and students at Buddhist schools should avoid the protest locations and nearby areas (and likewise exhort their friends and children to do so)'. ${ }^{27}$

Multiple reasons may be given for the apparent difference in the level of civic activism between Hong Kong Buddhist and Christian organizations during the Umbrella Movement. A first explanation is based upon the historical legacy of both religions. Buddhism and Christianity have different foundations in Hong Kong society. Both developed differently in relation to the political and social situation on the Chinese mainland, and in relation to the British colonial government. For example, feeling threatened by the rise of communism in mainland China, the British colonial government sought ways to promote Christian education in Hong Kong. This education was thought to raise people that could resist communism..$^{28}$ Therefore, Christianity was favored by the British as an ally in the fight against Chinese communism - more so than non-Christian or 'Chinese' religions, e.g. Buddhism. ${ }^{29}$ As a result, Christian organizations (mainly Catholic and Anglican) were encouraged to provide education and other social services. They had the opportunity to become important, elite institutions in Hong Kong, a position they still hold in the city today. This legacy is amongst others visible in the contemporary social service sector of Hong Kong. In the school year 2008-2009, 23 of Hong Kong's 458 secondary schools were

26 Source: Jennifer Ngo (27 October 2014). Religion on the Front Line Puts Faith into Practice: Christians, in Pursuing Equality and Justice, Have Long Been Part of the City's Fight For Freedom. South China Morning Post. See http://www.scmp.com/news/hong-kong/article/1625126/ religion-occupy-central-front-line-puts-faith-practice?page=all.

27 Source: Buddhistdoor (24 October 2014). Unattached Involvement: Expressing Socially Engaged Buddhism. Buddhistdoor Global. See http://www.buddhistdoor.net/features/ buddhistdoor-view-unattached-involvement.

28 Esler (2015).

29 Leung \& Chan (2003). 
Buddhist, approximately $5 \%$ of all the schools in Hong Kong..$^{30}$ While this may seem significant, it pales in comparison to the services (mainly educational) provided by the Hong Kong Catholic Church and Catholic missionary organizations. At the end of the twentieth century, $35 \%$ of all social services in Hong Kong were still provided by Catholic organizations. As of 2014, the Catholic Church ran 264 schools with over 165,000 students, six hospitals, and thirteen clinics. ${ }^{31}$

A second reason for the difference in the presence of Buddhist and Christian symbols and leadership during the Umbrella Movement is the position that both religions hold in the contemporary PRC. As several of my informants stressed, ideas regarding the freedom of religion are critical here. For example, a professor I met at Hong Kong University - after I told him that I was interested in learning more about Buddhist and Christian engagement in Hong Kong's political life - said that in the 'one country, two systems' policy, Buddhism, Daoism, and Confucianism emphasize the 'one country' part, whereas Christianity in Hong Kong mainly emphasizes 'two systems'. ${ }^{22}$ Similar assumptions were made by media sources, some of whom suggested that Buddhist organizations appear to be relatively satisfied with the status quo of Buddhism in the PRC and with recent attempts by the CCP to promote 'Chinese religions' such as Buddhism and Daoism. ${ }^{33}$ Most media sources argued that for these reasons, Hong Kong Buddhist organizations kept a low profile during the 2014 Umbrella Movement. In the same light, some media sources suggested that for Christian groups, the protests were not merely about attaining universal suffrage; they were more a way of expressing anxiety vis-à-vis Communist infiltration in Hong Kong's society, and the likely decrease in religious freedom in the city. One news report for instance observed that 'the protests now roiling in Hong Kong are about democracy. But there is an undercurrent of another, much older tension: between Christianity and Communist China' (see also the chapter of Tsai on the tensions between Christianity and the state in the PRC, this volume). ${ }^{34}$

\footnotetext{
30 Yeung \& Chow (2010, p. 6).

31 Catholic Truth Society (2013, p. 667).

32 Personal communication, professor, HKU, 7 September 2012.

33 Source: Shai Oster (25 October 2014). How Smashed Jesus Shrine Reveals Christian Undercurrent to Hong Kong Protests. Bloomberg. See http://www.bloomberg.com/news/print/2014-10-28/ christians-lead-h-k-protests-in-test-of-china-s-control.html.

34 Source: Ned Levin (3 October 2014). Hong Kong Democracy Protests Carry a Christian Mission for Some. Wall Street Journal. See http://www.wsj.com/articles/ hong-kong-democracy-protests-carry-a-christian-mission-for-some-1412255663.
} 
If one looks beyond politics in the PRC and in the HKSAR one can discern different reasons underpinning the absence of Buddhism in the Hong Kong Umbrella Movement. One reason has its genesis in the ways religion is organized in Hong Kong. In Hong Kong today, official Buddhist leadership is exercised by the Hong Kong Buddhist Association. Founded in 1945, the Association is

an umbrella body based on individual, voluntary membership rather than temple or sect affiliation. Its members tend to be of the Mahayana, or Daai Sing, northern tradition, and include Taiwanese and Japanese sects whose members have Hong Kong resident status, but have less affinity with Tibetan and Nepali traditions. HKBA, in addition to representing Buddhists locally, enjoys membership in the World Fellowship of Buddhists. ${ }^{35}$

Even though on paper the Hong Kong Buddhist Association is the overarching Buddhist organization in Hong Kong, only a small minority of Hong Kong Buddhist organizations are affiliated to it. Moreover, the fact that this Buddhist Association has no political organ makes it hard for it to express a strong activist voice.

In contrast, an important and strong organization within the Hong Kong Catholic Diocese is the Justice and Peace Commission. This Commission was established in 1977 to increase the Church's participation in social actions and to promote civic participation among Hong Kong's lay Catholics..$^{36}$ In early October 2014, the Justice and Peace Commission issued an official statement on behalf of the Hong Kong Catholic Diocese, calling for dialogue and reconciliation between different parties involved in the Umbrella Movement. Public prayer meetings were organized during the Movement by the Commission, some for the purpose of promoting democracy, others to promote dialogue and peace.

Another factor determining Hong Kong Buddhist organizations' presence or absence during the Umbrella Movement relates to local religious leadership. As I wrote earlier, the Hong Kong Buddhist Association issued a statement in early October 2014 urging Buddhists not to become involved in the protests. Consequently, no Buddhist clergy of the Hong Kong Buddhist Association was seen in the streets. However, even though officially the Hong Kong Buddhist Association was not so much involved with the protests, at local levels, nor in individuals' appreciation of the visibility 
of their religious leaders, the picture was slightly different. Leaders of local Buddhist organizations made personal decisions whether to join the protests or not. One example is the newly appointed abbot of a temple in Tsuen Wan, who maintained that 'a monk should be involved with social work, not political'. He did, however, explain the difficulty underpinning this decision: 'When I talk about politics, they say I'm a political monk. If I don't, they think I don't care about social issues. That's a dilemma'. His personal solution is to focus on and teach the dharma, rather than touching on issues of political concern.$^{37}$ However, some Buddhist monks in Hong Kong chose to do otherwise. Francis, a Theravāda lay Buddhist in his mid-40s, made mention of a Buddhist monk who actively commented on the protests on Facebook, based on his observations and experiences in the streets. While Francis appreciated the monk's engagement, his friends scorned the monk for being too attached and for not seeing clearly the impermanence of the situation. ${ }^{38}$

Regardless of the teachings of the Buddhist organizations and leaders mentioned above, my informants' perceptions of what should take priority within their faith, and how to be a 'good' Buddhist are mostly based on personal considerations. Individual believers do not always follow the actions of faith leaders. In many cases, they choose their own trajectories. In the rest of this chapter, I focus on this by presenting and analyzing some narratives of my informants. Even though I present only a handful of these narratives, they are representative of far more Buddhist individuals I spoke to. By focusing on their ideas regarding salvation, I will show that it was not only the reasons stated above (the ways in which Buddhism is organized in Hong Kong and the position its holds with regard to politics in the HKSAR and the PRC) that were of relevance to my informants' motivations for civic engagement: their decisions were also made on the basis of personal considerations.

\section{Individual motivations for civic engagement}

Nearly a month after the Hong Kong Umbrella Movement started, the editors of the Internet organization Buddhistdoor commented on the following: 
In Hong Kong, the question is whether Buddhists could have had more of a presence in the streets - not to support a particular side, but to bridge the physical and ideological divide between opposing parties. (...) Maybe Buddhist temples and charities could have set up tents and booths where protesters and police alike could enjoy refreshments for free. When the scuffles and brawls broke out, perhaps Buddhists could have been present to physically protect belligerents from one another, without worrying how others might react to their mediation. Another powerful statement might have been to hold a meditation 'flash mob'. ${ }^{39}$

In their article, the editors attempted to discuss how Hong Kong Buddhists might respond to the protests in a Buddhist manner, especially considering - as indicated above - the absence of visible Buddhist leadership in the streets. They posed the following question: 'Can Buddhists be socially engaged while remaining ideologically and emotionally unattached?'40

For my Buddhist informants, their individual decision to join the protests or not was less colored by the example set by Buddhist organizations and leaders, probably because the latter were distinguished by their absence. For example, Adam, a Buddhist in his early 40s, said, after I asked him in the final weeks of the Umbrella Movement if he thought that Buddhist leaders in Hong Kong could have done more, that they should have promoted: 'COMPASSION! COMPASSION! COMPASSION!'41

The individual reflections on the Umbrella Movement resulted in different manners of civic engagement. Teresa, a Buddhist in her late 3os, opted not to join the Umbrella Movement. Her reasoning was that when it comes to fulfilling one's aspirations, personal effort will be more effective than economic or political involvement. She wrote: 'Buddhist teaching is about how to be mindful and achieve physical, psychological and mental peace by evaluating our thinking process'. ${ }^{42}$ Eventually, becoming mindful will lead to a change in the environment. In effect, Teresa was saying that "when one's mind becomes purified, society will also be purified'. ${ }^{43}$

In contrast to Teresa, Francis, the Buddhist in his mid-40s, engaged more actively in the Umbrella Movement, being guided by spiritual engagement.

39 Source: Buddhistdoor (24 October 2014). Unattached Involvement: Expressing Socially Engaged Buddhism. Buddhistdoor Global. See http://www.buddhistdoor.net/features/ buddhistdoor-view-unattached-involvement.

40 Ibid.

41 Personal communication via email, Adam, 22 November 2014.

42 Personal communication via email, Teresa, 22 November 2014.

43 Cho (2000, p. 77). 
In early October 2014, Francis actively began using his Facebook account again after nearly two years of relative silence. He started by changing his profile picture into the picture of a yellow ribbon. When I questioned him about his reappearance on the social media platform, he replied:

I try only to share articles which are written by people who hold mild opinions or express their feelings, but not any 'reports' or 'facts', as you can't be sure what is true or false. (...) As a Buddhist, we are told to be aware of how we use our words: we should try not to spread any information we are not sure about in order to avoid others being influenced by our words. (... ) We can voice our own opinion, but should not be spreading uncertain information. ${ }^{44}$

By using Facebook as a medium, Francis expressed his engagement with the protests in a manner he saw justified by Buddhist doctrines. His engagement could lead to the elimination of societal obstacles (often called 'defilements') derived from the three poisons of desire, hatred and ignorance..$^{45}$ Although Francis did not directly attempt to eliminate desire, hatred or ignorance, he steadfastly avoided spreading information that might feed these root causes. By doing this, he related spirituality to activist engagement. $\mathrm{He}$ also indirectly related his engagement to the ideals of 'engaged Buddhism'.

'Engaged Buddhism' is an academic category that alludes to the teachings of particular Buddhist teachers in Asian and non-Asian countries, of all different Buddhist schools. Through advocating particular teachings and practices, engaged Buddhist leaders seek to achieve 'a stable order and a just society, seen as necessary or prior conditions for the discovery of genuine freedom (or awakening) by each person' ${ }^{4}{ }^{6}$ According to this definition, a just society is seen as a prerequisite for reaching salvation. This can be achieved through offering social services and/or being politically active. Even though the movement of engaged Buddhism is not as well-developed in Hong Kong as in other Asian countries, its ideologies have played a significant part in the ways in which my informants responded to the Umbrella Movement, either actively or spiritually.

In many countries in Asia today, Buddhist organizations and leaders adhere to the values of engaged Buddhism. Even though 'socially and politically engaged Buddhism continues to grow and diversify in Asia and 
the West, [and] continues to challenge conventional assumptions about the nature and direction of Buddhism', ${ }^{47}$ it is at the same time 'too diverse to be considered a single movement, and still too new to have developed a theoretical framework for Buddhism's engagement with contemporary issues' ${ }^{48}$ The teachings of engaged Buddhist masters are often a 'response to a grave crisis facing the country, such as war, invasion, deep poverty, ecological crisis, or human rights abuse'. ${ }^{49}$ By responding to such crises in an engaged and nonviolent manner, particular Buddhist masters highlight the relevance of Buddhist teachings for the modern world..$^{5}$ Included among renowned Buddhist leaders who adhere to these engaged Buddhist values are the Vietnamese master Thich Nhat Hanh, His Holiness the Dalai Lama of Tibet, Cambodian monk Maha Ghosananda, Dr. Ahangamage Tudor Ariyaratne in Sri Lanka and Taiwanese nun Cheng-yen, the foundress of the charitable Tzu Chi Foundation. ${ }^{51}$ Among lay practitioners are the Thai activist Sulak Sivaraksa, and Burmese politician Aung San Suu Kyi, a noted Buddhist lay person who is often seen acting out the ideals of engaged Buddhism. ${ }^{52}$

Being an academic category, 'engaged Buddhism' entails many different aspects, and is somewhat controversial. For example, some scholars and Buddhist leaders consider social services and political activism to be traditional components of the Buddhist religion, while others argue that Buddhist spirituality is separate from civic activism. ${ }^{53}$ Another issue regards salvation, and the question of whether suffering is the consequence of individual tendencies to cling to the self which can only be eradicated through personal liberation, ${ }^{54}$ or whether it can in part be collective and caused by the state and other social institutes. ${ }^{55} \mathrm{~A}$ last point of discussion regards the actual practices that need to be undertaken to eliminate, or at least reduce, individual and/or collective suffering. For Buddhist monk Maha Ghosananda, one way of becoming spiritually engaged in the conflict in Cambodia was to organize meditative 'peace walks'. Ghosananda recognized 'the need for inner peace to create social peace and [suggested] the use

49 King (2012, p. 196); see also Truong (1998/2000).

50 King (2005).

$5^{1}$ Bond (2003); Huang (2003); Park (2010); Weiner (2003).

$5^{2}$ Henry (2006); Kittel (2011).

53 For a good discussion on this debate, see Queen (2003); Yarnall (2003).

54 Deitrick (2003).

55 Cho (200o); Hershock (1999). 
of Buddhist meditation to reach this goal' $5^{6}$ For him, mental purification forms the basis for reaching salvation. On the other hand, in response to the 2011 Occupy Wall Street Movement, American Zen teacher Lewis Richmond offered his reflections on the question of how Buddhists should respond to the protests. ${ }^{57}$ While some of his Buddhist friends instructed occupiers to emphasize non-violence, compassion, and meditation, Lewis expressed a more active approach. He argued for a true awakening, one similar to the awakening that Prince Gautama experienced when he left his palace and was confronted with the 'four sightings' (the old, the poor, the sick, and the dying). His awakening was not based on meditation ('Gautama, after all, was not schooled in meditation when he experienced the four sightings') but on anger. Thus, emphasis on anger, and consequent civic activist engagement, might lead people to gain positive merit, as 'performing morally good deeds with the right intention earns the individual karmic merit necessary for movement toward nirvana'. ${ }^{8}$

Consciously or unconsciously, my Hong Kong Buddhist informants relate in important ways to these discussions concerning engaged Buddhism. Most of them express a wish to reduce suffering (both individual suffering and the suffering in society), attain happiness in the 'here and now' (reflected in Thich Nhat Hahn's famous quote: 'happiness is here and now') and eventually reach enlightenment. Salvation is an aspiration that needs to be reached individually. However, opinions differ as to how this should be done: through focusing on individual salvation or by attempting to reduce suffering in society.

This was most prominent in the narrative of Adam, the Theravāda Buddhist in his early 4os. Adam is one of my few Buddhist informants who actively went to the occupied areas to show his support. In an interview in 2012, he said: 'I hope the philosophy of Buddhism can be applied in Hong Kong. The world would be a lot lovelier'. ${ }^{59}$ With this statement, he clearly expressed his wish for being engaged, not only with himself but with society. Adam grew up without a religious belief. He went to school and university, and got himself a good job at a local airline company. For many years, he was 'rushing and running' to earn enough money to be able to have a luxurious lifestyle, to own an apartment, to drive around in his own car,

56 Weiner (2003, p. 116).

57 Source: Lewis Richmond (16 November 2011). Occupy Buddha: Reflections on Occupy Wall Street. Huffington Post. See http://www.huffingtonpost.com/lewis-richmond/occupyBuddha_b_1114139.html.

58 McCleary (2007, p. 55), original emphasis.

59 Interview, Adam, Thai restaurant, Tai Mei Tuk, 19 January 2012. 
and to wear fashionable clothes. Then, through an alumni event at his previous university, he came into contact with Buddhism. This changed his outlook on life. He no longer only focused on securing a luxurious material lifestyle for himself, but became concerned with the welfare of others. He quit his job and went to Malawi, to work in a Buddhist orphanage. Upon returning to Hong Kong, he started working in a newly constructed Buddhist monastery in the New Territories. In his own words, Buddhism showed him happiness, and it is this happiness that he hopes every Hong Kong resident can experience.

Nevertheless, in June 2014, before the Umbrella Movement had actually started, when I pressed him further on the actual engagement he desired from Buddhist leaders, he rhetorically asked:

What did the Buddha do 2,6oo years ago, when his kingdom was overtaken by other rulers? He didn't say they should fight; he didn't do anything. And what about Thich Nhat Hanh and the Dalai Lama? They don't fight. When Thich Nhat Hanh was expelled from his country, he didn't fight his way back in..$^{60}$

Perhaps paradoxically, Adam did join the occupation. For him, it is important to always try to find the middle path. Both physically fighting and not engaging are reflections of choosing sides. For Adam, choosing the middle path, that is, not becoming attached to an opinion or side in the debate, is an important condition of his aspiration to salvation. In his response to my questions, he mentioned other Buddhist leaders - the Buddha himself, Thich Nhat Hanh, and the Dalai Lama - who, in his eyes, expressed similar ways of engagement.

Similar to Adam, Emily, a Buddhist in her mid-3os, explicitly placed her response to the Umbrella Movement in the broader context of Buddhist teachings vis-à-vis struggles over social justice, in effect implicitly relating the Umbrella Movement to the ideals of engaged Buddhism. Initially, Emily supported the Movement, especially in the first days, right after the police violence had taken place. On Sunday 28 September, she tried to go out into the streets at night, but could not get further than Admiralty station. During the weeks that followed, her attitude changed as a result of the increasing violence occurring in the streets. In mid-October, she indicated via WhatsApp that she wanted to take a break from the restless environment and protests. She said: 'We need to learn how to manifest 
democracy in a peaceful way'. I asked her if staying away from the protests was not an act too passive in the struggle for universal suffrage. 'Not really', she answered, 'Buddhist noble silence is the most powerful [method]. Think about Thich Nhat Hanh and his sangha: how did they react to the Vietnamese Government? ${ }^{\text {6i }}$ Similar to Adam, by emphasizing the links between the Hong Kong Umbrella Movement and other iconic struggles fought in other countries during different times, the Movement took on an extra dimension for Emily as a way of aspiring to societal and eventually personal salvation that reaches beyond the specific context of Hong Kong.

Emily and Adam mentioned the struggles fought by the Dalai Lama and by Thich Nhat Hanh. While the Dalai Lama has never visited Hong Kong due to political reasons, Thich Nhat Hanh travels to the region once every few years, attracting crowds of almost 10,00o people for his public speeches. In conversations with other informants, other Buddhist leaders were mentioned as well. Some referenced the progressive Australian Theravāda monk Ajam Brahn, who advocates nuns' rights in the sangha, or the Sri Lankan monk Ariyaratne's emphasis on non-violence. Being closely situated to Taiwan, most of my Buddhist informants spoke highly of the Buddhist nun Cheng Yen, foundress of the charitable organization Tzu Chi, and some of them looked to the civic engagement of this movement during the 2014 Sunflower Movement in Taiwan for guidance. By relating to these and other Buddhist leaders and movements, my informants signified their personal engagement as part of the larger movement of engaged Buddhism and related their struggles as Buddhists to other historical struggles, e.g. in Sri Lanka, Tibet, Taiwan, or Vietnam. As such, their engagements transcended the specific locale of Hong Kong and reached beyond Hong Kong and China.

\section{Conclusion}

In this chapter, I showed how my informants engaged with the Umbrella Movement in a variety of spiritually and actively engaged ways. While some went to the protest sites, others stayed at home to meditate. Again others decided to disengage from the protests altogether. While different in terms of civic engagement, there is significant similarity in these narratives regarding the perception of how to act as 'good' Buddhists. Taken together, all of these personal narratives are related to religious notions of salvation: being spiritually or actively engaged or disengaged will lead to a reduction

61 Personal communication via WhatsApp, Emily, September-October 2014. 
of suffering and, by extension, will bring people a step closer to reaching Nirvāna.

Based on the individual narratives presented above, I argue that religion as expressed by my Buddhist informants indicates civic engagement in politics to be not so much an issue of the relationship between religion and politics, but more about future salvation and personal responsibilities to act as 'good' Buddhists. For my informants, the Umbrella Movement was not solely a sociopolitical movement aimed at achieving universal suffrage and keeping the HKSAR a politically and economically unique city within the PRC. Equally important were the ideals of engaged Buddhism that were indirectly highlighted, and that developed alongside and in response to other religious movements and institutions in both mainland China and globally.

My Buddhist informants' reflections on the Umbrella Movement revealed that their decisions to engage in the Movement were related to commitments made on an individual basis. While some Buddhists found it important to actively or spiritually engage with the protests, and to try to bring an open mindset to the movement, others used similar arguments to not get involved, and to not worsen the polarities already rife in Hong Kong society. Even though Buddhist motivations were all based on the same religion, my informants all expressed different answers and subsequent outcomes, indicating the diversity of the religion and, more specifically, the plurality of (engaged) Buddhism.

This shows that although informed by disciplinary and historical religious decrees, aspirations to salvation are primarily personal. Individuals need not necessarily follow the same political practices as those advanced by the religious organizations to which they belong, nor of the religious leaders representing them. In effect, while many individuals are undoubtedly influenced by religious structures and leadership, they make decisions based on personal considerations and choices. This is most apparent in cases where the authority of religious leaders and organizations is fragmented, such as in the case of Buddhism.

It also attests that the Umbrella Movement was not merely a local movement sparked by context-specific politico-economic factors. Instead, the narratives surrounding the Umbrella Movement were related to larger temporal religious movements taking place in different times and regions. This can be compared to Kuo's argument that, influenced by social gospel agenda and 'public theology' (following American Christian fundamentalism of the 1980s), Christian leaders started to promote 'public theology' post-1997, by commenting on social, economic, and political policies in 
both Hong Kong and the PRC, much to the annoyance of the CCP. For my Buddhist informants, international norms have come to play a role in the Umbrella Movement as well, although less present. For them, these larger temporal movements were initiated by renowned engaged Buddhist leaders of various Buddhist schools; for example, Thich Nhat Hanh and the Dalai Lama. Consequently, for them the Umbrella Movement extended beyond the spatial boundaries of the HKSAR and the PRC, and beyond the temporal dimension of the Movement.

\section{Bibliography}

Adler, Richard and Judy Goggin. 2005. 'What do we Mean by "Civic Engagement"?' Journal of Transformative Education, 3(3): 236-353.

Asad, Talal. 2003. Formations of the Secular: Christianity, Islam, Modernity. California, CA: Stanford University Press.

Ashiwa, Yoshiko and David Wank. 2009. Making Religion, Making the State: The Politics of Religion in Modern China. Stanford, CA: Stanford University Press.

Bond, George. 2003. 'Sarvodaya Shramadana's Quest for Peace'. In Christopher Queen, Charles Prebish and Damien Keown, eds. Action Dharma: New Studies in Engaged Buddhism. London: RoutledgeCurzon, pp. 128-135.

Catholic Truth Society. 2013. Hong Kong Catholic Church Directory 2014. Hong Kong: Catholic Truth Society.

Cheung, Alvin. 2015. 'Melancholy in Hong Kong'. World Policy Journal, 31(4): 97-106. Constable, Nicole. 2009. 'Migrant Workers and the Many States of Protest in Hong Kong'. Critical Asian Studies, 41(1): 143-164.

Cho, Sungtaek. 200o. 'Selflessness: Toward a Buddhist Vision of Social Justice'. Journal of Buddhist Ethics, 7: 76-85.

Deitrick, James. 2003. 'Engaged Buddhist Ethics: Mistaking the Boat for the Shore'. In Christopher Queen, Charles Prebish and Damien Keown, eds. Action Dharma: New Studies in Engaged Buddhism. London: RoutledgeCurzon, pp. 252-269.

Esler, Joshua. 2015. 'Transcendence and the Mundane at the Edge of the Middle Kingdom: Protestantised and Pragmatic Tibetan Buddhism in Hong Kong'. In David Kim, ed. Religious Transformation in Modern Asia: A Transnational Movement. Leiden: Brill, pp. 3-25.

Formichi, Chiara and Paul O'Connor. 2015. 'Introduction: Overlooked Religions in Hong Kong'. Asian Anthropology, 14(1): 3-7.

Gombrich, Richard. 1988/2006. Theravāda Buddhism: A Social History from Ancient Benares to Modern Colombo. London: Routledge. 
Hao, Zhidong, Shun Chan, Wen-ban Kuo, Yik Tam \& Ming Jing. 2014. 'Catholicism and Its Civic Engagement: Case Studies of the Catholic Church in Hong Kong, Macau, Taipei, and Shanghai'. Review of Religion and Chinese Society, 1(1): 48-77. Henry, Phil. 2006. 'The Sociological Implications for Contemporary Buddhism in the United Kingdom: Socially Engaged Buddhism, a Case Study'. Journal of Buddhist Ethics, 13: 1-43.

Hershock, Peter. 1999. 'Changing the Way Society Changes: Transposing Social Activism into a Dramatic Key'. Journal of Buddhist Ethics, 6:154-181.

Huang, Julia. 2003. 'The Buddhist Tzu-Chi Foundation of Taiwan'. In Christopher Queen, Charles Prebish and Damien Keown, eds. Action Dharma: New Studies in Engaged Buddhism. London: RoutledgeCurzon, pp. 136-153.

Hui, Victoria. 2015. 'Hong Kong's Umbrella Movement: The Protests and Beyond'. Journal of Democracy, 26(2): 111-121.

King, Sallie. 2005. Being Benevolence: The Social Ethics of Engaged Buddhism. Honolulu, HI: University of Hawai'i Press.

King, Sallie. 2012. 'Socially Engaged Buddhism.' In David McMahan, ed. Buddhism in the Modern World. London: Routledge, pp. 195-213.

Kittel, Laura. 2011. 'Healing Heart and Mind: The Pursuit of Human Rights in Engaged Buddhism as Exemplified by Aung San Suu Kyi and the Dalai Lama'. International Journal of Human Rights, 15(6): 905-925.

Kuah-Pearce, Khun Eng. 2003/2009. State, Society and Religious Engineering: Towards a Reformist Buddhism in Singapore. 2nd ed. Singapore: Institute of Southeast Asian Studies.

Kuah-Pearce, Khun Eng. 2009. 'Defining Hong Kong as an Emerging Protest Space: The Anti-Globalization Movement'. In Khun Eng Kuah-Pearce and Gilles Guiheux, eds. Social Movements in China and Hong Kong: The Expansion of Protest Space. Amsterdam: Amsterdam University Press, pp. 91-115.

Leung, Beatrice and Shun-hing Chan. 2003. Changing Church and State Relations in Hong Kong, 1950-2000. Hong Kong: Hong Kong University Press.

Li, Kitman, Ka-hing Cheung and Kun-sun Chan. 1998. 'The Social Role of Catholics in Hong Kong Society'. Social Compass, 45(4): 513-531.

Lopez Jr., Donald. 2002. 'Introduction'. In Donald Lopez Jr. ed. A Modern Buddhist Bible: Essential Readings from East and West. Boston, MA: Beacon Press, pp. vii-xli.

Mak, Bill. 2012. 'Theravāda Teachings and Buddhist Meditation Training in Hong Kong'. International Journal for the Study of Humanistic Buddhism, 3: 19-38.

McCleary, Rachel. 2007. 'Salvation, Damnation, and Economic Incentives'.Journal of Contemporary Religion, 22(1): 49-74.

McGuire, Meredith. 2008. Lived Religion: Faith and Practice in Everyday Life. Oxford: Oxford University Press. 
McMahan, David. 2008. The Making of Buddhist Modernism. Oxford: Oxford University Press.

Nedilsky, Lida. 2009. 'Institutionalizing the Representation of Religious Minorities in Post-1997 Hong Kong'. In Siu-keung Cheung, Joseph Lee and Lida Nedilsky, eds. Marginalization in China: Recasting Minority Politics. New York, NY: Palgrave Macmillan, pp. 211-235.

Nedilsky, Lida. 2014. Converts to Civil Society: Christianity and Political Culture in Contemporary Hong Kong. Waco, TX: Baylor University Press.

Orsi, Robert. 2005. Between Heaven and Earth: The Religious Worlds People Make and the Scholars Who Study Them. Princeton, NJ: Princeton University Press.

Park, Pori. 2010. 'New Visions for Engaged Buddhism: The Jung to Society and the Indra's Net Community Movement in Contemporary Korea'. Contemporary Buddhism: An Interdisciplinary Journal, 11(1): 27-46.

Queen, Christopher. 2003. 'Introduction: From Altruism to Activism'. In Christopher Queen, Charles Prebish and Damien Keown, eds. Action Dharma: New Studies in Engaged Buddhism. London: RoutledgeCurzon, pp. 1-35.

Smith, Carl. 2005 [1985]. Chinese Christians: Elites, Middlemen, and the Church in Hong Kong. Hong Kong: Hong Kong University Press.

Swearer, Donald. 1995/2010. The Buddhist World of Southeast Asia, 2nd ed. Albany, NY: State University of New York Press.

Truong, Thanh-dam. 1998/2000. "Asian” Values and the Heart of Understanding: A Buddhist View'. In Josiane Cauquelin, Paul Lim and Birgit Mayer-König, eds. Asian Values: An Encounter with Diversity, and ed. Richmond, state: Curzon, pp. 43-69.

Wang, Yun Ray. 2016. 'Hong Kong Christianity and National Identity: From Civilizing, to Civilize, and to Re-Civilization'. Paper presented at New Religious Nationalism in Chinese Societies, Leiden (Netherlands), April 21-22, 2016.

Weiner, Matthew. 2003. 'Maha Ghosananda as a Contemplative Social Activist'. In Christopher Queen, Charles Prebish and Damien Keown, eds. Action Dharma: New Studies in Engaged Buddhism. London: RoutledgeCurzon, pp. 110-127.

Yarnall, Thomas. 2003. 'Engaged Buddhism New and Improved? Made in the USA of Asian Materials'. In Christophr Queen, Charles Prebish and Damien Keown, eds. Action Dharma:New Studies in Engaged Buddhism. London: RoutledgeCurzon, pp. 286-344.

Yeung, Gustav and Wai-yin Chow. 2010. 'To Take Up your own Responsibility: The Religiosity of Buddhist Adolescents in Hong Kong'. International Journal of Children's Spirituality, 15(1): 5-23. 


\section{About the author}

Westendorp, Mariske. Ph.D. in Religion in Chinese Urban Society, Department of Cultural Anthropology and Development Studies, Radboud University Nijmegen, the Netherlands.

Email: m.westendorp@ftr.ru.nl 



\section{Index}

All-under-heaven 22, 202-205, 209, 212-213, 216, 218,223

Bailian jiao (白蓮教) 22

Baire weixin (百日維新) see Hundred Days' Reform

Buddhism (Chinese) 359

Confucianism combined 41

Daoism combined 10

Engaged 407n27, 411n39, 412-417

Humanistic 34, 359-36o, 362, 364, 366

Sphere $131,133,135,137$

Buddhism (Tibetan) 10, 36n 53 , 38, 281, 284-286, 291, 302

Encampment 46, 279-281, 284-288, 291-296, 302-303

Immolation 46, 279, 281, 284, 296-299, 301-304

Cai Yingwen (蔡英文) 28,361

Catholicism 25, 27, 37, 47, 131, 133-134, 138, 206, 214,256

Catholicism sphere 131, 133-134

Chen Shuibian (陳水扁) 27, 32-33, 158, 234, 246,387

China

Chinese nation (zhonghua minzu, 中華民

族) $16,23,92,99$

Chinese people (zhongguoren, 中國人) 57

Chinese (han, 漢) 22-23, 31, 61-62, 64, 75,

78, 81-82, 92, 94, 102, 180-181, 193, 201-203, 208-209, 213, 223, 280, 285, 287, 291, $344-346,352,374,388$

Chinese (hua, 華) 56,65, 182

Chinese state (zhongguo, 中國) 22, 30, 56, 58,92

Chögar see Buddhist encampment

Christianity see Protestantism

Christianity compared 23-24, 101

Chunqiu (春秋) 59, 200, 202

Ciji (慈濟) 28, 360

Civil religion 10, 14, 21, 28, 33-35, 36n54, 43-44, $47,203,205^{-20} 7$

Cixi (慈禧) 22, 91

Confucianism passim

As religion 199, 206-211

Buddhism combined 41

Cultural Revolution 25, 29, 168, 215-216, 217n76, $234,240,243,256,259,287-288,311,375,381$

Dalai Lama 39, 151, 279-28o, 283-285, 287, 296-298, 303-304, 413, 415-416, 418

Daodejing (道德經) 265, 268
Daoism passim

Daojiaojie (道教界) 131

Buddhism combined 15, 18, 23, 37, 217n76, 256,408

Daojiao (道教, Taoism) see Daoism

Democratic Progressive Party (DPP) 27-28, 30, $33,44,148,349,366,382,387-393$

Deng Xiaoping (鄧小平) 29, 31, 156, 162, 217-218, 280,285

Document 6 313-315, 325

Document 19 219, 311-315, 325

Dong Zhongshu (董仲書) 201-202

Eight-Nation Alliance (八國聯軍) 155

Evil cult 22, 40-41, 238-239, 243, 245, 319

Falungong (法輪功) 40-41, 131, 168

Fenling (分靈) 260, 374

Fenxiang (分香) 374

Foguangshan (佛光山) 341, 354, 359-364

Fojiao (佛教) see Buddhism

Folk religion 10, 15, 18, 22, 25, 34, 40-41, 312n9, $373-377,379,382,390$

Fuji (扶乩) see Spirit-writing

Fuluan (扶鸞) see Spirit-writing

Guojia zonjiaoju (國家宗教局) see State Administration for Religious Affairs

Guojiao (國教) see National Religion, State Religion

Guomindang (國民黨) see KMT

Guoxue (國學) see State Confucianism

Guoxuere (國學熱) see National Studies Fever Guozu (國族) see Nation, Definition

Hakka (客家) 119, 345-347, 365

Han (漢) see Chinese

Hanjian (漢奸) 236

High culture $340,342-343,347,350$, 352-354

Hu Jintao (胡錦濤) 42, 223, 245, 324

Hu Yaobang (胡耀邦) 285

Huangdi (共帝) see Yellow Emperor

Hui (回) 181

Huijiao (回教) see Islam

Patriotism 192-194

Hua (華) see Chinese

Human civilization $55,58-59,66,73$

Hundred Days' Reform 22, 91, 98, 254, 258

Imagined community $13,137,204,282,301$

Islam 10, 25, 27, 37-38, 46, 131, 133, 138, 179-185, $187-189,191-194,214,243,256,312,357 \mathrm{n}_{42}$ Islam sphere 131,133 
Jiang Jieshi (Chiang Kaishek, 蔣介石) 24-27,

$147,156-159,165-166,168,207,241,345,363$

Jiang Jingguo (蔣經國) 26-27, 241

Jiang Zemin (江澤民) 314

Jiating jiaohui see Protestantism, House Church

Jidujiao (基督教) see Christianity

Jixia Academy 200, 209

Kang Youwei (康有為) 91, 98, 210, 212-213 Kongjiao (孔教) see Confucianism, Religion Kuomindang (國民黨; KMT; the Nationalist Party) 24-28, 33, 37-41, 44-45, 143-145, 156$165,167-170,210-211,213,234-235,237-242$, 244-246, 259, 340, 344-348, 350, 352-353, $360,363-366,382,388-393$

Li Denghui (Lee Teng-hui, 李登輝) 27, 32, 246, $347-348,388$

Liang Qichao (梁啟超) 16, 23, 55, 78, 91, 93, 95, 98-99, 112-213, 254, 256

Ma Yingjiu (Ma Yingjeou, 馬英九) 168-169, $344,349,388$

Mao Zedong (毛澤東) 25, 31, 211-213, 215-217, 222-223

May Fourth Movement 100, 112, 253, 255 Mazu (媽祖) 374

Taiwanese identity $382,385-386,390,392$

Minzu (民族) see Nation, Definition

Mixin (迷信) 207, 255

Muslim 25, 96, 99, 179-194, 206

Nation

Definition 15-16

Nation-state $17,20-21,46,92-93,95-96$, 98-99, 107, 112-113, 131-132, 179-18o, 193-194, 199, 207, 210-211, 215-217, 220, $224,256,340 n 3$

National religion 137, 210, 254, 257, 263, 269,272

National Studies Fever 243-244

Nationalism

Civic 282, 365-366

Definition 282

Great 81,213

Hard 279, 281, 295-296, 303

Small 81,213

Soft 279, 281, 291, 295, 302-303

Neidan (內丹) 259, 261-262

New Life Movement 259

One Country, Two Systems

Hong Kong 408

Taiwan 29

Orthodoxy 25, 46, 66, 74, 201, 203-205, 209, 237-241, 246-247, 312ng

Orthopraxy 46, 205-206, 213
Patriotic education base $31,35,146,15^{2}, 235 \mathrm{n} 7$

Patriotism 192-194

Pilgrimage

Mazu 47, 376-379

Muslim (hajj) 46, 179

Presbyterian Church in Taiwan 27, 46, 341, 354, 364-367

Protestantism 25, 27, 37, 131, 133-134, 138, 206,

214, 256

Anglican 29, 406-407

House church 46, 315-319, 321, 324-325, 327-331

Sphere 135,137

Qigong (氣功) $214,217,261$

Religion

Abnormal 313

Autonomy 30, 34, 36, 38-39

Definition 14-15

Freedom 10, 14, 19, 27-30, 37-39, 41-42, 193, 206n29, 214, 264, 280, 286, 297, 309, 313-314, 319-320, 324-325, 329, 331, 365, 367,408

Normal 312-313

Sphere $117-118,128-129,131-134,136-138$

Religionization 256, 258, 260, 273

Religious nationalism 9, 11, 14, 16-17, 21, 25, 30, 43-47, 139, 193, 215, 280-281, 309-310, 329-330, $373,380-381,390-391$

Renjian fojiao (人間佛教) see Buddhism, Humanistic

Sanzi aiguo yundong (三自愛國運動) see Three-Self Patriotic Movement

Self-determination $280,284,295,297-298,302$, $304,343,347,365-367$

Shouwang Church (守望教會) 32, 319, 320, 324

Sinification 95

Sovereignty $15-16,22,29,35-36,38-40,42,45$, $78,82,117,125,138,145,165-167,188,321,323$

Sphere

Religion see Religion Sphere

Spirit-writing 119-120, 125, 241, 260-261, 266-267, 273

State

Definition 15

State Confucianism 22-23, 34, 46, 209-210, 219

State religion 10, 13, 17-18, 20-23, 25, 27-28, $30-32,34-35,43,45,47,138,212,274,326$

State Administration for Religious Affairs

(SARA) 9-10, 35-37, 40, 246, 314, 320, 331

Sun Huiming (孫慧明) 245

Sun Yatsen (孫逸先, 孫中山) 7, 23, 157, 166-168, 180, 207, 208n35, 210-211, 213, 221, 241 
Taiwan Jidu Zhanglao Jiaohui (臺灣基督長老 教會) see Presbyterian Church in Taiwan

Taiwanese

Definition passim

Three-Self Patriotic Movement (TSPM) $36 \mathrm{n}_{53}$, 312, 316-318

Tianxia (天下) see All-under-heaven, or Human civilization

Tianzhujiao (天主教) see Catholicism

Tibet 39, 82, 108, 147, 151, 170, 206, 279-281, 283-285, 288-293, 295-301, 303-304, 413, 416

Tibetan Buddhism 10, 36n $53,38,281,284-286$, 291,302

Umbrella Movement 30, 35, 37, 47, 397-402, 404-405, 407-412, 415-418

Under the heaven see Tianxia

Unity Sect see Yiguandao

Wang Fuzhi (王夫之) $45,56,58,64,75,81$, $83-84,112$

Wang Jingwei (汪精衛) 234, 236

Wen Jiabao (溫家寶) 221, 324

Western Learning 118, 125

Wu Boxion (吳伯雄) 241, 245

Xi Jinping (習近平) $31,42,129,170,219 n 88$, 219n9o, 222-223, 309, 324, 332

Xianxue (仙學) 261
Xiejiao (邪教) see Evil Cult

Xingyun (星雲) 359

Xinshenghuo Movement (新生活運動) see New Life Movement

Xixue (西學) see Western Learning

Yellow Emperor $31,63,67,69,74,209,220$, $262-263,268$

Yidi (夷狄) 6on18, 64

Yiguandao (I-Kuan Tao, 一貫道) 233, 238n17

Yuanmingyuan(圓明園) 144

Zhang Binlin (章炳麟; or Zhang Taiyan, 章太 炎) $56,75,81,91,96,98-99,112$

Zhang Peicheng (張培成) 239

Zhanguo (戰國) 59, 200

Zhengtong (正統) 238

Zhong (忠) 66, 240

Zhongguo (中國) see Chinese state

Zhongguoren (中國人) see Chinese people

Zhonghua minzu (中華民族) see Chinese nation

Zhongyuan (中原) 58, 200

Zhou Enlai (周恩來) $145,157,213$

Zongjiao (宗教) see Religion

Zongjianjie (宗教界) see Religion, Sphere

Zongjiaohua (宗教化) see Religionization 
